\title{
INNE SPOJRZENIE
}

WYOBRAŻENIA HISTORII

W FILMACH WOJCIECHA JERZEGO HASA

JANA JAKUBA KOLSKIEGO

FILIPA BAJONA I ANNY JADOWSKIEJ

- STUDIUM PRZYPADKÓW 


\section{REDAKCJA SERII WYDAWNICZEJ \\ „FILMO!ZNAWCY”}

\section{PWSFTViT}

prof. dr hab. Jolanta Dylewska (współprzewodnicząca Komitetu Redakcyjnego)

dr Piotr Mikucki, dr Anna Zarychta

\section{UNIWERSYTET ŁÓDZKI}

prof. zw. dr hab. Ryszard W. Kluszczyński (współprzewodniczący Komitetu Redakcyjnego) prof. dr hab. Tomasz Ktys, prof. dr hab. Piotr Sitarski

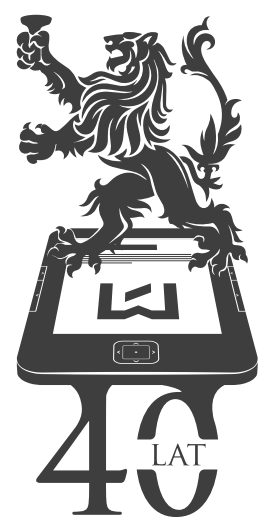

WYDAWNICTWA

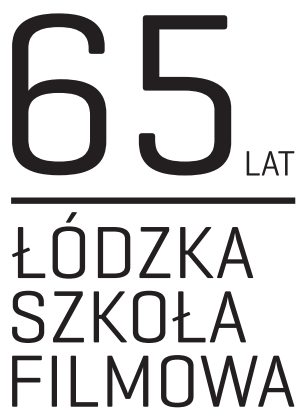

UNIWERSYTETU
ŁODZKIEGO 
Natasza

KORCZAROWSKA-RóżYCKA

\section{INNE SPOJRZENIE}

WYOBRAŻENIA HISTORII

W FILMACH WOJCIECHA JERZEGO HASA

JANA JAKUBA KOLSKIEGO

FILIPA BAJONA I ANNY JADOWSKIEJ

- STUDIUM PRZYPADKÓW

\section{FILMO!ZNAWCY}

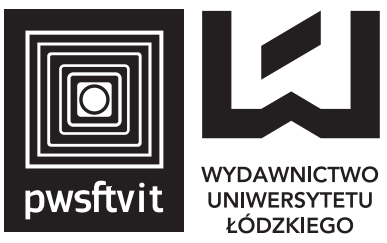

ŁÓDŹ 2013 
Natasza Korczarowska-Różycka - Zakład Historii i Teorii Filmu Katedra Mediów i Kultury Audiowizualnej, Instytut Kultury Współczesnej Uniwersytet Łódzki, 91-431 Łódź, ul. Franciszkańska 1/5 rozio@wp.pl

\section{RECENZENT}

Andrzej Pitrus

REDAKTOR WYDAWNICTWA UŁ

Katarzyna Gorzkowska

SKŁAD I ŁAMANIE

Oficyna Wydawnicza Edytor.org

PROJEKT OKŁADKI

Adrian Dutkowski

Na okładce wykorzystano zdjęcia z filmów Poznań 56 Filipa Bajona i Szyfry Wojciecha Jerzego Hasa

(C) Copyright by Uniwersytet Łódzki, Łódź 2013

(C) Copyright for this edition by Wydawnictwo Biblioteki PWSFTviT, Łódź 2013

Wydane przez Wydawnictwo Uniwersytetu Łódzkiego

i Wydawnictwo Biblioteki PWSFTviT

Wydanie I (dodruk). W.06125.13.0.H

ISBN Wydawnictwa Uniwersytetu Łódzkiego 978-83-7525-848-6

ISBN Wydawnictwa Biblioteki PWSFTviT 978-83-8787-064-5

Wydawnictwo Uniwersytetu Łódzkiego

90-131 Łódź, ul. Lindleya 8

www.wydawnictwo.uni.lodz.pl

e-mail: ksiegarnia@uni.lodz.pl

tel. (42) 6655863 , faks (42) 6655862

Wydawnictwo Biblioteki Państwowej Wyższej Szkoły Filmowej, Telewizyjnej i Teatralnej 90-323 Łódź, ul. Targowa 61/63

www.filmschool.lodz.pl

wydawnictwo@filmschool.lodz.pl

ksiegarnia.filmschool.lodz.pl

tel./faks (42) 6345870 , (42) 2755870

Druk i oprawa: Quick Druk 


\section{Spis treści}

Wstęp

\section{CzęŚć PIERWSZA: SpojRzenie GombrowiczowsKie}

Rozdział I. ...byliśmy jak z oleodruku - jak ze starego, familijnego albumu umarła fotografia. Czy Szyfry Wojciecha Jerzego Hasa to Pornografia?

Rozdział II. Co się stało z Żydami z Ostrowca? Pornografia Jana Jakuba Kolskiego

CZęŚĆ DRUgA: SPOJRZENIE DZIECKA (I NIE TYLKO)

Rozdział III. Chciałem zejść z pomnika, najkrócej mówiąc. Poznań 56 Filipa Bajona

CzęŚć trZecia: SpojRZENIE (POST)HistoryKa

Rozdział IV. Czy Sikorski mógł zginąć w Dallas? Generał. Zamach na Gibraltarze Anny Jadowskiej

Zakończenie 325

Bibliografia

Spis fotografii 339

Summary 341

Od Redakcji 343 



\section{Wstęp}

Uderzające jest intelektualne, malarskie i mitologiczne bogactwo wszystkich gatunków polskiego pisarstwa historycznego $\mathrm{w}$ zestawieniu $\mathrm{z}$ ubóstwem i schematyzmem myślenia i wizjonerstwa futurystycznego. Spory o przyszłość nigdy tu nie osiaggały tej temperatury emocjonalnej, co spory o przeszłość, bo tylko przeszłości swojej Polacy czuli się panami i gospodarzami.

Jerzy Jedlicki

Tak się dziwnie dzieje, że największy prestiż nie tylko własnej literaturze, ale własnemu narodowi przynoszą ludzie (pisarze) „źle” o swoim narodzie piszący.

Konstanty Jeleński

...wynalazczość jest potwierdzeniem wolności twórczej, która choć nie ma wpływu na wydarzenia, to może je przynajmniej mnożyć. Działanie nie polega tu na zwykłym spisywaniu historii, tylko na wynajdywaniu jej - kto tworzy zwielokrotnione czy alternatywne ciągi wydarzeń, ten stara się przełamać ograniczenia narzucane przez tradycje narodowe i podręczniki historii, mierząc $\mathrm{w}$ nie oskarżycielsko-parodystycznym ostrzem.

Fredric Jameson

W skierowanej do polskiego czytelnika przedmowie do tomu Proza historyczna autor zebranych w nim artykułów pisze:

Pierwsze wydarzenie, które pamiętam jako specyficznie historyczne, to inwazja na Polskę we wrześniu 1939 roku. [...] Fascynowały mnie opowieści o szarży polskiej kawalerii na niemieckie czołgi. Czy były one prawdziwe, czy też nie, ta zasłyszana historia pozwoliła mi dostrzec różnicę między rzeczywistością przeszłą i teraźniejszą. Bitwa kawalerii z nowoczesnymi czołgami nauczyła mnie nie tylko, że przeszłość stale trwa w teraźniejszości (wykorzystanie przez Polskę wojsk kawaleryjskich do walki z nowocześnie uzbrojoną armią niemiecką), lecz także, że fikcja (w tym wypadku 
rycerska waleczność polskich kawalerzystów) może trwać, bez względu na upływ czasu, nieodmienne nadając życiu sens ${ }^{1}$.

Cytuję słowa Haydena White'a nie po to, by udowodnić, iż polska historia stanowi przedmiot szczególnego zainteresowania jednego z najbardziej wpływowych współczesnych badaczy. Chodziło mi raczej o podkreślenie wpływu wspomnianych przez White'a opowieści na kształtowanie się zbiorowej (ten proces nie dotyczy bowiem jednostek, lecz ma wymiar społeczny) świadomości historycznej.

Odnotowana przez White’a trwałość fikcji (fikcyjnych wyobrażeń) jest efektem jej produkowania i transmitowania w nieskończonym łańcuchu inwariantnych powtórzeń. $W$ procesie multiplikacji biorą udział nie tylko opowieści zastyszane, lecz także - a może przede wszystkim - „opowieści, które można zobaczyć". Wydaje się bowiem, iż podobnego typu refleksję dotyczącą fikcji nadającej życiu sens mogłaby wywołać filmowa opowieść Andrzeja Wajdy Lotna (1959), w której znalazła się (kontrowersyjna²) scena szarży polskiej kawalerii na niemieckie czołgi. Nie bez znaczenia, jak sądzę, pozostaje również - pojawiające się w odniesieniu do (zastyszanych) opowieści o tej szarży - stwierdzenie White'a: „[niezależnie od tego] Czy były one prawdziwe, czy też nie...". Zdaniem Bronisława Baczki:

Od zarania dziejów społeczeństwa stale tworzą globalne wyobrażenia siebie samych, czyli idee-obrazy, za pomocą których nadają sobie tożsamość, postrzegają swoje wewnętrzne podziały, legitymizują swoją władzę i wypracowują modele stanowiące wzór do naśladowania dla ich członków $[\ldots]^{3}$.

Niezwykle istotną funkcję w procesie formowania się tożsamości zbiorowej odgrywają wyobrażenia dotyczące historii. Symptomatyczna wypowiedź White'a dowodzi, iż wydarzenia historyczne (w tym wypadku kampania wrześniowa 1939 r.), których wspomnienie przechowuje pamięć (indywidualna i zbiorowa), same w sobie znaczą często mniej niż zrodzone przez nie imaginacyjne wyobrażenia ${ }^{4}$. Nie bez przyczyny najważniejszym źródłem, z którego Polacy do dziś czerpią informację o Powstaniu Warszawskim jest Kanał (1957) Andrzeja Wajdy - film, który w sposób niezwykle sugestywny ukształtował ikonografię tego wydarzenia ${ }^{5}$.

1 Hayden White, Proza historyczna, tłum. zbiorowe, Universitas, Kraków 2009, s. 9-10.

2 Przypomnijmy, iż wspomniana scena została uznana za niezgodną z $\mathrm{t} w$. prawdą historyczną, a sam film wywołał ogromne kontrowersje w kręgach historyków.

3 Bronisław Baczko, Wyobrażenia społeczne. Szkice o nadziei i pamięci zbiorowej, tłum. Małgorzata Kowalska, Wyd. Naukowe PWN, Warszawa 1994, s. 14.

4 Tamże, s. 15.

5 Zob. Martyna Olszowska, Mit Powstania Warszawskiego a polskie kino narodowe, [w:] Kino polskie jako kino narodowe, red. Tadeusz Lubelski, Maciej Stroiński, korporacja ha!art, 
Już w 1905 r. Johan Huizinga w wykładzie o wielce znaczącym tytule Pierwiastek estetyczny w myśli historycznej przekonywał, iż „tym, co łączy studia nad historią z twórczością artystyczna, jest sposób tworzenia obrazów" ${ }^{\prime \prime}$. We współczesnej historiografii zwraca się uwagę na postępujący proces estetyzacji historii, którego celem staje się obcowanie z przeszłością i „przeżywanie” jej na sposób estetyczny, co umożliwia czytanie historycznych fikcji tak, aby wzbudzały w nas doznanie, jakie zazwyczaj wywołują dzieła sztuki (por. koncepcja doświadczenia historycznego jako doświadczenia historycznego Ankersmita) ${ }^{7}$. Nie bez wpływu na to zjawisko pozostaje z pewnością fakt, iż obecnie poznajemy (i zapamiętujemy) historię „zapisaną w obrazach”. Coraz liczniejszy krąg historyków przejawia skłonność do posługiwania się obrazami jako świadectwami historycznymi. Nawet w malarstwie portretowym - wyjaśnia John Zammito - a tym bardziej w przedstawieniu historycznym naszym zamiarem jest wysunięcie wiarygodnego roszczenia o czymś rzeczywistym ${ }^{8}$. Peter Burke scharakteryzował tę tendencję - posługując się określeniem Williama Mitchella - jako "zwrot obrazowy" (pictorial turn) w pisarstwie historycznym?. Wedle Burke’a należy także uwzględnić oddziaływanie obrazów na wyobraźnię historyczna, gdyż to właśnie obrazy pozwalają nam na bardziej plastyczne „wyobrażenie" sobie przeszłości ${ }^{10}$. W pisarstwie historycznym dostrzegalny staje się wpływ poetyki kina (tzw. efekt Rashomona) ${ }^{11}$. Tradycyjna historiografia powinna zatem znaleźć dopełnienie $\mathrm{w}$ historiofotii (Hayden White) definiowanej jako „reprezentacja historii i refleksja nad nią tworzona $\mathrm{w}$ obrazach wizualnych i w dyskursie filmowym"12. Zdaniem White'a w badaniach historycznych zbyt rzadko wykorzystuje się obrazy jako podstawowe medium reprezentacji dyskursywnej, w ramach której komentarze werbalne służyłyby jedynie konkretyzacji znaczenia,

Kraków 2009, s. 142. Podobną funkcję w odniesieniu do rewolucji 1917 r. spełnił film Październik (1928) Sergiusza Eisensteina.

6 Zob. Peter Burke, Naoczność, tłum. Justyn Hunia, Wyd. Uniwersytetu Jagiellońskiego, Kraków 2012, s. 29.

7 Zob. Ewa Domańska, Mikrohistorie, Wyd. Poznańskie, Poznań 1999, s. 99.

8 John Zammito, W strone trwałego historyzmu, tłum. Adam Ostolski, [w:] Teoria wiedzy o przeszłości na tle wspótczesnej humanistyki, red. Ewa Domańska, Wyd. Poznańskie, Poznań 2010, s. 216.

9 Zob. Peter Burke, Naoczność, dz. cyt., s. 30. Autor przytacza także argumenty przeciwników „zwrotu obrazowego", którzy kwestionują źródłową wartość obrazów m.in. ze względu na to, iż „pokazują one jedynie konwencje przedstawieniowe, jakie panują w danej kulturze" (tamże, s. 210).

10 Tamże, s. 31.

11 Zob. Vanessa R. Schwartz, Film and History, [w:] Film Studies, ed. James Donald and Michael Renov, Sage, Los Angeles-London-New Delhi-Singapore 2008, s. 207.

12 Zob. Hayden White, Historiografia i historiofotia, tłum. Łukasz Zaręba, [w:] Film i historia. Antologia, red. Iwona Kurz, Wyd. Uniwersytetu Warszawskiego, Warszawa 2008, s. 117. 
które można przekazać tylko za pomocą środków wizualnych ${ }^{13}$. Warto także podkreślić rosnące znaczenie filmu w edukacji historycznej. Autorzy podręcznika Teaching History with Film dowodza, iż filmy "przepisują” historię, wykorzystując w tym celu te same "narzędzia” (narracja), które stosowane są w tradycyjnej historiografiii ${ }^{14}$. Zwracają także uwagę na fakt, iż filmy powinny być analizowane nie tylko w odniesieniu do wydarzeń historycznych, o których traktuja lecz także w odniesieniu do epoki, w której powstały ${ }^{15}$. W tym sensie „filmy fikcji” można potraktować jako „dokumenty społeczne" ${ }^{\prime 16}$. Jak zauważa Marek Hendrykowski:

W unaoczniających nam, z niezrównaną intensywnością wyrazu to, co przeminęło, filmowych obrazach historii - podobnie jak w malarstwie historycznym i fotografii - toczy się, prowadzona za pośrednictwem języka ruchomych obrazów, gra, której stawką jest pamięć zbiorowa ${ }^{17}$.

A skoro gra toczy się o najwyższą stawkę, stricte retoryczne wydać się może pytanie:

\section{Dlaczego (nie?) warto zajmować się (zapisaną w języku ruchomych obrazów) historią (narodową)?}

Jednym z fundamentalnych dyskursów współczesnej kultury jest dyskurs tzw. końca historii.

13 Tamże, s. 118-119. Autor podkreśla, iż świadectwa wizualne nie powinny być traktowane jako uzupełnienie zapisów werbalnych, lecz jako „,autonomiczny dyskurs, zdolny do mówienia o rzeczach inaczej niż dyskurs werbalny, oraz o rzeczach, o których można się wypowiadać tylko [podkr. moje - N.K.-R.] za pomocą obrazów wizualnych". White stawia dość radykalną - w kontekście tradycyjnej historiografii - tezę, iż zapisy wizualne „stanowią dużo wierniejszą podstawę do odtworzenia scenerii i atmosfery przeszłości niż wszystko, co można wyczytać z samych tylko świadectw pisanych".

14 Zob. Alan S. Marcus, Scott Alan Metzger, Richard J. Paxton, Jeremy D. Stoddard, Teaching History with Film. Strategies for Secondary Social Studies, Routledge, New York-London 2010, s. 71.

15 W tym sensie Bonnie and Clyde (1967) Arthura Penna więcej „mówi” nam o dekadzie lat 60. niż o epoce Wielkiego Kryzysu (por. s. 74 i n.). Preferowaną przez autorów metodą badawczą jest analiza komparatystyczna. Dla przykładu, w części poświęconej filmowym reprezentacjom wojny w Wietnamie dokonano analizy porównawczej dwóch obrazów: Zielonych beretów (1968) Johna Wayne'a i Plutonu (1986) Olivera Stone’a (s. 76-80).

16 Zob. Vanessa R. Schwartz, Film and History, dz. cyt., s. 205. Paradygmatycznym przykładem „społecznej" lektury filmu jest studium Od Caligariego do Hitlera Siegfrieda Kracauera.

17 Marek Hendrykowski, Film jako źródło historyczne, Wyd. Ars Nova, Poznań 2000, s. 74. 
Nie brakuje twierdzeń, że w ponowoczesności słabnie znaczenie historii, gdyż zarzuca się ideę postępu, co ma doprowadzić do panowania przestrzeni, w której symultaniczne wydarzenia, fragmentaryczna i różnorodna temporalność zjawisk sprawia, że czas pojmowany jako uporządkowana sekwencja wydarzeń straci na znaczeniu ${ }^{18}$.

Krytyka pojmowania historii jako jednolitego procesu - podkreśla Georg G. Iggers - podważyła rozumienie nauki, będące fundamentem służących historii badań i prowadzące w rezultacie do jednolitej historiografii $^{19}$. Nawet jeśli uznamy, iż apokaliptycznie (choć przez niektórych badaczy z satysfakcją) obwieszczony ",koniec" historii nie nastąpił, musimy przyznać, iż historia jako nauka - przynajmniej w swej tradycyjnej („pozytywistycznej") formule związanej z korespondencyjną teorią prawdy - straciła status uprzywilejowanej metody reprezentacji (rozumianej jako propozycja najlepszego tekstowego substytutu ${ }^{20}$ ) przeszłości. Zaatakowano historię jako dyscyplinę dostarczającą obowiązującego obrazu przeszłości, która odgrywa rolę społeczno-polityczną integrując wspólnotę czy naród wokół pewnej tradycji oraz legitymizując i wspierając władzę ${ }^{21}$.

Dyskurs „końca historii” doskonale wpisuje się w sieć innych dyskursów - głównie postzależnościowych (koniec historii rozumianej jako Foucaultowski dyskurs władzy) i transnarodowych (koniec historii rozumianej jako ideologia państwa narodowego ${ }^{22}$ ). Odwrót od narodowo-historycznych paradygmatów widoczny jest w coraz wyraźniej transnarodowo ukierunkowanych naukach historycznych ${ }^{23}$. Zaś na obszarze

18 Elżbieta Hałas, Symbole i społeczeństwo. Szkice z socjologii interpretacyjnej, Wyd. Uniwersytetu Warszawskiego, Warszawa 2007, s. 55.

19 Georg G. Iggers, Historiografia XX wieku, tłum. Agnieszka Gadzała, Wyd. Naukowe PWN, Warszawa 2010, s. 73.

20 Zob. Frank Ankersmit, Pochwała subiektywności, tłum. Tomasz Sikora, [w:] Pamięć, etyka $i$ historia, red. Ewa Domańska, Wyd. Poznańskie, Poznań 2002, s. 71. Autor wyszczególnia trzy podstawowe cechy (tradycyjnie ujmowanej) narracji historycznej: 1) stanowi ona reprezentacje przeszłości; 2) reprezentacja ta składa się z prawdziwych twierdzeń; 3) opis przeszłości współkształtują reguły etyczne i wartości (tamże, s. 74).

21 Zob. Ewa Domańska, Historie niekonwencjonalne, Wyd. Poznańskie, Poznań 2010, s. 83.

${ }^{22}$ W związku z tym coraz częściej podejmowaną kwestią jest rola tzw. profesjonalnej historiografii w kształtowaniu i umacnianiu nacjonalizmu. Georg Iggers pisze: „Uderzające jest to, że z chwila, kiedy historia została zorientowana na badania, a więc stała się neutralna, równocześnie jednak uległa znacznemu upolitycznieniu. To nowe zainteresowanie historią i wsparcie udzielane jej przez państwo oraz inne instytucje związane były bezpośrednio ze wzrostem nacjonalizmu. Celem badań historycznych stało się współdziałanie w konstruowaniu tożsamości narodowej". Zob. Georg G. Iggers, Użycia i nadużycia historii, [w:] Pamięć, etyka i historia, dz. cyt., s. 110.

23 Zob. Doris Bachmann-Medick, Cultural turns, tłum. Krystyna Krzemieniowa, Oficyna Naukowa, Warszawa 2012, s. 317. Foucault wzywał do rewizji historii traktowanej jako wspornik narodowej przeszłości. Wedle filozofa: „Funkcja historii w obrębie ideologii burżuazyjnej polegała na pokazywaniu, w jaki sposób owe potrzebne kapitalizmowi 
nauk społeczno-kulturowych wspierają tę tendencję zwolennicy translational turn (przekład rozumiany jako wielowarstwowy proces interkulturowej komunikacji ${ }^{24}$ ) i spacial turn (transnacjonalizacja oznacza w tym wypadku nowy sposób myślenia o przestrzeni, która nie zamyka się już w granicach państwa narodowego $\mathrm{O}^{25}$ ).

W rodzimej refleksji badawczej kryzys myślenia w kategoriach narodu kojarzony bywa najczęściej z gwałtownym załamaniem się po $1989 \mathrm{r}$. romantycznego modelu samorozumienia wspólnoty narodowej. Proces transformacji

można określić jako przejście od modelu romantycznego narodu do modelu liberalnego (demokratycznego) społeczeństwa ${ }^{26}$. [...] "Naród" to ciało jednorodne, byt duchowy, którego rdzeniem jest tradycja. To ona określa jego tożsamość i przeznaczenie. „Społeczeństwo" natomiast jest strukturą pluralistyczną, niejednorodna, bytem empirycznym, którego dynamicznym rdzeniem są jego aktualne interesy ${ }^{27}$.

Zwrot transnarodowy implikuje zarazem kryzys "pamięci historycznej" (na marginesie pozostawiam dyskusyjność samego pojęcia), rozumianej jako wpajana opowieść, której ramą referencyjną jest naród²8.

Podczas gdy narodowe piętra pamięci ufundowane są na budowanej i pogłębianej tożsamości narodowej, piętra ponadnarodowe wykazują tendencję zarówno do fragmentaryzacji, jak i globalizacji świadomości historycznej ${ }^{29}$.

Polscy historycy coraz częściej wskazują na konieczność dokonania zwrotu transnarodowego. W praktyce oznacza to rozszerzenie kontekstu, w którym dotychczas ujmowane były kluczowe wydarzenia rodzimej historii. Te interpretowane były zazwyczaj wyłącznie w perspektywie lokalnej, podkreślającej wyjątkowość polskiego losu na tle innych narodów

wielkie narodowe jedności były zakorzenione w odległych epokach oraz jak potwierdzały i utrzymywały swą jedność, przechodząc przez różne rewolucje". Zob. Michel Foucault, Powrót do historii, [w:] Filozofia, historia, polityka: wybór pism, tłum. Damian Leszczyński, Lotar Rasiński, Wyd. Naukowe PWN, Warszawa-Wrocław 2000, s. 104.

24 Tamże, s. 318.

25 Tamże, s. 352.

26 O ile nie zaznaczono inaczej, wyróżnienia (pogrubienia, kursywy, rozspacjowania) pochodzą od autorów cytowanych tekstów.

27 Dariusz Gawin, Od romantycznego narodu do liberalnego społeczeństwa, [w:] Kultura narodowa i polityka, red. Joanna Kurczewska, Oficyna Naukowa, Warszawa 2000, s. 184-185.

28 Zob. Paul Ricoeur, Pamięć, historia, zapomnienie, tłum. Janusz Margański, Universitas, Kraków 2006, s. 523.

29 Zob. Antoon Van den Braembussche, Historia i pamięć, tłum. Ewa Domańska, [w:] Historia: o jeden świat za daleko?, red. Ewa Domańska, Wyd. Instytutu Historii UAM, Poznań 1997, s. 110. 
europejskich ${ }^{30}$. Paradygmatycznym przykładem historii ujmowanej w wymiarze transnarodowym może być Katyń ${ }^{31}$, o którym Marcin Kula pisze:

\begin{abstract}
Zbrodnię katyńską rozpatruje się najczęściej jako zbrodnię Stalina przeciwko Polakom. To, że była ona zbrodnią przeciw Polakom, nie ulega wątpliwości. Można nawet dodać, iż Stalin był najpewniej szczególnie uczulony na Polaków. „Na tym samym wdechu" należałoby jednak zwrócić uwagę, że Stalin zbrodniczo potraktował niejeden naród. Także na to, że wręcz w tym tragicznym lesie, jako w stałym miejscu enkawudowskich rozstrzeliwań, spoczywają szczątki ludzi różnych narodowości ${ }^{32}$.
\end{abstract}

Z drugiej jednak strony zwraca się uwagę na niebezpieczeństwo homogenizacji historii lokalnych, podporządkowanych autorytarnie narzuconemu, hegemonialnemu dyskursowi jednoczącej się Europy. Z poczucia owego zagrożenia zrodził się postulat wypracowania kodeksu zachowania

30 Za Marią Janion można określić ten typ interpretacji polskiej historii mianem herezji mesjanistyczno-patriotycznej.

31 Warto pod tym kątem przyjrzeć się filmowi Katyń Andrzeja Wajdy. Tworzenie transnarodowej kultury historycznej wymusza „traktowanie przeszłych konfliktów między narodami oraz krzywd wzajemnie sobie w przeszłości wyrządzanych w duchu porozumienia i pojednania". Tym należy zapewne tłumaczyć wprowadzanie przez Wajdę do opowieści o zbrodni katyńskiej kontrowersyjnej, zdaniem większości piszących, postaci "dobrego Rosjanina".

32 Marcin Kula, Historia ponadnarodowa jako wyzwanie dla badań historycznych i dydaktyki historii, referat wygłoszony na konferencji Wspólnej Polsko-Niemieckiej Komisji Podręcznikowej Historyków i Geografów (Łódź, 4-6 czerwca 2009 r.). Cyt. za: Robert Traba, Przeszłość w teraźniejszości. Polskie spory o historię na początku XXI wieku, Wyd. Poznańskie, Poznań 2009, s. 39.

"Zwrot transnarodowy" zaowocował ożywioną dyskusją nad koniecznością de-konstrukcji tzw. miejsc pamięci, które lokowane były zazwyczaj w obrębie dyskursów narodowych (w Polsce specyficzne jest odnoszenie owych miejsc - zwłaszcza w świadomości potocznej - do "miejsc martyrologii narodu polskiego"). Austriaccy badacze skupieni wokół Moritza Csáky'ego obiektem de-konstrukcji uczynili Europę Środkowo-Wschodnią , jako hybrydowy region, w którym na identyfikację narodową nakładały (przeplatały) się również różne tożsamości regionalne i trans- bądź międzynarodowe. [...] W austriackim manifeście nowego podejścia do badania miejsc pamięci podkreślane jest, że ważne są nie tylko elementy i kody «zgromadzone» w konkretnym «miejscu pamięci», nie tylko ich wspomniana już wieloznaczność, lecz dodatkowo również ich translokalna i transnarodowa proweniencja. W efekcie Europa Środkowo-Wschodnia jawi się jako terytorium endogennej i egzogennej (Pluralität) wielości. Tak więc tzw. narodowe kultury, jako obrońcy jedynego prawa do praobecności, swojej autentyczności i wyłączności, ciągle przenikały się z «obcymi elementami» i odmiennymi kodami kulturowymi. Endogenna wielość oznacza tyle, że w przeciągu wieków sąsiadowały tu ze sobą różnorodne ludy, kultury i języki. [...] Egzogenna wielość jest natomiast sumą tych elementów kulturowych, które napływały z zewnątrz". Zob. Robert Traba, Przeszłość w teraźniejszości, dz. cyt., s. 158. W nurt rozważań transhistorycznych (transnarodowych) doskonale wpisuje się fascynująca Niesamowita Słowiańszczyzna Marii Janion. 
w dziedzinie polityki historycznej. Zasadniczym punktem takiego kodeksu byłaby autonomia poszczególnych wspólnot pamięci, którym należy się respekt w stosunku do ich wspomnień/doświadczeń oraz wspomnień/doświadczeń innych ${ }^{33}$.

Można by w tym miejscu przytoczyć wiele dowodów wskazujących na pozytywne skutki (i to nie tylko w tzw. dyskursie miejsc pamięci), wynikające $z$ poszerzania się - w ramach zwrotu transnarodowego - perspektyw badawczych. W moim przekonaniu znacznie bardziej interesujące są jednak przypadki kontrowersyjne, odzwierciedlające trudności, z jakimi zmierzyć się muszą zwolennicy idei transnarodowej. Posłużę się w tym miejscu jednym tylko - ale niezwykle symptomatycznym - przykładem fabularnego filmu Strajk (2006). Wyreżyserowany przez Volkera Schlöndorfa obraz to

Opowieść klasyka niemieckiego kina o polskiej drodze do „Solidarności” i historii pierwszego ruchu wolnościowego w Europie Wschodniej po 1945 roku. Pierwszy [...] film zachodnioeuropejskiego reżysera, który próbuje stworzyć z wydarzenia „zza żelaznej kurtyny" jeden z mitów fundacyjnych współczesnej Europy. Na dodatek jest to niemiecki reżyser kreujący symboliczny wizerunek „polskiego Gdańska”! ${ }^{34}$

Z przytoczonej wypowiedzi wynika, iż Strajk miał pełnić funkcję narracji integrującej rozproszone doświadczenia narodów wchodzących w skład europejskiej wspólnoty.

Kiedy, jak w przypadku wielkich transformacji zachodzących w Europie i w świecie po 1989 r., poszukuje się dla nich ram znaczeniowych, wówczas w konstrukcji pamięci zbiorowej ważną funkcję pełni wybór takich wydarzeń, które mogą stać się symbolami zmiany, chociaż ta zachodziła w dłuższym okresie, a nie w jakimś przełomowym momencie ${ }^{35}$.

Doświadczenie „Solidarności” (a zwłaszcza Sierpień '80) uznawane bywa za centralny wątek największej zbiorowej narracji emancypacyjnej w powojennych dziejach Polski ${ }^{36}$. Film Schlöndorfa miał dowieść, iż powyższa teza wymaga uwzględnienia znacznie szerszego - transnarodowego - kontekstu (nie bez przyczyny w nazwie gdańskiego Centrum Solidarności pojawia się określenie: Europejskie). Niezwykle znaczący

33 Robert Traba, Przeszłość w teraźniejszości, dz. cyt., s. 63.

34 Tamże, s. 83.

35 Elżbieta Hałas, Symbole i społeczeństwo, dz. cyt., s. 67.

36 Zob. Przemysław Czapliński, Polska do wymiany. Późna nowoczesność i nasze wielkie narracje, Wyd. W.A.B., Warszawa 2009, s. 181. 
wydaje się zatem fakt, iż tak euforycznie (również przez polskich historyków wyczulonych na wszelkie odstępstwa od tzw. prawdy historycznej) awizowany film praktycznie nie zaistniał w zbiorowej świadomości „Europejczyków”. Konieczne wydaje się zatem postawienie pytania, czy przyczyny porażki Strajku (na marginesie pozostawiam kwestię - wysoce dyskusyjnych moim zdaniem - walorów artystycznych samego filmu ${ }^{37}$ ) należy upatrywać jedynie w niewłaściwym wyborze „mitu fundacyjnego" ${ }^{38}$ (co wikła nas nieuchronnie w relację pomiędzy tzw. historią pierwszego i drugiego stopnia ${ }^{39}$ ). A może wypada uznać - i ta konstatacja wydaje się znacznie bardziej istotna - iż niepowodzenie Strajku ilustruje fundamentalną niemożność ustanowienia (przynajmniej w "polu produkcji kulturowej") takiego mitu, z którym mogliby się identyfikować wszyscy zamieszkujących hybrydowy (transnarodowy) region Europy Środkowo-Wschodniej ${ }^{40}$.

W poczuciu tożsamości zbiorowej, przede wszystkim narodowej, istotnym elementem konstytuującym więź grupową jest poczucie wspólnej przeszłości ${ }^{41}$. Państwa narodowe - podkreśla Bauman - promują i czynnie propagują uniformizm:

Wychwalają a gdy trzeba wymuszają jednorodność etniczna, religijną, językową i kulturalną. Uprawiają propagandę na rzecz wspólnych poglądów i postaw. Pieczołowicie konstruują wspólne dziedzictwo historyczne i robia, co moga, by zdyskredytować lub wyciszyć pamięć zdarzeń rozsadzających postulowaną spójność narodowej tradycji. Pielęgnują poczucie wspólnej misji, wspólnego losu, wspólnego przeznaczenia ${ }^{42}$.

37 Przypadek Strajku nasuwa nieuchronne skojarzenia z innymi (nieudanymi) „projektami europejskimi", realizowanymi na długo przed tzw. zwrotem transkulturowym (mam na myśli m.in. film Krzysztofa Zanussiego Z dalekiego kraju).

38 Osobnej uwagi domaga się kwestia, czy artykułowana expresis verbis (przez zwolenników zwrotu transkulturowego) potrzeba jednoczących ponadnarodowe zbiorowości mitów fundacyjnych oznacza zażegnanie diagnozowanego wiele lat temu przez Lyotarda kryzysu (a raczej końca) „,wielkich narracji”?

39 Tę pierwszą w uproszczeniu określić można jako historię zdarzeniową, tę drugą jako „historię w naszych głowach” (wspótczynnik humanistyczny wedle terminologii Floriana Znanieckiego).

40 Konstruktywnym przykładem filmu kontestującego historię traktowaną jako pojedyncza opowieść z wyraźną moralną konkluzją jest, zdaniem Roberta Rosenstone'a, Far from Poland (1984) Jill Gudmilow. Wedle autora reżyserka przedstawiła w filmie „historię Solidarności przez pryzmat rywalizujących ze sobą głosów i obrazów, które nie łączą się w spójna jednoznaczną opowieść". Zob. Robert Rosenstone, Zobaczyć przeszłość, tłum. Piotr Witek, [w:] Teoria wiedzy o przeszłości na tle wspótczesnej humanistyki, dz. cyt., s. 331.

41 Robert Traba, Przeszłość w teraźniejszości, dz. cyt., s. 252.

42 Zygmunt Bauman, Wieloznaczność nowoczesna, nowoczesność wieloznaczna, tłum. Janina Bauman, Wyd. Naukowe PWN, Warszawa 1995, s. 94. 
A także wspólnej mitologii. W kontekście interpretacji Baumana oddziaływanie mitów - stanowiących przecież niezwykle ważny składnik tożsamości narodowej - może zostać uznane za przyczynę niebezpiecznych postaci nacjonalizmu i szowinizmu, chęci kulturowego bądź politycznego zawładnięcia innymi narodami lub grupami etnicznymi. Tak rozumiane mity

zawierają w sobie fikcję i zmyślenie, co prowadzi do wytworzenia się wśród członków narodu zafałszowanego obrazu własnej grupy oraz innych narodów, a także nieprawdziwych interpretacji historii. [...] Z wizerunku własnego narodu eliminują pewne wydarzenia, postacie lub zjawiska, które zostały uznane za niewygodne, a $\mathrm{w}$ to miejsce przesadnie uwydatniają inne ${ }^{43}$.

Zgodnie z ideologią państwa narodowego wspólną przeszłość winna odzwierciedlać jedna (meta)narracja. Zdiagnozowany przez Lyotarda koniec wielkich narracji ${ }^{44}$ oznacza jednakże, iż - jak głoszą zwolennicy postcolonial turn - naród nie może mieć jednej, standardowej narracji ${ }^{45}$, gdyż jest ona efektem wielu, konkurujących ze sobą opowieści. Wychodząc od tezy, iż „być właścicielem historii, to znaczy posiadać władzę i kontrolować tożsamość, której historia jest gwarantem"46, wprowadza się plu-

43 Zob. Dariusz Wadowski, Tożsamościowa funkcja polskich mitów narodowych, [w:] Tożsamość polska w odmiennych kontekstach. Tożsamości osób, zbiorowości, instytucji, red. Leon Dyczewski, Dariusz Wadowski, Wyd. KUL, Lublin 2009, s. 424.

44 Choć - jak zauważa Przemysław Czapliński - w codziennej praktyce społecznej wielkie narracje są nieustannie obecne: „Demontaż wielkiej narracji nigdy nie jest zakończony; metanarracja istnieje w nas, wyłania się z gazet i telewizji, ze zwykłej rozmowy - być może nawet jest warunkiem wstępnym porozumienia w życiu zbiorowości. Dlatego komunikacja społeczna zawsze zagrożona jest zrastaniem się kolejnych segmentów, przekształcaniem historii w metonimię, zamianą tego, co pojedyncze, w to, co ogólne, zgodą na kliszowanie dziejów". Zob. Przemysław Czapliński, Polska do wymiany, dz. cyt., s. 86.

45 Wedle Iggersa przykładem takiej jednogłosowej narracji narodowej jest opublikowany w 1986 r. Zarys dziejów Polski autorstwa Jerzego Topolskiego: „Polska jawi się tu jako etnicznie homogeniczny naród, w którym jedynie odrobinę miejsca zajmują Żydzi, Litwini, Niemcy, Ukraińcy i Romowie, a kwestia Holocaustu jest niemal zupełnie przemilczana". Zob. Georg G. Iggers, Użycia i nadużycia historii, dz. cyt., s. 114.

46 Ewa Domańska, Wprowadzenie, [w:] Pamięć, etyka i historia, dz. cyt., s. 25. Na ten aspekt w odniesieniu do „filmów pamięci narodowej” zwraca uwagę Witold Mrozek. Autor konstatuje, iż filmy te kreują wizerunek narodu jako wspólnoty homogenicznej. Dla przykładu, w filmie Generat "Nil” (2009) Ryszarda Bugajskiego znajduje się scena groteskowego posiedzenia sądu, która „w niebezpieczny sposób igra z mitem «żydokomuny», zbliżając się do granicy antysemityzmu”. Funkcją tej sceny jest „oczyszczenie narodowej wspólnoty z odpowiedzialności za powojenne stosunki w Polsce”. „Kabaretowe przeakcentowanie" udziału „obcych” („diabolicznych ubeków żydowskiego pochodzenia”) w stalinowskich zbrodniach „wpisuje się w mechanizm polityki historycznej, mający na celu zmarginalizowanie wstydliwego dziś udziału polskiej wspól- 
ralistyczne pojęcie „historii mniejszości”, odnoszących się do przeszłości podporządkowanych i marginalizowanych grup społecznych (subaltern $)^{47}$. W miejsce jednej metanarracji ${ }^{48}$ otrzymujemy zatem wielość równoprawnych mikrohistorii:

Kiedy umarła wiara w jedną prawdziwą historię, pozostaje wiązka narracji lokalnych, wachlarz perspektyw na historię. Wielość staje się wartością samą w sobie, a nawet najwyższą wartością, do której odnoszą się wszystkie inne wartości ${ }^{49}$.

Przekonaniu, że poradzimy sobie bez wielkich narracji towarzyszy zbiorowe zainteresowanie małymi narracjami - czyli nie tym, jak przedstawia się ogólna historia całego społeczeństwa, lecz czyjaś indywidualna, idiomatyczna biografia ${ }^{50}$. Wedle koncepcji Benedicta Andersona źródłem poczucia wspólnoty jest splot narracji, skoncentrowanych wokół kluczowych dla danego narodu wartości i fantazmatów, zaś w tworzeniu narodowej tożsamości kluczową rolę odgrywa konstruowanie miejsc, w których zbiorowość się kończy, miejsca wykluczenia i negacji51. Z tego faktu wynika uprzywilejowana pozycja, jaką we współczesnej refleksji kulturowej zajmują Łzw. dyskursy postzależnościowe. Jeśli postzależność jest stanem wszechstronnej niejasności, fundamentalnym zamazaniem różnic, doświadczeniem znikających podstaw, to narracje postzależnościowe usiłują nas z tą rzeczywistością skonfrontowaćs2. Ale czy oznacza to, iż pisanie historii z punktu widzenia którejkolwiek z grup uciskanych przybliży nas do

noty narodowej w budowie Polskiej Rzeczpospolitej Ludowej". Zob. Witold Mrozek, Film pamięci narodowej, [w:] Kino polskie jako kino narodowe, dz. cyt., s. 312. Zreprodukowanie w Katyniu homogenicznego wzorca miało przeciwdziałać dekonstrukcji założycielskiego mitu bazującego na przekonaniu o „bezgrzeszności” powojennego społeczeństwa polskiego.

47 Ewa Domańska, Historie niekonwencjonalne, dz. cyt., s. 90-91.

${ }^{48}$ Choć - jak zauważa Rita Felski - z perspektywy socjologicznej można by mówić nie o śmierci wielkich narracji, ile o ich rozmnożeniu, gdyż coraz więcej grup postrzega siebie jako podmioty aktywności historycznej w sferze publicznej. Zob. Rita Felski, Fin de siécle, fin de sexe, tłum. Magdalena Zapędowska, [w:] Pamięć, etyka i historia, dz. cyt., s. 297.

49 Tamże, s. 298.

50 Przemysław Czapliński, Polska do wymiany, dz. cyt., s. 273.

51 Zob. Monika Żółkoś, Tworzenie pamięci. O powieściach autobiograficznych Ewy Kuryluk, [w:] Kultura po przejściach, osoby z przeszłościa. Polski dyskurs postzależnościowy - konteksty i perspektywy badawcze, red. Ryszard Nycz, Universitas, Kraków 2011, s. 274. W wojnie o "prawo do historii” zwolennicy metanarracji negują „politycznie poprawną" wielokulturowość, gdyż zagraża ona zbiorowemu poczuciu narodowej tożsamości. Zob. Joan W. Scott, Po historii?, tłum. Paulina Ambroży, [w:] Pamięć, etyka i historia, dz. cyt., s. 217.

52 Przemysław Czapliński, Języki niezależności, [w:] Kultura po przejściach, osoby z przeszłościa, dz. cyt., s. 45. 
„prawdy”? Czy celem dziejopisarstwa - pytają autorki książki Powiedzieć prawdę o historii - jest wspieranie mniejszości i ich dobrego samopoczucia, czy też dążenie do obiektywnej prawdy o przeszłości? ${ }^{53}$ Narracje subaltern

\begin{abstract}
mogą również zaprzeczać istnieniu różnic wewnątrz grupy lub minimalizować je, zakładając, iż wszyscy mają wspólną opowieść. Mogą one sprzyjać samozadowoleniu i przekonaniu o własnej słuszności, mentalności „my kontra oni” oraz rozjątrzonemu poczuciu męczeństwa, oburzenia i pokrzywdzenia ${ }^{54}$.
\end{abstract}

Zdaniem Andrzeja Szpocińskiego jedną z najistotniejszych zmian dokonujących się we współczesnej kulturze historycznej jest tzw. prywatyzacja przeszłości ${ }^{55}$. Oznacza ona postępujący proces autonomizacji pamięci rodzinnej i lokalnej w stosunku do „monolitycznej” pamięci narodowej. W formie „klasycznej” odwołania do przeszłości lokalnej potwierdzały przynależność danej społeczności regionalnej do nadrzędnej względem niej społeczności narodowej. Pamięć lokalną konstruowano tak, by odpowiadała kanonowi pamięci narodowej ${ }^{56}$. W kulturze współczesnej przeszłość lokalna (regionalna) postrzegana jest poza kontekstem narodowym $^{57}$. Na gruncie polskiej socjologii zjawisko „regionalizacji pamięci” analizowane jest w kontekście procesu transformacji ustrojowej po 1989 r., który oznaczał także konieczność transformacji symbolicznej:

53 Joyce Appleby, Lynn Hunt, Margaret Jacob, Powiedzieć prawdę o historii, tłum. Stefan Amsterdamski, Zysk i S-ka, Poznań 2000, s. 13.

54 Tamże, s. 297-298.

55 Andrzej Szpociński, O współczesnej kulturze historycznej Polaków, [w:] Przemiany pamięci społecznej a teoria kultury, red. Bartosz Korzeniewski, Instytut Zachodni, Poznań 2007, s. 33. Nie brakuje jednak głosów sprzeciwu wobec zjawiska „prywatyzacji pamięci”, które przyczyniać się może do atomizacji społeczeństwa. Negatywną konsekwencją konstruowania „sprywatyzowanych” wersji przeszłości jest fakt utrwalania, a nie znoszenia międzyludzkich barier. „Prywatna pamięć” może być satysfakcjonująca dla jednostek, lecz nieużyteczna dla społeczeństwa. Por. Alison Landsberg, Prosthetic memory: the ethics and politics of memory in an age of mass culture, [w:] Memory and popular film, ed. Paul Grainge, Manchester University Press, Machester-New York 2003, s. 145.

56 Zob. Robert Traba, Przeszłość w teraźniejszości, dz. cyt., s. 237. Autor analizuje to zjawisko na przykładzie regionu warmińsko-mazurskiego: „Wybiera się z pamięci lokalnej postacie wybitnych działaczy ruchu polskiego, wybiera się zdarzenia, które decydowały o polskości Warmii i Mazur, bo te wybory pasują do opowieści o narodzie polskim i jego historii".

57 W polskim kinie tradycyjny typ odniesienia „region - naród” W sposób paradygmatyczny reprezentuje trylogia śląska Kazimierza Kutza. Jako przykład „regionalizacji pamięci" (z pewnymi zastrzeżeniami) można wskazać obraz Angelus (2001) Lecha Majewskiego. Nie można jednak wyodrębnić - i uznaję to za fakt niezwykle znamienny - zjawiska „regionalizacji pamięci” jako osobnego nurtu kinematografii po 1989 r. 
istota zmian zachodzących w ostatnim czasie w sposobach odwoływania się do przeszłości lokalnej polega na tym, że dotychczas przeszłość lokalna była obecna w dyskursie publicznym tylko w jeden sposób, w ramach którego pamięć o wydarzeniach związanych ze społecznością lokalną była pamięcią wydarzeń cenionych i upamiętnianych przede wszystkim dlatego, że reprezentują one wartości ważne z punktu widzenia narodu, którego grupa ta pozostaje członkiem (typ odniesienia „region - naród”). Obecnie [...] przeszłość lokalna postrzegana jest jako wartość autonomiczna ${ }^{58}$.

Zjawisko „prywatyzacji pamięci” ma charakter globalny i zdaniem wielu badaczy związane jest m.in. $\mathrm{z}$ marginalizowaniem $-\mathrm{w}$ procesie upamiętniania - roli państwa narodowego na rzecz społeczności lokalnych. Frank Ankersmit, odwołując się do koncepcji Pierra Nory, pisze:

Upamiętnianie nie pozostaje już w służbie tych dośrodkowych sił, które w ubiegłym stuleciu uczyniły z narodu najważniejszy czynnik kształtujący społeczeństwo oraz historię, lecz wspomaga siły odśrodkowe, uważane powszechnie za główną cechę postmodernizmu. Współczesne upamiętnianie oraz powrót pamięci, którego jest ono wyrazem, zrodziły się na grobie państwa jako centrum wszelkiej twórczej polityki. [...] Dzisiaj upamiętnianie zachowuje całą siłę i autentyczność w tym, co nierozerwalnie wiąże się z lokalnościa, regionem, miastem, wioska, czy też, mówiąc ogólnej, z tym, czym dana społeczność we własnym mniemaniu różni się od reszty społeczeństwa czy narodu ${ }^{59}$.

Paradygmatycznym przykładem prywatyzacji pamięci wydaje się jeden z najgłośniejszych polskich filmów ostatnich lat - Róża (2011) Wojciecha Smarzowskiego. Film ten stanowi doskonałe odzwierciedlenie rozmaitych problemów sygnalizowanych przez współczesne cultural turns. Po pierwsze - na co zwraca uwagę Robert Traba - powoływanie się na osobną pamięć mniejszości narodowych (w tym wypadku Mazurów), jako dowód pluralizmu, może paradoksalnie potwierdzać tezę o istnieniu jednej polityki historycznej, którą spaja jednolita „,wspólnota pamięci”, bo

58 Zob. Bartosz Korzeniewski, Transformacja pamięci. Przewartościowania w pamięci przeszłości a wybrane aspekty funkcjonowania dyskursu publicznego o przeszłości w Polsce po 1989 roku, Wyd. Poznańskiego Towarzystwa Przyjaciół Nauk, Poznań 2010, s. 171.

59 Zob. Frank Ankersmit, Narracja, reprezentacja, doświadczenie. Studia z teorii historiografii, tłum. zbiorowe, Universitas, Kraków 2004, s. 395-396. Pierre Nora podkreśla, iż wraz z zanikiem tradycyjnych wspólnot wiejskich nastąpiła radykalna zmiana w sposobach funkcjonowania pamięci. W przeszłości pamięć była fenomenem o charakterze kolektywnym (przekazem międzypokoleniowym sięgającym czasów mitycznych), związanym z narodem i jego historią. W sytuacji, gdy idea zjednoczonego „narodu” została wyparta przez ideę „społeczeństwa” (konotującą zróżnicowanie i sekularyzację), „pamięć-historię" zastąpiła zmultiplikowana „prywatna pamięć" (la mémorie particuculiére) różnych grup społecznych. Zob. Naomi Greene, Empire as Myth and Memory, [w:] The Historical Film: History and Memory in Media, ed. Marcia Landy, Rutgers University Press, New Jersey 2001, s. 246. 
wynika z niej, że w Polsce istnieje jedna, monolityczna „polska pamięć” $\mathrm{i}$ „inna” - pamięć mniejszości narodowych ${ }^{60}$.

Wielka narracja - potwierdza Przemysław Czapliński - jak każda metahistoria, jest do pewnego stopnia językiem repertuarowym, zbiorem toposów. A jednak nie zestaw klisz jest tu najistotniejszy, lecz mechanizm składniowy: pozwala on snuć opowieść indywidualną wyłącznie jako zdanie wtrącone między stereotypy. Zasadniczy wzorzec nie ulega zmianie [...], lecz właśnie jego trwałość pozwala opowiedzieć o przypadku odrębnym. Dzięki temu wyjątek [...] potwierdza regułę ${ }^{61}$.

Po drugie, Róża doskonale wpisuje się w dyskurs postzależnościowy, w którym uprzywilejowaną perspektywą interpretacji dziejów staje się perspektywa ofiar. Trudno jednak za stricte rewizjonistyczny uznać w Polsce film, w którym rola ofiary tradycyjnie (że wspomnę tylko Kobietę samotna Agnieszki Holland czy Matkę królów Janusza Zaorskiego) przypada kobiecie, nawet jeśli jest ona przedstawicielką mniejszości, której dzieje stanowiły dotychczas „białą plamę" w narodowej historii ${ }^{62}$. Paradoksalnie - na co zwraca uwagę Bartosz Korzeniewski - rozpowszechnienie się dyskursu wiktymizacyjnego ma w Polsce tę konsekwencję, że sprzyja uaktywnieniu się odwiecznego kompleksu martyrologiczno-heroicznego, wyrażającego się w poczuciu bycia ofiarą historii ${ }^{63}$.

W świetle teorii głoszących zmierzch idei państwa narodowego i koniec wielkich narracji zrozumiałe stają się kontrowersje ${ }^{64}$ wokół tzw. nowej polityki historycznej, którą postrzegać można jako kolejny „instytucjonalny bastion świadomości zbiorowej poddanej władzy polskich mitów" ${ }^{\prime \prime 5}$. Nowa polityka historyczna odnosi się do sfery

60 Robert Traba, Przeszłość w teraźniejszości, dz. cyt., s. 73.

61 Przemysław Czapliński, Polska do wymiany, dz. cyt., s. 77.

62 Los tytułowej bohaterki stanowi tu egzemplifikację losu „wszystkich polskich kobiet” - przypomnijmy, iż film otwiera wstrząsająca scena gwałtu, którego ofiarą nie jest przecież Róża.

63 Bartosz Korzeniewski, Transformacja pamięci, dz. cyt., s. 65.

64 Nie można jednak wykluczyć, iż sprzeciw wobec nowej polityki historycznej jest pochodną znacznie szerszego zjawiska, sięgającego korzeniami okresu PRL. „Kiedy polityka historyczna - jak zauważa Korzeniewski - polega przez długie lata na fałszowaniu historii narodowej i jest formą propagandy historycznej, wywołując zrozumiałą nieufność i reakcje obronne społeczeństwa, efektem długofalowym staje się oderwanie społecznych wyobrażeń o przeszłości od korygującego wpływu instytucjonalnych form promowania określonych postaw wobec przeszłości, a co za tym idzie - generalna nieufność do instytucjonalnych form oddziaływania na wyobrażenia o przeszłości”. Zob. Bartosz Korzeniowski, Transformacja pamięci, dz. cyt., s. 105.

65 Zob. Andrzej Werner, Polskie, arcypolskie..., Wyd. Biblioteki „Więzi”, Warszawa 2011, s. 235. 
wartości i symboli, konstrukcji pamięci i wyboru tradycji, tworzenia lub też odtwarzania tożsamości zbiorowej, w tym - narodowej. Ten rodzaj myśli i działań wnika bardziej intensywnie w życie publiczne i świadomość zbiorowa ponieważ jego domeną jest to, co powszechnie widziane i odczuwane - nazewnictwo ulic i placów, szkół i uczelni, uroczyste obchody i rytuały państwowe ${ }^{66}$, wznoszenie pomników i budowa muzeów ${ }^{67}$.

Nowa polityka historyczna starała się narzucić model jednej hegemonialnej pamięci „wszystkich Polaków”, definiowanych jako monolityczny naród ${ }^{68}$. Zdaniem Roberta Traby nowa polityka historyczna skazuje społeczeństwo na pozytywistyczna, „przednowoczesną" wersję historii Polski, w której stare mitotwórcze treści opakowane zostaną w nowoczesne środki narracyjne, powielając utarte i w gruncie rzeczy populistyczne sposoby myślenia o narodzie ${ }^{69}$. Brak zainteresowania „,czasem przyszłym” nadaje tak rozumianej polityce historycznej charakter nostalgiczny „,z bólem niezrozumienia, zagubienia w teraźniejszości, cierpienia w nieodległej przeszłości i «jasnością̨ czasów, gdy Rzeczypospolita była państwem pełniącym na arenie międzynarodowej funkcję podmiotu" ${ }^{\prime \prime 7}$.

Znacznie poważniejsze oskarżenie pod adresem nowej polityki historycznej formułują ci badacze, którzy widzą w niej narzędzie (skutecznie) uniemożliwiające wypełnianie tzw. białych plam historii. Na dowód warto przytoczyć znamienną wypowiedź Joanny Tokarskiej-Bakir dotyczącą - czekającego (?) wciąż na filmową reprezentację - problemu czystek rasowych dokonywanych w czasie okupacji przez elitarne oddziały Armii Krajowej:

Na przeoranej nową polityką historyczną Kielecczyźnie zapewne nieprędko przyjmie się do wiadomości tę niewygodną prawdę o „Wybranieckich"71. Jest gorzka ironia,

66 Transmitowana przez telewizję publiczną uroczysta premiera (17 września 2007 r.) filmu Katyń, w której wzięli udział m.in. prezydent RP Lech Kaczyński, prymas Polski Józef Glemp oraz minister kultury i dziedzictwa narodowego Kazimierz Ujazdowski miała taki właśnie "państwowo-rytualny" charakter.

${ }_{67}$ Andrzej Mencwel, Polityka historyczna i wizja polityczna, [w:] Rodzinna Europa po raz pierwszy, Universitas, Kraków 2009, s. 38.

68 Robert Traba, Przeszłość w teraźniejszości, dz. cyt., s. 77.

${ }_{69}$ Robert Traba, Historia - przestrzeń dialogu, Instytut Studiów Politycznych PAN, Warszawa 2006, s. 107.

70 Zob. Krzysztof Zamorski, Nostalgia i wzniosłość a refleksja krytyczna o dziejach. Kiedy „polityka historyczna" ma sens?, [w:] Pamięć i polityka historyczna. Doświadczenia Polski i jej sąsiadów, red. Sławomir M. Nowinowski, Jan Pomorski, Rafał Stobiecki, Wyd. Ibidem, Łódź 2008, s. 59.

${ }^{71} \mathrm{~W}$ opinii historyków jeden z najgłośniejszych oddziałów partyzanckich polskiego ruchu oporu, działający w Obwodzie Kieleckim. Nazwa oddziału wskazuje na wyjątkowy charakter jednostki, gromadzącej ludzi „niejako wybranych” (służbę pełnili wyłącznie 
iż jak dotąd tylko w wyroku, który zapadł w stalinowskiej Polsce, sąd miał odwagę nazwać po imieniu popełnione przez nich czyny ${ }^{72}$.

W świetle takich wypowiedzi nie powinien dziwić fakt, iż dla najmłodszego pokolenia filmowców symbolem (wszelkiego) zła stał się $\mathrm{w}$ ostatnich latach prawicowy polityk - faszysta (vide schematyczne Bez wstydu Filipa Marczewskiego $\left.{ }^{73}\right)$.

Reasumując, polityka historyczna byłaby przykładem instytucjonalnej kontroli pamięci - „instrumentalnej logiki utrzymywania dobrego samopoczucia narodu kosztem zapominania o tym, co owemu samopoczuciu mogłoby szkodzić" ${ }^{\prime \prime 4}$. Dowodziłaby także, iż instytucjonalizacja pamięci zbiorowej nie jest zjawiskiem odnoszącym się wyłącznie do Orwellowskich (Rok 1984) reżymów totalitarnych. O tym zjawisku - w kontekście Łw. tradycji wynalezionych - pisze Eric Hobsbawm. Wszystkie wymyślone tradycje wykorzystują historię jako środek legitymizowania działania i cementowania więzi grupowych. Instrumentalne traktowanie historii jest szczególnie widoczne $\mathrm{w}$ przypadku tradycji służących umacnianiu instytucji, pozycji lub relacji władzy. Historia,

która staje się zasobem wiedzy czy ideologii narodu, państwa lub ruchu, nie jest tożsama z tą która rzeczywiście trwa w pamięci ludzi, lecz czymś, co zostało wyselekcjonowane, spisane, zobrazowane, spopularyzowane i zinstytucjonalizowane przez ludzi, których funkcją jest robienie takich rzeczy ${ }^{75}$.

Zdaniem Mary Douglas celem rewizjonistycznych działań instytucji demokratycznych (dla przykładu autorka analizuje dokonywaną średnio co dziesięć lat „aktualizację” podręczników historii, które - jak zauważa

żołnierze narodowości polskiej). O partyzantach „Wybranieckich” posłowie mówią z trybuny sejmowej, ich imię nosi jedna ze szkół na Kielecczyźnie, a liczne na tym terenie pomniki i tablice pamiątkowe przypominają o ich wyczynach. Wszyscy natomiast pomijają zabójstwa Żydów, których w latach II wojny dopuścili się "Wybranieccy”. Zob. Joanna Tokarska-Bakir, Barabasz" i Żydzi. Z historii oddziatu AK "Wybranieccy", [w:] Okrzyki pogromowe. Szkice z antropologii historycznej Polski lat 1939-1946, Wyd. Czarne, Wołowiec 2012, s. 177-229.

72 Tamże, s. 219.

73 Zrealizowany w 2012 r. film Marczewskiego może stanowić potwierdzenie, iż radykalna prawica zaakceptuje raczej dewiację seksualną (ambitny debiutant zmierzył się bowiem z tabu kazirodztwa) niż „bohatersko-ofiarniczą”.

74 Por. Joyce Appleby, Lynn Hunt, Margaret Jacob, Powiedzieć prawdę o historii, dz. cyt., s. 320.

75 Eric Hobsbawm, Wprowadzenie. Wynajdowanie tradycji, [w:] Tradycja wynaleziona, red. Eric Hobsbawm, Terence Ranger, tłum. Mieczysław Godyń, Filip Godyń, Wyd. Uniwersytetu Jagiellońskiego, Kraków 2008, s. 17-20. 
Fredric Jameson - pisane są z myślą o legitymizacji określonych tradycji narodowych $)^{76}$

nie jest uzyskanie idealnego obrazu zdarzeń. Tak przed rewizja, jak i po niej, lustro - o ile można tak nazwać historię - wciąż zniekształca odbicie. Celem rewizji jest dopasowanie owych zniekształceń do aktualnie panującej atmosfery. [...] Kiedy przyjrzymy się dokładniej konstruowaniu minionego czasu, odkryjemy, że proces ów ma bardzo niewiele wspólnego z przeszłościa, za to mnóstwo - z teraźniejszością. Instytucje tworzą sfery cienia, gdzie niczego nie można dostrzec i nie zadaje się żadnych pytań. Inne obszary prezentowane są w najdrobniejszych szczegółach, podlegają starannej kontroli i ścisłej organizacji. Historia wyłania się w nieprzewidzianym kształcie jako rezultat działań nakierowanych na bezpośrednie cele praktyczne ${ }^{77}$.

Warto by się także zastanowić, czy dyskurs „postnarodowy” i „postzależnościowy" ma szansę stać się w Polsce dyskursem dominującym? Wszakże

nie mamy jeszcze do czynienia ze społeczeństwem wielokulturowym, a martyrologiczno-heroiczna wizja narodowej historii jest wciąż mocno ugruntowana, co z pewnością utrudnia przyjęcie internacjonalistycznego wzorca. [...] zaimplementowanie nowego, uniwersalnego i koncyliacyjnego języka rozprawiania o „trudnej” przeszłości pociągnęło za sobą reakcję zwrotną w postaci pojawienia się silnych tendencji do reheroizacji polskiej historii i prób uczynienia z niej podbudowy dla konstruowania nowych form patriotyzmu afirmującego polskość ${ }^{78}$.

Polityka pamięci historycznej - wedle Elżbiety Hałas - jest domeną państwa ze względu na takie ważne jej funkcje, jak legitymizacja porządku społecznego, konstytuowanie tożsamości zbiorowych, idealizacja wartości. Pamięć - w dużej mierze za sprawą mediów - nabiera charakteru zabawowego, stając się pamięcią homo ludens.

Pojawia się brak odpowiedzialności za pamięć, coraz częściej następują naruszenia pamięci zbiorowej - rodzaj przemocy symbolicznej, czemu sprzyjają niejasne reguły

${ }^{76}$ Frederic Jameson, Postmodernizm, czyli logika późnego kapitalizmu, tłum. Maciej Płaza, Wyd. Uniwersytetu Jagiellońskiego, Kraków 2011, s. 24.

77 Mary Douglas, Jak myśla instytucje, tłum. Olga Siara, Wyd. Naukowe PWN, Warszawa 2011, s. 75-76. W dalszej kolejności autorka pisze: „Instytucje systematycznie sterują pamięcią jednostek i kanalizują nasze spostrzeżenia, nadając im formę kompatybilną z relacjami, jakie same sankcjonują" (s. 106). „[...] każda instytucja zaczyna kontrolować pamięć swoich członków; sprawia, że wypierają z pamięci doświadczenia nieprzystające do jej szlachetnego obrazu i przywodzi im na myśl wydarzenia podtrzymujące tę wizję natury, która pasuje do rzeczywistości instytucjonalnej. Wyposaża członków w kategorie myślowe, ustanawia warunki samowiedzy i ustala tożsamość" (s. 131).

78 Bartosz Korzeniewski, Transformacja pamięci, dz. cyt., s. 60. 
komunikowania doświadczeń przeszłości. W odpowiedzi, aby zapobiegać dowolnym interpretacjom i relatywizmowi, powołuje się specjalne instytucje, których zadaniem ma być ochrona pamięci ${ }^{79}$.

W kontekście nowej polityki historycznej - ujawniającej skłonność do podtrzymywania (w dużej mierze za pomoca „tekstów kultury") monolitycznej wizji przeszłości - powraca pojęcie kanonu (w rozumieniu kanonicznych ujęć historii) uznane przez badaczy postmodernistycznych za relikt nowoczesności. Okazuje się, iż w społeczeństwie demokratycznym

uprzywilejowani w sferze publicznej politycy mogą zasobami kultury narodowej względnie dowolnie operować: zamykać ją w sztywnym kanonie akceptowanej przez siebie przeszłości lub uczynić z niej zespół zasad regulatywnych, umożliwiających jej przeniesienie do przyszłości ${ }^{80}$.

Do niedawna podkreślano ścisły związek nowej polityki historycznej z kulturą audiowizualną (zwłaszcza filmową):

Kinematografia polska - pisze w tekście o znamiennym tytule Film pamięci narodowej Witold Mrozek - od kilku lat staje się w mniejszym czy większym stopniu instrumentem praktyk społecznych, mających pomóc dominującemu obozowi prawicy w osiągnięciu określonych celów ${ }^{81}$.

Powyższy przykład wskazuje, iż autorzy wypowiadający się - zazwyczaj w tonie krytycznym - o "filmach pamięci narodowej” łączą to zjawisko z nową polityką historyczną („,efekt Foucault”: dyskurs historii identyfikowany z dyskursem władzy?), którą określały:

1) afirmacja historii narodowej,

2) sprzeciw wobec tradycji patriotyzmu krytycznego (ukształtowanej w latach 70. w kręgu lewicowej opozycji demokratycznej, a reprezentowanej współcześnie m.in. przez Jana Józefa Lipskiego i Jana Błońskiego), wspierającego się na stałej dyspozycji do obalania mitów narodowych, walki ze stereotypami, stałej podejrzliwości wobec jakoby z natury potencjalnie groźnej idei narodu oraz na przekonaniu o konieczności stałego rewidowania pamięci historycznej $j^{82}$,

3) dekretowanie „odgórne” (dominująca rola państwa w kształtowaniu społecznych postaw wobec przeszłości).

79 Elżbieta Hałas, Symbole i społeczeństwo, dz. cyt., s. 64.

80 Joanna Kurczewska, Kanon kultury narodowej, [w:] Kultura narodowa i polityka, dz. cyt., s. 57.

81 Witold Mrozek, Film pamięci narodowej, dz. cyt., s. 295.

82 Zob. Bartosz Korzeniewski, Transformacja pamięci, dz. cyt., s. 198. 
W „filmach pamięci narodowej” nie znalazła odzwierciedlenia teza, iż

Świadomość historyczna często zakłada mnogość tradycji i wizji przeszłości. [...] Nie istnieje jeden, lecz wiele wizerunków przeszłości. [...] społeczna świadomość przeszłości jest mnoga, nie pojedyncza, i że jest ona w różny sposób społecznie uwarunkowana. Nie ma też żadnej przyczyny a priori, dla której owe różne świadomości powinny zrosnąć się w jedną ${ }^{83}$.

"Filmy pamięci narodowej" stanowić mogą także dowód na to, iż sztuka filmowa przyczynia się do petryfikacji określonych wyobrażeń historii nie tylko w warunkach niewoli, kiedy to tak przekazywana historia odgrywała doniosłą rolę czynnika służącego podtrzymywaniu zbiorowej pamięci, słowem - instrumentu przetrwania ${ }^{84}$. Autorzy współcześnie produkowanych filmowych wyobrażeń historii do tego typu wspólnotowego (czy wręcz „egzystencjalnego") alibi nie mogą się już odwołać.

Jeśli za sztandarowy przykład „filmu pamięci narodowej” uznamy - wzorem piszących o tym zjawisku - Katyń Andrzeja Wajdy ${ }^{85}$, musimy podkreślić ewidentny w przypadku tego filmu brak (choć problem ten nie dotyczy wyłącznie utworu Wajdy) wspomnianego przez Roberta Trabę „opakowania" (starych mitotwórczych treści w nowe środki narracyjne). Krytyczna recepcja filmu dowodzi, iż wobec nowej fali (medialnych) atrakcji „etosowa” pamięć jawi się jako nazbyt koturnowa i fabularnie nieatrakcyjna $^{86}$. Byłby zatem Katyń - zrealizowany przy użyciu gwarantującego (zdaniem twórcy) powszechną zrozumiałość, lecz niemożliwego dziś do zaakceptowania języka niewolniczego patriotyzmu ${ }^{87}$ - świadectwem tezy, iż obecnie

Twórców wcielających w materię filmową pożądane interpretacje można wspierać publicznymi dotacjami lub nakazywać szkołom, aby wysyłały na ich film dzieci do kin, ale o sukcesie decyduje dostosowanie się do poetyki kultury masowej. Zmianę świadomości historycznej ludzi wywoła film przede wszystkim atrakcyjny ${ }^{88}$.

83 Zob. Antoon Van den Braembussche, Historia i pamięć, dz. cyt., s. 109.

84 Zob. Marek Hendrykowski, Film jako źródło historyczne, dz. cyt., s. 76.

85 Doskonałym uzupełnieniem refleksji nad Katyniem jako "filmem pamięci narodowej” może być przeprowadzona w duchu Orwellowskim analiza - pochodzącej z Dantona Andrzeja Wajdy - sceny „przepisywania historii na użytek polityki” (chodzi o fragment, w którym malarz David wymazuje z fresku rewolucjonistę Fabre'a). Zob. Peter Burke, Naoczność, dz. cyt, s. 186.

${ }^{86}$ Lech Nijakowski, Polska polityka pamięci. Esej socjologiczny, Wyd. Akademickie i Profesjonalne, Warszawa 2008, s. 128.

87 Zob. Monika Nahlik, "Katyń" w czasach popkultury, [w:] Kino polskie jako kino narodowe, dz. cyt., s. 332.

88 Lech Nijakowski, Polska polityka pamięci, dz. cyt., s. 48. 
Niezbyt przekonująco brzmi jednak teza, iż alternatywną w stosunku do „kina pamięci narodowej” propozycją mogą być filmy w rodzaju Jeża Jerzego (2011) - „,niepoprawnej politycznie [czytaj: kuriozalnej] ${ }^{89}$ historii absolutnej mniejszości w naszym społeczeństwie"90 czy Wojny polsko-ruskiej (2009) Xawerego Żuławskiego, w której „nowym bohaterem narodowym jest nie akowiec, ale dresiarz walczący o byt w nowym wspaniałym kapitalistycznym świecie, zaś patriotyzm zyskuje wymiar groteskowy, ograniczając się do decyzji, od kogo kupić siding"91.

$\mathrm{W}$ polemikach $\mathrm{z}$ "kinem pamięci narodowej” za niezwykle znaczący uznaję fakt nieustannego odnoszenia się do tekstów kanonicznych (dla przykładu "bohater akowiec" to oczywista aluzja do Wajdowskiego Popiołu $i$ diamentu). Nie po raz pierwszy okazuje się, iż

Do wytwarzania nowych narracji u schyłku nowoczesności potrzebne okazują się choćby jako kontekst negowany, prześmiewany, dekonstruowany - wielkie opowieści wykształcone przez nowoczesność, ponieważ zrozumienie nowego społeczeństwa jako nowego porządku narracyjnego rządzącego się nowymi regułami wymaga przemyślenia idei dawnych ${ }^{92}$.

Powyższa konstatacja wymaga jednak znaczącego uzupełnienia. „Wielkie opowieści”, aby można je było uznać za ów (negowany) kontekst, stanowić muszą integralny składnik tzw. pamięci żywej. Dla wyjaśnienia posłużę się przykładem wspomnianego powyżej Popiołu i diamentu. Słynnej sceny ",spirytusu u Rudego"93 przywołanej w Pierścionku $z$ orłem w koronie (1992) nie sposób czytać poza kontekstem wcześniejszego arcydzieła Wajdy. Jestem jednak przekonana, iż ta sama scena „zacytowana" (sparodiowana) w Yumie (2012) Piotra Mularuka dla współczesnego młodego widza - do którego adresowany był film - nie znaczy już nic. $W$ procesie społecznej komunikacji - a dotyczy to w sposób szczególny pola produkcji kulturowej - niezbędne jest wypracowanie własnego języka. Twórca, który próbuje uczestniczyć w tym procesie, ograniczając się wyłącznie do parodiowania "tekstów kanonicznych", nieuchronnie - jak dowodzi znamienny przykład Człowieka z... (1995) Konrada Szołajskiego - skazany jest na porażkę.

89 O ile nie zaznaczono inaczej, dopiski w nawiasach kwadratowych pochodzą ode mnie - N.K.-R.

90 Informacja zwarta w materiałach prasowych dystrybutora filmu.

91 Zob. Monika Nahlik, „Katyń” w czasach popkultury, dz. cyt., s. 346.

92 Przemysław Czapliński, Polska do wymiany, dz. cyt., s. 16.

93 Niezwykle ważnej w historii polskiego kina, ale czy oddającej... prawdę tamtych czasów? Czyż nie jest ona - jak wspominał Tadeusz Konwicki - jedynie „modną pozą, dziwnym fasonem, nie naszym szpanem", (nieprawdziwym) obrazem pokolenia Kolumbów, „odbitego już w lustrze sztuki”? Zob. Tadeusz Konwicki, Wschody i zachody księżyca, Oficyna Wyd. Interim, Warszawa 1990, s. 58. 


\section{Historia czy... wyobrażenie historii?}

Pamięć zbiorowa - pisze Bronisław Baczko - może funkcjonować tylko w określonym obszarze symbolicznym, dzięki grze całej sieci wyobrażeń, rytuałów i stereotypów itp., które odnoszą się do pewnej szczególnej przeszłości, modelując ją i łącząc z doświadczeniami teraźniejszości oraz z oczekiwaniami przyszłości ${ }^{94}$. Wedle Cassirera punktem przecięcia dwóch postulowanych w badaniach historycznych punktów widzenia na przeszłość - perspektywicznego i retrospektywnego - jest zawsze teraźniejszość. Historyk

Nie może wyjść poza warunki swego aktualnego doświadczenia. Wiedza historyczna jest odpowiedzią na konkretne pytania, odpowiedzią którą musi dać przeszłość; ale same pytania stawia i dyktuje teraźniejszość - stawiają je i dyktują nasze aktualne potrzeby moralne i społeczne ${ }^{95}$.

Pomiędzy teraźniejszością a przeszłością istnieje ścisła współzależność. Przeszłość jest interpretowana (konstruowana ${ }^{96}$ ) w aspekcie $a k t u-$ alnych doświadczeń. Nie powstaje jako prosty efekt upływu czasu, lecz stanowi rezultat procesów kulturowej konstrukcji i reprezentacji, a kształtowana jest przez określone motywacje, oczekiwania, nadzieje i aspiracje w ramach konkretnej teraźniejszości ${ }^{97}$. Ta zasada wydaje się obowiązywać także w przypadku filmowych wyobrażeń historii. W pewnym sensie wszystkie filmy traktujące o wydarzeniach z przeszłości mogą być uznane za wypowiedzi odnoszące się do teraźniejszości. W ogóle nie ma filmów historycznych - mówił Andrzej Wajda przy okazji premiery

94 Bronisław Baczko, Wyobrażenia społeczne, dz. cyt., s. 228.

95 Ernst Cassirer, Esej o człowieku. Wstęp do filozofii kultury, tłum. Anna Staniewska, Czytelnik, Warszawa 1998, s. 289.

96 Orientacja „konstruktywistyczna” - na co zwraca uwagę Martin Jay - pojawiła się w refleksji historiograficznej już w latach 30. Jest ona widoczna chociażby u Michaela Oakeshotta, który stwierdził, iż: „Rzeczą historyka nie jest odkrywać, odzyskiwać czy nawet interpretować; jest nią kreować i konstruować. [...] Jedyna możliwa różnica między surowym materiałem historii a historią jako taką polega na tym, że ta druga okazuje się bardziej spójna i zrozumiała. Właściwości te pochodzą jednak od samego historyka, ponieważ «historia jest doświadczeniem historyka. Nie jest 'wytworzona' przez nikogo prócz historyka; pisanie historii jest jedynym sposobem jej wytwarzania»". Zob. Martin Jay, Historia i doświadczenie. Dilthey, Collingwood, Scott i Ankersmit, [w:] Pieśni doświadczenia. Nowoczesne amerykańskie i europejskie wariacje na uniwersalny temat, tłum. Agnieszka Rejniak-Majewska, Universitas, Kraków 2008, s. 316.

97 Zob. Jan Assmann, Pamięć kulturowa. Pismo, zapamiętywanie i polityczna tożsamość w cywilizacjach starożytnych, tłum. Anna Kryczyńska-Pham, Wyd. Uniwersytetu Warszawskiego, Warszawa 2008, s. 104. 
Popiołu i diamentu - każdy film jest współczesny, bo widzowie odczytują problem filmu zawsze jako problem dzisiejszy ${ }^{98}$.

Teraźniejszość determinują (legitymizują) przeszłe zdarzenia. A raczej należałoby mówić o zdeterminowaniu teraźniejszości przez wyobrażenia przeszłości, bo - zdaniem George’a Steinera - właśnie takie wyobrażenia, równie wybiórcze jak każdy inny mit, dają każdej „nowej erze” jej poczucie tożsamości, zacofania i postępu ${ }^{99}$. Mity (dotyczy to w sposób szczególny tzw. mitów fundacyjnych) nastawione są przede wszystkim na konstytuowanie pożądanych przez daną grupę społeczną obrazów przeszłości. W tym aspekcie interesująca wydaje się koncepcja Iana Barboura. Badacz traktuje mity jako wyobrażenia - dotyczące zwłaszcza przyrody i historii - które dostarczają sposobów organizowania doświadczenia i interpretowania świata. Nie są one ani dosłownymi obrazami rzeczywistości, ani użytecznymi fikcjami, stąd powinny być analizowane nie tyle ze względu na ich status epistemologiczny, ile na pełnione przez nie funkcje ${ }^{100}$. Barbour podkreśla przede wszystkim społeczną funkcję mitu:

Mity przyczyniają się do integracji społeczeństwa. Są one czynnikiem spajającym wspólnotę i przyczyniającym się do wzrostu solidarności wewnątrzspołecznej, poczucia tożsamości grupowej i unikania konfliktów. Działają na rzecz stabilności kulturowej $[\ldots]^{101}$.

Formułowany na gruncie teoretycznym postulat badania przeszłości w aspekcie teraźniejszości wiązać się może z koniecznością poddania

98 Zob. Tadeusz Lubelski, Strategie autorskie w polskim filmie fabularnym lat 1945-1961, Wyd. Rabid, Kraków 2000, s. 158-159.

99 Zob. Keith Jenkins, Żyć w czasie, lecz poza historia; żyć w moralności, lecz poza etyka, [w:] Pamięć, etyka i historia, dz. cyt., s. 241.

${ }^{100}$ Barbour zasadniczo posługuje się pojęciem „modelu” rozumianym jako „symboliczne przedstawienie, w określonym celu, wybranych aspektów zachowania jakiegoś złożonego systemu. Stanowi on narzędzie wyobraźni, służące bardziej do organizowania doświadczenia niż do opisywania świata. [...] Modele reprezentują trwałe komponenty strukturalne, które mity przekazują w formie opowieści. [...] Modele są wynikiem refleksji nad żywotnymi, przekazywanymi z pokolenia na pokolenie mitami. [...] Modele mogą skupiać w sobie elementy strukturalne pochodzące z kilku mitów". Zob. Ian G. Barbour, Mity, modele, paradygmaty, tłum. Marek Krośniak, Znak, Kraków 1984, s. 39-40.

101 Tamże, s. 34-35. Wyjaśniając stabilizującą funkcję mitu, Barbour powołuje się na koncepcję Lévi-Straussa, wedle którego „w wielu mitach występują struktury binarne z dwoma przeciwstawnymi elementami. W strukturze logicznej tych mitów owo początkowe przeciwstawienie zostaje przezwyciężone; często jest to wynikiem wprowadzenia jakiegoś trzeciego elementu. Te formalne własności mitu, w szczególności występujące w nim sprzeczności i powiązania logiczne, mają swój odpowiednik w strukturze społeczeństwa. Istnienie przeciwstawnych elementów wewnątrz społeczeństwa łagodzone jest przez mit, który służy właśnie jako ten trzeci element, pośredniczący miedzy aspektami systemu społecznego pozornie niemożliwymi do pogodzenia". 
zmitologizowanej przeszłości reinterpretacji, przebiegającej zgodnie z aktualnymi potrzebami społecznymi. W praktyce oznacza to, iż często sięgamy do przeszłości (a raczej do jej wyselekcjonowanych - a przez to już w pewien sposób zinterpretowanych - elementów) nie po to, by zrozumieć teraźniejszość, lecz po to, by w przeszłości poszukać dla naszego „dzisiaj" historycznej legitymizacji. A zatem to nasze współczesne potrzeby decydują o tym, co nas interesuje w przeszłości oraz co i w jakim kształcie w niej dostrzegamy ${ }^{102}$.

Badanie (wedle zwolenników modelu konstrukcyjnego - konstruowanie) przeszłości jest procesem zdeterminowanym społecznie i kulturowo, przebiegającym zgodnie z kodem kulturowym właściwym danej wspólnocie.

Istota pracy historyka jest zatem determinowana przez zakorzenienie $\mathrm{w}$ kulturze, decydujące o tym, w jaki sposób strukturalizujemy, kategoryzujemy i metaforyzujemy świat, a więc ostatecznie rozstrzygające o komunikowanym obrazie świata. Wynikiem tego jest przekonanie, że ład, jaki dostrzegamy w świecie (przeszłości), nie jest porządkiem, jaki możemy w nim odnaleźć, ale jaki możemy mu jedynie zadać. "Zadany sens świata” jest wynikiem sięgnięcia po tzw. „sensy kultury” (archetypy, paradygmaty symboliczne, metafory dominujące, mity fundamentalne $)^{103}$.

W odniesieniu do narracji historiograficznej należałoby zatem mówić o przeszłości podwójnie zmediatyzowanej. Dwa typy pośrednictwa ustanawiane są przez kulturę materiałów źródłowych ${ }^{104}$ oraz przez kulturę, w której zakorzeniony jest historyk. Wyzwaniem, przed jakim staje twórca historycznych wyobrażeń (zwłaszcza w kontekście Ricoeurowskiej filozofii $d \nmid u g u)$, jest utrudniona weryfikacja źródeł dotyczących w szczególny sposób najbardziej traumatycznych wydarzeń („,faktów”"105) w XX-wiecznej historii Polski (pamiętajmy, iż Kanał powstał wedle scenariusza napisanego przez uczestnika powstańczego dramatu). Odchodzi bowiem pokolenie, które - wzorem Tadeusza Konwickiego - mogłoby zaświadczyć: pamiętam z mojej pamięci. Gdy zanika pomost pomiędzy zdarzeniami a człowiekiem, zaś pomostem tym są wspomnienia i świadkowie, nawet najbardziej traumatyczne z owych zdarzeń przestaje być znaczące:

${ }^{102}$ Zob. Barbara Szacka, Pamięć zbiorowa, [w:] Wobec przeszłości. Pamięć przeszłości jako element kultury współczesnej, red. Andrzej Szpociński, Wyd. Instytutu im. Adama Mickiewicza, Warszawa 2005, s. 28.

${ }^{103}$ Zob. Marek Woźniak, Przeszłość jako przedmiot konstrukcji. O roli wyobraźni w badaniach historycznych, Wyd. Uniwersytetu Marii Curie-Skłodowskiej, Lublin 2010, s. 45.

${ }^{104}$ Por. Jerzy Topolski, Czy historyk ma dostęp do przeszłej rzeczywistości? Problem źródet historycznych, [w:] Historia: o jeden świat za daleko?, dz. cyt., s. 56-70.

105 Do fundamentalnej, wedle zwolenników tzw. nowej historii, opozycji pomiędzy „wydarzeniem” i „faktem” powrócę w rozdziale poświęconym filmowi Generat Anny Jadowskiej. 
Później jest już tylko łaska tych, co nadejda, ich wizje, ich pomysły na to, co zrobić z tym wszystkim, co zostało, w jaki sposób nadać temu wszystkiemu znaczenie, bo przecież to, co nie ma znaczenia, co nie ma sensu, nie istnieje ${ }^{106}$.

Wedle Assmanna wymieranie pokolenia świadków najstraszniejszych zbrodni oznacza „,kres pewnej epoki pamięci zbiorowej: żywemu wspomnieniu zagraża zagłada, a formy kulturowej pamięci stają się problematyczne". To zjawisko stanowi egzystencjalne jądro współczesnego dyskursu historiozoficznego ${ }^{107}$. W kontekście „końca epoki świadków” (diagnozowanego głównie $\mathrm{w}$ odniesieniu do problemu reprezentacji i pamięci Holocaustu) oraz ekspansji orientacji narratologicznych podkreślana jest konieczność dokonywania reinterpretacji historii i metod jej badania. Jak podkreśla Jacques Le Goff:

Krytyka pojęcia faktu historycznego doprowadziła między innymi do uznania „rzeczywistości historycznych" przez długi czas niedostrzeganych przez historyków. Obok historii politycznej, historii gospodarczej i społecznej, a także historii kultury - narodziła się historia przedstawień. Ta zaś przybrała różne formy: historii ogólnych koncepcji społecznych, czyli historii ideologii, historii struktur mentalnych wspólnych dla danej grupy społecznej, społeczeństwa albo epoki, czyli historii mentalności, historii wytworów umysłu związanych nie z tekstem, słowem ani gestem, ale z wyobrażeniami plastycznymi, czyli historii wyobrażeń [podkr. moje - N. K.-R.], która pozwala traktować źródła literackie, podobnie jak źródła artystyczne, jako źródła historyczne sensu stricto, pod warunkiem, że bierze się pod uwagę ich specyfikę $[\ldots]^{108}$.

W erze „kulturowo pozyskiwanej pamięci”109, (postpamięci) określanej także mianem kultury posttraumatycznej, pamięć zbiorowa jest kształtowana i kreowana zasadniczo daleko bardziej przez „wyprodukowaną" przeszłość, jaką zawierają obrazy dokumentalne, fabularne czy programy telewizyjne (a także historyczne gry komputerowe, instalacje i przekazy

106 Zob. Katarzyna Jasiewicz, Łukasz Olędzki, Od nostalgii do fascynacji - doświadczanie przeszłości, [w:] Kultura przyjemności. Rozważania kulturoznawcze, red. Jan Grad, Hanna Mamżer, Wyd. Naukowe UAM, Poznań 2005, s. 200-205.

107 Jan Assmann, Pamięć kulturowa, dz. cyt., s. 27. "Świadkowie” stanowią fundament struktury konektywnej tworzącej w obrębie społeczeństwa "symboliczny świat znaczeń". Spajająco działa powiązanie teraźniejszości z przeszłością dokonujące się drogą włączania opowieści z innego czasu do horyzontu teraźniejszości (ten wątek jest silnie eskponowany w Poznaniu 56 - struktura konektywna manifestuje się u Bajona w swym „pierwotnym” oralnym (przedtekstualnym) charakterze: jej „nośnikiem” jest postać dziadka-powstańca). Tamże, s. 32.

${ }^{108}$ Jacques Le Goff, Historia i pamięć, tłum. Anna Gronowska, Joanna Stryjczyk, Wyd. Uniwersytetu Warszawskiego, Warszawa 2007, s. 35.

109 Zob. Dominick LaCapra, Historia w okresie przejściowym. Doświadczenie, tożsamość, teoria krytyczna, tłum. Katarzyna Bojarska, Universitas, Kraków 2009, s. 125. 
multimedialne), niż poprzez samą pamięć o wydarzeniach z przeszłości ${ }^{110}$. Tekst musi zastąpić świadectwo. Nie możemy ponownie doświadczyć przeszłości, ale możemy ją skonceptualizować poprzez historyczne przedstawienia, które służą jako simulacra przeszłości ${ }^{111}$. Fredric Jameson pisze o kulturze symulakrum:

W ten sposób modyfikacji ulega sama przeszłość: to, co kiedyś było organiczną genealogią burżuazyjnego projektu zbiorowego [...] w międzyczasie przekształciło się w olbrzymi zbiór obrazów, ogromne fotograficzne symulakrum. Sugestywne hasło Deborda dziś jeszcze lepiej pasuje do „prehistorii” pozbawionego historyczności społeczeństwa, które to, co uważa za przeszłość, traktuje jak teatralną rupieciarnię. Można by rzec [...], że przeszłość jako „przedmiot odniesienia” jest stopniowo brana w nawias, a następnie w całości wymazywana, tak że zostają nam po niej jedynie teksty ${ }^{112}$.

A raczej teksty-obrazy. Obrazy (choć nie tylko) stają się „protezami” pamięci (implementują - wypalaja - „żywą" pamięć nie przeżytych osobiście doświadczeńn $\left.{ }^{113}\right)$. Trudności w ocenie tego zjawiska - w kategoriach ontologicznych (Czy „pamięć protetyczną” można potraktować jako „sprawdzian istnienia przeszłości" ?"114 W jaki sposób digitalizacja, podważając Bazinowską wiarę w obraz wynikającą z indeksalnej natury fotografii, oddziałuje na jej „protetyczną" funkcję? ${ }^{115}$ ) i etycznych - potęguje fakt, iż fałszywy obraz historii może upowszechniać artefakt uznany za dzieło sztuki (filmowej) ${ }^{116}$.

${ }^{110}$ Zob. Marek Woźniak, Przeszłość jako przedmiot konstrukcji, dz. cyt., s. 241.

111 Zob. Hans Kellner, Etyczny moment w teorii historii, tłum. Ewa Domańska, [w:] Historia: o jedne świat za daleko?, dz. cyt., s. 97.

112 Fredric Jameson, Postmodernizm, czyli logika kulturowa późnego kapitalizmu, dz. cyt., s. 18. Wedle autora w kulturze symulakrum nawet zabytki historyczne, uporządkowane i oczyszczone, nie są już pozostałościami przeszłości, lecz jej błyszczącymi symulakrami (tamże, s. 320).

113 Zob. Alison Landsberg, America, the Holocaust, and the Mass Culture of Memory: Toward a Radical Politics of Empathy, "New German Critique" 1997, no. 71, s. 66.

${ }^{114}$ Por. Joyce Appleby, Lynn Hunt, Margaret Jacob, Powiedzieć prawdę o historii, dz. cyt., s. 269.

115 Zob. Celia Lury, Prosthetic Culture. Photography, Memory and Identity, Routledge, London-New York 1998, s. 173.

${ }^{116} \mathrm{O}$ zagadnieniu społecznych skutków odbioru w aspekcie tzw. prawdy historycznej pisze Tadeusz Lubelski. Autor analizuje pod tym kątem świadectwa krytycznej recepcji Popiołu i diamentu. Zob. Tadeusz Lubelski, Strategie autorskie w polskim filmie fabularnym lat 1945-1961, dz. cyt., s. 150-175.

W kontekście problemu prawdy - poświadczonej doświadczeniem ciury akowskiego - Tadeusz Konwicki upominał się o obraz „Polski grobów, Oświęcimia, wywózek na Sybir, wyrzynanych partyzantek, Polski głodu i sieroctwa, Polski tortur i więzień, Polski przegranej wojny i przegranej nadziei". W ironicznym komentarzu podsumował: „Ani słowa więcej o filmie, arcydziele trzydziestopięciolecia. Dość zrzędzenia, złośliwostek, jakiegoś starczego czepiania się. Padam plackiem przed filmem Popiót $i$ diament, cenię go szanuję, uważam, admiruję, wysoko stawiam”. Zob. Tadeusz Konwicki, Wschody i zachody księżyca, dz. cyt., s. 58-59. 
Czynnikiem najsilniej determinującym świadomość i pamięć zbiorową okazuje się zmediatyzowana (czytaj: skomercjalizowana) historia. O nobilitacji „niekanonicznych” form reprezentacji przeszłości najlepiej świadczy fakt uhonorowania prestiżową nagrodą Pulitzera kontrowersyjnego komiksu Maus (1986) Arta Spiegelmana ${ }^{117}$. Podejmowana przez badaczy kwestia społecznej - i moralnej - odpowiedzialności nie ogranicza się wyłącznie do obszaru kultury audiowizualnej. Etyczność jest istotną kategorią krytyczną i interpretacyjną $\mathrm{w}$ wielu dziedzinach badań nad kulturą:

W teorii historiograficznej problem etyczności badań z większą intensywnością zaczął pojawiać się w kontekście dyskusji na temat odpowiedzialności historyka za nieobecnych zmarłych oraz kwestii przedstawiania przeszłości. [...] Etyczna kategoria odpowiedzialności i długu wobec żyjących w przeszłości ujawnia się z jednej strony w roli historyka jako reprezentanta zmarłego, a z drugiej - jako badacza, który w tekście przedstawia go i opisuje ${ }^{118}$.

Powyższa konstatacja w sposób oczywisty odnosi się również do filmowych dyskursów przeszłości. Stąd też przedmiotem zainteresowania historyków coraz częściej staje się praktyka kształtowania (konstruowania) - za pomocą "obrazów” - społecznych wyobrażeń dotyczących przeszłych wydarzeń. W sposób świadomy posłużyłam się w tym miejscu wywodu pojęciem „wyobrażenia”. Wedle Rolanda Barthesa dyskurs historyczny już ze względu na samą strukturę, a nie "substancję treści” - należy ujmować jako przetworzenie wyobrażeniowe ${ }^{119}$. Tą dyrektywą kierowałam się w badaniach nad filmem. W pełni zgadzam się bowiem z Markiem Hendrykowskim, który pisze:

Historia na ekranie w każdym filmie - zarówno dokumentalnym, jak i fabularnym jest historią wyobrażoną. Tak czy inaczej przybiera ona w danym tekście filmowym postać swoistego komunikatu o przeszłości (a więc jej pewnego symbolicznego przedstawienia). I, co bardzo ważne, staje się komunikatem służącym jego nadawcy (realizatorowi, reżyserowi, producentowi, twórcy) do opisania, czyli wyobrażenia [podkr. moje - N.K.-R.], jakiegoś zjawiska w postaci obrazów kinematograficznych ${ }^{120}$.

W dyskusjach zogniskowanych wokół kwestii etycznych nie brakuje głosów wskazujących na konstruktywne przykłady oddziaływania prze-

117 Warto odnotować, iż sam autor postulował, by zaklasyfikować Maus do literatury faktu (nonfiction). Zob. Marianne Hirsch, Żałoba i postpamieć, tłum. Katarzyna Bojarska, [w:] Teoria wiedzy o przeszłości na tle współczesnej humanistyki, dz. cyt., s. 258.

${ }^{118}$ Ewa Domańska, Wprowadzenie, [w:] Pamięć, etyka i historia, dz. cyt., s. 19.

119 Roland Barthes, Dyskurs historii, tłum. Adam Rysiewicz, Zbigniew Kloch, „Pamiętnik Literacki" 1984, nr 75, s. 234.

${ }^{120}$ Marek Hendrykowski, Film jako źródło historyczne, dz. cyt., s. 45. 
kazów audiowizualnych. Dla przykładu, Thomas Elsaesser pisze o terapeutycznej funkcji (związanej z problemem przepracowania traumy) amerykańskich filmów poświęconych wojnie wietnamskiej, które $w$ imieniu narodu wykonały „pracę żałoby”. W ten sposób wojna mogła „wejść do historii", a nie jedynie na karty historycznych książek ${ }^{121}$. Sądzę, iż tę samą funkcję - w odniesieniu do II wojny światowej (a zwłaszcza Powstania Warszawskiego) - spełniły filmy polskiej szkoły filmowej. Tadeusz Lubelski w sposób niezwykle celny zinterpretował ten bezprecedensowy w dziejach polskiego kina fenomen oddziaływania kina na wspólnote, wskazując na Popiót i diament jako paradygmatyczny przykład realizacji "strategii psychoterapeuty". W opinii badacza najistotniejszym aspektem recepcji filmu Wajdy był - często podkreślany w świadectwach odbioru -

terapeutyczny moment pojednania widzów, owo „scalenie niezrośniętej Polski”, poczucie, że to nie tylko "mój” zachwyt, ale „wszystkich, którzy film widzieli”. I po drugie, świadomość przemożnego emocjonalnego oddziaływania obrazu, oglądanego „W zakrzepłym milczeniu”, przemieniającego rzeczywistość po seansie ${ }^{122}$.

Czy podobną funkcję mają do spełnienia filmowe wyobrażenia historii realizowane współcześnie?

\section{Ogólne ramy metodologiczne}

W wybranej przeze mnie metodzie badawczej chodzi o priorytet badania konkretnych tekstów przy jednoczesnej rezygnacji z abstrakcyjnej „wielkiej teorii" przykładanej a priori do instrumentalnie wykorzystywanych przykładów. Stosowane w pracy „narzędzia” (wykorzystywane na obszarze rozmaitych culture turns) traktuje pluralistycznie. I tak, kategorie analityczne właściwe dla performative turn („karnawał”, „dramat społeczny”, „protestacja”) stosuję jedynie w rozdziale poświęconym Poznaniowi 56 Filipa Bajona; pojęcia z obszaru postcolonial turn („,syndrom posttraumatyczny”, ,postpamięć" ${ }^{\prime 23}$ ) aplikuję do tekstu o Pornografii Jana

${ }^{121}$ Thomas Elsaesser, Subject Positions, Speaking Positions, [w:] The Persistence of History. Cinema, Television and the Modern Event, ed. Vivian Sobchack, Routledge, New York-London 1996, s. 146.

122 Tadeusz Lubelski, Strategie autorskie w polskim filmie fabularnym lat 1945-1961, dz. cyt., s. 153.

${ }^{123}$ Wprowadzone do refleksji kulturowej przez Marianne Hirsh pojęcie postpamięć rozumiem jako „treści zapamiętane, żywo tkwiące w świadomości każdego z nas, które nie pochodzą z naszego własnego doświadczenia, ale z doświadczenia naszych bliskich, 
Jakuba Kolskiego; pewne założenia interpretative turn („,re-inskrybować teksty poprzez kontekstualizującą interpretację, czyli interpretować teksty innymi tekstami"124) adaptuję dla potrzeb analizy Szyfrów Wojciecha Hasa, zaś narrative turn stanowi kontekst interpretacyjny wyłącznie dla filmu Anny Jadowskiej Generat. Jestem przekonana, iż żaden z przywołanych powyżej turns nie może stanowić nadrzędnej ramy metodologicznej obejmującej wszystkie omawiane przeze mnie przypadki. Są to bowiem utwory niezwykle zróżnicowane pod względem stylistycznym, powstałe na przestrzeni kilku dekad, realizowane przez rożnych autorów ${ }^{125} \mathrm{w}$ odmiennych kontekstach społeczno-politycznych (cezura 1989 r.) i warunkach produkcyjnych. I - co wydaje mi się niezwykle istotne - niemieszczące się $\mathrm{w}$ żadnej $\mathrm{z}$ dominujących $\mathrm{w}$ danym okresie „szkół” czy „formacji” (polska szkoła filmowa ${ }^{126}$, "trzecie kino", kino moralnego niepokoju $)^{127}$. Moim celem było wydobycie i podkreślenie wyjątkowego charakteru poszczególnych filmowych tekstów. Taka strategia umożliwiła mi zaprezentowanie czytelnikowi różnorodnych wyobrażeń historii $\mathrm{w}$ tych tekstach zawartych. W dwóch przypadkach wspomniane wyobrażenia dotyczą konkretnych (choć o trudnym do ustalenia statusie) wydarzeń historycznych (poznański Czerwiec w Poznaniu 56, katastrofa gibraltarska w Generale), w pozostałych - pewnego szczególnego okresu (wojna i okupacja w Szyfrach i Pornografii). Wszystkie filmy łączy

którzy doświadczenie to nam przekazali, mówiąc o nim, a tym samym przeżywając je $\mathrm{z}$ nami powtórnie. Jest to więc pamięć nasza, ale nie nasza zarazem. Pamięć o tym, co powstało poza moim doświadczeniem, ale jest częścią mojego doświadczenia w tym sensie, że przekazane mi, zostało przeze mnie przyswojone, zagarnięte i w swoisty sposób przeżyte. Można by powiedzieć, że podstawowe znaczenie dla tej pamięci mają: empatia i splecenie narracji o swoim doświadczeniu bliskiej mi osoby z moim doświadczeniem". Zob. Katarzyna Kaniowska, Postpamięć indywidualna-postpamięć zbiorowa jako kategorie poznania w antropologii, [w:] Pamięć i polityka historyczna, dz. cyt., s. 67-68.

${ }_{124}$ Zob. Doris Bachmann-Medick, Cultural turns, dz. cyt., s. 76.

${ }^{125} \mathrm{~W}$ książce posługuję się pojęciem autora rozumianego jako „twórca (podmiot sprawczy, nadawca) komunikatu" (filmowego). W szczególnie uzasadnionych, jak sądzę, przypadkach, wprowadzam pojęcie autora wewnętrznego - "figury", której obecność manifestuje się w tekście i „pozostaje w ścisłym związku z indywidualnymi właściwościami przejawianymi przez strukturę danej wypowiedzi filmowej". Por. Marek Hendrykowski, Autor, [w:] Słownik pojęć filmowych, t. 3, red. Alicja Helman, Wyd. „Wiedza o Kulturze", Wrocław 1992, s. 7.

${ }^{126}$ A przecież i w wypadku tego stricte już historycznego pojęcia coraz częściej formułowane są zastrzeżenia, które w sposób syntetyczny ująć można za pomocą pytania „szkoła czy autorzy?"

${ }^{127}$ Z przyczyn oczywistych pominęłam filmy historyczne - zrealizowane w okresie 19661989 - wspierające oficjalny dyskurs władzy (w części poświęconej Szyfrom wspominam o Barwach walki, zaś w rozdziale o Generale Anny Jadowskiej przywołuję Katastrofe $w$ Gibraltarze). W okresie transformacji ustrojowej podzieliły one los podręczników historii „,beznadziejnie skażonych ideologią marksistowską”. 
jedno - nie traktują one bezpośrednio o przeszłości (w tym sensie nie są one konwencjonalnymi filmami historycznymi ${ }^{128}$ ), lecz o sposobach reprezentowania przeszłości.

Dokonując selekcji, wybrałam filmy, których twórcy proponują widzowi reprezentacje historii nieprzystające do tradycyjnych wyobrażeń społeczeństwa na temat własnej przeszłości. A zatem przedmiotem demitologizacji nie jest $\mathrm{w}$ tych filmach historia sama $w$ sobie (już samo założenie takiej możliwości - w odniesieniu do tego, co było i do czego w żaden sposób nie mamy już dostępu - wydaje się absurdalne), lecz jej rozliczne, utrwalone $\mathrm{w}$ świadomości zbiorowej wyobrażenia. Twórcy analizowanych przeze mnie filmów nieustannie odwołują się do tych wyobrażeń. To właśnie wspomniane odwołania nadają owym filmom charakter „wielośladowych intertekstów".

Należałoby się zastanowić, czy filmy, w których wyobrażenia historii poddane zostały demitologizacji, mogą spełniać podstawowe funkcje realizowane przez dyskursy historiograficzne:

- funkcja legitymizacyjna (dostarczanie historycznej legitymizacji dla zjawisk teraźniejszych),

- funkcja waloryzacyjna (wybór fragmentów przeszłości służących jako punkt odniesienia dla podejmowanych współcześnie działań),

- funkcja socjalizacyjna (wytwarzanie więzi między członkami wspólnoty poprzez określenie pożądanych wartości i wskazanie strategii ich realizacji $)^{129}$.

Nawet jeśli na powyższe pytanie udzielimy odpowiedzi negatywnej, musimy przyznać, iż filmy te odgrywają niezwykle istotną rolę w procesie kształtowania zbiorowej świadomości historycznej. Stanowią bowiem świadectwo sprzeciwu wobec zjawiska mitologizacji historii.

${ }^{128}$ Dla przykładu Robert Rosenstone wymienia sześć dystynktywnych cech tego typu filmów:

1. Historia prezentowana jest jako opowieść (story) zawierająca (budujące) przesłanie moralne.

2. Proces historyczny ukazywany jest poprzez losy jednostek (zazwyczaj mężczyzn).

3. Historii nadaje się formę opowieści zamkniętej, linearnej i jednoznacznej. W celu wywołania emotywnego zaangażowania odbiorcy historia pokazywana jest $\mathrm{w}$ formie udramatyzowanej i spersonalizowanej (zbliżenia twarzy, ilustracja muzyczna).

4. Historia uzyskuje na ekranie określony „wygląd” (film ukonkretnia historyczne krajobrazy, budynki, przedmioty - pokazuje nie tylko to, jak wyglądały, lecz także, w jaki sposób były używane).

5. Historia ukazywana jest jako jednolity proces (historia pisana ma charakter analityczny - wyodrębnia poszczególne zjawiska w obrębie procesu historycznego).

Zob. Robert Rosenstone, The Historical Film: Looking at the Past in a Postliterate Age, [w:] The Historical Film, dz. cyt., s. 54-57.

${ }^{129}$ Zob. Marek Woźniak, Przeszłość jako przedmiot konstrukcji, dz. cyt., s. 65. 
Pojęcie „mitologizacji” rozumiem za Barbarą Szacką nie jako fałszowanie przeszłości, lecz jako pozbawianie postaci i wydarzeń historycznych wieloznaczności, i przekształcanie ich w jednowymiarowe symbole wartości ważnych w życiu grupy. Mitologizacja przeszłości dokonuje się w pamięci zbiorowej, która - zdaniem niektórych badaczy - zdecydowanie różni się od historii. O ile bowiem historia dopuszcza możliwość zmiany interpretacji, jest świadoma złożoności zjawisk, zachowuje dystans wobec tego, o czym mówi, wie, że na wszystko można patrzeć z różnych perspektyw, godzi się z niejasnością i wieloznacznością motywów i zachowań, to pamięć zbiorowa upraszcza, jest stronnicza i uznaje tylko jeden punkt widzenia - wyklucza zatem wieloznaczność, a nadto sprowadza wydarzenia do mitycznych archetypów ${ }^{130}$. Do najczęściej stosowanych sposobów przekształcania pamięci zbiorowej (wedle klasyfikacji zaproponowanej przez Roya Baumeistera i Stephena Hastingsa) należą:

1. Pomijanie (selektywne przemilczanie niewygodnych faktów).

2. Fałszowanie (zaprzeczanie czemuś co się zdarzyło i/lub twierdzenie, że miało miejsce coś, czego nigdy nie było).

3. Wyolbrzymianie i upiększanie („rozdymanie” pewnych fragmentów prawdy historycznej do rozmiarów wielkiego, ważnego dla grupy mitu i przedstawianie drobnych osiągnięć jako wiekopomnych triumfów).

4. Wiązanie versus odrywanie, czyli manipulowanie związkami (akcentowanie jednych i pomijanie innych przyczyn wydarzeń, tj. stronnicza interpretacja).

5. Obwinianie nieprzyjaciół (podkreślanie prawdziwych i domniemanych win wrogów - innych, obcych - dla minimalizowania własnych przewin, a w krańcowych przypadkach przypisywanie wrogowi własnych nieprawości).

6. Zrzucanie winy na okoliczności.

7. Konstruowanie kontekstu (redukowanie skomplikowanej sieci uwarunkowań i sytuowanie wydarzeń w kontekście odpowiadającym pozytywnemu wizerunkowi grupy $)^{131}$.

W tym miejscu poczynić muszę istotną uwagę. Filmy stanowiące przedmiot analizy nie zostały wybrane ze względu na walory stricte artystyczne. Są one, w mojej opinii, najbardziej reprezentatywnymi przykładami zjawiska, które na użytek swojej pracy określiłam mianem innego spojrzenia. Wybór takiej metody selekcji sytuuje mnie w kręgu historycznych badań z obszaru pictorial turn. Studia mieszczące się w tym paradygmacie - na co zwraca uwagę Peter Burke - biorą w nawias lub usuwają

\footnotetext{
${ }^{130}$ Zob. Barbara Szacka, Czas przeszły - pamięć - mit, Wyd. Naukowe Scholar, Warszawa 2006, s. 23-24.

131 Tamże, s. 29-30.
} 
na margines kwestię "sztuki” lub walorów estetycznych, częstokroć wysuwając istotne wnioski z prac artystów, którzy nie byli specjalnie wybitni ${ }^{132}$. Oczywiście, są wśród analizowanych przeze mnie filmów dzieła wybitne. Świadomość rangi artystycznej Szyfrów i Poznania 56 musiała znaleźć odzwierciedlenie w badawczej refleksji (jak również w liczbie zapisanych stron), którą tym filmom poświęciłam. W rozdziale pierwszym zdecydowałam się zamieścić analizy dwóch filmów. W obu przypadkach zasadniczym kontekstem interpretacyjnym była twórczość Witolda Gombrowicza (ze szczególnym uwzględnieniem powieści Pornografia). Uprzedzając późniejsze konstatacje, mogę stwierdzić, iż „spojrzenie Gombrowiczowskie" znacznie wyraźniej manifestuje się w filmie Wojciecha Hasa stanowiącym - wedle założeń interpretative turn - ,jedynie" kontekstualizujacą interpretację Pornografii.

Akceptując pluralizm metod wspierających moje działania analityczne daleka jestem jednak od akceptacji (przypisywanego postmodernistom) poglądu, wedle którego strategie badawcze są wyłącznie wytworem „wyobraźni poetyckiej”"133, a zatem ...anything goes ${ }^{134}$. Pracując nad książka, przyjęłam założenie, iż

Nie wystarczy współdziałać z kulturoznawczymi turns przez surfowanie po teoriach w napowietrznych interdyscyplinarnych przestrzeniach pośrednich. Nieodzowne jest raczej zakotwiczenie $\mathrm{w}$ danej dyscyplinie naukowej. $\mathrm{W}$ żadnym razie bowiem reorientacje kulturoznawcze nie zastąpią pracy dyktowanej wymaganiami dyscypliny [...]. Raczej staną się podstawowym warunkiem pracy interdyscyplinarnej dopiero, kiedy będą korzystać z merytorycznego i metodycznego dorobku poszczególnych dyscyplin ${ }^{135}$.

Badania prowadzone przy wykorzystaniu metod należących do rozmaitych culture turns starałam się "zakotwiczyć" w dyscyplinie szczegółowej - filmoznawstwie. Punktem wyjścia był dla mnie każdorazowo tekst filmowy. Zaakceptowałam fundamentalne dla New History założenie, zgodnie z którym filmy stanowią pełnoprawne narzędzie badania

${ }^{132}$ Zob. Peter Burke, Naoczność, dz. cyt., s. 18.

${ }_{133}$ Zob. Georg G. Iggers, Historiografia XX wieku, dz. cyt., s. 115.

${ }^{134}$ Dla przykładu, Hayden White, wielokrotnie oskarżany o (moralny) relatywizm (czytaj: głoszenie tezy, iż wszystko jest równoprawne), deklarował, iż przyjęcie relatywistycznego punktu widzenia oznacza jedynie, iż nasze sądy są uwarunkowane i oparte na przygodnej, niepełnej wiedzy, dlatego też interpretacje historyczne winny być rozpatrywane w zależności od polityczno-kulturowego kontekstu, w którym powstały. O etycznych podstawach badawczej postawy White'a, który w szczególny sposób akcentował ideologiczne uwikłanie dyskursu historycznego, służącego często jako instrument umacniania dominującej władzy, pisze Domańska. Zob. Ewa Domańska, Historia egzystencjalna, Wyd. Naukowe PWN, Warszawa 2012, s. 37-39.

${ }^{135}$ Zob. Doris Bachmann-Medick, Cultural turns, dz. cyt., s. 59. 
historii i nie powinny być analizowane w kontekście historii pisanej, lecz przy uwzględnieniu ich własnych reguł reprezentacji ${ }^{136}$. Dokonując analizy filmowych tekstów, usiłowałam postępować zgodnie z wytycznymi ogólnej teorii kulturowej, gdyż jest ona wolna od „,uniwersalistycznych pretensji" - nie tworzy schematów, nie narzuca z góry reguł odczytywania, nie ustanawia „kryteriów poprawności” interpretacji ${ }^{137}$. W ramach teorii kulturowej na plan pierwszy wysuwa się nie tyle teoretyzowanie, ile rozmaite praktyki interpretacji uruchamiające zróżnicowane konteksty kulturowe, w jakich uczestniczy tekst ${ }^{138}$. Za Barbarą Babcock przyznaję, iż myślenie i pisanie oznacza dla mnie zawsze dialog z innymi tekstami, stąd licznie pojawiające się w książce cytaty i rozbudowane przypisy, które

bardziej niż inwokacjami są jednak środkami przetwarzania monologicznego widowiska dialog, otwierania własnego dyskursu na dyskursy innych. To także uczone sposoby zawieszania toku swej myśli i komentowania jej, przyznawania, że czytanie i pisanie, podobnie jak inne widowiska kulturowe, wiąże się z zawłaszczaniem, wchłanianiem i przetwarzaniem tekstów pisanych przez innych ${ }^{139}$.

Kierując się wskazówkami zawartymi w eseju Clifforda Geertza O gatunkach zmaconych, wybrałam - jako nadrzędną koncepcję pracy - studium przypadków. Ten wybór oznacza odejście od ideału wyjaśniania związanego z pojęciem prawa naukowego i zwrot ku ideałowi wynikającemu z koncepcji konkretnego przypadku i interpretacji ${ }^{140}$. Studium przypadków stanowi obecnie preferowaną - zwłaszcza na obszarze historiografii - metodę badawczą w obrębie tzw. metodologii praktycznej. Jedynie dogłębne, "miażdżące” i rozkładające materiał badawczy analizy, zdaniem Ewy Domańskiej, chronią przed projektowaniem teorii na materiał. $\mathrm{Z}$ analiz generuje się pojęcia interpretacyjne, dbając o ich nasycenie empirią ${ }^{141}$.

Wojciech Jerzy Has, Jan Jakub Kolski, Filip Bajon i Anna Jadowska „zapisali" na taśmie filmowej różnorodne wyobrażenia historii. Sądzę

136 Zob. Robert Rosenstone, Introduction, [w:] Revisioning History. Film and the Construction of a New Past, ed. Robert Rosenstone, Princeton University Press, Princeton 1995, s. 3.

137 Zob. Anna Burzyńska, Kulturowy zwrot teorii, [w:] Kulturowa teoria literatury. Główne pojęcia i problemy, red. Michał Paweł Markowski, Ryszard Nycz, Universitas, Kraków 2006, s. 43.

138 Tamże, s. 74.

139 Barbara Babcock, "Poukładaj mnie w nieporzadek": fragmenty i refleksje na temat rytualnego btazeństwa, [w:] Rytuat, dramat, święto, spektakl. Wstęp do teorii widowiska kulturowego, red. John J. MacAloon, tłum. Katarzyna Przyłuska-Urbanowicz, Wyd. Uniwersytetu Warszawskiego, Warszawa 2009, s. 169.

${ }^{140}$ Clifford Geertz, O gatunkach zmąconych (Nowe konfiguracje myśli społecznej), [w:] Postmodernizm. Antologia przekładów, red. Ryszard Nycz, tłum. Zdzisław Łapiński, Wyd. Baran i Suszyński, Kraków 1997, s. 214.

${ }^{141}$ Ewa Domańska, Historia egzystencjalna, dz. cyt., s. 173. 
jednak, iż już przy pierwszej lekturze ich dzieł widz odniesie wrażenie, iż „wspólnie” patrzą oni na polską historię w inny sposób. Powstałe w efekcie tego innego spojrzenia filmy nie są „oknem na przeszłość” (Rosenstone). Tym, na czym skupia się uwaga widza jest bowiem nie tyle sama historia, ile „medium”, poprzez które się ona „uobecnia”. W tym sensie wybrane przeze mnie filmy stanowić mogą przykład White'owskiej historiofotii: refleksji nad historią i - a może przede wszystkim - jej obrazową (filmową) reprezentacją.

Perspektywę umożliwiającą mi scalenie - w jeden spójny (a jednocześnie wydobywający podkreślaną wielokrotnie różnorodność) wywód - tak odmiennych przypadków i interpretacji określiłabym w sposób metaforyczny (co wyraźnie podkreślam) jako spojrzenie etnologiczne,

które również może i powinno kierować się na własną kulturę; na własne społeczne instytucje, normy, wartości, nawyki. Ten rozwój spojrzenia etnologicznego jest prowokowany zwłaszcza przez konfrontację z obcością. W taki sam sposób zdystansowane spojrzenie obserwatora przychodzącego z zewnątrz może kierować się również na własną kulturę i ukazywać ją w tak niezwykłym świetle, że dostrzegalne stają się $\mathrm{w}$ niej rzeczy dotychczas niedostrzegane ${ }^{142}$.

Przejawów spojrzenia „etnologicznego” poszukiwałam w filmowych wyobrażeniach historii powstałych na przestrzeni ponad czterdziestu lat. Za Markiem Hendrykowskim mogę przyznać, iż przedmiotem mojego zainteresowania nie była „przeszłość w całym jej bezmiarze, lecz historia na taśmie filmowej jako pamięć symboliczna i forma tradycji, której kulturowe wyobrażenia zapisane zostały w formie ruchomych obrazów"143.

Spojrzenie "etnologiczne" - spojrzenie "obcego" - czy po prostu inne spojrzenie musi ulec rozszczepieniu. Mając świadomość ryzyka popełnienia "błędu kategorialnego", polegającego na zastosowaniu wobec "obcego" („etnologa”) figury pars pro toto (wedle „definicji”: „wszyscy obcy są tacy sami" $\left.{ }^{144}\right)$, zaproponowałam dywersyfikację innego spojrzenia. Kompozycyjny układ pracy determinują trzy „warianty” spojrzenia:

1. Spojrzenie Gombrowiczowskie (w Szyfrach i Pornografii).

2. Spojrzenie dziecka (w Poznaniu 56).

3. Spojrzenie (post)historyka (w Generale).

Wyróżnione przeze mnie „warianty" nie zostały narzucone a priori, lecz - by posłużyć się Kracauerowską metaforą - „znalezione” w samej materii filmowych tekstów.

${ }^{142}$ Doris Bachmann-Medick, Cultural turns, dz. cyt., s. 35.

${ }^{143}$ Zob. Marek Hendrykowski, Film jako źródło historyczne, dz. cyt., s. 68.

${ }^{144}$ Zob. Zygmunt Bauman, Wieloznaczność nowoczesna, nowoczesność wieloznaczna, dz. cyt., s. 105. 
Metafora innego spojrzenia stanowi także czytelne odwołanie do pewnej metody badania przeszłości, określanej mianem „historii alternatywnych" (słowo "alternatywny" używane jest tu poprzez skojarzenie z łacińskim alter - „odmienny, inny”). Autorzy reprezentujący tę orientację badawczą rezygnuja, co wydaje mi się niezwykle istotne, z wszelkich ujęć totalizujących. Nie próbują dowieść, iż historia powinna być tak właśnie pisana, a jedynie, że tak można pisać o przeszłości ${ }^{145}$. Sądzę, iż podobną deklarację mogliby złożyć twórcy wybranych przeze mnie filmów.

Wprowadzenie cezury czasowej - wzięłam pod uwagę filmy zrealizowane pomiędzy rokiem 1966 a 2009 - pozwoliło mi na wyodrębnienie pewnego okresu $\mathrm{w}$ historii polskiego kina, będącego przedmiotem analizy. Pierwsza z wyznaczających ten okres dat granicznych wydaje się cezurą oczywistą. W 1965 r. powstały przecież dzieła uznawane za epilog polskiej szkoły filmowej (Popioły Andrzeja Wajdy i Salto Tadeusza Konwickiego). Analizowane przeze mnie Szyfry Wojciecha Hasa zrealizowane zostały już po „zamknięciu” szkoły, ale pozostają one - co zrozumiałe w sferze jej oddziaływań.

Poza polem mojego bezpośredniego zainteresowania znalazły się filmy szkoły polskiej. Wynika to z faktu, iż filmom tym - ze szczególnym uwzględnieniem wyobrażeń historii w owych filmach zwartych - poświęcono już bardzo wiele miejsca w refleksji filmoznawczej (i to nie tylko polskiej). Wydaje się, iż są to sprawy - by posłużyć się określeniem Czesława Miłosza - zbyt gruntownie już rozprawione. A przecież filmy szkoły są w mojej książce w pewien sposób nieustannie obecne. Stanowią bowiem - ze względu na poruszaną $\mathrm{w}$ nich problematykę historyczna, a przede wszystkim sposób jej ujęcia (też przecież niejednoznaczny, sytuujący owe filmy pomiędzy etosem demitologizującym i wyznawczym ${ }^{146}$ ) - naturalny kontekst dla dzieł późniejszych. Niezależnie od osobistych preferencji badawczych, zajmując określone stanowisko,

musimy jednak liczyć się z tym wszystkim, od czego się odwracamy, z przestrzenią istniejącą poza naszym polem widzenia, za nami, przestrzenią, którą być może odrzucamy, ale która w znacznej mierze warunkuje właśnie naszą zdolność poruszania się $[\ldots]^{147}$.

Drugą z dat granicznych wybrałam bardziej ze względów pragmatycznych (na początku 2010 r. rozpoczęłam pracę nad książką i brałam pod uwagę filmy stosunkowo najnowsze), choć nie jest to wybór przypad-

${ }^{145}$ Zob. Ewa Domańska, Mikrohistorie, dz. cyt., s. 20-22.

${ }^{146}$ Zob. Andrzej Werner, Polskie, arcypolskie..., dz. cyt., s. 113.

147 Zob. Georges Didi-Huberman, Strategie obrazów. Oko historii 1, tłum. Janusz Margański, korporacja ha!art, Kraków 2011, s. 9. 
kowy. W latach 2005-2007 realizowana była w Polsce nowa polityka historyczna. Powstały w 2009 r. Generat Anny Jadowskiej stanowi, w moim przekonaniu, bezpośrednią - choć paradoksalną - reakcję na założenia tejże polityki. Co równie ważne, i uznaję to za fakt niezwykle symptomatyczny, wśród filmów zrealizowanych po 2009 r. nie znajduję żadnego dzieła wyróżniającego się podobnym nowatorstwem (rozumianym zwłaszcza w aspekcie formalnym) ujęcia problematyki historycznej.

Na koniec pragnę zwrócić uwagę na jeszcze jedną niezwykle znamienną kwestię. Zdaniem Joann Scott

Historia staje się wyrazem i gwarantem tożsamości, jej rewizja lub reinterpretacja stwarza zagrożenie dla istnienia (a także autentyczności, prawdziwości, znaczenia, realności) jednostki narodowej, rasowej, etnicznej, płciowej czy też indywidualnej ${ }^{148}$.

W świetle tak postawionej tezy nie powinien zaskakiwać fakt, iż autorzy głoszący pochwałe (filmowego) mitoburstwa odczuwają przemożną potrzebę, by się z tej podejrzanej „skłonności” przed czytelnikiem usprawiedliwić. Aby dostąpić godności krytyka mitu, trzeba wyjść poza kragg osobistych preferencji i odwołać się do „kontekstu”. I tak, mitoburstwo musi być przede wszystkim „reakcją na coś"149. W sposób reprezentatywny realizuje tę „terapeutyczną" strategię książka Marty Piwińskiej Legenda romantyczna i szydercy - pozycja należąca dziś do „demitologizującego kanonu".

Napisana została bezpośrednio po roku 1968. Stanowi reakcję na szowinizm narodowy tego okresu, w szyderczych wątkach naszej kultury szuka odtrutki. Ciasny postromantyczny patriotyzm musi się wydać w takim kontekście nie tylko podejrzany, lecz wręcz odpowiedzialny za ciemne siły, które się nań powołują. Może to on właśnie je zrodził?150

W podobnym kluczu rozpatrywać można - wyraźnie zauważalne po 1989 r. - nasilanie się tendencji do odkrywania ciemnych stron narodowych dziejów, związanych głównie z zadawaniem krzywd mniejszościom

${ }^{148}$ Joan W. Scott, Po historii?, dz. cyt., s. 222.

${ }^{149}$ Ten schemat obowiązuje także (przede wszystkim) w odniesieniu do twórczości artystycznej. Doskonale sprawdził się jako kontekst interpretacyjny kultury popaździernikowej (m.in. filmów szkoły polskiej): „Przeżycie okresu stalinowskiego i jego rozumienie jako inwazji mitów, niepodważalnych dogmatów, języka magicznych zaklęć stwarzających dowolnie rzeczywistość, choć w istocie tak bardzo z nią skłóconych, rozumienie jednostronne, ale przecież usprawiedliwione społeczną praktyką w której wszyscy uczestniczyli, było jedną z przyczyn demitologizacyjnej furii, jaka owładnęła znaczną i jakościowo ważną częścią polskiej kultury po Październiku '56". Zob. Andrzej Werner, Polskie, arcypolskie..., dz. cyt., s. 58.

150 Tamże, s. 129. 
narodowym ${ }^{151}$. Wspomniana "oświeceniowo-emancypacyjna” tendencja stanowiłaby $\mathrm{w}$ tym wypadku reakcję na - spowodowaną utrzymującym się przez dziesięciolecia rozziewem pomiędzy sferą pamięci oficjalnej i prywatnej - silną mitologizację społecznych wyobrażeń o przeszłości w kierunku bezkrytycznej afirmacji historii Polski i koncentracji na krzywdach, jakie ponieśli Polacy w przeszłości ${ }^{152}$. Dogodnych ram interpretacyjnych dostarczyć może także dyskurs transnarodowy. Dokonywanie krytycznych rewizji obrazu przeszłości można by w tym ujęciu uznać za symptom tworzenia się pamięci globalnej ${ }^{153}$.

W sytuacji, gdy nie istnieje żaden (zwłaszcza polityczny) kontekst, do którego - w charakterze alibi - można by się odwołać, pozostaje argument ostatni i niepodważalny: brak wewnętrznej wolności. W przedmowie do II wydania Polskie, arcypolskie... Andrzej Werner pisze:

Jesteśmy wolni, a jednocześnie (auto)zniewoleni. W życiu publicznym, nawet towarzyskim, ale także w kulturze. Wystarczy jedno zdanie na jakiś bardziej zasadniczy temat: tradycji, historii $[\ldots]$, a natychmiast pojawi się pytanie, jakie funkcje polityczne spełnia, jakiej postawie odpowiada. Jaką gazetę czyta jej autor i w jakiej drukuje ${ }^{154}$.

Dającą się odczuć w mojej książce fascynację kinem szyderców maskuje - nie wiem, na ile skutecznie - postawa "naukowego obiektywizmu". Zdradza ją jednak sam wybór analizowanych filmów. Wprawdzie nie ma

Nic bardziej naturalnego dla twórczej działalności kulturalnej niż programowa nieufność wobec wszelkich aktów świadomości i stanów podświadomości dzielonych przez ogół. Nieufność wobec wszystkiego, co ustalone, gotowe, przyjmowane bezrefleksyjnie. Nawet jeśli owe formy i treści kultury okazują się wygodne, a więc potrzebne zbiorowości, jeśli chronią ją przed niepokojem, przed poniżeniem, służą autoidentyfikacji, spełniają mnóstwo pożytecznych funkcji. A zatem jeśli nawet są żywe społecznie, mogą oznaczać martwotę kultury zastygłej w ustalonym kształcie, niezdolnej do rozwoju, póki ktoś nie podważy, nie rozbije uświęconych form ${ }^{155}$.

Aby postąpić w zgodzie z tradycją polskiego piśmiennictwa, szukam alibi pozwalającego wytłumaczyć się ze skłonności do filmowego mitoburstwa. I znajduje je... na kartach Dziennika Witolda Gombrowicza. A zatem - na zakończenie - strawestuję tylko słowa pisarza: jestem Polka, doprowadzonq do ostateczności przez Historię (polskiego kina).

${ }^{151}$ Temperatura społecznej debaty wokół książki Tomasza Grossa Sąsiedzi (czy filmu Pokłosie Władysława Pasikowskiego) dowodzi jednakże trwałości utrwalonych w pamięci zbiorowej wyobrażeń i wzorców odnoszenia się do przeszłości.

152 Zob. Bartosz Korzeniewski, Transformacja pamięci, dz. cyt., s. 105.

153 Tamże, s. 66.

154 Andrzej Werner, Polskie, arcypolskie..., dz. cyt., s. 14.

155 Tamże, s. 232. 


\section{CzęŚć PIERWSZA}

\section{Spojrzenie Gombrowiczowskie}

Niedawno pewien znakomity uczony, odznaczony nagrodą Nobla, dziwił się po przeczytaniu jednej mojej książki, że tak mało jestem Polakiem - bo dla niego Polacy to była śmierć bohaterska na polu walki, Szopen, powstania i ruina Warszawy. Odpowiedziałem:

- Jestem Polakiem, doprowadzonym do ostateczności przez Historię. 



\title{
Rozdział I
}

\section{...byliśmy jak z oleodruku \\ - jak ze starego, familijnego albumu umarta fotografia Czy Szyfry Wojciecha Jerzego Hasa to Pornografia?}

\author{
Sytuacje w świecie są szyfrem. \\ Niepojęty bywa układ ludzi i w ogóle zjawisk. \\ To, tutaj... przerażająco wymowne - \\ ale nie dawało się zrozumieć, odcyfrować w pełni. \\ Witold Gombrowicz, "Pornografia” \\ Przeszłość to panoptikum zrobione z okruchów... \\ Witold Gombrowicz
}

\section{(A)historycyzm Hasa}

W 1960 r. nakładem Biblioteki „Kultury” ukazała się w Paryżu Pornografia Witolda Gombrowicza. W tym samym roku na skutek radykalizacji polityki kulturalnej w Polsce (czego dowodem była sławetna czerwcowa uchwała KC w sprawie kinematografii) dokonano „zamknięcia" polskiej szkoły filmowej. Wyraźny odwrót od tzw. linii Października („Odwilż... wolność na $45 \%$, prawda na $\left.47 \%{ }^{\prime \prime}\right)$ był bowiem równoznaczny z zakazem podejmowania drażliwego i budzącego rozliczne kontrowersje ( $w$ opinii autorów uchwały filmy szkoły nie zawierały ,,jasnej i słusznej oceny politycznej wydarzeń okupacyjnych i wojennych"²) dyskursu historycznego, w który trudno było wpisać „,istotne problemy narodu budującego socjalizm"

1 Oto - w syntetycznym skrócie - Gombrowiczowska diagnoza polskiego Października. Zob. Witold Gombrowicz, Dziennik 1953-1956, Wydawnictwo Literackie, Kraków 1989, s. 308.

2 Zob. Uchwata Sekretariatu KC w sprawie kinematografii, [w:] Syndrom konformizmu? Kino polskie lat sześćdziesiątych, red. Tadeusz Miczka, Wyd. Uniwersytetu Śląskiego, Katowice 1994, s. 27.

3 Tamże, s. 29. 
Jakkolwiek wydaje się niemożliwe udzielenie jednoznacznej odpowiedzi na pytanie o wpływ twórczości Gombrowicza na rodzime kino tego okresu ${ }^{4}$, to jest rzeczą godną uwagi, iż publikacja Pornografii „awizowała" niejako powstanie nurtu filmów o charakterze rewizjonistycznym, które krytyka uznała za epilog szkoły polskiej. W krótkim odstępie czasu pojawiły się filmy niezwykle radykalnie - nawet jak na standardy szkoły rozprawiające się z narodową tradycją. Wspomniane filmy stanowić mogą rodzaj forpoczty, zapowiadają już (toczącą się na przełomie lat 60. i 70.) dyskusję nad dziedzictwem polskiego romantyzmu ${ }^{5}$.

4 W interesujący, ale i prowokujący (zwłaszcza jeśli chodzi o dobór przykładów) sposób pisze o kulturowej recepcji Gombrowicza w Polsce Jean-Pierre Salgas. W tym miejscu - z przyczyn oczywistych - ograniczę się wyłącznie do wątku "Gombrowicz a kino". Francuski krytyk pisze: „zastanawiać się można nie tylko nad kinem narodowo-katolickim (Zanussi, Kawalerowicz, Kieślowski...), ale i nad przerwanym dziełem Andrzeja Munka (Eroica) i twórczością Andrzeja Wajdy, który wydaje się stale wahać pomiędzy Mickiewiczem (koniunkturalne wychwalanie mitu narodowego w stylu epoki - od Kanału w 1957 po Pana Tadeusza w 1999 poprzez Popiót i diament) a refleksja, która kładzie Polaków na prokrustowym łożu ich kolejnych Form: Człowiek z marmuru, Człowiek z żelaza...". Zob. Jean-Pierre Salgas, Witold Gombrowicz lub ateizm integralny, tłum. Jan Maria Kłoczowski, Czytelnik, Warszawa 2004, s. 268.

5 Efektem owej dyskusji były m.in. Filozofia a mesjanizm Andrzeja Walickiego (1970), Listopadowy wieczór Andrzeja Kijowskiego (1972), Legenda romantyczna i szydercy Marty Piwińskiej (1973) czy prace Marii Janion i Marii Żmigrodzkiej: Goraczka romantyczna (1975), Romantyzm i historia (1978). W tym samym paradygmacie należałoby umieścić głośną wystawę Romantyzm i romantyczność w sztuce polskiej XIX i XX wieku, zorganizowaną w 1975 r. (październik-listopad) przez warszawską Zachętę.

Barbara Szacka zwraca uwagę na różnicę w podejściu do tradycji romantycznej pomiędzy dekadą lat 60. i 70. Zdaniem badaczki wspomniana różnica związana jest z narastającym w drugiej połowie lat 70. kryzysem PRL i dochodzeniem do głosu pokolenia, które w swojej biografii nie miało bezpośredniego doświadczenia wojennego. W latach 60. „wyraźnie zaznaczał się zwrot ku czasom najdawniejszym, czasom początku państwa i Polski przedrozbiorowej oraz niechęć do romantycznego, dziewiętnastego wie$\mathrm{ku}^{\prime \prime}$. Dla tej dekady reprezentatywne może być stanowisko sceptycznie nastawionych do nowego ustroju środowisk, promujących jednak koncepcję tzw. realizmu politycznego. Środowiska te „krytycznie oceniały dziwiętnastowieczne powstania, ponieważ z perspektywy niedawnych bolesnych doświadczeń jawiły się one jako przedsięwzięcia, które przyniosły jedynie straty i utwierdzały romantyzm polityczny, szkodliwy w obecnych warunkach". Badania przeprowadzone w drugiej połowie lat 70. wśród studentów warszawskich uczelni wykazały zanik „realizmu politycznego” i wzrastające zainteresowanie wiekiem XIX. „Straciły popularność takie wartości, jak «rozwój gospodarczy» $\mathrm{i}$ «reformy społeczne», zyskała natomiast «walka zbrojna» $\mathrm{i}$ «niepodległość» oraz wszystkie uosabiające je postacie, w tym przede wszystkim Józef Piłsudski [...]. wyraźnie było widać, że uwagę tego pokolenia zaczęła absorbować kwestia niezawisłego bytu państwowego i romantyczne postawy znów zyskiwały atrakcyjność". Zob. Barbara Szacka, Czas przeszły - pamięć - mit, Wyd. Naukowe Scholar, Warszawa 2006, s. 206-209.

Dla pełnego obrazu sytuacji należy dodać, iż ugruntowane w zbiorowej świadomości przekonanie o fundacyjnym charakterze tradycji romantycznej w procesie kształtowa- 
Nie tylko o kwestie literackie w owej dyskusji chodziło. Jak podkreśla Piotr Zwierzchowski

Lata 60. to przecież czas pisania na nowo polskiej pamięci i tożsamości narodowej. W ówczesnej kulturze popularnej odpowiedzi na pytanie o „bycie Polakiem” unikały kontrowersji, starały się pomijać sprawy nieprzyjemne, stanowiące zadrę w pamięci narodowej. Komplikację związane z polskim losem musiały ustąpić miejsca wyobrażeniom zawartym $\mathrm{w}$ autostereotypach ${ }^{6}$.

Filmy określane mianem „epilogu” polskiej szkoły filmowej potraktować można jako reakcję na oficjalny dyskurs historyczny władz. W 1965 r. powstały: Salto Tadeusza Konwickiego, Popioły Andrzeja Wajdy oraz telewizyjny film Stanisława Różewicza Na melinę $e^{7}$ który - ze względu na

nia się polskiej tożsamości narodowej w okresie PRL zaowocowało paradoksalną strategią wynaradawiania przez to, co narodowe. Wedle Marioli Dopartowej: „Pompatyczne celebrowanie rocznic i świąt, patronat wielkich romantyków i «neoromantyków» nad kolejnymi sezonami kulturalnymi czynił wszystko to, co jedynie użyczało swej nazwy, coraz bardziej obcym i pustym, pozbawionym znaczenia dla zbiorowości, którą jakoby miało integrować". Zob. Mariola Dopartowa, Artystyczne "szkoły polskie" wobec tożsamości narodowej w XIX i XX wieku, [w:] Kino polskie jako kino narodowe, red. Tadeusz Lubelski, Maciej Stroiński, korporacja ha!art, Kraków 2009, s. 21. Doskonałym przykładem tego typu praktyk mogą być huczne obchody Roku Mickiewiczowskiego, nad którym patronat objął Bolesław Bierut. Kulminacyjnym momentem obchodów było uroczyste odsłonięcie (zniszczonego podczas Powstania Warszawskiego i zrekonstruowanego po wojnie) pomnika wieszcza.

6 Piotr Zwierzchowski, Przygody Franka Dolasa albo co Giuseppe robił w Warszawie, „Kwartalnik Filmowy" 2012, nr 77-78, s. 191.

7 Film powstał na kanwie opowiadania Jana Józefa Szczepańskiego Wszarz, które ukazało się w zbiorze Buty i inne opowiadania, opublikowanym dopiero w 1956 r. Zdaniem Marii Janion „szydercza” proza Szczepańskiego wpisuje się w paradygmat artystycznych polemik z romantycznymi mitami i Sienkiewiczowską tradycją literatury konsolacyjnej (Żukrowski, Wańkowicz). „Naczelny problem i temat Szczepańskiego - pisze Janion - jako pisarza wojennego mógłby być określony jako krytyczna analiza legendy romantycznej. [...] Zgodnie z założeniami Szczepański wybiera wątki fabularne ostro obnażające konflikty moralne, wynikające ze starcia wyobrażeń idealnej rycersko-romantycznej wzniosłości i okrutnego procederu partyzancko-wojennego". Niezwykle znamienny jest fakt, iż Szczepański wprowadza, jako jeden z wiodących motywów twórczości, temat konfliktu między bohaterem-pisarzem a odbiorcami. Charakterystyczny jest pod tym względem - analizowany szczegółowo przez Marię Janion - fragment opowiadania Kromka chleba: „Autorzy listów powoływali się na swoją znajomość narodowej psychiki, na najwyższe moralne i literackie autorytety, na wychowawczą doniosłość «polskiego męczeństwa». Byli głęboko dotknięci bezczelnością i nihilizmem takiego «szargania», uważali mnie za szkodnika, za koniunkturalnego aferzystę, za cynika kalającego własne gniazdo albo po prostu za błazna, który usiłuje zwrócić na siebie uwagę. Wielu negowało stanowczo autentyczność mojej relacji i ręczyło, że jest ona "wyssana z palca»". Janion podsumowuje: „Występujący w końcu dość często w dziejach literatury konflikt między autorem a czytelnikami przybierał tu jednak niepokojące rozmiary: nacisk patriotycznych stereotypów 
kontrowersyjność tematu - doczekał się oficjalnej premiery dopiero w roku $1981^{8}$. To właśnie kameralny, ascetyczny w formie dramat Różewicza wykazuje najbliższy związek z treściami Gombrowiczowskiej Pornografii (mam na myśli przede wszystkim skoncentrowany wokół postaci Siemiana i Karola wątek AK-owski). Historia prowokacji, jakiej dopuszcza się oddział partyzancki oraz pozbawiony moralnego uzasadnienia wyrok śmierci na „wszarzu” destabilizują uświęcony tradycją wizerunek polskiego podziemia. W nowej (?) sytuacji politycznej niezgodność z obowiązującym schematem filmu wojennego (a za taki uznać należy „moczarowskie” Barwy walki Passendorfera ${ }^{9}$ ) stała się powodem

naruszał zbyt drastycznie prawo pisarza do wypowiedzenia prawdy". Zob. Maria Janion, Płacz generała. Eseje o wojnie, Wyd. Sic!, Warszawa 1998, s. 154-157.

8 Zaproponowany przez Stanisława Różewicza obraz podziemia okazał się nie do zaakceptowania także w wolnej Polsce. O skandalu, który wywołała w 1990 r. telewizyjna premiera sztuki Tadeusza Różewicza Do piachu w reżyserii Kazimierza Kutza pisała m.in. Maria Janion: „Sprzeciw płynął ze strony tych, którzy uważali, że pisarz spotwarzył swą sztuką całą organizację i unieważnił wartość czynu zbrojnego ludzi walczących w szeregach AK. [...] Córka Komendanta Głównego AK, ciesząc się ze zniesienia «dawnej cenzury», postulowała ustanowienie «nowych kryteriów cenzury moralnej» (tamże, s. 327-328). (Podobne poruszenie w środowisku AK-owskim wywołała publikacja wspomnień Stefana Dąbskiego (tom pt. Egzekutor ukazał się w 2010 r.) z dywersyjnego oddziału AK na Rzeszowszczyźnie, zajmującego się wykonywaniem wyroku na zdrajcach).

Przemysław Czapliński przypomina, iż wyreżyserowane przez Kutza przedstawienie było wznowieniem sztuki Różewicza po jedenastoletniej przerwie. Poprzednie wystawienie, wyreżyserowane w 1979 r. w warszawskim Teatrze Na Woli przez Tadeusza Łomnickiego, zostało zaatakowane przez prasę partyjną i zdjęte z afisza. Czapiński przytacza znamienną opinię Janusza Majcherka, wedle którego agresywne w tonie reakcje na wersję z 1990 r. (autor omówił je na łamach miesięcznika „Teatr") należy usytuować w kontekście „rozmaitych kampanii przeciwko dziełom literackim, teatralnym czy filmowym (Majcherek wymienia m.in. casus opowiadań Tadeusza Borowskiego, Trans-Atlantyku Witolda Gombrowicza, Śmierci porucznika Sławomira Mrożka, polskiej szkoły filmowej czy Pamiętnika z powstania warszawskiego Mirona Białoszewskiego) oskarżanym wiecznie o to samo: podkopywanie narodowego ducha, obalanie zbiorowych mitów, burzenie krzepiących fikcji i wyciąganie niemiłych prawd. [...] Reakcje, z jakimi spotkała się telewizyjna premiera Do piachu, mówią o czymś, co dotyczy spraw bezpośrednio niezwiązanych ze sztuka, z teatrem. Są sygnałem, znakiem psychospołecznej sytuacji. Spętanie polskimi mitami, uwięzienie w zbiorowych wyobrażeniach, pilnowanie pewnej obowiązującej wizji, wszystko to trwa". Zob. Przemysław Czapliński, Polska do wymiany. Późna nowoczesność i nasze wielkie narracje, Wyd. W.A.B., Warszawa 2009, s. 98.

W pewnym sensie casus inscenizacji Kutza przypomina „spór o Szymborską”. Oba przypadki mogą świadczyć o diagnozowanej przez Czaplińskiego „schizofrenii kultury polskiej w latach dziewięćdziesiątych. Kultura kanoniczna była monolityczna, opierała się na lekturach dziewiętnastowiecznych (i ich dwudziestowiecznych derywatach), podtrzymujących spoistość narodowo-religijną”. Kanon ten nadaje się „do prowadzenia symbolicznych wojen, nie zaś do rozumienia rzeczywistości" (tamże, s. 251).

9 Zob. Ireneusz Siwiński, "Barwy walki” albo tęsknota za legenda, [w:] Syndrom konformizmu? Kino polskie lat sześćdziesiątych, dz. cyt., s. 127-146. 
obłożenia przez cenzurę utworu Różewicza wieloletnim zakazem rozpowszechniania. Zgodnie z wytycznymi partii filmy o tematyce wojennej miały bowiem pełnić ściśle określoną funkcję w procesie kreowania „nowej pamięci”:

W latach sześćdziesiątych, zwłaszcza w drugiej połowie, w wielu wypowiedziach można przeczytać o konieczności zaprzeczenia klęsce, przypominania o heroizmie polskiego żołnierza i świadomości ostatecznego zwycięstwa. Bitwy przegrane we wrześniu 1939 roku doprowadziły do zwycięstwa nad faszyzmem sześć lat później. [...] „Nowa pamięć" miała być przyczynkiem do dumy narodowej, opartej na heroicznej przeszłości oraz kreującej wspólnotę (motyw „zgody narodowej”) ${ }^{10}$.

W kontekście problematyki podejmowanej w wymienionych wcześniej filmach Wajdy, Konwickiego czy Różewicza, Szyfry Wojciecha Jerzego Hasa wydawały się dziełem stosunkowo „bezpiecznym" ${ }^{11}$.

Obraz zrealizowany w 1966 r., choć uznany za przełomowy w twórczości reżysera, spotkał się z dość chłodnym przyjęciem części krytyki. Kontrowersje wzbudziła przede wszystkim forma filmu, a dokładniej: dość niefortunne, zdaniem recenzentów, połączenie partii realistycznych ze - stanowiącymi autonomiczne segmenty - scenami wizyjnymi ${ }^{12}$. A przecież Has idzie tu za wskazaniem Gombrowicza, u którego

10 Piotr Zwierzchowski, "Jak być kochana" i "Szyfry" - wojna, pamięć i kino polskie lat sześćdziesiatych, [w:] Filmowe ogrody Wojciecha Jerzego Hasa, red. Małgorzata Jakubowska, Kamila Żyto, Anna M. Zarychta, Wyd. PWSFTviT, Łódź 2011, s. 81-84. Za wspornik ideologii "nowej pamięci" służyły pozycje podejmujące "oficjalną" polemikę z „szydercami” za taką można uznać chociażby książkę Zbigniewa Załuskiego Siedem polskich grzechów głównych. We wstępie Załuski explicite tłumaczył strategię autorską: „Chcę trochę pobronić naszej historii, naszej historii romantycznej. Chcę jej bronić przed wrogami, którzy surowo potępiając niecodzienne czyny, ofiarność przezwali ofiarnictwem, bohaterstwo - bohaterszczyzna, a lekkomyślność - kabotyńską pozą i zwykły idiotyzm uznali za nasze wady narodowe". Zob. Zbigniew Załuski, Siedem polskich grzechów głównych, Wyd. Iskry, Warszawa 1968, s. 7.

11 Potwierdzeniem tej tezy mogą być bardzo pochlebne opinie członków Komisji Kolaudacyjnej (m.in. Czesława Petelskiego, Wincentego Kraśko, Tadeusza Zaorskiego), która obradowała w sprawie filmu Hasa 23 maja 1966 r.

12 W wielu wypadkach - na co zwraca uwagę Zwierzchowski - „niechęć wobec onirycznych wizji i upominanie się o realizm historii nie wynikały z rozważań nad językiem kina. W kinie głównego nurtu sięgnięcie w pamięć gwarantowało obraz jednoznaczny. Pamięć miała być równoznaczna z potocznie rozumianą prawdą. Filmy Hasa tego komfortu nie zapewniały. Brakowało jednoznaczności i pozytywnego komentarza, które były podstawą „nowej pamięci” [...]. W filmach Hasa rozszyfrowywanie przeszłości wiąże się z niebezpieczeństwem naruszania mitu, fundamentu pamięci, który daje możliwość bezpiecznego zakotwiczenia w teraźniejszości. [...] U Hasa dominują pytania, a propozycje odpowiedzi są niejednoznaczne i nieostateczne. Kino «nowej 
Nie bardzo wiadomo, co należy do „akcji zewnętrznej”, co do „wewnętrznej”, co zdarzyło się "naprawdę”, a co się „śniło”. Każda rzeczywistość obiektywna jest skażona elementami subiektywnego, a każda subiektywność (skoro jako subiektywność zostaje nazwana, skoro zostanie przypisana określonemu podmiotowi) jest zarazem powrotem do zewnętrzności, ponowną obiektywizacją ${ }^{13}$.

W Szyfrach nie dochodzi jednak do zrównania statusu zdarzeń „obiektywnych" i "subiektywnych". Has wyróżnia bowiem partie „oniryczne" za pomocą określonych rozwiązań formalnych (do tego wątku powrócę w dalszej części tekstu), stanowiących dla widza czytelną wskazówkę interpretacyjną. Płaszczyzna filmowego tekstu staje się obszarem konfrontacji dwóch „pól semantycznych”: „realności” i „,snu” (?). Napór żywiołu oniryczności nie rozrywa jednak realistycznej tkanki utworu, ale nadaje światu przedstawionemu typową dla Hasa "gęstość".

Mimo przekonania o złożonym i wymykającym się wszelkim generalizacjom charakterze polskiej szkoły filmowej, w powszechnej świadomości utrwalił się model „opowieści wzorcowej”, którego paradygmatyczną realizacją był Popiót i diament (1958). Wojciecha Hasa, ze względu na wcześnie (o czym świadczy debiutancka Pętla) ujawnione predylekcje estetyczne, sytuowano często na marginesie nurtu, a jego filmy miały być dowodem ostentacyjnego wręcz braku zainteresowania historią. O trwałości tego przekonania świadczą słowa autorki jednej z najnowszych monografii reżysera:

Gdy z perspektywy czasu, znając późniejszą twórczość Hasa, ogląda się ten film [Szyfry] [...], zastanawiającą kwestią jest podjęcie przez tego „maga kina” takich właśnie tematów: wojny, holocaustu i poczucia odpowiedzialności za wydarzenia minione. Co prawda, historia była obecna w twórczości filmowej tego twórcy, niemniej zawsze stanowiła jedynie ledwie naszkicowane tło dla zasadniczego tematu. Wojciecha Hasa nigdy tak naprawdę nie interesowała historia (sfera zbiorowej świadomości, która była tematem wielu filmów na przykład Andrzeja Wajdy czy Andrzeja Munka). Szyfry to wyjątek paradoksalnie potwierdzający tę regułę. Autora Rękopisu fascynował po pro-

pamięci» nie miało podobnych problemów. Może też dlatego Jak być kochana i Szyfry -mimo że cieszyły się sporą frekwencją - nie mogły zdominować potocznych wyobrażeń Polaków na temat wojny. Były bez szans w konkurencji z wizją przedstawioną przez ówczesne kino popularne: seriale, filmy batalistyczne czy komedie wojenne, które proponowały wizerunek wojny i Polaka o wiele bardziej atrakcyjny dla widza, mniej niepokojący i wpisujący się w mitologie narodowe, oparty na realizmie potwierdzającym wiarygodność historyczną i emocjonalną". Zob. Piotr Zwierzchowski, "Jak być kochana" i "Szyfry" - wojna, pamięć i kino polskie lat sześćdziesiatych, dz. cyt., s. 76-86.

13 Andrzej Falkiewicz, Polski Kosmos. 10 esejów przy Gombrowiczu, Wyd. A, Wrocław 1996, s. 18. 
stu upływ czasu, uwikłanie konkretnego człowieka w jakieś historyczne wydarzenia, w ciągle powtarzające się, nie do końca określone sytuacje dziejowe: wojny, pogromy ${ }^{14}$.

Wobec „nieprawomyślnego" dzieła Hasa zastosowano zatem tę samą strategię, jaką posłużono się w odniesieniu do Gombrowiczowskiej Pornografii - postanowiono bronić autora przed nim samym za pomocą argumentów, których dostarczały inne jego dzieła. Artur Sandauer - skądinąd zagorzały orędownik twórczości Gombrowicza - wykazał, posługując się cytatami z Dziennika:

Obawiam się, że to wszystko, co napisałem dotąd - już ze sto stronic - jest okropnym świństwem. Nie jestem w stanie tego ocenić, bo w długim obcowaniu z tekstem zatraca się wyczucie, ale lękam się... coś mnie ostrzega... Czyż więc trzeba będzie wywalić wszystko do kosza, całą wielomiesięczną robotę, zaczać od początku? ${ }^{15}$

iż powstawaniu Pornografii towarzyszyły rozterki natury etycznej. Określając powieść mianem „niesmacznej ramoty, gdzie pod zadymionym przez krematoria niebem dwaj panowie dają upust swym wyszukanym gustom", w konkluzji wyraził podziw dla pisarza, któremu sumienie nakazywało zniszczenie tekstu ${ }^{16}$.

Zgodnie z tą samą „obronną" strategią uznano, iż II wojna światowa jest w Szyfrach jedynie pretekstem do przeprowadzenia wiwisekcji psychiki głównego bohatera owładniętego Proustowską obsesją czasu. Konrad Eberhardt w eseju poświęconym Szyfrom zanotował:

Wojna spełnia tutaj funkcję alibi, ale przecież Tadeusz jeszcze przed opuszczeniem kraju był obcym we własnej rodzinie (rozwód był planowany od dawna), jego żona, Zofia, już dawniej zdradzała objawy psychopatyczne, a Jędrek, ów późniejszy zaginiony - żył w kręgu doznań, do którego nikt nie miał dostępu. W tym sensie zaginął już wcześniej ${ }^{17}$.

Wydaje się jednak, iż pomijanie historycznego kontekstu Szyfrów (podobnie jak w przypadku Pornografii) prowadzi do całkowitego rozminięcia się z sensem generowanym przez filmowy tekst.

14 Iwona Grodź, Zaszyfrowane w obrazie. O filmach Wojciecha Hasa, słowo/obraz terytoria, Gdańsk 2008, s. 179-180.

15 Witold Gombrowicz, Dziennik 1953-1956, dz. cyt., s. 298.

16 Zob. Artur Sandauer, Witold Gombrowicz - człowiek i pisarz, [w:] Gombrowicz i krytycy, red. Jan Błoński, Wyd. Literackie, Kraków 1984, s. 125-126.

17 Konrad Eberhardt, O polskich filmach, Wyd. Artystyczne i Filmowe, Warszawa 1982, s. $107-108$. 
Szyfry i Pornografię łączy perspektywa oglądu historycznych zdarzeń. Jest to perspektywa zewnętrzna.

Wojna jest u Gombrowicza rzeczą zawsze odsunięta, odrzuconą, odroczoną. W życiu Gombrowicza sprawą zasadniczą był jego dystans do wojny w Polsce. Raczej luźno z wydarzeniami drugiej wojny światowej wiąże się fabuła powieści rozgrywającej się w czasie wojny, Pornografii, z wyjątkiem tych sytuacji, gdy wydarzenia te zmuszają bohaterów do ukrywania się w kraju. [...] Jeśli cokolwiek, to właśnie nieobecność wojny w Gombrowiczowskiej powieści odzwierciedla nieobecność Gombrowicza w wojennej Polsce. Jak zresztą mógłby Gombrowicz pisać o wojnie w Polsce w sposób wiarygodny, jeśli jej nie doświadczył, tak jak doświadczyło jej wielu innych ważnych pisarzy? [...] Tego rodzaju decyzję można uznać za wybór etyczny, w tym sensie, że Gombrowicz nie rościł sobie prawa do przeżyć, których nie miał18.

W Pornografii ów dystans wobec wojny - czy prowokacyjne wręcz lekceważenie "faktów" - zasygnalizowany został w Informacji, stanowiącej integralną część utworu:

Tej Polski wojennej nie znam. Nie byłem przy tym. W ogóle Polski od 1939 r. nie oglądałem. Opisałem to tak, jak sobie wyobrażam. To więc jest Polska imaginacyjna i nie przejmujcie się, że czasem pomylone, czasem może fantastyczne, bo nie o to tutaj chodzi i to zupełnie bez znaczenia dla spraw tutaj się odbywających ${ }^{19}$.

Mimo autorskiego zastrzeżenia, pełniącego funkcję alibi, krytycy rozpoznali zastosowaną w powieści - jakże typową dla Gombrowicza - strategię prowokatora. Nieprzypadkowo pisarz osadził akcję w konkretnym miejscu - „w byłej Polsce, w byłej Warszawie” (a także w sandomierskim majątku Hipolita) - i czasie („w 1943-im”).

Dla krytyków „obsceniczne” okazało się przede wszystkim połączenie podszytej perwersją erotyki z okupacyjnym realizmem. Pornografia to próba dekonstrukcji stereotypów ugruntowanych w literaturze wojennej. Zdaniem Jerzego Jarzębskiego w utworach pokolenia Kolumbów temat wojny współbrzmiał z problematyką miłosną. Gombrowicz szokował jednak

poetyką natężonego do ostatnich granic dysonansu. Podczas gdy „Kolumbowie” usiłują reaktywować romantyczną mitologię wraz z jej skojarzeniem heroizmu i erotyki - on rozbija i doprowadza do absurdu tamte stereotypy $[\ldots]^{20}$.

18 David A. Goldfarb, Eksplozja słowa, [w:] Witold Gombrowicz - nasz współczesny, red. Jerzy Jarzębski, Universitas, Kraków 2010, s. 708-709.

19 Witold Gombrowicz, Pornografia, Wyd. Literackie, Kraków 1997, s. 5.

20 Jerzy Jarzębski, Gra w Gombrowicza, PIW, Warszawa 1982, s. 308. 
Przedmiotem zainteresowania Gombrowicza jest nie tyle sama historia (odmowa uczestnictwa w „polskim losie” - z której rozliczył się pisarz w Dzienniku czy powieści Trans-Atlantyk - skazała Gombrowicza na „Polskę imaginacyjną”), ile jej obraz utrwalony w literaturze. Obraz, dodajmy, zdaniem pisarza całkowicie podporządkowany stereotypowym wyobrażeniom. Z tego przekonania wyrasta potrzeba estetycznego dystansu. Gombrowicz sprzeciwia się „,oswajaniu piekła” ${ }^{21}$ i domaga niemożliwego: postuluje chłodny obiektywizm na przekór konwencjom literatury martyrologicznej, fałszującym stosunek Polaków do wojny:

Gdy zbliżasz się z piórem w ręku do gór milionowej męki - odnotował pisarz w 1956 roku - ogarnia cię lęk, szacunek, zgroza, pióro drży w dłoni, a twoje wargi nie stać na nic oprócz jęku. Ale jękami nie robi się literatury. Ani pustką à la Borowski. Ani „sumieniem” à la ksiądz Andrzejewski²2.

Pornografię można potraktować jako świadectwo estetycznej postawy Gombrowicza wobec tematu wojny i okupacji (jak opisać góry milionowej męki, nie wpadając jednocześnie w pułapkę Formy?), a zarazem jako element znacznie szerszej strategii twórczej. Powieść jest bowiem paradygmatyczną realizacją postulowanej przez pisarza strategii demitologizacji Historii. Gombrowicz, jeśli w przeszłość zaglądał, to raczej po to, by ją zinterpretować, zrewidować jej wizerunek z rodzajem chłodnego, demistyfikującego dystansu ${ }^{23}$.

${ }^{21}$ Może to właśnie podejmowane przez polskich twórców próby „oswajania piekła” (a nie daleki od martyrologicznego kanonu sposób ujęcia tematu) sprawiły, że Kornblumenblau (1990) Leszka Wosiewicza nie stał się - toutes proportions gardeés - filmowym odpowiednikiem obozowych opowiadań Borowskiego.

22 Witold Gombrowicz, Dziennik 1953-1956, dz. cyt., s. 326. Podobnego typu zastrzeżenie wobec narracji historycznych formułuje Hans Kellner. Zdaniem autora tego typu narracje stanowić mogą przykład „upiększenia” - horror przeszłości staje się w nich formalnie piękny dzięki eksplanacyjnej mocy opowieści. Zob. Hans Kellner, Etyczny moment w teorii historii: przedstawiając doświadczenie poznania, [w:] Historia: o jeden świat za daleko?, red. Ewa Domańska, Wyd. Instytutu Historii UAM, Poznań 1997, s. 86.

23 Jerzy Jarzębski, Podglądanie Gombrowicza, Wyd. Literackie, Kraków 2000, s. 15. W tym aspekcie (problem wyrażalności doświadczeń traumatycznych ) autor Pornografii wydaje się niezwykle bliski Conradowi (Gombrowiczowskie góry milionowej męki, Conradowskie jądro ciemności). Wedle Tomasza Kunza Conrad stawia tezę, która doskonale koresponduje z filozofią pisarstwa Gombrowicza: „Gdy człowiek mierzy się z nieludzkim [...], ceną za ocalenie człowieczeństwa musi być «rozwianie się rzeczywistości» i triumfalny powrót powierzchownej prawdy: powierzchownej, bo zbudowanej na uspołecznionym, a więc intersubiektywnie zrozumiałym i komunikowalnym systemie pojecć, artystycznych przedstawień i skonwencjonalizowanych estetycznych symbolizacji [...]". Zob. Tomasz Kunz, Granice przedstawialności doświadczenia. Narracja jako terapia (na przykładzie "Jądra ciemności" Josepha Conrada), [w:] Kulturowa teoria literatury. Poetyki, problematyki, interpretacje, red. Teresa Walas, Ryszard Nycz, Universitas, Kraków 2012, s. 505. 
Historia? Trzeba abyśmy się stali burzycielami własnej historii, opierając się tylko na naszej teraźniejszości - gdyż właśnie historia stanowi nasze dziedziczne obciążenie, narzuca nam sztuczne wyobrażenie o sobie, zmusza abyśmy upodabniali się do historycznej dedukcji zamiast żyć własną rzeczywistością ${ }^{24}$.

Strategią dystansu posłużył się także Wojciech Has. W Szyfrach ma ona podwójny - zewnątrz- i wewnątrztekstowy charakter. W aspekcie wewnątrztekstowym dystans jest pochodną specyficznej sytuacji fabularnej. Wykorzystanie typowego dla kina rozrachunkowego motywu powrotu bohatera po latach umożliwiło Hasowi ulokowanie protagonisty na pozycji zdystansowanego obserwatora. $Z$ tej perspektywy rzeczywistość jawi się jako szyfr.

Miejsce - pisze Hans Belting - fundowało sens dla zamieszkujących je ludzi. Jego tożsamość żywiła się historią, która wydarzyła się w tym miejscu. Miejsca rozporządzały zamkniętym systemem znaków, działań i obrazów, do których klucz posiadali wyłącznie ludzie osiedli na tym miejscu; obcy mogli być tylko odwiedzającymi ${ }^{25}$.

Kraków - rodzinne miasto Tadeusza (i Hasa!) - staje się dla przybysza miastem fantomem: labiryntem o zatartych przez deszcz i mgłę konturach. To miejsce doświadczane jako atopiczne - „nie-miejsce”, niedające się włączyć do żadnej sieci miejsc, wymykające się dostępowi i tym samym wykazujące radykalną niedostępnośćc ${ }^{26}$. Has ukazuje zatem „obcość” Tadeusza (także) od strony „przeżywanej przestrzenności”. Tadeusz, niczym repatriant (lecz bardziej „turysta"), wraca do ojczyzny, która tymczasem stała się dlań obcym światem ${ }^{27}$. Różnica wojennych doświadczeń (Wojna rozdzieliła nas na zawsze ${ }^{28}$ ) i ponad dwudziestoletni pobyt na obczyźnie sytuują bohatera filmu Hasa na zewnątrz rzeczywistości, której mechanizm stał się absolutnie nieprzejrzysty (Wydaje mi się, jakby to wszystko działo się w jakimś innym świecie).

Mimo iż Has zdecydowanie unika problematyki politycznej i nic nie wskazuje na to, by motywem tak długiej nieobecności Tadeusza (byłego żołnierza armii Andersa?) w kraju był lęk przed represjami, w Szyfrach pojawiają się jednak aluzje sugerujące kierunek dokonujących się po woj-

24 Witold Gombrowicz, Dziennik 1953-1956, dz. cyt., s. 173.

25 Hans Belting, Antropologia obrazu. Szkice do nauki o obrazie, tłum. Mariusz Bryl, Universitas, Kraków 2007, s. 78.

26 Bernhard Waldenfels, Topografia obcego, tłum. Janusz Sidorek, Oficyna Naukowa, Warszawa 2002, s. 202.

27 Tamże, s. 38.

28 Wszystkie cytaty z omawianych filmów zapisywane są kursywą. 
nie „zmian”. W inteligenckich salonach pija się już wyłącznie trunki zza wschodniej granicy. Doktor Gross (którego postawa przywodzi na myśl formułę Miłosza: „Ketman pracy zawodowej”29) z zażenowaniem częstuje Tadeusza „rosyjskim” koniakiem. W „nowej” Polsce - jak ironicznie podkreśla antykwariusz - „właścicielem” sklepu może być już tylko „lud pracujący”. W kontekście omawianych „zmian” Tadeusz wydaje się osobą anachroniczną - należącą do innej epoki i formacji społecznej. Nie dziwi zatem, iż najczęściej powtarzaną w filmie frazą jest zdanie: nie rozumiem/ nie rozumiesz. Podwójna luka $\mathrm{w}$ typowo polskim życiorysie nadaje biografii Tadeusza wyraźny rys Gombrowiczowski: ominął go nie tylko komunizm, ale i hitleryzm, a te dwa doświadczenia nakładają się na siebie i wzajemnie wzmacniają ${ }^{30}$.

Podstawową opozycja, na której ufundowana została struktura Szyfrów jest zatem - kluczowa także dla zrozumienia Pornografii - relacja wiedzy i niewiedzy, rozumienia i nierozumienia. Tadeusz, wzorem Witolda, w każdej niemal scenie klasyfikuje interlokutorów podług stopnia informacji, jaką posiadają oni na temat sensu zdarzeń ${ }^{31}$.

W początkowej sekwencji filmu Tadeusz zjawia się w paryskim mieszkaniu ciotki. Z rozmowy dowiadujemy się o całkowitym niemal braku kontaktu z rodziną pozostałą w Polsce. Pełna dystansu, pozbawiona sentymentów postawa Tadeusza wobec „sprawy Polskiej” nasuwa skojarzenia z Gombrowiczem, w którego twórczości trudno byłoby doszukać się typowej dla literatury emigracyjnej estetyki nostalgii. Rozluźnienie więzów z krajem - uczuciowe i emocjonalne oderwanie się od Polski stanowiło, zdaniem pisarza, podstawowy warunek duchowego rozwoju człowieka (artysty) ${ }^{32}$.

Tadeusz nie próbuje nawet ukrywać braku zainteresowania losami najbliższych, zdawkowo tłumacząc zaistniałą sytuację: Ja nie umiem pisać listów. Ciotka, zadając Tadeuszowi pytanie: Czy miateś jakieś wiadomości

29 O tej odmianie „aktorstwa dnia codziennego” Miłosz pisze: „Ponieważ znalazłem się w warunkach, na których zmianę nie mam żadnego wpływu, a mam tylko jedno życie i życie to upływa - rozumuje człowiek - powinienem starać się zrobić z niego rzecz możliwie najlepszą. [...] Tak powstaje Ketman pracy zawodowej. [...] Stanowi on poważną siłę motoryczną i jest jedną z przyczyn ogromnego pędu ku kształceniu się [...]. Co jest jednak najważniejsze, dokonywanie eksperymentów chemicznych, budowanie mostów, sztuka poetyckiego przekładu, leczenie chorób - są czymś zasadniczo wolnym od fałszu. Państwo natomiast korzysta z tego ketmana, bo chemicy, inżynierowie i lekarze są potrzebni". Zob. Czesław Miłosz, Zniewolony umysł, Krajowa Agencja Wydawnicza, Kraków 1990, s. 96-98.

30 Andrzej Werner, Polskie, arcypolskie..., Wyd. Biblioteki „Więzi”, Warszawa 2011, s. 242.

31 Jerzy Jarzębski, Gra w Gombrowicza, dz. cyt., s. 362.

32 Zob. Witold Gombrowicz, Dziennik 1953-1956, dz. cyt., s. 95, 163. 
stamtad?, wymownie patrzy na krewnego, a przed wypowiedzeniem słowa "stamtąd" znacząco zawiesza głos. Słowo to brzmi wyjątkowo złowieszczo i odnosi się do owianej grozą przestrzeni zaludnionej przez „zjawy": pogrążoną w obłędzie żonę Zofię i syna - alkoholika Maćka. Widmem nawiedzającym teraźniejszość jest jednak przede wszystkim najmłodszy syn Tadeusza - zaginiony przed laty Jędrek.

Zrozumiałe staje się zatem, iż podróż tam Tadeusz traktuje początkowo jedynie w kategoriach „turystycznych” (mimochodem wspomina ciotce o planowanym "na jesieni" objęciu posady administratora w prywatnym college'u pod Londynem). Użyte przez Tadeusza sformułowanie Mam przed soba ponad rok wakacji wyznacza a priori ramy czasowe wizyty w Polsce, nadając tej wizycie charakter tymczasowy i niezobowiązujący.

A przecież pomiędzy tymi dwoma światami, ,parysko-londyńskim” i „,krakowskim”, istnieje rodzaj korespondencji ustanawianej zarówno na poziomie fabularnym (Tadeusz porusza się na trasie Londyn - Paryż Kraków), jak i formalnym. W tym symetrycznym układzie jeden świat spełnia wobec drugiego funkcję zwierciadlanego odbicia. Paradoksalnie, analizując "rymowanie się światów” na płaszczyźnie formalnej, można odnieść wrażenie, iż świat "paryski” jest statyczny (konwencjonalnie „pocztówkowe” kadry towarzyszące czołówce), zaś świat „krakowski” - dynamiczny (migawki z Rynku). W obu wypadkach "dokumentalne" wstawki mają charakter pozadiegetyczny ${ }^{33}$, dzięki czemu dają się odczytać jako rodzaj odautorskiego komentarza. W ten sposób Has porozumiewa się z widzami „ponad” bohaterem, którego cechuje zaskakująca zdolność mimikry ${ }^{34}$, czyniąca tak nieznośną każdą myśl, iż w jego osobistej sytuacji jest coś nienormalnego, co go od innych ludzi odróżnia ${ }^{35}$ :

Wrósł w anglosaskie tło jak mało kto z polskich powojennych emigrantów. Był rzeczowy, chłodny, zadowolony z siebie. [...] Teraz wszystko, co się było stało w jego kraju i co się nadal działo, było w jego pojęciu „nienormalne” w stosunku do anglosaskiego świata, do którego za wszelką cenę starał się przystosować36.

W nietypowych dla Hasa rozwiązaniach formalnych (paradokumentalne ujęcia z krakowskiego Rynku) dostrzec można świadectwo

33 W opowiadaniu Kijowskiego migawkowe obrazy z Krakowa zostały przypisane subiektywnemu spojrzeniu bohatera. Zob. Andrzej Kijowski, Szyfry, [w:] Pseudonimy. Zbiór opowiadań, Czytelnik, Warszawa 1964, s. 191.

34 Tą samą cechą (i podobnym życiorysem) obdarzył Has bohatera swego wcześniejszego filmu Jak być kochana. Tadeusz mógłby być anonimowym mężczyzną którego w samolocie lecącym do Paryża spotyka Felicja.

35 Andrzej Kijowski, Szyfry, dz. cyt., s. 84-85.

36 Tamże. 
wiary w „światy minione” (o której trudno orzec, czy jest tylko wyrazem nostalgii za miejscem autobiograficznego doświadczenia - w przeciwieństwie do Gombrowicza Has tę Polskę wojenna zna, był przy tym), ale też dowód definiującej jego twórczość (jakże głęboko Gombrowiczem „podszytej”) ambiwalencji.

Interpretacyjną intuicję zdaje się potwierdzać prolog rozgrywający się w paryskim apartamencie ciotki. Starsza kobieta obsesyjnie gromadzi przedmioty i to właśnie zagracone do granic możliwości, tak lubiane przez Hasa „,antykwaryczne” wnętrza są odpychające i wywołują u widza klaustrofobiczne wrażenie (podczas rozmowy ciotka z wyrzutem powiadamia Tadeusza o poczynaniach jego byłej żony: Zofia spieniężyła już prawie wszystkie pozostawione w Krakowie meble).

Ale i w dawnym krakowskim mieszkaniu ciotki obwiązuje czas przeszły niedokonany ( $w$ jednej $z$ ostatnich scen filmu, gdy Tadeusz samotnie przegląda rodzinne zdjęcia, $w$ dalekim planie widoczny jest zegar z nieruchomym wahadłem). Liczne wskazówki tekstualne sugerują dwuznaczny status filmowego czasu. Has poddaje czas mumifikacji - akcja jedynie pozornie rozgrywa się w „teraźniejszości” (współczesnej momentowi realizacji filmu). Tadeusz - niczym Józef z Sanatorium pod Klepsydra przekraczając próg (mieszkania Zofii), wkracza bowiem w „teraźniejszą" przeszłość, a zatem także w (wojenną) Historię. Jakże różnić się będą jednak wykreowane przez Hasa obrazy historycznych zdarzeń od tych, które przez lata (oficjalnie) kształtowały społeczne wyobrażenia o przeszłości.

\begin{abstract}
Kilkudziesięcioletnie uprzywilejowanie w pamięci oficjalnej doświadczenia II wojny światowej z punktu widzenia Polski centralnej oraz oparcie na tym doświadczeniu ujednoliconego jej obrazu, który w okresie PRL-u miał do spełnienia ważne ideologiczne funkcje (co dodatkowo wzmocnione zostało obiektywną okolicznością powojennego przesunięcia granic), doprowadziło do ukształtowania się funkcjonującego w świadomości społecznej stereotypu tego wydarzenia, który wykazuje cechy dużej trwałości ${ }^{37}$.
\end{abstract}

Gęsta, nieomal namacalna przeszłość zbudowana jest z rozproszonych śladów i okruchów (cudzych) wspomnień. Hasowska metafora śladu (śladami są w Szyfrach przede wszystkim fotografie) sytuuje nas w kręgu Gombrowiczowskiej refleksji. Pisarz - piewca Młodości, tak niestrudzenie walczący z przeczasiała Formą - dostrzegał przecież głęboko zakorzenioną w człowieku potrzebę „odzyskiwania” przeszłości. We fragmencie Dziennika poświęconym Boskiej Komedii pisał:

37 Bartosz Korzeniowski, Transformacja pamięci. Przewartościowania w pamięci przeszłości a wybrane aspekty funkcjonowania dyskursu publicznego o przeszłości w Polsce po 1989 roku, Wyd. Poznańskiego Towarzystwa Przyjaciół Nauk, Poznań 2010, s. 102-103. 
Obcowanie z przeszłością jest więc ciągłym dopracowywaniem się jej, powoływaniem do bytu... ale ponieważ odczytujemy ją ze śladów, jakie pozostawiła, a te ślady są zależne od przypadku, od materiału, w jakim zostały przekazane, kruchego lub mniej kruchego, od przygód rozmaitych w czasie, jest przeto ta przeszłość, chaotyczna, przypadkowa, fragmentaryczna...

Przeszłość to panoptikum zrobione z okruchów... tym ona naprawdę jest... Więc jednak daje do myślenia, że my ją chcemy, mimo wszystko, mieć pełna, żywą wypełnioną osobami, konkretną... i że to $\mathbf{w}$ nas potrzeba taka uparta... [podkreślenie moje - N.K.-R.] ${ }^{38}$.

W polskiej kulturze za artystyczny wyraz „potrzeby tak upartej” uznać można całą twórczość Wojciecha Hasa.

Polisemiczny charakter Hasowskiego czasu doskonale koresponduje ze strukturą przestrzenną Szyfrów. Przestrzeń, w której porusza się Tadeusz, jest przestrzenią klaustrofobicznie ograniczoną. Przestrzeń zamknięta

może być przypadkowa, codzienna, pozbawiona symbolicznych odniesień, jest oczywiście przestrzenią osaczenia czy alienacji. [...] w przestrzeni alienacji postacie nie znalazły się w następstwie swoich działań, ale w następstwie działania mechanizmów, których przyczyny i znaczenie muszą pozostać niedocieczone i niezrozumiałe $[\ldots]^{39}$.

„Niedocieczone i niezrozumiałe” są w istocie motywy, które skłoniły Tadeusza do odwiedzenia kraju. Has podkreśla pozaracjonalny (vide wizje ewokowane w (pod)świadomości Tadeusza pod wpływem wspomnień) charakter mechanizmów działających niejako „w zastępstwie” bohatera. W newralgicznym momencie Has posługuje się elipsą. Pomiędzy sceną w Paryżu (ujawniającą sceptyczny stosunek Tadeusza do projektowanego przez ciotkę spotkania z rodziną) a sceną w pociągu (relacji Paryż-Kraków) następuje gwałtowne cięcie montażowe, które widz odebrać musi jako nieoczekiwany - pozbawiony logicznego uzasadnienia - przeskok.

Podczas pierwszego spotkania z ojcem Maciek deklaruje: My mieszkamy ciagle w tym dużym wspólnym pokoju. Ta rzeczowa uwaga kryje podwójne znaczenie. $W$ sensie dosłownym stanowi potwierdzenie tego, o czym wcześniej poinformowała Tadeusza ciotka. W sensie symbolicznym - poprzez czytelne odwołanie do tytułu powieści Uniłowskiego przywołuje w pamięci widza przygnębiający nastrój Hasowskiej adaptacji Wspólnego pokoju (1960).

W rodzimej kulturze dom ma status mityczny. Wedle Gombrowicza nad oleodrukowym wizerunkiem szlacheckiego dworku unosi się duch

38 Witold Gombrowicz, Dziennik 1961-1966, Wyd. Literackie, Kraków 1986, s. 230.

39 Jan Błoński, Dramat i przestrzeń, [w:] Przestrzeń i literatura, red. Michał Głowiński, Ossolineum, Wrocław 1978, s. 203. 
Mickiewicza, który ów wizerunek skąpał w blaskach bogobojnej cnoty i tak stworzył ideał (życia, polskości), od którego polska kultura nie potrafiła się już wyzwolić ${ }^{40}$. Dom stał się domem-symbolem. To

dom-Polska, dom rodzinny, idealny dwór szlachecki, odwieczne chłopskie gospodarstwo, wzorowe małżeńskie stadło. [...] Los bohaterów wyznaczony był tedy poprzez stosunek do symbolicznej, ponadczasowej Siedziby: mogli całym swym życiem odtwarzać wciąż na nowo ideał "osiadłości”, [...] mogli wreszcie mocą niełatwej osobistej decyzji pozbawić się prawa do rodzinnego życia, by wpierw zadbać o całość Ojczyzny lub społeczną sprawiedliwość [...]. Niezdolność do założenia normalnej rodziny (o ile nie stoi za nią społeczny czy patriotyczny nakaz) stała się w tych warunkach znamieniem poważnego duchowego defektu $[\ldots]^{41}$.

Przedwojenny świat Szyfrów był - podobnie jak w Pornografii - światem zbankrutowanych wartości. W filmie Hasa odtworzony został jeden z wariantów powtarzającego się niemal we wszystkich utworach Gombrowicza fabularnego wzorca, którego sednem jest

konflikt bohatera z rodzina, opuszczenie lub wprost ucieczka z domu i próba stworzenia nowego porządku (bytu, wartości) na własny rachunek, bez pomocy autorytetów. [...] bohater [w Pornografii Fryderyk/Witold, w Szyfrach Tadeusz] może być w punkcie wyjścia akcji outsiderem i samotnikiem, który powraca bądź odwiedza jakiś „układ rodzinny” po to, by go rozbić i skompromitować ${ }^{42}$.

Has podąża za Gombrowiczem, portretując rodzinę w stanie rozkładu. Atrofia uczuć i emocjonalna próżnia, w jakiej wegetują bohaterowie, nie ma - co zostało wyraźnie podkreślone w literackim pierwowzorze Szyfrów - bezpośredniego związku z wojną:

[Tadeusz] Jędrka nie szukał. [...] Z wielkiej odległości, z jakiej patrzył na to wszystko, co się stało w kraju, w jego domu rozbitym, do którego miał nigdy nie wrócić, było mu właściwie wszystko jedno, jak to się stało. To, że Jędrek nie żyje, wydawało mu się jak gdyby naturalne, gdyż w pewien sposób przestał żyć od dawna, od tego dnia, w którym go po raz ostatni zobaczył, na dwa miesiące przed wojna, w oknie lukstorpedy na dworcu krakowskim, obok Zofii, już wówczas dalekiej i obcej ${ }^{43}$.

A zatem rozpad domu jako uświęconego tradycją centrum moralnych wartości dokonał się na długo przed Zagładą (w Paryżu Tadeusz

\footnotetext{
40 Jerzy Jarzębski, Podgladanie Gombrowicza, dz. cyt., s. 42.

41 Tamże, s. 13-14.

42 Tamże, s. 20.

${ }^{43}$ Andrzej Kijowski, Szyfry, dz. cyt., s. 82.
} 
wspomina o planowanym jeszcze przed okupacją rozwodzie z żoną, która - jak dobitnie podkreśla ciotka - zawsze była dziwna). Ten wyraźnie zaznaczający się w filmie Hasa wątek obnaża fałsz warunkowanego tradycją przekonania, iż jedynie udział (i śmierć) w walce może stanowić dla mężczyzny usankcjonowany społecznie powód porzucenia rodziny ${ }^{44}$.

Fundamentalny dla interpretacji rodzinnego dramatu brak porozumienia i zanik uczuć stanowi ukrytą w tekście Hasa wskazówkę. Tłumaczy bowiem w pewien sposób bierność Tadeusza, który od zakończenia wojny nie podjął żadnych kroków w celu odnalezienia syna. Wydaje się jednak, iż przyczyn tak niezrozumiałego zachowania należałoby poszukiwać znacznie głębiej. Tadeusz naznaczony został piętnem bohaterów Gombrowicza, którzy nie potrafili odnaleźć się w „familijnym scenariuszu" i odgrywali w nim rolę bezwzględnych demaskatorów. Fakt pozostawania "na zewnątrz" rodzinnej psychodramy - rozegranej w duchu Freuda, lecz pozbawionej waloru terapeutycznego - czyni z Tadeusza postać iście Gombrowiczowską.

Andrzej Kijowski jeszcze silniej niż Has akcentował edypowy charakter więzi łączącej Zofię z synami. Dotyczy to nie tylko - obecnego w Szyfrach - wątku Jędrka, który z zazdrości o matkę wydał na śmierć jej kochanka. Perwersją nacechowane są także relacje Zofii i Maćka. Kazirodcze tabu stanowi ukryty podtekst „ekspiacyjnych” wypowiedzi Tadeusza:

Łączyło ich dwoje coś, czego nie można było określić zwyczajnie jako związek matki z synem. W takim związku Tadeusz mógłby uczestniczyć, był w końcu mężem Zofii, ojcem Maćka. Między nimi było jednak coś więcej, jakaś zmowa czy jakieś doświadczenie wspólne, czy pokrewieństwo znacznie głębsze, z którego on, Tadeusz, był zupełnie wykluczony ${ }^{45}$.

W Szyfrach "wątek edypowy" ujawnia się w planie tekstualnym dwukrotnie. Po raz pierwszy w postaci przeznaczonego dla ojca dopisku (Maciek umieścił tę znamienną adnotację w liście adresowanym do ciotki): Sam z nia [tzn. z matka] jestem i nie ma dla mnie żadnej możliwości odłaczenia się od niej. Po raz drugi - podczas inicjalnej rozmowy z ojcem, w której Maciek podkreśla fizyczną atrakcyjność Zofii (Zdziwisz się, jak mało się zestarzała $\left.{ }^{46}\right)$.

\footnotetext{
44 Potwierdzeniem siły tego stereotypu może być scena pożegnalnej rozmowy rotmistrza Andrzeja z żoną w Katyniu Wajdy. Inaczej w Szyfrach Hasa - tu wojna wydaje się stanowić formę dogodnego (i akceptowanego społecznie) alibi, maskującego prawdziwy powód opuszczenia bliskich.

45 Zob. Andrzej Kijowski, Szyfry, dz. cyt., s. 157.

46 Zauważmy, iż uwaga poczyniona przez Maćka nie znajduje potwierdzenia w faktach. Zofię widzimy tak, jak musiał ją widzieć Tadeusz: podstarzałą i na wpół obłąkaną.
} 
Ale czy jedynie „naznaczającym” układ rodzinny kompleksem Edypa można tłumaczyć niechęć Tadeusza wobec bliskich? Skomplikowany, aporetyczny rys osobowości Tadeusza pozwoli ujawnić wnikliwa analiza pierwszej sceny wizyjnej. Dowodzi ona bowiem istnienia zasadniczego konfliktu pomiędzy świadomością i podświadomością bohatera. Wizja została włączona w obręb stricte realistycznej sekwencji paryskiej. W trakcie rozmowy z ciotka, dotyczącej pozostałej w Krakowie rodziny, z ust Tadeusza pada znamienne słowo: Zapomniałem... To słowo-klucz inicjuje pojawienie się ciągu wizyjnych scen skoncentrowanych wokół postaci Jędrka. Oniryczne obrazy wyświetlające się na „wewnętrznym ekranie" stanowią oczywiste zaprzeczenie wypowiedzianych słów. Nie sposób przy tym jednoznacznie ustalić, czy pojawiają się one w umyśle Tadeusza w czasie teraźniejszym (jako efekt rozmowy), czy też mają charakter retrospektywny (wedle tej interpretacji wizje nawiedzały Tadeusza $\mathrm{w}$ przeszłości i w tym sensie stanowią potwierdzenie, iż Tadeusz nigdy nie zapomniał...).

W skomplikowanym układzie rodzinnym na plan pierwszy wysuwa się relacja ojciec-syn. W filmie Hasa zyskuje ona zdecydowanie polisemiczny charakter, przez co zbliża się do Gombrowiczowskiego rozumienia symboliki Ojca i Syna.

Wspomniana relacja rozpatrywana na płaszczyźnie „kulturowej” odsyła do postulatu sformułowanego w Trans-Atlantyku - „zastąpić Ojczyznę Synczyzną":

Chceszże, aby wszyscy Chłopcy wasi tylko za Ojcami wszystko w kółko powtarzali? Oj, wypuść Chłopaków z ojcowskiej klatki, a niech i po bezdrożach polataja, niechże i do Nieznanego zajrzą! Owóż to Ojciec stary dotąd na źrebaku swoim oklep jechał, a nim powodował wedle myśli swojej... a niechże tera źrebak na kieł weźmie, niech Ojca swego poniesie gdzie oczy poniesą! ${ }^{47}$

Bunt Jędrka (w praktyce oznaczający zdradę podziemnej organizacji) wobec etosu bohaterskiego reprezentowanego przez Tadeusza byłby faktyczną realizacją tego postulatu. Realizacją o tyle "perwersyjną" (i jakże Gombrowiczowską - zważywszy na czas akcji Trans-Atlantyku), gdyż dokonującą się w realiach wojennych - w "momencie ostatecznym”.

Inny układ znaczeń ujawni się na płaszczyźnie „psychoanalitycznej”. Podczas analizy relacji rodzinnych w aspekcie kompleksu Edypa akcent przeniesiony zostanie z ojca na matkę:

47 Witold Gombrowicz, Trans-Atlantyk, Wyd. Literackie. Kraków 1988, s. 60. 
Symbolika relacji [...] między Ojczyzną a Synczyzna, którą Gombrowicz posługuje się jawnie, a nawet ostentacyjnie, wyraża w jego twórczości tylko jeden aspekt tego psychokosmologicznego problemu. Drugi aspekt, głębszy, ukrywa się w twórczości pisarza w relacjach, w które zarówno Ojczyzna, jak i Synczyzna wchodzą z tym, co umownie można nazwać matczyzną. Ostentacja symboliki Ojca i Syna jest tu rodzajem kamuflażu, maski w sensie Freudowskim [...]. Problem matczyzny jest najgłębszym problemem twórczości Gombrowicza ${ }^{48}$.

Psychoanalityczny trop pozwala „uchylić" determinizm doświadczenia wojennego. Odczytywane w tym kluczu Szyfry stają się uniwersalną (ponadhistoryczną) analizą rodzinnej traumy. Kompleks ojca - ,kapłana" (bohaterskiej) Formy i sytuacja całkowitego podporządkowania się neurotycznej matce (sygnalizowane przez ciotkę „dziwactwa" Zofii) mogły doprowadzić do wytworzenia się systemu zależności o charakterze emocjonalno-erotycznym. Konsekwencją owego uzależnienia była pogłębiająca się u Jędrka psychoza lękowa o podłożu masochistycznym (Bał się...) i demaskulinizacja Maćka ${ }^{49}$.

48 Danuta Danek, Oblicze. Gombrowicz i śmierć, [w:] Gombrowicz i krytycy, dz. cyt., s. 726. Wydaje się, iż "dyskurs matczyzny” i „dyskurs homoseksualnego pożądania” należą do tego samego obszaru zjawisk. Gombrowicz w obu przypadkach posługuje się strategią kamuflażu, przemilczenia, maski. W zbiorach Rity Gombrowicz odnaleziony został fragment Dziennika, który nie znalazł się ani w paryskiej, ani w krakowskiej wersji tekstu. Chodzi o partię poświęconą jednemu z „młodych przyjaciół” Gombrowicza Alejandro Rusovitchowi, w której umieszczony został znamienny passus: „Podczas tych dni spędzonych w Goya i pod wpływem Alejandra wrócił do mnie dawny sentymentalny bunt przeciw rodzinie, przeciw matce [...]. Ach, nie kochać matki, nie kochać matki! I to nie z powodu wyżej wymienionej kazuistyki moralnej. To był raczej nakaz piękności, jakiejś nowej piękności, powiedzmy «młodej», która podszeptywała: jesteś brzydki, gdy ją kochasz, jesteś piękny i świeży, witalny i wolny, nowoczesny i poetyczny, kiedy jej nie kochasz... Jesteś piękniejszy jako sierota niż jako matczyny syn". Zob. Rita Gombrowicz, Gombrowicz w Argentynie. Świadectwa i dokumenty 1939-1963, tłum. Anna Husarska, Sophie Bogdan, Ossolineum, Wrocław-Warszawa-Kraków 1991, s. 88.

Dla odmiany we Wspomnieniach polskich pisarz posłużył się figurą sobowtóra, który - jak zauważył Artur Sandauer - pojawia się na Gombrowiczowskiej scenie, by wziąć na siebie odpowiedzialność za niewyrażalne w pierwszej osobie praktyki (szerzej na ten temat $\mathrm{w}$ rozdziale poświęconym Pornografii Kolskiego). Czyżby ambiwalencja uczuć żywionych wobec własnej matki to temat zbyt „drastyczny”, aby realizować go - w "pierwszej osobie" - w tekście tak wyraźnie opartym na pakcie autobiograficznym? Gombrowicz przywdziewa zatem maskę „znajomego studenta”, który zwierza się pisarzowi z pragnienia zabicia matki. Zob. Witold Gombrowicz, Wspomnienia polskie. Wędrówki po Argentynie, Res Publica, Warszawa 1990, s. 107.

49 „Rysy ma dziwnie wiotkie, zamazane jakby, skóra na twarzy porowata, bezbarwna, oczy wyblakłe, z jakąś mętną nutką apatii. [...] Jest niezręczny i wulgarny, nieobyty, niemęski [...]. Jest niezdrowy, nieudany, «unfeigned»". Andrzej Kijowski, Szyfry, dz. cyt., s. 92. 
W tym punkcie wywodu konieczne wydaje mi się zwrócenie uwagi na konsekwencje wynikające z decyzji obsadowych Hasa, który powierzył rolę Maćka Zbigniewowi Cybulskiemu. Na poziomie metatekstowym stanowi to oczywiste odwołanie do Wajdowskiego Popiołu $i$ diamentu. W ten sposób odsłonięty zostaje przed widzem kolejny poziom dyskursu polemicznego "zaszyfrowanego" w gęstej materii filmowego tekstu. A przecież już w samym Popiele... zainicjowana została - tak chętnie podejmowana w następnej dekadzie - gra oparta na specyficznej ambiwalencji „mitu Cybulskiego”. We wspomnieniu poświęconym aktorowi Andrzej Wajda zapisał:

Drażniła niepomiernie poza Cybulskiego. Uważał siebie za emanację pokolenia - i to w dodatku pokolenia, które przedstawiał w filmie; tymczasem tylko w niewielkim stopniu sam do niego należał. Wojna 1939 roku, ruch oporu, Powstanie Warszawskie i powojenne porachunki z Armią Krajową [...] nie miały do jego biografii żadnego odniesienia. Przeciwnie, jeżeli był w cokolwiek zaangażowany, to w powojenną rzeczywistość - poprzez organizacje studenckie, akcje żniwne, amatorskie występy świetlicowe ${ }^{50}$.

Konstatacje Wajdy pozwalają zakwestionować zasadność twierdzeń, wedle których Maciek Chełmicki w interpretacji Cybulskiego był w powszechnym odczuciu "postacią wzorcową bo uosabiającą w oczach odbiorców mityczną przeszłość pokolenia wojennego" ${ }^{\prime 2}$. A jednak to właśnie Wajda - jak nikt inny - potrafił dostrzec znaczenie "mitu Cybulskiego" w życiu zbiorowości. Przejmującym świadectwem bólu odłączenia od

50 Zob. Andrzej Wajda, [w:] Cześć, starenia! Wspomnienia o Zbyszku Cybulskim, red. Mariola Pryzwan, PIW, Warszawa 2007, s. 206.

51 Zob. Agnieszka Morstin, Mocne filmy i głębokie kompleksy, „Kwartalnik Filmowy” 2012, nr 77-78, s. 207. Autorka słusznie jednak podkreśla, iż w Jak być kochanq Has zaproponował widzom inną wersję „losu Polaka” niż ta, która utrwaliła się w zbiorowej świadomości za sprawą „,kanonicznego dyskursu o bohaterstwie”, jakim był niewątpliwie Popiót $i$ diament: „Pięćdziesiąt lat temu Cybulski stworzył przecież we współpracy z Hasem bohatera, którego wizerunek do dziś jest pod wieloma względami niczym przysłowiowy kij włożony w mrowisko. Mrowisko polskich mitów i kompleksów. [...] z ethosu rycerskiego, z którym można utożsamiać postać Chełmickiego, w Hasowskiej opowieści nie zostało już nic prócz głębokiego wstydu i frustracji niespełnionego w swych ambicjach bohaterskich Rawicza [...]" (tamże, s. 207-208).

Bezpośrednim nawiązaniem do Wajdowskiego Popiołu i diamentu jest scena, w której ukryta za zasłoną Felicja przysłuchuje się kombatanckim wynurzeniom Wiktora. Kontrapunktem dla pijackiego mitomańskiego bełkotu Rawicza jest piosenka Czerwone maki na Monte Cassino, upamiętniona przez Wajdę w słynnej „scenie spirytusowej”. 
tego mitu ${ }^{52}$ było zrealizowane już po tragicznej śmierci aktora Wszystko na sprzedaż (1969).

Warto odnotować, iż w drugiej połowie lat 60. Cybulski stał się aktorem-wehikułem, którym chętnie posługiwano się dla przeprowadzania dekonstrukcji romantycznego mitu tyrtejskiego ${ }^{53}$. „Doprowadzony do skrajności typ bohatera emanującego szczególną mitologią" ${ }^{54}$ to przede wszystkim Kowalski-Malinowski z Salta Tadeusza Konwickiego. U Konwickiego postać grana przez Cybulskiego expresis verbis ujawniała jednoznacznie romantyczny rodowód swojej biografii, lecz ostatecznie rodowód ten zostaje zdemaskowany jako fikcja tworzona na użytek zbiorowości spragnionej afirmatywnych (ugruntowanych na fundamencie romantycznej tradycji) narracji tożsamościowych. Konwicki nawiązał zatem do romantycznego mitu w formie zdegradowanej ${ }^{55}$. Tadeusz Lubelski podkreśla, że w latach dzielących Salto od Popiołu i diamentu "legenda Chełmickiego" stopniowo degenerowała się na oczach odbiorców ${ }^{56}$. Has - wzorem Konwickiego ponownie ${ }^{57}$ sięgnął po tę „,zdegenerowaną legendę", by dokonać bolesnej

52 Por. Tadeusz Lubelski, Strategie autorskie w polskim filmie fabularnym lat 1945-1961, Wyd. Rabid, Kraków 2000, s. 174.

53 Do tego nurtu zaliczyć można również komedię Giuseppe w Warszawie Lenartowicza, poprzedzającą Salto Konwickiego i Szyfry Hasa. Dzięki roli w Popiele i diamencie oraz stanowiącym jej „dopełnienie” kreacjom we wspomnianych wyżej filmach, Cybulski - jak pisze Iwona Kurz - stał się znakiem pokolenia (do którego skądinąd sam nie należał, jako kilka lat młodszy od swoich bohaterów) i wcieleniem losu, który przypadł Polsce i Polakom. Zob. Iwona Kurz, Twarze w tłumie. Wizerunki bohaterów wyobraźni zbiorowej w kulturze polskiej 1955-1969, Wyd. Świat Literacki, Warszawa 2005, s. 202.

54 Cytat z wywiadu udzielonego przez Konwickiego na łamach „Argumentów” zaczerpnęłam z tekstu Tadeusza Lubelskiego. Zob. Tadeusz Lubelski, Salto Konwickiego, czyli artysta i odbiorcy, [w:] Studia filmoznawcze, t. III, red. Jacek Trzynadlowski, Wyd. Uniwersytetu Wrocławskiego, Wrocław 1981, s. 113.

55 Pisałam o tym szerzej w we fragmencie poświęconym analizie Salta. Zob. Natasza Korczarowska, Ojczyzny prywatne, Wyd. Rabid, Kraków 2007, s. 97-100.

56 Zdaniem Lubelskiego Konwicki świadomie przywołał w Salcie tę dwuznaczna, "podejrzaną" legendę, którą w równej mierze tworzył publiczny, jak i pozaartystyczny wizerunek aktora. Zob. Tadeusz Lubelski, Bohater Konwickiego, [w:] Człowiek z ekranu. Z antropologii postaci filmowej, red. Mariola Jankun-Dopartowa, Mirosław Przylipiak, Wyd. Arcana, Kraków 1996, s. 65-66. Wystarczy wspomnieć filmy, w których wystąpił Cybulski w dekadzie „naszej małej stabilizacji” (Rozwodów nie będzie, Pingwin, Juto Meksyk czy Jowita).

57 Po raz pierwszy uczynił to w filmie Jak być kochana. Biorąc pod uwagę konstrukcję postaci odtwarzanych przez Cybulskiego, Jak być kochana i Szyfry można potraktować jako dyptyk. Na niezwykle ironiczny wydźwięk imienia bohatera Jak być kochana - Wiktor - zwrócił uwage Paul Coates. Zob. Paul Coates, The Red and the White. The Cinema of People's Poland, Wallflower Press, London-New York 2005, s. 130. 
wiwisekcji zbiorowej świadomości pokolenia ${ }^{58}$, którego ideologiem - jak stwierdził Wajda - paradoksalnie stał się Cybulski.

Niezależnie od dwuznaczności sensów generowanych przez filmowy Popiół $i$ diament, musimy zgodzić się z tezą o psychoterapeutycznej (mediumicznej) funkcji postaci granej przez Cybulskiego:

aktor wypowiedział to, co nie zostało wypowiedziane w innych dziełach i na innych poziomach dyskursu publicznego. Wypowiedział bohaterstwo, czystość, tragizm, wypowiedział klęskę niezawinioną. Wymowność roli Maćka opierała się też na tym, że mógł on być medium narodowej żałoby i narodowej klęski $[\ldots]^{59}$.

W dyptyku Hasa Rawicz-Maciek pełni podobną funkcję, lecz tym razem należy w nim widzieć medium skrzętnie skrywanych narodowych kompleksów. W przypadku bohatera Szyfrów byłby to przede wszystkim kompleks uczestnictwa w wojnie prowadzonej z perspektywy sublokatorskiego pokoju z używalnością kuchni ${ }^{60}$ wymierzony $\mathrm{w}$ - jakże trafnie zdiagnozowany przez Hasa (Bohaterowie leża na cmentarzach $^{61}$ ) i Konwickiego ${ }^{62}$ - polski mit

58 Pokolenia, które - jak podkreśla Antonina Kłoskowska - też nie było przecież „,statystyczną reprezentacją ogółu, ale krystalizacją wartości wysublimowanych reprezentacyjnych, nie reprezentatywnych". Zob. Antonina Kłoskowska, Kultury narodowe u korzeni, Wyd. Naukowe PWN, Warszawa 2005, s. 313.

59 Iwona Kurz, Twarze w ttumie, dz. cyt., s. 202.

${ }_{60}$ Ten jakże istotny - w kontekście przyjętej przez Hasa strategii demitologizacyjnej - wątek doskonale koresponduje z obrazem wojny i okupacji zawartym w książce Kazimierza Wyki Życie na niby. Pamiętnik po klęsce (piszę o tym w dalszej części wywodu).

Groteskowy obraz wojennej konspiracji widzianej z perspektywy pokoju z używalnością łazienki ukazał Lenartowicz w filmie Giuseppe w Warszawie (1964). Warto zwrócić także uwagę na kontekst, w jakim przywołana została w tym filmie tradycja romantyczna. Przypomnijmy dla przykładu scenę, w której Stanisław (w tej roli Zbigniew Cybulski) znad talerza spaghetti komentuje - za pomocą cytatów z wiersza do $M^{* * *}$ Mickiewicza skandaliczne (?) zachowanie Maryśki wobec przystojnego Włocha. Celem groteskowej deformacji nie wydaje się jednak ostateczna rozprawa $\mathrm{z}$ tradycją. $\mathrm{W}$ finale filmu Lenartowicza - jak w Munkowskiej Eroice - zostają zakwestionowane reguły groteskowej narracji. Wizyjne sceny przenoszą widza w zaświaty - krainę śmierci, która w planie tekstualnym (zgodnie z regułami przyjętymi w komedii) nie mogła się urzeczywistnić.

Na marginesie można zastanawiać się także nad inną kwestią. Sposób ujęcia tematyki okupacyjnej może budzić kontrowersje (podobne do tych, które po latach zdają się wywoływać odnoszące się do okresu PRL filmy Stanisława Barei). Czyż bowiem padające z ekranu słowa, jak choćby: W Warszawie nie ma Niemców, tylko sami przebrani partyzanci, nie fałszują - w oczach współczesnego widza - obrazu czasów Zagłady? Oczywiście jest to pytanie stricte retoryczne, trudno bowiem założyć, iż film Lenartowicza mógłby dla kogokolwiek stanowić podstawę wiedzy historycznej.

61 Te słowa (narodowe credo i Gombrowiczowska "gęba" zarazem), w których wyraża się bezwzględny imperatyw śmierci za ojczyznę, podsumowują "załganą" autobiografię Rawicza w słynnej scenie kawiarnianej z Jak być kochana.

62 A jednocześnie to przecież Konwicki na kartach powieści Kompleks polski każe wypowiedzieć Trauguttowi znamienne słowa: „Nie wiem czy był sens. Wiem, że był mus”, 
polegnięcia ${ }^{63}$ (,imperatyw mityczny" ${ }^{164}$ ), do którego doskonale przylega formuła Slavoja Žižka: „przejście przez umarłego Innego" ${ }^{65}$. Fundamentalne dla tego mitu zanegowanie bezwzględnej wartości ludzkiego życia stanowi dowód, iż istnieją wartości pozbawione transcendentalnego zakorzenienia - wartości wywodzące się z doświadczenia narodowego i zrozumiałe tylko w obrębie jego dziejów ${ }^{66}$. Polski mit polegnięcia to integralny element „świadomości romantycznej" typowej dla społeczeństwa (Chełmickich i wracających do umierającej Warszawy Górkiewiczów), w którym

wszystkie czynności mogą tu być spełniane bez wiary w swą wartościowość, natomiast z uczuć i wzruszeń, myśli i wierzeń wytwarzanych przez wszystkie przeminione i cudze postaci działalności, tworzą się struktury psychiczne, mające za zadanie utrzymać poczucie wartości osobistej i zbiorowej $\mathrm{w}$ jednostkach i warstwach $\mathrm{w}$ ten sposób skłóconych z własną rzeczywistością i związać to poczucie właśnie z tym rozdarciem życiowym ${ }^{67}$.

w których - wedle Stanisława Barańczaka - zawiera się jedyna możliwa odpowiedź na pytanie o sens walki (i śmierci) z potęgą Wielkiego Bezsensu. Zob. Stanisław Barańczak, Etyka i poetyka, Znak, Kraków 2009, s. 378.

${ }^{63}$ „Polec to zupełnie co innego niż zginąć, umrzeć, wyzionąć ducha, dokonać żywota, rozstać się ze światem, zdechnąć czy paść na polu. [...] Tylko ludziom z mojego pokolenia zaczyna coś grać w duszy, coś jak niebiańskie organy, gdy usłyszą o poleganiu. Bo polegnięcie to specjalny uroczysty akt w ohydzie śmierci. Do polegnięcia przygotowuje się mężczyzn już od dziecka. Z piętnem polegnięcia rosna, dojrzewają, sublimują swoje jestestwo, aby w końcu polec, jednak nie później niż w wieku dojrzałym. [...] Polegnięcie wymyślili Polacy". Zob. Tadeusz Konwicki, Nic albo nic, Czytelnik, Warszawa 1973, s. 67-68.

Za paradygmatyczny - w kontekście polskiego mitu polegnięcia - tekst kultury można uznać opublikowany w 1900 r. Katechizm polskiego dziecka Władysława Bełzy (znany także jako Wyznanie wiary dziecięcia polskiego lub Katechizm młodego Polaka, a spopularyzowany pod pierwotnym tytułem Kto ty jesteś?). Utwór kończy się znamiennymi słowami:

- A w co wierzysz?

- W Polskę wierzę!

- Coś ty dla niej?

- Wdzięczne dziecię.

- Coś jej winien?

- Oddać życie.

Tragiczno-ironicznym podsumowaniem efektów patriotycznej edukacji w duchu polskiego mitu polegnięcia są słowa "straconych” bohaterów Wajdowskiego Kanału:

- Będa nas czcić przyszłe pokolenia. Nie damy się żywcem.

- Właśnie, po polsku.

64 Zob. Maria Janion, Płacz generała, dz. cyt., s. 283.

65 Zdaniem Žižka: „Jeden z podstawowych mechanizmów ideologicznej [w sensie psychoanalitycznym] legitymizacji polega na potwierdzaniu istniejącego porządku poprzez przedstawienie go jako realizacji marzenia, jednak nie naszego marzenia, ale marzenia Innego, marzenia zmarłych przodków, marzenia przeszłych pokoleń". Cyt. za: Jan Sowa, Fantomowe ciało króla. Peryferie zmagania z nowoczesna forma, Universitas, Kraków 2011, s. 278.

66 Zob. Paweł Śpiewak, Pamięć po komunizmie, słowo/obraz terytoria, Gdańsk 2007, s. 176.

67 Stanisław Brzozowski, Głosy wśród nocy. Studia nad przesileniem romantycznym kultury europejskiej, Wyd. Krytyki Politycznej, Warszawa 2007, s. 87. 
Mit ten stanowi zatem "twarde jądro" tożsamości wspólnoty narodowej, które - jak podkreśla Marek Zaleski - „zawsze określa nas na wskroś, ale na co dzień przebywa poza słowami (jest tym, co psychoanaliza określa mianem Realnego)" ${ }^{\prime 6}$.

Przyjmując postawę zachowania każdego życia za wszelka cenę - godzącą bezpośrednio w ten polski mit - Maciek z Hasowskich Szyfrów lokuje się „poza” narodem postrzeganym jako wspólnota umierania:

Każdy, kto w takim otoczeniu wyłamuje się z pędu ku zagładzie i przeważającej tendencji do pielęgnowania i eksploatowania swoich ran, kto - innymi słowy - chce żyć, zamiast umierać, wychodzi na zdrajcę, witalnego pyszałka ${ }^{69}$.

Dlatego Chełmicki - symbol pokolenia, do którego należy przecież i syn Tadeusza - w finale Popiołu i diamentu „musi zapłacić za swój niefrasobliwy witalizm, za to, że nie umarł, gdy umierali inni: musi zginąć" ${ }^{70}$. To dzięki tej śmierci - samemu faktowi, bo już chyba nie okolicznościom zaprzeczającym polskiej ars bene moriendi ${ }^{71}$ (choć i tę śmierć

${ }^{68}$ Marek Zaleski, Czy polski dyskurs postzależnościowy może wybić się na niezależność, [w:] Kultura po przejściach, osoby z przeszłościa. Polski dyskurs postzależnościowy - konteksty i perspektywy badawcze, red. Ryszard Nycz, Universitas, Kraków 2011, s. 33. Zaleski podkreśla, iż w systemach demokratycznych nie musimy na co dzień konfrontować się z założycielskimi mitami tożsamościowymi wspólnoty: „nie czujemy ich mocy sterowniczej - przeciwnie, często poddajemy je krytycznej rewizji, ale ich siła ujawnia się w sytuacjach kryzysowych i dramatycznego zagrożenia. Wtedy powracają jako figury dyskursu wytwarzanego wokół «twardego jądra» [...]”. Doskonałym przykładem „reaktywacji” mitu tożsamościowego w warunkach demokracji jest „dyskurs Smoleński”, odtwarzający "pierwotną scenę uzależnienia (tu: idealizowana męczeńska ofiara przywracająca zagrożoną narodową wspólnotę i demonizowane siły zła zagrażające wspólnocie)" (tamże, s. 33-34).

Marcin Kula komentuje: „plakat, w którym pod nazwą «Katyń» zestawiono daty 1940 i 2010, był, moim zdaniem, nadużyciem. Puszczanie w tych dniach w telewizji, jako tła dla przedstawionych wydarzeń, piosenki Warszawskie dzieci pójdziemy w bój... było dyskusyjne, podobnie jak nadawanie krypcie prezydenckiej na Wawelu nazwy «Katyńska». Pisanie «bohaterowie» o Zmarłych jest niestosowne. Plakat, na którym przedstawia się Prezydenta jako bohatera, jest bezsensowny («Za prawdę, honor i godność Polaków złożył najwyższą ofiarę»)". Zob. Marcin Kula, Naród, historia i... dużo kłopotów, Universitas, Kraków 2011, s. 397.

69 Maciej Stroiński, Naród jako wspólnota umierania. Andrzej Wajda, niemiecki idealizm i mesjański witalizm, [w:] Kino polskie jako kino narodowe, dz. cyt., s. 88.

70 Tamże, s. 102.

71 Śmierć Chełmickiego mogłaby stanowić doskonały argument dla zwolenników tzw. poprawnej politycznie interpretacji Powstania Warszawskiego, wedle której: „gdyby Powstanie nie doszło do skutku albo szybko się skończyło, byłoby jeszcze gorzej. Za sprawą Stalina młodzież powstańcza zostałaby wymordowana metodą katyńską, wygubiona na Syberii albo w pozostałej części zniewolona". Na dowód tej tezy przytacza się casus Krzysztofa Kamila Baczyńskiego, którego jeszcze pięć lat po śmierci poszukiwali funkcjonariusze UB. Wynika z tego, że jedynie polegnięcie w Powstaniu (bo już nie 
Wajda estetycznie celebruje, by umierający wśród śmieci akowiec - wzorem sybirskich zesłańców z przywołanego w Szyfrach poematu Anhelli„był piękny”), Chełmicki - w przeciwieństwie do bohatera Szyfrów, który "ośmielił się" przeżyć - mógł wejść ze śmietnika historii prosto w narodową mitologię̨72. „Oto Sztuka głosi: Śmierć, bo cóż szczytniejszego nad Śmierć? Ta jest wielkością w naszym wszystkich miar pojęciu i wszechczasów i ta wielkość daje"73. Nieprzypadkowo w eseju o znamiennym tytule Wajda, czyli polski los Jean-Luc Douin podsumowuje:

Aby być Polakiem, nie wystarczy mieć narodowość. Bycie Polakiem to przeznaczenie: oznacza ono, że jest się skazanym na męczeństwo i opór. „Polak, wzniosły w cierpieniu, osłabiał potęgę swych ciemięzców, oddając życie" - pisał Balzak ${ }^{74}$.

Stygmatem polskiej literatury (czy szerzej: Sztuki) - jak pisze Maria Janion - jest poczucie obcości wobec mitu europejskiej „szczęśliwości”. Historia pojmowana jest tu na sposób romantyczny - jako najwyższy wysiłek budowania wartości, które stale podlegają zagrożeniu i stale doma-

śmierć od kuli w plecy w „czasach pokoju”) „ratuje polski honor z imponderabiliami”. Dotyczy to nie tylko szeregowych żołnierzy Powstania, lecz - w większym jeszcze stopniu - jego przywódców. Tomasz Łubieński pisze: „Tymczasem Powstanie nie ma bohatera wyższego wojskowego stopnia. [...] Byłby każdy z dowódców Powstania, gdyby poległ, to warunek, bohaterem narodowym i żadna reżimowa propaganda nie dałaby mu rady. Ale nikt z dowództwa nie zginał, choć wszyscy byli gotowi, tak się złożyło". Zob. Tomasz Łubieński, Ani triumf, ani zgon... Szkice o Powstaniu Warszawskim, Wyd. Nowy Świat, Warszawa 2009, s. 25, 86.

W tym samym paradygmacie „imperatywu śmierci za ojczyznę” umieścić można refleksję Marii Janion dotyczącą znamiennego zapisku z Dzienników czasu wojny Zofii Nałkowskiej: „,dowiedziawszy się o dalszych losach osobistości rządowych, przebywających w Rumunii czy w Paryżu, w miesiąc po wybuchu wojny Nałkowska zauważa: «Ale nie słychać, by ktoś z tych ludzi popełnił samobójstwo». W ten sposób też dotyka dna hańby [podkr. moje - N.K.-R.]". Zob. Maria Janion, Płacz generała, dz. cyt., s. 174-175.

72 Z tej perspektywy scena samobójczej śmierci porucznika Jerzego w Katyniu stanowić może symboliczne domknięcie Wajdowskiego dyskursu o narodzie jako wspólnocie umierania. Nie dziwi zatem, iż w przywołanym filmie „oskarżycielskie” słowa: Wybierasz martwych zamiast $\dot{z} y w y$ ch $i$ to jest chore wypowiedzieć mogła tylko osoba dopuszczająca się zdrady (zaprzedana nowej władzy dyrektorka szkoły). W Moich notatkach $z$ historii odnaleźć można wyrażoną expresis verbis wykładnię filozofii twórczej Wajdy. Artysta notuje: „Wiedzieliśmy, że jesteśmy głosem naszych zmarłych, że naszym obowiązkiem jest danie świadectwa o tych, którzy byli lepsi. Bo my uratowaliśmy się tylko dlatego, że byliśmy gorsi, mieliśmy mniej śmiałości, mniej odwagi, mniej pomysłowości, mniej wyobraźni, albo może właśnie zbyt wiele wyobraźni". Zob. Andrzej Wajda, Moje notatki z historii, „Kwartalnik Filmowy” 1996/1997, nr 15-16, s. 9.

73 Stanisław Wyspiański, Wyzwolenie. Noc listopadowa, Wyd. Literackie, Kraków 1987, s. 68.

74 Jean-Luc Douin, Wajda, czyli polski los, tłum. Grażyna Stryszowska, „Kwartalnik Filmowy" 1996/1997, nr 15-16, s. 189. 
gają się ostatecznych ofiar poniesionych w ich obronie. Świadectwem tej historiozofii jest , jeden z najwspanialszych, najczystszych utworów literatury polskiej" - opowiadanie Sérénité Jarosława Iwaszkiewicza, w którym czytamy:

Jakże może myśleć o szczęściu człowiek, należący do narodu, którego głównym mitem jest mit powstania. Nie mit szczęśliwości wiecznej [...], tylko mit powstania. My wszyscy żyjemy dlatego, aby kiedyś odbyło się to obrzędowe niejako ofiarowanie na ołtarzu ojczyzny hekatomby chłopców i dziewcząt $[\ldots]^{75}$.

Symbolicznego (dokonującego się poprzez transmisję heroicznych narracji) aktu ofiarowana chłopców (synów) na ołtarzu ojczyzny dokonuje także Tadeusz. W sensie socjologicznym rodzina Tadeusza staje się laboratoryjnym przykładem „negatywnej akulturacji”. A w postaci Jędrka wiecznego („zmumifikowanego") dziecka - „zakodowana” została Gombrowiczowska filozofia dzieciństwa:

W wypadku Gombrowicza - pisze Ewa Graczyk - pamięć dzieciństwa nie jest czymś, co można i trzeba przywrócić, ofiarować czytelnikom. Jest to raczej negatywność - odmowa - wypalająca w strukturze semantycznej tekstów szczególnego rodzaju dziury, białe plamy, odejmujące coś, kwestionujące świat dorosłych, świat dorosłego naporu sił i znaczeń. Jest to coś, co podaje w wątpliwość postęp, metafory rozwoju i kumulacji ${ }^{76}$.

Dwuznaczną rolę $\mathrm{w}$ rodzinnym dramacie pełni przede wszystkim Zofia ${ }^{77}$. Jej współczesna egzystencja sprowadza się do kompulsywnego odgrywania (uderza nieruchomy wyraz twarzy, nieobecne spojrzenie i mechanicznie wypowiadane słowa żałobnego tekstu) rytuału Mater Dolorosa, który w udręczonej świadomości ma wywołać efekt paramnezji czyli percepcji czasu, stapiającej w jedna, nierozróżnialną całość rozróżnialne dotąd sfery przeszłości i teraźniejszości ${ }^{78}$. Matka, wedle słów Maćka, żyje przeszłościa, jakby śmierci nie było wcale albo jakby sama już nie żyła. W finale Szyfrów Zofia staje się przeszłością sama w sobie,

75 Zob. Maria Janion, Płacz generała, dz. cyt., s. 144. Podobną wizję „silniejszego od szczęścia łańcucha ofiar niewinnych” odnajduje autorka w „starobielskiej” prozie Józefa Czapskiego.

76 Ewa Graczyk, Przed wybuchem wstrzasnać. O twórczości Witolda Gombrowicza w okresie międzywojennym, słowo obraz/terytoria, Gdańsk 2004, s. 32.

77 Polemiczny wobec stereotypu matki Polki wizerunek kobiety zaproponował Gombrowicz w Pornografii, kreując postać „świątobliwej” pani Amelii.

78 Zob. Marek Zaleski, Formy pamięci, Instytut Badań Literackich PAN, Warszawa 1996, s. 59. 
widmową i „odcieleśnioną" - do niej należy przecież „głos zza grobu”, który Tadeusz usłyszy na koniec w słuchawce telefonu. Pełne lęku błaganie o pomoc to $\mathrm{w}$ istocie bezwzględny imperatyw wierności wobec "tego, co było".

Zofia „obwarowuje” swą egzystencję przedmiotami - pamiątkami po zmarłym synku. Has intensyfikuje semantyczny potencjał rzeczy. Wypełniające wspólny pokój fotografie, rysunki, stare zeszyty szkolne to znaki mentalnego uwikłania w przeszłość. Ale nie tylko. Pełnią one także (a może przede wszystkim) funkcję teatralnych rekwizytów pozwalających Zofii „wejść" w rolę cierpiącej matki.

Zauważmy, że Has w szczególny sposób sugeruje „teatralność” zachowania Zofii. Sceny z jej udziałem konstruowane są tak, by bohaterka nigdy nie pojawiała się w kadrze sama. Zofia - „,aktorzyca ostatniego rzędu, szlachetna, niezłomna, bolejąca, nic nie robi tylko deklamuje!"79cierpi „wobec" Tadeusza, bo to jego obecność „wyzwala” w niej styl zachowania podyktowany Formą („zbolałej matrony"). Postać Zofii naprowadza nas na trop Gombrowiczowskich obsesji zafiksowanych na matce, w której pisarz dostrzegał nieuświadomioną nieautentyczność i nienaturalność, a tym samym skłonność do zakładania masek, przyjmowania póz $\mathrm{w}$ celu poprawienia swego wizerunku ${ }^{80}$.

Całkowite pogrążenie się Zofii w przeszłości oznacza triumf pamięci traumatycznej, która zdaniem Dominicka LaCapry

przenosi ze sobą do teraźniejszości i przyszłości doświadczenie, w ramach którego wydarzenia są ponownie kompulsywnie doświadczane tak, jakby między przeszłością a teraźniejszością nie istniała żadna odległość ani różnica. W pamięci traumatycznej przeszłość nie jest po prostu zamkniętą i skończoną historią. Wciąż żyje w doświadczeniu i nawiedza czy mami jednostkę $[\ldots]^{81}$.

A przecież Zofia w czasie okupacji odrzuciła tradycyjną rolę „żałobnej wdowy" "82, a miejsce walczącego na froncie męża natychmiast zajął przy jej boku Marian (ten „niekanoniczny” rys charakteru Zofii został podkre-

79 Witold Gombrowicz, Wspomnienia polskie. Wędrówki po Argentynie, dz. cyt., s. 107.

80 Agnieszka Kowalczyk, Rodzina jako źródło cierpień w twórczości Witolda Gombrowicza, Universitas, Kraków 2006, s. 62.

81 Dominick LaCapra, Historia w okresie przejściowym. Doświadczenie, tożsamość, teoria krytyczna, tłum. Katarzyna Bojarska, Universitas, Kraków 2009, s. 76.

82 Dekonstrukcji tego "mitu” (tu: w znaczeniu konstruktu kulturowego) podjął się wcześniej Kazimierz Kutz w ostatniej części debiutanckiego Krzyża walecznych (1959). Zauważmy jednak, iż jeden zdekonstruowany „mit” zostaje natychmiast zastąpiony innym - nazwijmy go „konstruktywnym” mitem politycznym (Ziemie Odzyskane jako wolna - jak wynika z noweli Wdowa - od walk ideologicznych Gomułkowska „ziemia obiecana"). 
ślony w opowiadaniu doktora Grossa, który zasugerował, że matka poświęciła Jędrka, by chronić życie pojmanego przez SS kochanka).

Jednoznaczną ocenę poczynań bohaterów utrudnia fakt, iż reżyser unika typowych dla martyrologicznych wyobrażeń wojny podziałów na prześladowców i ofiary. Has ukazuje w Szyfrach dwa odmienne typy doświadczenia wojennego. Do ich konfrontacji dochodzi podczas rozmowy Tadeusza ze starszym synem, która rozpoczyna się w taksówce, a kończy w pokoju hotelowym. Podczas tej rozmowy padają znamienne słowa, odzwierciedlające dramat wynikający z niemożności porozumienia:

Tadeusz: Nie mów mi, na czym polega wojna, bo ją widziałem.

Maciek: Nie wiesz tylko, jak ona wyglada, kiedy sie ja prowadzi w domu, w sublokatorskim pokoju z używalnościa kuchni, z udziałem kobiet $i$ dzieci. Jak wyglada, kiedy się krzyżuje $z$ miłościa. Brałeś udział w wojnach wielkiej armii, ale nie wiesz, jak wyglada, kiedy się toczy pośrodku życia.

Tadeusz w protekcjonalno-pogardliwy sposób traktuje opowieści Maćka o wojennej codzienności. Sprawia wrażenie człowieka, który nie został zainfekowany obsesją pamięci - wojna to dla niego w dosłownym tego słowa znaczeniu przeszłość: nieodwołalnie zamknięta i podporządkowana konwencjom martyrologicznej narracji (Czytałem o tym wszystkim). Od Maćka żąda niemożliwego - amnezji (Miałeś dość czasu, żeby o tym zapomnieć), która pozwoli synowi zapomnieć o traumatycznych przeżyciach i zastąpić pozorną („,przeszłą") egzystencję życiem prawdziwym („,teraźniejszym"). A przecież Maciek (i w pewnym sensie także Jędrek) należy do pokolenia, które kończąc dwadzieścia lat około roku 1940

nie miało już poczucia autonomii życia prywatnego. Nieomalże nie było w ciągu dnia takiej chwili, która nie byłaby uzależniona od jakiejś decyzji politycznej czy zakłóceń w życiu publicznym. Te dzieci, ci młodzi ludzie znaleźli się od razu w historii $[\ldots]^{83}$.

Pomiędzy bohaterami Szyfrów wyraźnie rysuje się podział na „lepszych” („prawdziwych”?) i „gorszych” Polaków. Ci pierwsi doświadczyli wojny w kraju, ci drudzy (jak Tadeusz) uczestniczyli w wojnie „nierzeczywistej”. Podejmując ten wątek, Has wpisuje się w dyskurs o polskiej „pękniętej” pamięci II wojny światowej, lecz jednocześnie przyjmuje $\mathrm{w}$ tym dyskursie odmienną ${ }^{84}$ perspektywę oglądu. Ze strony

83 Philippe Ariés, Czas historii, tłum. Bella Szwarcman-Czarnota, Wyd. Marabut, Gdańsk 1996, s. 33.

84 Barbara Szacka podkreśla, iż o charakterze polskiej pamięci decyduje jej fragmentaryzacja spowodowana wielością i różnorodnością doświadczeń wojennych i okupacyjnych: „Specyfiką polskiej pamięci o drugiej wojnie jest natomiast to, że była, i chyba wciąż jest, pamięcią pęknięta, podzieloną na pamięć dwu odmiennych doświadczeń: okupacji 
Maćka Tadeusz spotyka się z ledwie maskowaną wrogością. O wzajemnej idiosynkrazji świadczy scena powitania na dworcu - Maciek, odbierając ojca z pociągu, ostentacyjnie unika jakiegokolwiek zbliżenia fizycz-

sowieckiej we wschodniej części przedwojennej Polski i okupacji niemieckiej w jej zachodniej części, która też zresztą była doświadczana inaczej na ziemiach włączonych do Rzeszy i tych, na których utworzono Generalne Gubernatorstwo". Zob. Barbara Szacka, Czas przeszty - pamięć - mit, dz. cyt., s. 153.

Na zapisaną w filmowych kadrach mape polskiej „pękniętej” pamięci o wojnie należałoby "nanieść" także świadectwa oficerów z II części Eroiki Munka (też przecież niejednolite - bo złożone zarówno z doświadczeń oficerów o spopielonych oczach, jak i tych o oczach płonacych*) czy bohatera Jeziora Bodeńskiego Janusza Zaorskiego. A jeśli tak - to również Rawicza z Jak być kochanq i Tadeusza z Kornblumenblau (choć to "świadectwa" nieuchronnie uwikłane w pytania o prawo - zwłaszcza nas współczesnych - do oceny czynów w tych świadectwach upamiętnionych). Tu jest miejsce również dla świadectw tych, „których warunki szczególnie okrutnej partyzanckiej wojny ze szczególnie okrutnymi przeciwnikami stawiały często w sytuacjach wymuszających decyzje i działania moralnie wątpliwe". Pozostaje także kwestią do dyskusji, czy ową "mapę wojennej pamięci" należy poszerzyć o świadectwa "odstępstw” ${ }^{\prime \prime}$ W formie konwersji na rzecz narodowości wroga - i zdrady w postaci działania na szkodę narodowych wartości i służących im ludzi". Zob. Antonina Kłoskowska, Kultury narodowe u korzeni, dz. cyt., s. 303-312. O świadectwa „pękniętej pamięci” upomniał się ostatnio - w duchu Różewicza (Do piachu), a także Komorowskiego (Stajnia na Salwatorze, 1967), Konwickiego (Jak daleko stąd, jak blisko, 1972) czy Orzechowskiego (Wyrok śmierci, 1980) - Marcin Kryształowicz we wstrząsającym filmie Obława (2012).

* Odwołuję się w tym miejscu do oflagowych wspomnień Mariana Brandysa. Zob. Tragedia lewicujacych liberałów, rozmowa z Marianem Brandysem, Warszawa, 27 lipca 1981, [w:] Jacek Trznadel, Hańba domowa, Wyd. Antyk, Komorów 2006, s. 281.

O społecznym sprzeciwie wobec praktyk „poszerzania” mapy pamięci o II wojnie światowej i nieustającej próbie narzucania „mitów i stereotypów, które pretendują do typowości, choć są w istocie jedynie projektami świadomości zbiorowej" świadczą m.in. reakcje na opublikowany w 1976 r. tom Literatura wobec wojny i okupacji pod redakcją Marii Janion. Autorka wspomina o formułowanych wówczas (a brzmiących niezwykle aktualnie) zarzutach: „Jeden dotyczył tego, że poprzez swoją pochwałę cywilności, pisanie «na klęczkach» o Białoszewskim kwestionuję «powinności obywatelskie i patriotyczne Polaka» oraz podważam moralne sensy, które towarzyszyły wyborowi drogi walki i oporu wobec okupanta. [...] To była batalia o to, by narzucić społeczeństwu jeden, zaaprobowany przez ludzi, uważających się za «jedynych prawdziwych» przedstawicieli «kombatantów», obraz wojny, uznany za jedynie «patriotyczny». Wszystko brało się z chęci jednostronnego widzenia wojny, a także z jego funkcji konsolacyjnej. [...] Oczywiście, że podobnie rzecz się miała z Borowskim [...]. Trochę podobne zarzuty kierowane były pod adresem Leopolda Buczkowskiego [...]. To podobny styl oburzenia, kiedy się wyciąga te same argumenty, groźnie odwołuje do skalanej pamięci i poniżonej symboliki narodowej. Później historia się powtórzyła po telewizyjnej premierze, już w roku 1990, a więc po przełomie, sztuki Różewicza Do piachu, która wywołała falę protestów byłych żołnierzy AK. [...] Coś podobnego miało miejsce z okazji obchodów pięćdziesięciolecia wybuchu powstania warszawskiego. Jakakolwiek uwaga krytyczna czy sąd podważający sensowność decyzji o wybuchu powstania budziły ogromne sprzeciwy tych, którzy uważali, że Polska jest w ten sposób znieważana, obrażana jest nasza tradycja, podważana tożsamość narodowa". Zob. Maria Janion, Płacz generała, dz. cyt., s. 325-328. 
nego ${ }^{85}$. Zdaniem Zofii, podjęta przez męża decyzja o porzuceniu rodziny miała decydujący wpływ na eskalację psychotycznych reakcji Jędrka. Ale wyrzuty czynią Tadeuszowi nie tylko najbliżsi. Antykwariusz, z którym spotyka się bohater w sprawie zaginionego syna, interpretuje motywy kierujące Tadeuszem $\mathrm{w}$ duchu psychoanalizy: Ja swoja wojnę skończyłem, a pan chce ja dalej prowadzić, bo cią̇y na panu jakiś kompleks nieobecności czy nieuczestnictwa.

Podczas okupacji konspiracyjna działalność polityczna i wojskowa miała zaplecze w krakowskich domach. Część z nich łączyła swą nową funkcję z tradycyjnymi funkcjami domu, część została przeznaczona wyłącznie do dyspozycji działaczy podziemia ${ }^{86}$. Tadeusza, reprezentującego etos czynnej walki, nie interesuje jednak cywilny wymiar wojny prowadzonej z perspektywy sublokatorskiego pokoju z używalnościa kuchni. Z wyraźnym zniecierpliwieniem traktuje opowieści Maćka, który koncentruje się na okupacyjnej „skarlałej” codzienności: odmrożonych w kolejkach po węgiel dłoniach czy nieheroicznej („,wdowiej”) pracy matki piekącej ciastka ${ }^{87}$.

Demitologizującym i jakże gorzkim świadectwem owego "skarlenia” - świadectwem „społecznej śmierci” miasta, w którym zamarły gesty wewnętrznego sprzeciwu - jest „krakowski” pamiętnik Kazimierza Wyki. Na kartach nieukończonego eseju o wielce wymownym tytule Pamiętnik po klęsce odżywa emocjonalny klimat czasu i miejsca, w którym rozgrywało się "życie na niby" (okupacyjna egzystencja Maćka). W pismach Wyki - jak w dyptyku Hasa - akcentowanie specyfiki miejsca, w którym kształtowały się doświadczenia wojenno-okupacyjne, zdradza stosunek twórcy wobec historii (w przypadku Hasa mylnie interpretowany jako nikłe zainteresowanie). Wyka wspomina:

85 Paul Coates odnalazł tu czytelne odwołanie do sceny pierwszego spotkania Maćka ze Szczuką w Popiele i diamencie. W filmie Wajdy - podobnie jak w Szyfrach - kontakt Maćka z „nieznajomym” zostaje nawiązany poprzez banalną czynność zapalania papierosa. Zob. Paul Coates, The Red and the White, dz. cyt., s. 131.

86 Anna Czocher, W okupacyjnym Krakowie, Wyd. Oskar, Gdańsk 2011, s. 174.

${ }_{87}$ Niezwykle interesującego zapisu okupacyjnej codzienności w Krakowie dostarcza Joanna (2010) Feliksa Falka. Obraz Falka to poruszający zapis pauperyzacji i degradacji społecznej krakowskiej inteligencji. Dla odmiany, w zrealizowanej w tym samym roku „baśniowej” Małej maturze Janusza Majewskiego (akcja filmu rozgrywa się na przełomie lat 1946/1947), wojna w żaden sposób nie wpłynęła na ekonomiczny status inteligencji. Dowodzi tego wystój wytwornej willi „pani mecenasowej” (i usługująca mieszczańskiej femme fatale pokojówka w nieskazitelnie białym czepeczku!), w której czas „magicznie” zatrzymał się w roku 1939. Zupełnie odmiennego świadectwa dostarcza w tym względzie Katyń Andrzeja Wajdy. 
Warszawa była [...] zbyt wielkim środowiskiem miejskim, ażeby ją można w trybie czysto administracyjnym, przy braku kolaboracji uświadamiającej okupantowi atmosferę psychiczną środowiska, zamienić na miasto potulne, polakierować na kolor germański i czuć się u siebie. Dlatego stolicę GG umieszczono w mieście, które można było tymi sposobami przemalować na niemiecko. [...]

Na fizjognomii duchowej Krakowa najbardziej może zaważyło to, że miasto nie zaznało walki i oporu. Obeszli je bokami i swoi, i Niemcy. Zostało łupem gotowym, nietkniętym, z którego żadnych soków nie wycisnął krzepiący opór, wszystkie zaś siły przeżarł i rozdrapał najeźdźca. Gdy pomnik, zabytek, dzieło sztuki pada od pocisku armatniego albo pożaru, lecz jako ofiara w nieuniknionej rozrzutności wojny, jako zapłata za nieustępliwość, w tej stracie jest coś krzepiącego. Nie wszystko ginie, ze zniszczenia materialnego narasta nowa wartość, na rdzeniu ściele się słój nowej legendy. To poznała Warszawa i tak imponuje dumą. Ale widzieć, jak rzeczy najcenniejsze gina, jak miejsca najbardziej szacowne się plugawią jak dorobek stuleci rozwłócza, widzieć co dzień nowy wyłom i żadnym odruchem buntu nie móc gniewowi dać ujścia, milczeć, milczeć, bo nic nie pomoże, nic nie uratuje aktualnie, aż dopiero w wielkim rachunku [...].

A to jest codzienny dzień Krakowa od chwili obdarzenia miasta siedzibą gubernatora. Ciągła strata, ciągły widok poniżenia i zepchnięcia, na które nie da się niczym odpowiedzieć. [...] wreszcie cios dla miasta najdotkliwszy: uderzono w uniwersytet. [...] Zamiast zaciekłości przyszło zastraszenie, zamiast hartu, gestu wewnętrznego oporu - przekonanie, że „mogło być gorzej”. Przyszedł strach na zapas ${ }^{88}$.

Tadeusz odrzuca tę rewizjonistyczną wobec mitu bohaterskiego „wersję" wojennego doświadczenia. A przecież tragiczny, heroiczno-święty („i czwórkami do nieba szli..." ${ }^{89}$ ) obraz wojny "podszyty” był całą powszedniością okupacji, jej „„życiem na niby” (przyjmowaniem - jak tłumaczy ojcu Maciek - nieprawdziwego życia za jedyne prawdziwe). O tym - jakże często przemilczanym - rysie okupacyjnej rzeczywistości pisze Antonina Kłoskowska:

Zmiana trajektorii w Schütze'owskim sensie ${ }^{90}$, rozumiana jako wykolejenie, w szczególny sposób odbiła się na życiu części Polaków, często młodych, których przysto-

88 Kazimierz Wyka, Życie na niby. Pamiętnik po klęsce, Wyd. Literackie, Kraków 1984, s. 107, 286-287. O obowiązującym do dzisiaj jednostronnym sposobie oceny wojennej przeszłości, w której pozytywnie waloryzowane są wyłącznie czyny bohaterskie (straceńcze), pisze Lech Nijakowski: „Romantyczny kult bohaterów IV RP jest oczywiście ześrodkowany na powstaniu warszawskim jako centralnej figurze symboliczno-mesjanistycznej, fundującej wolność Polaków. Przelewając w powstaniu krew, składając ofiarę z życia pokolenia Kolumbów, Polacy potwierdzili, że są godni pełnej suwerenności. [...] Z kolei chwalebna decyzja o niewywoływaniu powstania w Krakowie zamienia się w tchórzliwą kapitulację". Zob. Lech Nijakowski, Polska polityka pamięci. Esej socjologiczny, Wyd. Akademickie i Profesjonalne, Warszawa 2008, s. 220.

89 Marta Piwińska, Legenda romantyczna i szydercy, PIW, Warszawa 1973, s. 258.

90 Tzn. jako „wydarzenie dramatyczne, wytrącające z normalnego biegu życia i dotkliwe w skutkach”. Zob. Antonina Kłoskowska, Kultury narodowe u korzeni, dz. cyt., s. 305. 
sowanie do warunków okupacji nie miało charakteru wyraźnego rozdziału między sferą prawdziwego życia i przejściowej „fikcji”, dotkliwej przez realne groźne naciski. Przymuszeni materialną koniecznością, wchodzili w świat okupacyjnego handlu, spekulacji, nierzadko w nieuniknionych kontaktach z Niemcami, zawsze nielegalnych i zagrożonych obozem lub śmiercią. [...] Czasami dawali się uwieść obrazowi niemieckiej potęgi [casus Jędrka] i z kategorii biernych narodowo przechodzili do kategorii aktywnych kolaborantów i narodowych odstępców ${ }^{91}$.

Has, kreśląc duchowy pejzaż miasta, w którym toczyło się okupacyjne życie, ukazuje - wzorem Wyki ${ }^{92}$ - nierozerwalny splot etyki i ekonomii: „odsłania podszewkę zjawisk, by uchwycić materialne, gospodarcze mechanizmy, produkujące masowo schizofrenię społeczną, gdyż jej przejawem jest przecież «życie na niby»"93. Wyka

nie obawiał się odsłonięcia tej nietragicznej prawdy o okupacji, jakkolwiek wiedział o tym, co trafnie zauważył Kijowski, że ciśnienie tradycji uczuciowej oraz swoistej estetyki historycznej "po prostu nie pozwoli szmuglowanego boczku uczynić symbolem okupacji, równorzędnym do brzozowego krzyża na bezimiennej mogile partyzanta" ${ }^{94}$.

Studium Wyki o „niemoralności pracy jako obowiązku patriotycznym" przełożone na narrację, w której odzwierciedla się konkretne doświadczenie jednostki to par excellence opowieść Maćka: ...każdy żył poniżej swojej wartości. Ambicja było nie mieć ambicji. Wkrótce okazało się, na przykład, że na nieróbstwie i handlu można zarobić wielkie pieniądze. I w drugim roku okupacji pieniądze budziły szacunek, pod warunkiem, że zarobione zostały w sposób niegodziwy. Idealnym towarem był ten, który po prostu wcale nie istniat. To „życie na niby" - upokarzająca egzystencja poniżej własnej wartości - odpowiadało całkowicie obcej Tadeuszowi „cywilnej” filozofii, która nakazywała zachowanie każdego życia za wszelka cenę $e^{95}$.

91 Tamże, s. 306. W analizie fenomenu „życia na niby” autorka odwołuje się właśnie do książki Wyki. Kłoskowska pisze: „Dla większości Polaków okupacja była sytuacją długotrwałego kryzysu wymagającego szczególnego rodzaju zewnętrznego przystosowania pod względem ekonomicznych, codziennych zachowań praktycznych i psychiki. Kazimierz Wyka określił tę formę bytu narzuconego przez ekstremalne warunki jako «życie na niby» toczące się «W ramach oficjalnie istniejącej rzeczywistości» i skrajnie przeciwstawne prawdziwemu życiu «zamykającemu się pośród swoich». [...] Pojęcie «życie na niby» stworzone przez krytyka i teoretyka literatury zostało szeroko spopularyzowane w interpretacjach okresu okupacji [...]" (tamże, s. 305-306).

92 Zob. Kazimierz Wyka, Gospodarka wyłaczona, [w:] tenże, Życie na niby, dz. cyt., s. $138-175$.

93 Maria Janion, Płacz generała, dz. cyt., s. 187-188.

94 Tamże, s. 189.

$95 \mathrm{Te}$ „prywatno-cywilną" opcję filozoficzną reprezentuje w literaturze polskiej Miron Białoszewski. Zdaniem Marii Janion Pamiętnik z powstania warszawskiego to próba radykalnego 
Manifestacyjny gest Tadeusza - gest odmowy uczestnictwa w rytuale okaleczonej pamięci - można potraktować również jako formę „zbawczej narracji” („narracyjnego fetyszyzmu”), uznawanej za jedną z możliwych strategii unikania konfrontacji z traumą. Zdaniem Katarzyny Bojarskiej:

Jest to tworzenie i posługiwanie się narracjami, w sposób świadomy bądź nieświadomy nastawionymi na zacieranie śladów traumy i utraty, które powołały je do życia. Zarówno narracyjny fetyszyzm, jak i przeciwstawiona mu praca żałoby stanowią odpowiedź na stratę, na przeszłość, która ze względu na swój traumatyczny charakter nie chce odejśćc ${ }^{96}$.

Maciek wypomina ojcu, iż to jego kombatanckie opowieści „wypaczyły" stosunek Jędrka do wojny. Wizualizacją tego przekonania są oniryczne partie filmu, w których Tadeusz - ubrany w zniszczony mundur z 1914 r. - towarzyszy małemu Jędrkowi ${ }^{97}$.

Co istotne, przeżycia Tadeusza są w dużej mierze zapośredniczone przez ściśle określony typ fikcji literackiej. Można domniemywać, iż bohater przekazywał Jędrkowi własne wspomnienia w formie ukształtowanej zgodnie ze schematem obowiązującym $\mathrm{w}$ literaturze patriotycznego frazesu, która krzepi cierpiący naród „Kmicicem z Zagłobą w Tobruku, Narwiku i w Warszawie" ${ }^{\prime \prime 8}$.

zakwestionowania romantycznego kanonu: „«Uratować, co się da i kogo się da» to też jest i postawa moralna, i historiozoficzna, tyle tylko, że zupełnie antyromantyczna. «Myśmy żyli. Wciąż» brzmi jak wyrzut, również wyrzut wobec historii". Elementarną potrzebę „przeżycia” odzwierciedla bezładne gorączkowe „miotanie się", stąd przekonanie, iż Pamiętnik... traktuje w istocie o fenomenologii ruchu cywilnego podczas powstania: „Cywilne trzymanie się ziemi - wyraźne w «lataniu» to [...] nędzna, tchórzliwa, płaska i cywilna ucieczka od śmierci". Braku akceptacji dla tego rodzaju postaw dowodzi gwałtowny atak, który - w myśl zasady, że każdy Polak powinien być powstańcem i każdym powinna kierować wola walki, a nie przetrwania - na autora Pamiętnika... przypuścił m.in. Wojciech Żukrowski (Mironek w powstaniu). Zob. Maria Janion, Wojna i forma, [w:] Literatura wobec wojny i okupacji, red. Michał Głowiński, Janusz Sławiński, Ossolineum, Wrocław 1976, s. 220-267.

96 Katarzyna Bojarska, Żałoba $i$ melancholia w "Tworkach", czyli na co badaczowi Zagłady freudowska psychoanaliza, [w:] Freud i nowoczesność, red. Zofia Rosińska, Universitas, Kraków 2009, s. 225.

97 Partie wizyjne przywodzą na myśl komentarze Clifforda Geertza dotyczące „świadectw" brytyjskich żołnierzy walczących na zachodnich frontach I wojny światowej. Geertz podkreśla zupełną nieadekwatność scenerii doświadczeń wojennych z tym, co budowało wyobraźnię wielu spośród tych, którzy się w tej scenerii śmierci znaleźli. Mamy tu do czynienia z sugestia, iż oto kultura, przejawiająca się w tym wypadku przez literacko (autor wskazuje tu na „literackość późnoromantyczną”) ukształtowaną wrażliwość i wyobraźnię, oferuje stosowne artykulacje i być może zrozumienie doświadczeń, gdy te odchodzą w przeszłość. Zob. Dorota Wolska, Odzyskać doświadczenie. Sporny temat humanistyki wspótczesnej, Universitas, Kraków 2012, s. 183-185.

98 Zob. Maria Janion, Wojna i forma, dz. cyt., s. 219. 
O wpływie literatury, która ukształtowała poglądy Tadeusza świadczy ostatnia scena filmu, rozgrywająca się w pokoju hotelowym. $\mathrm{Na}$ stoliku, tuż obok aparatu telefonicznego, widoczna jest przez chwilę okładka książki. Ulubioną - o czym świadczy lekko podniszczona obwoluta - lekturę Tadeusza stanowi antologia Men at War: The Best War Stories of All Time. Wydany po raz pierwszy w 1942 r. tomik zawierał przedmowę autorstwa Ernesta Hemingwaya (w zbiorze znalazły się również trzy inne quasi-autobiograficzne teksty pisarza). Zgromadzone w antologii opowiadania (począwszy od biblijnej historii Dawida i Goliata po literackie świadectwo bitwy o Midway) to zapis wojennych doświadczeń kilkudziesięciu pokoleń. Intencją autorów antologii, opublikowanej tuż po przystąpieniu Stanów Zjednoczonych do wojny, było wzbudzenie w społeczeństwie amerykańskim patriotycznego zapału. Propagowanie szczytnego celu, jakim była walka z nazizmem, oznaczało jednak rezygnację z tekstów stricte pacyfistycznych bądź demaskujących - przez drastyczność frontowych szczegółów (model „ekspresjonistyczny") - "romantyczną" utopię.

Podobną strategię przyjął wobec młodszego syna Tadeusz, o czym dobitnie świadczą pełne goryczy słowa Maćka: Ty mu opowiadałeś o tamtej wojnie, jakby to był najlepszy okres w twoim życiu ${ }^{99}$. Ten wzorzec (dla Maćka: antywzorzec) narracji aktualizować będą kolejne pokolenia. W narrację tę wpiszą się także (naznaczone wszakże tragiczną ironia, której brak zapewne w opowieściach Tadeusza) wojenne wspomnienia Chełmickiego, przywołane $\mathrm{w}$,"scenie spirytusowej” z Popiotu i diamentu (A jednak to były czasy... życie było fajne).

Zdaniem Marii Janion zmitologizowany stosunek pokolenia Tadeusza do I wojny światowej można jednak w pewien sposób zracjonalizować, odwołując się do specyfiki narodowych dziejów: „Polskie życie intelektualne i emocjonalne bowiem - co zupełnie zrozumiałe - skupiło się na odzyskanej niepodległości, którą przyniosła Polsce właśnie wojna i zrodzony z niej niepodległościowy czyn zbrojny. W tej sytuacji trudno było rozliczać się z wojną $[\ldots]^{\prime \prime 100}$.

99 Maria Janion podkreśla, iż w podobnej retoryce utrzymane były teksty zamieszczane w prasie międzywojennej: „«straszne frazesy», opiewając rasowość i rdzenność polskiego żołnierstwa, przechodziły pobłażliwie nad tragicznymi dylematami wojny, traktując pokój jako okres przygotowania do Wielkiej Przygody i do umierania za ojczyznę, co tak raduje żołnierskie serca. [...] Nie trzeba chyba się rozwodzić nad tym, że stosunek [...] do wojny został ukształtowany przez odpowiednie wzory literackie, zwłaszcza zaś przez Sienkiewicza i jego szkołę ułańskiego westernu". Zob. Maria Janion, Wojna i forma, dz. cyt., s. 194.

${ }^{100}$ Maria Janion, Płacz generała, dz. cyt., s. 31. 


\title{
Patriotyzm "westernowy"
}

Postawa Tadeusza wobec wojny (a raczej wojen) wpisuje się w głęboko zakodowany w zbiorowej świadomości ${ }^{101}-\mathrm{w}$ dużej mierze za sprawą Sienkiewiczowskiej szkoły - wzorzec „westernowy”.

\begin{abstract}
Mitologiczny komunał porządkuje rzeczywistość wojenną i okupacyjną według tego samego schematu [...]. W Polsce doświadczenie wojenne ciągle układało się i układa $\mathrm{w}$ ten sam romantyczny, przeważnie westernowy [...] wzór. [...] ujęcie westernowe nakładało się na [...] tradycyjny kult żołnierza, żołnierskości, żołnierskiej mentalności oraz bohaterskości i męskości, rozumianych jednoznacznie w kategoriach żołnierskich, to znaczy kierujących się przeciw cywilnej mięczakowatości i słabości, przeciw cywilnemu defetyzmowi i dekadentyzmowi $[\ldots]^{102}$.
\end{abstract}

Westernowy kanon został ufundowany na gruncie specyficznie rozumianej męskości. Zdaniem Gombrowicza wywodzący się z Sienkiewiczowskiej Trylogii wzorzec (,"cnota opieprzona grzechem, grzech ocukrzony cnotą"103) „,spowodował katastrofę naszego rozumu i zaszpuntował wyobraźnię tak, że wiek nasz przeżywaliśmy jak na innej planecie i niewiele z myśli współczesnej przenikało do nas" ${ }^{\prime 104}$. W ramach wspomnianego wzorca ${ }^{105}$ społeczną rolę mężczyzny - niezależnie od uwarunkowań historycznych

101 Taki doskonale zakonserwowany rezerwat przedwrześniowej „mentalności żołnierskiej” pokazał Munk w II części Eroiki. Roli Sienkiewicza w kształtowaniu narodowych postaw sporo uwagi poświęcił Gombrowicz w Dzienniku 1953-1956.

102 Maria Janion, Wojna i forma, dz. cyt., s. 217, 198.

${ }_{103}$ Witold Gombrowicz, Sienkiewicz, [w:] Dziennik 1953-1956, dz. cyt., s. 358.

104 Tamże, s. 352.

${ }^{105}$ Zauważmy, że Tadeusz wpisuje się także we wzorzec postulowany przez Andrzeja Trzebińskiego. Autorka monografii poświęconej twórczości głównego ideologa Konfederacji Narodu zwraca uwagę, iż wzór męskości propagowany w tekstach Trzebińskiego (m.in. w dzienniku i nieukończonej quasi-autobiograficznej powieści Kwiaty z drzew zakazanych) przypomina ideał „żelaznego mężczyzny” z Męskich fantazji Klausa Theweleita. Militarysta (szerzej: „żelazny człowiek”) czuje się zagrożony emocjami i afektami. „Nośnikiem” tego zagrożenia są głównie kobiety, które Theweleit nazywa uciążliwym dodatkiem do prawdziwego męskiego życia (w Szyfrach negatywny fantazmat „histerycznej kobiecości" realizuje się w postaci Zofii). Skuteczne zabezpieczenie może mężczyźnie zapewnić jedynie "długi proces samokontroli, samoobserwacji i dystansowania się do samego siebie. Chodzi o stłumienie afektów i budowanie sztywnych binarnych przeciwieństw. [...] Najważniejszym zadaniem «żelaznego mężczyzny» jest zniszczenie lub podporządkowanie sobie wszystkiego, co grozi przekształceniem go z powrotem [...] w człowieka słabego. [...] Celem jest utrzymanie rzeczywistości na dystans, bo tylko taki stan gwarantuje [...] bezpieczne życie". Zob. Elżbieta Janicka, Sztuka czy naród? Monografia pisarska Andrzeja Trzebińskiego, Universitas, Kraków 2006, s. 213-231. 
- pojmuje się w kategoriach służby żołnierskiej ${ }^{106}$. Gombrowicz dostrzegał anachroniczność tego wzorca skonfrontowanego z rzeczywistością kraju ulegającego po zakończeniu I wojny przyspieszonej transformacji społeczno-kulturowej:

Ze wszystkich kończących się po pierwszej wojnie środowisk, stylów, duchów, najwspanialej wykańczało się ziemiaństwo, duch szlachecki. Był to duch okazały, który wczoraj jeszcze rządził krajem, urobiony przez tradycję, polerowany przez literaturę, zawierający w sobie prawie wszystkie krasy polszczyzny. Jakim widowiskiem były męki szlagonów, dobrodusznych, poczciwych, zażywnych a ograniczonych, gdy wszystko zaczynało kurczyć się im w rękach i musieli stawić czoło nowoczesności zbrojni w garść truizmów z Weyssenhoffa i Sienkiewicza! 107

Wpajany w procesie edukacji patriotycznej wzorzec Sienkiewiczowski spotykał się ze sprzeciwem także ze strony części „postępowej” młodzieży. Czesław Miłosz wspomina:

w wieku piętnastu lat wkraczałem już w domenę sztuk, co oznaczało myśl postępową i wygłaszałem w szkole odczyty przeciw Trylog i i Sienkiewicza. [...] Widocznie już wtedy zacząłem czytać „Wiadomości Literackie” i poetów Skamandra, którzy do prawej strony sceny politycznej odnosili się wrogo. W każdym razie Sienkiewicz był wtedy papierkiem lakmusowym ${ }^{108}$.

${ }^{106}$ W Dzienniku pisarz zanotował: „Polakowi (w przeciwieństwie do rasy łacińskiej) nie wystarcza, że do pewnego stopnia jest on mężczyzną, chce on być mężczyzną bardziej niż jest [...]. I jeśli się zauważy, że historia zmuszała nas do życia wojskowego i wojowniczego, ów gwałt psychiczny staje się zrozumiały". Zob. Witold Gombrowicz, Dziennik 1953-1956, dz. cyt., s. 172.

Andrzej Kijowski zwraca uwagę, iż tak definiowaną „,wojowniczą” męskość znamionuje (bliski Gombrowiczowi) rys niedojrzałości. Byłaby to zatem męskość niepełna, "dzieckiem - i Sienkiewiczem - podszyta”. Ten typ męskości reprezentuje w Szyfrach Tadeusz, o którym Kijowski pisze: „Nie osiągnął w porę dojrzałości; doskonały świat męski, ukształtowany wedle chłopięcych marzeń i będący ich przedłużeniem, jest światem dziecinnym". Zob. Andrzej Kijowski, Szyfry, dz. cyt., s. 114.

Podążając tym tropem zadajmy pytanie, czy Tadeuszowi można by przypisać autorstwo umieszczonego w Ferdydurke listu (anonimowego podoficera "o wyjątkowo zmysłowej i lirycznej duszy”) do nowoczesnej pensjonarki, w którym czytamy: „Ślepa karność mnie obowiązuje. Na rozkaz muszę oddać życie. Jestem niewolnikiem. Wszak wodzowie zawsze mówią do nas - chłopcy, bez względu na lata. Nie wierz mej metryce, to szczegół czysto zewnętrzny, żona i dzieci to dodatek tylko, jam nie żaden rycerz, lecz chłopak wojskowy, z chłopięca, wierna, ślepą duszą [...]". Zob. Witold Gombrowicz, Ferdydurke, Wyd. Literackie, Kraków 1986, s. 151.

107 Witold Gombrowicz, Wspomnienia polskie. Wẹdrówki po Argentynie, dz. cyt., s. 40.

${ }^{108}$ Czesław Miłosz, Wyprawa w dwudziestolecie, Wyd. Literackie, Kraków 2011, s. 7-8. 
Do cierpienia i śmierci Jędrka nie przyczynił się zatem brak ojca, który w zdegradowanym świecie winien spełnić funkcję duchowego przewodnika. To właśnie ojciec wytworzył w młodszym synu zmitologizowany - Sienkiewiczowski - obraz wojny. Tadeusz byłby zatem kluczowym $\mathrm{w}$ procesie pierwotnej socjalizacji "znaczącym innym", narzucającym dziecku własną definicję (wojennej) rzeczywistości.

Ponieważ dziecko nie wybiera swych znaczących innych, jego identyfikacja z nimi jest quasi-automatyczna. Z tego samego powodu jego internalizacja ich konkretnej rzeczywistości jest quasi-nieunikniona. Dziecko nie dokonuje internalizacji świata jego znaczących innych jako jednego z możliwych światów. Internalizuje go ono jako Świat, jako jedyny istniejący i jedyny, jaki daje się pomyśleć, jako świat tout court ${ }^{109}$.

Obraz tego świata - w brutalnym zderzeniu ze „skarlałą" (niedającą się wpisać w romantyczny kanon tyrtejski czy straceńczy) krakowską okupacyjną codziennością - okazał się obrazem fałszywym.

Kluczem do podświadomości dziecka, w której zakodowany został obraz Tadeusza (ojca-winnego) są maniakalne rysunki ${ }^{110}$ Jędrka:

Twarz zawsze ta sama [...] tysiąc portretów ojca, tysiąc jego wcieleń we wszystkich uniformach, jakie przesunęły się przez ulice miasta. [...] Rysował wszystko, co widział, utrwalał ołówkiem, kredką, tuszem, farba, wszystkie postacie mężczyzny odzianego w kostium wojenny, wszystkim nadawał rysy ojca, jakby wojna była jego, Tadeusza, wyłącznym dziełem ${ }^{111}$.

Ale Maciek obarcza winą za „zakażenie” Jędrka wojenną gorączką nie tylko Tadeusza. Odpowiedzialna za los Kolumbów (i ich młodszych braci) wydaje się tradycja, za której sprawą dzieci od najmłodszych lat ulegały niebezpiecznej fascynacji „westernowym” obrazem wojny. Tak należy rozumieć oskarżenie sformułowane przez Maćka: A potem przygotowano go do tej wojny, która miała się dla niego stać życiem prawdziwym ${ }^{112}$. Z rozproszonych

${ }^{109}$ Peter L. Berger, Thomas Luckmann, Społeczne tworzenie rzeczywistości, tłum. Józef Niżnik, PWN, Warszawa 2010, s. 197.

${ }^{110} \mathrm{~W}$ interpretacji Andrzeja Kijowskiego to pierwszy prawdziwy strach przed śmiercią przeprowadza dziecko przez granicę człowieczeństwa. Rysunki Jędrka w symboliczny sposób odzwierciedlają ten "liminalny" stan istoty ludzkiej, postawionej w obliczu zagrożenia. Manifestująca się w rysunkach chłopca chorobliwa fascynacja wojną byłaby formą rekompensaty za życie w stanie nieustannej zależności od dorosłych. Zob. Andrzej Kijowski, Kompleks Dżyngis-Chana, [w:] Szósta dekada, PIW, Warszawa 1972, s. 87-88.

${ }^{111}$ Andrzej Kijowski, Szyfry, dz. cyt., s. 184-185.

${ }^{112}$ Jako komentarz do wypowiedzi Maćka dotyczącej edukacji patriotycznej w Polsce międzywojennej mógłby posłużyć fragment Dzienników czasu wojny Zofii Nałkowskiej: „Pozwoliliśmy na kultywowanie głupoty i frazesu, na kultywowanie niewiedzy i chro- 
w filmie wypowiedzi Maćka wyłania się - jakby na marginesie głównego wątku - Gombrowiczowskie rozumienie inicjacji jako procesu przyswajania przez jednostkę ,języka tajemnicy":

społeczeństwo tworzy coś w rodzaju „wspólnej klatki” utkanej z przeświadczeń powszechnych, z obowiązującej ogólnie ideologii, wyznaczającej semantykę każdego zjawiska. Powstaje coś, co Gombrowicz nazywa "językiem tajemnicy". Proces wychowania, akulturacji jednostki polega na uczeniu się tego „języka", dojrzałość - na internalizacji stereotypów ${ }^{113}$.

Warto przy tym zauważyć, iż zdaniem Gombrowicza ,język tajemnicy" może być językiem całej wspólnoty (np. narodowej), ale także idiolektem kodem porozumiewania się specyficznym dla pewnej społeczności:

W obrębie grupy jednostek, związanych wspólnymi poglądami na świat, wspólną „,ideologią", funkcjonuje [...] ,,język tajemnicy”, czyli zbiór stereotypowych haseł wywoławczych o hermetycznej wykładni ${ }^{114}$.

W Szyfrach taką społecznością, posługującą się hermetycznym i całkowicie niezrozumiałym dla przybysza z zewnątrz językiem, byłby krąg ludzi związanych z „konspiracją", a w szerszym, symbolicznym znaczeniu - ci wszyscy, na których nie zaciążył kompleks nieuczestnictwa. Funkcję „ideologii” spełniałoby w tym wypadku zbiorowe doświadczenie wojny i okupacji. W efekcie „internalizacji stereotypów”, o którym pisał Gombrowicz, zbiorową ofiarę poniosło całe pokolenie Maćka:

Nowe dzisiaj Hamlety. - Dom. - Dzieci. - Kobieta. -

[...] „Mój synu - mówi matka - ho, to twój ojciec z bronią

walczył za świętość naszą i zdobył się na czyn..."

[...] Mój ojciec był bohater, a my jesteśmy nic! ${ }^{115}$

nienie jej, i strzeżenie niby skarbu. Ukrywano prawdziwy stan rzeczy, odgradzano ludzi dorosłych od rzeczywistości, lekceważono i tępiono tych, którzy myśleli inaczej. [...] Trudno było czytać gazety bez obrzydzenia, nie można było słuchać radia. Pamiętam tę ankietę «Polski Zbrojnej» na temat literatury dla żołnierzy. [...] Straszne frazesy Rembeka w tej ankiecie, frazesy Szczuckiej [...]. Kult głupoty i nieszczerości, kult uczuć wmówionych". Zob. Zofia Nałkowska, Dzienniki czasu wojny, Czytelnik, Warszawa 1970, s. 75-76. Odnotujmy, iż po 1945 r. krytyka wzorca edukacji patriotycznej obowiązującego w okresie II Rzeczpospolitej stała się jednym z wiodących wątków w dyskursie politycznym. Znalazło to swoje odzwierciedlenie w sferze kultury (za przykład reprezentatywny dla nurtu obrachunków wrześniowych Andrzej Werner uznał m.in. powieść Bohater do wynajęcia Tadeusza Kwiatkowskiego z 1956 r., w której „wątek edukacyjny" jest bardzo silnie eksponowany).

${ }^{113}$ Jerzy Jarzębski, Gra w Gombrowicza, dz. cyt., s. 142.

114 Tamże, s. 221.

${ }^{115}$ Stanisław Wyspiański, Wyzwolenie. Noc listopadowa, dz. cyt., s. 155. 
Starszy syn Tadeusza zorganizował w mieszkaniu skrzynkę kontaktową podziemnej organizacji, a po jej rozwiązaniu - jak nakazywał rycerski etos - „poszedł do lasu”. Mimo upływu lat nie potrafił uporać się z wojenną traumą i odnaleźć w "cywilnym” życiu (tę niemożność potęguje z pewnością obsesyjnie kultywowana przez matkę pamięć o zaginionym bracie). Żyje w czasie minionym i w świecie, będącym tylko chwilową umową jak okupacja, która uświęciła przestępstwo i mistyfikację ${ }^{116}$.

Obraz wojny i okupacji, jaki wyłania się z relacji Maćka i doktora Grossa ${ }^{117}$, to rzeczywistość zdegradowana - świat pozoru, w którym niewiele znaczący ludzie zyskiwali nieśmiertelną sławę:

116 Andrzej Kijowski, Szyfry, dz. cyt., s. 94.

117 Ta postać - o marginalnym (z pozoru) znaczeniu w filmowej diegesis - wydaje mi się bardzo interesująca. Zasymilowany w powojennej rzeczywistości doktor Gross - należący przecież do „pokolenia Chełmickich” - może być paradygmatycznym przykładem zdolności do przepracowania (wojennej) traumy. Wspomina o tym fenomenie Maria Janion: „,kiedy nauczyciel tuż po wojnie chciał przeprowadzić na lekcji spór między pozytywistami a romantykami, klasa miała podzielić się na dwie części - jedni mieli być pozytywistami, a drudzy romantykami - to nikt z klasy, z tych dzieci, nie chciał być romantykiem. Bo to było po klęsce Powstania Warszawskiego. [...] Wszyscy chcieli być pozytywistami. Myślę, że to bardzo dobrze oddaje ogólny nastój, przede wszystkim emocjonalny, ale intelektualny również, tego naszego nastawienia, poszukiwania sposobu na życie". Zob. Pokój i socjalizm, czyli wygnanie i przemoc, rozmowa z Marią Janion, Warszawa, 19 września 1981, [w:] Jacek Trznadel, Hańba domowa, dz. cyt., s. 93. Dodajmy, że motyw wojennej traumy jako usprawiedliwienia "ukąszenia heglowskiego" pojawia się w wielu wypowiedziach twórców kultury zanotowanych przez autora Hańby domowej.

Ze zdecydowanym sprzeciwem wobec tego typu rozumowania wystąpił Witold Gombrowicz. Zdaniem Gombrowicza - pisze Paweł Śpiewak - „nie ma mowy o czarownym uwodzeniu intelektualistów przez Nową Wiarę. Nie ma i nie było żadnego «ssania absurdu». [...] Powiada w Dzienniku, że wojna zastała ich (inteligentów czy intelektualistów), «przewróconymi, ogłupiałymi, wypróżnionymi», ogłuszonymi. Polscy pisarze, jak i przeciętny polski inteligent, nie potrafili przeżyć koszmaru wojny do dna. [...] Zamiast tego pojawiły się konwencjonalne sformułowania o tym, że trzeba, że powinno się wyciągnać z «wielkiego» przeżycia wielką naukę [...]". Zob. Paweł Śpiewak, Pamięć po komunizmie, dz. cyt., s. 205-206. Jest to istotny wątek w debacie „rozliczeniowej” z lat 90. Pojawiły się wówczas głosy (m.in. pisał o tym ks. Józef Tischner), iż: „Powinniśmy również zastanawiać się [...] czy ocena przeszłości ma się dokonywać wedle miar nam współczesnych (wiedząc ex post, czym był komunizm i jak się zakończył), czy też mamy osądzać poszczególne wydarzenia wyłącznie z perspektywy historycznej [...]. Trzeba więc poznać czas, motywy kogoś, kto wstępował do partii komunistycznej. [...] A zrozumienie zawsze wymaga tego, by uchwycić doświadczenie konkretnych osób, pojąć czas i okoliczności ludzkich decyzji" (tamże, s. 178).

(Przeżywany przez Janion dylemat powraca jako temat refleksji w esejach Kijowskiego. Krytyk, analizując światopogląd generacji, której okres dojrzewania przypadł na lata wojny, nazywa go „pozytywistycznym frazesem”: „Tego, co pojęło ciało Polaka naznaczone plagami wojny totalnej, duch jego do dziś pojąć nie może. Z historii wojny ułożył sobie romantyczny dramat i zamknął go prowincjonalną pointą: rozpoczął nowe życie w nowej epoce z pozytywistycznym frazesem na ustach". A w innym miejscu pisze: „Druga wojna światowa była ideowym zwycięstwem lewicy. Zwycięstwo 
Jakiś Kruk albo Sęp, albo Jurand, albo Kmicic, albo Krak, w więc ktoś z literatury czy baśni, ktoś bezimienny, kto na czas wojny przybrał imię heroiczne i drapieżne, i taką postać przybrał, a dzisiaj znowu nazywa się Marian czy Zygmunt, jest lekarzem, urzędnikiem, leśniczym, chłopem, dróżnikiem kolejowym, księdzem, może jest kobietą która nazywa się Grażyna... ${ }^{118}$

Ironiczny monolog Tadeusza stanowi potwierdzenie szerszego zjawiska. W uformowany pod wpływem Sienkiewicza ${ }^{119}$ model patriotyzmu

to inaczej przedstawiało się na planie politycznym, inaczej na planie intelektualnym. Wśród lewicy intelektualnej pokutowały anachroniczne schematy. W rozgrywce ideowej posługiwała się analogią historyczna, przy czym głównym zasobem jej doświadczenia historycznego były dzieje XIX wieku, opracowane przez klasyków. Nieprzypadkowo cały wysiłek skierowany został na przewartościowania historyczne i literackie, nieprzypadkowo lewica szukała argumentów w filozofii oświecenia [...]. Mam na myśli przede wszystkim «Kuźnicę» i jej epigonów. Zamiast studiować współczesność we wszystkich jej niejasnych przejawach, intelektualiści z kręgu «Kuźnicy» wdali się w polemikę, która była dokładnym prawie przedłużeniem polemiki tradycyjnej: bohaterszczyzna czy praca organiczna [...]". Zob. Andrzej Kijowski, Narodziny frazesu oraz Pokłońmy się ideom martwym, [w:] Szósta dekada, dz. cyt., s. 218, 242).

Powojenną działalność Grossa można by uznać za rodzaj „pozytywistycznej pracy u podstaw” (zauważmy, że w „inteligenckim” Krakowie pacjentkami doktora Grossa są „,wiejskie baby”). Ta interpretacja wymaga jednak koniecznego uzupełnienia. O poziomie komplikacji postaci Grossa (i fiasku „strategii wyparcia”) świadczy bowiem fakt, iż to tę postać czyni Has „nośnikiem” bohaterskiego mitu Mariana - mitu, o jednoznacznie romantycznym rodowodzie.

118 Andrzej Kijowski, Szyfry, dz. cyt., s. 172-173.

119 Pod przemożnym wpływem tego wzorca pozostawała polska literatura wojenna. W krytycznym omówieniu opowiadań Wojciecha Żukrowskiego Z kraju milczenia, opublikowanych w 1946 r. Wilhelm Mach podkreślał: „Gdyby w tej wojnie nie czołgi i karabiny maszynowe - byłaby to jakaś dawna romantyczna wojna, taka, w której słychać brzęk szabel Skrzetuskich i Wołodyjowskich - o ile nie dawniejsza”, zaś Kazimierz Wyka wspominał o „barokowym sarmatyzmie przenikniętym zawsze krzepką żołnierskościa, prostą wiarą i zaufaniem do Boga, który Polskę z najgorszych opresji wyprowadzi". W tym samym paradygmacie literatury rycersko-konsolacyjnej należy umieścić Hubalczyków Melchiora Wańkowicza, w których „autor samym sposobem zapisu (nazwijmy go Sienkiewiczowskim) uwodzi czytelników, bez większego zachodu zresztą - naśladując tylko największego może uwodziciela wśród pisarzy polskich, jakim był Sienkiewicz". Zob. Maria Janion, Płacz generała, dz. cyt., s. 145-151. Należy jednak wziąć pod uwagę, iż nie był to w czasie wojny wzorzec jedyny. Kłoskowska, zwracając uwagę na niejednolity charakter konspiracji, podkreśla: „Własne potrzeby i kryteria oceny elitarnych kręgów ruchu oporu były w dziedzinie estetycznej równie selektywne i wysublimowane, jak w dziedzinie moralnej. Jan Strzelecki i przywódcy Szarych Szeregów odwoływali się w swej osobistej refleksji do Norwida i Brzozowskiego raczej niż do Sienkiewicza". Zob. Antonina Kłoskowska, Kultury narodowe u korzeni, dz. cyt., s. 315.

Interesującym przyczynkiem do dyskusji nad społecznym znaczeniem tradycji sienkiewiczowskiej może być analiza tekstów literackich sytuowanych w obrębie polskiego dyskursu postzależnościowego. W tym korpusie tekstów mieści się powieść Krfotok (1998) Edwarda Redlińskiego, w której - na co zwraca uwagę Przemysław Czapliński 
doskonale wpisywały się powszechne w czasie wojny ${ }^{120}$ praktyki konspiracyjne:

Lektura Trylogii Sienkiewicza - pisze Kłoskowska - kształtowała w wielu pokoleniach postawy wobec własnej grupy narodowej i ojczyzny jako wartości. Nazwiska Sienkiewiczowskich bohaterów przybierane jako pseudonimy przez młodzież okresu okupacji wskazują na związek tej lektury z udziałem w walce - szczególnie dramatycznej postaci działania społecznego ${ }^{121}$.

Zdiagnozowany przez Tadeusza mechanizm narodowego mitotwórstwa doskonale ilustruje historia Mariana ${ }^{122}$ opowiedziana przez doktora Grossa. Niczym niewyróżniający się przed wojną kuzyn Zofii (sympatyczny

- pojawiają się „Kmicice z «Solidarności» i Kmicice w sutannach”: „watażkowie i wąsate nieroby, pseudopatrioci, frenetyczni kochankowie ojczyzny, ścigający się "nie o życie, ale o sławną śmierć»". Zob. Przemysław Czapliński, Języki niezależności. Jak jest artykułowana w literaturze niepodległość odzyskana przez Polskę w 1989?, [w:] Kultura po przejściach, osoby z przeszłościa, dz. cyt., s. 48-49.

${ }^{120}$ Kijowski przyjmuje znacznie szerszą perspektywę. Esej Sienkiewicz i polska nerwica stanowi eksplikację tezy, wedle której całe życie ideowe w Polsce naznaczone jest stygmatem sienkiewiczowskim. Żywotność Sienkiewiczowskiego wzorca widoczna jest zwłaszcza w momentach politycznych i kulturowych przełomów: „Przychodzą jednak wydarzenia wewnętrzne lub zewnętrzne, które kładą kres wysiłkom, odbierają energię twórczą strach albo przymus łamią reformatorów, czy też doświadczają oni poczucia samotności w zbyt rozległej przestrzeni kulturalnej i tracą związek z podłożem, więc wracają do niego, wkopują się w glebę rodzimą, aby się w niej oczyścić, aby w niej spocząć. [...] Każda kultura ma swoją sferę idealna, do której odwołuje się w momentach wyczerpania. [...] W dziejach polskiej literatury nie ma epoki, którą wszystkie pokolenia zgodnie uznałyby za klasyczną; zamiast narodowej klasyki mamy arkadyjski mit swojszczyzny". Zob. Andrzej Kijowski, Sienkiewicz i polska nerwica, [w:] Granice literatury. Wybór szkiców krytycznych i historycznych, t. I, Biblioteka „Więzi”, Warszawa 1991, s. 239-240.

${ }^{121}$ Antonina Kłoskowska, Socjologia kultury, Wyd. Naukowe PWN, Warszawa 1983, s. 427. W dalszej części wywodu Kłoskowska dowodzi niezwykłej żywotności Sienkiewiczowskiego wzorca. Potwierdzenia tego fenomenu należy poszukiwać na obszarze kina popularnego, odwołującego się do doświadczenia wojennego: „Bohaterowie Sienkiewicza i pokrewne im postacie filmów poświęconych drugiej wojnie światowej i okupacji sięgają do wspólnej tradycji bohatera nie pozbawionego, przy swej odwadze, męstwie i poświęceniu, pewnej ambiwalencji nieobcej postaciom romantycznym, ale właściwym także i typom współczesnej światowej kultury masowej. Na podstawie analizy treści przekazów można stwierdzić, że bohater typu Kmicica lub kapitana Klossa [...] może być ujmowany zarówno jako reprezentant wartości narodowych, jak i wątków zbliżonych do fabuły popularnych utworów kultury masowej, prezentujących schemat pozornie złego, w istocie szlachetnego bohatera i operujących tą ambiwalencją dla wzmocnienia zainteresowań odbiorców” (tamże, s. 471-472). Nie wnikając w dyskusyjną kwestię „wartości narodowych" Klossa, warto zwrócić uwagę na podkreślany przez socjologa fakt, iż „Sienkiewiczowski wzorzec" bohatera wojennego to korelat elementów wywiedzionych z polskiej tradycji romantycznej i pochodzących spoza rodzimej kultury (,,western”).

122 Zwraca uwagę symboliczna zbieżność imion. Kuzyn Zofii nosi imię generała Langiewicza - bohatera z okresu powstania styczniowego - o którym mimochodem wspomina Maciek podczas wizyty w Gorczy. 
głuptasek, który rozśmieszał Zofię swoimi błazeństwami) podczas okupacji stał się herosem z narodowego panteonu. Dzięki niemu - jak stwierdza lekarz to, co robiliśmy, nabierało jakiejś wartości, jakiegoś uroku. Może potrzebowaliśmy bohaterów i stworzyliśmy go sami na miarę naszych pragnień. Nie wiem... Dowodzi to tylko jednego - byt dla nas niezbędny.

O sile oddziaływania stereotypu nieśmiertelnego bohatera świadczy fakt, iż Gross mylnie interpretuje scenę śmierci Mariana (Tadeusz zarzuca doktorowi kłamstwo, wydaje się jednak, iż lekarz kreuje tylko „odpowiednią" dla mitu bohaterskiego wersję zdarzeń, w której nie mieści się przypadkowy strzał w plecy - w rzeczywistości Marian zginął podczas próby ucieczki po zatargu z Jędrkiem). Gross, mimo krytycznej świadomości, pozostaje strażnikiem zmitologizowanych wyobrażeń przeszłości:

Gross: Jeżeli tamte czasy maja dla mnie jakaś wartość, zawdzięczam to tylko Marianowi. [...] Tadeusz: Dlaczego mi pan mówi teraz o Marianie?

Gross: Aby pana przekonać, że nie mógł zginać!

I znów - jak w Pornografii - zaleciało teatralną sztampą patriotycznej konspiracji... ${ }^{123}$

Z urywków relacji, wspomnień, półprawd i zmyśleń rodzi się Gombrowiczowska wizja wojny. Okupacyjny terror, choć nieustannie odczuwalny (kulminacją jest aresztowanie Jędrka), wydaje się zaledwie tłem dla „historii prywatnej”.

W Pornografii akcja koncentrowała się wokół perwersyjnej gry, prowadzonej przez podstarzałych podglądaczy „w cieniu krematoryjnych pieców" (przypomnijmy, iż przedstawione zdarzenia rozgrywają się w 1943 r.). W Szyfrach badawcze spojrzenie Tadeusza ujawnia skomplikowane relacje w obrębie erotycznego układu, w który uwikłani są wszyscy członkowie rodziny.

I tu podąża Has śladami Gombrowicza, w którym krytycy widzieli autora opętanego obsesją demaskowania podszewki rodzinnych rytuałów ${ }^{124}$. Działania Gombrowiczowskich bohaterów prowadziły w efekcie do dekonstrukcji mitu ,"szlacheckiego gniazda" ${ }^{\prime 25}$, u Hasa celem ataku staje się tradycyjna rodzina mieszczańska (choć o wyraźnie zasugerowanym szlacheckim - jak dowodzi tego jedna z wizji - rodowodzie). W utworach

${ }^{123}$ Witold Gombrowicz, Pornografia, dz. cyt., s. 101.

${ }^{124}$ Jerzy Jarzębski, Gra w Gombrowicza, dz. cyt., s. 399. O fundamentalnym znaczeniu tematu rodzinnego w twórczości Gombrowicza pisze w swej monografii Agnieszka Kowalczyk. Zob. Agnieszka Kowalczyk, Rodzina jako źródło cierpień w twórczości Witolda Gombrowicza, dz. cyt.

125 Wyjątkiem od tej reguły jest m.in. małżeńskie stadło Filipa z opowiadania Na kuchennych schodach, a przede wszystkim rodzina Młodziaków z Ferdydurke. 
Gombrowicza destrukcja ${ }^{126}$ rodziny jest wynikiem celowych i świadomych działań bohatera (i/lub jego ",sobowtóra”). W Szyfrach zauważalny jest brak aspektu sprawczego działań Tadeusza, który przebieg podszytego perwersją rodzinnego dramatu jedynie "rekonstruuje”. Wydaje się również, iż wyłącznym celem Hasa nie było instrumentalne wykorzystanie języka "dramatu rodzinnego". Has nie dąży bowiem do nadmiernej uniwersalizacji rodzinnej opowieści, tj. do uczynienia z niej - wzorem Gombrowicza - modelu objaśniającego dynamikę dziejów, ewolucję systemów wartości, obyczajów, struktur socjalnych, politycznych ${ }^{127}$ (choć ten wątek jest oczywiście w filmie obecny).

W Pornografii i Szyfrach tragedia rodzinna z czasów okupacji to w istocie groteskowy korowód „pomst, ucieczek i zdrad”, naśladujący ostentacyjnie banalny wzorzec melodramatu: „układali ulotki, dzielili gazetki, dawali sobie instrukcje, potem pili wódkę, potem patrzyli po sobie, myśląc, kto kogo zdradza, kto kogo opuszcza. Marian, Zofia, Maciek, ta dziew-

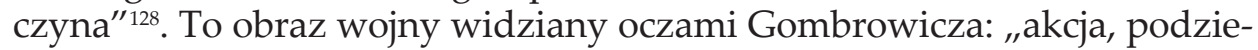
mie, wódz, konspiracja - jak z kiepskiego romansu"129. Has nie aktualizuje w filmie romansowego wzorca. A jednocześnie wskazuje na potencjalnie tkwiące w samej rzeczywistości zagrożenie. Poskładana z fragmentów wspomnień okupacyjna opowieść z łatwością mogłaby się przekształcić na ekranie $\mathrm{w}$ „kinematograficzny mit"130 - stać się historią w podwójnym znaczeniu (jako res gestie, czyli całokształt zeszłych wydarzeń i rerum gestarum, czyli tekst narracyjny ${ }^{131}$ ) „zainfekowaną” melodramatycznym wirusem.

${ }^{126}$ Warto jednak zauważyć, iż charakterystyczna dla Gombrowicza ambiwalencja wobec Formy przejawia się także w dyskursie rodzinnym. Dla przykładu, w Trans-Atlantyku nie dochodzi do postulowanego aktu ojcobójstwa (czyli zastąpienia Ojczyzny Synczyzną), zaś horror zostaje w finale „rozbrojony” oczyszczającym śmiechem, którego apologetyczna funkcja wobec rodzinno-patriotycznego rytuału przywodzi na myśl słynne „Kochajmy się” Pana Tadeusza. Zob. Jerzy Jarzębski, Gra w Gombrowicza, dz. cyt., s. 432.

127 Tamże, s. 377.

128 Andrzej Kijowski, Szyfry, dz. cyt., s. 186-187.

129 Witold Gombrowicz, Pornografia, dz. cyt., s. 88.

130 Takim określeniem posłużył się Jurij Łotman w tekście poświęconym wpływom sztuki filmowej na rozumienie i percepcję historii. Na przykładzie filmu SVD (1927) Kozincewa i Trauberga autor wykazuje, w jaki sposób dokonuje się świadoma i konsekwentna translacja zdarzeń z przeszłości na język melodramatycznych sztamp. Kod gatunkowy staje się pryzmatem, w którym załamuje się materiał historyczny. Co jednak wydaje się najistotniejsze, Łotman podkreśla, iż w wypadku analizowanego filmu wybór tego akurat gatunku został podyktowany jego adekwatnością w stosunku do rzeczywistości historycznej: „Historia dekabrystów została opowiedziana w języku kinematograficznego mitu, dlatego że w samej istocie ruchu dekabrystów uwidoczniała się naiwność «sentymentalnej gorączki» kinematografu". Zob. Bogusław Żyłko, Przedmowa tłumacza, [w:] Boris Uspienski, Historia i semiotyka, tłum. Bogusław Żyłko, słowo/obraz terytoria, Gdańsk 1998, s. 12-13. Do tej kwestii powracam w rozdziale poświęconym Poznaniowi 56 (zob. "Walka z komunizmem” jako (Kunderowski) kicz).

131 Tamże, s. 20. 
A przecież wpisując skomplikowany miłosny wątek w narrację o doświadczeniach II wojny, Has nie tyle konfrontuje „mit Podziemia” z okupacyjną rzeczywistością "jak z kiepskiego romansu", ile upomina się o pamięć „pękniętą". W myśl zasady: tak (też) bywało...

Odnotujmy jednak, że melodramatyczny wzorzec ujawnia się w Szyfrach nie tylko w skali makro (na poziomie struktury organizującej rozproszone sensy dzieła), lecz również w skali mikro - na poziomie struktury organizującej percepcję. Dla przykładu, tryb pracy wyobraźni Tadeusza uformowanej przez spetryfikowany kod melodramatu, można zrekonstruować na podstawie sceny rozgrywającej się w krakowskiej kawiarni. Tadeusz, zaintrygowany głosem w słuchawce telefonicznej, umawia się na spotkanie z nieznajomą. W zatłoczonym lokalu jego wzrok zatrzymuje się na atrakcyjnej, elegancko ubranej damie, która stanowi standardowe wyobrażenie femme fatale (bohater najwyraźniej podejrzewa, iż anonimowy głos należał do Jadwigi - kobiety, która odebrała Mariana Zofii i po części przyczyniła się do śmierci Jędrka). Zawiedziony w swych oczekiwaniach, z wyraźnym rozczarowaniem odkrywa, iż Jadwiga to nieefektowna brunetka w ortalionowym kapelusiku.

Szyfry byłyby zatem... „nieudaną tragedią”? Uwikłaną w (melodramatyczną) "niższość" opowieścią o niezłomnych bohaterach (Marian) i bezbronnych ofiarach (Jędrek)? Agnieszka Morstin-Popławska pisze:

Kreując postać Jędrka - nieobecnego chłopca-zagadki, którego istnienie pochłonęła wojna - Has zdołał stworzyć przekaz naruszający (w sposób delikatny, ale jednak wystarczająco widoczny) kulturowe tabu mówienia o dziecięcym doświadczeniu zła, które nie tylko czyni z dziecka ofiarę, ale także głęboko wpływa na jego psychikę i duchowość. Jeśli bowiem traktujemy dziecko jako podmiot w pełni autonomiczny, to nie możemy zanegować jego zdolności do otwarcia się na doświadczenie zła, w konfrontacji z którym nie zawsze jest ono tylko niewinną ofiara, ale czasem bywa także zdumiewająco pojętnym uczniem, by innym razem stać się i jednym, i drugim ${ }^{132}$.

\section{Szyfry jako... „romans kryminalny”}

Poszukując chłopca-zagadki Tadeusz zmuszony jest zająć pozycję śledczego, próbującego roz-szyfrować hermetyczną rzeczywistość. Wzorem sędziego z Gombrowiczowskiej Zbrodni z premedytacja spełnia zarazem funkcję katalizatora, który odkrywa kłębowisko kompleksów i perwersji przelewające się pod cienką powłoką życia rodzinnego (w obu tekstach realizowany jest podobny "schemat inwersji”: zamiana stereotypu żałoby na stereotyp śledztwa) ${ }^{133}$.

\footnotetext{
${ }^{132}$ Agnieszka Morstin-Popławska, Jak daleko stąd do raju? Religia jako pamięć w polskim filmie fabularnym, Universitas, Kraków 2010, s. 198.

${ }^{133}$ Jerzy Jarzębski, Gombrowicz i panny, [w:] tenże, Podgladanie Gombrowicza, dz. cyt., s. 74.
} 
Tadeusz to typowy bohater Gombrowiczowski, zabłąkany w świat obcych symboli. Niczym bohater Kosmosu błądzi w mrocznym labiryncie bez wyjścia, gubiąc się nie tylko w chmarze obiektów, ale też w swych iluzjach, rojeniach, projekcjach ${ }^{134}$. W „romansie kryminalnym” (kwalifikacja gatunkowa autorstwa Gombrowicza) pojawia się sobowtór Tadeusza: „kantowski podmiot detektywa-winnego, więźnia zjawisk, wśród których próbuje on odczytać znaki"135.

Teoretycy literatury wielokrotnie zwracali uwagę na predylekcję Gombrowicza do gier prowadzonych w oparciu o skonwencjonalizowane reguły gatunkowe.

Jednym z chętniej wykorzystywanych przez pisarza gatunków literackich była powieść detektywistyczna, do której nawiązania pojawiają się już w debiutanckim Pamiętniku z okresu dojrzewania. Gatunek z obszaru kultury popularnej, który pisarz wybiera dla przeciwstawienia się sztuce wysokiej, to jedna z owych „starych landar"136 pozwalających - pod pozorem gry ${ }^{137}$ - przemycić do tekstu „kontrabandę" filozofii i odsłonić wzajemną ontologiczną relatywność faktów i ról człowieka, kształtujących się niejako na naszych oczach, a pozbawionych bytu absolutnego i niewątpliwego ${ }^{138}$.

Elementy typowe dla powieści detektywistycznej odnaleźć można również w heterogenicznej strukturze Pornografii. Zdaniem Michała Legierskiego

Krótki czas (około dziesięć dni) i wyizolowane od reszty świata miejsce akcji sugerowałoby, że Pornografia jest powieścią kryminalną. Ale trop ten prowadzi na manowce,

${ }^{134}$ Michał Legierski, Modernizm Witolda Gombrowicza, Instytut Badań Literackich PAN, Warszawa 1999, s. 210.

${ }^{135}$ Jean-Pierre Salgas, Witold Gombrowicz lub ateizm integralny, dz. cyt., s. 203.

${ }^{136}$ Schemat „kryminalnego romansu” w Zbrodni z premedytacja pod względem funkcjonalnym stanowi odpowiednik schematu „dobrodusznej polskiej powieści wiejskiej”, na którym wzorowana jest Pornografia. W rozmowie z Dominikiem de Roux Gombrowicz stwierdza: „Posługuję się formami klasycznymi, bo są najdoskonalsze i do nich czytelnik się przyzwyczaił. Ale proszę nie zapominać - ważne - że u mnie forma jest zawsze parodią formy. Posługuje się nią, ale umieszczam się poza nią. Tak, coraz bardziej szukam powiązania pomiędzy tymi dawnymi, czytelnymi, gatunkami literackimi a możliwie najświeższym, najnowszym przeżyciem świata. Przewozić najaktualniejszą kontrabandę takimi landarami, jak Trans-Atlantyk lub Pornografia, to mi odpowiada!". Zob. Witold Gombrowicz, Testament. Rozmowy z Dominique de Roux, Wyd. Literackie, Kraków 1996, s. 141.

${ }^{137}$ Dla przykładu, w Zbrodni z premedytacja Gombrowicz doprowadza do absurdu wnioskowanie zgodne z logiką detektywistycznego schematu („,śledztwo zakończone wskazaniem sprawcy"), czego dowodem jest finałowe uduszenie trupa ex post.

${ }^{138}$ Kazimierz Bartoszyński, O nieważności "tego, jak było naprawdę", [w:] Gombrowicz i krytycy, dz. cyt., s. 391. Wielu interpretatorów podkreślało, iż już we wczesnym opowiadaniu Gombrowicza Zbrodnia z premedytacja intryga kryminalna jest zaledwie pretekstem dla rozwinięcia traktatu psychologiczno-moralnego, o czym świadczą m.in. liczne odwołania do Zbrodni i kary Dostojewskiego. 
brak tu zagadki (wiadomo, kto i dlaczego popełnia zabójstwa), nie ma też detektywistycznej gry, jak tego wymagają reguły gatunku ${ }^{139}$.

Schemat powieści detektywistycznej służy pisarzowi na ogół do ujawniania reguł tekstotwórczych. Paradygmatycznym przykładem stosowanej przez Gombrowicza strategii jest opowiadanie Zbrodnia z premedytacja, w którym

wieloznaczność wynika z zastosowania poetyki onirycznej: wydarzenia fabularne przepływają niczym obrazy marzenia sennego. Zarówno one, jak i dwugłosowa narracja każą nam przejść do satyry menippejskiej, w której zawsze, w większym lub mniejszym stopniu, mamy demaskowanie środków wyrazu, chwytów i motywów, konstytuujących utwór ${ }^{140}$.

$\mathrm{O}$ ile $\mathrm{u}$ Gombrowicza ironiczne wypowiedzi bohatera-narratora (wspomniana „dwugłosowa narracja”) ujawniają dystans postaci nie tylko do przyjętej/narzuconej „roli” detektywa ${ }^{141}$, lecz także wobec samej sytuacji dramaturgicznej śledztwa, a samo śledztwo toczy się zawsze w duchu powagi-śmiechu, o tyle w Hasowskich Szyfrach przeważa tonacja elegijna.

Has wykorzystuje schemat powieści detektywistycznej, którym z takim upodobaniem posługiwał się Gombrowicz ${ }^{142}$. Rekonstrukcja faktów

${ }^{139}$ Michał Legierski, Modernizm Witolda Gombrowicza, dz. cyt., s. 56.

${ }^{140}$ Tamże, s. 244.

${ }^{141} \mathrm{~W}$ Zbrodni z premedytacją „wewnętrzne pęknięcie perspektywy narracyjnej zdradza się tym, że sędzia śledczy, jako narrator występujący w pierwszej osobie, opisuje samego siebie tak, jakby oglądał siebie z zewnątrz". Zob. Olaf Kühl, Gęba erosa. Tajemnice stylu Witolda Gombrowicza, tłum. Krzysztof Niewrzęda, Maria Tarnogórska, Universitas, Kraków 2005, s. 112. W opowiadaniu Andrzeja Kijowskiego podobną funkcję pełnią te fragmenty, w których monolog wewnętrzny Tadeusza przekształca się w dialog z samym sobą.

${ }^{142}$ Pod względem konstrukcyjnym Szyfry przypominają także Iwonę, księżniczkę Burgunda (oraz - oczywiście - Zbrodnię z premedytacja). W obu wypadkach funkcję katalizatora (demaskatora) spełnia postać niema/bierna/nieobecna. Jędrek, wokół którego ogniskują się wszystkie działania dramatis personae, wzorem tytułowej bohaterki dramatu Gombrowicza, "ujawnia” rodzinne perwersje i kompleksy. W Szyfrach, podobnie jak w Iwonie..., przywrócenie społeczno-kulturowego status quo wymaga odprawienia rytuału ofiarniczego („morderstwo"/,,samobójstwo” Iwony, wiktymizacja Jędrka). Zabójstwo jest zatem próbą zażegnania kryzysu, wywołanego przez "niepożądany” element. Jędrek - w czym do złudzenia przypomina Iwonę - jest postacią „nieapetyczną": to kość („ość”) w gardle zbiorowości. Zauważmy, że abiektalny stosunek do wskazanych postaci wynika z ich radykalnej Inności (niemożliwa do zaakceptowania „brzydota” Iwony, perwersyjna miłość do matki i „zdrada” Jędrka). Wobec Innych wspólnota musi zastosować radykalne środki zaradcze. A wpisanie Jędrka w scenariusz ofiarniczy jest przecież także formą zabójstwa. To drugie symboliczne morderstwo (na tożsamości chłopca) stanowi rewers morderstwa faktycznego. Gdyby zaś potraktować Iwonę... i Szyfry jako opowieści o kryzysie męskiego pożądania, przywrócenie status quo nosiłoby wszelkie znamiona kapitulacji (Księcia wobec heteroseksualnej normy, Tadeusza wobec małżeńskiego obowiązku). 
zastąpiona została konstrukcją z pozoró $\mathrm{w}^{143}$, zaś strukturę opowiadania podporządkowano "zasadzie immanencji” („śledztwo” toczy się w zamkniętym kręgu podejrzeń $)^{144}$.

W Pornografii i Szyfrach manifestuje się - wyraźna u obu twórców skłonność do kreowania światów klaustrofobicznych, hermetycznych i dla przybysza z zewnątrz nieprzenikalnych.

\begin{abstract}
Ponieważ świat jest układem tajemnic - pisze Andrzej Kijowski - zespołem układów zamkniętych kryjących wzajem przed sobą swe sekrety [...] jedynym systemem komunikacji jest szyfr - język tajemny, symboliczny. Wysiłek poznawczy, jaki podejmuje człowiek próbujący dostać się do wewnątrz układu zamkniętego (a ten wysiłek jest życiem samym, skoro żyć można tylko w komunikacji z cudzą tajemnicą i skoro tylko w spotkaniu z przeciwieństwem każda jakość określa samą siebie) - otóż wysiłek ten polega na nieustannym szukaniu klucza do tajemnych szyfrów i odgadywaniu symboli. [...] Wszystkie opowieści Gombrowicza, skonstruowane wedle zasady śledztwa, opisują wdzieranie się poprzez symbole w układ zamknięty; uważny bohater gromadzi symbole, jak poszlaki ukrytego przestępstwa ${ }^{145}$.
\end{abstract}

Zgodnie z regułami gatunkowymi klasycznej powieści detektywistycznej rozwikłanie zagadki kryminalnej powinno być jednoznaczne. Has - podobnie jak Gombrowicz - preferuje relatywizm poznawczy: pozostawia śledztwo bez konkluzywnego zakończenia, proponując odbiorcy wielość odczytań.

Śledztwo „otwiera” Tadeusza na Historię, która - wedle Gombrowicza - nie stanowi rzeczywistości zamkniętej i zakończonej, jest wciąż niegotowa, bo powstaje na przecięciu tego, co się z dawnych czasów zachowało, z wysiłkami poznającego podmiotu ${ }^{146}$. Ogniskiem szpiegowskiej, logicznej struktury Gombrowiczowskich opowiadań był układ zamknięty i jego „Tajemnica"147. W podobny sposób skonstruowane są Szyfry. W filmie Hasa rzeczywistość, w której porusza się Tadeusz, ustrukturowana jest na kształt koncentrycznych (błędnych) kół połączonych wspólnym środkiem - niedającą się rozszyfrować Tajemnicą: kto i jakiego powodu zabił Jędrka?

Tadeusz, kierując się wskazówkami udzielanymi przez kolejnych rozmówców, zatacza coraz szersze kręgi. Początkowo porusza się wyłącznie w obrębie Rynku i Starego Miasta. Z hotelu jedzie do mieszkania Zofii i Maćka, stamtąd idzie do gabinetu doktora Grossa, a później do pobli-

${ }^{143}$ Tadeusz jest jednak - w porównaniu z bohaterami Gombrowicza - postacią pozbawioną właściwości „demiurgicznych” („reżyserskich”). W odniesieniu do Szyfrów bardziej zasadne byłoby zatem zastosowanie określenia "re-konstrukcja z pozorów”.

${ }^{144}$ Szczegółowej analizy porównawczej opowiadania Zbrodnia z premedytacja pod kątem obecności w nim schematu gatunkowego kryminału dokonał Bartoszyński. Zob. Kazimierz Bartoszyński, O nieważności „tego, jak było naprawdę", dz. cyt., s. 388-390.

145 Andrzej Kijowski, Strategia Gombrowicza, [w:] Gombrowicz i krytycy, dz. cyt., s. 454.

${ }_{146}$ Michał Głowiński, Gombrowicz i nadliteratura, Wyd. Literackie, Kraków 2002, s. 233.

${ }^{147}$ Andrzej Kijowski, Strategia Gombrowicza, dz. cyt., s. 458. 
skiego antykwariatu. Następnie opuszcza Kraków i odwiedza Gorczę (rozmawia z furmanem i leśniczym), a zwieńczeniem podróży jest wizyta w cysterskim klasztorze. Po klęsce poszukiwań droga wiedzie ponownie na Rynek (spotyka się z Jadwigą w Sukiennicach) i do mieszkania byłej żony. Paradoksalnie, im bardziej Tadeusz oddala się od ",centrum” (mieszkanie Zofii), tym bardziej obezwładniające staje się poczucie „zamknięcia”.

Przestrzeń jest zatem nie tyle labiryntem (jak z początku można by sądzić), ile „magicznym” układem pierścieni. Działająca w tej przestrzeni irracjonalna siła zmusza bohatera, by nieustannie powracał do punktu wyjścia (podobną strategią posłużył się Has w Pamiętniku znalezionym $w$ Saragossie ${ }^{148}$. Brak progresji fabularnej pozwala dostrzec, iż zdarzeniom w Szyfrach jedynie pozornie nadano porządek linearny. $\mathrm{W}$ istocie czas zostaje unieruchomiony, zaś bohater przemieszcza się ruchem kolistym. Śledztwo ma tu charakter regresywny - prowokując "świadków” do powrotu w przeszłość, Tadeusz „wstrzymuje czas" i zmusza interlokutorów do odtwarzania dawnych „ról” („konspiratora", „zazdrosnego kochanka" itd.).

To - jakże charakterystyczne dla utworów Gombrowicza - „zapętlenie" można interpretować w kategoriach przestrzennych, co podkreślone zostało w Szyfrach poprzez konstrukcję przestrzeni, której nadano formę koncentrycznych kręgów.

Przekonanie o pozaracjonalnej zasadzie organizującej porządek świata przedstawionego powstaje jednak nie tylko $\mathrm{w}$ oparciu o relacje przestrzenne. Do jego ugruntowania w świadomości widza w dużej mierze przyczynia się charakter zależności pomiędzy bohaterami. Wydaje się bowiem, iż pomiędzy wszystkimi pojawiającymi się na ekranie postaciami istnieje rodzaj tajemnej korespondencji. Ujawnione $\mathrm{w}$ filmie powiązania nie dają się wytłumaczyć logicznie za pomocą odwołań do wojny, podczas której bohaterowie brali udział w działalności podziemnej. Pojęcie „konspiracji” zyskuje tym samym głębsze, symboliczne znaczenie. Przestrzeń, w której toczy się śledztwo Tadeusza przypomina sieć tajnego sprzysiężenia, w którym wszyscy mają („Konspiracja nie kończy się nigdy"149) lub mogli mieć jakiś związek ze śmiercią Jędrka. Tadeusz stopniowo ulega chorobliwej podejrzliwości wobec każdej napotkanej osoby. Tę obsesję podsyca Maciek, wyjaśniając ojcu - na podstawie przypadkowo zaobserwowanej ulicznej scenki - mechanizmy działania „organizacji": Może jedziesz z nimi w tym samym przedziale kolejowym, może ustęuję im miejsca $w$ tramwaju, może mijamy się na ulicy... Kafkowską atmosferę niesamowitości potęguje zastosowany w omawianej scenie klucz

\footnotetext{
${ }^{148}$ Ten strukturujący porządek filmowego opowiadania ruch bohatera po okręgu nie ma odpowiednika w opowiadaniu Kijowskiego. Stanowi zatem dowód autorskiego (w znaczeniu indywidualnej sygnatury autorskiej) podejścia Hasa do adaptowanego tekstu.

149 Andrzej Kijowski, Szyfry, dz. cyt., s. 126.
} 
wizualny. Postacie „konspiratorów” poruszają się w wąskim gardle ślepej uliczki (wylot zamyka niewysoki mur poziomo segmentujący kadr). Identycznie ubrani mężczyźni filmowani są konsekwentnie w planach dalekich, a precyzyjna organizacja ruchu wewnątrzkadrowego czyni z postaci marionetki sterowane przez niewidzialnego Sprawcę.

Mimo podejmowanych wysiłków, historia Jędrka pozostanie dla Tadeusza na zawsze Tajemnica, i to nie tylko ze względu na naturalny proces związany z „wymazywaniem” przeszłości przez upływający czas. Tadeusz nie dopuszcza do siebie możliwości zaistnienia zdarzeń $\mathrm{w}$ innej niż kanoniczna formie. A przecież - jak zauważa Aleida Assmann - obiektywizm jest nie tylko kwestią metody i krytycznych standardów, ale także mortyfikacji, obumarcia, wyblaknięcia cierpienia i osobistych uwikłańn ${ }^{150}$.

Wbrew sugestiom Maćka (Jędrek nie należał do konspiracji, żądał rozwiązania organizacji, a jego postawa stanowiła zagrożenie dla członków podziemia) Tadeusz wierzy, iż dziecko padło ofiarą prześladowań zbrodniarzy i/lub szaleńców. Ojciec niewzruszenie trwa w uporze. Ten brak zgody na oczywistość faktów wywołuje u Maćka konwulsyjną reakcję. W histeryczny sposób ujawnia prawdę o aresztowaniu brata. Tragedia Jędrka, którego "zabrali nasi”, ewokuje w pamięci „bulwersujący” przypadek Siemiana z Gombrowiczowskiej Pornografii. W obu wypadkach karą za tchórzostwo był wyrok śmierci wydany przez organizację podziemną. Tchórz - zdrajca Sprawy - pojawia się jako „ktoś przekraczający granice pomiędzy społecznością ofiar a sprawcami przemocy, w tajny sposób porusza się tu i tam, zacierając swoim działaniem granice między «nami» a «nimi», wrogami ${ }^{151}$. Pomiędzy "nami" a "nimi" jest miejsce tylko dla Baumanowskich bytów niedecydowanlych - dla "obcych”.

W sytuacji - pojmowanego w kategoriach Girardowskich - moralnego (wojennego) kryzysu nie są brane pod rozwagę bardziej ekonomiczne formy uporania się z obcym niż te, które nastawione są na wydzielenie tego, co odmienne, i stale uwzględniają $w$ rachubach skrajny przypadek unicestwienia obcego ${ }^{152}$. Jędrek/Siemian to paradygmatyczny przykład "obcego". A raczej Freudowskiego niesamowitego, które w postaci samowicie-swojskiego zagnieżdża się w domu. Niesamowite - to coś,

${ }^{150}$ Aleida Assmann, Przestrzenie pamięci. Formy i przemiany pamięci kulturowej, tłum. Piotr Przybyła, [w:] Pamięć zbiorowa i kulturowa. Współczesna perspektywa niemiecka, red. Magdalena Saryusz-Wolska, Universitas, Kraków 2009, s. 106.

${ }^{151}$ Małgorzata Czermińska, O dwuznaczności sytuacji ofiary, [w:] Kultura po przejściach, osoby przeszłościa, dz. cyt., s. 96. Przeprowadzona przez autorkę analiza opowiadania Jarosława Iwaszkiewicza Młyn nad Lutynia pod kątem motywu „wyroku na (dziecięcym) zdrajcy" ujawnia zaskakujące podobieństwo tekstu literackiego z Hasowskimi Szyframi. W obu przypadkach temat ofiary jest realizowany w wersji „tragedii rodzinnej i opowieści o traumie wojennej, która powraca niby «hydra pamiątek», żeby zatopić szpony w uspokojonym sercu" (tamże, s. 97).

152 Tamże, s. 48. 
co budzi trwogę, co zaś sprowadza się do tego, co od dawna znane, znajome $^{153}$ (ale też coś, co wiąże się ze śmiercią, ze zwłokami lub z powracaniem zmarłych $\left.{ }^{154}\right)$. I co należy zabić.

Dwuznaczny status Jędrka nie wynika wyłącznie $z$ faktu wykroczenia poza opozycję: obcy/swój. W równym stopniu konstytuuje ów status przeciwieństwo: obecny/nieobecny. Wobec przestrzeni, nad którą dziecko sprawuje nieograniczoną symboliczną władzę, można zastosować kategorię non-absent past: „przeszłość, której nieobecność się manifestuje”.

Owa non-absent past jest ambiwalentną i liminalną przestrzenią „niesamowitego", jest przeszłością, która krąży jak widmo i jako taka nie poddaje się kontroli i opiera się ostatecznym interpretacjom. Okupują ją ",niesamowite”, , widmowe artefakty”, które wytrącają nas ze swojskości, z poczucia bezpieczeństwa ${ }^{155}$.

Jędrek to widmowy artefakt - „zaginiony, który zniknął bez śladu” i obdarzony został statusem „nieobecnego (znikniętego ${ }^{156}$ ) ciała”:

Ów ambiwalentny status zaginionego (żywego lub martwego) nie poddaje się dychotomicznym kwalifikacjom obecny-nieobecny. $Z$ tego punktu widzenia zaginione ciało stanowi niejako paradygmat samej przeszłości, która zarazem jest i nie-jest ${ }^{157}$.

Tadeusz uporczywie próbuje przywrócić światu strukturalny ład ${ }^{158}$. Dlatego też poszukiwać będzie nie tyle nieobecnego ciała Jędrka, ile ludzi odpowiedzialnych za jego zniknięcie (a przede wszystkim za „męczeńską” śmierć). Tylko uznając Jędrka za zabitego (nie zmarłego, lecz właśnie za zamordowanego), ojciec może obdarzyć go jedynym akceptowalnym statusem - statusem ofiary.

${ }^{153}$ Zygmunt Freud, Niesamowite, [w:] Pisma psychologiczne, tłum. Robert Reszke, Wyd. KR, Kraków 1997, s. 236.

154 Tamże, s. 253.

${ }^{155}$ Ewa Domańska, Historie niekonwencjonalne, Wyd. Poznańskie, Poznań 2010, s. 187.

156 Autorka analizuje fenomen „znikniętych” na przykładzie argentyńskich los desaparecidos („,tych, którzy zniknęli bez śladu”). „Desaparecido - tłumaczy Artur Domosławski - to ktoś, kto wyszedł z domu i przepadł; albo ktoś, kogo zabrali z domu i nigdy nie oddali, nigdy nie pozwolili mu wrócić. Desaparecido nie ma grobu - przecież nie ma dowodu na to, że nie żyje, on jest tylko «zniknięty», gdzieś zaginał, gdzieś się zapodział. [...] Desaparecido nie jest kimś, kto umarł - nic o jego śmierci nie wiadomo, nic pewnego, nikt przecież nie widział ciała - a zarazem to ktoś, kogo nie ma wśród żywych" (tamże, s. 184).

157 Tamże, s. 184.

158 Zniknięte ciało stawia opór systemowi - nie pozwala „wypełnić pustego grobu”. Jedynie przekształcenie desaparecido w zidentyfikowane i pogrzebane szczątki umożliwia „odprawienie rytuałów, zaleczenie ran, uzdrowienie i odbudowanie społeczności” (tamże, s. 188). 


\section{Umarte fotografie jako protezy widzenia}

Dla zrozumienia „ślepoty” Tadeusza (który uporczywie widzi w Jędrku „ofiarę niewinną") pomocna może być interpretacja kluczowej sekwencji rozgrywającej się $\mathrm{w}$ pociągu. Forma strukturowania kolejno następujących po sobie ujęć ujawnia kulturowe uwarunkowania percepcji indywidualnej. $\mathrm{W}$ wagonie restauracyjnym bohater wertuje album ze zdjęciami ilustrującymi wojenną hekatombę. Prawie wszystkim fotografiom przygląda się w sposób beznamiętny. Zdjęcia nie szokują być może dlatego, iż - jak stwierdza Barthes - ogladane z perspektywy naszej wolności zdają nam się zbyt intencjonalne i pozbawione niejednoznaczności. Reakcja Tadeusza dowodzi, iż samo oznaczanie grozy przez fotografa nie wystarczy, byśmy jej doznali ${ }^{159}$.

Lektura zawartego w albumie specyficznego wizualnego świadectwa wyznaczy Tadeuszowi gotowy "scenariusz" projektowanej wizyty. Zdjęcie - zdaniem André Rouillé - nie funkcjonuje nigdy poza ekspresja, gdyż fotografia nie jest, z natury, dokumentem. Dokument bowiem nie może stanowić jakiejkolwiek esencji czy też noematu fotografii ${ }^{160}$. Rouillé precyzuje:

Przekazy medialne, poprzez fotografię-dokument, wskazują nam, co powinno się widzieć i w jaki sposób powinno być to widziane. Informacja staje się zatem jedynie nośnikiem albo raczej pretekstem do emitowania wizualnych zaleceń ${ }^{161}$.

Fotografia organizuje i determinuje sposób postrzegania świata. Nie odbija, ale transformuje rzeczywistość. Fotografia - podkreśla François Soulages - nie jest restytucją przedmiotu-świata, lecz wytwarzaniem obrazów, które interpretują niektóre widzialne i możliwe do sfotografowania zjawiska, pochodzące $\mathrm{z}$ konkretnego świata danego w przestrzeni i czasie ${ }^{162}$.

Bezgraniczne zaufanie do fotografii-dokumentu - uleganie złudzeniu, „że to tak było"163 - powoduje przekształcenie żywej tkanki rzeczywistości

159 Roland Barthes, Mitologie, tłum. Adam Dziadek, Wyd. KR, Warszawa 2000, s. 139-141.

${ }^{160}$ Zob. André Rouillé, Fotografia. Między dokumentem a sztuka wspótczesna, tłum. Oskar Hedemann, Universitas, Kraków 2007, s. 19.

161 Tamże, 182.

${ }^{162}$ François Soulages, Estetyka fotografii. Strata i zysk, tłum. Beata Mytych-Forajter, Wacław Forajter, Universitas, Kraków 2007, s. 30.

${ }^{163}$ Legitymizującą funkcję fotografii pojawiających się w strukturze Szyfrów podkreśla Anne Guérin-Castel. W odniesieniu do zdjęcia z egzekucji, wieńczącego czwartą sekwencję wizyjna, autorka pisze: „jak fotografie albumowe, jest świadectwem, że «to tak było»". Zob. Anne Guérin-Castel, Dwoista forma "Szyfrów" Wojciecha Jerzego Hasa - prawda do rozszyfrowania, tłum. Teresa Rutkowska, „Kwartalnik Filmowy” 2000, nr 29/30, s. 51 . 
w skodyfikowany system kulturowych odniesień. Tadeusz rozszyfrowuje rzeczywistość, kierując się wskazówkami zawartymi w albumie. Album, wyjaśnia Rouillé:

Podobnie jak archiwa, czy też inne systemy gromadzenia danych [...] nie jest jedynie pasywnym zasobnikiem. Nie tylko bowiem gromadzi, zbiera, archiwizuje i klasyfikuje obrazy, ale tworzy też określony sens, proponuje pewną wizję i na swój sposób symbolicznie porządkuje rzeczywistość.

[...] fotografia-dokument i album (lub archiwa) pełnią przeciwstawne, ale i uzupełniające się wzajemnie role: fotografia rozbija rzeczywistość na fragmenty, a album i archiwa ponownie scalają te fragmenty w jedną całość według pewnego porządku ${ }^{164}$.

W tym kontekście na szczególną uwagę zasługuje kompozycja scen rozgrywających się $\mathrm{w}$ wagonie restauracyjnym. Podczas gdy bohater przegląda stronice ze zdjęciami, następuje nieoczekiwana przerwa w podróży. Tadeusz, zaciekawiony, wygląda przez okno. Tuż przy nasypie kolejowym, w środku lasu, grupa robotników kopie rów. Jeden z pracowników odwraca głowę i patrzy w stronę Tadeusza - „odwzajemnia” (?) jego spojrzenie. Pociąg rusza, a Tadeusz powraca do przerwanej lektury, ale jego spojrzenie ponownie „wędruje” za okno.

Ta z pozoru całkowicie „neutralna” semantycznie scena nabiera nowego znaczenia w kontekście oglądanych przez Tadeusza zdjęć. Spojrzenie robotnika wydaje się znaczące, pełne rozpaczy czy niemego wyrzutu, zaś cała sytuacja nieodparcie kojarzy się z obrazami masowych egzekucji z czasów wojny (wykopywanie zbiorowych grobów przez przyszłe ofiary).

Zdaniem Hansa Beltinga zależność od mediów technicznych wywołuje kryzys w sposobie obcowania z obrazami:

Zbroimy się $\mathrm{w}$ protezy widzenia po to, by aparatom pozostawić sterowanie naszą percepcją. W doświadczeniu obrazów mamy do czynienia z podobną abstrakcja, jak w doświadczaniu ciała: nabiera ona w doświadczeniu technicznego zapośredniczenia, którego nie jesteśmy już w stanie kontrolować cieleśnie. Podobnie dzieje się w przypadku produkcji obrazowej massmediów. Przyznajemy im większy autorytet aniżeli własnej percepcji ${ }^{165}$.

Obrazy strukturują prercepcję rzeczywistości. Tadeusz nie potrafi już dostrzec tego, co w istocie dzieje się przy torach. Sugestywne zdjęcie, obraz-interpretacja, rekompensujący brak doświadczenia (Wydaje mi się, jakby to wszystko działo się w jakimś innym świecie), staje się dla bohatera swoistą protezą widzenia (fot. 1-6).

${ }^{164}$ André Rouillé, Fotografia, dz. cyt., s. 112.

${ }^{165}$ Hans Belting, Antropologia obrazu, dz. cyt., s. 36. 

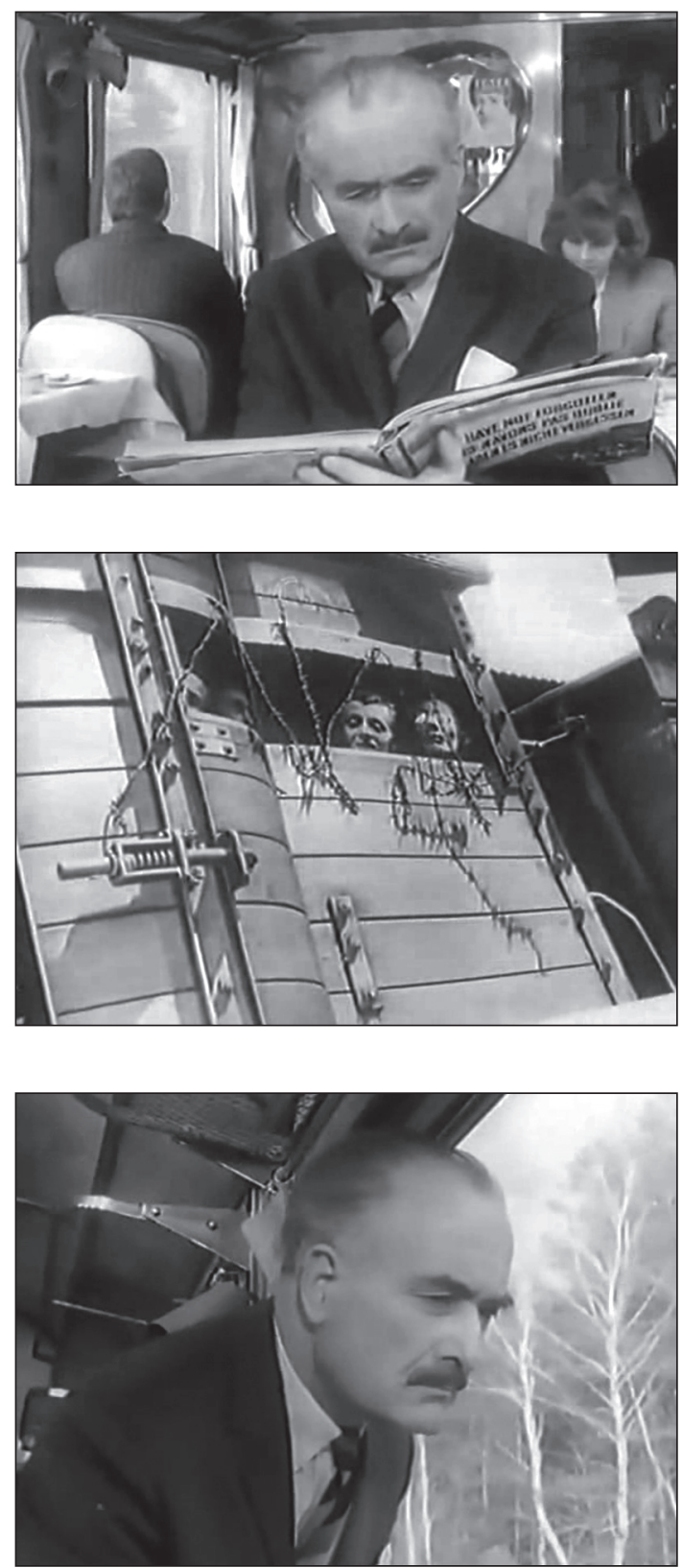

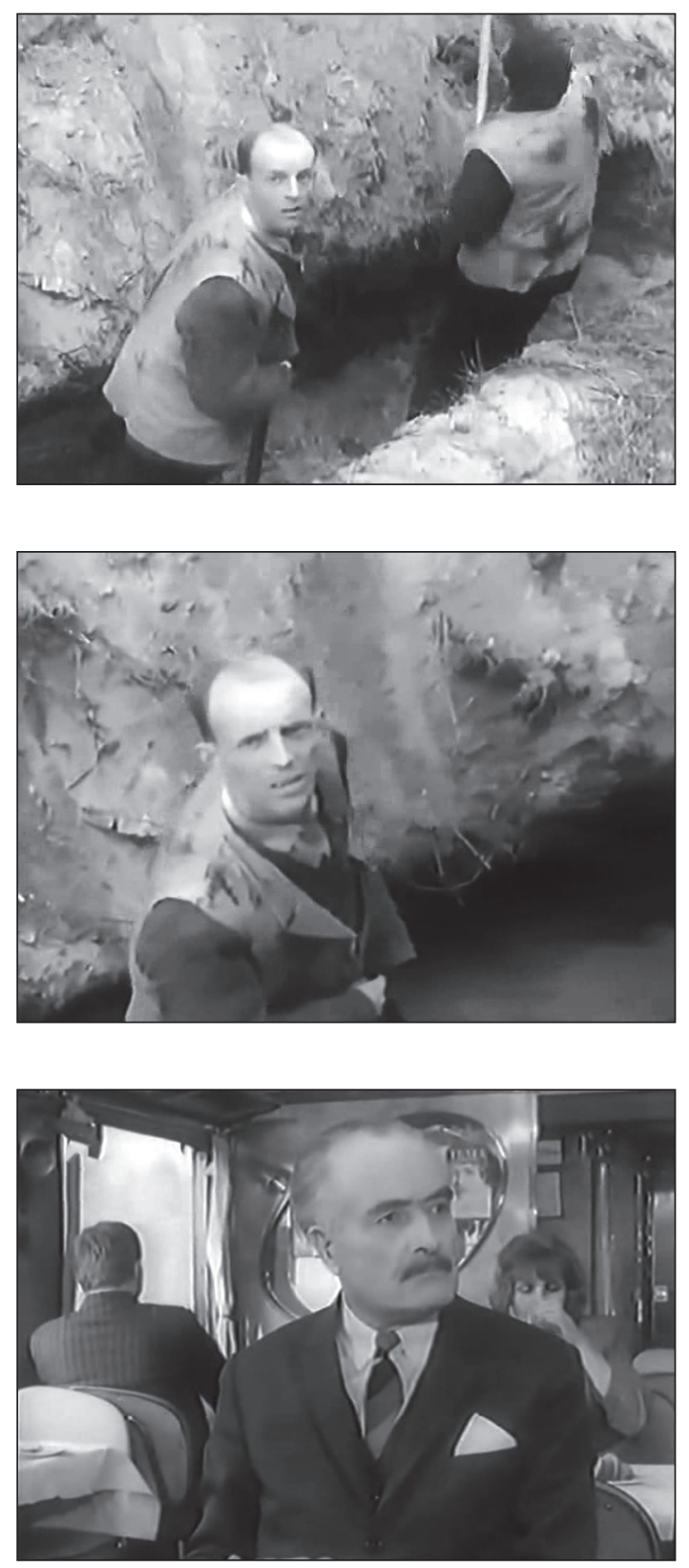

Fot. 1-6. Szyfry (1966, reż. Wojciech Jerzy Has) Lektura albumu-świadectwa 
W analizowanej sekwencji ujawnia się mistrzostwo Hasa, który potrafił narzucić widzowi identyfikację ze spojrzeniem bohatera. Subiektywny punkt widzenia Tadeusza zostaje przypisany odbiorcy (w kluczowym ujęciu tej sekwencji robotnik kieruje spojrzenie bezpośrednio w stronę kamery-widza), który zmuszony jest postrzegać rzeczywistość przez pryzmat jego świadomości ${ }^{166}$.

Obraz fotograficzny formuje nie tylko świadomość (sposób „lektury” teraźniejszości), lecz w wyraźny sposób wpływa także na podświadomość bohatera. Dowodzi tego sekwencja wizyjna zakończona statyczną fotografią-dokumentem (archiwalne zdjęcie z 1940 r., na którym uwieczniono egzekucję Polaków na Ursynowie). Treść wizji (wędrówka Jędrka w wąwozie, gdzie odbywa się rozstrzeliwanie więźniów) to rozwinięta $\mathrm{w}$ mininarrację fabularną sytuacja przedstawiona na zdjęciu.

Skąd jednak - pyta Hans Belting - przychodzą obrazy, które przeżywamy w marzeniu sennym? Czy są to rzeczywiście nasze własne obrazy i czyż nie są one także śladami dominujących w kulturze obrazów kolektywnych, do czego oczywiście zaliczają się także wspomnienia? [...] Wizja jest porównywalna do snu nie tylko jako podróż (jako podróż w inny świat lub jako odwiedziny w innym świecie), ale także jako fenomen obrazowy $[\ldots]^{167}$.

Sceny, w których pojawia się kilkuletni Jędrek, to wizje-wspomnienia, ukształtowane pod wpływem rozmaitych wzorców kulturowych

${ }^{166}$ Charakterystyczna dla powieści Gombrowicza narracja subiektywna to także jeden z podstawowych wyróżników twórczości Wojciecha Hasa. Również w Szyfrach - przy zachowaniu pozorów obiektywizmu - rzeczywistość przedstawiona jest funkcją psychiki głównego bohatera. Ujawnieniu stopnia personalizacji narracji służą ujęcia, zrealizowane dla kontrastu w poetyce paradokumentalnej. Sceny uliczne, sfilmowane „bezosobową" kamera, nie zostały sfunkcjonalizowane dramaturgicznie i wyraźnie wyodrębniają się ze struktury opowiadania.

Omawiane wcześniej obrazy, w których zarejestrowany został strumień życia - banalna miejska codzienność - sugerują iż apokalipsa jest doznaniem jednostkowym, którego nie powinno się uniwersalizować (zwróćmy uwagę, iż doktor Gross, rówieśnik Jędrka, nie zdradza objawów „stygmatyzacji” wojenną trauma, a Maciek wspomina, że dawni przywódcy podziemia - odpowiedzialni za śmierć Jędrka - doskonale zasymilowali się w powojennej rzeczywistości). Kraków stał się przestrzenią postapokaliptyczną jedynie w subiektywnym doświadczeniu Tadeusza, Maćka i Zofii, a po części także starego antykwariusza. Z tego powodu nie do końca mogę zgodzić się z konkluzją Paula Coatesa, wedle którego wizyjne partie filmu Hasa stanowią (metaforyczne) świadectwo niewypowiedzianej (z powodów cenzuralnych) i nieprzepracowanej wojennej traumy, która jest obecna w samym środku polskiej rzeczywistości. Zob. Paul Coates, The Red and the White, dz. cyt., s. 132-133.

${ }^{167}$ Hans Belting, Antropologia obrazu, dz. cyt., s. 91-92. 
(reprezentowana przez cytaty z Anhellego tradycja romantyczna, martyrologiczne tableaux z powstańczych rycin Grottgera ${ }^{168}$, fotograficzna dokumentacja Holocaustu). Te specyficzne „wspomnienia”, które nie maja zdaniem Birgit Neumann

żadnej podstawy w przeszłości, lecz jedynie odpowiadają na aktualne potrzeby jednostki, mogą wprawdzie rościć sobie prawo do bycia wewnętrzną rzeczywistościa, jednak opuszczają obszar pamięci, przechodząc do przestrzeni idiosynkratycznych fantazji. [...] Najwidoczniej, ludzie skłonni są „importować” takie artystyczne elementy do repertuaru własnej pamięci i w konsekwencji błędnie zapamiętywać je jako osobiste wspomnienia, które dostarczają wyjątkowo przystępnych odpowiedzi na indywidualne pytania i tym samym w szczególny sposób służą redukcji przypadkowości. Pamięć indywidualna, jak można wnioskować, wydaje się kształtować według kompleksowej „zasady montażu”169.

Historia Jędrka demaskuje funkcjonowanie kulturowo przekazywanych schematów wykorzystywanych do re-konstruowania przeszłości oraz ujawnia ich wpływ na formowanie się psychiki/pamięci jednostkowej ${ }^{170}$.

Kluczowy dla filmu motyw fotografii odnosi się do świata pozorów, w którym uwięzieni są bohaterowie Hasa. Obsesja nierzeczywistości dręczyła także narratora Pornografii. W artystycznym „salonie warszawskim" i anachronicznym ziemiańskim dworku Hipolita znajdują schronienie ludzie próbujący desperacko utrzymać się w ryzach narzuconej przez tradycję Formy. Świat Pornografii to spotęgowana nierzeczywistość: egzystencja w czasie przeszłym i groteskowe próby ignorowania nieuchronnej katastrofy w mieszkaniu na Kruczej, gdzie resztki przedwojennej inteligencji „w ciężkim dymie podejmują dawne, byłe rozmowy nasze i spory o sztuce"171. Dla odzwierciedlenia fikcyjnego statusu tego świata bohater Gombrowicza posłużył się metaforą obrazu: „byliśmy jak z oleodruku - jak ze starego, familijnego albumu umarła fotografia"172.

${ }^{168}$ Malarstwo patriotyczne wpływa nie tylko na formalny kształt wizji bohatera, lecz jest także obecne w „obiektywnej” przestrzeni publicznej (ryciny Grottgera znajdują się w antykwariacie), co świadczy o skali oddziaływania tego typu przedstawień ikonicznych. Kontekst miejsca (antykwariat) nadaje jednak owym przedstawieniom charakter „obiektów archiwalnych”, które utraciły już zdolność kształtowania postaw społecznych.

${ }^{169}$ Birgit Neumann, Literatura, pamięć, tożsamość, tłum. Artur Pełka, [w:] Pamięć zbiorowa i kulturowa, dz. cyt., s. 257-264.

${ }^{170} \mathrm{~W}$ tym przypadku chodziłoby o collected memory - społecznie i kulturowo ukształtowaną pamięć indywidualną.

${ }^{171}$ Witold Gombrowicz, Pornografia, dz. cyt., s. 6.

172 Tamże, s. 14. 
O ile jednak Witold potrafił zdobyć się na dystans w stosunku do świata-pozoru, o tyle Tadeusz bierze pozór za rzeczywistość.

Poszukując w strukturze filmu Hasa punctum $^{173}$, natrafiamy na słynną fotografię wykonaną przez operatora SS w warszawskim getcie. Po prawej stronie znajdują się uzbrojeni niemieccy żołnierze, po lewej - mężczyźni i kobiety $z$ tobołkami. Na pierwszym planie $-w$ tzw. mocnym punkcie zdjęcia, na przecięciu linii złotego podziału ${ }^{174}$ - stoi kilkuletni chłopczyk $\mathrm{z}$ rękoma uniesionymi nad głową w geście poddania. Zwraca uwagę doskonała, niezwykle klarowna kompozycja fotografii - jej specyficzne... piękno. O tym aspekcie wspomina Susan Sontag:

Nawet te zdjęcia, które przemawiają tak przeszywająco na temat konkretnego wydarzenia historycznego, dostarczają nam zastępczego poczucia swoistego uwieńczenia wydarzeń, dzięki zamknięciu ich w pięknie będącym jednym z aspektów wieczności. [Tak jak] mały żydowski chłopiec sfotografowany w 1943 roku podczas likwidacji getta $\mathrm{w}$ Warszawie, z podniesionymi rękoma, poważny $\mathrm{w}$ swym przerażeniu - ten, którego podobiznę niema bohaterka filmu Bergmana Persona zabrała do szpitala psychiatrycznego jako fotopamiątkę tragedii ${ }^{175}$.

Dziecko, usytuowane centralnie w kadrze, wyróżnia się z tłumu, stając się uniwersalną (bo całkowicie anonimową) „ikoną Zagłady”. A także multiplikowaną w nieskończoność „ikoną kultury masowej żerującej na Holocauście":

Potrzeba mitu jest silniejsza niż pokora wobec faktu. [...] Widok takich ofiar, które symbolizuje chłopiec ze zdjęcia, przeszywa na wskroś nasze serca, ale też wyzwala $\mathrm{w}$ nas mniej lub bardziej konwencjonalne sposoby reakcji. Ten typ ofiary dziecięcej jest bowiem - by tak rzec - kulturowo oswojony i emocjonalnie zaakceptowany. [...] Słowem - do takiej ofiary łatwo się przyznać, bo niepokalana i czysta; wizerunek takiej ofiary łatwo uwewnętrznić i z nią samą się identyfikować, bo bohaterska ${ }^{176}$.

173 Szyfry traktuję jako całościową jednolitą strukturę, w której punctum stanowi wyróżniający się, przykuwający („przeszywający”) wzrok element.

${ }_{174}$ Zob. Jacek Leociak, Doświadczenia graniczne. Studia o dwudziestowiecznych formach reprezentacji, Instytut Badań Literackich PAN, Warszawa 2009, s. 251.

175 Susan Sontag, O fotografii, tłum. Sławomir Magala, Wyd. Artystyczne i Filmowe, Warszawa 1986, s. 105.

${ }^{176}$ Jacek Leociak, Doświadczenia graniczne, dz. cyt., s. 251-252. W łańcuchu multiplikacji wspomnianego zdjęcia doskonale mieści się zrealizowana w 1985 r. etiuda Mitko Panova $Z$ podniesionymi rękami, przedstawiająca dalsze hipotetyczne losy "chłopca z getta". Zamiana statusu ofiary na status ocaleńca nie miała na celu, jak sądzę, zaspokojenia pragnienia odbiorcy, by „koszmarna opowieść ogólna miała w przypadku chłopca ze zdjęcia swój jednostkowy wyjątek. Żeby wypuściła go ze swych szponów [...]. Słowem [...] by chłopiec przeżył, by ocalał" (tamże, s. 248). Ocalając chłopca, reżyser postąpił 
Tadeusz, przeglądając w pociągu album z fotografiami, wyraźnie zatrzymuje się na tym zdjęciu, a po przerwanej lekturze do niego właśnie powraca. W świadomości bohatera zachodzi opisany przez Aleidę Assmann proces przechodzenia od rozproszonych i bardzo zróżnicowanych wspomnień biograficznych do form pamięci „twardej”, czyli zorganizowanej, wspólnie podzielanej i wiążącej ${ }^{177}$. Zdjęcie-dokument okazuje się brakującym elementem, niezbędnym do przepracowania traumatycznego doświadczenia utraty syna.

Anonimowy chłopiec z getta i Jędrek stają się jednością (warto zwrócić uwagę na uderzające podobieństwo dzieci - chłopcy noszą nawet identyczne ubranka z krótkimi spodenkami odsłaniającymi kościste kolana). Dla Tadeusza oznacza to możliwość zinterpretowania losów syna w dających się zaakceptować kategoriach wiktymizacji - Jędrek to bezbronna ofiara wojennego terroru. Indywidualny przypadek staje się częścią większej struktury, zostaje włączony w niezbędny dla jego zrozumienia kontekst. Mieści się bowiem w specyficznej formule polskiego patriotyzmu, którą stanowi „przykucie przez ofiary niewinne” ${ }^{\prime 178}$. Podmiot o cechach

wbrew oczekiwaniom odbiorcy, dla którego "getto boy" stał się nienaruszalnym symbolem ofiary niewinnej (na podobnej zasadzie "gra" z oczekiwaniami odbiorczymi Munk w słynnej scenie z czołgiem w I części Eroiki).

Widzę tu strategię podobną do tej, którą posłużył się Zbigniew Libera w fotograficznym cyklu Pozytywy (2002), by dokonać ingerencji w żywe struktury pamięci. Wedle Ewy Domańskiej, składające się na cykl fotografie to wyraz sprzeciwu wobec zjawiska komercjalizacji ikonicznych obrazów przeszłości. Należy je czytać „,w kategoriach możliwości manipulowania tym, co uważamy za dokumenty, źródła wiedzy o przeszłości. Można też za ich pomocą pokazać, jak owe obrazowe toposy, reprodukowane w mediach, przeistaczają się w zbanalizowane obrazki, które nie wywierają już większego wrażenia, zostają niejako udomowione; wchodzą w kanon i dopiero drastyczna manipulacja tymi obrazami może poruszyć opinię publiczną i przypomnieć to, do czego owe oryginały się odnoszą". Zamiana "negatywu” (archiwalne zdjęcie więźniów Oświęcimia wykonane w 1945 r.) w "pozytyw” (fotografia Mieszkańcy autorstwa Libery) odnosi się do dwóch rodzajów ideologii: „ideologii pamięci martyrologicznej” oraz „ideologii pamięci skomercjalizowanej”. Libera obie poddaje krytyce: „nie chcemy już dłużej być postrzegani jako ofiary - zdaje się mówić, portretując «mieszkańców», ale jestem też przeciwko kulturze konsumpcyjnej, która pożera najważniejsze i najpoważniejsze obrazowe ikony naszych czasów, zamieniając je w zbanalizowane obrazy przemocy, którymi epatowani jesteśmy na co dzień". Zob. Ewa Domańska, Historie niekonwencjonalne, dz. cyt., s. 235-242.

177 Aleida Assman, 1998 - Między historia a pamięcia, tłum. Magdalena Saryusz-Wolska, [w:] Pamięć zbiorowa i kulturowa, dz. cyt., s. 152.

${ }^{178}$ Wojciech Chudy w książce Społeczeństwo zakłamane przytacza charakterystykę polskiego patriotyzmu, autorstwa Marii Janion: „Polakiem jest ten, kto tych ofiar niewinnych nie może zapomnieć, najokrutniejsza krytyka Polski nie może przekroczyć tego niewidzialnego łańcucha, który łączy nas z naszymi niewinnymi ofiarami. Nie możemy 
ofiary jest - jak podkreśla Hanna Gosk - w narracji losu polskiego podmiotem sprawczym:

Polacy w ciągu minionych dwóch wieków (z krótką przerwą w latach 1918-1939) przywykli do pozycji ofiary i już w dobie romantyzmu zdołali [...] dokonać niezwykłej pracy interpretacyjnej, bowiem przekuli ów skądinąd upokarzający status w heroiczną figurę męczennika, niesłusznie krzywdzonego, „,cierpiącego za miliony"179.

Cierpienie „niewinnych ofiar” zyskuje bardzo wyraźną sankcję religijną gdyż przez dwieście lat podtrzymywano w polskiej kulturze silną więź między patriotyzmem a chrześcijaństwem, ugruntowaną na wierze w wartość ofiary ${ }^{180}$. Nieprzypadkowo zdjęcie, stanowiące wedle Tadeusza symboliczne potwierdzenie statusu Jędrka jako ofiary niewinnej, jest jednocześnie pamiątką pierwszej komunii świętej.

Zdaniem niemieckich socjologów, w ramach struktury scenariusza ofiarniczego sceny z przeszłości

komponowane są z dekoracji, które zna się raczej z dokumentów dotyczących prześladowań i zagłady ludności żydowskiej. [...] Takie postępowanie można określić jako [...] modulację ram lub jeszcze lepiej jako „zamianę ram”: schemat ramowy, który pierwotnie kontekstualizował opis jednego wydarzenia, przerobiony zostaje na użytek zupełnie innego zdarzenia. [...] Rysuje się tu proces, kiedy to Holocaust przejmuje funkcję dominującej narracji dla każdej formy opowieści, która ma do czynienia $\mathrm{z}$ ofiarami i sprawcami ${ }^{181}$.

Narracja Holocaustu, której symboliczną reprezentacją jest zdjęcie z getta, staje się „schematem ramowym” w pełnej luk narracji osobistej Tadeusza. Fotografia-dokument to znaczący element struktury, dzięki któremu opowieść rodzinna odzyskuje uniwersalny sens. Przezwyciężenie aporii sensu oznacza jednak dla Tadeusza konieczność wyeliminowania niedających się wpisać w przyjęty schemat fragmentów z przeszłości.

W rozmowie z antykwariuszem Tadeusz wypowiada znamienną kwestię: Szukam tego dziecka zabitego dwadzieścia lat temu, bo mi jest najbliższe. To

zapomnieć tych ofiar. Nie możemy zapomnieć tych cierpień i dlatego nie zerwiemy z polskością". Zob. Wojciech Chudy, Społeczeństwo zakłamane, Oficyna Naukowa, Warszawa 2007, s. 273-274.

${ }^{179}$ Hanna Gosk, (Nie)obecność opowieści o wstydzie w narracji losu polskiego, [w:] Kultura po przejściach, osoby przeszłościa, dz. cyt., s. 85.

180 Przemysław Czapliński, Polska do wymiany, dz. cyt., s. 37.

${ }^{181}$ Harald Welzer, Sabine Moller, Karoline Tschuggnall, "Dziadek nie byt nazista“. Narodowy socjalizm i Holocaust w pamięci rodzinnej, tłum. Paweł Masłowski, [w:] Pamięć zbiorowa i kulturowa, dz. cyt., s. 362-372. 
paradoksalne stwierdzenie zdradza ukrytą intencję działań Tadeusza. Nie mają one na celu odnalezienia syna (ojciec wie, że Jędrek nie żyje ${ }^{182}$ ), lecz stanowią desperacką próbę rekonstytucji czasu minionego. W przytoczonej wypowiedzi słowo „dziecko" nie jest transparentne, stanowi bowiem klucz do psychiki bohatera. Tadeusz nie poszukuje dorosłego Jędrka (który - gdyby żył - miałby trzydzieści siedem lat), lecz Jędrka-dziecko: bezbronnego chłopczyka utrwalonego na fotografii, która, jak śmierć, jest uprowadzeniem obiektu $\mathrm{w}$ inny świat, w inny rodzaj czasu ${ }^{183}$. Na trop tego dziecka z innego świata naprowadza Tadeusza zdjęcie-ślad przechowywane przez Zofię. Kierując na to zdjęcie uporczywe spojrzenie bohater mógłby zapytać:

Cóż to więc znaczy „żył w przeszłości?” W teraźniejszości mojej odnajduję jakieś ślady [...] i z nich wyprowadzam tamto niegdysiejsze istnienie, ja muszę je sobie odtworzyć. Na to wszakże, abym mógł o kimś powiedzieć, że "był” (niesłychane słowo, będące czymś w rodzaju ,jest”, ale osłabionego), musi mi się to „był" ukazać, ale na widnokręgu samym mej teraźniejszości, jako dziwny punkt skrzyżowania dwóch promieni: jednego, który ze mnie pochodzi, z mego wysiłku odtwarzającego, i z drugiego, który rodzi się z zewnątrz, na samym przecięciu przyszłości i przeszłości, w samym punkcie przemijania, i pozwala odczuć, że to, co było, ciągle „jest”, jest jako coś „byłego"184 (fot. 7-9).

Programowy optymizm poznawczy powieści detektywistycznej zakładał "twardość" opisywanych faktów. W Szyfrach - jak w Kosmosie zakwestionowana została obiektywność „zdarzen'”, zaś bohater brnie przez sytuacje, które zostały niejako wykreowane przez sam akt narra$\mathrm{cji}^{185}$. W powieści Gombrowicza bohater-narrator relacjonował historię (,stwarzał świat”) samemu sobie. W filmie Hasa Tadeusz skazany jest na wiele pozostających we wzajemnej sprzeczności opowieści (Zofii, Maćka, Grossa, Jadwigi). Przeszłość (a do pewnego stopnia także warunkowana przez nią teraźniejszość) okazuje się trenem walki „cudzych” interpretacji. W efekcie Jędrek staje się dla Tadeusza jedynie konstruktem - splotem wielorakich narracji pozbawionym stabilnej tożsamości. Aby Jędrka

${ }^{182} \mathrm{~W}$ opowiadaniu tę przynoszącą ukojenie („Teraz wiadomo już, że Jędrek nie żyje”. „Lepiej") wiedzę wyraża monolog wewnętrzny Tadeusza:

- Szukałem Jędrka - przypomniał.

- Bo wiedziałem, że nie żyje - odrzekł.

Zob. Andrzej Kijowski, Szyfry, dz. cyt., s. 181, 188.

${ }^{183}$ Christian Metz, Fotografia i fetysz, tłum. Anna Oleńska, Sławomir Sikora, „Kwartalnik Filmowy" 2006, nr 54, s. 248.

${ }^{184}$ Witold Gombrowicz, Dziennik 1961-1966, dz. cyt., s. 230.

${ }^{185}$ Jerzy Jarzębski, Gra w Gombrowicza, dz. cyt., s. 480. 

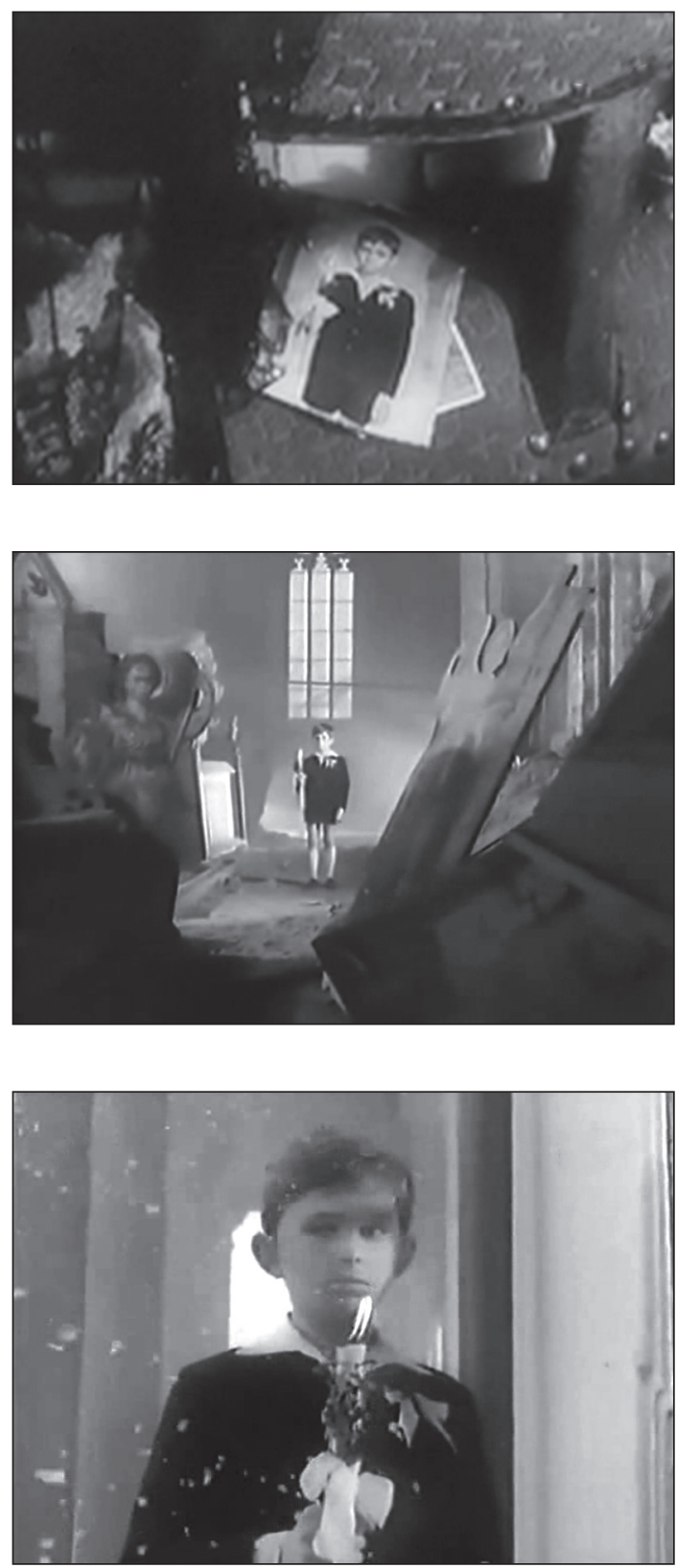

Fot. 7-9. Szyfry (1966, reż. Wojciech Jerzy Has) "Mumifikacja" obiektu 
„przyszpilić”, Tadeusz potrzebuje Formy: zdjęcia-pamiątki. To zdjęcie staje się Gombrowiczowskim „przedmiotem-medium” - zamrożonym kawałkiem chorej przeszłości, w każdej chwili gotowej zaatakować teraźniejszość, okaleczyć ją zmusić tego, kto się z nią zetknął, do nieustannego powielania tego samego scenariusza ${ }^{186}$.

Komunijne zdjęcie Jędrka pojawia się w strukturze filmowego opowiadania trzykrotnie, pełniąc funkcję wizualnego interwału segmentującego tekst. Szczególną funkcję tego właśnie zdjęcia w doświadczeniu Tadeusza (nasuwa się tu nieuchronne skojarzenie z obsesyjnym stosunkiem Barthesa do fotografii matki z okresu dzieciństwa) podkreśla „sekwencja inicjalna” w mieszkaniu Zofii. To właśnie Zofia ofiarowuje Tadeuszowi fotograficzny zbiór pamiątek po zaginionym synku. Wśród nich znajduje się fotografia komunijna. Kamera - podążając za selekcjonującym spojrzeniem Tadeusza - nieco dłużej skupia się na zdjęciu, akcentując tym samym jego wyjątkowość. Czy o wyborze zadecydował jedynie przypadek - moment koncentracji uwagi niczym nie umotywowany? A przecież wyłuskana ze zbioru pozornie identycznych fotografii konwencjonalna komunijna pamiątka zaczyna ogniskować wokół siebie obsesyjnie powracające myśli i skojarzenia. Staje się świadectwem destrukcyjnego działania Formy.

Dramatyczne wyznanie Maćka (Nasi go zabrali) stanowi rodzaj radykalnej transgresji (siła rażenia tych słów mogłaby rozsadzić bastiony Formy, co dla Tadeusza oznaczałoby konieczność wkroczenia w rejony tabuizowane i przyjęcie do wiadomości, że Jędrka uśmiercili nasi za zdradę). Zabicie dziecka jest przecież „fenomenem granicznym”: radykalna formą obcości, która

dotyczy tego wszystkiego, co pozostaje poza wszelkim porządkiem i stawia nas wobec wydarzeń, które podają w wątpliwość nie tylko jakąś określoną interpretację, lecz samą "możliwość interpretacji”. [...] To, co obce, radykalnie da się ująć tylko jako nadwyżka, wybryk, przekraczający istniejący horyzont sensu ${ }^{187}$.

Można także uznać, iż to wyznanie stanowi dla Maćka formę przezwyciężenia kompleksu ojca na płaszczyźnie epistemologicznej. Maciek, sytuując się na pozycji jedynego depozytariusza prawdy, zyskuje nad ojcem przewagę. Tym należy tłumaczyć fakt, iż początkowo utwierdza Tadeusza w oficjalnej wersji zdarzeń (Jędrka zabrało SS) i podsuwa fałszywe tropy (Jędrka widziano we Włoszech).

${ }^{186} \mathrm{O}$ funkcji mediumicznych przedmiotów w powieści Gombrowicza Opętani pisze Ewa Graczyk (Przed wybuchem wstrząnać, dz. cyt., s. 183).

${ }^{187}$ Bernhard Waldenfels, Topografia obcego, dz. cyt., s. 34-35. 
Scena wyznania to jedyny bodaj w filmie moment, w którym nawiązuje się intymny - bo oparty na dosłownej fizycznej bliskości - kontakt Maćka i Tadeusza. Przywołana scena jest nośnikiem wielorakich znaczeń: symbolizuje (niemożliwe) porozumienie syna z ojcem, a zarazem perwersyjną symbiozę kata i ofiary. Ta jakże kluczowa dla Szyfrów scena ewokuje w pamięci widza inny kanoniczny obraz: agonię Szczuki w objęciach Maćka Chełmickiego ${ }^{188}$. W Szyfrach ten "drugi” Maciek wymierza w swego ojca (,,ideowego" przeciwnika) śmiertelny strzał, ujawniając mu niemożliwą do zaakceptowania prawdę o śmierci Jędrka. W tym jednym symbolicznym obrazie zawiera się cały tragizm tradycyjnego (sięgającego wieku XIX) konfliktu etosu rycerskiego (Tadeusz) i etosu konspiracyjnego (Maciek) - etosu, w którym milcząco przyzwala się, w imię „,wyższej konieczności", na skrytobójcze wyroki wykonywane na dzieciach.

Po wyznaniu Maćka uruchomiony zostaje ciąg asocjacji. Kamera wyrusza w podróż po labiryncie meandrycznej (pod)świadomości Tadeusza. Dokonuje się to w onirycznej sekwencji, w której komunijna fotografia „ożywa”, a statyczny obraz przekształca się w mikronarrację.

Sekwencja sprawia wrażenie delirycznej wizji - produktu ogarniętego gorączką umysłu. A przecież w partiach wizyjnych Has posługuje się „szyfrem” - symbolicznym językiem wyrażającym wewnętrzne doświadczenie Tadeusza, w którym utrwalona została pamięć kulturowego dziedzictwa (omawiana sekwencja to świadectwo zakodowanych w pamięci lektur i obrazów). Demontaż „realistycznej” narracji przez wprowadzanie w jej obręb sekwencji onirycznych przywodzi na myśl pisarską metodę Konwickiego, którego bohaterowie - podobnie jak Tadeusz -

wręcz obsesyjnie przywołują rozmaite okruchy zmitologizowanej świadomości zbiorowej; we wspomnieniach, snach czy też wyobraźni prześladuje ich rekwizytornia narodowej pamięci, w jej kostiumy ubierają swoje osobiste przeżycia ${ }^{189}$.

W najbardziej rozbudowanej (ze wszystkich pojawiających się w Szyfrach) sekwencji wizyjnej chłopiec w komunijnym ubranku pełni funkcję

188 Por. Marek Hendrykowski, Styl i kompozycja "Popiotu i diamentu” Andrzeja Wajdy, [w:] Analizy i interpretacje. Film polski, red. Alicja Helman, Tadeusz Miczka, Wyd. Uniwersytetu Śląskiego, Katowice 1984, s. 82; Tadeusz Lubelski, Strategie autorskie w polskim filmie fabularnym 1945-1961, dz. cyt., s. 165.

189 Andrzej Werner, Czarno-biała, biało-czerwona?, [w:] Sporne sprawy polskiej literatury wspótczesnej, red. Alina Brodzka, Lidia Burska, Instytut Badań Literackich PAN, s. 24. Odnotujmy, iż w okresie poprzedzającym premierę Szyfrów ukazała się jedna z najważniejszych powieści Konwickiego - Sennik współczesny (1963). 
przewodnika po dantejskim piekle zbudowanym z narodowych symboli. Powolna panorama odsłania przed widzem krajobraz po klęsce. Biel zimowego pejzażu potęguje wrażenie niesamowitości. Wśród sczerniałych - wystających z ziemi niczym ręce umarłych - gałęzi błąkają się niedobitki $\mathrm{z}$ rozbitego oddziału kawalerii.

Sekwencja rządzi się logiką marzenia sennego: wśród żołnierzy rozpoznajemy Tadeusza, zaś sceneria przywodzi na myśl ikonograficzne i literackie reprezentacje powstania styczniowego - w pewnym momencie na ekranie pojawia się nawet kryta słomą furmanka: paradygmatyczny element mitologii powstańczej ${ }^{190}$.

Wędrówka Jędrka to widowisko pasyjne wiodące nas - przy wtórze mistycznych strof poematu Anhelli Słowackiego ${ }^{191}$ - przez kolejne stacje męki narodu: las-cmentarzysko i opustoszały szlachecki dwór ${ }^{192}$ (topika powstania styczniowego), zburzony kościół (kolejne piętro intertekstualnych nawiązań, tym razem - via Gombrowicz ${ }^{193}$ - do Nie-Boskiej Komedii), masowe groby (ikonografia II wojny). Ostatnią stacją jest wąwóz, w którym dokonuje się egzekucja. Hitlerowcy w mundurach, psy, wycelowane w skazańców lufy karabinów maszynowych. Oto obraz polskiej Golgoty. Chrześcijańska symbolika religijna jest w tej partii

${ }^{190}$ W szyderczy sposób do mitologii powstania styczniowego nawiązuje (zapewne nieświadomie) w swej relacji o okolicznościach śmierci młodszego brata Maciek. Na takim samym „powstańczym” chłopskim wozie nasi wywieźli Jędrka do gorczańskiego lasu, by go tam rozwalić. Zob. Andrzej Kijowski, Szyfry, dz. cyt., s. 102.

${ }^{191}$ Na ten właśnie poemat Słowackiego - w kontekście edukacji wojenno-patriotycznej ośmioletniego chłopca - powołuje się Jarosław Marek Rymkiewicz. Autor wspomina: „[Matka] Jeszcze Anhellego czytała. W tym też był z pewnością pomysł pedagogiczny - na tak zwanych kompletach, które odbywały się w naszym mieszkaniu, uczyłem się na pamięć różnych patriotycznych wierszyków, raczej takich sobie, i matka, która była mądrą kobieta, prawdopodobnie chciała podnieść moje wychowanie patriotyczne na wyższy poziom. [...] Oni [tj. powstańcy z 1944 r.] właśnie dlatego poszli się bić, bo w szkole dowiedzieli się od Mickiewicza, Słowackiego, że Polska to jest coś, za co się umiera. Coś ważniejszego niż ich życie. To była ważna etyczna nauka [...]". Zob. Ani guzika, z Jarosławem Markiem Rymkiewiczem rozmawia Krzysztof Masłoń, „Rzeczpospolita" 2008, nr 233 (8134). Korzystałam z tekstu dostępnego na stronie: http://tma.org. pl/ht/rymkiewicz_ani_guzika.html.

192 Bezpośrednie odwołania do powstania styczniowego pojawiają się w wypowiedziach Maćka dotyczących historii dworu w Gorczy, w którym podczas powstania miał stacjonować generał Marian Langiewicz.

193 Symbolika „zrujnowanego kościoła” czytelna jest w Gombrowiczowskim opisie mszy, zaczerpniętym z Pornografii: „Kościół przestał być kościołem. Wdarła się przestrzeń już kosmiczna, czarna [...]. Tak dalece, że światło świec, a nawet światło dnia, wdzierając się przez witraże, stało się czarne jak noc". Zob. Witold Gombrowicz, Pornografia, dz. cyt., s. 17-18. 
filmu wszechobecna ${ }^{194}$ - płonąca świeca w rękach Jędrka (stacja I, II i III), pokryta pajęczynami Pieta i strzaskane figury aniołów (stacja II), krzyże (stacja III). Warto zwrócić szczególną uwagę na kompozycję filmowych kadrów zamykających omawianą sekwencję. Na pierwszym planie Jędrek, towarzysząc księdzu w ostatniej posłudze, zstępuje powoli do najniższego kręgu piekła. W dole widoczne są sylwetki katów i ofiar, a także groby wypełnione rzędami ciał. Na drugim brzegu wąwozu w sporym oddaleniu - majaczą krzyże. To nie tylko wizualny "cytat" z Anhellego („Postawiono więc trzy krzyże z najwyższego, jakie było w tym kraju, drzewa. I wystąpili trzej męczennicy..."), ale i czytelne odwołanie do romantycznej wizji „Chrystusa narodów”. Nieoczekiwaną puentą onirycznej sekwencji jest statyczny obraz - fotografia-dokument (scena rozstrzelania na Ursynowie) (fot. 10-12).

Analizowana sekwencja dowodzi, że Hasowi bliskie jest Gombrowiczowskie rozumienie podświadomości jako obszaru przejawiania się traumatyzmu kultury ${ }^{195}$. O dokonanych przez Gombrowicza przekształceniach w obszarze pojęć freudowskiej psychoanalizy pisze Andrzej Kijowski:

O ile w klasycznej psychoanalizie za podświadomość uważa się nie wyrażone i nie zrealizowane treści psychiczne osobnika, według Gombrowicza można by ją uznać za niewidoczny ślad cudzej presji - za rany i blizny zapoznanych starć z ludźmi, za podrzucone przez nich z wolna działające trucizny ${ }^{196}$.

Śladów podobnej refleksji doszukać się można w Szyfrach. Oniryczne fragmenty filmu wskazuja, że dla Hasa podświadomość jest sferą „zmediatyzowaną" przez uniwersum symboli. Trudno jednoznacznie ustalić status onirycznych obrazów. Nie znajdziemy w Szyfrach wskazówki

${ }^{194}$ To być może stało się powodem, dla którego piszący o filmie uznali Szyfry za ewokację eksterminacji wojennej widzianej oczyma Polaków. Zob. Anne Guérin-Castel, Dwoista forma "Szyfrów" Wojciecha Jerzego Hasa - prawda do rozszyfrowania, dz. cyt., s. 51. Warto zauważyć, iż w tekście opowiadania Kijowskiego odniesienia do Zagłady Żydów są nieliczne i „zaszyfrowane”. Dla przykładu, Maciek - opowiadając Tadeuszowi o szczegółach okupacyjnej egzystencji w Krakowie - ironizuje: „Niemcy w domu są konieczni do uchronienia mieszkania od dalszych rekwizycji, ich wizytówki przybite do drzwi wejściowych stanowią także ochronę przed policją. [...] Obok tego konieczna jest drukowana kartka z napisem «Arische Wohnung», mieszkanie aryjskie. Sam taką kartkę kupiłem, kupowano je w papierniczych sklepach masowo jako interesującą nowość, coś w rodzaju nowego środka dezynfekcyjnego". Zob. Andrzej Kijowski, Szyfry, dz. cyt., s. 96.

195 Zob. Maria Janion, Forma gotycka Gombrowicza, [w:] taż, Prace wybrane. Romantyzm i jego media, Universitas, Kraków 2001, s. 525.

196 Andrzej Kijowski, Strategia Gombrowicza, dz. cyt., s. 441. 

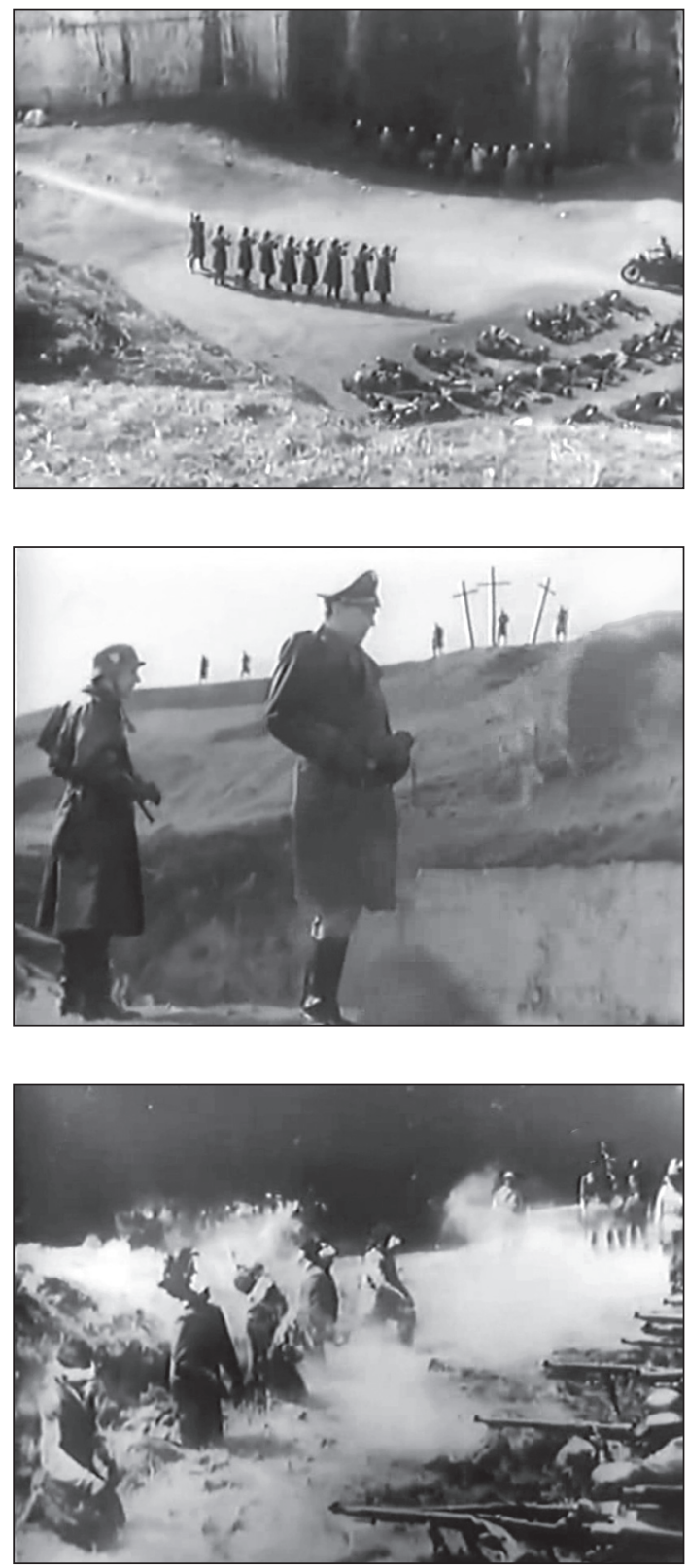

Fot. 10-12. Szyfry (1966, reż. Wojciech Jerzy Has) Ikonografia II wojny 
umożliwiającej dookreślenie owych wizji - mogą być zarówno snem, jak i zapisem strumienia świadomości. W obu przypadkach należałoby je potraktować jako filmowy ekwiwalent Gombrowiczowskiej narracji pierwszoosobowej, umożliwiającej odbiorcy bezpośredni wgląd w psychikę bohatera ${ }^{197}$. Barokowość owych wizji - kontrastujących ${ }^{198} \mathrm{z}$ ascetyczną poetyką partii ",realistycznych" - dowodzi nie tyle hipertrofii przypadkowych asocjacji, lecz odsyła do wspólnej przestrzeni kulturowej, stanowiącej rezerwuar owych symboli.

Dokonujący się $\mathrm{w}$ podświadomości Tadeusza proces asocjacyjny zamyka się w granicach wyznaczonych przez "truciznę" fotografii. Funkcję inicjacyjną pełni komunijne zdjęcie Jędrka (wymiar jednostkowy). To ono uruchamia łańcuch skojarzeń łączących - poprzez patriotyczno-religijną symbolikę - miejsca odległe w czasie i przestrzeni. Zwieńczeniem całego procesu jest również fotografia, dzięki której indywidualna historia zostaje wpisana w szerszą perspektywę historii zbiorowości. To strategia bliska Gombrowiczowi, który na kartach Dziennika zanotował: „Ja nie piszę dla narodu, ani narodem, ani z narodu. Piszę sobą, z siebie. Ale czy mój gąszcz nie łączy się kryjomo z gąszczem narodu?" 199 Przytoczone słowa to autokomentarz do Pornografii, traktowanej jako wykładnia "polityki” pisarza, która realizuje się $\mathrm{w}$ procesie „przechodzenia od patologii prywatnej do narodowej" 200 .

Nagromadzenie elementów symbolicznych należących do patriotycznego decorum czyni z omawianej sekwencji analizę mechanizmów determinujących plastyczny kształt wizji pojawiających się w podświadomości bohatera. Stereotypowy charakter owych wizji jest efektem oddziaływania reprezentacji ikonicznych, ale warto też zwrócić uwagę na funkcję języka poetyckiego. Nie bez przyczyny onirycznym obrazom towarzyszą fragmenty Anhellego. Stanowią one czytelne odwołanie do Gombrowiczowskiej Ferdydurke, w której „atak na Słowackiego”"201 („Dla-cze-go,

197 Typowym „strumieniem świadomości” jest, zdaniem Jerzego Jarzębskiego, początkowy fragment Kosmosu, w którym przeplatają się doznania, obrazy i wspomnienia z rożnych porządków czasowych i przestrzennych, nadające sens temu, co bohater aktualnie przeżywa. Charakterystyczną cechą tego typu zapisów jest - odczuwalne także w Szyfrach-wrażenie "nadmiaru”.

198 Podstawowe znaczenie ma właśnie - niedostrzeżona przez krytykę - zasada kontrastu. Wydaje się, że przy realizacji Szyfrów Has narzucił sobie „regułę dyscyplinującą", nie pozwalając, by poetyka marzenia sennego zdominowała wizualny porządek dzieła.

199 Witold Gombrowicz, Dziennik 1957-1961, Wyd. Literackie, Kraków 1988, s. 256.

${ }^{200}$ Jean-Pierre Salgas, Witold Gombrowicz lub ateizm integralny, dz. cyt., s. 85.

${ }^{201}$ Przypomnijmy, iż lekcja języka polskiego w Ferdydurke to literackie przepracowanie autobiograficznego doświadczenia z lat szkolnych. We Wspomnieniach polskich znalazł się wielce sugestywny opis tego doświadczenia: „Pewnego razu nasz profesor, Ciepliński, zadał nam wypracowanie klasowe o Słowackim. Znudzony wiecznym kadzeniem wieszczowi [podkr. moje - N.K.-R.], postanowiłem dla odmiany dać mu bobu. Począ- 
dla-cze-go, dla-cze-go, Wa-cek-Sło-wac-ki-i-musz-ka-pchła"202) staje się jednocześnie atakiem na zmumifikowany polski romantyzm.

Wraz z prześmiewanym Pimką - pisze Jean-Pierre Salgas - Gombrowicz nadaje ostateczny kształt owemu gestowi profanacji narodowej świętości, której jądrem jest poezja - religia literacka i patriotyczna. Właśnie ta forma świętości podtrzymuje niedojrzałość kraju, choć udaje, że go wychowuje ${ }^{203}$.

Salgas podkreśla jednak, iż dopiero w późniejszym Trans-Atlantyku (a także w Pornografii) sprzeciw pisarza wobec romantyzmu będzie manifestował się $\mathrm{w}$ dużej mierze na płaszczyźnie wypowiedzi. W walce z romantyzmem Gombrowicz odnawia styl sarmacki, wprowadzając do polskiej świątyni inne tradycje i gatunki ${ }^{204}$. Polem bitwy staje się materia języka. Autoeksplikację strategii Gombrowicza stanowi diatryba Przeciw poetom - wielki ateistyczny manifest filozoficzny skierowany przeciwko religii narodowej i literackiej ${ }^{205}$ :

Zmyślanie wierszy, parodiowanie wieszczów - wszystko po to, by sprofanować świątynię i - jak w Pornografii - zburzyć katedrę. Podobnie jak prawdziwa msza, która pełni jedynie funkcję społeczna, "poezja” jest małym obrzędem wymyślonym przez poetów dla podtrzymania temperatury ${ }^{206}$.

W Szyfrach zestawienie profetycznej poezji wieszcza ze scenami martyrologii narodu (podobnym zabiegiem posłuży się - w odniesieniu do

tek, o ile pamiętam, brzmiał jak następuje: «Juliusz Słowacki, ten złodziej, który okradał Byrona i Szekspira i nic własnego nie potrafił wymyślić». Dalszy ciąg nie ustępował początkowi. Profesor Ciepliński postawił pałkę i zagroził, że prześle wypracowanie do Ministerstwa, na co ja zapytałem, dlaczego zmusza uczniów do hipokryzji". Zob. Witold Gombrowicz, Wspomnienia polskie. Wẹdrówki po Argentynie, dz. cyt., s. 30.

A przecież groteskowy opis lekcji polskiego w Ferdydurke nie tylko do ataku na wieszcza (jeśli w ogóle) się sprowadza. W latach międzywojennych był to - jak pisze Andrzej Werner w odniesieniu do Apokryfu rodzinnego Hanny Malewskiej - „opór przeciw temu, co mocne, co znajdowało oparcie w silnych instytucjach. A zarazem przeciw temu, co niekonieczne kulturalnie martwe, nieautentyczne w warunkach niepodległej państwowości, oderwane od funkcji, jakie spełniało w czasach rozbiorów, w podbitym narodzie. Więcej - szkodliwe, bo przez swe funkcje jednoczące pod sztandarem polskości zamazywało istotne podziały, zamazywało obraz, na którym nie było już miejsca na Berezę i pałkarzy, na politykę wobec mniejszości narodowych, na postępującą w późnych latach trzydziestych zarazę totalitaryzmu w rodzimym wydaniu". Zob. Andrzej Werner, Polskie, arcypolskie..., dz. cyt., s. 237.

${ }^{202}$ Witold Gombrowicz, Ferdydurke, dz. cyt., s. 42.

${ }^{203}$ Jean-Pierre Salgas, Witold Gombrowicz lub ateizm integralny, dz. cyt., s. 78.

204 Tamże, s. 83.

${ }^{205}$ Tamże, s. 164.

206 Tamże, s. 188. 
Mickiewiczowskich Dziadów - Tadeusz Konwicki w Lawie) pozwala na zobrazowanie procesu formowania się (pod)świadomości zbiorowej. Romantyczne stereotypy ukształtowały z pewnością psychikę Tadeusza. A w okresie międzywojnia (gdy mundur wojskowy był koniecznym elementem dekoracji domowej ${ }^{207}$ ) szkoła, stanowiąca w Ferdydurke antywzorzec edukacji, dręczyła zastępy uczniów pytaniem: „Dlaczego w poezjach wielkiego poety, Juliusza Słowackiego, mieszka nieśmiertelne piękno, które zachwyt wzbudza?" ${ }^{208}$ Wśród tych uczniów był z pewnością Maciek, a po nim Jędrek: „przeanielony” chłopiec z komunijnej fotografii.

Zdjęcie-pamiątka pełni magiczną funkcję: stwarza iluzję bytu triumfującego nad śmiercią:

Nie chcąc pamiętać o nicości - pisze Soulages - wymyślamy, nie zdając sobie z tego sprawy, byt, realne, zdjęcie i jego stałe odniesienie. Jak wiele poczucia bezpieczeństwa Barthes'owskie "to-co-było" daje temu, który nie chce uwierzyć w mijający czas i czas stracony, w nieodwracalną śmierć ${ }^{209}$.

Obiektowi utrwalonemu na fotograficznej kliszy grozi mumifikacja nieodwołalne przekształcenie w przedmiot. Ten "przedmiot”, nieżyjący syn Tadeusza, obdarzony zostaje egzystencją wyobrażeniowa, realizującą się już tylko w obrazie. Zmarły, w archaicznym rytualnym geście, „wymienia” swoje utracone ciało na obraz, by z jego pomocą pozostawać wśród żywych ${ }^{210}$.

Tadeusz zdaje się nie przyjmować do wiadomości, że Jędrek byłby dziś dojrzałym, prawie czterdziestoletnim mężczyzną. W pamięci ojca tkwi obraz dziecka z komunijnej fotografii. Świadczą o tym nie tylko oniryczne sceny z udziałem syna, ale i fakt, że w Krakowie Tadeusz zwraca uwagę na chłopców, którzy wiekowo odpowiadają Jędrkowi sprzed wojny: uporczywie wpatruje się w dziecko czekające na Jadwigę pod kawiarnią i kilkuletniego malca z walizeczką, którego widzi przez chwilę przez okno taksówki.

Przy tym ostatnim obrazie warto zatrzymać się nieco dłużej. Bardzo długa, zrealizowana w jednym ujęciu scena jazdy taksówką przez labirynt krakowskich ulic wydaje się mieć charakter stricte realistyczny. Zauważmy jednak, iż spojrzenie kamery jest w tej scenie tożsame ze spojrzeniem Tadeusza, który ulokował się na tylnym siedzeniu samochodu i przez cały czas podróży nie będzie w kadrze widoczny. W taksówce Maciek rozpoczyna swą afektowaną okupacyjną opowieść. Ponaglony

\footnotetext{
${ }^{207}$ Andrzej Kijowski, Szyfry, dz. cyt., s. 115.

${ }^{208}$ Witold Gombrowicz, Ferdydurke, dz. cyt., s. 43.

${ }^{209}$ François Soulages, Estetyka fotografii, dz. cyt., s. 122.

${ }^{210}$ Zob. Hans Belting, Antropologia obrazu, dz. cyt., s. 38.
} 
przez zniecierpliwionego ojca (Mów mi tylko o tym, co może mieć dla mnie znaczenie) przechodzi do rzeczowej relacji o aresztowaniu Jędrka. Przy słowach: Jędrek został zabrany z końcem listopada 44 roku... po lewej stronie kadru pojawia się sylwetka chłopca z walizeczką. Dziecko - najwyraźniej zagubione $\mathrm{w}$ tłumie przechodniów - powoli przechodzi na prawą stronę i staje tuż przy tylnej szybie taksówki. Chłopiec wykonuje obrót o 180 stopni, a spojrzenie Tadeusza - unieruchomionego wewnątrz samochodu - skoncentrowane jest wyłącznie na nim.

W omawianej partii filmu nie pojawia się jakiekolwiek ujęcie „obiektywizujące”, które pozwoliłoby dookreślić ontologiczny status postaci chłopca. Być może jest on jedynie projekcją umysłu Tadeusza - sobowtórem Jędrka, którego „ożywiło” wspomnienie Maćka. Finał analizowanej sceny doskonale wpisuje się w Hasowską filozofię czasu, której symboliczną reprezentacją staje się figura oko-okno/lustro. Spojrzenie bohatera przez/w szklaną powierzchnię okna/lustra w idiolekcie Hasa oznacza transgresję - wkroczenie w inny wymiar czasu. Byłby to czas marzenia sennego, podczas którego przebywamy w teraźniejszości wyobrażonej,

umieszczonej w punkcie czasowym, który z niczym się nie łączy. Jest to określenie czysto negatywne, sprowadzające się do tego, że nie będąc w stanie powtórnie przeżyć w wyobraźni czy w pamięci jakiegoś okresu przeszłości, ani też przenieść się w przyszłość, nie znajdujemy się ani w przyszłości, ani w przeszłości, lecz nie znajdujemy się także w realnej teraźniejszości, to znaczy w momencie, który mógłby przez nas [...] być określony w związku z innymi podziałami i okresami czasu ${ }^{211}$.

Figura oko-okno/lustro pojawia się w filmach Hasa z obsesyjną regularnością. Nie oznacza to jednak, iż można ją potraktować jako konwencjonalny chwyt (np. sygnalizujący retrospekcję), mający ułatwić widzowi orientację $\mathrm{w}$ filmowej diegezie. Figura ta ma bowiem charakter idiomatyczny i w żadnym razie nie można jej wpisać w jeden skodyfikowany system znaczeń.

Selektywne (,wyłuskujące” z rzeczywistości tylko chłopców przypominających zaginionego syna) spojrzenie Tadeusza ujawnia - jakże typową dla Gombrowicza - "grę zwierciadlanych odbić", w której (nieobecny) bohater zatraca swą indywidualna, jednostkową tożsamość w niekończącym się łańcuchu multiplikacji. Sobowtórem Jędrka jest w tym samym stopniu chłopiec z getta, anonimowy chłopiec z walizka, chłopiec (syn?) towarzyszący Jadwidze w Sukiennicach (fot. 13-15).

${ }^{211}$ Maurice Halbwachs, Społeczne ramy pamięci, tłum. Marcin Król, PWN, Warszawa 1969, s. 84 . 

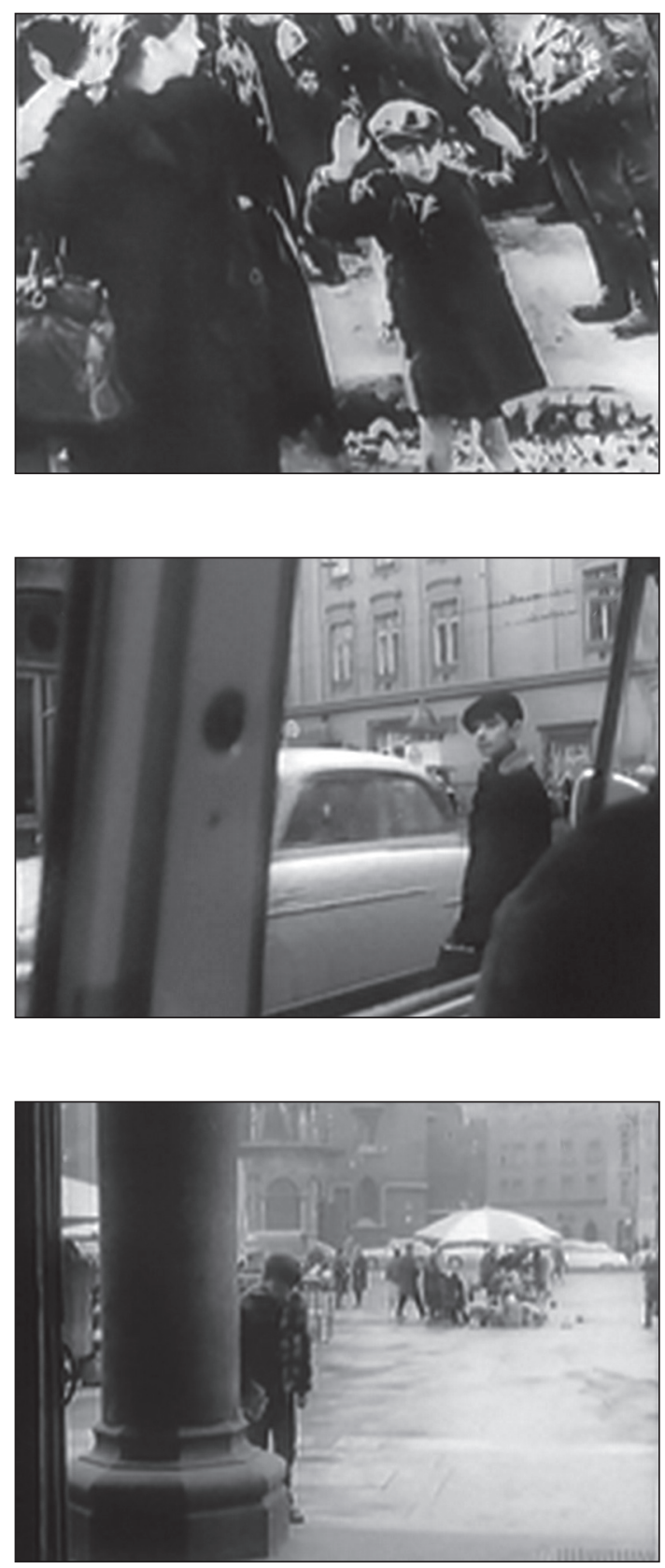

Fot. 13-15. Szyfry (1966, reż. Wojciech Jerzy Has) "Gra zwierciadlanych odbić" 
Każda fotografia - podkreśla Soulages - jest postrzegana nie tylko za pomocą wzroku, rozumu i świadomości, ale także poprzez wyobraźnię i nieświadomośćc ${ }^{12}$. Wydaje się, iż zdjęcie-pamiątka w magiczny sposób przywraca zmarłego syna do życia (życia wyobrażonego - egzystencji w obrazie, wizji, wspomnieniu) i staje się dla Tadeusza niezbitym dowodem istnienia ",tego-co-było".

Fotografia - potwierdza Roland Barthes - nie przypomina przeszłości (zdjęcie nie ma w sobie nic proustowskiego). W jej działaniu na mnie nie chodzi o odbudowanie tego, co runęło (w wyniku działania czasu, odległości), a jedynie o poświadczenie, że to, co widzę - naprawdę istniało. [...] Fotografia ma w sobie coś wspólnego ze zmartwychwstaniem ${ }^{213}$.

Komunijne zdjęcie Jędrka pełni jeszcze jedną istotną funkcję. Dzięki fotografii-pamiątce może zostać zrealizowany fantazmatyczny scenariusz, w którym chłopcu przypada tradycyjnie rola ofiary. Taki scenariusz wyklucza zarazem możliwość interpretacji śmierci Jędrka w kategoriach „nie-ofiarniczych" - jako wyrazu buntu przeciwko narzuconej społecznie "gębie" ofiary ${ }^{214}$. Wyjaśnienie sensu owej śmierci dokonuje się zatem poprzez wpisanie niezrozumiałego zjawiska („Jędrek poniósł karę za zdradę") w istniejący („,ofiarniczy”) paradygmat.

Zdjęcie służy ujawnieniu paradoksu wiktymizacji ukrytego w strukturze filmowego tekstu: Inny, który ma być chroniony (także w sensie symbolicznym, czyli: ocalony w pamięci), jest dobry o tyle, o ile pozostaje ofiarą ${ }^{215}$.

Obowiązek pamiętania - pisze Paul Ricoeur - nie ogranicza się do pilnowania materialnego śladu, pisemnego czy innego, minionych faktów, lecz podtrzymuje poczucie bycia zobowiązanym względem tych innych, o których dalej powiemy, że ich już nie ma, choć byli. [...] pośród tych wszystkich innych, wobec których jesteśmy zadłużeni, pierwszeństwo, ze względów moralnych, przyznajemy ofiarom ${ }^{216}$.

${ }^{212}$ François Soulages, Estetyka fotografii, dz. cyt., s. 297.

${ }^{213}$ Roland Barthes, Światto obrazu, tłum. Jacek Trznadel, Wyd. KR, Warszawa 1996, s. $138-139$.

${ }^{214}$ Symboliczne znaczenie śmierci Jędrka staje się oczywiste w świetle filozofii Witolda Gombrowicza. Danuta Danek pyta: „Czy ktokolwiek w utworach Gombrowicza umiera śmiercią naturalną? z w y c z a j n i e? śmierć w jego twórczości też jest zawsze w y n a t u r z o n a, z naddatkiem kształtowania jej przez działania człowieka, i czy też Iwona nie ginie, ponieważ odmawia kontrgęby? i Władzio ginie, ponieważ odmawia kontrgęby!". Zob. Danuta Danek, Oblicze. Gombrowicz i śmierć, [w:] Sztuka rozumienia. Literatura i psychoanaliza, Instytut Badań Literackich PAN, Warszawa 1997, s. 241.

${ }^{215}$ Zob. Slavoj Žižek, Kruchy absolut, tłum. Maciej Kropiwnicki, Wyd. Krytyki Politycznej, Warszawa 2009, s. 68.

${ }^{216}$ Paul Ricoeur, Pamięć, historia, zapomnienie, tłum. Janusz Margański, Universitas, Kraków 2006, s. 117-118. 
Scenariusz ofiarniczy wyklucza subwersywne elementy z mitycznej biografii Jędrka. Nie mieści się w niej podejrzenie o zdradę organizacji, zemsta na niewiernym kochanku matki czy fascynacja militarną potęgą wroga, a także zarażenie złem. O takich „okupacyjnych” dzieciach - o ich gapiostwie $^{217}$ - pisał Kijowski:

Pamiętam je z czasów wojny. Podchodziły bez obawy do samochodów i czołgów
wszystkich możliwych armii, brały czekoladę i chleb od kogo się dało, zawsze jedna-
kowo chłodne i jednakowo ciekawe. Spokojnie patrzyły na krew; zjawiały się na miej-
scu zamachu lub egzekucji, gdy tylko umilkły strzały. Odpędzone przez żandarma,
przybliżały się ostrożnie, gdy tylko odwrócił od nich uwagę. Bezkarne i bezpieczne,
nielitościwe i odważne. Gdy likwidowano getto, zapełniały wozy tramwajowe, które
przejeżdżały bez zatrzymywania się przez dzielnice objętą akcją. Przejeżdżały raz,
wracały i jeszcze raz jechały, niesyte wrażeń. Są milczącym, anonimowym, nie za-
uważonym prawie świadkiem śmierci, nieszczęścia, zbrodni, podobne do wron, któ-
re zlatują się na pobojowiska. Nie cenią życia, więc nie wzrusza ich krew. Są zawsze
po stronie silniejszego: raz po stronie porządku, innym razem po stronie zbrodni218.

Takiej nieprzystającej do paradygmatycznego wizerunku dziecka-ofiary wykładni Tadeusz nie jest w stanie zaakceptować: Mój syn był jeszcze dzieckiem. Coś tam wygadat z głupoty, rozumie pan? A może oszalat ze strachu, albo oszaleli ci, co go zabili. Ojciec ulega złudzeniu, dzięki któremu rzeczywistość wojenna wyłącza się ze strumienia czasu i staje wieczną teraźniejszością (tak jak i Jędrek na zawsze pozostaje w świadomości Tadeusza dzieckiem w odświętnym garniturku). Dezintegracja osobowości Tadeusza jedynie pozornie stanowi potwierdzenie zjawiska międzypokoleniowego (potraktowanego przez Hasa à rebours) przekazywania traumy, w którym

poprzez często nieświadome procesy utożsamienia - szczególnie z bliskimi - może dojść do opętania przeszłością i ponownego przeżywania widmowych posttraumatycznych symptomów wydarzeń i doświadczeń, których się bezpośrednio nie przeżyło ${ }^{219}$.

Teraźniejszość „opętaną przeszłością” kształtują bowiem nie tyle subiektywne doświadczenia, ile utrwalone przez tradycję i transmitowane kulturowo stereotypy. To właśnie wedle owych stereotypów konstruowane są role, jakie poszczególne jednostki musiały odgrywać w ramach martyrologicznych narracji. Zauważmy, iż od wczesnego dzieciństwa Jędrek świadomie przygotowywał się do odegrania przeznaczonej mu roli $\mathrm{w}$ narodowym misterium:

\footnotetext{
${ }^{217}$ W ten właśnie sposób określa Zofia stupor Jędrka: jako gapiostwo.

${ }_{218}$ Andrzej Kijowski, Kompleks Dżyngis-Chana, dz. cyt., s. 87-88.

${ }^{219}$ Dominick LaCapra, Historia w okresie przejściowym, dz. cyt., s. 61.
} 
Całe dni spędzał w tłumie dewotek. Wpatrzony w ołtarz z tym swoim dziwnym uśmieszkiem, który nie schodzit mu z twarzy. [...] Wszystko robit inaczej, nie tak jak inni chtopcy, dla zabawy, dla ciekawości... ale tak jakby się chciał tym zamęczyć, wyniszczyćc20.

Świadczy o tym również znamienna wypowiedź doktora Grossa, w której podkreślone zostały masochistyczne skłonności chłopca, predestynujące go do roli ofiary:

Tak, takie rzeczy zdarzaja się u chłopców, tyle że u Jędrka trwało to dtużej i miało jakiś sens, może religijny... Uderzony... uderzony, prosze pana, nie oddawat. Raz naraził się szkolnemu siłaczowi, ten zmasakrował go do krwi. Miał do mnie zaufanie albo wybrat mnie sobie na widza do tego teatru, w którym grat. Chłopcy na ogót opowiadaja o swoich zwycięstwach i przewagach, on przeciwnie - chwalit się swoimi upokorzeniami. Tym, że uderzony nie oddawat, tak jak mówiłem, albo że pozwalał masakrować się silniejszym od siebie ${ }^{221}$.

Ten wyjątkowy rys psychiki Jędrka potraktować można w kategoriach Girardowskich jako element stygmatyzujący „przyszłą” ofiarę. Oczywiście, nie jest to jedyna możliwość interpretacji. Scena rozgrywająca się w gabinecie Grossa zdecydowanie wyróżnia się w strukturze filmowego tekstu. Jest bowiem w sposób wyjątkowy „podminowana” ukrytym dyskursem psychoanalitycznym. Ujawnione przez lekarza masochistyczne skłonności sytuują Jędrka w Gombrowiczowskim „kręgu perwersji” ${ }^{222}$. Chorobliwą fascynację Jędrka wojennym teatrem, w którym istnieje wyraźny podział na role "oprawców" i „ofiar”, zdradzają również sporządzone przez chłopca rysunki esesmanów. Jędrek obsesyjnie skupia się na „kostiumach” determinujących społeczne role: mundurach wyższych rangą oficerów - „całym tym śmietniku form pustych, niepotrzebnych" ${ }^{223}$.

O przemożnej sile martyrologicznych stereotypów świadczy fakt, iż wbrew intencji reżysera, który zrealizował Szyfry w duchu Gombrowiczowskim, czyli jako polemikę z narodowym mitotwórstwem, Marcin Maron pisze:

Jędrek to nie tylko osamotnione i zalęknione dziecko; Jędrek to także siła, która niewyjaśnioną mocą dąży do spełnienia swego losu w niewinnym, jednostkowym poświęceniu - ofierze życia - splecionym nieodwołalnie w jedną całość z poświęceniem innych i dokonującym się w piekle dziejowego kataklizmu. [...] Na poziomie zwykłego zaszeregowania faktów Jędrek pozostaje zagubionym dzieckiem, na innym jednak

${ }^{220}$ Cytat z filmu Hasa.

${ }^{221}$ Cytat z filmu Hasa.

${ }^{222}$ Masochizm to przecież podstawowy rys znamionujący figury Innych - „,seksualnych odmieńców” (tytułowy "tancerz" z opowiadania Tancerz Mecenasa Kraykowskiego czy Gonzalo z Trans-Atlantyku).

${ }^{223}$ Andrzej Kijowski, Szyfry, dz. cyt., s. 186. 
poziomie - Jędrek to uosobienie ofiary. [...]. Potwierdzeniem powyższej interpretacji staje się końcowy fragment drugiej wizji, w którym to Jędrek, niosąc w ręku zapaloną świecę, zstępuje wraz z księdzem w rozpadlinę kamieniołomu - miejsca kaźni - łącząc swój los z losem innych - niewinnie cierpiących i ginących za ojczyznę ${ }^{224}$.

Z dotychczasowych rozważań wynika, iż wspomniany powyżej fragment (jak i cała sekwencja, z której ten fragment pochodzi) demaskuje mechanizmy konstruowania wyobrażeń i dowodzi jedynie tego, iż narracje wytwarzane $\mathrm{w}$ podświadomości Tadeusza powstają pod wpływem spetryfikowanych wzorców ${ }^{225}$. Wprowadzone do filmu partie wizyjne służą uświadomieniu, jak wielki wpływ na psychikę bohatera wywarły utrwalone w zbiorowej pamięci obrazy fotograficzne i malarskie. Umysł Tadeusza reprodukuje preegzystujące wzorce ikoniczne w postaci rozwiniętych narracji, w które wplecione zostały szczegóły biograficzne.

Wojciech Has - na co zwróciła uwagę Alicja Helman 226 - charakteryzując Tadeusza, pominął ten szczególny rys psychiki bohatera, który Andrzej Kijowski objaśnił pod koniec opowiadania: „Nigdy nie zastanawiał się ani nad własnym, ani nad cudzym postępowaniem, nie analizował uczuć ani postaw. Postępował według wzorców, których dostarczali mu inni, to jest ci, którzy budzili z jakichś szczególnych powodów jego podziw"227. Dopiero w Krakowie „zrozumiał, że jego mądrość i moralność były rodzajem rzemiosła - umiejętnością zastosowania gotowych wzorów w sytuacji będącej drobnym wariantem innych, podobnych czy identycznych, które już miały miejsce” ${ }^{228}$. Wychodząc „na zewnątrz” świata-pozoru, Tadeusz zyskuje niezbędną wiedzę, która pozwoli mu zakończyć śledztwo:

${ }^{224}$ Marcin Maron, Dramat czasu i wyobraźni. Filmy Wojciecha J. Hasa, Universitas, Kraków 2010, s. 240-241. W podobnym kontekście interpretacyjnym osadzona jest także analiza funkcji postaci Jędrka autorstwa Anne Guérin-Castel: „dziecko, jedna z niemal anonimowych ofiar wojny, pozbawionych chwały, jakby jedyna istota ludzka w tym pochodzie jeźdźców, krucha inkarnacja rycerza z finałowej sceny Anhellego, wieszczącego godzinę rewolucji powszechnej, milczący posłaniec, który wiedzie żołnierzy do kościoła i znika”. Zob. Anne Guérin-Castel, Dwoista forma "Szyfrów" Wojciecha Jerzego Hasa - prawda do rozszyfrowania, dz. cyt., s. 48.

${ }^{225} \mathrm{O}$ znaczeniu przekazów medialnych (zwłaszcza fotografii-dokumentu) w procesie kształtowania osobistych narracji biograficznych pisałam wcześniej. W tym miejscu warto przytoczyć wypowiedź François Soulagesa dotyczącą pokrewieństwa fotografii i snu: „Każdy odbiór zdjęcia stanowi interpretację, w czym fotografia przypomina marzenie senne. Nie wiąże się ona zatem z językiem jednoznacznym, oczywistym i uniwersalnym". François Soulages, Estetyka fotografii, dz. cyt., s. 297.

${ }^{226}$ Zob. Alicja Helman, Rzeczywistość mówi językiem znaków, [w:] Widziane po latach. Analizy $i$ interpretacje filmu polskiego, red. Małgorzata Hendrykowska, Wyd. Poznańskiego Towarzystwa Przyjaciół Nauk, Poznań 2000, s. 141.

227 Andrzej Kijowski, Szyfry, dz. cyt., s. 152.

228 Tamże. 
- Kto go zabił? Kruk? Gryf? Ptak czy zwierzę z mitologii wojny? To symbole. Kto go zabił?

- Ja - powiedział i przedarł kartkę.

- My - dodał - kłamcy, twórcy pustych znaków ${ }^{229}$.

Takiego stopnia samoświadomości bohaterowi filmowej adaptacji Szyfrów nie dane będzie jednak osiągnąć. Prawda stanowi bowiem aberrację, która stabilnemu światu pozoru grozi „wypadnięciem z Formy”. A przecież prawda - obwarowana społeczno-kulturowym tabu - nadaje historii Tadeusza indywidualny rys, wyróżniając ją z tysiąca innych opowieści, tworzących homogeniczną (martyrologiczną) narrację o polskim losie. Ten wątek został bardzo mocno wyeksponowany w opowiadaniu. Kijowski pisze:

I dalej, dalej opowiadał, nie wiedząc już, czy własne dzieje opowiada, czy cudze, tak były jednakowe i tak już opisane, tak popularne. Czuł, że mu się kurczy ta opowieść, tak jak skurczyło się całe życie do kilku dat zaledwie. Wszystko, co stanowiło główny ciężar jego opowieści, było już „lieux communs”, oczywistością historyczną. Opowiadać ją znaczyło powtarzać historię drugiej wojny światowej. [...] Mógł powiedzieć: „Syna mi zabili nasi”. Wtedy zapytano by, dlaczego. Lecz to nie jest pewne, czy by zapytano, ponieważ o takie rzeczy nietypowe, pokrętne, ciemne - lepiej nie pytaćc ${ }^{230}$.

W Gombrowiczowskiej Pornografii obsceniczny "spektakl, z żądzy impotenta poczęty" ${ }^{231}$, unicestwia w krwawym finale martwe konwencje Formy: „I przez sekundę, oni i my, w naszej katastrofie, spojrzeliśmy sobie w oczy"232. W Szyfrach Wojciecha Hasa bohater ponosi ostatecznie klęskę, wynikającą z niemożności uwolnienia się spod wpływu narodowej mitologii ofiarniczej. Tadeusz nie dociera bowiem w swym rozumowaniu do etapu, w którym dla bohatera-detektywa z Kosmosu staje się oczywiste, iż aby świat zrozumieć, trzeba wydostać się z błędnego koła - opuścić sferę hieroglifu (ale i ta postać - jak bohater Hasa - nie potrafi pozostać „na zewnątrz", o czym świadczy słynne zdanie puentujące powieśćc ${ }^{23}$ ) .

Has - wzorem Gombrowicza - każe bohaterowi zmierzyć się z chaosem rozpadających się elementów. Tadeusz, niczym "sędzia śledczy”,

229 Tamże, s. 193.

${ }^{230}$ Tamże, s. 158-159.

${ }^{231}$ Czesław Miłosz, Kim jest Gombrowicz, [w:] Gombrowicz i krytycy, dz. cyt., s. 195.

${ }^{232}$ Witold Gombrowicz, Pornografia, dz. cyt., s. 150.

${ }^{233}$ Witold Gombrowicz, Kosmos, Wyd. Literackie, Kraków 1988, s. 148. To oczywiście jedna z możliwych interpretacji enigmatycznego zakończenia powieści. Zdaniem Jerzego Jarzębskiego "potrawka z kury” to metatekstowy, niepowiązany z fabułą element "Z zewnątrz", rozbijający porządek świata przedstawionego i kompromitujący logikę narracji. Zob. Jerzy Jarzębski, Gra w Gombrowicza, dz. cyt, s. 109. 
podejmuje wysiłek nadania aporetycznemu światu uporządkowanej formy, odwołując się do spetryfikowanych wzorców. Pozbawiony zostaje wszakże demiurgicznej mocy kreowania rzeczywistości, którą swoich bohaterów obdarza Gombrowicz:

Pierwsze Osoby występują zrazu w roli śledzących [...], którzy usiłują zrekonstruować i wiernie opowiedzieć stan faktyczny. A jeśli to okazuje się niemożliwe, śledzący zmieniają się w sprawców - stają się dramaturgami, którzy sami wydarzenia konstruują ${ }^{234}$.

Szyfry, niczym Gombrowiczowska Zbrodnia z premedytacja, daje się odczytać jako historia triumfu Formy nad czystą faktycznością, choć w ujęciu Hasa nie nosi ona znamion parodii (dokonującej reductio ad absurdum wzorca powieści kryminalnej ${ }^{235}$ ). Hasowski bohater nie potrafi zakorzenić się w rzeczywistości inaczej niż poprzez Formę. Tym należy tłumaczyć jego zaskakujące - niewynikające wszakże w żaden sposób z logiki opowiadania - postanowienie pozostania w Krakowie. Z lęku przed „rozkawałkowaniem się" świata Tadeusz kurczowo chwyta się myśli przywracającej temu światu (pozorny) sens: „jestem rodzinie potrzebny". W ten sposób $\mathrm{w}$ indywidualnym doświadczeniu aktualizuje się arkadyjski mit swojszczyzny, odtwarzany wedle tradycyjnego Sienkiewiczowskiego scenariusza.

\begin{abstract}
Żyje w kulturze polskiej fenomen - pisze Kijowski - który nazwałbym sienkiewiczowską strukturą idei: wyraża się ona w uformowaniu losu bohaterów, którzy muszą oczyścić się ze świata współczesnego, aby powrócić do mitycznego, mgłą osłoniętego początku, do źródła, do pierwotnej arkadii. [...]

[Sienkiewicz] Całą awanturę intelektualną jaką przeżyć może człowiek, lub pokolenie, lub naród kulturalny, zamknął w kręgu familijnej mitologii. [...] Na co ci powiedział - świat, historia, ruch, rozwój, przemiana, bezmiar idei i przygód? Wróć, bądź dzieckiem, mężem, ojcem; bądź tym, czymeś się urodził: Polakiem bądź i katolikiem. To cię uzdrowi ${ }^{236}$.
\end{abstract}

Ferdydurke zamyka osławione: „,nie ma ucieczki przed gęba, jak tylko w inną gębę". W przypadku Tadeusza tą „,inną gębą" będzie dobrowolnie przybrana "gęba" troskliwego męża i ojca. Has ujawnia zatem Gombrowiczowski rys swego bohatera (,skos psychiczny"), pozbawiony jednak aspektu aktywnego. Wszak w Zbrodni... sędzia śledczy narzucił własną Formę otoczeniu (co prawda, Formę zastępując kontr-Formą), zaś Tade-

\footnotetext{
${ }^{234}$ Witold Gombrowicz, Pornografia, dz. cyt., s. 91-92.

${ }^{235}$ Kazimierz Bartoszyński, O nieważności "tego, jak było naprawdę”, dz. cyt., s. 395.

${ }^{236}$ Andrzej Kijowski, Sienkiewicz i polska nerwica, dz. cyt., s. 238-240.
} 
usz niepostrzeżenie „wśliznął się" w Formę, którą - jak sądził - udało mu się (po opuszczeniu ojczyzny/rodziny) nieodwołalnie przezwyciężyć.

Ostatecznie Tadeusz daje się pochwycić w pułapkę ${ }^{237}$ Formy/Form („Forma ofiarnicza”, „Forma rodzinna”). Z tego „pochwycenia” wynika decyzja o zniszczeniu niepokojących rysunków Jędrka. Ogień, w którym spopielone zostają ślady po "tym-co-było", nie przyniesie udręczonym protagonistom katharsis. Jedyną wartą zachowania relikwią po zmarłym dziecku okazuje się fotografia - fetysz przechowywany, opanowany, trzymany jak zdjęcie w portfelu ${ }^{238}$. Wedle Christiana Metza waga bezruchu i milczenia dla autorytetu fotografii wskazuje na jej silny związek ze śmiercią. Bezruch i cisza nie tylko stanowią bowiem dwa obiektywne aspekty śmierci, ale są zarazem jej podstawowymi symbolami - kształtują ją ${ }^{239}$.

W fotografii - która mumifikuje obiekt i utrzymuje pamięć o zmarłym jako o nieżywym ${ }^{240}$ - jest dla Tadeusza coś kojącego. Dzięki zdjęciu-pamiątce na „anhellicznym” życiorysie syna, który w wersji „,zapisanej” na fotograficznej kliszy doskonale wpisuje się w ofiarniczo-martrologiczną narrację „polskiego losu”, nie pojawi się już żadna rysa. Tak pomyślany finał czyni z Szyfrów traktat o pamięci zapośredniczonej przez „umarłe fotografie".

${ }^{237}$ Finał Szyfrów przywodzi na myśl zakończenie arcydzieła Hasa Sanatorium pod Klepsydrą. Tadeusz przyjeżdża do Polski z krótką wizytą (jesienią ma objąć funkcję administratora w college'u pod Londynem), ale przemożna „siła fatalna” wciąga go w krąg (polskiego) piekła, z którego nie zdoła się już wydostać. Niespodziewana decyzja o pozostaniu w Krakowie stanowi potwierdzenie ostatecznego zwycięstwa Formy.

${ }^{238}$ Christian Metz, Fotografia i fetysz, dz. cyt., s. 252.

239 Tamże, s. 248.

${ }^{240}$ Tamże, s. 249. 



\section{Rozdział II}

\section{Co się stało z Żydami z Ostrowca? Pornografia Jana Jakuba Kolskiego}

...spadło to na mnie znienacka po latach świńskich, zduszonych,
szarych lub wykrzywionych szaleńczo.
W ciągu których zapomniałem prawie co to jest uroda.
W ciągu których tylko trupi odór...
Znudziły mi się agonie. Ja, pisarz polski,
ja, Gombrowicz, za tym pobiegłem błędnym ognikiem,
jak za przynętą...

Witold Gombrowicz, "Pornografia”

Proza Witolda Gombrowicza uchodzi za wybitnie niefilmową. Spektakularna porażka ambitnego przedsięwzięcia Jerzego Skolimowskiego, który w 1992 r. odważył się zmierzyć z Gombrowiczowskim tekstem (Ferdydurke/Thirty Door Key ${ }^{1}$ ), utwierdziła artystów kina w przekonaniu, iż twórczość Gombrowicza jest fenomenem o charakterze autotelicznym i nieprzekładalnym na inny kod semiotyczny. Specyficzny język literackiej wypowiedzi, osławione Gombrowiczowskie "ja” (będące nie tylko podstawą narracji, lecz także fundamentem całej filozofii twórczej pisarza) czy ontologicznie dwuznaczny status świata przedstawionego (,realność" jako funkcja mówiącego podmiotu), czyniły z dzieł autora Kosmosu system hermetyczny.

1 Świadomie nie poświęcam temu nieudanemu filmowi większej uwagi. Abstrahując od problemów natury „instytucjonalnej” (Thirty Door Key jest międzynarodową koprodukcją i w tym sensie trudno go uznać za „film polski”), nie znajduję w adaptacji dokonanej przez Skolimowskiego czegoś, co określa się zwyczajowo mianem "sygnatury autorskiej" (bo trudno mimo wszystko za taką uznać zastosowaną wobec powieści strategię „uhistorycznienia” tekstu). Wobec tego „braku” (którego nie zniwelowały reżyserskie "koncepty" w rodzaju przemarszu ułanów przyodzianych w maski gazowe) analiza filmu musiałaby z konieczności sprowadzić się do "sprawozdania z lektury” (tekstu powieści Gombrowicza) w miejsce "sprawozdania z lektury lektury” (Ferdydurke "czytana" przez Skolimowskiego). 
Lęk potencjalnych adaptatorów potęgował być może fakt, iż pisarz wielokrotnie podejmował polemikę z egzegetami swojej twórczości. Utrzymane w niezwykle ostrym tonie dyskusje (toczone często na łamach prasy) świadczyły nie tylko o całkowitym rozminięciu się „,autorskiej intencji” z jej krytycznymi odczytaniami, lecz dowodziły wydatnie, iż Gombrowicz czyniąc z pisarstwa narzędzie służące autoanalizie - prowokacyjnie sytuował się na pozycji jedynego depozytariusza Prawdy i Sensu.

Wystarczy - zauważa Artur Sandauer - zajrzeć do którejkolwiek z jego książek, aby przekonać się, że - zamiast patriotyzmu - obowiązuje tu egotyzm, że jedynym nakazem moralnym tej twórczości jest wierność wobec siebie².

Dzieła Gombrowicza - w sposób szczególny - domagają się aktu twórczego czytania, rozumianego jako wysiłek oddania sprawiedliwości jednostkowości innego, z którym w sposób konieczny wiąże się zawieszenie zwyczajowych sposobów myślenia i odczuwania ${ }^{3}$. Twórcze czytanie podkreśla Derek Attridge - często znajduje wyraz w słowach (lub innym medium), tak jakby czytane dzieło domagało się w odpowiedzi nowego dzieła. W ten sposób jedno dzieło wytwarza potencjalnie nieskończony łańcuch odpowiedzi (czego i niniejszy tekst jest skromnym dowodem):

W odkrywczej odpowiedzi czytelnik próbuje odpowiedzieć na kształt językowy dzieła, proponując nową, własną formę (która z kolei wywoła dalsze odpowiedzi) - niezależnie od tego, czy będzie to literacki akt pisania, wewnętrzna kompozycja, mowa lub wystąpienie w dyskusji, czy zmiana zwyczaju

Podejmując decyzję o adaptacji tekstu Gombrowicza, reżyser wchodzi w skomplikowany system relacji. Dzieło pisarza to dziś rozbudowany intertekst, na który składają się utwory (i komentarze do nich) samego autora, a także krytyczne (częstokroć polemiczne) interpretacje teoretyków literatury. Każdy utwór Gombrowicza funkcjonuje w sieci intertekstualnych odniesień. Procedura adaptacyjna przypominać musi mozolną wędrówkę przez labirynt znaczeń, w której co chwila natrafiamy na śmiertelną pułapkę w postaci (pozornie rozkodowanych) pojęć-kluczy: Gęba, Pupa, Łydka...

2 Artur Sandauer, Witold Gombrowicz - człowiek i pisarz, [w:] Gombrowicz i krytycy, red. Jan Błoński, Wyd. Literackie, Kraków 1984, s. 126.

3 Zob. Derek Attridge, Jednostkowość literatury, tłum. Paweł Mościcki, Universitas, Kraków 2007, s. 121.

4 Tamże, s. 133. Wedle autora przykładem twórczej odpowiedzi na jednostkowość dzieła (tu: Szekspirowskiego Hamleta) jest sztuka Toma Stopparda Rosenkrantz i Guilderstern nie żyja (ze swej strony dodałabym jeszcze filmową adaptację wspomnianej sztuki). 
Kultura jest wszakże obszarem spotkań „niemożliwych”. Tekst Pornografii wyznacza płaszczyznę porozumienia pomiędzy twórcami należącymi do odrębnych, nieprzystawalnych do siebie światów. Powieść Gombrowicza wyrasta z potrzeby stworzenia języka, który umożliwiłby wypowiedzenie najintymniejszych lęków i obsesji autora. Opierając się pokusie "naiwnego" autobiografizmu (wszak polski pisarz Gombrowicz to figura $\mathrm{w}$ grze $\mathrm{z}$ czytelnikiem), ujawnia wstydliwe pożądanie, skryte w obawie przed społecznym tabu.

Uniwersum Pornografii wyznaczają granice autorskiego „ja”. Jak w obrębie owego ,ja” znaleźć miejsca niedookreślone - obszar konieczny dla swobodnych decyzji adaptatora? Fakt, iż po jedną z powieści Gombrowicza sięgnął Jan Jakub Kolski, wydaje się paradoksalny. Kolski to reżyser o wyraźnej sygnaturze autorskiej, specyficznym stylu i odrębnej, łatwo rozpoznawalnej poetyce. Twórca zamknięty w wykreowanym przez siebie świecie (który czasem okazywał się pułapką). Przed Pornografia tylko raz dał się skusić magii cudzego tekstu (Daleko od okna, 2000), ale wówczas kilkustronicowe, ascetyczne w formie opowiadanie Hanny Krall stanowiło jedynie impuls. Pornografia zaś to dzieło "pełne”, lokujące się w przestrzeni Gombrowiczowskiego intertekstu. Analiza filmowej wersji tego dzieła musi przybrać postać śledztwa naśladującego to, które zainicjowała para głównych powieściowych protagonistów. Sledztwa, w którym będziemy się poruszać śladami pozostawionymi przez autora (a raczej autorów - pisarza i adaptatora), kierując się słowami Gombrowicza:

[...] chcę z dzieła zrozumieć twórcę [...]. Muszę odnaleźć tego, kto opowiada, jako zrozumcie to - jedyną rzeczywistość, jedyny konkret. Tak tedy z dzieła muszę wnioskować o twórcy; ale znowu ta osobowość twórcy ułatwi mi i otworzy dzieło, wiążąc je nierozdzielnie z kimś... z czyimś konkretnym istnieniem ${ }^{5}$.

\section{Pornografia Witolda Gombrowicza}

jakżeż już byliśmy zmęczeni, zbrzydzeni, melodramatem Historii, jak spragnieni odświeżenia!

Witold Gombrowicz

Pornografia, jak wszystkie utwory Gombrowicza, jest prowokacją. Prowokacją wymierzoną jednocześnie w narodową tradycję, kulturowo-społeczne tabu, literaturę (a może Pornografia to "polski, nowoczesny,

5 Witold Gombrowicz, Dziennik 1957-1961, Wyd. Literackie, Kraków 1988, s. 177. 
erotyczny, poemat narodowy"? ${ }^{6}$. Intencja prowokatora ujawniona zostaje $\mathrm{w}$ tytule. $\mathrm{W}$ potocznym rozumieniu pornografia to "przedstawianie zjawisk seksualnych w sposób wchodzący w konflikt z przyjętymi w danej społeczności zakazami i obyczajami, poczuciem wstydliwości i dyskrecji"7.

Lektura utworów pornograficznych należy do „wstydliwych przyjemności", którym często oddajemy się z poczuciem winy. Czyżby Gombrowicz zapraszał czytelnika do lektury "pornograficznego" tekstu, maskując jego obsceniczność za pomocą konwencji literackich? Proponował udział w erotycznej grze ufundowanej na seksualnej perwersji podstarzałych voyeurów? A co gorsza, prowadził tę grę w cieniu krematoryjnych pieców (wszakże akcja powieści ${ }^{8}$ toczy się w 1943 r.)?

Dla Gombrowicza - pisze Ewa Graczyk - subwersja porządku wartości, którą przynosi ze sobą podskórna wszechobecność seksualności i pożądania, jest czymś bardzo atrakcyjnym. [...] Gombrowicz zdaje się antycypować feministyczną tezę głosząca, że prywatne jest polityczne. Sądzi, że aby naprawdę zmienić publiczną scenę, trzeba móc zaprezentować na niej to, czego tam dotąd nie było $[\ldots]^{9}$.

Nieprzyzwoitość, by nie rzec amoralność, takiej praktyki twórczej (podbudowanej „czarną legendą” pisarza pomawianego o dezercję ${ }^{10}$ ) sprawiła, iż Pornografię odrzucili nawet zagorzali orędownicy Gombro-

6 Tamże, s. 256.

7 Słownik terminów literackich, red. Michał Głowiński, Ossolineum, Wrocław 1988, s. 376.

8 Zdaniem Kolskiego w powieści posłużył się Gombrowicz uproszczonym schematem fabularnym: „Co się wyłoniło spod pięknych liter? Niewiele. Oto mniej więcej ta historia: Jest wojna. Do majątku Hipolita przyjeżdża jego przyjaciel Witold, literat. Towarzyszy mu poznany niedawno w Warszawie Fryderyk, człowiek ponury i tajemniczy. Obydwaj panowie są mężczyznami po pięćdziesiątce. Ponieważ pobyt na wsi jest dość nudny, Fryderyk i Witold znajdują osobliwą rozrywkę. Zaczynają pchać ku sobie szesnastoletnich Henię i Karola, by tym sposobem sycić swoją seksualność. Na koniec tej przygody, Henia i Karol zabijają pułkownika Siemiana, oficera AK, który popadł w strach i przez to stał się zagrożeniem dla organizacji". Zob. Jan Jakub Kolski, Pamięć podróżna. Fragmentozbiór filmowy, Wyd. PWSFTviT, Łódź 2011, s. 98.

9 Ewa Graczyk, Przed wybuchem wstrzasnać. O twórczości Witolda Gombrowicza w okresie międzywojennym, słowo obraz/terytoria, Gdańsk 2004, s. 253-266.

10 Decyzję o pozostaniu w Argentynie traktowano jako gest odrzucenia „mitologii polskiego nacjonalizmu romantycznego". Gombrowicz wielokrotnie powracał do tego tematu. W rozmowie z Dominikiem de Roux tłumaczył: „Nie była to żadna dezercja, gdyż Polska tak czy owak była już niedostępna. Zameldowałem się w poselstwie polskim w Buenos Aires zaraz po opuszczeniu statku, a potem, gdy w Anglii poczęto formować wojsko polskie, stanąłem w stroju adamowym przed komisją poborową poselstwa... dość, że pod względem formalnym byłem najzupełniej w porządku. Przedstawiłem siebie w Trans-Atlantyku jako dezertera, ponieważ w sensie duchowym byłem dezerterem. Co tu gadać, byłem wstrząśnięty, zdruzgotany, ale i szczęśliwy, że jakimś cudem znajduję się za oceanem". Zob. Witold Gombrowicz, Testament. Rozmowy z Dominique de Roux, Wyd. Literackie, Kraków 1996, s. 83. 
wicza. Przypomnijmy, że w 1965 r. Artur Sandauer obdarzył Pornografie mianem „niesmacznej ramoty, gdzie pod zadymionym przez krematoria niebem dwaj panowie dają upust swym wyszukanym gustom"11.

Obsceniczne czy wręcz „pornograficzne” zdało się krytykowi nie tyle ujawnienie autorskiej idée fixe (dojrzałość pożądająca młodości i pełen obrzydzenia stosunek do własnego starzejącego się ciała), lecz skorelowanie sfery seksualnych dewiacji z problematyką narodową. A przecież i ta ostatnia w Pornografii daleka jest (choćby tylko ze względu na wątek AK-owski) od ujęć kanonicznych. Po cóż zatem Gombrowiczowi historyczny (wojenny) konkret? Czy do walki ze sklerotyczną przeczasiała polską Formą (,głównie sarmacką przetrawioną przez romantyczne imaginarium $^{\prime 12}$ ) nie wystarczyłby pisarzowi szlachecki dworek ${ }^{13}$ - Gombrowiczowskie anty-Sopilcowo? Najwyraźniej jednak nie wystarczył, skoro nad Formą „,szlachecką"

nadbudowuje się już inna, potężniejsza, wytwarzana przez naród w obliczu zagrożenia swego bytu. Owa oparta o stereotyp patriotycznej tradycji, niejako odświętna Forma polska lepiej niż inne obwarowana jest przeciw bluźnierstwom obrazoburców [... $]^{14}$.

W czasach rozmaitych kryzysów społecznych i politycznych religijno-narodowy kod romantyzmu pozwalał na symboliczne opanowanie rzeczywistości, która pozostawała niesterowalna ${ }^{15}$. W sposób szczególny dotyczy to II wojny światowej, która wpłynęła na silną reprodukcję kodu romantycznego. Osadzona w wojennych realiach Pornografia dekonstruuje całą klasyczną triadę polskiego patriotyzmu: „rozmontowuje” mit romantycznego bohatera (Witold/Fryderyk), sprzysiężenie niepodległościowe (akcja konspiracyjna) i śmierć na polu bitwy (finałowy korowód trupów).

Powieść powstała na emigracji, w tzw. okresie argentyńskim, który pisarz prowokacyjnie określił jako „wakacje” ${ }^{16}$ - dwadzieścia cztery lata odpoczynku od historii. Dla Gombrowicza spotkanie z Argentyną było

11 Artur Sandauer, Witold Gombrowicz - człowiek i pisarz, dz. cyt., s. 125.

12 Zob. Jan Sowa, Fantomowe ciało króla. Peryferie zmagania z nowoczesna forma, Universitas, Kraków 2011, s. 204.

13 Kultura dworkowa musiała jednak wpłynąć na mentalność Gombrowicza, skoro pisarz czuł się tak dobrze na argentyńskich fermach i stancjach, których właściciele wiedli żywot podobny do życia staropolskich ziemian (tamże, s. 226).

14 Jerzy Jarzębski, Podgląanie Gombrowicza, Wyd. Literackie, Kraków 2000, s. 125.

15 Zob. Lech Nijakowski, Polska polityka pamięci. Esej socjologiczny, Wyd. Akademickie i Profesjonalne, Warszawa 2008, s. 142.

16 Gombrowicz przyznaje: „Wojna zdruzgotała mi rodzinę, pozycję społeczną, ojczyznę, przyszłość, niczego nie miałem, niczym nie byłem... A jednak. A jednak Argentyna... Jaki wypoczynek! Jakie wyzwolenie! [...] mam na myśli czas, gdy wraz z upadkiem Polski i wybuchem wojny światowej pękło mi wszystko, wszystek ład jakim żyłem dotychczas. Forma się rozluźniła! Wyjątkowa sposobność! Błogosławiona okazja, jedyna!" 
faustycznym zanurzeniem się w nieoczekiwanie odzyskanej młodości - wolnej od narodowych i patriotycznych serwitutów, uwolnionej od bolesnej pamięci wojny i klęski, naznaczonej wszelako tajonym poczuciem winy wobec tych, co giną podczas drugiej wojny światowej ${ }^{17}$.

Historia jest jednak obecna na kartach dzieł powstałych w Argentynie, stanowi istotny kontekst nie tylko dla powieściowych - jak dowodzą tego zapiski w Dzienniku - zdarzeń. W miarę upływu lat wyostrza się widzenie "sprawy polskiej”, radykalizuje ton wypowiedzi. W twórczości Gombrowicza nie ma miejsca na estetykę nostalgii manifestującą się w utworach kolejnych pokoleń emigranckich. Zdaniem pisarza to właśnie dystans - przestrzenny, czasowy i emocjonalny - umożliwia właściwą ocenę zjawisk. Rozluźnienie więzów z krajem to podstawowy warunek duchowego rozwoju,

ponieważ ojczyzna nie jest miejscem na mapie, ale żywą istnością człowieka. [...] Uważam, że literatura polska powinna obecnie przyjąć kierunek wręcz przeciwny temu, jaki miała dotychczas. Zamiast dążyć do jak najściślejszego związania Polaka z Polska, powinna raczej zabrać się do wypracowania pewnego dystansu pomiędzy nami a Ojczyzną. Musimy oderwać się uczuciowo i intelektualnie od Polski po to, aby uzyskać w stosunku do niej większą swobodę działania, aby móc ją stwarzać ${ }^{18}$.

Ten postulat Gombrowicz realizuje w Pornografii. Opisuje Polskę wyobrażoną fantasmagoryczną. Nie troszczy się - jak zaznacza w przedmowie - o realia „czasem pomylone, czasem może fantastyczne i zupełnie bez znaczenia dla spraw tutaj się odbywających"19. Informacja poprzedzająca właściwy tekst powieści pełni funkcję alibi: „Tej Polski wojennej nie znam. Nie byłem przy tym. W ogóle Polski od 1939 r. nie oglądałem”20. Stanowi zarazem dla odbiorców wskazówkę interpretacyjną która umożliwia rozpoznanie typowej dla pisarza strategii, którą Andrzej Falkiewicz określił mianem „stylizacji Gombrowicza”:

Zob. Witold Gombrowicz, Testament, dz. cyt., s. 93. Zdaniem Olafa Kühla to właśnie „dwudziestoczteroletnia emigracja w Ameryce Południowej staje się czytelna jako styl biograficzny człowieka, któremu obcość weszła w krew jako conditio życia i który ciagle uciekał przed identyfikacją z tym, co określone. Gdy w 1954 roku docierają do niego pierwsze fale sympatii z środowisk emigracyjnych, Gombrowicz wzdryga się". Zob. Olaf Kühl, Gęba erosa. Tajemnice stylu Witolda Gombrowicza, tłum. Krzysztof Niewrzęda, Maria Tarnogórska, Universitas, Kraków 2005, s. 287.

17 Aleksander Fiut, Zwiedzanie "Kontynentu Trzeciego Dnia Stworzenia”: Gombrowicz i Keyserling, [w:] Witold Gombrowicz - nasz współczesny, Universitas, Kraków 2010, s. 570.

18 Witold Gombrowicz, Dziennik 1953-1956, Wyd. Literackie, Kraków 1989, s. 95, 163.

19 Witold Gombrowicz, Pornografia, Wyd. Literackie, Kraków 1997, s. 5.

20 Tamże. 
Narrator Pornografii, działający w nieznanej autorowi rzeczywistości okupacyjnej, jest rodem z międzywojnia: jest literatem, który w rzeczywistość okupacyjną wnosi „ducha byłych kawiarń, Ziemiańskiej, Zodiaku czy Ipsu". Jest więc w oczywisty sposób stylizowany - odczuwa swój styl jako coś obcego i sam o tym mówi, że nie umie swego stylu tamtego z tym nowym, okupacyjnym pogodzić. Choć i stylizowany nie jest - boć przecie wszyscy wiedza, że ani narrator, ani jego twórca rzeczywistości okupacyjnej nie znali, ich wiedza o Polsce urwała się w 1939, właśnie na „duchu byłych kawiarń" 21 .

Gombrowicz, na co zwrócił uwagę Milan Kundera, wymyśla najbardziej fantastyczne, nieprawdopodobne historie, gwałcąc wszelkie reguły wiarygodności. Ale jego powieści rozgrywają się przecież w pełni określonym, historycznym czasie ${ }^{22}$. W Pornografii - pisze Jarzębski - czas historyczny nie jest biernym "tłem akcji” - historia i jej wydarzenia uzasadniają rozpad dawnego świata, kryzys form i wartości, bankructwo kostiumu ${ }^{23}$.

Uważny czytelnik nie da się zatem zwieść deklaracjom pisarza. Słowa odautorskiego komentarza - odzwierciedlające na pozór świadomość etyczną Gombrowicza - powodują interpretacyjną konfuzję. Zdaniem Sandauera:

Uprzedzić jednak zarzut nie znaczy - odeprzeć go, i jeżeli rzeczywiście „imaginacyjna", to po cóż gdzie indziej owe próbki okupacyjnego realizmu - owi przyjeżdżający po kontyngent Niemcy, te miasteczka bez Żydów? ${ }^{24}$

A przecież ten wątpliwej próby „okupacyjny realizm” to integralny komponent strategii prowokatora. Akcja Pornografii nie rozgrywa się wszakże w "Polsce, czyli nigdzie”, lecz w „byłej Polsce, w byłej Warszawie, na samym dnie faktu dokonanego" ${ }^{25}$. Wojenne „realia” stanowią niezbędny kontekst dla erotycznej gry. Obsceniczność ${ }^{6}$ rodzi się na styku dwóch rozłącznych sfer: zbiorowej (narodowej) traumy i jednostkowej perwersji. Zdaniem wielu krytyków, to właśnie obawa przed radykalnym

21 Andrzej Falkiewicz, Polski kosmos. 10 esejów przy Gombrowiczu, Wyd. A, Wrocław 1996, s. 64 .

22 Milan Kundera, Sztuka pozwieści, tłum. Marek Bieńczyk, Czytelnik, Warszawa 1991, s. 36.

23 Jerzy Jarzębski, Podglądanie Gombrowicza, dz. cyt., s. 208.

24 Artur Sandauer, Witold Gombrowicz - człowiek i pisarz, dz. cyt., s. 125.

25 Witold Gombrowicz, Pornografia, dz. cyt., s. 6.

26 Warto zauważyć, iż „obsceniczność” Pornografii nie jest efektem wyjątkowego skojarzenia problematyki okupacyjnej z seksualną. Według Jarzębskiego w utworach pokolenia Kolumbów temat wojny współbrzmi z tematem erotyki: „Gombrowicz szokuje swoich krytyków poetyką natężonego do ostatnich granic dysonansu. Podczas gdy «Kolumbowie» usiłują reaktywować romantyczną mitologię wraz z jej skojarzeniem heroizmu i erotyki - on rozbija i doprowadza do absurdu tamte stereotypy [...]". Jerzy Jarzębski, Gra w Gombrowicza, PIW, Warszawa 1982, s. 308. 
przekroczeniem tabu podyktowała pisarzowi konkretne rozwiązania konstrukcyjne. Gombrowicz posłużył się w Pornografii systemem „zwierciadlanych odbić", by obarczyć Innego odpowiedzialnością za czyny wykraczające poza społeczno-kulturową normę ${ }^{27}$.

Świadomość toczącej się wojny pozwoli czytelnikowi uzmysłowić sobie niestosowność gry, jakiej oddają się literaccy bohaterowie. Świat Pornografii to spotęgowana nierzeczywistość. Egzystencja w czasie przeszłym i groteskowe próby ignorowania katastrofy w "salonie warszawskim" na Kruczej, gdzie resztki przedwojennej „inteligencji z Ziemiańskiej” w zupie $z$ dymu $i$ zaduch $u^{28}$ podejmują dawne, byłe rozmowy i spory o sztuce.

Pornografia to zarazem diagnoza o stanie kraju w przededniu Apokalipsy, która ostatecznie unicestwi tradycję szlacheckiego dworku. Anachroniczny świat jak z oleodruku to "soplicowska” siedziba Hipolita - tubalnego, "radośnie gościnnego szlagona” ${ }^{29}$ - w której celebruje się rodzinne posiłki w asyście lokaja i dawnym obyczajem aranżuje małżeństwa. Szlachecki dwór polski, "co walczy mężnie i strzeże wiernie” w czasie narodowych katastrof, służy za schronienie powstańcom/partyzantom (zgodnie $\mathrm{z}$ tradycją $\mathrm{w}$ dworku Hipolita zostaje ukryty jeden z dowódców AK - Siemian). Gombrowicz, wprowadzając w świat „dobrodusznej powieści wiejskiej" Innego (Witolda/Fryderyka), ujawnia sztuczność Mickiewiczowskiej idylli. Gombrowiczowską filozofię szlacheckiego dworku można także interpretować w - jakże obcym Gombrowiczowi - paradygmacie „emigracyjnej nostalgii”. Rozpoznanie fundamentalnej różnicy umożliwia konfrontacja z filozofią twórczą autora Doliny Issy:

Miłosz w obliczu wojennej katastrofy [...] podejmuje niejako magiczny zabieg ufundowania domu-świata w oparciu o nieprzemijające wartości i transcendentną sankcję. Jest to operacja - niezależnie od tonu ironicznego przebijającego przez głos autora - pełna metafizycznej powagi i - jednak - wiary w stałość porządku świata. Gombrowicz wprost przeciwnie: w wojnie widzi nie tylko koszmar i cierpienie, ale także szansę na przebudowę społecznego życia i ideałów, przywrócenie jednostce wolności

27 Z taką interpretacją polemizuje m.in. Jerzy Jarzębski. Zdaniem krytyka postać sobowtóra często pojawia się $\mathrm{w}$ utworach poruszających kontrowersyjną problematykę, ale jego funkcja nie sprowadza się do zapewniania alibi narratorowi-bohaterowi. W postaci sobowtóra skupiają się najbardziej drażliwe metafizyczne kwestie „,ja”: „Gombrowicz nie tyle ukrywa się dla bezpieczeństwa osobistego za swoim sobowtórem [...], ile odczuwa autentyczne rozdwojenie ludzkiej istoty - jako naturę swego najintymniejszego życia prywatnego" (tamże, s. 313).

28 Doskonałą charakterystykę kawiarnianego towarzystwa z przedwojennej "Ziemiańskiej" odnaleźć można na kartach Wspomnień polskich (s. 87-90).

29 Witold Gombrowicz, Pornografia, dz. cyt., s. 37. 
i swobody bycia, obalenie norm i autorytetów. Dramat więc, jaki się w Gombrowiczowskim Domu rozgrywa, dotyczy spraw najgłębiej uniwersalnych; cóż dziwnego, że ów Dom mityczny jest równocześnie Kościołem? ${ }^{30}$

Kościołem - dodajmy - który runie pod naporem rozpętanych przez Fryderyka ciemnych sił.

Odwołując się do konwencji dobrodusznej polskiej powieści wiejskiej („Opowiem wam...” to sygnał narracji gawędowej), Gombrowicz wytwarza dystans nie tylko wobec zdarzeń i uczestniczących w nich postaci, lecz wobec samej formy opowiadania, zakorzenionej w tradycji szlacheckiej ${ }^{31}$. Pornografia realizuje zatem zasadę „pustej epickości”, która - jak uważa Michał Głowiński - pojawia się, gdy autor wypełnia gatunkowy wzorzec, pozbawiając go dawnych funkcji i uzasadnien' ${ }^{32}$.

Zdaniem Jerzego Jarzębskiego perwersja seksualna nie ma w powieści charakteru cynicznej prowokacji - jest sygnałem życia na pustyni martwych konwencji ${ }^{33}$. Zakazane, obwarowane kulturowym tabu pożądanie rozsadza Formę regulującą międzyludzkie stosunki. Dziewicę z białego dworku posiadł już jeden $z$ AK, świątobliwa pani Amelia rzuca się na parobka, mężczyzna pragnie chłopca.

Kluczowa dla powieści scena rozgrywająca się w kościele, to epifania erotycznego sacrum. Msza, na skutek bezbożnych praktyk Fryderyka „oklapła w strasznej impotencji" ${ }^{34}$, nieoczekiwanie wybucha cudownością. Zwykły kark szesnastoletni ${ }^{35}$ i kawałek policzka wywołują religijną ekstazę. I znów „niespodziewanie powracała ta sytuacja, najgłębsza, najistotniejsza i najboleśniejsza ze wszystkich moich: ja idący za chłopcem z gminu" ${ }^{\prime \prime}$.

Silnie obecny w twórczości Gombrowicza dyskurs homoerotyczny traktowany bywa (np. przez queer theory) jako integralny element strategii polegającej na nieustannych zmaganiach z (polską) Formą, obwarowującą „nienormatywną" seksualność rozlicznymi tabu. U nas bowiem kładzie się wielki nacisk na kategoryczne oddzielanie legalnych i pożądanych

30 Jerzy Jarzębski, Podgladanie Gombrowicza, dz. cyt., s. 24.

31 W rozmowie z François Bondym Gombrowicz powiedział: „Forma nie powinna być adekwatna wobec treści, ale - przeciwnie - niewłaściwa; to w ten właśnie sposób ujawniają się wszystkie inne niestosowności i zdobywa się ten konieczny dystans wobec formy, wobec całej tradycji i kultury". Cyt. za: Michał Głowiński, Parodia konstruktywna, [w:] Gombrowicz i krytycy, dz. cyt., s. 381.

32 Tamże, s. 376.

33 Jerzy Jarzębski, Gra w Gombrowicza, dz. cyt., s. 311.

34 Witold Gombrowicz, Pornografia, dz. cyt., s. 17.

35 Tamże, s. 19.

36 Witold Gombrowicz, Dziennik 1957-1961, dz. cyt., s. 138. 
męskich wspólnot - jako patriotycznych i państwowotwórczych - od podejrzanych, potępianych i represjonowanych homoseksualnych związków $^{37}$. Wedle tej interpretacji figura Obcego-homoseksualisty ${ }^{38}$ - stanowiąca zagrożenie dla "narodowego honoru heteroseksualnego" - może stać się symbolem wykluczenia z narodowej narracji historycznej:

W tym ujęciu najciekawsze i najbardziej płodne zdaje się powiązanie etyki tradycyjnej, heteroseksualnej i społecznie konstruktywnej, z aparatem represyjnie stosowanej Formy. Z tego punktu widzenia erotyka heteroseksualna kojarzy się z wychowaniem patriotycznym, w duchu służby narodowym i społecznym wartościom, z podporządkowaniem Młodych Starszym, z otamowaniem spontanicznych emocji i popędów ${ }^{39}$.

W Pornografii Eros łączy się z Tanatosem ${ }^{40}$. W krwawym finale Młodość zostaje skojarzona ze Starością, cielesna żądza unicestwia martwe konwencje Formy. W kościele międzyludzkim objawia się Prawda: „I przez sekundę, oni i my, w naszej katastrofie, spojrzeliśmy sobie w oczy"41.

„Akuszerem" prawdy jest w Pornografii Fryderyk. W tę postać zostaje wcielony mit Demiurga-Reżysera („,Król-władca i mistrz ceremoniału!” ${ }^{42}$ ). Podejmowane przez Fryderyka działania na płaszczyźnie fabuły konstytuują performatywny charakter powieści. Demoniczny rys tej postaci podkreśla Czesław Miłosz:

Kim jest [...] Fryderyk w Pornografii? Duchem ${ }^{43}$, rzeklibyśmy, bezcielesnym, gdyby nie to, że jego brzydota dojrzałego mężczyzny, jego cierpienie z powodu braku ciała narzucają mu rolę sprawcy, rajfura, który (przy pomocy poszlak) kojarzy parę szcze-

37 Zob. Maria Janion, Niesamowita Stowiańszczyzna, Wyd. Literackie, Kraków 2006, s. 270. Autorka analizuje pod tym kątem Gombrowiczowski Trans-Atlantyk, w którym Zakon Kawalerów Ostrogi stanowi polisemiczną (Konie czy Krowy?) „metaforę homospołecznej wspólnoty narodowej" (tamże, s. 272).

38 Paradygmatycznym przykładem Obcego w podwójnym sensie wykluczonego (jako cudzoziemiec i jako homoseksualista) jest oczywiście Gonazalo z Trans-Atlantyku. Uwiedzenie syna starego polskiego szlachcica, którego dopuszcza się puto, staje się gestem symbolicznym „wymierzonym” w Ojczyznę.

39 Jerzy Jarzębski, Podgladanie Gombrowicza, dz. cyt., s. 83-84.

40 W filmowej wersji Pornografii ten związek podkreśla scena (nieobecna w powieści), w której Henia i Karol - tuż przed planowanym zabójstwem Siemiana - odbywają na schodach miłosny akt. Nóż w ręku Karola staje się erotycznym fetyszem, a pożądanie kochanków potęguje świadomość śmierci, której za chwilę staną się sprawcami.

41 Witold Gombrowicz, Pornografia, dz. cyt., s. 150.

42 Tamże, s. 75.

43 Gombrowicz sugeruje dwuznaczny ontologicznie status bohatera, posługując się wspomnianym „systemem zwierciadlanych odbić”: „Taka musiała być w tej chwili myśl Fryderyka. Lecz, być może, podsuwałem jemu moją własną myśl. Ale kto wie - może on w tej chwili podsuwał mi, tak samo, swoją myśl... i o mnie myślał nie inaczej, niż ja o nim 
niaków, Karola i Henię, organizuje w wyobraźni cały spektakl i ten spektakl, z żądzy impotenta poczęty, z żądzy feudalnej władzy nad innymi, zastępującej seks, usamodzielnia się, dyktuje swoje prawa, aż po trupy dodawane „dla smaku”, dla symetrii, jak trup młodego Skuziaka ${ }^{44}$.

W interpretacji Miłosza Fryderyk to przede wszystkim cyniczny gracz, posługujący się ludzkimi figurami aż do finałowej zbrodni, w którą ostatecznie wikła parę młodych „,kochanków”.

Fryderyk jest postacią enigmatyczną, o mglistej (nieistotnej dla przebiegu zdarzeń) przeszłości ${ }^{45}$ i niedookreślonej tożsamości. To właśnie owa niedookreśloność czyni z Fryderyka bohatera „otwartego" na wielość wzajemnie wykluczających się konkretyzacji. Andrzej Kijowski widzi w nim odmieńca - „przez to, że artysta i Żyd [sic!] zarazem, który przypuszcza szturm na dwór polski, na układ familijny, patriarchalny" ${ }^{\prime \prime 6}$, dla Michała Legierskiego Fryderyk to „ucieleśnienie kultury niemieckiej” ${ }^{77}$.

Fryderyk nie przynależy z pewnością do towarzystwa z „byłej” Ziemiańskiej, choć zdradza artystyczne ciągoty (,Nie wiem, czy znany Panu mój feblik reżyserski? Ja też byłem jakiś czas aktorem, nie wiem czy znany panu ten szczegół mojej biografii?" $\left.{ }^{\prime 4}\right)$. W oczach narratora reprezentuje „męskość spotworniałą":

można było policzyć mu włoski wystające z uszu i wszystkie złuszczenia skóry bladej i piwnicznej - Fryderyk, mówię, zgarbiony, cherlawy, wklęśnięty, w binoklach, $\mathrm{z}$ ustami nerwowca, $\mathrm{z}$ rękami w kieszeniach - typowy inteligent miejski $[\ldots]^{49}$.

Fryderyka dręczy obsesja nieustannej samokontroli. Każdy niewinny gest czy mimochodem rzucone słowo sugerują niejasną, ukrytą treść

myślałem... więc możliwe, że każdy z nas hodował swoją myśl, umieszczając ją w drugim. [...] Cóż to za system zwierciadlany - on we mnie się przeglądał, ja w nim [...]". Witold Gombrowicz, Pornografia, dz. cyt., s. 54-55. Za pomocą konstrukcji sobowtórowej Gombrowicz sugeruje możliwość interpretacji postaci Fryderyka jako bytu wyobrażonego, narratorskiego alter ego, które spełnia w powieści funkcję Złego Demiurga.

${ }_{44}$ Czesław Miłosz, Kim jest Gombrowicz, [w:] Gombrowicz i krytycy, dz. cyt., s. 195.

${ }^{45} \mathrm{~W}$ powieści pojawiają się wprawdzie odniesienia do traumatycznej przeszłości Fryderyka, lecz nigdy nie zostaje wyjaśnione, jakiego typu przeżycia ukształtowały/zwichnęły psychikę bohatera: „Obawiam się, że Fryderyk... cierpi na jakieś zaburzenia psychiczne... obserwuję go od dłuższego czasu... no, po tych wszystkich cholernych przejściach [...]”. A w innym miejscu: „Nie mogła kłamać kredowa bladość jego, pochodząca stąd, że on wiedziat, co znaczy zabić". Witold Gombrowicz, Pornografia, dz. cyt., s. 96, 127.

46 Andrzej Kijowski, Strategia Gombrowicza, [w:] Gombrowicz i krytycy, dz. cyt., s. 435.

47 Michał Legierski, Modernizm Witolda Gombrowicza, Instytut Badań Literackich PAN, Warszawa 1999, s. 56.

48 Witold Gombrowicz, Pornografia, dz. cyt., s. 92.

49 Tamże, s. 13. 
(„,najuprzejmiej gawędził z panią Marią - czy jednak podtrzymywał rozmowę, aby czegoś innego nie powiedzieć?" ${ }^{50}$ ). Fryderyk nieustannie odczuwa konieczność tłumaczenia swobodnej ekspresji ciała na język konwencjonalnych form. Ten przymus objawia się na wyższym poziomie egzystencji bohatera jako potrzeba „realizowania” rzeczywistości w konwencji gry o wyraźnie sprecyzowanych regułach. Świadomość istnienia ściśle określonych zasad nadaje sens z pozoru absurdalnym czynnościom (podwinięcie nogawki, rozdeptanie robaka). Rzeczywistość, obfitująca w nieprzewidziane „zakłócenia” (śmierć pani Amelii, przybycie Siemiana), dziwnie sprzyja intencjom Reżysera ${ }^{51}$, zaś „ludzie idei" - stanowiący zagrożenie dla porządku gry - zostają „wyeliminowani”.

Fryderyk - ten „ogarnięty erotyczną obsesją reżyser międzyludzkich zbliżeń" 52 - demaskuje fałsz i wszechogarniający pozór Formy. W zdesakralizowanym świecie Pornografii zastępuje nieobecnego Boga (do niego - „pozbawionego zasad moralnych ateisty" - zwraca się w chwili agonii pani Amelia).

W kontekście prowadzonej przez Fryderyka gry, tajne sprzysiężenie zrodzone z obywatelskiego obowiązku ,zalatuje teatralną sztampą patriotycznej konspiracji" ${ }^{53}$.

Wątek zawłaszczania jednostki przez naród - zawłaszczania, któremu Trans-Atlantyk przeciwstawiał wyzwolenie od narodowego obowiązku i ekstatyczne hołdowanie bezwarunkowej indywidualności poza kategoriami „państwa” i „narodu” - w Porno-

50 Tamże, s. 15.

51 Należałoby wszakże zadać pytanie: Kto jest owym Reżyserem-Demiurgiem? Czy rzeczywistość „realizuje” scenariusz narzucony przez Fryderyka? W trakcie lektury zapominamy przecież, iż w Pornografii mamy do czynienia z rzeczywistością skonstruowaną - istniejącą wyłącznie w obrębie subiektywnej relacji narratora-bohatera (Witolda). „Narrator - konkluduje Jarzębski - może jedynie okazać zdziwienie, że świat otaczający tak akuratnie spełnia jego zachcianki. Wszak kolejno: Amelia - ze swoją religia przywracającą odwieczny ład w zrewoltowanym świecie, Wacław - z pokusami rodzinnego szczęścia w blaskach tradycyjnej moralności, a w końcu Siemian - domagający się trybutu dla patriotycznych, żołnierskich powinności - wszyscy oni rzucali kłody pod nogi Fryderykowi i Witoldowi [...]. Witold [...] jako narrator - obudowuje zdarzenia powieści siecią maskujących interpretacji („maskujących” w tym sensie, że z pomocą psychoanalizy bohaterów wydobywają z rzeczywistości przedstawionej immanentne jakoby konieczności, sprawiające, że akcja toczy się w tym, a nie innym kierunku); jako podmiot utworu - po prostu wysyła antagonistów na rzeź". Jerzy Jarzębski, Gra w Gombrowicza, dz. cyt., s. 372. Narrator nie tyle rekonstruuje sens zdarzeń poprzez opowiadanie o nich, lecz ów sens wytwarza, „maskując” strategie sensotwórcze za pomocą spetryfikowanych konwencji literackich (gawęda szlachecka, romans gotycki, powieść detektywistyczna, pikareska).

52 Jerzy Jarzębski, Gra w Gombrowicza, dz. cyt., s. 320.

53 Witold Gombrowicz, Pornografia, dz. cyt., s. 101. 
grafii egzemplarycznie uobecniają w horyzoncie kreacji nowego porządku ludzkiego losy akowca ${ }^{54}$.

Sprzysiężenie się wobec "przeinaczenia” Siemiana to typowo Gombrowiczowski „imperatyw sytuacyjny" ${ }^{\prime 5}$. Na pozór z działania A (pułkownik „zdradził”: „Siemian miał powiedzieć, że ani tej akcji, ani żadnej innej, już nie poprowadzi, oraz że wycofuje się raz na zawsze z konspiracji i «wraca do domu»" ${ }^{56}$ ) wypływa konsekwentnie działanie B (zawiązanie spisku: „Wyodrębnieni Siemianem, tym tajnym zadaniem naszym, my, mężczyźni stanowiliśmy osobną grupę"57), a jednak odczuwamy wyraźnie, że to nie w działaniach tkwi owa zasada kojarzenia (jeśli A to B: „Nie ma o czym gadać! Musi być zrobione!” ${ }^{58}$ ), lecz w stylistycznych osobliwościach narracji, wydobywających na jaw sztuczność całej sytuacji:

Dlaczego ta prawda walki naszej z wrogiem i najeźdźcą musiała objawiać się w stroju tak jaskrawym - i do jakiegoż stopnia było to rozwścieczająco-upokarzające! - jak z teatru marnego - choć przecież była w tym krew, była śmierć, i najprawdziwsza? [...] Powróciwszy do domu omal nie roześmiałem się głośno na widok Hipolita, który oglądał dwa noże kuchenne i próbował ich ostrza. Boże! Ten zacny grubas, przemieniony w mordercę i sposobiący się do zarzynania, był jak z farsy - i naraz partactwo naszej przyzwoitości, wpakowanej w mord i tak nieudolnej, uczyniło z nas przedstawienie grane przez trupę amatorów i bardziej zabawne niż groźne [podkr. moje - N.K.-R.] $]^{59}$.

A przecież akcja spiskowa „oddziału rezerwistów zespolonych w rozkładzie" ${ }^{\prime 60}$, ogniskująca się wokół pułkownika z AK, to nie ucieszna farsa odgrywana dla (nomen omen) zabicia ziemiańskiej nudy, lecz profanacja narodowych świętości:

Rozdział ósmy powieści, prześwietlający bohaterskiego Siemiana, jego romantyczną „maskę" i to, co ona ukrywa, jest [...] o wiele większym bluźnierstwem wobec polskich mitologii aniżeli zakłócona msza z początku $[\ldots]^{61}$.

54 Alfred Gall, Humanizm performatywny. Polemika z filozofia w praktyce literackiej Witolda Gombrowicza, tłum. Grzegorz Sowiński, Universitas, Kraków 2011, s. 261.

55 Jerzy Jarzębski, Gra w Gombrowicza, dz. cyt., s. 244.

56 Witold Gombrowicz, Pornografia, dz. cyt. s. 101.

57 Tamże, s. 105.

58 Tamże, s. 103.

59 Tamże, s. 102-105.

60 Tamże, s. 89.

${ }^{61}$ Jean-Pierre Salgas, Witold Gombrowicz lub ateizm integralny, tłum. Jan Maria Kłoczowski, Czytelnik, Warszawa 2004, s. 146. 
W ujęciu Gombrowicza podszyte perwersją -

gdy tak naprawdę chodzi o to aby

HEŃKA Z KAROLEM [...]

Potrzeba odwagi i uporu, bo musimy po cichu upierać się przy swoim choćby to wyglądało na lubieżne świństwo [podkr. moje - N.K.-R.] ${ }^{62}$

- działania konspiracyjne godzą bezpośrednio w patriotyczny stereotyp. Podkreślić należy także, iż u Gombrowicza ${ }^{63}$ "wątek AK-owski” nie ogranicza się wyłącznie do „sprawy Siemiana”. Warto pod tym kątem przeanalizować fragment, w którym Witold - wyraźnie (erotycznie) zafascynowany Karolem ${ }^{64}$ - wypytuje Hipolita o przeszłość chłopca:

No, cóż, Karol, owszem, niezły chłopak, syn rządcy, był w podziemiu [podkr. moje - N.K.-R.], wysłali go gdzieś pod Lublin i coś tam nabroił... iii, taka tam głupota, coś tam zwędził, postrzelił, czy jak tam, kolegę czy dowódcę, diabli wiedza, no, bzdura, potem zwiał stamtąd do domu $[\ldots]^{65}$.

Siemian i Karol to dwa, równie kompromitujące, oblicza wojennej konspiracji. Demaskacja mitu patriotycznego to poniekąd auto-demaskacja samego Gombrowicza, który w Dzienniku zanotował: „Ale ja może nie tyle bałem się wojska i wojny, ile tego, że mimo najlepszej woli, nie mógłbym im sprostać. [...] Jako żołnierz byłbym katastrofą. Przysporzyłbym wstydu sobie i wam" ${ }^{\prime 66}$.

Gombrowicz „unieważnia” okupacyjne realia, ale w centrum przedstawionych zdarzeń umieszcza Fryderyka, który dla narratora staje się reprezentantem wojennej grozy. Funkcję tej postaci w obrębie świata powieściowego definiuje Jarzębski: Gombrowicz-bohater ucieka przed pewną quasi-realną sytuacją naszkicowaną w świecie przedstawionym powieści. Gombrowicz-autor odżegnuje się od pewnego typu literatury: obywatelskiej, tyrtejskiej, martyrologicznej, oddanej na usługi narodu i dziejowej chwili. Ten drugi ogłasza więc rejteradę z obszaru tematyki walki lub męczeństwa, dominującej w polskiej literaturze powojennej. Pierwszemu Fryderyk potrzebny jest jako powiernik, drugiemu - jako motyw węzłowy

62 Witold Gombrowicz, Pornografia, dz. cyt., s. 109.

63 Kolski całkowicie pomija niechlubną przeszłość Karola w szeregach Armii Krajowej. W ten sposób czyni ze „sprawy Siemiana” przypadek odosobniony. Wydaje się to całkowicie niezgodne z intencją Gombrowicza.

64 „Jednakże mnie trudno było pytać o (chłopca), który wtrącając w taki gatunek podniecenia stał się wstydem moim [...]". Zob. Witold Gombrowicz, Pornografia, dz. cyt., s. 23.

65 Tamże.

66 Zob. Witold Gombrowicz, Dziennik 1953-1956, dz. cyt., s. 164. 
projektowanej intrygi powieściowej, motyw równoważący napraszającą się tu tematykę wojenno-patriotyczną. Równocześnie jednak podmiot utworu powiadamia adresata, że owo podstawienie bohatera-oryginała w miejsce wydarzeń historycznych jako motoru fabularnej intrygi nie oznacza bynajmniej radykalnego odwrócenia się od dziejowej burzy, szalejącej gdzieś w tle ${ }^{67}$. Okupacyjny terror wdziera się do hermetycznego świata gry. Te nieoczekiwane "pęknięcia” ujawniają inne oblicze narratora-bohatera.

Gombrowicz obdarzony jest darem widzenia braku. W zaskakującym, wywołującym interpretacyjną konfuzję fragmencie Pornografii Witold udaje się do miasteczka po naftę. Wycieczka, mająca urozmaicić monotonię wiejskiego życia, przeradza się w podróż inicjacyjną do piekła uświadomionej nieobecności.

Dobiliśmy w końcu do Ostrowca z hukiem rozgłośnym, podskakując na kocich łbach od czego trzęsły się nawet policzki, przejechaliśmy obok posterunków niemieckich przed fabryka, miasteczko było to samo, co dawniej, zupełnie to samo, te spiętrzenia i rury wielkich pieców fabryki, jej mur, dalej most na Kamiennej i szyny kolejowe i główna ulica, wiodąca do rynku, a na rogu kawiarnia Malinowskiego. Tyle tylko, że jakaś nieobecność stawała się wyczuwalna, nie było mianowicie Żydów. Jednakże sporo ludzi na ulicach, ruch nawet, miejscami ożywiony, tam baba śmiecie wyrzuca z sieni, tu ktoś idzie z grubym sznurem po pacha, przed sklepem spożywczym gromadka, a chłopczyk kamieniem usiłuje trafić we wróbla, który przysiadł na kominie. Zaopatrzyliśmy się w naftę i jeszcze kilka załatwiliśmy sprawunków i jak najszybciej opuściliśmy ten dziwny Ostrowiec i odetchnęliśmy, gdy bryczkę przyjęła znów na swoje miękkie łono ziemia zwykłej polnej drogi [podkr. moje - N.K.-R.] ${ }^{68}$.

Dramat Zagłady ginie w natłoku nieistotnych szczegółów (baba wyrzucająca śmiecie z sieni, dziecko celujące kamieniem do wróbla). Opis, zdecydowanie nazbyt drobiazgowy, ujawnia „wyczuloną na brak" świadomość narratora. Witold skupia się na detalach, „by czegoś innego nie powiedzieć". Przemilczenie staje się strategią twórcy, daremnie szukającego odpowiedniego języka dla wypowiedzenia tego, co nie daje się wypowiedzieć.

Gombrowicz traktuje Zagładę Żydów w kategoriach ostatecznych. W 1954 r. zanotował w Dzienniku: „Bezmiary zbrodni dokonanej na Żydach i mnie przeszyły na wskroś, i na zawsze" ${ }^{\prime \prime 9}$. Uciekający od historii na argentyńskie wakacje kosmopolita, wolny od wszelkich uprzedzeń Europejczyk, w swych „berlińskich pasażach”, nie może uwolnić się od dręczącej i jakże niestosownej myśli:

${ }^{67}$ Jerzy Jarzębski, Gra w Gombrowicza, dz. cyt., s. 330.

68 Witold Gombrowicz, Pornografia, dz. cyt., s. 50.

69 Witold Gombrowicz, Dziennik 1953-1956, dz. cyt., s. 126. 


\begin{abstract}
Musiałem przecież widywać na ulicach miasta, tak przyzwoitego, tak głęboko moralnego, nie tylko psy spotworniałe, ale i ludzi-potworów, któż mógł zaręczyć, że prawa stopa tego pana w pewnym wieku nie dławiła wtedy czyjegoś gardła aż do skutku. [...] Ręce zbrodnicze? Ależ skąd, nowe przecież, niewinne... Nowe i nie te same, a jednak, przecież, takie same... ${ }^{70}$
\end{abstract}

Te same, którymi dokonała się Zagłada. Obecność historii - podkreśla Alfred Gall - jest wynikiem korelacji teraźniejszości i przeszłości, która prześwieca przez powierzchowną normalność, zakorzenioną w percepcji rąk. „Zbliżenie” na wypielęgnowane ręce niemieckiej młodzieży jest jednocześnie zogniskowaniem uwagi na rękach brudnych, naznaczonych zbrodnią 71 . Za pomocą takich "zbliżeń" historia „podminowuje” tzw. porządną teraźniejszość. Dyskretna (acz natarczywa) obecność przeszłości jest drażniącym momentem, który podkopuje trwałość aktualnej realności. Przywołane w Dzienniku detale - obsesyjne wspomnienia rąk i haków - relatywizują programową wypowiedź Gombrowicza, że przeszłość można i należy "połknąć” i „zjeść"72. Wszakże Gombrowicz opowiadając się po stronie "gorszych" i skazanych na nieistnienie, sprzeciwiał się „oswajaniu piekła”...

Wybitni znawcy dorobku Gombrowicza podkreślaja, iż problematyka żydowska pojawia się w jego utworach niezwykle rzadko. Gombrowicz podejmował ją zazwyczaj $w$ dziełach quasi-fikcjonalnych i publicystycznych. Wedle Michała Głowińskiego:

Wątki żydowskie nie odgrywają w twórczości Gombrowicza większej roli, a jeśli występuja, to tylko w utworach najwcześniejszych, w Biesiadzie u hrabiny Kotłubaj pojawia się bowiem baron de Apfelbaum, a bohater Pamiętnika Stefana Czarnieckiego wywodzi się ze związku zubożałego, ale dumnego ze swego rodu hrabiego z żydowską bankierówną (de domo Goldwasser), już zresztą pobożną katoliczka, mimo że w różnych sytuacjach Pan Bóg myli się jej z Jehową?

Przy drugim z wymienionych przez krytyka tytułów warto się przez chwilę zatrzymać. Prześledzenie śladów recepcji jednego z najwcześniejszych tekstów Gombrowicza może bowiem stanowić przyczynek do dyskusji dotyczącej domniemanego antysemityzmu pisarza. Opowiadanie

70 Witold Gombrowicz, Dziennik 1961-1966, Wyd. Literackie, Kraków 1986, s. 150-151.

71 We wspomnianym fragmencie Gombrowicz pisze wprawdzie o „polskich konaniach wielotysięcznych", ale nie oznacza to, jak sądzę, próby zmarginalizowania męczeństwa Żydów. Pisarzowi chodziło bowiem o analizę (w kluczu autobiograficznym) wzorcowego spotkania „Polaka” z „Niemcami”: „Wiedziałem, że oni ze mną nie chcą być «Niemcami», podobnie jak ja z nimi nie chciałem być «Polakiem» [...]. A jednak hak tkwił w ścianie" (tamże, s. 152).

72 Alfred Gall, Humanizm performatywny..., dz. cyt., s. 423-428.

73 Michał Głowiński, Gombrowicz i nadliteratura, Wyd. Literackie, Kraków 2002, s. 44. 
znalazło się w tomie Pamiętnik z okresu dojrzewania, wydanym w $1933 \mathrm{r}$. Pierwotnie nosiło tytuł Krótki pamiętnik Jakóba Czarnieckiego (w edycji powojennej zmieniony na Pamiętnik Stefana Czarnieckiego). Literacki debiut Gombrowicza spotkał się z życzliwym przyjęciem krytyków. Nie w każdym przypadku powodem entuzjastycznych recenzji były stricte artystyczne walory dzieła. Na łamach narodowej „Gazety Warszawskiej” ukazał się tekst Adolfa Nowaczyńskiego poświęcony powieści Józefa Jeremskiego Przekleństwo życia. Można odnieść wrażenie, że powieść ta staje się dla autora jedynie pretekstem do diagnozy zagrożenia wynikającego $\mathrm{z}$ „promisculcji Arjów z Semitami". W dość obszernym fragmencie recenzji Nowaczyńskiw sposób bezpośredni - odnosi się do opowiadania Gombrowicza.

Ta z ducha przeciw-żydowska lektura utworu Gombrowicza pozwala dostrzec kłopot niejednoznaczności niektórych fragmentów Krótkiego pamiętnika Jakóba Czarnieckiego. To, co dla dzisiejszego czytelnika jawi się jako groteska i zjadliwa ironia, mogło być postrzegane zupełnie inaczej w latach trzydziestych, zwłaszcza $\mathrm{w}$ atmosferze nacjonalistycznego lęku przed „zażydzeniem kultury polskiej”. [...] Zawarta w Objaśnieniu sugestia, iż prawdziwym problemem opowiadania jest zagadnienie rasy, sterowałaby $\mathrm{w}$ przypadku rekonstruowanego tu obrazu czytelnika przekonaniem, iż dystans syna hrabiego do świata wszelkich wartości, jego niemożność internalizacji kodu polskiej kultury, jest rezultatem płynącej w jego żyłach krwi żydowskiej ${ }^{74}$.

Zdaniem krytyków to właśnie nieporozumienia wynikłe z błędnego odczytania „intencji autorskiej” podyktowały decyzję o zmianie tytułu opowiadania. Obdarzenie bohatera imieniem Stefana Czarnieckiego kultowego bohatera narodowego - jednoznacznie sytuuje tekst po stronie groteski i uniemożliwia nacjonalistyczna, antysemicką lekturę tekstu ${ }^{75}$. Po latach Gombrowicz podsumował dyskusję, która rozgorzała po jego debiucie $\mathrm{w}$ literackim środowisku przedwojennej Warszawy:

Ktoś pomawiany o lekki choćby antysemityzm nie mógł być popierany przez „Wiadomości" - a ja miałem pecha, że bohater jednego z moich opowiadań był urodzony z ojca polskiego arystokraty i matki-Żydówki. To wystarczyło, aby mnie obsypał pochwałami patologiczny żydożerca, Adolf Nowaczyński - a znów pochwały Nowaczyńskiego wystarczyły, aby ze strony „Wiadomości” powiało chłodem. Bogu ducha byłem winien, bo w tym opowiadaniu kwestie rasowe w potocznym tego słowa znaczeniu nic mnie nie obchodziły, mnóstwo Żydów przyjaciół miałem i nigdy antysemityzmowi się nie oddawałem - ale ta niewinność artysty cóż mogła przeciw politycznej furii redaktorów? ${ }^{76}$

74 Kazimierz Adamczyk, "Krótki pamiętnik Jakóba Czarnieckiego” wobec antysemityzmu, [w:] Witold Gombrowicz - nasz wspótczesny, dz. cyt., s. 339-343.

75 Tamże, s. 351.

76 Witold Gombrowicz, Wspomnienia polskie. Wędrówki po Argentynie, Res Publica, Warszawa 1990, s. 98. 
Kontrowersje wokół „kwestii rasowych” nie dotyczą jedynie najwcześniejszego epizodu literackiej biografii Gombrowicza. Autor Pornografii wielokrotnie odpierał oskarżenia o antysemityzm, wysuwane pod jego adresem głównie (choć nie wyłącznie ${ }^{77}$ ) przez prasę krajową ${ }^{78}$. Pisał o duchowym porozumieniu z Żydami ${ }^{79}$, spośród których rekrutowali się najzagorzalsi orędownicy jego twórczości. Dostrzegał ogromny potencjał intelektualny Żydów i chętnie otaczał się przedstawicielami tej nacji, co w kręgach warszawskich zjednało mu przydomek „żydowskiego króla". Do najbardziej przejmujących należą jednak te fragmenty prozy Gombrowicza, które układają się w dialog - trwającą przez lata dysputę z Brunonem Schulzem. Formalny pojedynek z Schulzem zyskuje wymiar tragiczny, gdy uświadomimy sobie, iż pisarz kontynuował spór z „wielkim i nieodżałowanym przyjacielem" jakby poza śmiercią i ludobójstwem (Schulz został zamordowany w 1942 r.).

Przez trzydzieści kilka lat (od 1933 po 1969) - pisze Jean-Pierre Salgas - obaj twórcy toczą ze sobą prawdziwy intelektualny pojedynek na miny, złożoną grę ról, która nakłada się na narodową polską grę "gąb" żydowskich i polskich $[\ldots]^{80}$.

Brak Brunona Schulza, brak wiernych czytelników z "Zodiaku” czy „Ziemiańskiej" - i klęska literatury niezdolnej wyrazić dramat tego braku. Z tych komponentów narodziło się jedno zagadkowe zdanie z Pornografii: „Tyle tylko, że jakaś nieobecność stawała się wyczuwalna, nie było mianowicie Żydów...".

77 W Dzienniku z 1965 r. Gombrowicz przytacza argumenty, jakimi posłużył się niemiecki krytyk żydowskiego pochodzenia Hans Mayer, dla „udokumentowania” antysemityzmu pisarza. „Grozi mi przede wszystkim «polski szlachcic» i w dodatku «emigrant», z czego już nietrudno przewekslować na «antysemitę», a nawet na «faszystę», z faszysty zaś tylko krok do «hitlerowca»". Witold Gombrowicz, Dziennik 1961-1966, dz. cyt., s. 196-197.

78 Ataki na Gombrowicza w związku z "kwestią żydowską" nie ustały po śmierci pisarza. Tadeusz Kępiński dostrzega na przykład w Gombrowiczowskiej apologii żydostwa „mechanizm rynkowy”, służący zjednywaniu przychylności wydawców, tłumaczy i krytyków - Żydów. „Gombrowicz - przekonuje Kępiński - mówi o Żydach, ale o czym mówi - nie wie, bo po prostu nie znał narodu żydowskiego ani nie spotkał się z wielorakimi emanacjami jego ducha. [...] O naszych kolegach, dawno przyrosłych do polskości, mówił zawsze per «Żyd», podczas gdy my, nawet w żartach, używaliśmy ich imion lub nazwisk. Drobiazgi? Nie, nie drobiazgi. Styl, zwyczaj, mentalność, postawa". Tadeusz Kępiński, Witold Gombrowicz. Studium portretowe, Wyd. Literackie, Kraków 1988, s. 154.

79 Relacjom z Żydami poświęcił m.in. obszerny fragment Wspomnień polskich. Gombrowicz podkreśla fundamentalną rolę Żydów w sporze, jaki toczył się o znaczenie pisarza w literaturze przed- i powojennej. „Żydzi zawsze i wszędzie byli pierwsi w zrozumieniu i odczuciu mojej pracy pisarskiej. Tak wyraźnie to się zaznaczało, iż czasem zastanawiałem się, czy we mnie jaka kropla ich krwi nie płynie [...]". Witold Gombrowicz, Wspomnienia polskie. Wędrówki po Argentynie, dz. cyt., s. 130-134.

80 Jean-Pierre Salgas, Witold Gombrowicz lub ateizm integralny, dz. cyt., s. 170. 


\section{Pornografia Jana Jakuba Kolskiego}

To chyba będzie pana najdroższa książka...

Podjęta już w demokratycznej Polsce - wiele lat po opublikowaniu Pornografii - decyzja o przeniesieniu utworu Gombrowicza na ekran wydaje się zrozumiała, jeśli weźmiemy pod uwagę deklarowaną po $1989 \mathrm{r}$. expresis verbis potrzebę dekonstrukcji mitotwórczych (monodyskursywnych: bohatersko-martyrologicznych) narracji. Także tych związanych z okresem wojny i okupacji:

Prędzej czy później II wojnę światową trzeba było opowiedzieć jeszcze raz, aby wyznaczyć jej miejsce w nowym etapie modernizacji. Nowa narracja o tamtych wydarzeniach musiała powstać [...], ale stworzenie nowych opowieści o wojnie oznaczało wypowiedzenie wojny. Już bez armat, czołgów, żołnierzy; nie na realnej ziemi, lecz na froncie symbolicznym - co nie znaczy, że bez ofiar ${ }^{81}$.

Pornografia wydaje się dla orędowników tej symbolicznej wojny orężem wymarzonym. „Wydaje się", albowiem rozerwanie wielkiej narracji wywołuje efekt domina w komunikacji społecznej: nie możemy już budować dzisiejszej tożsamości na podstawie wizerunku jedności społeczeństwa w okresie wojny i okupacji ${ }^{82}$. Nowa narracja

mogła więc uwzględniać zło czynione przez Polaków w czasie wojny, nasz narodowy spryt, cwaniactwo, szaber i antysemityzm - wszakże pod warunkiem jednoznaczności: zło musiało być w sposób wyraźny odizolowane od narodowej „normy wojennej", przekroczone zasługami, przelicytowane cierpieniem ${ }^{83}$.

Dla Jana Jakuba Kolskiego najważniejszym doświadczeniem wyniesionym z lektury Pornografii okazało się poczucie braku - braku... bohatera. Fryderyk z powieści Gombrowicza - pozbawiony przeszłości, powodowany niezrozumiałą pasją która każe mu uwikłać w krwawą zbrodnię parę nieletnich "młodzianków" - to zaledwie "figura retoryczna”. Taki typ bohatera wnosi do utworu literackiego tajemnicę, która stanowić może wyzwanie dla odbiorcy. Paradoks literatury polega wszakże na niedookreśleniu. Im większe pole niewiedzy o bohaterze, tym łatwiej go „oswoić" (co często oznacza: wpisać w tradycyjny paradygmat).

\footnotetext{
81 Przemysław Czapliński, Polska do wymiany. Późna nowoczesność i nasze wielkie narracje, Wyd. W.A.B., Warszawa 2009, s. 63.

82 Tamże, s. 99.

83 Tamże, s. 69.
} 
Czy Gombrowicz podsuwa jakiekolwiek wskazówki mogące pomóc w wypełnieniu tak rażących autora filmowej adaptacji (która - zdaniem Kolskiego - domaga się właśnie owego „wypełnienia”) luk w biografii bohatera? Kolski „zahacza” przeszłość Fryderyka na jednym enigmatycznym - a przez to otwartym na potencjalne (nad)interpretacje - fragmencie powieści: „Obawiam się, że Fryderyk... cierpi na jakieś zaburzenia psychiczne... obserwuję go od dłuższego czasu... no, po tych wszystkich cholernych przejściach nie on pierwszy i nie ostatni..." ${ }^{84}$

Reżyser wydaje się jednak bezradny wobec fundamentalnego pytania: Jakie motywy (inaczej mówiąc - cóż to za cholerne przejścia) kierują Fryderykiem? Dylemat adaptatora rodzi się z braku zgody na arbitralność decyzji pisarza, który z Fryderyka uczynił bezwzględnego Manipulatora pozbawionego jakichkolwiek moralnych zasad. Tę amoralność Gombrowiczowskiego bohatera podkreśla Kolski jedynie w scenie narady dotyczącej zabicia Siemiana (Fryderyk - wyzbyty skrupułów intrygant wprowadza w życie swój iście szatański plan przy wtórze kościelnych dzwonów). W filmie, co niezwykle ważne, impuls do rozpoczęcia perwersyjnej gry o wszystko - gry zakończonej krwawym korowodem trupów, wychodzi od Witolda. Scena rozgrywająca się w stodole jest par excellence sceną kuszenia:

Witold: Zauważyłeś, że Henia i Karol bardzo do siebie pasują?

Fryderyk: Jakoś ich nie podgląałem.

Witold: Ale ciekawe, że wcale ku sobie nie ciagna. Że nie ma między nimi wo ogóle tej chemii miłosnych połaczeń. [...] To znaczy, że żadna siła nie jest w stanie ich połaczyć.

Fryderyk: Ale tu nie potrzeba żadnej sity. Wystarczy kilka prostych sztuczek, jak przy układaniu piesków.

Witold: To popchnij ich ku sobie.

Fryderyk: Co powiedziateś?

Witold: Popchnij ich ku sobie. [...]

Fryderyk: Ty nie wiesz, na co ty mnie namawiasz. Tak patrzysz i nie wiesz, na co mnie namawiasz. Chcesz?

Witold: Chcę.

Anegdotyczny wymiar zyskuje opowieść Kolskiego, któremu właściwy klucz do postaci Fryderyka podsunął... placowy z węglowej górki ${ }^{85}$ :

84 Witold Gombrowicz, Pornografia, dz. cyt., s. 96.

85 Najwyraźniej od czasów Misia (1980) Stanisława Barei (w którym stary węglarz wyjaśniał narodowi znaczenie pojęcia "tradycja”) jest to profesja w rodzimym kinie uprzywilejowana. 
Placowy: Coś mi tu nie pasuje. A ten bohater, to, dlaczego tak dręczy te dzieci?

Reżyser: Dla zabawy. Dla... teatru...

Placowy: I zabija też... dla teatru?

Reżyser: Też.

Placowy: Mnie taki bohater nic a nic nie obchodzi. Co mnie może obchodzić wariat albo zboczeniec? Jak on zabija, albo namawia do morderstwa... to on musi mieć jakąś skazę, jakieś straszne życie za sobą [...]. Ktoś mu zabił rodzinę, albo ma jakieś wielkie cierpienie [podkr. moje - N.K.-R.] ${ }^{86}$.

Perwersyjna gra Fryderyka (Witolda?) musi zyskać „odpowiednią” Motywację ${ }^{87}$. Wydaje się bowiem, iż dręczenie dzieci samo w sobie nie jest dla Kolskiego wystarczająco amoralne. Amoralne staje się dopiero w kontekście Sprawy: AK-owskiej konspiracji, „zdrady” Siemiana, a przede wszystkim - Zagłady Żydów. Za pomocą Motywacji reżyser (mówiąc językiem Gombrowicza) „dorabia Fryderykowi gębę” i „przyprawia pupę”, odbierając tej postaci - tak fascynującą czytelnika powieści - „demoniczność". W filmowej Pornografii Fryderyk jest zaledwie „demonicznym (byłym) aktorem” i na taką też miarę „,skrojone” są jego bluźnierstwa („,aktem herezji" okazuje się... wypalenie świętego Piotra ${ }^{88}$ ).

Intuicja tzw. prostego człowieka (Fryderyk musi mieć jakaśs skaze niemożliwą do zracjonalizowania za pomocą „argumentu szaleństwa" ${ }^{89}$ ) znajduje odzwierciedlenie w systemie kultury. Ale nie tylko. Kolski, tworząc własną wersję biografii Fryderyka, podąża śladami prywatnych obsesji. A następnie desperacko poszukuje w tekście powieści usprawiedliwienia dla decyzji wynikających z osobistego doświadczenia. I znajduje je w przywołanym wcześniej opisie Ostrowca.

Tą zauważoną nieobecnością Żydów - pisze Kolski - Gombrowicz zwrócił na nich uwagę w stopniu upoważniającym do zadania pytania: Gdzie sa, jeżeli tak bardzo widocznie ich nie ma? Są w gettach, obozach koncentracyjnych, szafach, piwnicach, skrytkach pod podłogą ${ }^{90}$.

86 Jan Jakub Kolski, Pamięć podróżna, dz. cyt., s. 102-109.

${ }_{87}$ Wprowadzam wielką literę dla podkreślenia pokrewieństwa z Gombrowiczowską Formą.

88 Fryderyk nadaje papierosom imiona dwunastu Apostołów.

${ }^{89}$ Kolski sugeruje taką możliwość interpretacji działań bohatera. Niemal natychmiast zostaje ona jednak zanegowana. Obłąkany monolog Fryderyka o „krwawej komunii”, w którym z całą mocą objawia się jego szaleństwo, ma w istocie charakter prowokacji skierowanej pod adresem Witolda.

Kolski posłużył się tutaj ulubioną praktyką Gombrowicza, o której pisał Jarzębski. Pisarz wkłada w usta swoich bohaterów wypowiedzi wygłaszane „na próbę". Wygłoszone, stają się lustrem, w którym bohater jak gdyby przygląda się sam sobie. Zob. Jerzy Jarzębski, Gra w Gombrowicza, dz. cyt., s. 135.

90 Jan Jakub Kolski, Pamięć podróżna, dz. cyt., s. 77. 
Filmowym ekwiwalentem literackiego opisu stają się dokumentalne ujęcia (którym towarzyszy jazzowa trawestacja muzycznego leitmotivu) pojawiające się w czołówce Pornografii. To one "ustawiają" lekturę filmu, projektując już na wstępie jego przyszłą (możliwą) interpretację. Tym samym sytuują adaptację prozy Gombrowicza w paradygmacie dyskursu posttraumatycznego, a w samym filmie każą widzieć wezwanie do przepracowania traumy, które w sensie etycznym - jak podkreśla Dominick LaCapra - nie pociąga za sobą uniknięcia przeszłości, pogodzenia się z nią czy po prostu zapomnienia o niej, powrotu do status quo sprzed traumy ani zatopienia w teraźniejszości ${ }^{91}$.

Nieostre, sepiowe kadry, zestawione montażowo, tworzą syntezę „polskiej winy” przywodząc na myśl Campo di Fiori Czesława Miłosza92. W pierwszym ujęciu beztroscy, dostatnio ubrani spacerowicze przemierzają arterie miasta. W drugim - nędzarze z gwiazdą Dawida na opaskach wkładają do trumny znalezione na ulicy półnagie, odarte z wszelkiej ludzkiej godności, zwłoki. „Dziwny” Ostrowiec (Warszawa?), w którym „ruch nawet, miejscami ożywiony" - i getto. Futrzane pelisy - i „obsceniczna" nagość. Wstyd - i poczucie winy...

W warunkach polskich - pisze Hanna Gosk - opowieść o wstydzie wiedzie swój podziemny żywot, nie wychylając się na powierzchnię, bowiem podmiot o cechach heroicznej ofiary od dawna jest podmiotem sprawczym w utrwalonej w zbiorowej świadomości narracji losu polskiego, stanowiącej ramę modalną historycznych wariantów tożsamości narodowej $[\ldots]^{93}$.

Wypada zatem powrócić do prologu filmowej „opowieści o wstydzie” rozgrywającego się w „mieszkaniu na Kruczej”. Proza Gombrowicza stanowi dla potencjalnego adaptatora nie lada wyzwanie.

91 Dominick LaCapra, Historia w okresie przejściowym. Doświadczenie, tożsamość, teoria krytyczna, tłum. Katarzyna Bojarska, Universitas, Kraków 2009, s. 137.

92 W Warszawie przy karuzeli,

W pogodny wieczór wiosenny,

Przy dźwiękach skocznej muzyki,

Salwy za murem getta

Głuszyła skoczna melodia

I wzlatywały pary

Wysoko w pogodne niebo.

[...]

Rozwiewał suknie dziewczynom

Ten wiatr od domów płonących,

Śmiały się tłumy wesołe

W czas pięknej warszawskiej niedzieli.

93 Hanna Gosk, (Nie)obecność opowieści o wstydzie w narracji losu polskiego. Rekonesans, [w:] Kultura po przejściach, osoby z przeszłościa. Polski dyskurs postzależnościowy - konteksty i perspektywy badawcze, red. Ryszard Nycz, Universitas, Kraków 2011, s. 85. 
Trudność najważniejsza leży w specyfice narracji, której praktycznie nie da się przełożyć na inny język, tzn. nie da się przedstawić wydarzeń powieściowych jako konsekwentnego ciągu bez spoiwa wyjaśniającej opowieści. Bohater główny Gombrowicza - jak dobrze wiadomo - nie tylko jest alter ego autora, ale też pełni rolę narratora, który czytelnikowi i samemu sobie własną historię opowiada, tłumaczy sens kolejnych scen, a także własnych i cudzych, czasami bardzo ekscentrycznych działań ${ }^{94}$.

Kolski - zdając sobie sprawę z nieprzekładalności Gombrowiczowskiej pierwszoosobowej narracji na język obrazów - czyni monologi Witolda integralnym składnikiem filmowego tekstu. Początkowy monolog słyszalny $\mathrm{z}$ off-u to zacytowany przez reżysera, inicjalny fragment powieści ${ }^{95}$. Dzięki niemu odbiorca (czytelnik/widz) zostaje wprowadzony w konkretny przestrzenno-czasowy kontekst rozgrywających się zdarzeń (co ważne, Kolski unieważnia zastrzeżenie poczynione przez Gombrowicza w przedmowie powieści - zastrzeżenie, które nie mogło znaleźć się w filmie - „i nie przejmujcie się, że czasem pomylone, czasem może fantastyczne, bo nie o to chodzi i to zupełnie bez znaczenia...").

Narrator powieści - krytycznie zdystansowany obserwator - bez wątpienia należy jednak do salonu z „byłej Ziemiańskiej”, w którym mimo wszystko usitowaliśmy być $w$ dalszym ciagu artystami, pisarzami i myślicielami. Wprowadzone przeze mnie dopowiedzenie - owo „mimo wszystko" - wydaje się tautologią. Trwa przecież wojna, czas największego terroru. Nie o oczywistość wojennego kontekstu jednak chodzi. A zatem wypadnie raz jeszcze zapytać: mimo co?

W charakteryzującej „salon” wypowiedzi Witolda pojawia się sformułowanie przedziwnie niepasujące do stylu powieściowej narracji. I właśnie przez to "niedopasowanie” zwracające na siebie uwagę i niczym punctum - niepomijalne: „Tymczasem wrzała dyskusja - Bóg, proletariat, naród, sztuka - a smród zaglądał nam w nozdrza [podkr. moje - N.K.-R.]"96. Musimy zatem zadać pytanie: skąd dobywa się ten straszny dławiący zapach, czyniący dyskusję o „Bogu i sztuce” tak absurdalnie "nieprzyzwoitą" (Do dziś pamiętam - monologuje w filmie Witold - dźwięk słów używanych bezwstydnie: Bóg, sztuka, teatr, naród, proletariat)? Zanim jednak padnie odpowiedź, spróbujmy poszukać w filmie racjonalizacji dla narzucającego się z nieodpartą siłą wrażenia „nieprzyzwoitości”. Kolski wprowadza w obręb filmowego prologu scenę dialogową, której próżno by szukać w powieści. Gospodyni „salonu”, przedstawiając Fryderykowi pogrążonych w somnambulicznym odrętwieniu

\footnotetext{
94 Jerzy Jarzębski, Podgladanie Gombrowicza, dz. cyt., s. 122.

95 Fragment dotyczący cen żywności nie ma odpowiednika w powieści. Funkcję tego fragmentu omawiam nieco dalej.

96 Witold Gombrowicz, Pornografia, dz. cyt., s. 7.
} 
gości, akcentuje z wyraźną przyjemnością: mecenas, baronówna, kompozytor i znawca ezoteryki Wschodu... Zwięzłą charakterystykę podsumowuje równie lakoniczny - lecz jakże znaczący - komentarz: Ocaleni malarze, pisarze, poeci. Najpiękniejsza krew w Warszawie. Czy potrzeba czegoś więcej? (w ironiczny sposób puentuje wypowiedź gospodyni Fryderyk: Ja poprositbym jeszcze o zapatkę...).

Konstrukcja filmowego prologu prowokuje, by zastosować wobec „salonu warszawskiego" symbolikę lawy rodem z Mickiewiczowskich Dziadów. Jeśli artyści, pisarze i myśliciele (a u Kolskiego kosmopolityczni mecenasi i baronówny - wyelegantowani mężczyźni i damy w futrzanych pelisach z dokumentalnych zdjęć otwierających film) zgromadzeni (bezpieczni) w mieszkaniu na Kruczej to skorupa obmierzła: „zimna i twarda, sucha i plugawa", to gdzie należy szukać głębi gorejącej ogniem, którego „sto lat nie wyziębi"?

Gdybyż tylko Gombrowicz - dla którego to i tak „zupełnie bez znaczenia" - przesunął czas akcji powieści o kilkanaście miesięcy, odpowiedź byłaby oczywista: głębia to warszawscy Powstańcy. Ale Powstanie jeszcze nie wybuchło, jest rok 1943. Skąd zatem ogień i idący w ślad za nim... drażniący nozdrza (sumienia) „arystokratów” smród (poczucie winy)? Może z dogorywającego getta, którego los nikogo tu nie zajmuje, bo przecież najpiękniejsza krew w Warszawie (tymczasowo - jak pokaże niedaleka przyszłość) ocalała. A czy potrzeba czegoś więcej...

Dla Kolskiego jedno powieściowe zdanie - „Tyle tylko, że jakaś nieobecność stawała się wyczuwalna, nie było mianowicie Żydów" - uruchamia łańcuch skojarzeń, w którym Zagłada narodu nierozerwalnie łączy się z dramatem pojedynczego człowieka. Tragizm żydowskiego losu odciska swoje piętno na postaci narratora.

Żydzi z mojego filmu dali też twarz Witoldowi - pisze Kolski. - Bez nich byłby tylko chwiejna, bladą marionetką. A tak, skonfrontowany z ich strachem, mógł pokazać ludzką twarz i tę odrobinę odwagi, która czyniła z niego partnera dla moich, widza, emocji ${ }^{97}$.

Słowa reżysera odnoszą się do kluczowej dla filmu (a nieobecnej $\mathrm{w}$ powieści) sceny $\mathrm{w}$ magazynie nafty. Witold przypadkowo odkrywa żydowską rodzinę schowaną pod podłogą składziku. Kamera skupia się na zmizerowanych twarzach, przerażonych (głównie dziecięcych) oczach wpatrzonych w intruza. Starszy mężczyzna, któremu Żydzi zawdzięczają (chwilowe tylko) ocalenie, przyłapuje Witolda pochylonego przy szparze w deskach. Zapada krępująca, pełna napięcia cisza. Witold odlicza pieniądze należne za książkę, po czym wręcza mężczyźnie wszystkie banknoty.

97 Jan Jakub Kolski, Pamięć podróżna, dz. cyt., s. 136. 
Pomiędzy bohaterami ustala się milczące porozumienie. To chyba będzie pana najdroższa ksiażka... - mówi Sprawiedliwy.

W przywołanej scenie dramat Zagłady zostaje ukonkretniony. Staje się czymś realnym, na wskroś przejmującym. Po powrocie Witold nie może ukryć poruszenia. Jego zdenerwowanie potęguje beztroska Fryderyka, który - nieświadom doświadczenia, które stało się udziałem Witolda $\mathrm{z}$ zapałem pracuje $\mathrm{w}$ ogrodzie. W bukolicznej przestrzeni szlacheckiego dworku obowiązuje czas gry: Dzieci w coś się bawią. My bawimy się dziećmi. Henia i Karol zostają "sparzeni” na ciele martwego robaka (a w finale - per analogiam - na ciele martwego Siemiana/Wacława). Scena rozdeptywania glisty wydaje się - w zestawieniu z sekwencją w składzie nafty - niestosowna ${ }^{98}$. Właściwego sensu nabiera dopiero w kontekście filozofii Gombrowicza, który nazywa ból punktem wyjściowym egzystencji. Doznanie bólu autonomizuje się - „odrywa” od cierpiącego podmiotu. „Dla ludzi nowszej szkoły - pisze Gombrowicz - ból jest bólem gdziekolwiek by się pojawił, równie straszliwy $\mathrm{w}$ człowieku, jak w musze, wykształciło się W nas doznanie czystego cierpienia $[\ldots]^{\prime \prime 99}$.

W filmie Kolskiego nie ma bólu w stanie czystym. Mimo deklaracji reżysera ${ }^{100}$, wojna nie jest chimerą - czymś na poły nierealnym, na poły groteskowym. Gombrowiczowskie "pola zdziczałe wojną"101 nasycają się wojennym konkretem - krwia, gwałtem, śmiercią. Nocną ciszę przeszywają strzały (Siemian z ludźmi. Kropnęli kogoś...), partyzanci zostają rozstrzelani, żydowska rodzina (ta sama, którą ukrywał sprzedawca nafty, o czym świadczy porzucona w lesie laleczka) - wymordowana. Ale ten „konkret” obserwujemy z pozycji anonimowego świadka, który boi się podejść na tyle blisko, by rozpoznać twarze ofiar i oprawców. W scenach nocnych kamera przyjmuje punkt widzenia człowieka pochylonego nisko przy ziemi, znajdującego się w nieustannym ruchu. Momentami wydaje się nawet, że to spojrzenie nie należy do człowieka, lecz do oszalałego ze strachu zwierzęcia.

Strach panuje niepodzielnie w dworku Hipolita. Gospodarz boi się Niemców, którzy regularnie nawiedzają majątek w poszukiwaniu żywności (jedynie nieustannym, głęboko uwewnętrznionym lękiem można

98 Niestosowne jest z pewnością irytujące zachowanie Fryderyka, który z martwego robaka czyni obiekt „niesmacznej” (także w sensie dosłownym: Fryderyk ostentacyjnie - wobec innych - zjada robaka) prowokacji.

99 Witold Gombrowicz, Dziennik 1957-1961, dz. cyt., s. 39.

${ }^{100}$ Kolski wspomina: „Zdecydowałem się na taką realizację, która dawałaby poczucie obcowania z wojną niejako «przy okazji». Mimochodem i fragmentarycznie. Kamera dostała $\mathrm{w}$ tej sprawie autonomię. Ociera się o dramatyczne zdarzenia, ale nie zatrzymuje się. Biegnie dalej w swoich nocnych sprawach, o których nigdy się nie dowiemy". Jan Jakub Kolski, Pamięć podróżna, dz. cyt., s. 136.

${ }^{101}$ Witold Gombrowicz, Pornografia, dz. cyt., s. 25. 
tłumaczyć gorliwość i służalczość Hipolita - jakże nie licującą z etosem polskiego szlagona - względem nieproszonych gości). Choć w tym akurat przypadku strach wydaje się całkowicie nieuzasadniony. Mieszkańcy dworu żyją wprawdzie w poczuciu ciągłego zagrożenia ze strony okupanta, ale owo zagrożenie „materializuje się" jedynie poza granicami szlacheckiej sadyby - na polach zdziczałych wojna czy pod podłogą składziku nafty w dziwnym Ostrowcu. Kolski odbiera Niemcom (pojawiającym się w majątku - jak można wnioskować z pewnej familiarności cechującej wzajemne stosunki - regularnie) grozę, czyniąc z nich zło oswojone (przy pomocy daniny z... mleka i świeżych jaj).

We dworze rezyduje Siemian, z którego odwaga opadła jak, za przeproszeniem, gacie (ten strach Kolski „przekłada” na konkretne reakcje fizjologiczne - trzęsące się ręce, spływająca potem twarz). Gospodyni domu (w powieści: „strażniczka stereotypu” - wzorowana na Antoninie Gombrowiczowej stateczna matrona, której całe jestestwo ograniczało się do bycia matką) to w adaptacji Kolskiego udręczona strachem alkoholiczka (Wszędzie mam poukrywane butelki, na wypadek strachu...). Maria nieustannie się boi - niemieckich żołdaków gwałcących w lasach szlachcianki z okolicznych dworów, kanonady piorunów, a przede wszystkim świata, z którego został wygnany Bóg. A przecież to właśnie żona Hipolita - jak każe tradycyjny obyczaj - w momencie śmierci pani Amelii sięgnie po ten smętny, bezrobotny krucyfiks ${ }^{102}$, by nadać owej śmierci jakiś sens. Symboliczny gest wymierzony jest nie tylko w ateistę Fryderyka. To gest uczyniony wobec świata, któremu - za sprawą absurdalnych („pornograficznych") okoliczności śmierci świętych cnót kobiety ${ }^{103}$ - grozi wypadnięcie z Formy. I właśnie o umierajaca Formę - „sklerotyczny obyczaj, z którego uszła treść żywa"104 - wypada się teraz upomnieć.

Narrator powieściowej Pornografii - w drodze „do kościoła, na mszę, bo niedziela" - konstatował:

Mnie śmiać się chciało. Powóz, konie, ten furman, zapach gorącej skóry i lakieru, kurz, słońce, mucha uprzykrzona koło twarzy i jęk tych gum ocierających się o piasek - ależ od wieka wieków to znane, i nic, nic zupełnie się nie zmieniło! [...] Jakikolwiek sens... wojny, rewolucji, gwałtu, wyuzdania, nędzy, rozpaczy, nadziei, walki, furii, krzyku, zabójstwa, niewoli, hańby, zdychania, przekleństwa lub błogosławieństwa... jakikolwiek, mówię, sens był zbyt słaby, aby przebić się poprzez kryształ owej sielanki i pozostawał nienaruszony ów widoczek, dawno przeczasiały, będący już tylko fasadą... ${ }^{105}$

\footnotetext{
102 Tamże, s. 71.

${ }^{103} \mathrm{~W}$ dosłownym tego słowa znaczeniu „niepojęte” zdarzenie skrywa ciemność, która u Gombrowicza stanowi zawsze synonim tego, co erotyczne („,ciemne”) i niedookreślone (na poziomie języka).

${ }^{104}$ Witold Gombrowicz, Wspomnienia polskie. Wẹdrówki po Argentynie, dz. cyt., s. 38.

105 Tamże, s. 14-15.
} 
O tę wieczna, nienaruszalną "fasadę" soplicowskiego dworku ${ }^{106}$ miał do Gombrowicza pretensje Czesław Miłosz. W listach, których fragmenty umieścił Gombrowicz w swoim Dzienniku, Miłosz nazywa autora Pornografii don Kiszotem walczącym z baranami i wiatrakami, czyli z... przedwrześniową Polską:

Inaczej mówiąc, postępuje pan czasami jakby tamto, to jest cała likwidacja, straszliwie skuteczna, tam w Polsce, nie istniała, jakby Polskę zmiótł kataklizm księżycowy, a pan przychodził ze swoją odrazą do niedojrzałej, prowincjonalnej Polski sprzed 1939 roku. Być może rozprawianie się na własną rękę jest potrzebne, a nawet konieczne, tylko że dla mnie to są ludzie zbyt gruntownie już rozprawieni ${ }^{107}$.

Wydaje się, iż bliższy zrozumienia strategii Gombrowicza był Michał Głowiński. Zdaniem krytyka ta strategia najlepiej wyraża się w języku dystansu, który jest antydogmatyczny ${ }^{108}$. „Owa antydogmatyczność - pisze Głowiński - tak została pomyślana, że nie kieruje się przeciw jakimś konkretnym skamielinom ideologicznym, lecz uwrażliwia na wszelkie mity i clichés, chroni przed myśleniem zadowalającym się stereotypami"109.

Uniwersalny - antydogmatyczny - charakter strategii pisarskiej nie został w pełni rozpoznany. Znacznie łatwiej przychodziło krytykom wpisywać Gombrowicza w paradygmat powojennej „literatury szyderców" odzwierciedlającej - za pomocą parodii - paradoksalny stosunek do samej przeszłości patriotycznej, na którą powoływała się historiografia oficjalna, wykorzystując romantyczno-heglowski kostium dla własnych celów ideologicznych ${ }^{110}$.

Parodia atakowała nie tyle samą przeszłość, ile jej obraz zachowany w świadomości współczesnej, a ponieważ parodiować można tylko takie postawy lub działania, których mechanizmy znane są nie tylko parodyście, ale i odbiorcy, odgrywała rolę zbiorowego rytuału "na opak”, działającego katartycznie i wyzwalająco. W tamtym jeszcze okresie Jan Błoński precyzował to zjawisko następująco: „Niszczono substancję narodową - pisał w Zmianie warty - ponieważ niszczenie było jedynym aktem, w którym mogą się objawić świadomość patriotyczna i tym samym poczucie wolności". Dziś

${ }^{106}$ Fasadę, która przetrwała wszelkie dotychczasowe „apokalipsy”. Pisze Jan Sowa: „rozbiory były przełomem przede wszystkim na poziomie Symbolicznym i Wyobrażeniowym, a nie Realnym. Objawiły nieistnienie państwa polskiego, ale dokonało się to bez większego zaburzania mechanizmów, które tworzyły wcześniej ogólne ramy funkcjonowania sarmackiego świata, jak na przykład gospodarka folwarczno-pańszczyźniana [vide Gombrowiczowska Ferdydurke] i szlachecka kultura dworkowa". Zob. Jan Sowa, Fantomowe ciało króla, dz. cyt., s. 337.

${ }^{107}$ Witold Gombrowicz, Dziennik 1953-1956, dz. cyt., s. 26-27.

108 Zob. Michał Głowiński, Gombrowicz i nadliteratura, dz. cyt., s. 274.

109 Tamże.

${ }^{110}$ Maria Delaperriére, Pod znakiem antynomii. Studia i szkice o polskiej literaturze XX wieku, Universitas, Kraków 2006, s. 111. 
możemy dorzucić, że polskie parodie Historii miały jeszcze tę zasługę, iż obnażały iluzję totalnego jej opanowania, kładąc nacisk nie tyle na relatywizm przedstawianych faktów, co na relatywizm odbioru samego dyskursu historycznego ${ }^{111}$.

Wedle Głowińskiego tradycja szlachecka jest wprawdzie w Pornografii obiektem parodii, ale „parodii poważnej”

która nie anuluje tego, co parodiowane, więc nie czyni zdarzeń i spraw, będących przedmiotem relacji, jedynie elementem gry utrwalonymi schematami, wzorcami i - przede wszystkim - stereotypami. Wszystko to istnieje, wszystko regułom konsekwentnie realizowanego konceptu podlega, ale - jak zawsze u Gombrowicza - rzecz na tym się nie wyczerpuje, zawsze jest coś więcej ${ }^{112}$.

Wyczuwalny ambiwalentny stosunek ${ }^{113}$ pisarza do przeczasiałej Formy - wspomniane coś więcej - wynika także z faktu, iż Gombrowicz obdarza bohaterów świadomością nadchodzącej Apokalipsy. To już ostatnie chwile przed „awanturą", która obróci w perzynę polskie białe dworki. Trzaśnie! - huczy przy kolacji Hipolit - To, panie, będzie rzeź, będzie wybuch, awantura! Najgorzej, że nie ma dokąd wiać! Strach przed tym, co nieuchronne, wzmacnia obsesyjne przywiązanie do Formy.

„Kurczowe” postawy wobec przeszłości wzbudzają podejrzliwość Gombrowicza:

czasem klejnoty bywają właśnie świadectwem ubóstwa. Gdy w domu sąsiadów pokazują wam z nabożeństwem sygnet pradziadka, wolno pomyśleć, że teraźniejszość tej rodziny musi być pod zdechłym Azorem, skoro przeszłość tak jej imponuje ${ }^{114}$.

Tymczasem wszystko toczy się - jeszcze - w zgodzie z odwiecznym rytuałem. Gombrowiczowscy bohaterowie

nie wyobrażają sobie zmiany i boją się jej, żyjąc całkowicie w wymiarze płytkiej, chwilowej teraźniejszości. I albo ignorują nadciągającą burzę, albo - co jest taktyką bardziej wyrafinowaną - umieją przekształcić impuls wzywający do transformacji, przekroczenia w składnik utrwalania, konserwacji teraźniejszego stanu swojego ja ${ }^{115}$.

\footnotetext{
111 Tamże.

112 Tamże, s. 53.

${ }^{113}$ We Wspomnieniach polskich Gombrowicz przyznaje: „Kiedy pewne treści są na wykończeniu, ulegają rodzajowi sklerozy, uchodzi z nich treść żywa, a pozostaje tylko sztywność «czystej formy», jak by powiedział Witkiewicz. Otóż mnie pasjonował ten formalizm, drażniło mnie to, ale i zachwycało artystycznie - w mojej twórczości pełno takich form umierających [...]". Zob. Witold Gombrowicz, Wspomnienia polskie. Wędrówki po Argentynie, dz. cyt., s. 38.

114 Tamże, s. 124.

${ }^{115}$ Ewa Graczyk, Przed wybuchem wstrzasnać, dz. cyt., s. 39.
} 
Anachroniczność zakonserwowanej dworkowej tradycji podkreślają w filmie "oleodrukowe" scenki z patriotycznego albumu (puentowane niekiedy ironicznymi „komentarzami"). W salonie - pod patronatem patriarchalnych przodków spoglądających dostojnie z portretów - gra się Chopina (Panie Fryderyku, to strasznie smutne - protestuje Henia. - Prosze zagrać coś wesołego). Koncertowi przez okienną szybę - symbolizującą nieprzekraczalną granicę separującą "państwo" od "chamstwa” - przyglądają się w zachwycie wiejskie dzieci (fot. 1).

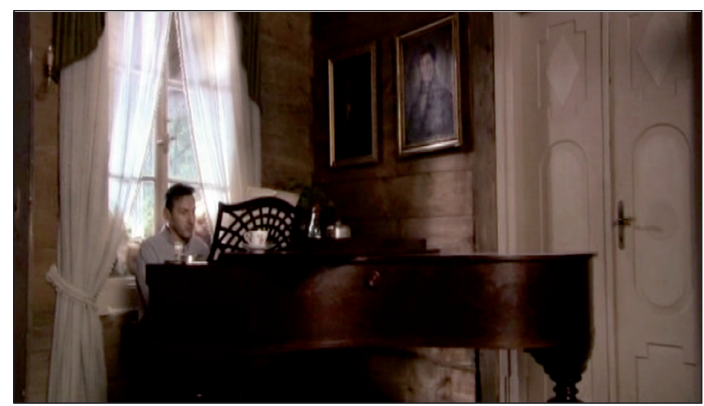

Fot. 1. Pornografia (2003, reż. Jan Jakub Kolski) „Parodia konstruktywna”

Wokół szlacheckiego dworku kłusuje „kiczowato stereotypowa” biała klacz (symbol przebrzmiałej swojskości ułanów i koni ${ }^{116}$ ) rodem z Lotnej Wajdy ${ }^{117}$ (ale ten "kanoniczny” obraz pojawia się tuż po sielankowym ujęciu warzywnego ogródka, w którym Witold odczytuje na głos fragment listu Fryderyka: Zachowuj się tak, jakbyś tkwił w walce narodowej, w AK, w dylemacie Polska-Niemcy, jakby o to chodziło... a nie o sparzenie Heńki z Karolem...).

Gospodyni dba o nienaruszalność społecznych podziałów. Do stołu nie podaje wprawdzie "niewidzialny” (Gombrowiczowskie: podano, wniesiono) lokaj, ale miejsce służby jest wyłącznie w kuchni (wystarczy wspomnieć karcący wzrok pani Marii, obserwującej z irytacją „nobilitację" Weroniki, która podczas koncertu zasiada z Fryderykiem przy pianinie).

W opisie okupacyjnej codzienności Kolski okazuje się reżyserem wyczulonym na konkret:

\footnotetext{
116 Andrzej Werner, Polskie, arcypolskie..., Wyd. Biblioteki „Więzi”, Warszawa 2011, s. 113.

117 Symbol (inaczej niż w filmowej Pornografii) przecież niejednoznaczny - łączący w obrębie jednego filmowego dyskursu dwie tendencje: krytyczną i sentymentalną (zdradzającą autorską fascynację „światem umarłych”). Tamże, s. 112-113.
} 
Gombrowicz miał w tej sprawie alibi. Zawarł je zresztą w kilku zgrabnych zdaniach umieszczonych przed książką [...]. No tak, zgoda - pisarzowi wolno. Pisarz ma i drugie alibi. Tym jest wyobraźnia czytelnika. Tyle Polski, ile wyobraźni - chciałoby się powiedzieć. Każda wyobrażona Polska musi być inna. Ale adaptator? Adaptator musi zadbać o najdrobniejszy szczegół. Ta Polska, która przedostanie się na ekran, musi się zgadzać w... detalach. Najdrobniejszych. Dopiero wtedy film jest zdolny wyrzucić widza ponad realizm ${ }^{118}$.

Pamiętając opowieści mamy o niedostatku nafty, sacharynie zamiast cukru, suszonej marchwi zamiast herbaty i zapałce dzielonej na czworo ${ }^{119}$, usuwa z powieści Gombrowicza lokaja usługującego w majątku Hipolita. W filmie Witoldowy monolog z off-u rozpoczyna zaś od drobiazgowego, niezwykle rzeczowego wyliczenia cen żywności w okupowanej stolicy: Tamtej wiosny kilogram kartofli kosztowat w Warszawie sześćdziesiąt groszy, litr mleka pięćdziesiąt cztery grosze, litr nafty jeden złoty dwadzieścia groszy, a natka pietruszki piętnaście groszy. Jakże wyraźny kontrast z biesiadnym rytuałem, w którym uczestniczą bohaterowie Gombrowicza. W powieści do stołu podano (niezwykle drażniąca, a przecież świadomie anachroniczna - w tych okolicznościach - wydaje się ta uporczywie powtarzana bezosobowa forma czasowników) zupki i serniki. „Cóż za podwieczorek! - egzaltuje się narrator-sybaryta - Ciasta i konfitury znalazły się na stole!"120.

W uniwersum Gombrowicza jedzenie, a raczej pochłanianie, „żarcie”, a nie interpretowanie, wymienianie myśli, jest główną figura, głównym sposobem ludowego konceptualizowania pańskiego sposobu istnienia ${ }^{121}$. Potrawy (sernik w Pornografii czy kalafior w Biesiadzie u hrabiny Kotłubaj) stają się zatem - jak pisze Falkiewicz - elementem "szyfru mistycznego", który pewną grupę społeczną wywyższa i czyni arystokracją:

\footnotetext{
${ }_{118}$ Jan Jakub Kolski, Pamięć podróżna, dz. cyt., s. 92.

119 Tamże, s. 93. Brak poszanowania dla okupacyjnych realiów był powodem odrzucenia przez Kolskiego pierwszej wersji scenariusza, opracowanej dla producenta przez Gerarda Bracha. Reżyser wspomina: „Scenariusz Bracha miał rozległość, nasycenie i soczystość pochodzące spod hojnego pióra. Bardzo hojnego. U Bracha zarówno salon warszawski, posiadłość Hipolita, jak i pałac pani Amelii, miały format zamków znad Loary. W filmie pana Bracha Polacy nieustannie popijali czerwone (zapewne francuskie) wino i popadali w nostalgię. Paryski ogląd Polski pod hitlerowską okupacją nie troszczył się o detale. I w tej sprawie rządziła hojność. Witold z Karolem jechali do Ostrowca po benzynę, zaś po kuchni «krążyło duże pudełko kuchennych zapałek». Prawdę mówiąc, to właśnie owo pudełko przeważyło szalę. [...] Ja, przyznam, mam obsesję w sprawie szczegółów. Mnie takie pudełko zapałek od Bracha pozbawia apetytu na film [...]" (tamże, s. 92-93).

${ }^{120}$ Witold Gombrowicz, Pornografia, dz. cyt., s. 37.

${ }^{121}$ Ewa Graczyk, Przed wybuchem wstrzasnać, dz. cyt., s. 114.
} 
Mimo wyraźnie manifestowanego zainteresowania narratorów i bohaterów dla spraw jadłospisu, nie wydaje się, żeby byli oni smakoszami. Nieważny jest dla nich smak i substancja odżywcza potraw; potrawy stają się interesujące dopiero przez to, co za ich pośrednictwem zostaje powołane. [...] W tym świecie je się po to, żeby we własnych oczach - i w oczach innych - potwierdzić swą przynależność do grupy wybranej ${ }^{122}$.

W tym kontekście zupełnie innego znaczenia nabiera fakt, że „eksces" - skandaliczne (erotyczne) zbratanie się niższości (Skuziak - młodość, ,lud") z wyższością (Amelia - starość, , arystokracja”) - w filmowej Pornografii wydarza się w ciemnym kredensie przy kawałku drożdżowego placka ${ }^{123}$.

U Kolskiego posiłków nikt jednak nie celebruje. Skromne chłopskie dania (jajecznica, suchy chleb, resztki stwardniałego sera) spożywa się w ciszy. Poprzez sceny posiłków Kolski ewokuje bowiem czas, w którym cały majątek człowieka stanowić mogła walizeczka wypełniona kawałkami spleśniałego pieczywa ${ }^{124}$.

To właśnie obsesja chleba nadaje ludzki rys postaci Fryderyka. Warto zwrócić uwagę na przekształcenia, jakim poddana została w filmie Kolskiego scena kolacji. W powieści to syntetyczny obraz „ziemiańskiej nudy". Bohaterowie Gombrowicza, żywi umysłowo, wynajdują sobie dziwaczne zabawy, aby nie ulec gnuśnej drętwocie, zakłócanej jedynie pobzykiwaniem much ${ }^{125}$. Znudzony Fryderyk, nie znajdując sposobu ożywienia zamierającej konwersacji, wcią̇ przekładał gałki z chleba. Pozornie niewinny gest - jak zwykle u Gombrowicza - zostaje w szczególny sposób zaakcentowany, przez co zyskuje głębszy symboliczny sens. Pisarz, podkreślając powtarzalność zachowań bohatera (wciąz przekładał), nadaje im charakter rytualny. Ten rytuał ma w sobie jednak coś z bluźnierstwa: w polskiej tradycji zabawa chlebem jest prawie świętokradztwem ${ }^{126}$.

${ }^{122}$ Andrzej Falkiewicz, Polski kosmos, dz. cyt., s. 93-94.

${ }^{123}$ O tym „fakcie” Fryderyk powiadamia (pomijając z jakiegoś powodu perwersyjny kontekst całego zajścia) rozhisteryzowanego Wacława. Wedle jego relacji pani Amelia mogła przyłapać Skuziaka podczas próby kradzieży ciasta. Dokonaną przez Fryderyka rekonstrukcję transgresyjnego zdarzenia można zatem określić jako „racjonalizację skandalu”.

${ }^{124}$ Barbara Szacka podkreśla: „ZZ dyskusji grupowych wynika, że w 2003 roku druga wojna światowa w pamięci Polaków to nie działania sił zbrojnych i samoloty zrzucające bomby, od których można zginąć, ale głód, walka o życie i przetrwanie, zniszczenia, grabieże. [...] Przekazem pamięci o wojnie jest nie tylko to, o czym mówią i milczą jej uczestnicy, każąc się domyślać skrytego za tym milczeniem koszmaru, który nie daje się nazwać, ale także ich zachowania: [...] «głód w obozie koncentracyjnym [...], głód na wschodzie [...], moja prababka jak umarła [...], to pod każdym materacem, w każdym miejscu, gdzie mogła, był suszony chleb, już spleśniały [...]»". Zob. Barbara Szacka, Czas przeszły - pamięć - mit, Wyd. Naukowe Scholar, Warszawa 2006, s. 167.

${ }^{125}$ Michał Legierski, Modernizm Witolda Gombrowicza, dz. cyt., s. 69.

126 Tamże, s. 179. 
W filmowej Pornografii bezrefleksyjne układanie gatek $z$ chleba nie pasuje do psychologicznego portretu Fryderyka. Ukradkowy, dostrzegalny wyłącznie dla widza ruch, jakim podczas kolacji wsuwa do kieszeni pajdę chleba, wydaje się niezrozumiały. Porażająca jest jednak jego troska, by nie uronić żadnego okruszka ze skradzionej kromki. Kradzież chleba w kontekście powieści, która eksponuje zasobność szlacheckiego dworu - wydaje się gestem całkowicie nielogicznym. W filmie pełną eksplikację znajdzie w scenie "spowiedzi”. Obsesyjny stosunek do przedmiotów (układanie chlebowych kulek, wielogodzinne czyszczenie butów) w metonimiczny sposób wyraża doświadczenie Auschwitz ${ }^{127}$.

Kolski postępuje wbrew strategii Gombrowicza, starając się od początku zjednać dla Fryderyka przychylność widza. Już w pierwszej scenie gwałtowność reakcji, jaką wywołują u niego pytania gospodyni „salonu warszawskiego" sugeruje, iż ma on za sobą traumatyczne przeżycia. Fascynacja postacią rodzi się tu z drobnych gestów, z "ekscentrycznego" sposobu, w jaki bohater zapala zapałkę.

Fryderyk Gombrowicza to rachityczny intelektualista, którego wątłe ciało - tak rażąco kontrastujące z rozbyczonym okropnie cielskiem Hipolita wyraża opór wobec pęczniejącej dookoła natury. Fryderyk nie może być obiektem seksualnego pożądania - jest cieleśnie nieatrakcyjny ${ }^{128}$. Przypomnijmy, iż wedle charakterystyki Witolda

można było policzyć mu włoski wystające z uszu i wszystkie złuszczenia skóry bladej i piwnicznej - Fryderyk, mówię, zgarbiony, cherlawy, wklęśnięty, w binoklach, z ustami nerwowca, z rękami w kieszeniach - typowy inteligent miejski na wsi czerstwej... ${ }^{129}$

Fryderyk u Kolskiego niewiele ma wspólnego z powieściowym „,cherlawym inteligentem w binoklach". Scena przed lustrem (w warszawskim prologu) podkreśla narcystyczne skłonności bohatera, ale - paradoksalnie - ustanawia także pewną formę pokrewieństwa między postacią ekranową i autorem literackiego pierwowzoru. Fryderyk staje się tu sobowtórem filmowego Witolda, a zarazem... samego Gombrowicza. Marcin Kępiński pisze, że Gombrowicz uwielbiał przeglądać się w lustrze, a pod-

${ }^{127}$ Zob. Alison Landsberg, America, the Holocaust, and the Mass Culture of Memory: Toward a Radical Politics of Empathy, "New German Critique" 1997, no. 71, s. 70-71. Autorka analizuje to zjawisko na przykładzie komiksu Maus Spiegelmana. Landsberg zwraca szczególną uwagę na fragment, w którym ocalony z Oświęcimia ojciec głównego bohatera obsesyjnie liczy tabletki.

${ }^{128}$ Andrzej Juszczyk, Apetyt na starość. Uwodzenie, pożądanie i przemoc w "Pornografii", [w:] Witold Gombrowicz - nasz wspótczesny, dz. cyt., s. 321.

${ }^{129}$ Witold Gombrowicz, Pornografia, dz. cyt., s. 13. 
rozdział Gombrowiczowskie lustro błazna (w poświęconej pisarzowi książce) rozpoczyna od znamiennej relacji Zofii Chądzyńskiej:

W lustrze spojrzał na swoją twarz, wymienił z nią kilka porozumiewawczych spojrzeń [...]. Jestem przystojny? - Masz „twarz". To jest w innych wymiarach niż „przystojny". - Nie, nie jestem przystojny. Jestem raczej piękny, Zofio. Patrzyłam na niego w lustrze. Znowu robił miny ${ }^{130}$.

Zapamiętana przez przyjaciółkę pisarza scenka - wraz z dokładnie zacytowanym dialogiem - znalazła się w filmowej Pornografii.

Fizyczna atrakcyjność Fryderyka - wbrew logice powieści - wzbudza pożądanie Witolda. Wedle Gombrowicza wszelka dojrzała męskość jest odpychająca. Pożądanie może wzbudzić jedynie chłopiec ${ }^{131}$. Kolski fałszywie rozpoznaje zatem istotę „pożądań" kierujących poczynaniami Witolda. Jest to szczególnie widoczne w „idyllicznej" scenie plenerowej, w której Witold lubieżnie obmacuje... Henię.

Od pierwszych scen dyskurs "podstawowy” (posttraumatyczny, tj. zogniskowany wokół pamięci o Zagładzie) podminowuje wewnętrzny dyskurs homoseksualnego pożądania. W prologu „na Kruczej” Fryderyk (nieco zbyt) gwałtownie odrzuca jednoznacznie erotyczne „, awanse” młodej gospodyni. Witold obserwuje całe zajście - lecz jego spojrzenie to element nieustannej gry odkrywania/zakrywania (narrator „ukrywa” się przed wzrokiem Fryderyka za liściem palmy - widzi, nie będąc widzianym). Fryderyk jest jednak świadomy obecności Innego (mężczyzny) - w pewnym sensie "zachowuje się wobec" jego spojrzenia. W scenie z lustrem narrator poufałym gestem kładzie rękę na ramieniu „przyjaciela”. Ten gest wywołuje u Fryderyka sprzeciw: Chyba się pan trochę zagalopowat, co?

W filmie Kolskiego lustro-symbol - w którym odbija się podwójny wizerunek Witolda/Fryderyka - „zszywa” dyskurs sobowtóra z dyskursem (homo)erotycznym (lub autoerotycznym ${ }^{132}$ ).

${ }^{130}$ Marcin Kępiński, Gombrowicza gry z kultura, Wyd. Akademickie i Profesjonalne, Warszawa 2006, s. 49. Studium portretowe uzupełnia wspomnienie Tadeusza Kępińskiego: „W pewnym okresie opanowuje go [Gombrowicza] kompleks «zwierciadła», co pozostanie mu na całe życie. [...] Stawał przed lustrem w przedpokoju: co za nos, co za usta, jaka rrasa (oczywiście miał arystokratyczne $r$ francuskie), wspaniała cała postać - mówił do nas o sobie - patrzcie i podziwiajcie te policzki, podziwiajcie brodę, spójrzcie na mądre czoło, przenikliwy bystry wzrok, piękne uszy". Tadeusz Kępiński, Witold Gombrowicz. Studium portretowe, dz. cyt., s. 52.

131 „Mężczyzna może być znośny dla mężczyzny tylko jako wyrzeczenie, gdy wyrzeka się siebie na rzecz czegoś - honoru, cnoty, narodu, walki... Ale mężczyzna będący tylko mężczyzną - co za potworność!" Witold Gombrowicz, Pornografia, dz. cyt., s. 120.

132 Należałoby wskazać raczej na „dyskurs autoerotyczny”, bo właśnie autoerotyzm stanowi logiczną konsekwencję tezy, iż Fryderyk i Witold to w istocie jedna - sobowtórowo podwojona - postać. 
Erotyzm jako sfera stosunków z „drugim” - pisze Maria Janion - ujawnia zazwyczaj najdobitniej zawiłości sobowtórstwa: wystarczy przywołać homoseksualną mitologię narcystyczną, poszukującą własnego odbicia w „innym”, a jakże zarazem „tożsamym". [...] U Gombrowicza [...] homoseksualizm stanowi przede wszystkim doświadczenie sobowtóra ${ }^{133}$.

Tak rozumiany motyw sobowtóra jest dystrybuowany w całym filmowym tekście. Scena o podobnej - do omówionej powyżej sceny z lustrem - wymowie powtarza się w majątku Hipolita. Kolski silnie eksponuje dążenie Witolda do fizycznej bliskości z Fryderykiem. W stodole Witold kładzie się obok przyszłego „wspólnika” i opiera głowę na jego muskularnym ramieniu. Zespolone ciała mężczyzn tworzą jedność.

Pomiędzy mężczyznami trwa nieustanna gra spojrzeń. Fryderyk „przyłapuje” Witolda, gdy ten zachwyconym wzrokiem podąża za Karolem i Henią. Intryga rodzi się na linii spojrzenia: Henia i Karol - Witold - Fryderyk. Ale, co istotne, to Witold - rzucając wyzwanie reżyserskim zdolnościom Fryderyka - inicjuje grę, w której stawką będzie „wszystko”.

W powieści Gombrowicza demiurgiczna moc Fryderyka objawia się Witoldowi podczas nabożeństwa.

Jedna ze scen kluczowych - komentuje pisarz - to ta w kościele, gdy pod naciskiem świadomości Fryderyka załamuje się Msza, a wraz z nią Bóg-Absolut. Wtedy z ciemności i próżni kosmosu wyłania się nowe bóstwo, ziemskie, zmysłowe, nieletnie, złożone $\mathrm{z}$ dwojga istot niedorozwiniętych, tworzących świat zamknięty - bo wzajemnie siebie przyciągają ${ }^{134}$.

Msza jest w Pornografii przykładem Gombrowiczowskiego „pustego rytuału". W tym rytuale widoczne są szczeliny - prześwity, przez które wdziera się kosmos zmysłowości: „Zwykły kark ${ }^{135}$ szesnastoletni, z włosami przystrzyżonymi i skóra zwyczajna (chłopca) trochę spierzchnięta"136.

${ }^{133}$ Maria Janion, Forma gotycka Gombrowicza, [w:] taż, Prace wybrane. Romantyzm i jego media, Universitas, Kraków 2001, s. 476. Badaczka podkreśla erotyczny aspekt Gombrowiczowskiego motywu sobowtóra, który interpretowany był zazwyczaj (m.in. przez Artura Sandauera) jedynie jako „chwyt-bezpiecznik, kamuflujący aluzję nazbyt personalną i oddalający podejrzenia od osoby autora". Można także przyjąć, iż sobowtór jest jedną z form maski, którą posługuje się Gombrowicz, by wyrazić konflikt między dążeniem do poetyckiego nazwania "dewiacji” a wynikającym z niego wstydem (o motywie maski pisze Olaf Kühl w Gębie erosa, dz. cyt., s. 212-220). W Pornografii Kolskiego motyw sobowtóra może być interpretowany w podwójnym znaczeniu: jako „system bezpieczeństwa" oraz jako "głos (homo)erotycznego pożądania".

${ }^{134}$ Witold Gombrowicz, Dziennik 1957-1961, dz. cyt., s. 254.

135 Olaf Kühl zwraca uwagę, iż ten szczegół (męskiej) anatomii zawsze wskazuje u Gombrowicza na obiekt erotyczny: „Umiejscowienie tego sygnału wynika z logiczną konsekwencją z usytuowania osoby skrycie pożądanej, podążającej za kimś, patrzącej z boku". Zob. Olaf Kühl, Gęba erosa, dz. cyt., s. 273.

${ }^{136}$ Witold Gombrowicz, Pornografia, dz. cyt., s. 19. 
Heideggerowska metafora „prześwitu” wskazuje - w języku przestrzeni - na miejsce zdarzenia (się) prawdy.

\begin{abstract}
Tkwi w prześwicie również pewna niespodzianość, zaskoczenie, coś nagle się otwiera i żadna tego przyczyna nie jest określona. [...] Pojęcie prześwitu [...] podkreśla fakt, że przejaśnienie, przerzedzenie dokonuje się wśród gęstwiny i braku jasności. Natura, bycie jest pełne tajemnic, pozostające $\mathrm{w}$ ciemnościach [...], odsłania się, pokazuje w świetle, w rozjaśnieniu, zawsze coś, co nigdy nie może być wzięte za całość, co nie może być „wszystkim”, lecz jest tylko refleksem, znakiem, przebłyskiem nieznanego, niewyczerpalnego ${ }^{137}$.
\end{abstract}

Ziejacy boskościa kark szesnastoletni to u Gombrowicza (erotyczna) figura pars pro toto: pojawiający się znienacka w pustce bezmiernej tej nocy „przebłysk nieznanego/nieznanej” i niewypowiadalnej rozkoszy. Cielesna obecność chłopca oznacza homoerotycznie zakodowane pożądanie, którego uwodzicielska moc kompensuje pustkę zdesakralizowanego wnętrza kościelnego ${ }^{138}$.

Cudowność, niczym we śnie, miejsca zawoalowane, których pożądamy, nie mogąc odgadnąć i krążymy wokół nich z niemym krzykiem, we wszechpożerającej tęsknocie, rozdzierającej, szczęsnej, zachwyconej.

Tak ja krążyłem wokół jeszcze spłoszony, niepewny... ale już rozkosznie przeniknięty zniewoleniem giętkim, które ujmowało - urzekało - zachwycało - czarowało - wabiło i podbijało - grało - i kontrast pomiędzy mrozem kosmicznym owej nocy a tym źródłem bijącym rozkoszy był do tego stopnia niezmierzony, iż pomyślałem mętnie, że Bóg i cud! Bóg i cud! ${ }^{39}$

Prześwit odsłania się nie za sprawą celebrowanego nabożeństwa, ale przeciw niemu ${ }^{140}$. Jeśli możemy w tym miejscu użyć pojęcia „parodia”, to z zastrzeżeniem, iż celem Gombrowiczowskiej parodii jest rozpoznanie struktury parodiowanego zjawiska, rozbrojenie wzorca z metafizyki i tajemniczej nieprzenikalności ${ }^{141}$.

Cud wydarza się również w „prześwicie metafizycznym” mszy w filmowej ${ }^{142}$ Pornografii. Ale jest to cud „przeznaczony” wyłącznie dla

\footnotetext{
${ }^{137}$ Hanna Buczyńska-Garewicz, Miejsca, strony, okolice. Przyczynek do fenomenologii przestrzeni, Universitas, Kraków 2006, s. 175-181.

138 Alfred Gall, Humanizm performatywny..., dz. cyt., s. 215.

139 Witold Gombrowicz, Pornografia, dz. cyt., s. 19.

${ }^{140}$ Michał Głowiński, Gombrowicz i nadliteratura, dz. cyt., s. 97.

${ }^{141}$ Jerzy Jarzębski, Gra w Gombrowicza, dz. cyt., s. 164.

${ }^{142}$ Charakterystyczne, iż scena ta rozgrywa się w zamienionej na kościół wozowni w... Popielawach. Strategia wpisywania w tekst własnej biografii jest bliska także Gombrowiczowi, który powieściowy dworek Hipolita wzorował na rodzinnym majątku w Małoszycach.
} 
Fryderyka. Kolski posłużył się tu ponownie konstrukcją sobowtórów: Weronika to Hela. Pojawienie się (a właściwie nagły „przebłysk w prześwicie") Weroniki w kościele zadziała jak terapia szokowa. Weronika to

„plama”, nieczystość czy resztka przeszłości, której nie można całkowicie wyeliminować ani zamienić w coś dobrego. [...] Resztka ta wywołuje często niekontrolowane i nieświadome reakcje podmiotu, polegające na rozgrywaniu w działaniu (acting out) i przymusowym powrocie treści wypartych ${ }^{143}$.

Zanim Fryderyk zdoła zracjonalizować nagły impuls (a następnie nadać wypartym ze świadomości traumatycznym wspomnieniom formę uporządkowanej narracji), uzna to, co wydarzyło się w kościele za cud: cud „,zmartwychwstania” jego zmarłej córeczki, Heli. Dla widza sens tego "cudownego" zdarzenia stanie się zrozumiały dopiero w finale. Ożywienie utraconego obiektu (Heli) można potraktować jako efekt działania „popędu reparacyjnego", będącego jednym z fundamentalnych aktów obronnych wobec poczucia lęku i wstydu. O reparacji w kontekście psychoanalitycznej teorii Melanie Klein pisze Ewa Domańska: „Reparacja wiąże się z potrzebą pojednania ze sobą w obliczu egzystencjalnej ambiwalencji wyborów. Jest ona rodzajem «pamięci przywracającej» równowagę podmiotowości po trudnych przejściach"144.

Hela-Weronika „objawia się” Fryderykowi niczym Gombrowiczowski chłopiec (Bóg $i$ cud!). Epifaniczny charakter owego „objawienia” znajduje odzwierciedlenie w przestrzennej konstrukcji sceny. Symbolikę przestrzeni buduje się tu w oparciu o opozycję przestrzeni „mroku” (sala, gdzie odprawiane jest nabożeństwo - ciemnia i próżnia kosmosu) i przestrzeni ,jasności" (prześwit, w którym mignie przez moment sylwetka Weroniki). Proces deifikacji dziewczyny kulminuje w ujęciu spełniającym funkcję prologu do sceny koncertu. We wspomnianym ujęciu zgeometryzowana i symetryczna kompozycja kadru nieuchronne przywodzi na myśl formę dwuskrzydłowego ołtarza z umieszczoną na centralnym miejscu figurą („świętej”) Weroniki (fot. 2).

${ }^{143}$ Dominick LaCapra, Psychoanaliza, pamięć i zwrot etyczny, tłum. Magdalena Zapędowska, [w:] Pamięć, etyka i historia, red. Ewa Domańska, Wyd. Poznańskie, Poznań 2002, s. 135.

${ }^{144} \mathrm{~W}$ aspekcie pamięci reparacyjnej autorka analizuje Wspomnienia z Rosji Jana Żarno, które traktuje jako materiał do studium „hermeneutyki przejścia”. W podobny sposób można zinterpretować spowiedź Fryderyka (tu pamięć reparacyjna uczestniczy w przepracowaniu traumatycznych doświadczeń, w których podmiot znajduje się w stanie przejścia pomiędzy kondycją ofiary a kondycją sprawcy). Zob. Ewa Domańska, Historie niekonwencjonalne, Wyd. Poznańskie, Poznań 2010, s. 131-145. 


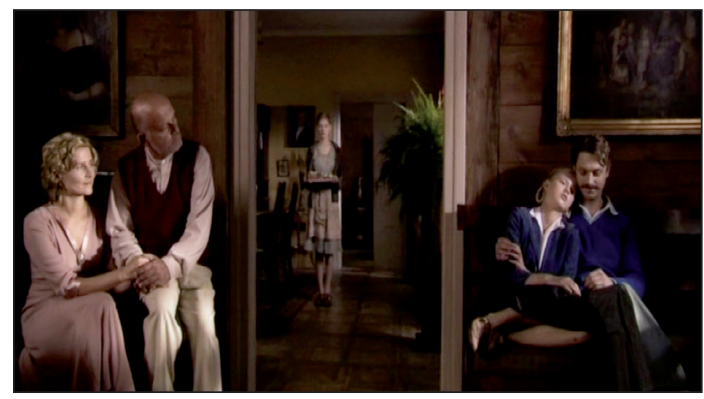

Fot. 2. Pornografia (2003, reż. Jan Jakub Kolski) „Deifikacja” Weroniki

Gdy w trakcie mszy Fryderyk gwałtownie pada na kolana, Witold zdaje się niezwykle poruszony tą nieoczekiwaną manifestacją pobożności: Nie zrozumiałem, co tak poruszyło Fryderyka. Nie dostrzegałem przyczyny. Kogoś zobaczył? Coś sobie przypomniat? Czy o przeżycie religijne tutaj chodzi, czy o kolejną prowokację mistrza ceremonii - „Co za aktor! Wyraźnie było widać szwy jego gry, on ich nie ukrywał" ${ }^{145}$ - który nawet w kościele nie wychodzi z roli?

Fryderyk $\mathrm{w}$ istocie nieustannie gra: bon vivanta (w stosunku do kobiet), wrażliwego artystę-patriotę (podczas szopenowskiego koncertu), pozbawionego skrupułów cynika (wobec wszystkich). W ludzki sposób traktuje jedynie młodziutką służącą Weronikę.

Zaniechanie - pisze Kolski - jest znakiem tego związku. Fryderyk powstrzymuje się od manipulowania dziewczyną. Przeciwnie, zdaje się, że tylko ona jest zdolna zapalić w jego oczach jakiś ślad światła, jakąś pamięć. [...] Weronika miała ożywiać nieżywego człowieka wkładaniem mu do ust coraz to nowych skrawków pergaminu z hebrajskim słowem „emet”, które on zaraz i tak wypluwał, upierając się przy śmierci. Weronika znalazła się w filmie po to, by zaświadczać o człowieczeństwie Fryderyka bardziej niż on sam ${ }^{146}$.

W finale Fryderyk pozostawia Weronice zielone szkiełko - jedyną pamiątkę po tragicznie zmarłej córce.

$\mathrm{Na}$ marginesie warto odnotować silnie wyeksponowany w filmie związek znaczeniowy pomiędzy muzycznym motywem przewodnim a postacią Heli/Weroniki. Motyw ten pojawia się w Pornografii czterokrotnie. W dwóch wypadkach (czołówka, zakończenie) ma on charakter niediegetyczny. W czołówce filmu towarzyszy ujęciom, w których zostały ukazane - filmowane od pasa w dół - sylwetki dwóch tańczących osób:

\footnotetext{
145 Witold Gombrowicz, Pornografia, dz. cyt., s. 85.

${ }^{146}$ Jan Jakub Kolski, Pamięć podróżna, dz. cyt., s. 137.
} 
mężczyzny i małej dziewczynki. Ponowne pojawienie się leitmotivu (tym razem utwór gra na fortepianie Fryderyk, a do jego wykonania zaprasza Weronikę) ewokuje w pamięci widza ustanowiony w początkowych partiach filmu kontekst ${ }^{147}$ (w tym wypadku odnoszący się do ukonstytuowanej w czołówce relacji: ojciec-córka). Motyw przewodni powraca w scenie "spowiedzi" - Fryderyk gwiżdże charakterystyczną melodię, bawiąc się dziewczęcą laleczką. Po raz ostatni słyszymy tę muzykę w finale - towarzyszy ona w drodze umierającemu Fryderykowi i kończy się $\mathrm{w}$ momencie, gdy na ekranie ujawniona zostaje zawartość należącej do niego walizeczki, w której jest wszystko (z przegródki wypada zdjęcie Fryderyka i Heli).

Kiedy przeszłość przeżywa się ponownie w sposób niekontrolowany - pisze LaCapra - wydaje się, jakby między nią a teraźniejszością nie było żadnej różnicy ${ }^{148}$. Wywołuje to w udręczonym umyśle Fryderyka efekt paramnezji ${ }^{149}$. Tym należy tłumaczyć fakt, iż w scenie „kuszenia” Fryderyk, odrzucając zaloty Weroniki, używa (nieadekwatnej do sytuacji, bo przecież Hela nie żyje) formy czasu teraźniejszego: Mam córkę w twoim wieku...

Obsesyjna samokontrola, reżim gry wedle przez siebie ustanowionych reguł, maskują strach przed obnażeniem. Ten strach ujawniają ostatnie - wypowiedziane tuż przed samobójczą śmiercią - słowa Fryderyka: Nie podgladaj mnie. Za niedyskrecje matka biła mnie po łapach ${ }^{150}$. Adresatem tych słów staje się widz - sadystyczny voyeur śledzący agonię bohatera. A zarazem słowa, w których wyraźnie podkreślony zostaje problem „obsceniczności” spojrzenia, doskonale „rymują się” z prologiem filmu. Przypomnijmy, iż dominantą prologu była właśnie kwestia voyeuryzmu - Witold podglądał Fryderyka, nie będąc (?) przez niego widzianym. W ten sposób wytwarza się w filmie rodzaj konceptualnej ramy.

Dla zrozumienia dramatu Fryderyka kluczowe znaczenie ma scena „spowiedzi”, podczas której okazuje się, że dyskurs służy tylko do odwrócenia naszej uwagi od prawdziwej mowy, odbywającej się $\mathrm{w}$ milczeniu, poza słowami, i wyrażającej to, czego słowa nie obejmowały ${ }^{151}$. Wspomniana scena została zogniskowana wokół problemu wypowia-

\footnotetext{
${ }^{147}$ Zob. Alicja Helman, O podstawach wzajemnego oddziatywania subkodów dźwiękowych $w$ dziele filmowym, "Studia Semiotyczne” 1977, t. VII, s. 111-112.

${ }^{148}$ Jan Jakub Kolski, Pamięć podróżna, dz. cyt., s. 137.

${ }_{149}$ Marek Zaleski, Formy pamięci, Instytut Badań Literackich PAN, Warszawa 1996, dz. cyt., s. 59.

${ }^{150}$ Te słowa wypowiedział Gombrowicz podczas spotkania z Zofią Chądzyńską. Przyjaciółka pisarza wspomina, iż Gombrowicz obawiał się „bycia przyłapanym” w sytuacjach „emocjonalnie intymnych”. Zob. Jan Jakub Kolski, Pamięć podróżna, dz. cyt., s. 121.

151 Witold Gombrowicz, Pornografia, dz. cyt., s. 69.
} 
dalności traumy i integracyjnej funkcji narracji ${ }^{152}$. Aktywność narracyjna staje się znacząca zwłaszcza w sytuacji zetknięcia się z doświadczeniami, które - poprzez swoją radykalną odmienność - uchylają się symbolizacji, nie dają się zasymilować i wpisać w ustandaryzowane formuły wyrażania ${ }^{153}$. W filmowej Pornografii akt ekspiacji to „narracja wstydu”:

Wstyd i upokorzenie - podkreśla Hanna Gosk - nie mają prostych wzorów opowiadalności. Angażują emocjonalnie podmiot komunikatu, zmuszają do nadania mu cech konfesji, negatywnej autoprezentacji, co staje się trudne, gdy opresyjne okoliczności zewnętrzne zdają się usprawiedliwiać upadki i kreować ów podmiot na pokrzywdzonego, któremu raczej wiele się wybacza, a nie obciąża balastem wstydu za własne położenie; wstydu przypominającego o winie czy współwinie ${ }^{154}$.

„Spowiedź" Fryderyka to filmowe punctum - moment, w którym wyartykułowany został ambiwalentny (nierozstrzygalny) status ofiary/ ocaleńca. Odzyskanie głosu to gest ocaleńczy - wszak mówić może jedynie ocaleniec ${ }^{155}$. Symbolicznym potwierdzeniem tego „ocalenia" wydaje się następująca tuż po "spowiedzi”, niezwykle dramatyczna scena, w której Fryderyk - ostatecznie uwolniony (?) od przeszłości usuwa z przedramienia obozowy tatuaż.

${ }^{152}$ Michael Roth w fascynującym eseju poświęconym filmowi Hiroszima, moja miłość (1959) Alaina Resnais analizuje problem wypowiadalności traumy w kontekście pisarstwa historycznego. W narracji historycznej (traumatyczna) przeszłość zostaje skonfigurowana - przekształcona w coś wypowiadalnego. Konsekwencją procesu przekształcania przeszłości w zintegrowaną, „znaczącą całość", może być to, co Claude Lanzmann określił - w odniesieniu do reprezentacji Holocaustu w filmie - mianem „obsceniczności rozumienia". Zob. Michael Roth, "Hiroshima Mon Amour". You Must Remember This, [w:] Revisioning History. Film and the Construction of a New Past, ed. Robert Rosenstone, Princeton University Press, Princeton 1995, s. 98-99.

153 Tomasz Kunz, Granice przedstawialności doświadczenia, [w:] Kulturowa teoria literatury 2. Poetyki, problematyki, interpretacje, red. Teresa Walas, Ryszard Nycz, Universitas, Kraków 2012, s. 498. Filmowa Pornografia i literackie Jądro ciemności, o którym pisze Kunz prezentują zbliżony typ narracji świadka. W przeciwieństwie do „spowiedzi” Fryderyka, która jest tylko „opóźnieniem nieuniknionego momentu śmierci” (Michel Foucault, Kim jest autor?, [w:] Szaleństwo i literatura, tłum. Michał Paweł Markowski, Wyd. Aletheia, Warszawa 1999 s. 201), opowiadanie bohatera Conradowskiego okazuje się zaledwie "wygodną fikcją" pozwalającą uporać się z nieznośną „prawdą doświadczenia”. Mimo to w obu tekstach bohaterowie - poprzez swoją terapeutyczną opowieść - zmierzają do odseparowania się od nieprzyswajalnego doświadczenia nie poprzez jego stłumienie, lecz eskludowanie - nadanie mu bezpiecznego kształtu czegoś, o czym można ,jedynie" zaświadczać (tamże, s. 504).

${ }^{154}$ Hanna Gosk, (Nie)obecność opowieści o wstydzie w narracji losu polskiego. Rekonesans, dz. cyt., s. 83.

155 Bożena Karwowska, „Kult ofiary” w oczach polskich pisarek emigrantek a „kult ocaleńca” w refleksji krytycznej na temat dyskursów wyzwoleńczych, [w:] Kultura po przejściach, osoby z przeszłościa, dz. cyt., s. 327. 
Scena "spowiedzi" ma wszelkie cechy seansu psychoterapeutycznego. Celem każdej terapii jest uleczenie pacjenta, czy choćby złagodzenie traumy ${ }^{156}$. W Pornografii ",spowiedź" nikogo jednak nie ocali (a opowiadanie nie okaże się formą zbawczej autonarracji - talking cure), bo przecież niektóre rany z przeszłości nie mogą zostać uleczone bez pozostawienia blizn - w pewnym sensie archiwów - w teraźniejszości ${ }^{157}$. „Spowiedź” Fryderyka nie jest kulturowo sankcjonowaną próbą zwalczenia śmierci poprzez opowieść ${ }^{158}$. Prawem paradoksu, jedyną szansąocaleniajest właśnie śmierć, lecz ta - wedle słów Nietzschego - gdy wreszcie przyniesie upragnione zapomnienie, to skręca przecież równocześnie kark teraźniejszości i istnieniu ${ }^{159}$.

W aspekcie pamięci ujawnia się prawdziwie nietzscheański rys Fryderyka - owładniętego duchem zemsty człowieka resentymentu ${ }^{160}$. Pisze Bogdan Banasiak:

Jego „wszystko rani”, dla niego każde, ściśle każde „wspomnienie jest raną ropiejącą". Tę pełną jadu pamięć Nietzsche nazywa pająkiem, duchem zemsty i pragnieniem zemsty, oczywiście zemsty wyłącznie w wyobraźni. A jaki jest skutek działalności pająka? Niezdolność podziwiania, szanowania, kochania (niemoc doceniania piękna i wielkości czegokolwiek bez poczucia osobistej obrazy); bierność; inkryminowanie winy i odpowiedzialności (pretensja do siebie, do innych i do świata - do wszystkich o wszystko). Oto moralność niewolnika - ma się on dobrze, gdy już wszyscy wokół są niegodziwi i słabi, gdy są... niewolnikami ${ }^{161}$.

I stąd być może u Fryderyka-Reżysera obsesyjna potrzeba gry, w której wszyscy stają się niewolnikami-marionetkami.

Fryderyk "odzyskuje głos”, lecz mówi o sobie, wybierając "mediatyzujacą" formę trzeciej osoby - „on"162. Dublowanie perspektyw narra-

${ }^{156}$ Zob. Bartosz Kwieciński, Obrazy i klisze. Między biegunami wizualnej pamięci Zagłady, Universitas, Kraków 2012, s. 163. Autor pisze o procesie odkrywania wspomnień jako psychodramie w kontekście filmu Shoah Lanzmanna.

${ }^{157}$ Dominick LaCapra, Historia w okresie przejściowym, dz. cyt., s. 137.

${ }^{158}$ Zob. Michel Foucault, Kim jest autor?, dz. cyt., s. 201.

${ }^{159}$ Friedrich Nietzsche, Pożyteczność i szkodliwość historii dla życia, [w:] Niewczesne rozważania, tłum. Leopold Staff, Wyd. Zielona Sowa, Kraków 2003, s. 65.

${ }^{160}$ Gilles Deleuze, Nietzsche i filozofia, tłum. Bogdan Banasiak, Wyd. Spacja, Warszawa 1993, s. 122.

${ }^{161}$ Bogdan Banasiak, (Aktywne) Zapomnienie, „Lamus. Pismo kulturalno-artystyczne” 2008, nr 2, s. 11-12.

$162 \mathrm{~W}$ pewnym sensie przypomina to doświadczenie ocalałych z Zagłady (przypomnijmy, że Fryderyk przeżył doświadczenie obozowe). W ich relacjach - jak pisze Dorota Krawczyńska - uwidacznia się rozbicie zasady jedności tego, który doświadcza z samym sobą (i z własnym doświadczeniem). Autorka posługuje się przykładem zaczerpniętym ze wspomnień Charlotte Delbo, francuskiej pisarki, która przeszła Oświęcim: „Mam uczucie, że to «ja» (self), które było w obozie, to nie byłam ja, to nie była ta osoba, która jest tu teraz, naprzeciw ciebie". Zob. Dorota Krawczyńska, Doświadczenie niemożliwe, [w:] Nowoczesność jako doświadczenie, red. Ryszard Nycz, Anna Zeidler-Janiszewska, Universitas, Kraków 2002, s. 211. 
cyjnych wydaje się chwytem służącym maskowaniu traumy i osiąganiu terapeutycznego efektu, polegającego na przywróceniu dyskursywnej kontroli nad dezintegrującym doświadczeniem ${ }^{163}$. W samym języku narracji odzwierciedla się rozpad tożsamości (tu: jako trwałość zachowania siebie), rozpatrywanej $\mathrm{w}$ „rejestrze etycznym” ${ }^{164}$. Wedle Paula Ricoeura:

Zachowanie siebie to w przypadku osoby taki sposób postępowania, że drugi człowiek może na nią liczyć. Ponieważ ktoś liczy na mnie, jestem obliczalny, mogę być rozliczany [...] przed innym. Pojęcie odpowiedzialności łączy oba znaczenia: liczyć na..., być obliczalnym w... Łączy je, dodając do nich zasadę odpowiedzi na pytanie "Gdzie jesteś?", postawione przez innego, który mnie wzywa. Odpowiedzią tą jest: „Oto ja!” Odpowiedzią, w której dochodzi do głosu zachowanie siebie ${ }^{165}$.

Forma „on” sygnalizuje, że mowa jest dla osoby cierpiącej po utraconym obiekcie jak „obca skóra”. Oznaczać może: Nawet kiedy mówię o swym własnym życiu, to tak jakbym mówiła o obcym ${ }^{166}$. Julia Kristeva podkreśla, iż w przypadku chorego na depresję język od doświadczenia uczuciowego oddziela przepaść: „Martwy język, którym mówi i w którym zapowiada swe samobójstwo, skrywa pogrzebaną żywcem Rzecz. [...] Mowa osoby z depresją jest maską - piękną fasadą skrojoną z obcego języka"167.

${ }^{163}$ Tomasz Kunz, Granice przedstawialności doświadczenia, dz. cyt., s. 499.

${ }^{164}$ Ricoeurowski podmiot - na co zwraca uwagę Małgorzata Kowalska - jest przede wszystkim „podmiotem etycznym": „Zachowanie siebie jako warunek tożsamości ipse w czasie ma więc dla filozofa sens wyraźnie etyczny. Sobą pozostaje ten, kto niezależnie od zachodzących w nim zmian fizycznych i psychicznych dochowuje wierności podjętym zobowiązaniom. Zobowiązanie nie jest zaś nigdy zobowiązaniem tylko wobec siebie, ale także i przede wszystkim wobec innego człowieka [...]. Dopiero taka wierność nadaje temu-który-jest-sobą wewnętrzną spójność i trwałość, pozwala powiązać poszczególne działania w jednolity projekt. Wynikają z tego dwie rzeczy. Po pierwsze to, że konstytutywnym elementem bycia sobą jest bycie dla innych [...]. Po drugie to, że $\mathrm{w}$ istocie dopiero poświadczenie siebie w stosunkach $\mathrm{z}$ innymi ustanawia «sobośćc jako osobową jedność, jako tożsamość jednoczącą wiele rodzajów działań i, co więcej, trwającą w czasie. $W$ tym sensie [...] bycie sobą może się w pełni aktualizować dopiero na poziomie etyki". Jest to tym istotniejsze zastrzeżenie, że podmiot w ujęciu Ricoeura nie jest podmiotem metafizycznym i/lub transcendentalnym, lecz podmiotem społecznym i historycznym: „działa zawsze w niewybranej sytuacji, w określonych warunkach historycznych i pod wpływem innych ludzi. A jednak jako sprawca działania ponosi odpowiedzialność za swoje czyny". Zob. Małgorzata Kowalska, Wstęp. Dialektyka bycia soba, [w:] Paul Ricoeur, O sobie samym jako innym, tłum. Bogdan Chełstowski, Wyd. Naukowe PWN, Warszawa 2003, s. XX-XXXII.

165 Paul Ricoeur, O sobie samym jako innym, dz. cyt., s. 273-274.

166 Julia Kristeva, Czarne słońce. Depresja i melancholia, tłum. Michał P. Markowski, Remigiusz Ryziński, Universitas, Kraków 2007, s. 58.

${ }_{167}$ Tamże. Warto zwrócić także uwagę na jeszcze jedną niezwykle istotną kwestię. Kristeva nazywa człowieka w depresji radykalnym ateistą. Badaczka analizuje depresję jako niemożność ustanowienia relacji z Ojcem Wyobrażeniowym (czyli jako brak identyfikacji z porządkiem symbolicznym, którego najważniejszym reprezentantem jest Ojciec): „utożsamienie z wyobrażeniowym ojcem dostarcza wyobrażeniowej podkładki dla 
Za pośrednictwem formy „on” pomiędzy ofiarę i ocaleńca zostaje wprowadzona jeszcze jedna kategoria: „świadek”. Fryderyk „zaświadcza” (w trzeciej osobie) o (swoim) wstydzie za nieudzielenie innemu (córce) odpowiedzi: „Oto ja!”

Fryderyka z filmowej Pornografii określić można mianem melancholika (we Freudowskim rozumieniu „melancholii” jako uczucia moralnej winy), który jest cały czas świadomy nienaprawialnego poczucia winy wobec utraconego obiektu uczuć168.

podmiotowości, która chroni przed depresją i melancholią". Zob. Michał P. Markowski, Przygoda ciała i znaków. Wprowadzenie do pism Julii Kristevej, [w:] Julia Kristeva, Czarne słońce, dz. cyt., s. XXIII-XXVII.

Odnosząc to stwierdzenie do filmowej Pornografii, możemy "uchylić" interpretacje ateizmu Fryderyka, dokonywane zwykle w kontekście filozofii Nietzschego (horyzont tych interpretacji wyznaczył niewątpliwie sam Gombrowicz poprzez niezwykle sugestywny opis mszy, która - na skutek „ekscentrycznego” aktu Fryderyka - „oklapła w strasznej impotencji... zwisająca... niezdolna już do zapłodnienia!"). Michał Legierski pisze: „Modernistyczny burzyciel i prorok wyzwolenia w Pornografii nie bez powodu nosi imię Fryderyk. Jego protoplastą duchowym jest Friedrich Nietzsche". Powieściowy Fryderyk to nietzscheański nadczłowiek, który „w sojuszu z mrocznymi siłami natury, wstrząsa sklerotycznym światem, rozsadza obezwładniający gorset obyczaju, rozdziera feudalny kokon ziemiańsko-katolicki, by uwolnić motyla młodości”. To także „artysta nietzscheański i awangardowy, który jednoczy sztukę i czyn". Zob. Michał Legierski, Modernizm Witolda Gombrowicza, dz. cyt., s. 119-127.

O nietzscheańskim rodowodzie powieściowego Fryderyka wspomina także Michał Głowiński. Wedle Głowińskiego Fryderyk nie jest ateistą tuzinkowym, który po prostu wie, że Boga nie ma. Teza „Bóg zmarł” to deklaracja nie tyle ateizmu, ile raczej nihilizmu - zaprzeczenia obiektywnego sensu wszelkich zjawisk. Tak rozumiany ateizm bliski jest Fryderykowi, który buduje w powieści świat, pragnie go wymodelować poprzez tworzenie nowych, nieznanych przedtem sytuacji. Taki świat, czy zastany, czy dopiero od podstaw budowany, nie ma z góry danych sensów, nie podlega tradycyjnej aksjologii. Zob. Michał Głowiński, Gombrowicz i nadliteratura, dz. cyt., s. 108.

Alfred Gall w interesujący sposób rozszerza nietzscheański kontekst, wykraczając radykalnie poza analizę postaci Fryderyka. Wedle autora nietzscheańska matryca przecina cały tekst powieści. Pornografia „śledzi konceptualnie pojmowaną sytuację, która ma za podstawę Nietzscheańskie hasło «śmierci Boga» i która konkretyzuje się jako doświadczenie drugiej wojny światowej. [...] W Pornografii nie chodzi więc o reprezentacje drugiej wojny światowej, lecz o egzemplaryczne modelowanie narracyjne tego wydarzenia na tle Nietzscheańskiej formuły «Bóg umarł». W tym sensie utwór jest powieścią koncepcyjna, która dokonuje refleksji nad podstawami zdesakralizowanej nowoczesności - w sytuacji Polski podczas drugiej wojny światowej". Zob. Alfred Gall, Humanizm performatywny..., dz. cyt., s. 210.

W filmie Kolskiego (biorąc pod uwagę radykalnie odmienną od Gombrowiczowskiej - w sensie generowanych znaczeń - sekwencję mszy oraz fakt, iż to od Witolda pochodzi impuls do tworzenia nowych sytuacji) Fryderyk jest raczej ateistą w znaczeniu przyjętym przez Kristevą. Gdybym zaś miała wskazać na „nietzscheański kontekst” dla postaci Fryderyka, to nie byłby to ateizm, lecz opozycja pamięci (historii) i życia, o której pisze Nietzsche w cytowanej rozprawie Pożyteczność i szkodliwość historii dla życia.

${ }^{168}$ Frank Ankersmit, Pamiętając Holocaust, tłum. Andrzej Ajschet, Andrzej Kubis, Joanna Regulska, [w:] Pamięć, etyka i historia, dz. cyt., s. 182-183. 
Kolski, poprzez „spowiedź” Fryderyka, opowiada zatem o winie. I o wstydzie. Tym „oczywistym”, bo związanym z wyparciem się - w momencie próby, na rampie - córki, która nie miała dobrej urody. Ale także o tym „przemilczanym”, o który w proteście przeciwko „zakłamywaniu” doświadczenia oświęcimskiego upomniał się Tadeusz Borowski:

Pierwszym obowiązkiem oświęcimiaków jest zdać sprawę z tego, co to obóz - tak, ale niech nie zapominaja, że czytelnik, który czyta te relacje i przebrnie wreszcie przez wszystkie okropności, nieodmiennie zapyta: no dobrze, ale jak to się stało, że właśnie pan(i) przeżył(a)? ${ }^{169}$

Kim jest zatem Fryderyk? Ocalonym (za jaką cenę?) czy ofiarą której (założona) pasywność przejawia się w niemożności racjonalizacji i werbalizacji doświadczenia, a zatem w tym, że ofiara pozostaje zawsze w pewnym sensie niema? ${ }^{170}$ Fryderyk, konstruujący własną tożsamość narracyjną jako Innego, to ofiara „z odroczonym wyrokiem”. Wszakże człowiek, któremu udało się przeżyć, nie staje się automatycznie ocaleńcem, gdyż ocalenie może oznaczać jedynie stan (w wypadku Fryderyka - czasowego) fizycznego pozostania przy życiu ${ }^{171}$.

Samobójstwo jest gestem rezygnacji. Fryderyk kapituluje - ale wobec czego? Czy - jak w przypadku bohatera Gombrowiczowskiego Ślubu (choć to tylko jedna z możliwych interpretacji) - jest to kapitulacja przed imperatywem Formy, dopełniającej zbrodnię (współwiny) karą? ${ }^{172}$

Jestem niewinny.

Oświadczam, że jestem niewinny, jak dziecko, ja nic

nie zrobiłem, o niczym nie wiem

Tu nikt za nic nie jest odpowiedzialny!

Odpowiedzialności w ogóle nie ma!

Jeżeli jednak jest trup, to musi być pogrzeb [...].

Nie, nie ma odpowiedzialności,

Muszą jednak zostać załatwione

Formalności... ${ }^{173}$

Sfera niewypowiadalnego to przeszłość Fryderyka, którą konstruuje Kolski z urywków cudzej autobiografii:

Fryderyk przyszedł z piekła. Był ojcem córki i mężem żony, którym nie podał wody na podróż do... krematorium. $Z$ tych decyzji (i innych, miej wiążących), musiały

169 Tadeusz Borowski, Alicja w krainie czarów, [w:] "Chamuły”, „gnidy”, "przemilczacze”... Antologia dwudziestowiecznego pamfletu polskiego, red. Dorota Kozicka, Universitas, Kraków 2010, s. 93-94.

${ }^{170}$ Bożena Karwowska, "Kult ofiary” w oczach polskich pisarek emigrantek..., dz. cyt., s. 327.

171 Tamże, s. 322.

172 Jerzy Jarzębski, Podgladanie Gombrowicza, dz. cyt., s. 105.

${ }^{173}$ Witold Gombrowicz, Ślub, [w:] tenże, Dramaty, Wyd. Literackie, Kraków 1988, s. 223. 
wyniknąć, i wyniknęły, najrozmaitsze konsekwencje. Chodziło - najprościej mówiąc - o uwiarygodnienie całej reszty świata, która miała otaczać bohatera, skoro on już... uwiarygodniony. To musiało oznaczać narodziny nowych, nienapisanych przez Gombrowicza zdarzen' ${ }^{174}$.

Poszukując swojego bohatera poza powieścią Gombrowicza, reżyser natrafił na ślad w postaci innego tekstu: wydanego w 1993 r. pamiętnika Calka Perechodnika Czy ja jestem morderca? Wstrząsający dokument Zagłady spisany przez policjanta $\mathrm{z}$ otwockiego getta powstawał w okresie, w którym toczy się akcja Pornografii (pomiędzy 7 maja a 18 sierpnia 1943 r.). Obu tekstom przyświecał podobny cel, by - jak pisze Maria Janion - dotknąc tematów uznawanych za tabu oraz sprzeciwić się pewnej „stylizacji retorycznej i hagiograficznej” 175 .

Pamiętnik Perechodnika, demaskujący "trzech protagonistów tragedii żydowskiej" (niemiecki sadyzm, polską podłość, żydowskie tchórzostwo), może być interpretowany nie tylko w perspektywie uniwersalnej, lecz w równej mierze w skali jednostki. Jako dokument osobisty stanowi bowiem próbę odpowiedzi na pytanie o indywidualny współudział w zbrodni. Odpowiedzi formułowanej przez człowieka, który „,bezustannie oskarża się o winę nieuchronienia żony i dziecka przed wysłaniem do Treblinki"176.

Calek Perechodnik to Fryderyk, który przed wejściem do obozu, na rampie schował się przed własną córką bo te kilka dni w bydlęcym wagonie, z trupami, w gównie zamienity go w zwierzę ${ }^{177}$ (w sensie Ricoeurowskim naruszyły decydujące o tożsamości człowieka "twarde jądro" rozumiane przez filozofa w sensie etycznym - jako zdolność dochowania słowa danego w obietnicy). Od tego momentu bezwzględne, „zwierzęce”, okrucieństwo naznacza wszelkie decyzje Fryderyka. Nieczuły na prośby pani Marii (Karol

${ }^{174}$ Jan Jakub Kolski, Pamięć podróżna, dz. cyt., s. 135.

${ }^{175}$ Maria Janion, Ironia Calka Perechodnika, [w:] Bohater, spisek, śmierć. Wykłady żydowskie, Wyd. W.A.B, Warszawa 2009, s. 270.

176 Tamże, s. 263.

177 Narrację wstydu można analizować także jako zapis procesu transhumancji. Analogicznie do analizowanej przez Domańską podróży do gułagu (we wspomnieniach Żarno), podróż bydlęcym wagonem do obozu (w opowieści Fryderyka) staje się liminalna przestrzenia transhumancji, w której dokonuje się - spowodowana wolą przeżycia - transgresja człowieczeństwa i wejście w obszar potworności. „Doświadczenia graniczne - pisze Domańska - związane z życiem w obozach czy gułagach częstokroć powodowały ontologiczne transformacje nazwane tutaj transhumancją czy przeczłowieczeniem. Zmieniały one ludzi w nie-ludzkie monstra [kilka dni w bydlęcym wagonie, z trupami, w gównie zamienity go w zwierze], byty liminalne, które we wspomnieniach odzwierciedlających przepracowanie pamięci często opisywane były pod postacią potworów lub zwierząt". Pojawiające się w obu narracjach odniesienie do Innego (w Pornografii gramatyczna trzecia osoba) oznacza, iż podmiot chce „w sposób symboliczny wyrazić swoją transformację («transhumancję», przeczłowieczenie), zaakceptować ją i pogodzić się ze zmienioną podmiotowością". Zob. Ewa Domańska, Historie niekonwencjonalne, dz. cyt., s. 149-152. 
nie może zabić, to jeszcze dziecko), odpowiada z lodowatym - „nie-ludzkim” rzec by można - spokojem: Jest wojna. A przecież nie o wojenny obowiązek tutaj chodzi, nie o Sprawę, lecz o „właściwy” finał prowadzonej z Witoldem gry. A zarazem - o wszystko...

Gombrowiczowska Pornografia przekształciła się na ekranie w moralny traktat o winie i karze, pojmowanych przede wszystkim w wymiarze jednostkowym. Sytuujemy się w obrębie dyskursu zainicjowanego pamiętnym esejem Biedni Polacy patrza na getto (1987) Jana Błońskiego. Autor postulował w nim etykę indywidualnej odpowiedzialności za ludobójstwo $^{178}$, którego naród polski nie jest winien, ale które dokonało się na naszej ziemi i tę ziemię jakoś na wieki wieków naznaczyło ${ }^{179}$. Poprzez gramatyczną formę trzeciej osoby, którą podczas „spowiedzi" posługuje się Fryderyk, uzewnętrznia się (wychodzi z ukrycia) pamiętny "kret” z wiersza Czesława Miłosza. Błoński, podejmując próbę interpretacji symbolu „kreta”, który pojawia się w utworze Biedny chrześcijanin patrzy na getto napisanym przez Miłosza w... 1943 (!) r., tłumaczy:

Ten kret posuwa się pod ziemią ale także jakby - poniżej naszej świadomości. To poczucie winy, do jakiej nie chcemy się przyznać. Pogrzebany pod ruinami między zwłokami Żydów, „nieobrzezany” boi się, że zostanie policzony przez morderców. Więc lęk przed potępieniem, lęk piekielny! Lęk nie-Żyda, który patrzy na walące się getto. Wyobraża sobie, że mógłby tu - przypadkiem - także zginać, i wtedy w oczach kreta, co umie rozróżnić popioły, wyda się „pomocnikiem śmierci”. [...] A zatem jest w tym chrześcijaninie lęk przed losem, jaki spotkał Żydów, ale jest także - stłumiony, zaszyfrowany przez niego samego - lęk przed tym, że zostanie potępiony. Potępiony przez kogo? Przez ludzi? Nie, ludzi już nie ma. To kret go potępia [...]. Własne moralne sumienie potępia (może potępić) biednego chrześcijanina. I on chciałby się przed tym kretem-sumieniem ukryć, bo nie wie, co mu powiedzieć ${ }^{180}$.

Fryderyk ukrywa się przed kretem-sumieniem w polskim szlacheckim dworku. Czas mierzony od opuszczenia przez Fryderyka obozu koncentracyjnego do „epifanicznego” doświadczenia w kościele traktować należy jako okres latencji między rzeczywistym uprzednim wydarzeniem („wyparcie się" córki) a wydarzeniem późniejszym („,zmartwychwstanie” dziecka), które w jakiś sposób je przypomina i inicjuje odnowione wyparcie (próba usunięcia tatuażu), oddzielenie, zamknięcie oraz niepożądane zachowanie (samobójstwo) ${ }^{181}$.

${ }^{178}$ Choć użyta w tytule eseju liczba mnoga (Polacy) sugeruje coś wręcz przeciwnego. Czapliński pisze: „Jednym z [...] wzorców ciągłości dziejowej jest tożsamość narodowa (Niemcy, Polacy): kto ją stosuje w opowiadaniu o historii, ten posługuje się narzędziem odpowiedzialności zbiorowej". Zob. Przemysław Czapliński, Polska do wymiany, dz. cyt., s. 83.

${ }^{179}$ Jan Błoński, Biedni Polacy patrza na getto, „Tygodnik Powszechny” 1987, nr 2.

180 Tamże.

${ }^{181}$ Dominick LaCapra, Historia w okresie przejściowym, dz. cyt., s. 155. 
W przeciwieństwie do Calka ${ }^{182}$, bohater Kolskiego mógł odpokutować swoją winę w obozie. Reżyser umocował w strukturze filmu rozproszone ślady obozowego doświadczenia Fryderyka:

Walizka z chlebem gromadzonym na wszelki wypadek, w buncie przeciw głodowi, który był. [...] Całonocne czyszczenie butów w takt pogwizdywanej przez siebie melodii. [...] Bezsenność i dramatyczna konieczność wypełnienia czymś czasu ${ }^{183}$.

A także nadwrażliwy, wyczulony na najdrobniejszy szelest słuch, który pozwala Fryderykowi „zobaczyć” motyla wykluwającego się pod powałą i Henię bezgłośnie odmawiającą wieczorny różaniec.

Fryderyka łączy też z Calkiem postrzeganie rzeczywistości w kategoriach (nie)ludzkiej gry. Gra usprawiedliwia bierność bohaterów Pornografii, służących jako nieświadome, bezwolne narzędzia w rękach Wielkiego Manipulatora. I bierność Żydów „wobec totalnego oszustwa niemieckiego", którą Perechodnik tłumaczy odwołując się do „ekspresjonistycznej wizji świata - teatru marionetek poruszanych przez Szatana - wizji jak ze złowrogiej groteski"184 Szatańska jest intryga Fryderyka (Witolda?), osiągająca swą kulminację w krwawej zbrodni. I bezwzględność, z jaką wyznacza on na egzekutora swojej woli nieletniego Karola. Czy samobójcza śmierć może okupić taki ogrom cierpienia? Nie ufam Kolskiemu, kiedy pisze o Fryderyku:

Więc może jest Żydem, właśnie uciekł z getta, udało mu się przybrać cudzą tożsamość i wszyć się z nią w aryjską rzeczywistość. Strach jest główną siła, która go napędza. Strach i żądza odwetu na Polakach - szmalcownikach, na AK, które w sporej części było antysemickie, w końcu - na wszystkich, których los Żydów nie obchodził185.

Wierzę Fryderykowi, fikcyjnej postaci, która opowiada w filmie historię Polaka ożenionego z Żydówkką.

182 Janion wspomina o pogardzie, jaką wobec postawy Calka manifestował Gustaw HerlingGrudziński. W Dzienniku pisanym noca znalazł się poświęcony Perechodnikowi passus: „Gdyby rozumiał, że istnieje coś gorszego jeszcze od śmierci, pojechałby do Treblinki razem z żoną i dzieckiem. Wybrał mały, nędzny ochłap życia (na większy nie mógł liczyć). O resztce jego życia resztkami człowieczeństwa lepiej zamilczeć. Z pobudek miłosierdzia”. Cyt. za: Maria Janion, Ironia Calka Perechodnika, dz. cyt., s. 264. „Nędzny ochłap życia" przypadł też w udziale Fryderykowi po opuszczeniu obozu. W tym kontekście samobójstwo okazuje się ze strony reżysera ",aktem łaski” wobec bohatera. „Dlaczego pozwoliłem umrzeć Fryderykowi? Bo zasłużył. Bo jego cierpienie nasyciło się do ostatka. Zreszta, pozwoliłem umrzeć... trupowi. A cóż to za łaska? Akurat taka, na jaką może sobie pozwolić reżyser filmowy". Jan Jakub Kolski, Pamięć podróżna, dz. cyt., s. 138-139.

183 Tamże, s. 138.

${ }^{184}$ Maria Janion, Ironia Calka Perechodnika, dz. cyt., s. 275.

${ }^{185}$ Jan Jakub Kolski, Pamięć podróżna, dz. cyt., s. 111. 
W Gombrowiczowskiej Pornografii niewytłumaczalne zachowanie Fryderyka wybuchało paroksyzmem zimnego okrucieństwa w "geometrycznym" (dla symetrii, która nas zespoli) akcie morderstwa. „Krwawa komunia" wieńcząca prowadzoną przez Rajfura-Reżysera ${ }^{186}$ grę ma charakter katharsis: „I przez sekundę, oni i my, w naszej katastrofie, spojrzeliśmy sobie w oczy"187. Climax rytualnego mordu to "zakulisowa" śmierć młodziutkiego Skuziaka. Finał rozpływa się w nic... ${ }^{188}$. Gombrowicz tłumaczy:

Dlaczego Fryderyk zabija go? On go zabija zupełnie tak samo, jak wrzucamy do zupy kawałek mięsa: żeby zupa była smaczniejsza. On chce sobie zaprawić zupę młodym i zamordowanym, potrzebny mu smak młodej śmierci. Działa, jak reżyser, to zresztą jego rola od początku, on chce dojść do nowych „rzeczywistości”, do nowych piękności i czarów, zestawiając ludzi [...]. Ten młody jest na uboczu, pęta się nie wiadomo po co, trzeba go włączyć w sytuację. Jak? Zabić. To jeden więcej rym w tym poemacie, ale „rym dla rymu”, bez żadnego innego uzasadnienia [podkr. moje - N.K.-R.] ${ }^{189}$.

W Gombrowiczowskim tekście ujawnia się kolejny „brak” (bez żadnego uzasadnienia), z którym musiał się uporać autor filmowej adaptacji. Zabicie Skuziaka dla rymu nie mieściło się najwyraźniej w „profilu psychologicznym" (Motywacja!) postaci stworzonej przez Kolskiego. I stąd dokonujące się w filmie "przeinaczenie": zamiast Józka Fryderyk zabija... siebie. Spektakularne - bo dla oczu spektatora przeznaczone, choć i nie przeznaczone (Nie podgladaj mnie...) - samobójstwo poprzedza niezwykłe ujęcie (pod względem dramaturgicznym można je uznać za miejsce "puste"). Tym, co przykuwa uwagę jest monochromatyczna tonacja barwna ze szczególnie mocnym akcentem w postaci rozległej płaszczyzny żółtego koloru (fot. 3).

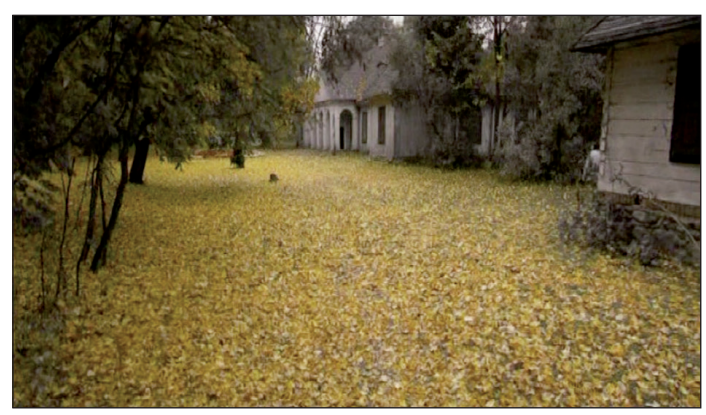

Fot. 3. Pornografia (2003, reż. Jan Jakub Kolski) „Kolor na usługach logiki wykluczeń"

\footnotetext{
${ }^{186}$ Witold Gombrowicz, Testament, dz. cyt., s. 133.

187 Witold Gombrowicz, Pornografia, dz. cyt., s. 150.

${ }^{188}$ Witold Gombrowicz, Testament, dz. cyt., s. 133.

${ }^{189}$ Tamże, s. 69-70.
} 
W moim przypadku usensownienie wspomnianego ujęcia dokonało się retroaktywnie i niespodziewanie, $\mathrm{w}$ trakcie jednej z wielokrotnie ponawianych lektur filmowego tekstu. Interpretacyjnego klucza dostarczył w tym przypadku wstrząsający fragment powieści Goldi (2004) Ewy Kuryluk:

Mamo, bukiet - podbiegłam do niej z liśćmi. - Co? - Wyrwała mi je z rąk. - Kto ci kazał zbierać same kanarkowe? Kto? - Rozglądała się dookoła. - Aach! - wykrzyknęła - to oni. Prowokacja! [...] Przyznaj się. Chcesz, żeby z nas wszystkich zrobili...?

W zacytowanym fragmencie trauma matki - cudem uratowanej z warszawskiego getta Żydówki - szczególnie silnie rezonuje w jej awersji do żółtego koloru, trwale wpisanego w historię antysemickich gestów, koloru na usługach logiki wykluczeń ${ }^{191}$. Po dywanie utkanym z żółtych liści wyrusza w swą ostatnią - przerwaną przez samobójczą śmierć - drogę filmowy Fryderyk. Jego biografia - stworzona przez Kolskiego z okruchów cudzego losu - doskonale wpisuje się w historię antysemickich gestów.

Pornografia interpretowana przez Kolskiego to "narracja wstydu”, o której pisze Hanna Gosk:

Narracja wstydu uderza w imponderabilia narracji losu polskiego, bezcześci jej święte miejsca, ujawnia "brud", o którym Mary Douglas pisze, iż generuje nasilenie aktywności "porządkującej” (a więc czyszczącej także pamięć z wstydliwych „plam”). Powtórzmy, pokątny żywot "brudu”/wstydliwych miejsc pamięci wspólnoty aktywizuje mechanizmy puryfikacyjne, a więc te, które „brud” (tu: wstydliwe aspekty narracji polskiego losu) wykluczaja, spychają w milczenie, by wiódł swój podziemny żywot, ukazując potworne oblicze ${ }^{192} \mathrm{~W}$ momentach rozszczelnienia narracji dominującej (powinnościowo-godnościowej) ${ }^{193}$.

Filmowa Pornografia to realizacja mieszcząca się w paradygmacie (polskiej) kultury posttraumatycznej ${ }^{194}$. A zatem może być ona traktowana

${ }^{190}$ Ewa Kuryluk, Goldi, Wyd. „Twój Styl”, Warszawa 2004, s. 117.

${ }^{191}$ Monika Żółkoś, Tworzenie pamięci. O powieściach autobiograficznych Ewy Kuryluk, [w:] Kultura po przejściach, osoby z przeszłościa, dz. cyt., s. 278.

${ }^{192}$ Czego - zdaniem autorki - dowodzą reakcje społeczne na Shoah Lanzmana czy Sąsiadów Grossa (na tej liście mogłoby się także znaleźć Pokłosie Pasikowskiego).

${ }^{193}$ Hanna Gosk, (Nie)obecność opowieści o wstydzie w narracji losu polskiego. Rekonesans, dz. cyt., s. 90 .

194 „Według definicji klinicznych - pisze Anna Mach - posttraumatyczność miałaby dotyczyć jednostek, które z powodu uczestnictwa w wydarzeniu „traumatycznym” (nagłym, niespodziewanym, niosącym paraliżującą przemoc, upokarzającym, uprzedmiotawiającym itp.) cierpią na jego długofalowe skutki, przeżywając lęki, obsesje, ataki paniki, depresje, zaburzenia poczucia bezpieczeństwa, miewając koszmary senne, chwilowe utraty świadomości itp. O ile jednak wymienione [...] objawy występować mogą u osób bezpośrednio dotkniętych urazem, o tyle kondycja posttraumatyczna stanowi raczej paradygmat określający kształt kultury, sposób funkcjonowania danej zbiorowości. Symptomy posttraumatryczne nie muszą zatem dotyczyć jedynie ocalonych z katastrof czy 
także jako tekst, który pyta o to, czy i w jaki sposób dziedzictwo zawierające kulturowo uzyskaną pamięć powinno stać się podstawą tożsamości dla dzisiejszych jednostek i grup. W grę wchodzą tu takie kwestie polityczne, jak zadośćuczynienie za zło wyrządzone w przeszłości, co w pewien sposób oddziałuje na następne pokolenia ${ }^{195}$.

Pornografia to trzecie ogniwo „żydowskiej trylogii" Kolskiego (Pogrzeb kartofla, Daleko od okna) wyrastającej z niezwykle osobistych ${ }^{196}$ przeżyć reżysera. Można zatem uznać, iż Kolski, podejmując w aspekcie postpamięci - która jest bardzo szczególną formą pamięci, gdyż jej relacja wobec przedmiotu czy źródła jest zapośredniczona nie poprzez wspomnienie, ale wyobraźnię i twórczość ${ }^{197}$ - temat Zagłady, realizuje strategię „prywatyzacji doświadczenia zbiorowego" ${ }^{198}$. I jedynie w tym sensie wydaje się bliski Gombrowiczowi (vide nieukończona Historia), który

ofiar rzeczywistej przemocy". Zob. Anna Mach, Polska kondycja posttraumatyczna - próba diagnozy, [w:] Kultura po przejściach, osoby z przeszłościa, dz. cyt., s. 217-218.

${ }^{195}$ Dominick LaCapra, Historia w okresie przejściowym, dz. cyt., s. 132.

196 O filmach Kolskiego jako zapisie bolesnego procesu akceptacji własnej odrębności, a zarazem niemożności pełnej identyfikacji z „żydowską tożsamością" pisałam w książce Ojczyzny prywatne. W filmowej Pornografii widoczny jest autobiograficzny ślad (i tu reżyser podąża tropem Gombrowicza). Zwróćmy uwagę, iż w scenie wyjazdu do kościoła Hipolit zachęca do udziału we mszy, którą - po spaleniu świątyni - odprawia się obecnie w wozowni w... Popielawach, czyli w miejscowości, w której Kolski spędził dzieciństwo (i którą wiele lat później uwiecznił w Historii kina...). Podobnie u Gombrowicza: „Miejsca opisywane $\mathrm{w}$ powieściach to zawsze miejsca zapamiętane $\mathrm{z}$ dzieciństwa. Jeszcze dziś można [...] wysiąść na dworcu w Ostrowcu z Pornografia w kieszeni lub trafić do Zakopanego z Kosmosem pod pachą i korzystać z nich niczym z najlepszego przewodnika". Zob. Jean-Pierre Salgas, Witold Gombrowicz lub ateizm integralny, dz. cyt., s. 132.

Dla odmiany Kolski nie dba specjalnie o realia geograficzne - majątek Hipolita, jak dowiadujemy się z prologu, znajduje się w Sandomierskiem (czyli w rodzinnych stronach Gombrowicza), Popielawy zlokalizować można natomiast w okolicach... Łodzi.

197 Zob. Marianne Hirsch, Żałoba i postpamięć, [w:] Teoria wiedzy o przeszłości na tle wspótczesnej humanistyki, red. Ewa Domańska, Wyd. Poznańskie, Poznań 2010, s 254.

${ }^{198}$ Kolski jest przedstawicielem "trzeciego pokolenia". W Piotrkowskiej i innych okolicach kina znalazł się wstrząsający autobiograficzny zapis dotyczący wojennych losów części rodziny: „Drogę do obozu przejechali wygodnie, w pulmanowskich wagonach, a potem już zwyczajnie - komin. Maksymilian Hendlisz wraz z żoną i dwiema córkami getto, obóz, komin. [...] urodziłem się wprawdzie jedenaście lat po wojnie, ale dotkliwie przez nią ograbiony". Zob. Jan Jakub Kolski, Piotrkowska i inne okolice kina, Wyd. Silesia Film, Katowice 1998, s. 5.

Jeśli przyjmiemy, iż postpamięć „wyzwala najczęściej jedną dwóch postaw - albo introwertyczne, traumatyczne zmaganie się z przeszłością i indywidualnie podejmowaną próbą przepracowania tak doświadczonej przeszłości, albo ekstrawertyczne, nacechowane poczuciem misji działanie na rzecz upublicznienia tegoż doświadczenia i wiedzy o nim", musimy uznać, że twórczość Kolskiego (zarówno literacka, jak i filmowa) to manifestacja postawy drugiego typu. Zob. Katarzyna Kaniowska, Postpamięć indywidualna - postpamieć zbiorowa jako kategorie poznania w antropologii, [w:] Pamięć i polityka historyczna. Doświadczenia Polski i jej sassiadów, red. Sławomir M. Nowinowski, Jan Pomorski, Rafał Stobiecki, Wyd. Ibidem, Łódź 2008, s. 72. 
czyni doświadczenie społeczne (i na dalszym planie - narodowe) aspektem doświadczenia wewnętrznego. Mówiąc o różnego rodzaju zamętach i metamorfozach społecznych, międzyludzkich i towarzyskich, tym samym, jakby w jednym ruchu, mówi o sobie $[\ldots]^{199}$.

Zarazem jednak Kolski - głównie za pomocą „dopisanej” powieściowemu Fryderykowi przeszłości - „stępia” ostrze Gombrowiczowskiego tekstu i osłabia jego demaskatorski ton. Jeśli obowiązuje tu Gombrowiczowska zasada symetrii - to na zasadzie á rebours (reżyser "odejmuje” z powieści jednego AK-owca, czyniąc ze sprawy Siemiana „eksces”).

Jeśli zaś miała być filmowa Pornografia bezkompromisowym (przeprowadzonym w duchu debiutanckiego Pogrzebu kartofla) atakiem na kolektywną polską świadomość (z której skutecznie udało się wyprzeć kreta-sumienie), po cóż (bo nie dla symetrii chyba) w tym zdegradowanym świecie martwych form tak piękna (a niemająca pierwowzoru w powieści) postać Sprawiedliwego z Ostrowca?

Pornografia Kolskiego traktuje o dręczącej reżysera od czasu filmowego debiutu odpowiedzialności Polaków wobec Żydów. O przeszłości istniejącej w nas (w jednostkach i zbiorowości) jako obce ciało, którego nie możemy zasymilować, ale też nie możemy się go pozbyćcon. O historycznej traumie, która nie tylko stawia nas w obliczu zagadnienia podświadomego tłumienia przeszłości, lecz także wobec problemu mitu (gdyż pamięć historycznej traumy ma skłonność do stawania się pamięcią mityczną) ${ }^{201}$. O nieusuwalnym, jak oświęcimski tatuaż Fryderyka, poczuciu winy, "wymazanym” z martyrologicznych narracji o II wojnie. A zatem o Holocauście, który jest

wezwaniem do nowego spojrzenia [podkr. moje - N.K.-R.] na nas, jako tych, którzy choćby w małym stopniu - pozwolili, aby miał miejsce. Każe nam inaczej patrzyć na samych siebie, czyli na własną przeszłość, bo tożsamość opiera się na pamięci. A to właśnie jest czymś, przed czym broni się znaczna część Polaków²02.

A więc jest Pornografia filmem o wszystkich uchylających się od moralnej odpowiedzialności „wydrążonych”, którym jedynie śmierć mogła przynieść wyzwolenie z piekła pamięci, bo kiedyś, ze strachu, schowali się przed własnym dzieckiem. Ale czy jest w niej... spojrzenie Gombrowicza?

${ }^{199}$ Ewa Graczyk, Przed wybuchem wstrzasnać, dz. cyt., s. 217.

200 Zob. Ewa Domańska, Mikrohistorie, Wyd. Poznańskie, Poznań 1999, s. 115.

${ }^{201}$ Zob. Antoon Van den Braembussche, Historia i pamięć. Kilka uwag na temat ostatnich dyskusji, [w:] Historia: o jeden świat za daleko?, red. Ewa Domańska, Wyd. Instytutu Historii UAM, Poznań 1997, s. 115-116.

${ }^{202}$ Jan Błoński, Biedni Polacy patrza na getto, Wyd. Literackie, Kraków 2008, s. 47. 


\section{Część dRuga}

\section{Spojrzenie dziecka (i nie tylko)}

Wspomnienia z dzieciństwa pokazują nam nasze pierwsze lata nie takimi, jakimi one były, lecz jakimi objawiły się w latach późniejszych, kiedy zostały wyrażone. Nie „wynurzają się” one - jak to jest się w zwyczaju mówić - w czasie ich ewokowania, ale są "kształtowane”, a na ich formowanie wpływa cała seria motywów, z których prawda historyczna wcale nie najważniejsza, wpłynęła na owo kształtowanie równie dobrze, jak i sam wybór wspomnień. 



\section{Rozdział III}

\section{Chciałem zejść z pomnika, najkrócej mówiq̨c Poznań 56 Filipa Bajona}

\section{Prolog: dzieciństwa raj (nie)utracony?}

Mieliśmy po dziewięć, dziesięć, jedenaście lat, nie więcej, nasz świat się wtedy właśnie zawalił. Tylko że nie wiedzieliśmy jeszcze o tym, choć powinniśmy byli wiedzieć. Ta jakaś cząstka rozumu, w jaki wyposażyła nas natura, rodzina i historia, którą w tym kraju ssie się nieomalże wprost z piersi matki i która wciąż przypomina swym złowieszczym głosem o tym, co powtarza się co lat kilkadziesiąt z regularnością uderzeń zegara; ta cząstka naszego rozumu musiała przecież od kilku dni w naszych głowach krzyczeć i zapewne nawet krzyczała, ale jeszcze to najgorsze, co było już zapisane przez los, przygniatające, miażdżące, nieodwracalne, co miało się spełnić i spełniać przez lata, tego nam widać nie wykrzyczała dotychczas do końca. [...].

Mieliśmy po dziewięć, dziesięć, jedenaście lat, nie więcej. Żaden z nas nie doświadczył później nigdy łaski zapomnienia ${ }^{1}$.

Jest kwestią godną uwagi, iż w powojennej kinematografii polskiej² tak niewiele znaleźć można filmów, w których bohaterem byłoby dziecko

1 Włodzimierz Odojewski, Koń pułkownika, [w:] Jedźmy, wracajmy, Wyd. Książkowe „Twój Styl", Warszawa 2008, s. 71-78.

2 Ten problem dotyczy w równej mierze powojennej literatury. Andrzej Kijowski zwrócił na ten fakt uwagę w eseju Kompleks Dżyngis-Chana: „Przeżycie historii zastyga we wzorzec, reprodukowany potem w nieskończoność przez następne pokolenia. Wielką literaturę powstań stworzyło pokolenie, które było czynnie lub uczuciowo zaangażowane w walkę, w jej wynik, które odczuwało jej wielkość wtedy, gdy się odbywała. Nigdy nie odezwał się jej mały bezbronny świadek, który krył się przed pożarem i mordem, i który zaraz potem wypełzał z piwnicy, by z ciekawością oglądać barwne mundury nadchodzących wojsk". Zob. Andrzej Kijowski, Kompleks Dżyngis-Chana, [w:] Szósta dekada, PIW, Warszawa 1972, s. 89. Należy jednak podkreślić, że tekst Kijowskiego powstał na długo przed polską premierą Malowanego ptaka Jerzego Kosińskiego (1989) czy publikacją tomu opowiadań Włodzimierza Odojewskiego Jedźmy, wracajmy (1993). 
- „świadek” historii. Jeszcze mniej jest takich obrazów, w których poprowadzono opowieść z perspektywy dziecięcego uczestnika zdarzeń (Śriadectwo urodzenia Stanisława Różewicza z 1962 r. przez długi czas - bo aż do momentu realizacji w 2010 r. Wenecji Jana Jakuba Kolskiego - pozostawało w tej materii jednym z nielicznych wyjątków).

Owa „znacząca nieobecność" dziecka w filmowym (i krytycznofilmo$w \mathrm{ym}^{3}$ ) dyskursie jest o tyle wymowna, iż obfitujący w dramatyczne wydarzenia polityczne "polski los” musiał naznaczyć najwcześniejsze etapy biografii rodzimych twórców kina. Tym więcej zainteresowania należy się zatem dziełom, które próbują "uchwycić" mitologem dzieciństwa, sytuując go w kontekście - zakłamywanej przez długie lata w oficjalnym dyskursie - historii Polski w okresie stalinizmu. W tej grupie dzieł (obok Poznania 56) powinny się znaleźć przede wszystkim Dreszcze Wojciecha Marczewskiego, Niedzielne igraszki Roberta Glińskiego i Cwat Krzysztofa Zanussiego - a zatem filmy, które określić można mianem obrazów rozrachunkowych. Odwołują się one bowiem - z niezbędnego dla dokonania rozrachunku dystansu - do wydarzeń z lat 50., objętych przez długie dziesięciolecia restrykcyjnym tabu milczenia.

We wszystkich wymienionych filmach autorzy podjęli próbę uczynienia $\mathrm{z}$ dziecka (w Niedzielnych igraszkach byłby to dziecięcy bohater zbiorowy) narracyjnego centrum. Bohater-dziecko, dzięki pewnym informacjom płynącym bezpośrednio z ekranu (jak w filmie Cwał), bądź dostępnym widzowi z innych źródeł (niebagatelną rolę odgrywa $\mathrm{w}$ tym wypadku znajomość społecznego kontekstu biografii autora), staje się w oczach widza nie tylko przewodnikiem po świecie ekranowym, lecz także specyficznym porte parole autora. Genezy filmowych fabuł należałoby zatem poszukiwać $\mathrm{w}$ prywatnych (a nawet intymnych) doświadczeniach reżyserów. Konieczność uwzględnienia w procesie interpretacji wymienionych filmów tropu biograficznego to stały element refleksji krytycznej, czego dowodem może być wypowiedź autora monografii Marczewskiego:

Do bardzo osobistego charakteru Dreszczy w pierwszym rzędzie przekonuje jawna w nich obecność wątków autobiograficznych. Aresztowanie ojca, pobyt w małym, prowincjonalnym miasteczku, udział w kilkumiesięcznym obozie harcerskim to elementy fabuły oparte na rzeczywistych przeżyciach reżysera z czasu jego dzieciństwa. [...] Można nawet zaryzykować stwierdzenie, że gdyby Marczewski urodził się dekadę wcześniej lub dekadę później, film o czasie jego inicjacji z pewnością by powstał, natomiast film o realiach polskiego stalinizmu - niekoniecznie ${ }^{4}$.

3 Dziecięcym bohaterom został poświęcony fragment najnowszej książki Małgorzaty Hendrykowskiej Film polski wobec wojny i okupacji, Wyd. Naukowe, Poznań 2011, s. 102-111.

4 Andrzej Szpulak, Filmy Wojciecha Marczewskiego, Wyd. Naukowe UAM, Poznań 2009, s. 136, 254. 
Obecność dziecięcego bohatera nieuchronnie wikła wspomniane dzieła w konteksty filmowej (auto)biografistyki, każąc w nich widzieć modelowy przykład posługiwania się tzw. retoryką szczerości. Implikowana „szczerość" owych dzieł byłaby w tym wypadku kwestią o tyle istotna, że - jak dowodzi przypadek Poznania 56 - widzów w znacznie większym stopniu interesowała "rzetelność" relacji historycznej (i jej rewelatorski charakter), niż wyrażona w dziele "prawda” o osobie autora. Tymczasem uważna lektura ujawnia, iż twórcy - choć umieszczają zdarzenia ekranowe w konkretnych realiach społeczno-politycznych - poszukują wspomnianego na wstępie mitologemu dzieciństwa, odwołując się do uniwersalnych modeli kulturowych. Tym samym filmy traktujące o dzieciństwie przypadającym na mroczny okres stalinizmu uzyskały na ekranie paraboliczny kształt opowieści inicjacyjnej5.

Przewodnikiem po filmowych opowieściach o „dzieciństwie w cieniu Historii" uczyniłam Włodzimierza Odojewskiego, bo to w jego utworach Historia

wkracza w życie człowieka właśnie wtedy, gdy przystępuje on do pierwszego rozpoznawania sensu świata. Ulubiona dla Odojewskiego forma opowiadania inicjacyjnego, opowiadania o dojrzewaniu, znajduje swoje głębsze uzasadnienie [...]. Schemat opowiadania inicjacyjnego ma [...] podwójny wymiar: wtajemniczenia w sens i wtajemniczenia w niepojęte zło. [...] Historia dokonuje [...] radykalnego cięcia [...] w tym znaczeniu, że zamyka dostęp do niewinności ${ }^{6}$.

Filmowe opowieści inicjacyjne to także opowieści o raju utraconym, w których - jak w biblijnym prawzorcu - na pierwszy plan wysuwa się figura Nieobecnego Ojca. Ojca rzeczywistego i Ojca - symbolu.

Zbiorowy bohater Niedzielnych igraszek to w przeważającej części dzieci-sieroty. Widz dowiaduje się wprawdzie o aresztowaniu (w efekcie „niewinnego" sztubackiego wybryku) "tylko" jednego ojca, ale możemy przypuszczać, że przypadek Józka ma charakter wzorcowy (partyjna aktywistka uspokaja, że osierocony chłopiec zostanie odesłany do domu dziecka - jak zwykle w takich okolicznościach). Ojcowie w filmie Glińskiego są nieobecni lub słabi i całkowicie zastraszeni (jak dozorca - tata Ryśka który w wojskowej bluzie z biało-czerwoną opaską odgrywa przed żoną bohatera, ale tylko do momentu, kiedy na horyzoncie podwórka pojawiają się tajniacy z UB). Nawet po śmierci Stalina - jak w czasach największych

5 Warto zauważyć, iż jedynie w Poznaniu 56 inicjacja dziecięcego bohatera przebiega dokładnie wedle trójfazowego schematu opisanego przez van Gennepa.

6 Przemysław Czapliński, Wzniosłe tęsknoty. Nostalgie w prozie lat dziewięćdziesiątych, Wyd. Literackie, Kraków 2001, s. 145-147. 
czystek - ludzie żyją w nieustannym lęku przed aresztowaniem. Na skutek fałszywego oskarżenia do więzienia trafia ojciec Tomasza z Dreszczy. Podczas rewizji w domu chłopiec staje się mimowolnym świadkiem upokorzenia rodzica, które - jak można sądzić - wpłynęło na osłabienie ojcowskiego autorytetu i późniejszy lekceważący stosunek Tomka do rodzica.

O ile dziecięcy bohater filmu Zanussiego pozostaje do końca pod zbawiennym wpływem etosu reprezentowanego przez bohaterską postać ojca (byłego żołnierza Armii Krajowej, który w obawie przed represjami zdecydował się po wojnie pozostać za granicą), o tyle Dreszcze (i Poznań 56) należy potraktować jako opowieści o autorytecie utraconym ${ }^{7}$, a także o desperackich poszukiwaniach autorytetu „zastępczego". Motywem pojawiającym się we wszystkich omawianych filmach jest osierocenie dziecka nie tylko w sensie dosłownym, lecz - co znacznie ważniejsze - symbolicznym (tatę Tomka zwolniono przecież z więzienia po Wydarzeniach Poznańskich). Wychowanie w duchu ojcowskich prawd nie stanowi dostatecznej siły oporu przeciw indoktrynacji - przybierającej w Dreszczach kuszącą (a zatem inną - i zdecydowanie bardziej niebezpieczną - niż w Potędze smaku Zbigniewa Herberta) postać druhny. Utożsamiając inicjację ideologiczną z inicjacją o charakterze erotycznym Marczewski prowokuje widza do odpowiedzi na pytanie, czy konwersja Tomka dokonałaby się równie łatwo, gdyby „,samogonny Mefisto w leninowskiej kurtce posyłał w teren wnuczęta Aurory", a funkcję duchowych przewodniczek spełniały nie „kobiety różowe płaskie jak opłatek”, lecz „chłopcy o twarzach ziemniaczanych" i „bardzo brzydkie dziewczyny o czerwonych rękach”? Reżysera interesował moment duchowego przełomu - stan zawieszenia pomiędzy „dawną” (dom rodzinny) i „nową” (obóz) wiarą. Świadectwem światopoglądowego chaosu jest w Dreszczach scena, w której Tomasz żarliwie modli się do Boga, by wytępił wszystkich kontrrewolucjonistów.

Dzieci z filmu Glińskiego są głęboko przekonane, że o ile Bóg - być może - wcale nie istnieje, to z pewnością zmartwychwstanie Stalin:

- Nieba nie ma i piekła też nie. A czy on też pójdzie do ziemi i zjedza go robaki?

- On?! On pójdzie do nieba.

7 Można je także interpretować w kontekście socjologicznym jako paradygmatyczne przykłady konfliktu pomiędzy socjalizacją pierwotną (w której fundamentalną rolę odgrywają tworzący środowisko rodzinne "znaczący inni”) a socjalizacją wtórną (dokonującą się w środowisku społecznym, które proponuje jednostce rozmaite „kontrdefinicje” rzeczywistości).

8 Zbigniew Herbert, Potęa smaku, [w:] Wiersze wybrane, red. Ryszard Krynicki, Wyd. a5, Kraków 2004, s. 283. 
Tę schizofreniczną logikę zaszczepia dzieciom nie tylko wszechobecna propaganda (deifikacja partyjnych „świętych"), lecz jest ona także (a może przede wszystkim) wpajana przez rodziców. Symbolicznym potwierdzeniem zaakceptowanych przez dorosłych zasad dwójmyślenia może być "podwójny portret” - Stalina i Matki Boskiej - który posłuży jako ostateczny dowód winy w przypadku ojca Józka.

Nazwisko generalissimusa pada w rozmowach dzieci niezwykle często. To jego postać może bowiem stanowić wzorcowy przykład figury Nieobecnego Ojca, pojmowanego na sposób symboliczny. W dwóch filmach (Niedzielne igraszki, Cwat) akcja rozgrywa się w roku śmierci Stalina, a część zdarzeń ekranowych bezpośrednio wiąże się z uroczystościami żałobnymi. Stalin traktowany jest przez dzieci jak ojciec (ten wątek jest wprawdzie nieobecny w Poznaniu 56, ale można go odnaleźć w retrospektywno-onirycznych partiach Wahadełka Filipa Bajona - podczas szkolnej zabawy noworocznej spod tradycyjnej maski Dziadka Mroza wyłania się twarz Josifa Wissarionowicza, który ojcowskim i pełnym aprobaty gestem przygarnia do siebie wychowywanego jedynie przez matkę Michałka). Jeden z przedstawicieli podwórkowej mikrospołeczności z filmu Glińskiego formułuje dziecięce uczucia wprost: On podobno bardzo kochat dzieci. I rozdawat złote medale młodym pionierom. I Pałac Kultury kazat dla polskich dzieci zbudować.

Śmierć „symbolicznego Ojca” burzy uświęcony (wedle reguł nowej wiary) ład (żałoba po Wielkim Ojcu nie wpływa zasadniczo jedynie na los bohatera Cwału -jeśli nie liczyć „drobnego incydentu”, który omal nie stał się przyczyną relegowania chłopca ze szkoły). Tę sytuację ilustrują Niedzielne igraszki. Agresja dzieci, wybuchająca paroksyzmem nienawiści wobec domniemanej morderczyni kota, zdaje się eskalować wraz z rosnącą świadomością, że Ojca nie ma już wśród nas - od słyszalnych spoza kadru słów: On umart. Umarł! zaczyna się przecież film Glińskiego. Rzeczywistość - zanim zdąży się na dobre w dziecięcym doświadczeniu ukonstytuować - rozpada się (w filmie Marczewskiego w sposób dosłowny) na oczach inicjowanego. "Osierocony" świat oferuje dziecku jedynie pakiet zdewaluowanych wartości. W Dreszczach ciśnięty w błoto portret Marksa i pociąg-widmo uwożący uczestników obozu w nieznaną przyszłość to czytelne znaki rozpoczynającej się właśnie politycznej odwilży. Ale w doświadczeniu dziecka są to przede wszystkim symbole Chaosu. Skutkiem rzeczywistego bądź symbolicznego usunięcia ojca z horyzontu dziecięcego świata jest poczucie osierocenia - wygnania z raju. Dla dziecka oznacza to konieczność wkroczenia w rzeczywistość, której doświadczenie układać się będzie odtąd w ciąg inicjacji. Dla Huberta z Cwatu to przede wszystkim inicjacja o charakterze „epistemologicznym”. Nieobecność ojca skazuje dziecko na samodzielne poszukiwanie odpowiedzi na zasadnicze 
pytania: Co to jest prawda? Czy istnieje prawda absolutna? Czy zawsze głoszenie prawdy oznacza opowiedzenie się po stronie dobra?

Cwał to jedyny spośród analizowanych filmów przykład opowieści o raju nieutraconym. Zadecydowało o tym przyjęcie - ujawnionej w pozadiegetycznym zakończeniu - perspektywy czasowego dystansu, dzięki której koszmar stalinizmu we wspomnieniach autora uległ transformacji w wyidealizowaną baśniową opowieść o rajskim dzieciństwie. Ojca (którego brak - mimo podkreślanej na każdym kroku „politycznie hańbiącej przeszłości" - odczuwa Hubert szczególnie boleśnie) zastępują dorośli, dalecy wprawdzie od modelowego wzorca z powiastek oświeceniowych, ale spełniający doskonale funkcję duchowych przewodników inicjowanego. I dzieje się tak pewnie dlatego, że w miejsce gotowych recept, do których przyzwyczaił młodych ludzi represyjny system (w Cwale - podobnie jak w Dreszczach - reprezentowany przez szkołę), oferują chłopcu jedynie prowokujący do samodzielnego myślenia zestaw pytań, wątpliwości, moralnie dwuznacznych rozwiązań. Pisze Alice Miller:

Choćby dziecko zaznało głodu, przeżyło ucieczkę i bombardowanie, a było przy tym poważnie traktowane przez rodziców jako samoistna osoba, z powagą i szacunkiem, nie zapadnie na psychiczną chorobę z powodu tych rzeczywiście przeżytych dramatycznych wydarzeń. Może nawet zachować w dobrej pamięci te przeżycia (jeśli miało przy sobie jakąś bliską osobę) i wzbogacić nimi swój wewnętrzny świat ${ }^{9}$.

Dzięki dorosłym (matce, a przede wszystkim ciotce i ludziom z jej najbliższego otoczenia) bohater Cwału przechodzi pomyślnie trudny egzamin z "patriotycznej dojrzałości”, który na ekranie przekształca się $\mathrm{W}$ archetypiczny rites of passage. $\mathrm{W}$ filmie Zanussiego stalinowskie realia przedstawione zostały w konwencji gry, w której zwyciężają - choć nie zawsze przy użyciu etycznie właściwych środków - szlachetniejsi. Czy to wystarczy, by utrwalony w powszechnej świadomości mit o rajskim dzieciństwie pozostał nienaruszony (domysłowi widza pozostawiono wszakże dalsze losy ciotki, Rotmistrza i zaginionego w trakcie ucieczki do Szwecji Dominika)? I czy dla odbiorcy, obeznanego z sytuacją polityczną pierwszej połowy lat 50., może przekonująco brzmieć „stara prawda, że o jakości życia nie decydują czasy i wydarzenia, a szczęśliwe dzieciństwo można stworzyć w każdych warunkach" ${ }^{\prime 10}$ ?

9 Alice Miller, Zniewolone dzieciństwo. Ukryte źródła tyranii, tłum. Barbara Przybyłowska, Media Rodzina, Poznań 1999, s. 34.

10 Beata Cyganek, Dzieciństwo. Ciężar samotności, [w:] Odwiecznie od nowa. Wielkie tematy w kinie przełomu wieków, red. Tadeusz Lubelski, Wyd. Rabid, Kraków 2004, s. 30. Wymownym komentarzem do tezy sformułowanej przez Alice Miller jest Wenecja Jana Jakuba Kolskiego. Film potraktować można jako porażające świadectwo „zarażenia złem”. Ten problem zostaje zasygnalizowany widzowi już w niezwykle „mocnym” prologu filmu, 
Reinterpretacja wydarzeń politycznych w filmach mówiących o tych wydarzeniach z punktu widzenia dziecięcego bohatera mogła dokonać się w dużej mierze dzięki temu, iż twórcy uczynili z Historii tło dla opowieści o charakterze uniwersalnym. Dzieci z filmu Glińskiego wydają się ofiarami stalinowskiego systemu - osierocone na skutek politycznych czystek, zredukowane w swej przestrzeni życiowej do granic klaustrofobicznego podwórka-więzienia, odtwarzające (nie)świadomie wszystkie cechy ideologicznego rytuału (podczas "niewinnej” zabawy w posagi nawet maluchy zastygają $\mathrm{w}$ hieratycznych pozach znanych $\mathrm{z}$ kanonu socrealistycznej ikonografii), łącznie z jego wojenną retoryką (,wodzowskie” przemówienie Józka podczas pogrzebu kota). A jednak kilka sekwencji Niedzielnych igraszek dowodzi bezzasadności przekonania o rajskim (bezgrzesznym) stanie, w jakim znajdowałyby się dzieci, gdyby w ich świat nie wkroczyła brutalna rzeczywistość polityczna. Jako przykład niechaj posłuży drastyczna scena, w której dzieci zmuszają obłąkaną kobietę do obnażenia się (pozornie bezsensowny bełkot bezdomnej stanowi dla widza wskazówkę, iż była ona ofiarą brutalnych ubeckich przesłuchań). Zwraca uwagę szczególny nastój tej sceny. Wrażenie spotęgowanego koszmaru - uzyskane dzięki dynamicznemu montażowi i sugestywnej warstwie akustycznej (przywodzącej na myśl archaiczne rytuały plemienne) - wywołuje nieuchronne skojarzenia z finałowymi partiami Władcy much Goldinga. Dziecięce okrucieństwo to raczej pierwotna, immanentna cecha natury ludzkiej, a nie efekt ideologicznej indoktrynacji.

w którym obserwujemy - odbywające się w przededniu września 1939 r. - szkolne ćwiczenia z Przysposobienia Wojskowego. Kilkuletni chłopcy przyodziani są w mundurki i „odczłowieczające” maski gazowe. W deszczu i błocie (sceneria przywodzi na myśl realia I wojny światowej) wykonują posłusznie komendy dowódcy - raz po raz dźgają bagnetami brzuchy „wyimaginowanych” wrogów. Eskalacja dziecięcej przemocy kulminuje we wstrząsającej scenie wyroku na volksdeutschu Zarubie: kilkuletni Marek wyręcza sparaliżowanego niemocą starszego brata - „żołnierza” lokalnego oddziału AK - i kończy „spartaczone” dzieło: miażdży głowę rannego znalezionym w pobliżu kamieniem (czy w „innej wersji” losu Marek mógłby przyjąc konspiracyjny pseudonim Ryś, który nosił diaboliczny, a przecież chłopięco niedojrzały - niemal dziecko jeszcze - bohater opowiadania Iwaszkiewicza Kościół w Skaryszewie?). Kolski przerywa okupacyjną opowieść o „idyllicznym” sezonie w Wenecji (tytuł opowiadania Włodzimierza Odojewskiego, które stało się kanwą scenariusza filmu), nie dopowiadając dalszych - powojennych losów Marka i Wiktora (przypomnijmy, że podobną strategią posłużył się Marczewski w Dreszczach). Do refleksji widza pozostawia zatem Kolski pytanie, czy na te "hipotetyczne” losy rzeczywiście mogły nie mieć wpływu minione czasy $i$ wydarzenia. Podobnie niejednoznaczna - w kontekście całego filmu - jest funkcja wspomnianego wcześniej prologu. Czy Kolski - wzorem Jerzego Kosińskiego - chce ostatecznie udowodnić, że dziecięca fascynacja złem znajduje ,jedynie" pożywkę w koszmarze wojennego świata (uwagi na temat Malowanego ptaka, zob. Maria Janion, Płacz generała. Eseje o wojnie, Wyd. Sic!, Warszawa 1998, s. 210-222), czy też - przeciwnie - to właśnie ów wojenny świat zaraża złem niewinną istotę ludzką? 
Wejście w świat przeżyć dziecka oznaczało dla twórców kina rozrachunkowego konieczność zmierzenia się z ulotną materią wspomnień, ulegających - w miarę powiększającego się dystansu czasowego - daleko idącym przekształceniom. Udzielając odpowiedzi na pytanie, w jaki sposób autorzy analizowanych dzieł dokonali reinterpretacji historycznych wyobrażeń, próbując ukazać je przez pryzmat dziecięcej świadomości, należałoby przyjrzeć się także formie, w której zostało zakodowane subiektywne spojrzenie dziecięcego bohatera.

Wydaje się, że we wszystkich filmach autorzy posłużyli się figurą „podwojonego" innego spojrzenia. Z jednej strony byłoby to spojrzenie dziecka, z którego perspektywy zostały przedstawione zdarzenia, z drugiej - spojrzenie wewnętrznego autora dzieła, który wpisuje w utwór własne przemyślenia na temat relacjonowanych zdarzeń, lecz dokonuje tego zabiegu z niedostępną dziecku "dojrzałą" świadomością (relacja pomiędzy tymi dwoma typami spojrzeń stanowi zasadniczy temat Poznania 56).

Podwojenie perspektywy widoczne jest w Niedzielnych igraszkach. Rejestrowane "obiektywną" kamerą partie filmu, które przypisać możemy spojrzeniu zdystansowanego obserwatora, lokującego się "na zewnątrz" świata przedstawionego, zostały kontrastowo zestawione $\mathrm{z}$ ujęciami, które dają się przypisać wyłącznie spojrzeniu bohatera dziecięcego należącego do tego świata. Z pozycji dziecka obserwujemy „niebosiężne” ściany podwórza-studni, pełnym dziecięcego zachwytu spojrzeniem obejmujemy postać „delegata” Józka, który - niczym na wojskowej paradzie - dosłownie "miażdży”, ustępującą przed jego monumentalnie wyolbrzymioną figura, podwórkową społeczność.

Najbliższy filmowego obiektywizmu wydaje się obraz Zanussiego. Autor posłużył się bezosobową narracja której status ulega nieoczekiwanej zmianie dopiero $\mathrm{w}$ zdecydowanie autotematycznym finale (ujawnienie rzeczywistej funkcji narratora jako bohatera działającego w obrębie świata przedstawionego to chwyt typowy dla poetyki baśni). Odczytanie filmowej fabuły jako historii quasi-autobiograficznej (relacjonowanej z punktu widzenia narratora-bohatera, który odtwarza na ekranie własne wspomnienia) dokonuje się w Cwale retroaktywnie.

Analogicznych przykładów podwójnego kodowania można doszukać się także w Dreszczach. Należąca już do klasyki polskiego kina „scena z portretem" ma charakter autoreferencyjny - tematyzuje problem filmowego spojrzenia. Jest zarazem na tyle pojemna semantycznie, że wymyka się jednoznacznym interpretacjom i powoduje u widza konfuzję. Komu bowiem należałoby przypisać spojrzenie odkrywające przed widzem „łzy” spływające po twarzy Marksa: Tomaszowi (ujęcie mieściłoby się wówczas w motywowanym realistycznie porządku diegezy - „łzy” to woda ściekająca po szkle) czy autorowi wewnętrznemu (w tym wypadku należałoby 
to ujęcie odczytywać wyłącznie na sposób symboliczny - jako pozadiegetyczny odautorski komentarz), a może obu tym instancjom jednocześnie?

Dublowanie perspektyw narracyjnych, łączenie partii subiektywnych (jak choćby tytułowych „dreszczy” z filmu Marczewskiego - odzwierciedlających podświadome lęki duchowo osieroconego dziecka) i obiektywnych, pozwoliło twórcom uniknąć ograniczającej możliwość artystycznej ekspresji formuły „dokumentu z tamtych lat". W analizowanych filmach dekonstrukcja wyobrażeń dotyczących historii dokonała się poprzez wzbogacenie kontekstu politycznego o znaczenia odwołujące się do archetypicznych wzorców kulturowych. Zamiast obrazów rozrachunkowych, mających zaspokoić społeczną potrzebę faktografii, powstały uniwersalne opowieści o rozpadzie dziecięcego (rajskiego?) świata. W tym świecie najboleśniej odczuwanym brakiem nie jest - zrozumiały u dziecka - brak świadomości politycznej, lecz brak figury Ojca, reprezentującej autorytet, miłość i bezpieczeństwo.

\section{Krzyżem [?] i strajkami wolność wywalczymy}

- Ty, tak wcale nie było.

- Ale tak mogło byćc11.

Poznań 56 wpisywany bywa zazwyczaj w scharakteryzowany w Pro$\log u$ nurt kina rozrachunkowego z dziecięcym bohaterem. Można także uznać, iż film stanowi przykład realizacji paradygmatycznych dla dekady lat 90. strategii, zmierzających do tego, by tradycyjne składniki polskiej tożsamości zbiorowej - religijność, nacjonalizm, antykomunizm, patriarchalną obyczajowość - zdeknostruuować, zdemontować i wyśmiać lub poddać horroryzacji ${ }^{12}$.

Po dokonaniu analizy artystycznego dorobku Bajona staje się oczywiste, iż temat filmu został przez reżysera gruntownie przemyślany. Bajon wspomina bowiem, iż już w 1973 r. zaczął pisać opowiadanie ${ }^{13}$,

11 Fragment rozmowy uczestników wydarzeń czerwcowych zasłyszanej w kinie „Wanda" po premierze filmu Bajona. Zob. Włodzimierz Braniecki, Szczun. Z Filipem Bajonem o Poznaniu, o jego wielkopolskiej trylogii filmowej rozmowy prawie o wszystkim, Wyd. „W drodze", Poznań 1998, s. 147.

12 Przemysław Czapliński, Polska do wymiany. Późna nowoczesność i nasze wielkie narracje, Wyd. W.A.B., Warszawa 2009, s. 22.

13 Reżyser ma na myśli opowiadanie Dobroczyńca, które na skutek ingerencji cenzury nie weszło do opublikowanego w 1975 r. zbioru Proszę za mna na górę. Warto zauważyć, iż Bajon nie był jedynym reżyserem zainteresowanym wydarzeniami Czerwca 1956 r. 
gdzie jest duży fragment poświęcony wypadkom poznańskim. Gdzie jest sytuacja dwóch braci, z których jeden był ubekiem, a drugi takim jeżyckim żulem. [...] Wypadki czerwcowe bardzo mocno we mnie siedziały i wiedziałem, że to jest rzecz, którą chciałbym kiedyś opisać. I w 1980 roku, jak już była "Solidarność", ja się do tego przygotowywałem. Zbierałem materiały. Wiedziałem, że trzeba o tym zrobić film. To wiedziałem. Bo w osiemdziesiątym byłby to inny film, on inaczej powinien wyglądać niż w $1996^{14}$.

W dziejach polskiej kinematografii Poznań 56 zajmuje - ze względu na oczekiwania towarzyszące realizacji filmu - miejsce szczególne. Jeśli przyjmiemy, iż jednym z podstawowych wyznaczników „filmu pamięci narodowej" jest to, że powstaje on z myślą o konkretnej publiczności (publiczności masowej, utożsamianej z „,całym narodem" ${ }^{15}$, a jego produkcja jest legitymizowana społeczną potrzeba, dzieło Bajona (z pozoru) doskonale mieści się $\mathrm{w}$ tej formule ${ }^{16}$.

Okoliczności powstania dzieła przybliża autorka monografii Bajona:

Poznań 56 powstał w 1996 roku na społeczne zamówienie, miał przypomnieć, uhonorować wydarzenia z 28 czerwca 1956 roku, pierwszego w dziejach powojennej Polski robotniczego buntu przeciw komunistycznej władzy. Zamówiony został przez Zarząd Regionu „Solidarność" w Poznaniu; by zdobyć pieniądze na jego realizację, utworzono nawet specjalną fundację. Jego premiera miała się odbyć w 40. rocznicę poznańskich wydarzeń, w kontekście Zjazdu NSZZ „Solidarność”, w obecności Lecha Wałęsy, solidarnościowego prezydenta. Choć scenariusz filmu był gotów rok wcześniej, zdjęcia do Poznania 56 rozpoczęto dopiero w maju 1996 roku, a w kraju urząd prezydenta sprawował już Aleksander Kwaśniewski. Bieg polityczno-społecznych wydarzeń rozminął się z wyjściową intencją ${ }^{17}$.

Tadeusz Lubelski wspomina o projektowanym w latach 70. obrazie Wielkie księstwo P., który mógł być pierwszym polskim filmem o Wypadkach Poznańskich. Obraz miał reżyserować Janusz Morgenstern. Do realizacji nigdy jednak nie doszło. Zob. Tadeusz Lubelski, Historia niebyła kina PRL, Znak, Kraków 2012, s. 15.

14 Włodzimierz Braniecki, Szczun, dz. cyt., s. 136. Jeśli - jak pisze Marcin Kula - wypowiadamy się o historii także poprzez milczenie (paradygmatycznym przykładem jest kłamstwo - "przemilczenie" - katyńskie jako fundament historiografii PRL), to, iż na film o Czerwcu musieliśmy czekać ponad 40 lat uznać można za znaczącą „wypowiedź” o naszych dziejach. Zob. Marcin Kula, Krótki raport o użytkowaniu historii, Wyd. Naukowe PWN, Warszawa 2004, s. 16.

15 Witold Mrozek, Film pamięci narodowej, [w:] Kino polskie jako kino narodowe, red. Tadeusz Lubelski, Maciej Stroiński, korporacja ha!art, Kraków 2009, s. 295.

16 Celowo używam tutaj określenia „formuła”, nie sądzę bowiem, aby na tym etapie refleksji nad polskim kinem narodowym można było mówić o wykształceniu się - przynajmniej na poziomie teoretycznym - gatunku „filmu pamięci narodowej”. Pragnę również wyraźnie podkreślić, iż formuły „film pamięci narodowej” nie stosuję w celu negatywnej oceny filmów (jak zdarza się to w dyskursach krytycznych poświęconych temu zjawisku).

17 Ewelina Nurczyńska-Fidelska, Czas i przesłona. O Filipie Bajonie i jego twórczości, Wyd. Rabid, Kraków 2003, s. 186. 
Dla interpretatora daleko istotniejszą kwestię stanowi innego rodzaju „rozminięcie” (Włodzimierz Braniecki - autor wywiadu-rzeki przeprowadzonego z Bajonem - posłużył się nawet określeniem: społeczny lincz ${ }^{18}$ ), którego świadectwa odnaleźć można w recenzjach towarzyszących pierwszym pokazom filmu. Dowodzą one, iż w społecznym przeświadczeniu zadanie artysty (nadal) polega nie tylko na nazwaniu minionych doświadczeń, lecz także (a może przede wszystkim) na uzgodnieniu opisu rzeczywistości z językiem społecznym - na powtórzeniu słów zbiorowego uniesienia ${ }^{19}$.

Recepcja dzieła Bajona nieuchronnie przywodzi na myśl dyskusję, która rozgorzała po premierze Kanału Andrzeja Wajdy - filmu, który podobnie jak Poznań $56^{20}$ nie zaspokoił dwóch fundamentalnych (zwłaszcza w odniesieniu do żyjących uczestników zdarzeń) potrzeb: faktografiii ${ }^{21}$ i konsolacji. Od Wajdy oczekiwano przede wszystkim alternatywnej narracji komemoracyjnej skierowanej przeciw narracji dominującej i tworzącej - wedle określenia Foucault - „przeciwpamięć" 22. Od Bajona - jednoznaczności ocen i kryteriów moralnych, których zastosowanie legitymizuje przekształcanie przeszłości w strukturę mityczną (z typowym dla owej struktury podziałem na "dobro" i „zło”).

Kanat i Poznań 56 traktowały o wydarzeniach tabuizowanych praktycznie przez cały okres funkcjonowania PRL. Pamięć o tych wydarzeniach była obszarem nieustannego konfliktu pomiędzy indywidualną pamięcią uczestników - jednostek i grup - o własnych przeżyciach i doświadczeniach a oficjalnie (nie)przekazywanymi obrazami przeszłości oraz oficjalnymi formami jej (nie)upamiętniania.

18 Braniecki, próbując odtworzyć atmosferę towarzyszącą powstawaniu Poznania 56, wspomina: „,...] jak już była realizacja tego filmu, to były straszne ataki na niego [współscenarzystę - Andrzeja Górnego]. Ciebie tak bowiem mijali, jakby bali się Ciebie atakować, a na niego, no, przecież chcieli go prawie społecznie zlinczować". Zob. Włodzimierz Braniecki, Szczun, dz. cyt., s. 124.

19 Zob. Przemysław Czapliński, Polska do wymiany, dz. cyt., s. 193. Autor w ten sposób scharakteryzował żądania formułowane w okresie pierwszej „Solidarności” pod adresem literatury.

20 Zestawienie Kanału z Poznaniem 56 prowokuje do zadania pytania o wpływ dzieła filmowego na kształtowanie się „wizji” przeszłości narodu. O ile bowiem - jak zauważa Tadeusz Lubelski - „istotne wątki narodowej historii minionych dwustu lat przyjęły kształt wyobrażeń powołanych do życia w jego [tj. Wajdy] filmach", o tyle wpływ filmu Bajona wydaje się w tym kontekście znikomy. Czy zadecydował o tym jedynie fakt, iż odnosząc się już bezpośrednio do zestawienia Kanał/Poznań 56 - Czerwiec nie był (jak Powstanie Warszawskie) wydarzeniem „mitycznym”, kształtującym tożsamość narodową Polaków? Zob. Tadeusz Lubelski, Wajda, Wyd. Dolnośląskie, Wrocław 2006, s. 6.

21 Zob. Władysław Bartoszewski, "Kanał”. Czy film o Powstaniu Warszawskim?, [w:] Pisma wybrane 1942-1957, t. I, Universitas, Kraków 2007 (pierwodruk: „Stolica” 1975, nr 23).

22 Elżbieta Hałas, Symbole i społeczeństwo. Szkice z socjologii interpretacyjnej, Wyd. Uniwersytetu Warszawskiego, Warszawa 2007, s. 69. 
W publicznej debacie pierwszej połowy lat 90. - w myśl tezy: „nie można opisać rzeczywistości bez wyraźnego jej oceniania" - upominano się (choć nie wszyscy z jednakowym uporem) o "odkłamanie" pamięci i zerwanie $z$ moralnym indyferentyzmem:

Amnezja czy może zakłamana pamięć jest faktem potwierdzanym przez badania opinii publicznej, wypowiedzi prasowe i dla losów nowego państwa oraz systemu demokratycznego faktem o znaczeniu podstawowym. Jak twierdzi wielu publicystów, historyków, księży, skutkiem czy po prostu korelatem niepamięci jest chaos w sferze etycznej. Nie będąc w stanie ocenić i zrozumieć działań i słów ludzi z przeszłości, brak nam też moralnych kategorii do oceny dzisiejszych czynów. Znijaczenie etyczne, relatywizacja zasad moralnych, psucie języka sięga od teraźniejszości do peerelowskiej przeszłości ${ }^{23}$.

W tym kontekście oczywista staje się konieczność wpisania filmu Bajona w dyskurs ówczesnej polityki pamięci. Ale czy Poznań 56 - kontrowersyjny głos $\mathrm{w}$ dyskusji o dziedzictwie PRL - okazał się w opinii walczących z etycznym znijaczeniem filmem par excellence rozliczeniowym? Jest to kwestia o tyle istotna, iż w 1991 r. Okręgowa Komisja Badania Zbrodni przeciwko Narodowi Polskiemu wszczęła śledztwo w sprawie Wypadków Poznańskich, ale do momentu premiery filmu w wyniku tego śledztwa nie zapadł żaden wyrok ${ }^{24}$.

Nieprzychylna recepcja Kanału i Poznania 56 zaświadcza o (względnej) autonomii pola produkcji kulturowej (z tego powodu Bourdieu nazwał je „uniwersum paradoksalnym”). Artysta działający w tym polu może bowiem zaoferować grupie odbiorców - do których dzieło potencjalnie było adresowane - „produkt” w pewnym stopniu niezależny od wartości wyznawanych przez te grupę ${ }^{25}$. Z drugiej jednak strony Kanał stanowi doskonałą ilustrację dokonującego się w polu produkcji kulturowej procesu kanonizacji. O uzyskaniu przez Kanat statusu "dzieła konsekrowanego" świadczy m.in. umieszczenie fotosów z tego filmu w Muzeum Powstania Warszawskiego (fakt ten stanowić może również odzwierciedlenie procesu przekształcania się wyobrażeń w fundamentalny dla badań historycznych „materiał źródłowy”). Z dystansu można uznać, iż to właśnie Kanał ukształtował ikonografię Powstania i po dziś dzień pozostaje - o czym pisałam we Wstępie - najważniejszym obrazem, z którego Polacy czerpią wiedzę o tym wydarzeniu. Nie sądzę jednak, aby podobną funkcję wobec Wydarzeń Poznańskich mógł spełnić w przyszłości Poznań 56.

23 Paweł Śpiewak, Pamięć po komunizmie, słowo/obraz terytoria, Gdańsk 2007, s. 174.

24 Śledztwo to - prowadzone przez IPN (Główną Komisję Ścigania Zbrodni przeciwko Narodowi Polskiemu) - trwa do dziś.

25 Zob. Pierre Bourdieu, Reguły sztuki, tłum. Andrzej Zawadzki, Universitas, Kraków 2001, s. 395-396. 
Przyczyn negatywnych reakcji, jakie wzbudził Kanał - a przecież także i Poznań 56 - doszukiwano się w sferze rozwiązań formalnych. Można zaryzykować tezę, iż kontrowersje budził nie tyle sam fakt dokonanej przez reżysera reinterpretacji historycznych wydarzeń, lecz „widoczność” (ujawnienie dyskursywnych szwów) owej reinterpretacji. W okresie realizacji Kanału funkcjom katartycznym (konsolacyjnym?) najskuteczniej służyły bowiem konwencje realistycznego opisu ${ }^{26}$ wojennej przeszłości (o czym świadczyć może popularność powieści Kolumbowie Romana Bratnego i filmowej „rekonstrukcji” zamachu na Kutscherę, dokonanej w Zamachu (1958) przez Jerzego Passendorfera):

nawet takie filmy jak Eroica oceniano z punktu widzenia wierności odzwierciedlenia prawdy historycznej. Była to z pewnością pomyłka, błędna kwalifikacja gatunku, niezrozumienie funkcji groteskowej deformacji rzeczywistości. Lecz myląc się powszechnie w odbiorze, publiczność wyrażała swoje racje, racje niebagatelne $[\ldots]^{27}$.

W przypadku Kanału nieprzychylne oceny można było usprawiedliwić faktem, iż Powstanie Warszawskie należało to tematów tabuizowanych w publicznym dyskursie, a film Wajdy był pierwszą artystyczną próbą ujęcia tych tragicznych (także w sensie konsekwentnego wymazywania ze społecznej pamięci) zdarzeń. W odniesieniu do filmu zrealizowanego w 1996 r. zarzuty o charakterze "faktograficznym” (przy jednoczesnym podkreślaniu wierności historycznej ${ }^{28}$ na poziomie rekonstrukcji

${ }^{26} \mathrm{Z}$ tego, być może, powodu znacznie lepiej niż film Bajona przyjęty został - utrzymany w formule teatru dokumentalnego - rocznicowy spektakl Oskarżony: Czerwiec 56, wyreżyserowany przez Izabellę Cywińską w poznańskim Teatrze Nowym (premiera: czerwiec 1981).

W sporze o realizm - na co zwracali uwagę piszący o polskiej kulturze powojennej mylące jest posługiwanie się czarno-białym schematem: „Warianty realistyczne sztuki (socrealizm, mały realizm) ukazywały rzeczywistość «zamówioną» przez państwo. Ale złośliwy duch dziejów sprawiał, że nawet wtedy, gdy artyści sięgali po groteskę, wspierali reżim. [...] kpiarze, demitologizujący polską kulturę, mimowiednie realizowali ten sam program kulturowy, co socjalistyczne władze, które mogły liczyć na zmniejszenie oporu ze strony społeczeństwa tylko w przypadku udanej krucjaty przeciw tradycji". Zob. Przemysław Czapliński, Polska do wymiany, dz. cyt., s. 112.

27 Andrzej Werner, Polskie, arcypolskie..., Wyd. Biblioteki „Więzi”, Warszawa 2011, s. 7980. W ocenach stanu kultury drugiej połowy lat 50. warto wziąć pod uwagę fakt, iż - jak podkreśla Werner - filmy Wajdy, Munka czy Hasa nie stały się ekranowymi bestsellerami (tamże, s. 78).

28 "Antykwaryczna” wierność - podkreśla Marek Hendrykowski - nie zapewnia jednak filmowi statusu dzieła sztuki. Zdaniem autora istnieje duże prawdopodobieństwo, iż publiczność kinowa odwróci się od tego typu „muzealnych" i „archeologicznych" przedstawień. Zob. Marek Hendrykowski, Film jako źródło historyczne, Wyd. Ars Nova, Poznań 2000, s. 77. 
scenograficznej ${ }^{29}$ ) wydają się już całkowicie bezpodstawne. Tadeusz Sobolewski na łamach „Gazety Wyborczej” zanotował: „Wychodząc z kina - wiemy o wypadkach poznańskich mniej niż wtedy, gdy szliśmy na film"30. W podobnym tonie wypowiadało się większość piszących o Poznaniu 56. Recenzja Piotra Machcewicza w „Polityce” ${ }^{31}$ nosiła znamienny tytuł: Historia nie ożyła, zaś Janusz Wróblewski w „Kinie” dał wyraz stricte subiektywnym emocjom towarzyszącym lekturze filmu:

Na ekranie robotnicy atakują budynek UB, zdobywają więzienie na Młyńskiej, niszczą zagłuszarkę Wolnej Europy, milicja strzela, giną ludzie, a ja patrzę na to wstrząsające widowisko zdziwionymi oczyma, zadając sobie pytanie, o co w tym wszystkim chodzi ${ }^{32}$.

Wedle Roberta Rosenstone'a kamera filmowa domaga się takiej ilości danych szczegółowych, która przekracza granice wiedzy dostępnej historykom. W związku z tym scenerię w filmie historycznym można określić mianem fikcjonalnego "substytutu”. Zob. Robert Rosenstone, "Walker". The Dramatic Film as (Postmodern) History, [w:] Revisioning History. Film and the Construction of a New Past, ed. Robert Rosenstone, Princeton University Press, Princeton 1995, s. 209.

29 W wielu obrazach historycznych - pisze Marc Ferro - to właśnie drobiazgowa troska o adekwatność szczegółów (wynikająca z przyjęcia perspektywy erudycyjnej i pozytywistycznej) odgrywa rolę wstydliwego okrycia, mającego zapewnić nieprzeniknioność sekretnej ideologii filmu, poddającej perwersyjnemu przekształceniu przeszłość, którą można by przedstawić inaczej. Zob. Marc Ferro, Film i historia, tłum. Tomasz Falkowski, Wyd. Naukowe PWN, Warszawa 2001, s. 238.

Teoretycy literatury - na co zwraca uwagę William Guynn - w nadmiarze szczegółów wypełniających narrację historyczną dostrzegają wymowny znak fikcjonalizacji, prowokujący do sceptycznego pytania: skąd to wiecie? Zob. William Guynn, Przekształcanie historii w filmie, tłum. Teresa Rutkowska, Karolina Kosińska, „Kwartalnik Filmowy” 2010, nr 69, s. 12. Obsesyjna wierność szczegółom nie stanowi gwarancji autentyzmu przedstawienia. Omawiając ten problem, Natalie Zemon Davis posłużyła się przykładem filmu Męczeństwo Joanny d'Arc (1928) Carla Theodora Dreyera. W tym filmie najpełniej wyraził się krytyczny stosunek Dreyera wobec praktyki multiplikowania "realistycznych detali" w kinie amerykańskim. Zob. Natalie Zemon Davis, "Any Resemblance to Persons Living or Dead": Film and the Challenge of Authenticity, "The Yale Review" 1987, vol. 76, issue 4, s. 467.

Zdaniem Hansa Ulricha Gumbrechta twórcy filmowi koncentrują się obecnie na środowisku historycznym, a nie na opowieści. W filmach w rodzaju Imienia róży czy Amadeusza manifestuje się skłonność do niezwykle drobiazgowej rekonstrukcji szczegółów historycznych. Stwarzanie widzowi złudzenia, iż znajduje się on wewnątrz środowiska historycznego okazuje się ważniejsze niż zainteresowanie go daną fabułą czy rozumowaniem. Zob. Hans Ulrich Gumbrecht, Gdy przestaliśmy uczyć się od historii, [w:] Pamięć, etyka i historia, red. Ewa Domańska, Wyd. Poznańskie, Poznań 2002, s. 198-199. Obsesyjna wierność szczegółom nie może być gwarancją autentyzmu.

30 Tadeusz Sobolewski, Wszystko osobno, "Gazeta Wyborcza” 1997, nr 12, s. 12.

31 Piotr Machcewicz, Historia nie ożyła, „Polityka” 1997, nr 6, s. 56.

32 Janusz Wróblewski, Krajobraz po bitwie, „Kino” 1997, nr 1, s. 21. 
Tymczasem - abstrahując nawet od zagadnienia, czy kino musi spełniać funkcje dydaktyczne, tj. uczyć „więcej” niż podręczniki historii - warto odnotować, iż bibliografia dotycząca Wydarzeń Poznańskich $\mathrm{w}$ roku premiery filmu składała się już z kilkunastu niezwykle rzetelnych opracowań o charakterze monograficznym ${ }^{33}$ (o ile uznamy, iż jakiekolwiek opracowania mogą być efektem „produkcji” wiedzy obiektywnej i weryfikowalnej). Dzięki temu Bajon nie musiał obawiać się zarzutu (formułowanego pod adresem Wajdy przy okazji Kanału), iż ukazana w filmie (zaledwie) połowa prawdy może wzmocnić nieprawdę drugiej połowy ${ }^{34}$. Przed Poznaniem 56 nie powstał natomiast żaden pełnometrażowy film fabularny poświęcony wydarzeniom Czerwca. Wobec braku ikonograficznej (filmowej) reprezentacji Czerwca impulsem dla reżysera mogło stać się hasło - by sparafrazować słynne wezwanie/wyzwanie Jacka Dukaja - Czerwiec 56 trzeba zrobic ${ }^{35}$ (jako fakt kulturowy).

Jeszcze bardziej absurdalne wydają się - zadawane przy okazji Poznania 56 - pytania o wiarygodność przekazu („płynny” charakter stosowanych kryteriów powoduje, że społeczną definicję "tego, co komu wolno" Bourdieu nazywa magicznym efektem konsekracji ${ }^{36}$ ) sformułowanego przez reżysera, który w Czerwcu '56 roku miał... zaledwie 9 lat („poznański rodowód” reżysera i jego wcześniejsze „wielkopolskie” filmy nie były, jak się okazało, przekonującym argumentem) ${ }^{37}$.

33 Czerwcowe wydarzenia doczekały się nawet „wersji pop”. W 2006 r. w wydawnictwie Zin Zin Press ukazał się komiks Poznański Czerwiec (scenariusz: Maciej Jasiński, Witold Tkaczyk, Wiktor Żwikiewicz, opracowanie graficzne: Jacek Michalski). Kolejnym krokiem powinna być „rodzinna gra planszowa”. W ofercie wydawnictwa Egmont skierowanej do dzieci znajduje się już przecież gra Mali Powstańcy, reklamowana na stronie wydawnictwa jako „lekcja historii w zupełnie nowej pomysłowej formie”, którą przygotowano we współpracy z Muzeum Powstania Warszawskiego. W zestawie świątecznym (grudzień 2012) obok Małych Powstańców można było znaleźć bonus w postaci gry Liberator, do której dołączono mini-figurkę samolotu (dla przypomnienia - w „katastrofie" samolotu typu liberator zginął gen. Władysław Sikorski).

34 Zob. Andrzej Werner, Polskie, arcypolskie..., dz. cyt., s. 82.

35 Odwołuję się do wywiadu opatrzonego tytułem: Stan wojenny trzeba zrobić, udzielonego w 2009 r. przez pisarza na łamach dodatku „Gazety Wyborczej” („Duży Format”)

36 Pierre Bourdieu, Reguty sztuki, dz. cyt., s. 399.

37 Ten wątek przewija się w polskiej refleksji krytycznej, o czym świadczy casus debiutu fabularnego Jana Jakuba Kolskiego. Kolski wspomina: „Po premierze filmu Pogrzeb kartofla któryś z krytyków oburzył się na to, że młody reżyser, Polak, zajmuje się sprawami, które go nie dotknęły (wojną i Żydami)". Zob. Jan Jakub Kolski, Piotrkowska i inne okolice kina, Wyd. Silesia Film, Katowice 1998, s. 5. Widać wyraźnie, iż w „polu (rodzimej) produkcji kulturowej” instancje „sakralizujące” prawo poszczególnych twórców do poruszania tematyki z obszaru najnowszej historii Polski odwołują się do kryteriów spoza tego pola (w tym wypadku byłoby to tzw. kryterium biograficzne). W przypadku Kolskiego (debiutującego w fabule) nie zadziałało także powszechnie stosowane kryterium, które - za Bourdieu - określę jako „fetysz nazwiska mistrza”. 
W krytycznych uwagach recenzentów odnaleźć można potwierdzenie, iż Bajon w sposób manifestacyjny zrezygnował w Poznaniu 56 z narracyjnej reintegracji przeszłości na rzecz walorów stricte estetycznych. Paradoksalnie jednak nagrodzie za zdjęcia, przyznanej filmowi na Festiwalu Polskich Filmów Fabularnych w Gdyni, nie towarzyszyła pogłębiona refleksja dotycząca możliwości spojrzenia na najbardziej traumatyczne wydarzenia z narodowej przeszłości właśnie jak na zjawiska estetyczne ${ }^{38}$. Tak oto dzieło ekranowe stało się w opinii krytyków świadectwem Benjaminowskiej tezy: „Historia rozpad(ł)a się na obrazy, nie na historie" ${ }^{39}$ (lub dowodem, iż we współczesnej kulturze obcujemy przede wszystkim z obrazami, a dopiero wtórnie niejako z opowiadanymi za ich pomocą historiami, zaś dzieło staje się obrazem swojej własnej, niosącej tekst, informacyjnej struktury i jej systemowych, nie zaś kontekstowych czy podtekstowych odniesien' ${ }^{40}$ ).

W tym ujęciu Poznań 56 stanowi zapis procesu wyzwalania się obrazu z porządku narracji. Potwierdzeniem tego faktu okazuje się doświadczenie odbiorcze (wszystko osobno), w którym film jawi się nie tyle jako sekwencje obrazów, ile obrazy sekwencji ${ }^{41}$.

Zdumienie budzi jednak fakt, iż „filmowej faktografii" oczekiwano po reżyserze, którego tuż po fabularnym debiucie zaliczono do „nurtu kreacyjnego" $^{\prime 42}$ kina moralnego niepokoju. Dostrzeżona już w Arii dla atlety

38 Por. Ani guzika, z Jarosławem Markiem Rymkiewiczem rozmawia Krzysztof Masłoń, „Rzeczpospolita” 2008, nr 233 (8134).

39 Bajonowi bliskie wydaje się „,antypozytywistyczne” stanowisko Benjamina, który atakował historystyczny sposób uprawiania nauki o dziejach, czyli podejście zmierzające do ustalenia ,jak było naprawdę", do uzyskania niezmiennego, obiektywnego obrazu faktów - niezależnego od punktu, z którego patrzy sam historyk. Zob. Adam Lipszyc, Sprawiedliwość na końcu języka. Czytanie Waltera Benjamina, Universitas, Kraków 2012, s. $495-550$.

Jednąze strategii antypozytywistycznych jest wprowadzenie do dyskursu historycznego dziecka jako „,agenta” historyka, załatwiającego za niego sprawy, których on sam-jako dorosły-załatwić nie potrafi. W refleksji Benjamina dzieckojestjednak „medium” pamięci mimowolnej, której przedmiotem może stać się tylko to, co nie zostało jawnie, świadomie „przeżyte”, co nie przytrafiło się podmiotowi jako „przeżycie”. Pamięć mimowolna („nocna") zostaje tym samym przeciwstawiona pamięci „dziennej” - ukierunkowanej, świadomej i celowej. Wydaje się, iż w filmie Bajona jesteśmy świadkami pracy pamięci "dziennej”, za pomocą której „dorosły szturmuje swoje wspomnienia” (tamże, s. 387).

40 Zob. Andrzej Gwóźdź, Obrazy i rzeczy. Film między mediami, Universitas, Kraków 2003, s. $41-42$.

41 Zob. Marianna Michałowska, Fragment - fetysz - fotografia, „Kwartalnik Filmowy” 2006, nr 56, s. 255-258.

42 Zasadność wyodrębnienia tego nurtu do dziś budzi zastrzeżenia. Zdaniem Andrzeja Wernera był to efekt manipulacji: „próba zantagonizowania środowiska, zwłaszcza przeciwstawienia «starszym» (politycznym, a więc nieartystycznym) młodszych kolegów. Wyodrębniono więc «nurt kreacjonistyczny» (czyli artystyczny właśnie), do które- 
predylekcja do zastępowania rekonstrukcji stylizacją rzeczywistości spektaklem, wierności realiom - estetycznymi upodobaniami ${ }^{43}$ stała się odtąd wyznacznikiem artystycznej postawy Bajona. Manifestuje się ona nie tylko w filmach, w których Historia stanowi ,jedynie" tło dla fikcyjnej fabuły $^{44}$, lecz także w dziełach, które w warstwie fabularnej odwołują się do konkretnych wydarzeń historycznych. Nie w każdym przypadku widzowie dali się „uwieść" wizjom reżysera, czego dowodzi chłodne przyjęcie Przedwiośnia, o którym Tadeusz Lubelski napisał: „Bajonowi nie zależało jednak na dialogu z odbiorca, tylko na popisywaniu się przed nim; taka jest natura jego uzdolnień" ${ }^{45}$.

Doskonałym przykładem filmowego kreacjonizmu jest Wizja lokalna 1901, w której Bajon - w sposób zapowiadający już Poznań 56 - postanowił zmierzyć się ze zmitologizowaną (,jednostronną") wersją narodowej historii. Zdaniem Eweliny Nurczyńskiej-Fidelskiej Wizja lokalna była

filmem trudnym, bo w jakiś przecież sposób stającym w opozycji wobec istniejącej $\mathrm{w}$ tradycji kulturowej pamięci o romantyczno-patriotycznym buncie młodych Polaków-uczniów, utrwalonym głównie przez Syzyfowe prace Stefana Żeromskiego czy, dla pewnego pokolenia, także przez film Młody las Józefa Lejtesa, zrealizowany na podstawie sztuki Jana Adolfa Hertza.

Ukazane i zinterpretowane przez Bajona zdarzenia we Wrześni 1901 roku nie mają z tamtą tradycją nic wspólnego, nie tylko dlatego, że zgodnie z prawdą historyczną przebiegały inaczej i w innej emocjonalnej atmosferze, również dlatego, że z woli scenarzysty i reżysera służyły refleksji przekraczającej dramatyzm samego wydarzenia ${ }^{46}$.

Porównanie Wizji lokalnej 1901 z późniejszym o szesnaście lat Poznaniem 56 pozwala dostrzec spójność artystycznej wizji Bajona. Dowodzi także ukrytego autotematyzmu jego dzieła. Jedna z początkowych sekwencji Poznania 56 rozgrywa się przecież w szkole. Bajon zadaje widzowi pytanie: Czy tak wiele się od czasów Wrześni zmieniło? Na bocznej ścianie wisi

go zaliczać się mieli wyrafinowani formalnie Marczewski, Bajon, Szulkin”. Zob. Andrzej Werner, Czarno-biała, biało-czerwona?, [w:] Sporne sprawy polskiej literatury współczesnej, red. Alina Brodzka, Lidia Burska, Instytut Badań Literackich PAN, Warszawa 1998, s. 15. Jakkolwiek pojęcie: „nurt kreacyjny” wydaje się dyskusyjne, wskazuje ono na twórców, którzy pod koniec lat 70. zaproponowali zupełnie inny - w stosunku do kina „rzeczywistości nieprzedstawionej" - model wypowiedzi filmowej.

43 Zob. Maria Kornatowska, Wodzireje i amatorzy, Wyd. Artystyczne i Filmowe, Warszawa 1990, s. 222.

44 W twórczości Bajona "fikcyjność” jest pojęciem wysoce umownym. Reżyser często korzysta bowiem z dokumentów i materiałów źródłowych, które stanowią podstawę dla filmowych fabuł (dla przykładu, inspiracją Arii dla atlety były losy polskiego zapaśnika z przełomu wieków Zbyszka Cyganiewicza, zaś burzliwe dzieje rodu Pszczyńskich (von Plessów) z Magnata to przetworzona historia rodziny von Teuss).

45 Tadeusz Lubelski, Historia niebyła kina PRL, dz. cyt., s. 153.

46 Ewelina Nurczyńska-Fidelska, Czas i przesłona, dz. cyt., s. 78. 
już, co prawda, portret Mickiewicza, lecz centralne miejsce - po dwóch stronach godła - zajmują Rokossowski i Cyrankiewicz. Uczniowie zgromadzeni w klasie nieoczekiwanie odmawiają zdjęcia tornistrów i zajęcia miejsca w ławkach. Poprzez takie wprowadzenie w filmową fabułę reżyser apeluje nie tylko do pamięci historycznej widza - trwające w milczącym uporze dzieci przypominają strajkujących rówieśników z Wrześni - lecz także do pamięci stricte filmowej. Scena w klasie ustanawia rodzaj „podwójnej” korespondencji - podkreśla ciągłość narodowych dziejów i ciągłość kultury, będącej tychże dziejów emanacją.

Bajon interpretuje historię w perspektywie „długiego trwania”. Symbolicznym łącznikiem pomiędzy przeszłością i teraźniejszością jest w filmie postać dziadka - byłego powstańca wielkopolskiego. Ta symboliczna postać pełni znaczącą funkcję pokoleniowego łącznika pomiędzy dwoma typami pamięci:

Jednocząca funkcja pamięci zbiorowej i jej symboli szczególnie wyraźnie przejawia się
w stosunkach międzypokoleniowych. Można bowiem wyróżnić ",pamięć krótką" i „pa-
mięć długą". Pierwsza organizuje się wokół wspólnego doświadczenia, związanego
z reguły z "dziejowym wydarzeniem”, jakie pewna klasa wieku przeżyła w okresie
swojej młodości, stając się tym samym właśnie pokoleniem. Druga pamięć powstaje
w wyniku działania mechanizmu społecznego, poprzez który przekazywane są wła-
ściwe pewnej określonej wspólnocie symbole, mity, rytuały itd., a który odnosi się do
odległej przeszłości, zwłaszcza do czasów "początku”, i na nowo tę przeszłość uak-
tualnia. Między tymi dwoma rodzajami pamięci można by chyba wyróżnić jeszcze
pamięć średniego trwania, powstającą w bezpośrednich kontaktach między dwoma
lub trzema kolejnymi pokoleniami, głównie dzięki przekazywaniu wspomnień ${ }^{47}$.

Na poziomie symbolicznym postać starego powstańca zaświadcza o nieustannej potrzebie sytuowania poszczególnych wydarzeń w jednym ciągu wspólnej tradycji, która łączy różne pokolenia i - poprzez odwoływanie się do "alfabetu" 48 wspólnoty - ułatwia ich porozumienie. Wspomnienia dziadka zaświadczają o tragizmie losu narodu: w $1918 \mathrm{r}$. państwo było pruskie i wojsko pruskie - w 1956 r. jesteśmy w ruskiej niewoli, ale do "powstańców” strzelają nasi. Niemożność pogodzenia się z tym faktem odzwierciedla postawa ciotki, która nazywa czołgistę - ubranego w polski mundur - Kacapem ${ }^{49}$. A przecież ten młody żołnierz, symboli-

47 Bronisław Baczko, Wyobrażenia społeczne. Szkice o nadziei i pamięci zbiorowej, tłum. Małgorzata Kowalska, Wyd. Naukowe PWN, Warszawa 1994, s. 234-235.

48 Pojęciem "alfabetu” jako praktyką komunikacyjną posługuje się Marcin Kula.

$49 \mathrm{~W}$ pierwszej fazie czerwcowego strajku demonstranci z sympatia, a niekiedy $\mathrm{z}$ entuzjazmem witali pojawienie się wojska na ulicach. Żołnierze - których obowiązywał bezwzględny zakaz użycia broni - bratali się z protestującymi, oddawali im karabiny i pozwalali na przejęcie czołgów. O godzinie 10.00 na posiedzeniu Biura Politycznego przyjęto wniosek I sekretarza KC PZPR Edwarda Ochaba o użycie Wojska Polskiego do 
zujący w oczach starej kobiety sowiecką władzę, też zginie z ręki „naszego" oficera.

Scena szkolna pełni w strukturze filmowego opowiadania istotną funkcję dramaturgiczną (awizuje przyszłe zdarzenia) i symboliczną (uwypukla szerszy - nieograniczający się jedynie do „klasy robotniczej” - zasięg protestu). A przede wszystkim dookreśla rolę, jaką w Poznańskim Czerwcu odegrały dzieci. Potwierdzenia tego faktu należy szukać wśród archiwalnych zdjęć (zwłaszcza na fotografiach Romańskiego „ożywionych" w filmie Bajona) i w relacjach historyków, którzy podkreślaja że wśród demonstrantów przeważali ludzie młodzi, byli wśród nich nawet chłopcy w wieku 12-15 lat ${ }^{50}$ (fot. 1).

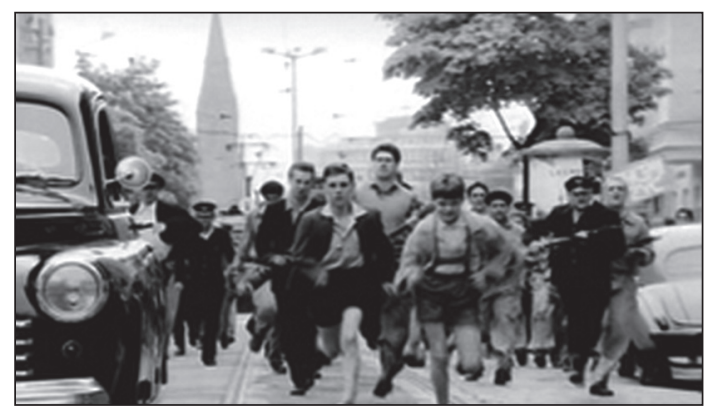

Fot. 1. Poznań 56 (1996, reż. Filip Bajon)

Główni „aktorzy” zdarzeń

Scena szkolnego strajku została sfunkcjonalizowana również w aspekcie psychologii postaci. W grupie zbuntowanych uczniów jedynie Darek - narrator filmowej opowieści - w zdecydowany i dość arogancki sposób (zwraca uwagę forma "ty”: Puszczaj. Puszczaj. No!) przeciwstawia się nauczycielce. Można także przyjąć, iż to właśnie Darek był inicjatorem szkolnego protestu. W krótkiej, ale niezwykle sugestywnej scence rozgrywającej się przed szkołą chłopiec wydaje ostatnie instrukcje spóźnionemu

spacyfikowania Poznania. Nowe oddziały wojska witały już okrzyki: „Przeciwko komu występujecie, to robotnicy obalają władzę. Jesteście Polakami, nie mordujcie naszych synów i ojców. Nie strzelajcie do braci". Apele kierowane pod adresem żołnierzy, by przeszli na stronę demonstrantów, nie poskutkowały. Sympatia tłumu przerodziła się w nienawiść. Pisze Makowski: „Gdy po godz. 13 przybyły w region WUBP czołgi, które ziały ogniem, wywołały u wielu demonstrantów szok. Żołnierz polski nie strzela do Polaków, do polskich kobiet i dzieci - to rosyjscy żołnierze w polskich mundurach! [...] Przekonanie, że to byli Rosjanie, łagodziło bolesne zderzenie stereotypu z rzeczywistością. Fakt, że polski żołnierz strzela do Polaków wywoływał u niektórych demonstrantów akty rozpaczy". Zob. Edmund Makowski, Poznański Czerwiec 1956. Pierwszy bunt społeczeństwa PRL, Wyd. Poznańskie, Poznań 2006, s. 121, 163.

50 Tamże, s. 105. 
- i wyraźnie wahającemu się - Piotrkowi. Bajon podkreśla tym samym specyficzne cechy charakteru Darka, które w przyszłości uczynią z niego „rewolucjonistę". A jednocześnie sugeruje, iż wchodzący w wiek dojrzewania chłopiec uznawać będzie wyłącznie autorytet mężczyzny.

Dla filmowej opowieści o Wydarzeniach Poznańskich Bajon planował tytuł Szczuny. "Szczun” to pojęcie idiomatyczne, nieprzetłumaczalne, zrozumiałe wyłącznie dla mieszkańców Wielkopolski. Użyte w tytule podkreśla - już na poziomie języka - „lokalność” autorskiej perspektywy. Wybór tytułu miał jednak znacznie poważniejsze konsekwencje znaczeniotwórcze. Dookreślał stosunek Bajona wobec kulturowego kanonu kształtującego społeczne oczekiwania. Tytuł filmu należy czytać jako „trop retoryczny” pozwalający na przełamanie dystansu, jaki stwarza przeszłość, przedstawiana na ogół w polskiej narracji historiograficznej w sposób koturnowy ${ }^{51}$. Szczuny miały być (bo ostatecznie film wszedł na ekrany pod innym tytułem) świadectwem niezwykłej odwagi reżysera, który - mając zapewne w pamięci artystyczną porażkę obrazu Śmierć jak kromka chleba (1994) Kazimierza Kutza ${ }^{52}$ oraz świadomość towarzyszącego realizacji filmu „na zamówienie społeczne” ryzyka popadnięcia w martyrologiczną i bogoojczyźnianą celebrę $e^{53}-\mathrm{w}$ ramach obchodów czterdziestej rocznicy Poznańskiego Czerwca chciał zejść z pomnika, najkrócej mówiąc... ${ }^{54}$

Odwołując się do koncepcji Jerzego Szackiego, można uznać, iż celem „antybrązowniczej” strategii Bajona było nie tyle „narzucenie świadomości grupowej innego mitu, zmiana tradycji czy też przekształcenie jej $\mathrm{w}$ antytradycję"55, lecz „ujawnienie jednostronnego charakteru wszelkich

51 Jerzy Topolski, Jak się pisze i rozumie historię. Tajemnice narracji historycznej, Oficyna Wyd. Rytm, Warszawa 1996, s. 108.

52 Można zaryzykować tezę, iż Poznań 56 stanowił bezpośrednią reakcję na film Kutza. Sporadycznie podejmowany w refleksji historyczno-filmowej wątek wzajemnych uwarunkowań filmów powstających w tym samym okresie i kontekście społeczno-politycznym wydaje mi się szczególnie inspirujący. Podobny mechanizm (sprzężenie zwrotne) odkrywam, konfrontując filmy-,,rekonstrukcje” historyczne: Generała (2009) Anny Jadowskiej (któremu poświęcam kolejny rozdział) z filmem Czarny czwartek (2011) Antoniego Krauzego.

53 Dla porównania warto prześledzić, jak wiele czasu ekranowego zajmują w filmie Kutza sceny odzwierciedlające wpływ religii na świadomość górników podejmujących decyzję o strajku. Wydaje się, iż to właśnie udział w zbiorowych nabożeństwach kształtuje jednolitą tożsamość grupy i obdarza ją konieczną do strajku siłą. W wypowiedziach towarzyszących premierze filmu reżyser zwracał szczególna uwagę na tak silnie eksponowany w Śmierci... motyw "poszukiwania energii moralnej w religii”.

54 Włodzimierz Braniecki, Sczczun, dz. cyt., s. 145.

55 Ten aspekt jest oczywiście w filmie (jak i w wypowiedziach Bajona dotyczących genezy Poznania 56) wyraźnie obecny. Antytradycją byłaby tradycja „martyrologiczno-ofiarnicza”, której - w ujęciu reżysera - reprezentatywnym przykładem jest Śmierć jak kromka 
wzorców, słowem, demonstrowanie wieloznaczności historii" ${ }^{56}$. A zatem demitologizacja. Wedle Roberta Traby to właśnie

jednostronne budowanie tożsamości grupowej rodzi w naturalny sposób formację (czasami całą generację) „odbrązawiaczy”. Zdejmowanie z piedestału postaci i wydarzeń ważnych, ale jednocześnie jednostronnie mitologizowanych nie jest ucieczką od wspólnoty, ale raczej odwrotnym zjawiskiem tego samego procesu: konstruowania demokratycznej pamięci narodu/społeczeństwa, tyle że bez patetycznej sakralizacji własnej historiii ${ }^{57}$.

Przyjęta w filmie strategia „antybrązownicza” miała przeciwdziałać temu, by Czerwiec stał się $\mathrm{w}$ pamięci zbiorowej wydarzeniem zmitologizowanym. Każdy bowiem kryzys „rewolucyjny” - jak pisze Bronisław Baczko - jest

"gorącym okresem" w historii tworzenia wyobrażeń społecznych. Zaistnienie rewolucji nadaje wyobraźni społecznej szczególny rozmach. Sama dynamika rewolucji, wstrząs struktur politycznych i społecznych, ale także nowe sposoby myślenia i wartościowania, nowa zasada prawomocności władzy, konflikty polityczne i społeczne odznaczające się obecnością mas, a zwłaszcza rewolucyjnego tłumu - wszystkie te czynniki pobudzają przyspieszoną produkcję znaczeń, jakie próbuje się nadać umykającym wydarzeniom, których skutki nieraz zaskakują politycznych i społecznych aktorów ${ }^{58}$.

Zastosowanej przez Bajona strategii odbrązawiania historii (w jej „łagodniejszym” wariancie) odpowiadała subiektywna (w podwójnym znaczeniu: subiektywizmu autora wewnętrznego i subiektywizmu bohatera-narratora) optyka prezentacji zdarzeń. Podskórnym nurtem podminowującym (rozsadzającym) główny dyskurs historyczny jest autobiografizm, wzmocniony ujawnieniem „społecznego tekstu biografii” twórców (Filipa Bajona i Andrzeja Górnego). Bajon opowiada o Wielkiej Historii

chleba Kazimierza Kutza. Zestawienie Poznania 56 z filmem Kutza potwierdza tezę Pierre'a Bourdieu dotyczącą pola produkcji kulturowej: „Proces, w którym zanurzone są dzieła, jest wytworem walki pomiędzy tymi, którzy zajmują (czasowo) dominującą pozycję w tym polu (dzięki swemu kapitałowi specyficznemu) i z tej przyczyny ciążą ku zachowawczości, czyli [...] jednym słowem - utrwalonego porządku symbolicznego, a tymi, którzy skłaniają się do heretyckiego zerwania, do krytyki utrwalonych form, do podważania obowiązujących modeli [...]". Zob. Pierre Bourdieu, Reguły sztuki, dz. cyt., s. 317.

56 Jerzy Szacki, Tradycja, Wyd. Uniwersytetu Warszawskiego, Warszawa 2001, s. 247.

57 Robert Traba, Historia - przestrzeń dialogu, Instytut Studiów Politycznych PAN, Warszawa 2006, s. 63-64.

58 Bronisław Baczko, Wyobrażenia społeczne, dz. cyt., s. 54. 
z perspektywy królestwa dzieci - podwórka ${ }^{59}$. Taka perspektywa odzwierciedla dystans między wydarzeniami a świadomością obserwatora, który jest aktorem i świadkiem tych wydarzeń, lecz w momencie, gdy je przeżywa, nie wie jeszcze, w jakim stopniu będą one Historią ${ }^{60}$.

U Bajona - odmiennie niż w Niedzielnych igraszkach - podwórkową społecznością nie rządzi polityka, lecz stylistyka plotkarstwa dziecięcego: „Co się stało, z kim się stało, czy będzie lekcja religii w szkole?" ${ }^{11}$ Reżyser precyzuje:

Najpierw trzeba sobie powiedzieć, że jestem dzieckiem podwórka. To, co widać w Poznaniu 56. Akcja rozgrywa się na tych podwórkach, które ja znam. To znaczy wiem, jak je fotografować, wiem, jak biegnie klatka schodowa, którędy można było przeskoczyć, żeby skrócić sobie drogę, co było widać przez okno, co widać z bramy, gdzie się można było schować, jak oszukać dozorcę. To był nasz mikroświat ${ }^{62}$.

[W Poznaniu 56] wracałem ze swoim tematem, ze swoim światem, który przykładałem jak kliszę do tego, co widziałem. Do tego, co pamiętałem. To było ciekawe. [...] Pisząc scenariusz, pisałem go pod pewne miejsca. I szukałem identycznych pod te klatki schodowe, pod te przejścia, pod te schody idące nad bramą ${ }^{63}$.

[Czerwiec 56] To było nagłe poczucie, że na podwórko weszła historia, że jesteśmy kimś ważnym ${ }^{64}$.

To właśnie na podwórku usłyszy Darek charakterystyczne „stukanie" Singera, które w świadomości dziecka (i widza) musi wywołać nieuchronne skojarzenia z krótkimi urywanymi seriami karabinu maszynowego. Akustycznie wzmocniony odgłos maszyny do szycia (dźwięk odbija się od ścian kamienic w wąskim gardle podwórka) awizuje mo-

59 Spojrzenie (choć nie w pełni konsekwentne) na Wydarzenia Czerwcowe z perspektywy dziecka (przy jednoczesnej eliminacji „spojrzenia inteligenckiego") wynikać mogło z obawy przed kolejną pułapką - pułapką "marksistowskiego dyskursu rewolucyjnego" (przypomnijmy casus filmu Wajdy Człowiek z marmuru, który określono mianem socrealizmu á rebours). Marksizm - zdaniem Ewy Domańskiej - stanowi klasyczny model „teorii lokalizacji", oferując spojrzenie na historię z punktu widzenia proletariatu. W dyskursie marksistowskim punkt wyjścia stanowi założenie, że „uciskani wiedzą lepiej”, tzn. że pozycja marginalizowanych i uciskanych (w wypadku Czerwca: uciskanych przez władzę ludową) grup społecznych jest pozycją uprzywilejowaną w tworzeniu wiedzy. Zob. Ewa Domańska, Historie niekonwencjonalne, Wyd. Poznańskie, Poznań 2010, s. 75.

60 Maria Delaperriére, Pod znakiem antynomii. Studia $i$ szkice o polskiej literaturze XX wieku, Universitas, Kraków 2006, s. 116. Powyższy cytat odnosi się do powieści Hanemann Stefana Chwina, opublikowanej w 1995 r. Autorka pisze dalej: „W Hanemannie exodus niemiecki 1945 roku utrwala się w oczach dziecka. Istnieje więc narrator-świadek, ale świadek-dziecko niezdolne do pełnej oceny tego, co widzi". Nie stawiam, oczywiście, tezy o bezpośrednim wpływie utworu Chwina na formę filmowej opowieści o Czerwcu '56, lecz pragnę wskazać na pewną wyraźnie zaznaczającą się we współczesnej kulturze tendencję do "prywatyzacji pamięci”.

61 Włodzimierz Braniecki, Szczun, dz. cyt., s. 13.

62 Tamże, s. 9.

63 Tamże, s. 115.

64 Tamże, s. 13. 
ment, w którym na podwórko wejdzie historia, burząc rajski porządek dziecięcego świata. Te same dźwięki jak z pepeszy powrócą w idyllicznej scenie „ogródkowej" zapowiadającej - w warstwie akustycznej - kluczową sekwencję wiecu przed Zamkiem.

Poznań 56 rozpoczyna się od prologu - serii poklatkowych zdjęć-portretów. Prezentacji osób dramatu towarzyszy monolog z off-u:

To jestem ja. Tak wtedy wygladałem. To mój ojciec. Był oficerem Urzędu Bezpieczeństwa. Nie wiem, jak się wtedy zachowat. Nie mówił mi. To Piotrek. Mój kolega z klasy. Tego dnia zaprzyjaźnit się ze mna. Nie lubił mnie przedtem. To ojciec Piotrka. Byt przywódca strajku. Nigdy się potem z nim nie spotkatem. To Zenek. On wiedziat, o co chodzi. Nie miał nigdy watpliwości.

Przed omówieniem konstrukcji prologu wypada poczynić jeszcze jedno istotne zastrzeżenie. Zarówno prolog, jak i epilog nie pełnią w Poznaniu 56 funkcji typowej dla "rewolucyjnej” narracji historycznej. Jedną $\mathrm{z}$ typowych strategii narracyjnych, za pomocą których $\mathrm{w}$ historiografii XIX i XX w. artykułowano „mit rewolucji” było bowiem „nagromadzenie negatywnie ocenianych faktów w czasach przed rewolucją oraz takie samo nagromadzenie faktów ocenianych pozytywnie (lub przemilczanie czy pomniejszanie negatywnych skutków) w czasach po rewolucji"65. W filmowej opowieści o Czerwcu uderzający jest nie tylko brak jednoznacznej - wyróżniającej „narrację mityczną” - interpretacji zdarzeń, lecz brak wspomnianego przed i po.

Prolog zawsze jest obszarem nacechowanym semantycznie. Konstrukcja prologu Poznania 56 ujawnia prymarną funkcję „pamięci jako sposobu bycia opowiadania” ${ }^{66}$. A zatem historia „zmediatyzowana" - ukazywana poprzez filtr jednostkowej pamięci - to zasadniczy temat filmu, temat już na wstępie wyraźnie sformułowany i niejako narzucony odbiorcy. Stanowiący zarazem formę alibi usprawiedliwiającego a priori „nadwyżkę fik$\mathrm{cji}^{\prime \prime 67}$ oraz nadmiar pojawiających się w narracji luk i niekoherencji ${ }^{68}$. Bo jakże mogło być inaczej, skoro po to, by

65 Zob. Jerzy Topolski, Jak się pisze i rozumie historię, dz. cyt., s. 221.

66 Gilles Deleuze, Kino, tłum. Janusz Margański, słowo/obraz terytoria, Gdańsk 2008, s. 277.

67 Wedle słów Halbwachsa we wspomnieniu z dzieciństwa „to nie dziecko siebie przeżywa, to dorosły odtwarza w sobie i wokół siebie cały zagubiony świat i wprowadza w ten obraz więcej fikcji niż prawdy". Zob. Maurice Halbwachs, Społeczne ramy pamięci, tłum. Marcin Król, PWN, Warszawa 1969, s. 145.

68 Choć są one za pomocą mechanizmów pamięciowych skutecznie maskowane. Zdaniem psychologów pamięć rejestruje pojedyncze zdarzenia w sposób uporządkowany semantycznie. Jednostka, uzyskawszy dostęp do fragmentarycznych danych, szuka sposobów ich porządkowania, a następnie tworzy spójną narrację, która nie musi być odzwierciedleniem rzeczywistego przebiegu zdarzeń. Zob. Barbara Szacka, Pamięć zbiorowa, [w:] Wobec przeszłości. Pamięć przeszłości jako element kultury współczesnej, red. Andrzej Szpociński, Wyd. Instytutu im. Adama Mickiewicza, Warszawa 2005, s. 26. 
przenieść się całkowicie w dawny stan ducha, trzeba by przywołać jednocześnie, i to bez wyjątku, wszystkie wpływy, które na nas wówczas działały, zarówno od wewnątrz, jak i z zewnątrz; to tak, jakbyśmy chcieli po to, by restytuować w całej jego realności jakieś wydarzenie historyczne, wyciągnąć z grobu tych wszystkich, którzy brali w nim udział jako aktorzy i jako świadkowie ${ }^{69}$.

Funkcja prologu jest jednak dalece bardziej skomplikowana, w czym manifestuje się - już na wstępie - niejednoznaczność sensów generowanych przez filmową opowieść o Czerwcu. Osobista narracja - pisze Domańska - przeplatana fragmentami narracji historycznej staje się krytyką oficjalnej historii produkowanej przez dominującą władzę $e^{70}$. Bajon - realizując ",antybrązowniczą" strategię - wybiera formułę spersonalizowanego (narracja prowadzona jest wszakże z perspektywy konkretnej jednostki - bezpośredniego uczestnika zdarzeń) świadectwa, które Ricoeur nazywa „podstawową strukturą pośredniczącą między pamięcią i historią"71. W aspekcie dokumentu świadectwo to jednak niejednoznaczne, obdarzone przez reżysera ambiwalentnym statusem, uchwycone w momencie zapisywalności. To świadectwo "mówione”, a zarazem "tekst pamięci” utrwalony na filmowej taśmie ${ }^{72}$.

Wybór świadectwa ma ściśle określone konsekwencje formalne (wszystko osobno to także wskazanie na niezdolność świadectwa do ujęcia całościowego, konkluzywnego, przejrzystego, teoretycznego samych wydarzeń; akcentowanie jego niezdolności do zamykania się w zreifiko-

69 Tamże, s. 137. Jacques Le Goff zwraca uwagę na źródłosłów słowa „historia”. Starogreckie istor oznacza „,́́wiadka” w znaczeniu „podglądacza” (czyli „,́́wiadka naocznego”): „Koncepcja wzroku jako głównego źródła poznania prowadzi do idei, że istor, «ten, który widzi», jest również «tym, który wie» [...]”. Zob. Jacques Le Goff, Historia i pamieć, tłum. Anna Gronowska, Joanna Stryjczyk, Wyd. Uniwersytetu Warszawskiego, Warszawa 2007, s. 158. Pytanie o status świadka musi być jednocześnie pytaniem o status owej wiedzy (w znaczeniu jej roszczenia do obiektywizmu).

70 Ewa Domańska, Historie niekonwencjonalne, dz. cyt., s. 71. Takie ujęcie pojawia się m.in. u Pierre'a Nory, który przeciwstawia pamięć znajdującej się w rękach władzy historii. „Nora - pisze Domańska - stawia po jednej stronie «naukową» prawdę historii, po drugiej prawdę przeżycia i wspomnienia; historia jest domeną zbiorowości, pamięć - prywatności; historia jest jedna, pamięć - mnoga; pamięć jest żywa i ewoluuje, historia jest niekompletną rekonstrukcją tego, czego już nie ma; pamięć jest zjawiskiem teraźniejszości; historia jest reprezentacją przeszłości" (tamże, s. 223).

71 Paul Ricoeur, Pamięć, historia, zapomnienie, tłum. Janusz Margański, Universitas, Kraków 2006, s. 36.

72 Ricoeur podkreśla, iż świadectwo staje się „dowodem dokumentalnym” w momencie zapisywalności. Wedle filozofa „ustne świadectwa stają się dokumentami dopiero wtedy, gdy zostaną utrwalone. Wówczas zostawiają przestrzeń oralną i wchodzą w przestrzeń pisma [...]. Możemy wtedy powiedzieć, że pamięć jest zarchiwizowana, zdokumentalizowana" (tamże, s. 237). 
wanych znaczeniach i jednocześnie zdolności do ich rozrywania $\left.{ }^{73}\right)$, epistemologiczne (świadectwo jako „dowód z doświadczenia”) ${ }^{74} \mathrm{i}$ - by tak rzec - etyczne ${ }^{75}$. Wydarzenie świadectwa umożliwia „zmartwychwstanie przeszłości". Odbiorcy zasugerowana zostaje - nigdy w pełni nie zrealizowana $^{76}$ - możliwość bezpośredniej konfrontacji z doświadczeniami osoby ${ }^{77}$ dającej świadectwo:

73 Taką charakterystykę świadectwa znaleźć można u Shosany Felman. Zob. Dorota Wolska, Odzyskać doświadczenie. Sporny temat humanistyki wspótczesnej, Universitas, Kraków 2012, s. 189-190.

74 Zdaniem Dominicka LaCapry świadectwo i historia - choć mają wiele cech wspólnych na poziomie narracji - to różnią się zasadniczo w odniesieniu do „twierdzeń prawdziwościowych i sposobu, w jaki ujmują one w ramy daną relację. Świadectwo formułuje twierdzenia prawdziwościowe dotyczące doświadczenia albo przynajmniej pamięci tego doświadczenia i - nieco subtelniej - wydarzeń [...]. Najtrudniejsze i najbardziej poruszające momenty świadectwa zawierają jednak nie tyle twierdzenia prawdziwościowe, ile «dowody» z doświadczenia - widoczne ponowne przeżywanie przeszłości przez świadka [...]. Historia formułuje twierdzenia prawdziwościowe dotyczące wydarzeń, ich interpretacji czy wyjaśnienia i - nieco subtelniej" - doświadczenia. Dominuje ona nad świadectwem i krytycznie testuje pamięć, nie utożsamiając się z nimi". Zob. Dominick LaCapra, Historia w okresie przejściowym. Doświadczenie, tożsamość, teoria krytyczna, tłum. Katarzyna Bojarska, Universitas, Kraków 2009, s. 170-171.

75 Etyczny wymiar świadectwa jest bardzo silnie akcentowany w filozofii Paula Ricoeura. Andrzej Zawadzki pisze: „Hermeneutyka Ricoeura otwiera drogę wyjścia z tego kregu [tj. z kręgu „śladów”], «odzyskując» rzeczywistość nie za pomocą korespondencyjnej, czy też manifestacyjnej koncepcji prawdy, lecz na drodze poświadczenia: «ja» świadka zaświadcza i potwierdza całym swym istnieniem, że coś się zdarzyło, a opowieść o tym nie jest tylko autoreferencjalną narracją, lecz do czegoś poza sobą się odnosi. «Epistemologia» świadectwa ma więc strukturę etyczną: prawdy się nie stwierdza ani nie udowadnia, lecz się za nią - i jej - odpowiada". Zob. Andrzej Zawadzki, Hermeneutyka śladu $i$ hermeneutyka świadectwa, [w:] Nowoczesność jako doświadczenie, red. Ryszard Nycz, Anna Zeidler-Janiszewska, Universitas, Kraków 2002, s. 340.

Potwierdzeniem uprzywilejowanej funkcji (audiowizualnego) świadectwa we współczesnej kulturze (nie tylko historycznej) może być fundamentalny - zwłaszcza w kontekście filozofii długu Ricoeura - akt powołania (w 1994 r.) „Survivors of the Shoah Visual History Foundation", gromadzącej relacje ostatnich żyjących świadków Zagłady.

76 „Świadectwo bowiem - podkreśla Zawadzki - cechuje się istotna, charakterystyczną podwójnościa, która nadaje mu dynamikę i jednocześnie decyduje o specyfice procesu jego rozumienia i interpretacji. Polega ona na nieustannym, nieusuwalnym napięciu w samej strukturze świadectwa, zachodzącym pomiędzy jego dwoma wymiarami: pomiędzy doświadczeniem wewnętrznym, bezpośrednim, niezapośredniczonym a jego zewnętrznymi przejawami; pomiędzy aktem wiary, wyznania, potwierdzenia a historycznymi znakami, działaniami, narracjami, które go uwierzytelniają i ukonkretniają. Świadectwo pełni więc rolę pośrednia, jest przekładem wymiaru pierwszego na wymiar drugi, przejściem z planu tego, co zobaczone, na plan tego, co powiedziane i opowiedziane" (tamże, s. 337).

77 W przypadku świadectwa traktowanego jako tradycyjny gatunek pisarstwa osobistego podkreślano, iż - jak pisze Małgorzata Czermińska - ma ono „charakter typowo epicki: narrator opowiada czytelnikowi o znanym sobie świecie, ludziach i zdarzeniach, przy czym w centrum tekstu znajduje się to, co przedstawione, natomiast zarówno narrator, 
Język świadectwa wykracza więc poza ograniczenia języka narracji, jakim zazwyczaj posługuje się historyk, języka, w którym bezosobowy, intersubiektywny głos zwraca się do równie bezosobowej i intersubiektywnej publiczności. [...] Świadectwo bowiem jest adresowane do nas jako indywidualnych, moralnych istot ludzkich, co skutecznie uniemożliwia nam chowanie się za moralnie neutralnym parawanem obiektywizmu historycznego ${ }^{78}$.

W aspekcie „świadectwa” film Bajona byłby dowodem - diagnozowanego współcześnie w dyskursie historycznym - zerwania z opozycyjnym traktowaniem pamięci i historii ${ }^{79}$. W badaniach nad wydarzeniami

jak odbiorca sytuują się gdzieś w tle. [...] Z czasem to złudzenie bezstronności świadectwa stopniało i rozwijająca się autorefleksja warsztatowa [...] wydobyła z ukrycia nieuchronną obecność JA [...]". Zob. Małgorzata Czermińska, Autobiograficzny trójkat. Świadectwo, wyznanie i wyzwanie, Universitas, Kraków 2000, s. 21-29.

78 Frank Ankersmit, Narracja, reprezentacja, doświadczenie. Studia z teorii historiografii, tłum. zbiorowe, Universitas, Kraków 2004, s. 385-386. Wydarzenie świadectwa zyskuje bezwzględny prymat nad aktem upamiętniania: „podczas gdy świadectwo znosi bariery między nami a przeszłą rzeczywistością, upamiętnianie przynosi skutek odwrotny, gdyż jego istotą jest gloryfikacja wydarzeń sprzed pięćdziesięciu, stu czy dwustu lat. Upamiętnianie ma swe źródło w barierze czasowej, celowo umieszcza przeszłość w odległości kilku dziesięcioleci czy stuleci i tym samym osłabia dramatyzm nawet najbardziej dramatycznych wydarzeń. Przeszłość jest tu naprawdę «przeszła». Ponadto świadectwo jest samą treścią doświadczenia, natomiast upamiętnianie ma charakter rytualny i radośnie celebruje formalność swych obrzędów. Świadectwo to treść, upamiętnianie to forma" (tamże, s. 388).

79 Wedle Ewy Domańskiej opozycyjne traktowanie ( $\mathrm{m}$ in. w tekstach wspomnianego Pierre'a Nory) historii i pamięci (nazywanej niekiedy - za Foucault - „przeciw-historią" lub - za Nora - „dyskursem ludzi bez historii” lub „historią tych, którzy nie mieli prawa do Historii") to efekt przyznania historii statusu stabilizatora porządku społecznego i legitymizatora władzy (zgodnie z tezą Foucault: „Historia jest dyskursem władzy”). Krytyka historii jako dyscypliny produkującej obowiązującą wiedzę o przeszłości była efektem procesów demokratyzacji („emancypacja grup mniejszościowych i afirmacja tożsamości indywidualnej i zbiorowej, która dotychczas określana była przez dominujące systemy władzy”) i dekolonizacji (,wewnętrznej” - wyzwalania się mniejszości etnicznych, religijnych, seksualnych oraz „ideologicznej” - wyzwalania się krajów spod jarzma systemów totalitarnych) historii. Domańska podsumowuje: „Podczas gdy historię określano jako instrument nacisku i identyfikowano z państwem, imperializmem, scjentyzmem i antropocentryzmem, pamięć kojarzono ze sfragmentaryzowaną i hybrydyczną kulturą ery globalizacji, dyskursem insurekcyjnym i rewindykacyjnym, tzw. «miękką wiedzą» i taktowano jako terapię [stąd wzmożone zainteresowanie problemami sytuującymi się na marginesie konwencjonalnych badań historycznych: doświadczeniami granicznymi, trauma, żałobą itp.] i sposób na udzielenie głosu tym, których historia go pozbawiła". Ponieważ pamięć poddała się procesom ideologizacji i okazała się tak samo dyspozycyjna, jak krytykowana przez nią historia (vide tzw. polityka pamięci), badaczka proponuje, by jako opozycyjne traktować pojęcia ",historia tradycyjna” $\mathrm{i}$ „historia niekonwencjonalna”. Tę ostatnią Domańska definiuje - za pomocą kategorii wprowadzonej przez Julię Kristevą - jako abiekt historii tradycyjnej i podkreśla jej terapeutyczny potencjał. Zob. Ewa Domańska, Historie niekonwencjonalne, dz. cyt., s. 15-25. 
z przeszłości (zwłaszcza o charakterze traumatycznym) została „dowartościowana" kategoria bezpośredniego świadka historii. W konsekwencji prowadzi to do „otwarcia się na wartość źródeł dotychczas darzonych nieufnością: bezpośrednich świadectw ustnych uczestników zdarzeń" ${ }^{80}$.

Umieszczony zaś w kontekście „lokalnym” Poznań 56 stanowiłby potwierdzenie fundamentalnego - zdaniem wielu badaczy - dla polskiej kultury po 1989 r. (choć zaznaczającego się już wcześniej ${ }^{81}$ zjawiska „prywatyzacji pamięci”. Jednym z ważnych aspektów tego zjawiska jest postrzeganie przeszłości przez pryzmat jednostki, która nie musi być już traktowana jako symbol zbiorowej identyfikacji. Prywatyzacja pamięci uniemożliwia monopolistyczne działania „pamięci centralnej” ${ }^{\prime 2}$, gdyż oznacza współistnienie w przestrzeni publicznej licznych „prywatnych pamięci". Recepcja filmu Bajona dowodzi jednak, iż zanegowanie legitymizującej funkcji „pamięci centralnej” nie oznacza automatycznie społecznego przyzwolenia na odrzucenie zasady hierarchiczności i uprzywilejowania pewnych interpretacji przeszłości formułowanych publicznie ${ }^{83}$.

Zdaniem teoretyków literatury - a można te konstatacje z powodzeniem odnieść także do filmu - świadectwo rodzi się w ciągłym starciu nie tylko ze wspomnieniem ulatniającym się z pamięci, ale także $\mathrm{z}$ formą jego przekazu. Wspomniany konflikt dotyczy wyboru języka, który mógłby odtworzyć przeszłe doświadczenia ${ }^{84}$. Artysta - wybierając świadectwo jako formę reprezentacji - może uczynić ów konflikt zasadniczym tematem dzieła. Doskonałym przykładem jest właśnie Poznań 56, w którym Bajon - stosując m.in. „poetykę fragmentu” (wszystko osobno) - wzorem współczesnych świadectw literackich tematyzuje problem języka:

80 Wyraźny od lat 80. XX w. zwrot w kierunku oral history wiąże autor - za Aleidą Assmann - z badaniami nad Holocaustem. To właśnie dowartościowanie ustnych relacji świadków prowadzi - zdaniem Assmann - do ujawnienia się trzeciej (obok „legitymizacyjnej” i „oświeceniowo-krytycznej” ) funkcji historii - funkcji „moralnej”. Zob. Bartosz Korzeniewski, Transformacja pamięci. Przewartościowania w pamięci przeszłości a wybrane aspekty funkcjonowania dyskursu publicznego o przeszłości w Polsce po 1989 roku, Wyd. Poznańskiego Towarzystwa Przyjaciół Nauk, Poznań 2010, s. 53.

81 Dla przykładu, w badaniach ankietowych przeprowadzonych w Polsce u progu transformacji ustrojowej znalazła potwierdzenie teza, iż w okresie PRL ustne relacje bezpośrednich świadków wydarzeń uznawano za najbardziej wiarygodną metodę upowszechniania wiedzy historycznej. Podobne wyniki uzyskano w badaniach powtórzonych w 2003 r., co dowodzi, iż „,zmiana ustrojowa nie spowodowała zaniku nieufności do prawd przekazywanych przez oficjalne środki przekazu". Zob. Barbara Szacka, Czas przeszły - pamięć - mit, Wyd. Naukowe Scholar, Warszawa 2006, s. 61-63.

82 Wedle definicji Marka Beylina rozumianej jako „określona konstrukcja przeszłości, rzutowana w teraźniejszość i wyróżniająca prawomocnych i nieprawomocnych uczestników sfery publicznej ze względu na ich działania w przeszłości". Zob. Barbara Szacka, Czas przeszty - pamięć - mit, dz. cyt., s. 160.

83 Tamże, s. 156-160.

84 Maria Delaperriére, Pod znakiem antynomii, dz. cyt., s. 93. 
Strategie przybliżania doświadczeń okazały się szczególnie cenne w relacjach wojennych, ale równocześnie podminowały tradycyjną formę narracji [...]. Już nie tyle nagromadzenie wydarzeń w porządku przyczynowo-skutkowym, co ich unaocznienie stało się źródłem fenomenologicznego podejścia do świadectw przeszłości ${ }^{85}$.

Narracja opisowa zastępuje tu narrację wydarzeniowa, showing wypiera telling. Ten typ narracji osłabia wątki wydarzeniowe na korzyść uobecniania przedstawianej rzeczywistości ${ }^{86}$. Filmowy prolog należy zatem potraktować jako eksplikację strategii reżysera, którego interesować będzie nie tylko opowiadana („zaświadczana”) historia, lecz w równym stopniu forma (,,język") owej opowieści. W tym znaczeniu Poznań 56 jest doskonałym przykładem współczesnej metanarracji historycznej, którą cechują:

Dowartościowywanie płaszczyzny snucia opowieści kosztem samej opowieści, rozmaite odmiany dyskursywizacji story i wprowadzanie metawymiarów na poziomie dyskursu [...], problemy z interpretacyjnym charakterem pamięci zastępującej równie interpretacyjną historię $[\ldots]^{87}$.

Otwierający dzieło Bajona monolog spoza kadru stanowi dla widza informację, że wszystkie przedstawione w filmie wypadki oglądać będzie z perspektywy jednego konkretnego narratora - kilkuletniego Darka. Dlatego - jak podkreśla Nurczyńska-Fidelska:

Zasadą konstruującą w filmie Poznań 56 niemal wszystkie te sposoby zaistnienia na ekranie pamięci o czerwcowych wydarzeniach 1956 jest [...] przyjęcie perspektywy narracyjnej utożsamionej z ich widzeniem przez dzieci - dwóch szczunów, przypadkowych uczestników tych zdarzeń ${ }^{88}$.

Tej zasadzie strukturującej filmowe spojrzenie podporządkowane zostały środki formalne. Kamerze udziela się niemal chorobliwa - lecz wynikająca z dziecięcej fizjologii - ruchliwość. Ukazuje ona zdarzenia z nieoczekiwanych, a przecież usprawiedliwionych pozycją zajmowaną przez bohatera-narratora, punktów widzenia. Dla przykładu warto bliżej przyjrzeć się sekwencji robotniczego wiecu przed Urzędem Miejskim. Wprowadzeniem do tej sekwencji jest kilka ujęć w planach ogólnych, ukazują-

85 Tamże, s. 104.

86 Znajdujemy się oto na antypodach stylu „powieściowego”, który polega przede wszystkim na kierowaniu uwagi na sam przebieg wydarzeń (tamże, s. 94-102).

87 Hanna Gosk, Historia w prozie polskiej o tematyce współczesnej po roku 1989, [w:] Co dalej, literaturo? Jak zmienia się wspótcześnie pojęcie i sytuacja literatury, red. Alina Brodzka-Wald, Hanna Gosk i Andrzej Werner, Instytut Badań Literackich PAN, Warszawa 2008, s. 51-52.

88 Ewelina Nurczyńska-Fidelska, Czas i przesłona, dz. cyt., s. 191. 
cych Darka i Piotrka spokojnie zajadających kiełbasę. Chłopcy, zwabieni odgłosami dochodzącymi z placu, podchodzą do ogrodzenia. Po chwili decydują się przedostać na plac przez szparę w płocie. Punkt widzenia kamery ulega zmianie. Zgromadzonych wokół Zamku manifestantów widzimy teraz "od środka” - jak gdyby kamera ulokowana została pomiędzy strajkującymi. Spojrzenie kamery - „krążącej” nieustannie wśród demonstrantów - odpowiada pozycji zajmowanej przez dziecko. Sylwetki robotników filmowane są od dołu, z perspektywy dziecięcych oczu. O sile oddziaływania filmowego obrazu decyduje fakt, iż logika figuracji ${ }^{89}$ omawianej sekwencji umieszcza widza w samym środku wydarzeń, zmuszając go jednocześnie do przyjęcia punktu widzenia przeciskających się w tłumie chłopców.

Darek, któremu przypisać możemy to filmowe spojrzenie, z trudem przedziera się przez zbiorowisko, a z racji swego wzrostu widzi przecież niewiele. Bohater znajduje się $w$ samym centrum manifestacji, ale nie zdaje sobie sprawy, że stał się właśnie świadkiem momentu w historii Poznańskiego Czerwca przełomowego. Wśród zgromadzonych błyskawicznie rozchodzi się informacja o uwięzieniu delegatów. Wiadomość ta

przyczyniła się $\mathrm{w}$ poważnym stopniu do przejścia $\mathrm{z}$ pokojowej fazy wydarzeń do użycia przemocy fizycznej, a następnie broni palnej przez demonstrantów w stosunku do instytucji, w których spodziewali się znaleźć rzekomo aresztowanych delegatów ZISPO ${ }^{90}$.

Obecny na placu ojciec Piotrka - członek robotniczej delegacji - bezskutecznie próbuje uciszyć wrzawę i zdementować plotkę, która stała się katalizatorem nastrojów ludzi zgromadzonych przed Zamkiem. Plac staje się Turnerowską areną - ramą, która funkcjonuje jako tło dla rzeczywistej antagonistycznej interakcji. Działania są tu

wyraziste, ludzie jasno określeni, nadeszła decydująca chwila. Intryga może toczyć się za kulisami, ale scena na froncie jest otwartą areną. [...] W silnych, solidnie umocnionych systemach politycznych taką areną może być najwyższy sąd apelacyjny, parlament, zgromadzenie ustawodawcze. Ale dla reżimu, który utracił legitymizację, areną bywają ulice miasta, gdzie manifestacja siły ludu może wystarczyć do usunięcia ancien régime $[\ldots]^{91}$.

89 Pojęciem „logika figuracji” - odnoszącym się do przestrzennej i czasowej organizacji pola wizualnego, która determinuje pozycję widza - posługuje się Michael Ann Holly. Zob. Gillian Rose, Interpretacja materiałów wizualnych, tłum. Ewa Klekot, Wyd. Naukowe PWN, Warszawa 2010, s. 68.

90 Edmund Makowski, Poznański Czerwiec 1956, dz. cyt., s. 98.

91 Victor Turner, Gry społeczne, pola i metafory, tłum. Wojciech Usakiewicz, Wyd. Uniwersytetu Jagiellońskiego, Kraków 2005, s. 111. 
Na arenie do decyzji dochodzi się przemoca, perswazją lub groźbą użycia przemocy, i to zradykalizowanie działań inicjuje ostatnią fazę gry społecznej ${ }^{92}$. Dynamiczne ruchy kamery odzwierciedlają narastające podniecenie. Kamera - w serii szybko następujących po sobie szwenków wyławia $z$ frenetycznego tłumu pojedyncze, pełne napięcia twarze. To szczytowy moment manifestacji:

Napięcie emocjonalne $\mathrm{w}$ tłumie osiągnęło już takie nasilenie, że tylko nieliczni zachowali zdolność do racjonalnej oceny docierających do nich wiadomości. Gdy informacje o aresztowaniu delegatów ogłoszono przez głośniki radiowozu, zaczęły się tworzyć grupy zdecydowanych uwolnić aresztowanych delegatów ${ }^{93}$.

Wystarczyło już tylko rzucone przez „performatywnego partyzanta" ${ }^{\prime 94}$ Zenka hasło: Na więzienie!, by - jak wspomina uczestnik tamtych zdarzeń - uświadomić sobie, że z zamierzonych i oczekiwanych rozwiązań nic już nie będzie. Uczestnicy manifestacji stali się żywiołem na dziko. Krzyczano. Śpiewano. Ludzie byli bardzo podnieceni ${ }^{95}$. To podniecenie udzieliło się także Darkowi, który za chwilę znajdzie się w grupie szturmującej więzienną bramę.

Bajon nie przedstawia historii w postaci uporządkowanej sekwencji zdarzeń, lecz stara się - nadając obrazom (właściwą wspomnieniom) formę „delirium wizualnego" ${ }^{\prime 96}$ - odzwierciedlić na ekranie chaos towarzyszący (każdej) rewolucji. Choć może bardziej adekwatne - biorąc pod uwage sceny palenia akt i uwalniania więźniów, bratania się z „,wrogiem” czy „pogańskich” tańców wokół ogniska - byłoby Bachtinowskie pojęcie karnawalizacji $^{97}$ - czasowego odwrócenia porządku i zrytualizowanej

92 Tamże, s. 122.

93 Edmund Makowski, Poznański Czerwiec 1956, dz. cyt., s. 99.

94 Wyjaśniam to pojęcie $\mathrm{w}$ dalszej części tekstu.

95 Edmund Makowski, Poznański Czerwiec 1956, dz. cyt., s. 84-85.

96 Maurice Halbwachs, Społeczne ramy pamięci, dz. cyt., s. 88.

97 Julia Kristeva rozpatruje „karnawałowość” jako tekstową transgresję. Zdaniem badaczki tekst oparty na strukturze karnawałowej ma charakter polifoniczny. Polifoniczność i karnawałowość są dla Kristevej pojęciami nierozerwalnie połączonymi. Zob. Hermann Bausinger, Konteksty uczestnictwa w karnawale, tłum. Barbara Chmielewska, [w:] Karnawał. Studia historyczno-antropologiczne, red. Wojciech Dudzik, Wyd. Dromena, Warszawa 2011, s. 283.

Wedle kategorii Bachtinowskich Poznań 56 byłby dyskursem polifonicznym, który cechuje mnogość samodzielnych, niespójnych głosów i świadomości oraz nieobecność odgórnego, uprzedmiotawiającego stosunku homofonicznej, odautorskiej strategii narracyjnej do postaci. W filmie można odnaleźć wszystkie atrybuty polifoniczności:

1. Fragmentaryczność w prezentacji fabuły (,wszystko osobno”) i otwartość struktury, dzięki którym brak totalizującego domknięcia dyskursu i definitywnych konkluzji 
anarchii: Święto! Dzisiaj rządzi kto inny! Tym samym Bajon - w czytelny sposób odnosząc się do „karnawałowego" okresu pierwszej „Solidarności” - stara się przedstawić Wypadki Poznańskie jako „orgiastyczne święto ludów prymitywnych" ${ }^{\prime \prime}$.

Postrzeganie traumatycznego wydarzenia z narodowej historii jako karnawału doskonale wpisuje się w Bajonowską strategię „odbrązawiania":

Karnawał jest słabym kandydatem do uznania za wielki moment historyczny, do heroizacji koniecznej w procesie konstruowania mitu politycznego. Karnawalistyczna interpretacja odejmuje powagę doświadczeniom przeszłości, pozbawia autorytetu, przesuwając te doświadczenia do sfery doświadczeń homo ludens. [...] Jej przeciwieństwem jest obraz martyrologii [...] wpisujący się w tradycję polskich doświadczeń historycznych. Ta interpretacja ma swoje symbole - męczeństwo księdza Popiełuszki i górników z Kopalni „Wujek”99.

Ujęcie karnawalistyczne - sprzeciwiające się stricte martyrologicznej interpretacji przeszłości - nieuchronnie sytuuje film Bajona w dyskursie „Solidarności”. I w tym kontekście (choć nie tylko - rozwijam ten wątek w dalszej części wywodu) Poznań 56 można potraktować jako osobistą wypowiedź Bajona odnoszącą się do społecznego ruchu z lat 80., który „wstrząsnął pamięcią Polaków":

(film dopuszcza wielość interpretacji przedstawionych zdarzeń, a stanowisko odbiorcy ma wynikać z refleksji nad dialektyką ścierających się postaw).

2. Brak uprzedmiotowienia „dyskursów” i postaci (ich wypowiedzi, dialogów, działań); niezamykanie ich w obrębie własnego wszechogarniającego dyskursu, poszanowanie ich podmiotowości i wolności (żadna z postaci „nie służy za tubę głosu autorskiego, w ogólnej strukturze utworu słowo bohatera ma rangę wyjątkowo samodzielna, rozlega się obok słowa autorskiego, w sposób szczególny kojarzy się z nim i z równie pełnobrzmiącymi słowami innych bohaterów").

3. Rozgrywanie dialogu nie tylko między wieloma osobami, ale także między innymi elementami świata przedstawionego oraz struktury formalnej (dialektyka autentyczności i fikcjonalności, dynamiczne napięcie pomiędzy różnymi stylami narracji - „paradokumentalnym" i "kreacyjnym”, a także dynamiczne napięcie pomiędzy odmiennymi interpretacjami tych samych faktów - „powstanie narodowe” czy „rewolta głodowa”, „wolność" czy bejmy).

Zob. Tomasz Kłys, Polifonia i naoczność idei: "Iluminacja” Krzysztofa Zanussiego, [w:] Kino polskie: reinterpretacje, red. Ewelina Nurczyńska-Fidelska i Konrad Klejsa, Wyd. Rabid, Kraków 2008, s. 147-155.

98 Na ten aspekt karnawału zwraca uwagę Krzysztof Kłopotowski: „Już w stanie wojennym zauważyłem, że ruch ten [tj. „Solidarność”] przypominał orgiastyczne święto ludów prymitywnych. Załamują się wtedy hierarchie społeczne i wszyscy wydają się równi, żeby wyłonił się z chaosu nowy układ świata. „Kultura” paryska nie chciała tego wydrukować, więc głosiłem słowo w odczytach po kościołach, aż przyjęło się w mowie potocznej”. Zob. Krzysztof Kłopotowski, Wajdy flirty z władza, "W Sieci” 2012, nr 3, s. 26.

99 Elżbieta Hałas, Symbole i społeczeństwo, dz. cyt., s. 87. 
Nie oznacza to jednak, że do społecznej świadomości powróciła tylko obiektywna wiedza o przeszłości - w obiegu znalazły się przede wszystkim zmityzowane wizje przeszłych wydarzeń, podania przekazywane w rodzinie, uwidoczniły się też stereotypy i uprzedzenia. [...] Tematy, takie jak Katyń, gułag, Czerwiec '56, były to częściej figury dyskursu mitycznego [...] niż elementy historycznej debaty ${ }^{100}$.

Temat filmu stwarzał doskonałą okazję do obrachunku z solidarnościową mitologia, wszak Czerwiec 1956 r. (podobnie jak w następnych latach „Solidarność"!) interpretowano przez odniesienie do ramy znaczeń niesionych przez ruch robotniczy, z jego symbolicznym mitem klasy robotniczej jako demiurga historii i mitem strajku generalnego, umożliwiającego rytuały strajkowe, które ten mit podtrzymują i wzmacniają ${ }^{101}$. A sam karnawał „Solidarności” Bajon skomentował lakonicznie w przywoływanym często wywiadzie-rzece: „Człowieka z żelaza bym nie nakręcił...”

W przeciwieństwie do oficjalnego święta karnawał

triumfalnie obchodził chwilowe uwolnienie od panującej prawdy i istniejącego ustroju, chwilowe zniesienie wszystkich hierarchicznych stosunków, przywilejów, norm i zakazów. Był on autentycznym świętem czasu, świętem stawania się, zmian i odnowienia. Wrogi był uwiecznieniu, spełnieniu i finałowi ${ }^{102}$.

Karnawał jest zjawiskiem zrytualizowanym, lecz dynamicznym - to świat dokonywania się, a nie świat substancji ${ }^{103}$. Świat karnawału

nie jest całkowicie zdefiniowany, lecz przeciwnie - bogaty w możliwości i otwarty na innowacje. Nie jest on ani wyłączną funkcją porządku, ani częścią sił zmiany i równości jako zasady sprawiedliwości społecznej. Jest czymś pośrednim i prawdopodobnie służy obydwu tym stanom. Z pewnością jednak to w tym świecie spełnia się ludowa kreatywność ${ }^{104}$.

Zdaniem badaczy ambiwalentną naturę karnawału doskonale odzwierciedla pojęcie krystalizacji antystruktury. "Zrobić karnawał” znaczy tyle, co "zrobić chaos”, w którym wszystko się miesza i nikt nie wie, gdzie czego szukać ${ }^{105}$. Karnawał to rytuał, w którym społeczna zasada

${ }^{100}$ Lech Nijakowski, Polska polityka pamięci. Esej socjologiczny, Wyd. Akademickie i Profesjonalne, Warszawa 2008, s. 122.

101 Elżbieta Hałas, Symbole i społeczeństwo, dz. cyt., s. 85.

${ }^{102}$ Michaił Bachtin, Twórczość Franciszka Rabelais'ego, tłum. Anna i Andrzej Goreniowie, Wyd. Literackie, Kraków 1975, s. 67.

${ }^{103}$ Roberto DaMatta, Karnawat równości i karnawat hierarchii, tłum. Marta Kolankiewicz, [w:] Karnawat. Studia historyczno-antropologiczne, dz. cyt., s. 329.

104 Tamże, s. 333.

105 Zob. Victor Turner, Karnawat, rytuat i zabawa w Rio de Janeiro, tłum. Iwona Kurz, [w:] Karnawat. Studia historyczno-antropologiczne, dz. cyt., s. 305. 
odwrócenia ${ }^{106}$ jest jednak stosowana w sposób świadomy - nie oznacza unicestwienia hierarchii czy nierówności, lecz jedynie poddanie ich kontrolowanemu doświadczeniu, czasowemu przestawieniu ${ }^{107}$. „Robienie chaosu" stanowi żelazny punkt w starannie zaplanowanym scenariuszu święta. Ta "reguła a priori” w „karnawale” Czerwca '56 nie obowiązuje.

Poznański „karnawał” to groteskowy „świat na opak” - świat, w którym zawieszone zostały wszelkie tradycyjnie uznawane prawa (Był sad, sadu nie ma. Było więzienie, więzienia nie ma...). W tym "zawieszeniu” zawiera się wywrotowy potencjał karnawału. Czerwcowym „świętem” rządzi eksces - pośród żołnierzy biegają... wielbłądy wypuszczone z miejscowego „zoologu"108, a ruchem ulicznym dyryguje intronizowany na jeden

106 Wiele teorii post-Bachtinowskich kwestionuje tę, zdawałoby się fundamentalną dla karnawału, zasadę. W świetle tych teorii inwersja to tylko jedno ze „zbiorowych wyobrażeń" na temat karnawału. W karnawale, traktowanym jako zjawisko społeczne, wydarzenie polityczne czy ekonomiczne, nie ma mowy o żadnej inwersji ani o zerwaniu logicznej ciągłości między świętem a życiem codziennym - zwłaszcza, jeśli brać pod uwagę społeczną organizację karnawału i ścierające się w nim sfery wpływów. Zob. Michel Agier, Karnawat i tożsamość: uwagi teoretyczne i metodologiczne, tłum. Katarzyna Przyłuska-Urbanowicz, [w:] Karnawat. Studia historyczno-antropologiczne, dz. cyt., s. 352-355.

Współcześnie zwraca się szczególną uwagę na ograniczenia teorii Bachtina, wynikające z kontekstu politycznego, w jakim owa teoria powstała. Zdaniem niektórych badaczy książki o Rabelais'm i Dostojewskim nie dotyczą w istocie fenomenu karnawału, lecz traktują o stalinowskim zakazie śmiechu. Karnawał w sensie Bachtinowskim nie jest obecnie możliwy, ponieważ nie istnieją już homogeniczne społeczności („,lud”), które mogłyby go obchodzić lub przeciw którym można by się buntować.

${ }^{107}$ Roberto DaMatta, Karnawał równości i karnawat hierarchii, dz. cyt., s. 337.

108 Wprowadzona do opowieści o tym Czerwcu „scena z wielbłądami” okazała się - w społecznym odbiorze - niezwykle kontrowersyjna. A przecież jej genezy należy poszukiwać nie w obszarze tzw. prawdy historycznej, lecz w przestrzeni „prywatnej” pamięci dziecięcych świadków - pamięci, której mechanizm ośrodkiem narracji może uczynić (z pozoru) nieistotny (czy nieznajdujący oparcia w „faktach") szczegół. Oto charakterystyczny przykład „zoomu” pamięci - wojenne wspomnienie Jarosława Marka Rymkiewicza: „Ale wtedy, w 1943 roku, nie ponieśliśmy właściwie żadnych strat. Paliły się wszystkie domy naokoło, a my straciliśmy tylko kanarka, który przez zapomnienie został w mieszkaniu na stole - zabiła go fala gorąca, kiedy z okien wyleciały szyby". Zob. Jarosław Marek Rymkiewicz, Ani guzika, z Jarosławem Markiem Rymkiewiczem rozmawia Krzysztof Masłoń, dz. cyt.

I jeszcze jedno dziecięce świadectwo - Tomasza Łubieńskiego z Powstania Warszawskiego: „Najboleśniejszym przeżyciem z tego czasu była dla mnie sprawa psa, irlandzkiego setera imieniem Lord. Miałem go po stryju, który poszedł na akcję «Burza» i poległ wkrótce potem. Pewnej nocy obudziło nas drapanie do drzwi: to Lord, który zaginął gdzieś wśród strzelaniny, przybiegł do nas kilkadziesiąt kilometrów przez linię frontu. Następnego dnia pogryzły go i przepędziły miejscowe brytany. Oszalały ze strachu, wrócił do majątku dziadka i stamtąd wziął go na wojnę radziecki major. I czasem zastanawiam się, czy mój Lord doszedł do Berlina". Zob. Tomasz Łubieński, Ani triumf, ani zgon... Szkice o Powstaniu Warszawskim, Wyd. Nowy Świat, Warszawa 2009, s. 44. Zadajmy czysto retoryczne - jak sądzę - pytanie: Czy ta niezwykle sugestywna (rzecz by można „filmowa” ",sekwencja” mogłaby się znaleźć w filmie o tym Powstaniu? 
dzień „Król-Błazen” w więziennym pasiaku ${ }^{109}$. Ale bajzel dzisiaj - podsumowuje ze stoickim spokojem dziadek Piotrka - Ale bajzel. W dziewięćset osiemnastym też byt taki bajzel. Ino zimniej (fot. 2-3).
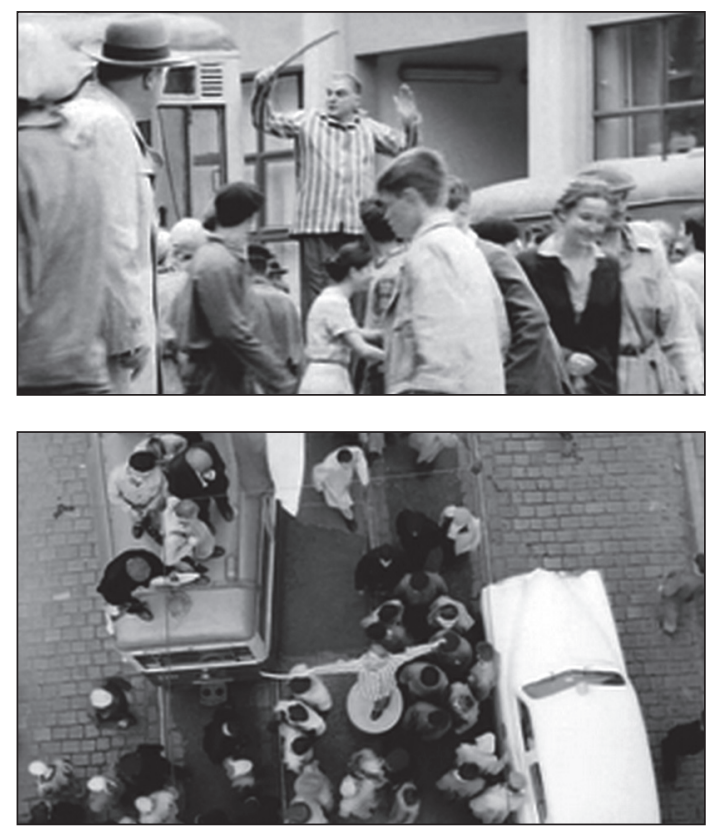

Fot. 2-3. Poznań 56 (1996, reż. Filip Bajon) Protestacja przekształcona w karnawał

W ramach karnawału błazeństwo jest „usankcjonowanym brakiem szacunku". Trzeba w nim dostrzegać (przede wszystkim) formę ironicznego komentarza, służącego - w paradoksalny sposób - społecznemu instytucjonalizowaniu pytań i wątpliwości ${ }^{110}$. Błazen niepodzielnie włada

Przywołaną „scenę z wielbłądami” potraktować można jako paradygmatyczny przykład funkcjonowania „pamięci autobiograficznej”, o której Tomasz Maruszewski pisze: „Kiedy mówimy o doświadczeniach dotyczących świata zewnętrznego, mamy na myśli szczególny rodzaj doświadczeń - odnoszą się one do rzeczy i zdarzeń, które mają dla nas duże znaczenie osobiste. [...] Pamiętamy także wygląd szpitala, w którym poddaliśmy się pierwszej operacji, ale nie pamiętamy swojej reakcji na październik 1956 roku, choć wszystko działo się w tym samym czasie. Przykład ten dobitnie pokazuje, że czymś zupełnie innym jest ważność jakiegoś zdarzenia z osobistego i z historycznego punktu widzenia". Zob. Tomasz Maruszewski, Pamięć autobiograficzna, Gdańskie Wyd. Psychologiczne, Gdańsk 2005, s. 73-74.

${ }^{109}$ Przywołana scena w nieoczekiwany sposób ewokuje w pamięci widza groteskowy finał Kornblumenblau Leszka Wosiewicza.

${ }_{110}$ Zob. Barbara Babcock, "Poukładaj mnie w nieporzadek”: fragmenty i refleksje na temat rytualnego błazeństwa, [w:] Rytuat, dramat, święto, spektakl. Wstęp do teorii widowiska kulturowego, 
przestrzenią miasta. Place, aleje i ulice stają się w karnawale rewersem swoich codziennych funkcji ${ }^{111}$. W Poznaniu 56 na fasadzie Zamku - symbolu opresyjnego systemu - widnieje słynny napis wymalowany biała farbą: Mieszkania do wynajęcia. Ten napis to symboliczne potwierdzenie przejęcia przez "lud" (jego męską część, bo kobiet w tym tłumie nie widać) przestrzeni władzy. Robotnicza rewolta - wzorem karnawału - naznacza strukturę miejską.

Jako estetyczny odpowiednik protestu społecznego, karnawał żąda dla siebie ulic, placów i innych przestrzeni publicznych nie tylko dla chwilowej przyjemności zabawy, ale również po to, by pośrednio [...] potwierdzać swoje prawo do tych miejsc. [...] Walka w obronie swoich rewirów, opanowywanie placów miast i miasteczek, „ścieranie się" czy rywalizacja o prymat artystyczny to - podobnie jak strajki i masowe protesty - działania miejskie $[\ldots]^{112}$.

W ujęciu Bajona siłą sprawczą Czerwca (zarówno w sensie pozytywnym, jak i negatywnym) są wyłącznie mężczyźni ${ }^{113}$, co stanowić może potwierdzenie tezy o maskulinizacji karnawału ${ }^{114}$. Peter Burke zwraca uwage na fakt, iż struktura stowarzyszeń karnawałowych była zdominowana głównie przez młodych mężczyzn. $Z$ tego powodu rozgrywane w trakcie

red. John J. MacAloon, tłum. Katarzyna Przyłuska-Urbanowicz, Wyd. Uniwersytetu Warszawskiego, Warszawa 2009, s. 170.

${ }^{111}$ Roberto DaMatta, Karnawat równości i karnawał hierarchii, dz. cyt., s. 291.

112 Tamże, s. 386, 394. Karnawał dostarcza okazji do konfliktu, który najczęściej objawia się pod postacią starć między zorganizowanymi grupami, ale w skrajnych przypadkach może prowadzić do protestów społecznych, wynikających z różnic klasowych lub rasowych. Dla przykładu, lipcowe święto w Santiago de Cuba zostało w 1953 r. wykorzystane jako przykrywka dla nieudanego buntu Fidela Castro (tamże, s. 388).

${ }^{113}$ Poznań 56 mógłby stanowić istotny przyczynek do dyskusji nad filmowymi reprezentacjami kobiet w życiu społeczno-politycznym okresu PRL. Zdaniem Artura Żmijewskiego aktywne postawy kobiet należą w polskim kinie do sfery „nieprzedstawianego". $\mathrm{Z}$ tego też powodu filmu o Annie Walentynowicz [Strajk w reżyserii Volkera Schlöndorffa], która „zamieniła strajk zdominowany przez partykularne żądania socjalne w strajk antyreżimowy i namówiła Wałęsę, żeby kontynuował protest" Polacy nie byli w stanie nakręcić. Zob. Artur Żmijewski, "Katyń", "Karole”, "Świadectwo", czyli praca ideologii, [w:] Kino polskie 1989-2009. Historia krytyczna, Wyd. Krytyki Politycznej, Warszawa 2010, s. 214.

${ }^{114}$ Część badaczy polemizujących z koncepcjami Bachtina podważa zasadność argumentów świadczących o demokratycznym charakterze karnawału. Dietz-Rüdiger Moser twierdzi, że igrzyska karnawałowe były inscenizacją wystawianą przez niewielu dla wielu. Pierwotnie żeńska cześć „ludu” była wykluczona z partycypacji w karnawale (dopiero bulla papieska z $1701 \mathrm{r}$. zezwoliła kobietom na branie w nim udziału - był to jednak udział bierny), co najwyżej przedstawiano je na scenie, zazwyczaj w niekorzystny sposób. Zob. Michał Mrugalski, Przemysław Pietrzak, Spory o Bachtinowska koncepcje karnawału, [w:] Karnawat. Studia historyczno-antropologiczne, dz. cyt., s. 125. 
karnawału zawody i turnieje powinny być interpretowane jako rytuały potwierdzające męskośćn ${ }^{115}$.

Z („,dziecięcej”) perspektywy przyjętej przez Bajona istotne wydają się przede wszystkim analizy antropologiczno-socjologiczne, wpisujące karnawał nie tyle w „rytuały męskości”, ile w kontekst obrzędów inicjacyjnych. Zdaniem Milli Cozart Riggio nieformalne grupy formujące się w mieście na czas święta

dawały poczucie posiadania domu, alternatywnej rodziny, która prawdopodobnie lepiej rozumie potrzeby nastolatków w stanie zagrożenia niż ich własne rodziny. [...] W nieuniknionym okresie buntu przeciwko władzy rodzicielskiej, towarzyszącemu rytuałowi przejścia w dorosłość, wymykanie się z domu [...] umożliwiało młodzieńcom wejście w twórczy świat "gdzie indziej”"116.

Uchwycony przez Bajona duch „powagi-śmiechu” odzwierciedla ambiwalentną naturę karnawału ${ }^{117}$ : komizm rozbijający utrwalone konwencje dyskursu publicznego (w tym także - na poziomie metatekstowym - filmowego dyskursu historycznego) i dramatyzm wynikający z wtargnięcia żywiołu w „monologiczną" strukturę fasadowej rzeczywistości.

Materialna granica między światem rytualnym a powszednim jest nietrwała; może przebiegać w zupełnie innym miejscu niż sugerowałyby to utarte rozróżnienia przestrzenno-czasowe [...]. Świadomość tych fluktuacji [...] pozwoliłaby na przykład

${ }^{115}$ Peter Burke, Przekład kultur: karnawał w dwóch albo w trzech światach, tłum. Koryna Dylewska, [w:] Karnawat. Studia historyczno-antropologiczne, dz. cyt., s. 290.

${ }^{116}$ Milla Cozart Riggio, Czas poza czasem? Miejska dialektyka karnawału, tłum. Koryna Dylewska, [w:] Karnawat. Studia historyczno-antropologiczne, dz. cyt., s. 397.

117 Podkreślana przez Bachtina „dwugłosowość” znalazła odzwierciedlenie w dyskusjach, ogniskujących się wokół fundamentalnych kwestii podejmowanych przez rosyjskiego badacza. Do dziś wątpliwości budzi np. kwestia, czy karnawał to zaledwie jednostronna inwersja pozostająca w obrębie dominującej hierarchicznej struktury i pełniąca wyłącznie funkcję wentyla osłabiającego społeczne frustracje, czy też prowadzi on, w określonych kontekstach, do znacznie bardziej radykalnego zawieszenia porządku społecznego w uznaniu „powszechnej, wesołej względności” bytu. Zob. Michał Mrugalski, Przemysław Pietrzak, Spory o Bachtinowska koncepcję karnawału, dz. cyt., s. 144.

Zdaniem Dominicka LaCapry Bachtin zbudował idealny model karnawału, nie biorąc pod uwagę analiz empirycznych. W konsekwencji przypisał karnawałowi wyłącznie funkcję kontestacyjną wobec społeczeństwa. Tymczasem wiele karnawałów można uznać za siły zdolne wzmacniać struktury społeczne. Dla przykładu, karnawał w Romans z 1580 r. stał się katalizatorem konfliktu klasowego, który wywołał erupcje przemocy, ta zaś pozwoliła klasom wyższym wyeliminować przeciwników z klas niższych. Zob. Dominick LaCapra, Bachtin, marksizm i karnawat, tłum. Łukasz Wróbel, [w:] Ja Inny. Wokót Bachtina. Antologia, t. 2, red. Danuta Ulicka, Universitas, Kraków 2009, s. 438. Niezależnie od wspomnianych różnic wszyscy badacze podkreślają iż dzięki udziałowi w karnawale "grupy zdominowane" zyskują szansę zdystansowania się wobec świata elit, (czasowej) zmiany swojej pozycji w strukturze społecznej i zrekompensowania sobie niższości społeczno-ekonomicznej wyższością karnawałową. 
zrozumieć, w jaki sposób karnawał potrafi niemal niepostrzeżenie przeistoczyć się ze święta katarktycznego w święto wywrotowe: chwilowe zniesienie napięcia [...] może stać się rewoltą polityczna, gdy "rytm rytualnej gry zostaje zaburzony”, a tożsamości polityczne wytworzone w samym rytuale znajdują przedłużenie w życiu politycznym $^{118}$.

Karnawał upaja się potencjalnym niebezpieczeństwem i możliwością wybuchu przemocy w zgromadzeniach publicznych lub na wrażliwych obrzeżach społecznych ${ }^{11}$. W świat zakwestionowanych norm wdziera się „karnawałowy brud”120 (dostrzegalny w filmie w „obscenicznej” sekwencji linczu na funkcjonariuszu UB).

${ }^{118}$ Michel Agier, Karnawat i tożsamość: uwagi teoretyczne i metodologiczne, dz. cyt., s. 356-357.

${ }_{119}$ Milla Cozart Riggio, Czas poza czasem? Miejska dialektyka karnawału, dz. cyt., s. 384.

${ }^{120}$ Wedle Dominicka LaCapry przemoc jest elementem, który pozwala uchwycić różnicę pomiędzy Bachtinowskim modelem karnawału a teorią kultury René Girarda: „Dla Girarda kryzys ofiarniczy, charakteryzujący się chaotycznym niezróżnicowaniem i ogólną «przemocą mimetyczną», jest przezwyciężany przez arbitralny wybór kozła ofiarnego lub ofiary, w których koncentruje się ambiwalencja. Gwałtowne wygnanie ofiary rytualnie ogranicza przemoc i generuje jasne opozycje, na jakich przypuszczalnie opiera się społeczeństwo i kultura, włączając te pomiędzy niewinną wspólnotą a winną ofiarą. [...] Natomiast karnawał w interpretacji Bachtina jest, na odwrót, sposobem odniesienia do ambiwalencji, który wyklucza przemoc, a zarazem traktuje mechanizm kozła ofiarnego śmiertelnie poważnie. Bachtin jednakże czasami pozwala sobie na naiwny populizm, który ignoruje możliwość zwrócenia się zarówno egalitarnej wspólnoty, jak i autorytarnej elity ku rozwiązaniu siłowemu (ku przemocy) i poszukiwaniu kozła ofiarnego, zwłaszcza gdy ofiary stają się prześladowcami". Zob. Dominick LaCapra, Bachtin, marksizm i karnawat, dz. cyt., s. 439. Sądzę, iż Bajonowi bliższa wydaje się interpretacja Girarda. Funkcja sekwencji linczu nie sprowadza się jednak u Bajona do ilustracji Girardowskiego kryzysu ofiarniczego, lecz stanowi istotny element w obrębie strategii walki z kiczem.

Kontekstu dla interpretacji sekwencji linczu może dostarczyć także koncepcja Victora Turnera. Autor analizuje „rewolucyjną przemoc” (na przykładzie masakry w Guanajuato w czasie meksykańskiej rewolucji niepodległościowej 1810 r.), odwołując się - przez analogię - do Freudowskiego terminu: „proces pierwotny”. Rewolucja to paradygmatyczny przykład procesu pierwotnego, rozumianego jako „obsesyjnie intensywny ruch społeczny". W odniesieniu do działania rewolucyjnego można przyjąć, iż proces pierwotny nie jest rozwinięciem świadomego modelu, lecz stanowi erupcję doświadczenia kumulatywnego zbiorowości, której „najgłębszym potrzebom i pragnieniom, duchowym i materialnym, rządzące elity, działające analogicznie do Freudowskiej cenzury w systemach psychologicznych, przez długi czas odmawiały jakiegokolwiek prawa do uzewnętrznienia się. [...] Wyrasta on [proces pierwotny] raczej z głębokich ludzkich potrzeb bardziej bezpośrednich i egalitarnych sposobów rozróżniania i doświadczania relacji, potrzeb, które zostały stłumione lub skrzywione przez te wtórne procesy, które decydują o homeostatycznym funkcjonowaniu zinstytucjonalizowanej struktury społecznej. Z tego powodu proces pierwotny cechuje się gwałtownością i impetem, które często dosłownie zmiatają osoby i grupy usiłujące ograniczyć jego nieumiarkowanie [...]. Im dłużej było tłumione pragnienie communitas, tym bardziej fanatyczną formę przybierze proces pierwotny, gdy wreszcie zostanie wyzwolony". Zob. Victor Turner, Gry społeczne, pola i metafory, dz. cyt., s. 91-92. 
Bachtinowska teoria karnawału miała decydujący wpływ na zwrot performatywny $\mathrm{w}$ naukach o kulturze ${ }^{121}$. Performative turn postuluje włączenie do analizy działań społecznych modeli ról i analogii teatralnych. Zwolennicy zwrotu performatywnego zakładają bowiem, iż zróżnicowane procesy społeczne mogą być rozpoznawane dopiero za pomocą instrumentarium analizy rytuału. W obrębie performative turn "rytuał” z przedmiotu badawczego przekształca się w kategorię analizy umożliwiającą uchwycenie zjawisk, które pierwotnie nie należały do tradycyjnego zakresu przedmiotowego w węższym sensie. Kluczowe dla zwrotu performatywnego Turnerowskie pojęcie "dramatu społecznego" pozwala interpretować Wydarzenia Czerwcowe nie tyle jako karnawałowy obszar "antystrukturalnej wolności”, lecz jako sformalizowany proces przekształcania pewnych wartości i celów. „Dramat społeczny” należy bowiem traktować $\mathrm{w}$ jego pełnej formalnej postaci i sekwencyjnej strukturze. Bachmann-Medick wyjaśnia, iż dla idealno-typowego przebiegu dramatów społecznych, które sięgają od walk po władzę w obrębie grup aż po napięcia w stosunkach międzynarodowych, znamienne są cztery fazy:

1. Naruszenie ładu (naruszenie normy społecznej, złamanie reguły, wykroczenie przeciw prawu).

2. Kryzys (rozszerzenie i zaostrzenie się sytuacji naruszenia ładu aż do punktu kulminacyjnego).

3. Opanowywanie (strategie rozwiązywania konfliktu za pomocą postępowania na drodze prawnej lub przez akty rytualne, mechanizmy łagodzenia, ale także militarne środki przymusu).

4. Ponowna integracja lub ostateczny rozpad (pojednanie lub akceptacja niemożności przezwyciężenia stanu naruszenia ładu) $)^{122}$.

Nietrudno zauważyć, iż Poznański Czerwiec stanowić może paradygmatyczną realizację Turnerowskiego schematu „dramatu społecznego"123. Można oczywiście zdać pytanie, czy wspomniana sekwencyjność

${ }^{121}$ Zob. Doris Bachmann-Medick, Cultural turns, tłum. Krystyna Krzemieniowa, Oficyna Naukowa, Warszawa 2012, s. 119 i n.

122 Tamże, s. 142.

${ }^{123}$ Pewne wątpliwości budzą natomiast inne, „pozarewolucyjne” przykłady „dramatów społecznych" podane przez Turnera. Na stricte mechaniczny sposób adaptowania Turnerowskiego schematu do analizy zdywersyfikowanych zjawisk zwrócił uwagę Clifford Geertz: „Gościnność, z jaką obrzędowa wersja analogii dramaturgicznej wita każdy przypadek, jest jej najsilniejsza, a zarazem najsłabszą stroną. Potrafi odkryć utajone cechy procesów społecznych, ale narzucając mocno zróżnicowanym sprawom nużącą jednostajność". Zob. Clifford Geertz, O gatunkach zmaconych, [w:] Postmodernizm. Antologia przekładów, red. Ryszard Nycz, tłum. Zdzisław Łapiński, Wyd. Baran i Suszyński, Kraków 1997, s. 226. Zastrzeżenie poczynione przez Geertza można odnieść do całokształtu zjawisk określanych mianem performative turn. 
cechuje wydarzenia "same w sobie", czy też jedynie ich tekstową (tu: filmową) reprezentację (zasadność stawiania takich pytań zostaje unieważniona na obszarze narrative turn). Wydaje się, iż przedstawione w Poznaniu 56 wydarzenia można interpretować zarówno w aspekcie „karnawału”, jak i „dramatu społecznego”. Owa podwójność wynika w dużej mierze z zastosowanej w filmie strategii dublowania perspektywy. Poznański Czerwiec jako „karnawał” jawi się in statu nascendi w doświadczeniu kilkuletniego Darka - bezpośredniego uczestnika zdarzeń (spojrzenie „od wewnątrz"). Te same wydarzenia w świadomości dorosłego Darka, opowiadającego o tych wydarzeniach z czasowego dystansu (spojrzenie „z zewnątrz") układają się już - ex post - w sekwencyjny scenariusz „dramatu społecznego".

Akcentowana w filmie multiplikacja spojrzenia zwraca uwage na kwestię pamięci. Przekonanie, że podczas wiecu przed Zamkiem tłum „stał się żywiołem na dziko" motywuje decyzję o rezygnacji z precyzyjnego oznaczania czasu i miejsca zdarzeń. Do tej formuły powraca Bajon dopiero pod koniec filmu (w sekwencji szpitalnej), by podkreślić stopniową "normalizację" sytuacji w brutalnie spacyfikowanym mieście. Wspomniana sekwencja wiecu rozpoczyna się od serii statycznych kadrów, słyszymy charakterystyczny trzask uruchamianej raz po raz migawki aparatu fotograficznego. Taki zabieg formalny można odczytywać na sposób symboliczny - jako próbę odzwierciedlenia (przy pomocy środków stricte filmowych) ewokujących wspomnienia mechanizmów pamięciowych („teraz zapisuj”), które w psychologii określa się terminem „lampy błyskowej":

Już sama nazwa tej formy pamięci wskazuje, że mamy pewne zdarzenie z przeszłości, oświetlone mocnym światłem i zapisane w bardzo dokładny sposób. Ponieważ powstały obraz pamięciowy jest bogaty w szczegóły, ma on dużą moc perswazyjną [...]. Mechanizm „teraz zapisuj" jest egzemplifikacją „,magnetowidowego" czy „,fotograficznego" [podkr. moje - N.K.-R.] działania pamięci ${ }^{124}$.

Rozwiązania formalne zastosowane przez Bajona w sekwencji wiecu mają na celu wytrącić widza z automatyzmu postrzegania. Kwestionują zarazem - ustanowioną w prologu - tożsamość spojrzenia kamery i bohatera-narratora. Odbiorcy zasugerowana zostaje możliwość alternatywnej - wobec przedstawionej wcześniej - interpretacji kadrów otwierających tę sekwencję. Zdaniem historyka:

${ }^{124}$ Tomasz Maruszewski, Pamięć autobiograficzna, dz. cyt., s. 99-100. 
Dużą rolę w rozpoznawaniu uczestników wydarzeń, kwalifikowaniu ich do zatrzymań i aresztowań odegrały fotografie wykonane przez funkcjonariuszy UB, którzy ubrani po cywilnemu znajdowali się 28 czerwca wśród demonstrantów ${ }^{125}$.

Spojrzenie odkrywające przez widzem uchwycone w statycznych kadrach zdarzenia rozgrywające się na Placu Zamkowym może należeć do takiego właśnie anonimowego pracownika Urzędu Bezpieczeństwa przemieszczającego się wśród demonstrantów. Tej postaci, nie ujawnionej bezpośrednio $\mathrm{w}$ diegezie, należałoby zatem przypisać autorstwo wykonywanych gorączkowo zdjęć. Bajon wspomina: „Zdjęć jest sporo, chociaż reprodukuje się stale te same. Robili zdjęcia agenci, co łatwo poznać po ustawieniu obiektywu, bo pstrykali zdjęcia z ukrycia, spod płaszcza"126.

Wątek fotografów z UB powraca w filmie jeszcze dwukrotnie. Aparat chowa $\mathrm{w}$ teczce tajemniczy mężczyzna, który wysyła chłopców z ważną informacją dla swojej matki. Zdjęcia robi kobieta ukrywająca się w mieszkaniu jednej z kamienic. Ulokowaną w oknie tajniaczkę zdradza odbicie szkła obiektywu dostrzeżone przypadkowo przez Zenka (podczas szarpaniny z kobieta, która nie chce zdradzić miejsca ukrycia aparatu zostaje zastrzelony towarzyszący Zenkowi robotnik). Aparat fotograficzny to w filmie Bajona symbol „dyscyplinującego spojrzenia władzy” świadomej znaczenia i subwersywnej siły masowych protestów ${ }^{127}$.

Wnikliwa analiza sekwencji wiecu umożliwia dekonstrukcję nadrzędnej - jak się początkowo zdawało - zasady strukturującej filmowe spojrzenie. Wypada zatem powrócić do prologu Poznania 56. Funkcją monologu z off-u było przypisanie opowieści konkretnej i wyraźnie spersonalizowanej instancji nadawczej. W czasie lektury filmu ujawnione zostają przed widzem liczne odstępstwa od tej zasady. Pojawia się problem $\mathrm{z}$ atrybucją gdyż widz nie może w sposób jednoznaczny odpowiedzieć na pytanie: kto widzi? Na ekranie przedstawiono bowiem zdarzenia, których Darek nie mógł być bezpośrednim świadkiem. Chło-

${ }^{125}$ Edmund Makowski, Poznański Czerwiec 1956, dz. cyt., s. 220.

${ }^{126}$ Poznańskie szczuny. Z F. Bajonem rozmawia Z. Pietrasik, „Polityka” 1996, nr 26, s. 71.

${ }^{127}$ Dyscyplinujące spojrzenie władzy (wątek „panoptikum” kulminuje w epilogu Poznania 56) analizuje Przemysław Czapliński. W kontekście studium Michaela Foucault Nadzorować i karać Czapliński pisze: „Reżimy dyscyplinarne powstają w wyniku wielowiekowych prób i błędów, okresami szczególnie wzmożonego eksperymentowania władzy są chwile zamętu - katastrof, epidemii, buntów. Każda z tych eksplozji jest swoistym karnawałem [podkr. moje - N.K.-R.], czyli momentem transgresji praw i podziałów społecznych. Można sobie jednak wyobrazić, jak świętu chaosu przygląda się gdzieś z boku doradca króla, obmyślając warunki, które pozwoliłyby zapanować nad powszechnym zmieszaniem". Zob. Przemysław Czapliński, Języki niezależności, [w:] Kultura po przejściach, osoby z przeszłościa. Polski dyskurs postzależnościowy - konteksty i perspektywy badawcze, red. Ryszard Nycz, Universitas, Kraków 2011, s. 54. 
piec nie uczestniczył w rozmowie Staszka z Zosia, nie towarzyszył Piotrkowi w wyprawie na Targi, nie słyszał dramatycznego (I teraz też wytrzymamy...) monologu Kaczmarkowej. Musimy zatem uznać, iż w tych przykładowo wybranych scenach została ujawniona obecność „Innego”. Rozszczepieniu ulega zatem także filmowe spojrzenie - pierwsze należy do tego, kto w Wydarzeniach Czerwcowych bezpośrednio uczestniczył (Darek), drugie - do tego, komu bliższa wydaje się perspektywa profesorów (re)konstruujących przebieg "ekscesów” z bezpiecznej perspektywy kolejowego wagonu (autor wewnętrzny). Konsekwencją wspomnianego „rozszczepienia” jest niejednorodność emocjonalnej tonacji filmu (zaangażowanie versus dystans).

W strukturze filmowego opowiadania zakodowana została wielość perspektyw ${ }^{128}$, na którą

zwrócił uwagę Freud, analizując źródła zniekształceń w procesie przywoływania wspomnień [...]. Podmiot może pojawić się jako zewnętrzny obserwator bądź sytuować się wewnątrz historii, zależnie od intencji i celów wyznaczonych w akcie odtwarzania. Konstrukcja punktu widzenia wiązałaby się w każdym z przypadków z odmiennym przeżyciem emocjonalnym (szczególnie intensywnym, gdy przyjmuje perspektywę „,bycia wewnątrz") ${ }^{129}$.

Otwierający Poznań 56 monolog pełni jeszcze jedną istotną funkcję znaczeniotwórczą. $W$ analizach poświęconych filmowi zwracano uwagę na to, iż Wypadki Poznańskie ukazane zostały z perspektywy dziecka. Najczęściej pomijano zaś fakt, iż w przywoływanym wielokrotnie monologu słyszmy przygaszony głos dojrzałego mężczyzny ${ }^{130}$. Zaznaczony w warstwie akustycznej czasowy dystans wobec relacjonowanych zdarzeń podkreśla także gramatyczny czas przeszły. W trakcie lektury filmu ten dystans zostaje zniwelowany (poza prologiem narrator nie ujawnia swojej obecności), a odbiorca ulega iluzji, iż przedstawione zdarzenia ogląda in statu nascendi z „,wewnętrznej” - dziecięcej perspektywy. Jest to efekt często wykorzystywany w literackich opowieściach o dzieciństwie:

${ }^{128}$ Zaryzykuję tezę, iż to właśnie wspomniana wielość perspektyw nie pozwala na umieszczenie filmu Bajona w kontekście tzw. pamięci protetycznej. Wydaje się również, że autorefleksyjny charakter wypowiedzi nie sprzyja wzbudzeniu u widza empatii (przypomnijmy, iż jest to pojęcie kluczowe w refleksji nad „pamięcią protetyczną"). Por. Alison Landsberg, Prosthetic memory: the ethics and politics of memory in an age of mass culture, [w:] Memory and popular film, ed. Paul Grainge, Manchester University Press, Machester-New York 2003.

${ }^{129}$ Jan Kordys, Kategorie antropologicznie i tożsamość narracyjna. Szkice pogranicza neurosemiotyki i historii kultury, Universitas, Kraków 2006, s. 146.

${ }^{130}$ Por. Ewelina Nurczyńska-Fidelska, Czas i przesłona, dz. cyt., s. 194. 
Z wykorzystaniem dziecięcej percepcji łączy się stosowanie zabiegu wejścia w świat poprzez unaocznienie, uobecnienie chwili opisywanej poprzez użycie czasu teraźniejszego narracji. Czas taki pozwala wytworzyć iluzję uczestnictwa w danym momencie, wcielanie się w postać opisującą tę jedyną wybraną chwilę $e^{131}$.

A przecież prolog Poznania 56 nie może „zniknąć” z horyzontu naszej świadomości. To nie dziecko wprowadza nas $\mathrm{w}$ dziejącą się tu i teraz historię, lecz dorosły przywołuje z pamięci dawno minione zdarzenia. W wypadku tak „podstępnego zmieszania dwóch głosów” Lejeune postuluje lekturę „podejrzliwą”, którą zacząć wypada od pytania: Kto mówi? Czy jest to głos dziecka, czy głos dorosłego? Czy też dorosłego naśladującego głos dziecka? ${ }^{132} \mathrm{~W}$ filmie Bajona - niczym w klasycznym opowiadaniu autobiograficznym - dominuje głos narratora dorosłego i to on organizuje tekst - dzieciństwo pojawia się tylko poprzez pamięć dorosłego. Przekazanie dziecku funkcji narratora oznaczałoby bowiem - wedle Lejeune'a - odstąpienie od kodu prawdopodobieństwa autobiograficznego i wkroczenie w przestrzeń fikcji ${ }^{133}$.

Poznań 56 to filmowy zapis konfrontacji dwóch, toczących się jakby równolegle i nierozerwalnie ze sobą splecionych opowieści. Formalny kształt, jaki Bajon nadał narracji o Czerwcu, jest owej dwoistości doskonałym wyrazem. Odzwierciedla się w niej bowiem perspektywa bezpośredniego uczestnika zdarzeń, a jednocześnie perspektywa zdystansowanego narratora, który dokonuje interpretacji owych zdarzeń w "czasie teraźniejszym" (w czasie aktu narracji). Warto przywołać w tym miejscu klasyczne studium Maurice'a Halbwachsa Społeczne ramy pamięci. Tu bowiem (obok fundamentalnej tezy sformułowanej w tytule) pojawia się, wyrażone expresis verbis, przekonanie, iż odtwarzanie (a raczej rekonstruowanie) w pamięci przeszłych wydarzeń dokonuje się zawsze w teraźniejszości i odpowiada naszym aktualnym zajęciom. Przyczyna ponownego pojawienia się owych wydarzeń w świadomości nie leży, by tak rzec, w nich samych, lecz wynika z ich związku z dzisiejszymi ideami i postrzeżeniami. Teraźniejszość - i jej rewers w postaci tak często używanej metafory obrazu - jako dziedzina aktu przypominania staje się u Halbwachsa samym centrum pamięci, która pozostaje zawsze tylko teraźniejszym zbiorem reprezentacji ${ }^{134}$.

${ }^{131}$ Zob. Zofia Podniesińska, (Re)konstrukcje dzieciństwa traumatycznego, [w:] Trauma, pamięć, wyobraźnia, red. Zofia Podniesińska, Józef Wróbel, Wyd. Uniwersytetu Jagiellońskiego, Kraków 2001, s. 68.

${ }^{132}$ Philippe Lejeune, Wariacje na temat pewnego paktu. O autobiografii, tłum. zbiorowe, Universitas, Kraków 2001, s. 93-94.

${ }^{133}$ Tamże.

${ }^{134}$ Zob. Michał Libera, Kategoria performatywności we współczesnej socjologii pamięci, [w:] Wobec przeszłości, dz. cyt., s. 40-41. Należy jednak zwrócić uwagę na rewers owego zjawi- 
Sposób, w jaki przeszłość obecna jest w Poznaniu 56, bliska jest sposobowi ujmowania przeszłości w kontekście doświadczenia psychoanalitycznego. W (krytycznej wobec freudyzmu) interpretacji Jeana Piageta w tego typu doświadczeniu

Mamy do czynienia z aktualnym rozumieniem przez podmiot jego przeszłości, a nie z bezpośrednią jej znajomością. [...] przeszłość jest rekonstruowana w funkcji teraźniejszości, podobnie jak teraźniejszość jest wyjaśniana przez przeszłość. [...] A jak rozpoznaje się tę przeszłość? Poprzez wspomnienia rekonstruowane w kontekście, który jest kontekstem teraźniejszości i istnieje w funkcji teraźniejszości ${ }^{135}$.

Podobnie pisze o sposobie „doświadczania przeszłości” jako tekstu odczytywanego w perspektywie teraźniejszości Boris Uspienski. Zdarzenia, o których pamięć jest nadal żywa w świadomości uczestników procesu historycznego, są selekcjonowane i usensowniane ze współczesnego punktu widzenia:

Tak tworzy się doświadczenie historyczne - nie jest to ta realna wiedza, która stopniowo odkłada się (kumuluje się) w czasie, razem ze zdarzeniami, w postępującym ruchu historii (w sensie res gestae), lecz te związki przyczynowo-skutkowe, które są postrzegane z synchronicznego (aktualnego dla danego momentu) punktu widzenia. [...] doświadczenie historyczne nie jest czymś absolutnie i obiektywnie danym, zmienia się ono $\mathrm{w}$ czasie i występuje $\mathrm{w}$ istocie jako pochodne od naszej rzeczywistości. Później mogą zachodzić kolejne zdarzenia, określające nową lekturę doświadczenia historycznego, jego reinterpretację. Tak więc przeszłość odczytuje się na nowo z punktu widzenia zmieniającej się teraźniejszości. W tym też sensie historia jest grą teraźniejszości i przeszłości [podkr. moje - N.K.-R.] ${ }^{136}$.

Można zatem powiedzieć - konkluduje Uspienski - że przeszłość jest czasem przepuszczonym przez (współczesną) refleksję ${ }^{137}$.

Pamięć świadka kształtowały przez lata nie tylko osobiste wspomnienia, lecz także przeczytane lektury i ślady ikonograficzne (o funkcji fotografii piszę w dalszej części wywodu) ${ }^{138}$. Przeszłość pojawia się zatem

ska objawiającego się przede wszystkim w wymiarze zbiorowym. Robert Traba pisze: „W ten sposób powracamy do wątku społecznych ram funkcjonowania historii. Poprzez organizowanie pamięci zbiorowej dokonuje się rewaloryzacja teraźniejszości. [...] przez pryzmat byłych wydarzeń oraz zachowań i wartości, jakim hołdowały minione pokolenia, dokonywana jest ocena współczesnych faktów, postaci oraz wartości". Zob. Robert Traba, Historia - przestrzeń dialogu, dz. cyt., s. 63.

135 Jean-Claude Bringuier, Conversations libres avec Jean Piaget. Cyt. za: Jacques Le Goff, Historia i pamięć, dz. cyt., s. 60.

${ }^{136}$ Boris Uspienski, Historia $i$ semiotyka, tłum. Bogusław Żyłko, słowo/obraz terytoria, Gdańsk 1998, s. 27.

137 Tamże, s. 29.

${ }^{138}$ Na konieczność uwzględnienia podwójnej perspektywy oglądu zdarzeń odtwarzanych w pamięci świadków zwracał uwagę Stanisław Różewicz w rozmowie z Konradem 
w Poznaniu $56 \mathrm{w}$ formie tekstów i utekstowionych wspomnień - pamiętników, relacji, opublikowanych pism, archiwów, pomników ${ }^{139}$. W takim ujęciu dzieło Bajona potraktować można jako dowód „postmodernistycznej lektury świadectwa"140. W samej strukturze filmu, w którym została podjęta próba "skonstruowania jednostkowej przeszłości jako muzeum zbiorowych śladów", odnaleźć można wskazówkę, by odczytywać diegezę jako konstrukt dyskursywny, a nie historyczny:

Wypowiedź historyczna zaprzecza swojej selektywności, cząstkowości i ograniczoności, odwołując się do takiego przedstawiania swojej wersji wydarzeń, jakby była ona "gotowa i niezmienna". Wypowiedź dyskursywna zaś, przeciwnie, odsłania własną cząstkowość, ograniczenia i selektywność, wiążąc swój punkt widzenia nie tyle $\mathrm{z}$ "gotową i niezmienną" wersją historii, ile z konkretną a zatem zawodną perspektywą jednostkową ${ }^{141}$.

Poznań 56 to (filmowy) zapis procesu przekształcania minionych doświadczeń w opowiadanie:

Wrażenia zarejestrowane organami zmysłów, utrwalone w pamięci, stają się wspomnieniami, składnikiem szerszej struktury świadomości. Konstrukcja ta nie jest jednak niezmienna, gdyż to, co określa się zwykle mianem doświadczenia, podlega ciągłej restrukturalizacji; stale przepisujemy historie, zmieniamy oceny osób, wydarzeń należących do naszej przeszłości ${ }^{142}$.

Pierwszą opowieść konstruuje dziecięcy bohater - w jego świadomości Wypadki Poznańskie układają się w "awanturniczy” scenariusz.

Eberhardtem, przeprowadzonej przy okazji premiery filmu Opadty liście z drzew (1975). Artysta podkreśla: „po upływie lat, do postaw obserwatora czy świadka już nie można wrócić. [...] Z jednej strony nasza wiedza o drugiej wojnie światowej uległa poszerzeniu i wzbogaceniu, bo mamy i fotografie, i taśmy dokumentalne, i pamiętniki [...]. Z drugiej strony jednak nastąpiło jak gdyby zawężenie widzenia i odczuwania pewnych spraw. Bo pewne sytuacje, pewne nastoje, pewne fakty zatarły się $\mathrm{w}$ pamięci - nie ma już do nich bezpośredniego dojścia”. Zob. Konrad Eberhardt, Mówić własnym głosem, „Kino” 1975, nr 11, s. 20.

${ }^{139}$ Dominik LaCapra, History and Criticism. Cyt. za: Linda Hutcheon, Historiograficzna metapowieść: parodia i intertekstualność historii, tłum. Janusz Margański, [w:] Postmodernizm. Antologia przekładów, dz. cyt., s. 389.

${ }^{140}$ Frank Ankersmit pisze: „Historyk modernistyczny kieruje się drogą rozumowania prowadzącą od źródła i świadectwa do ukrytej za owym źródłem rzeczywistości historycznej. Natomiast dla postmodernisty świadectwo nie wiedzie do przeszłości, ale do innej interpretacji przeszłości [...]". Zob. Frank Ankersmit, Historiografia i postmodernizm, tłum. Ewa Domańska, [w:] Postmodernizm. Antologia przekładów, dz. cyt., s. 159.

${ }^{141}$ Por. Susannah Radstone, Kino/pamięć/historia, tłum. Justyna Jaworska, [w:] Film i historia. Antologia, red. Iwona Kurz, Wyd. Uniwersytetu Warszawskiego, Warszawa 2008, s. 249-251.

${ }^{142}$ Jan Kordys, Kategorie antropologiczne i tożsamość narracyjna, dz. cyt., s. 143-144. 
Dla przykładu warto przywołać scenę, w której podekscytowany Darek relacjonuje koledze wydarzenia, w których przed chwilą brał udział. Chaotyczne, z typową dla dziecka emfazą "wyrzucane” słowa ewokują w pamięci widza zapamiętane z dzieciństwa powieści przygodowe „dla dorastających chłopców":

Piotrek: I coście z giwerami zrobili?

Darek: Wzięlimy, rozdalimy. Jedna komenda się broniła. Mielimy dwóch rannych, to my pojechali. Ale nas ostrzelali. Kierowca pognat w trzcine, a my za nim. Z Zenkiem. Jak zatopki. No i my potem zabrali takiemu jednemu motor. Pojechalimy do radia i tam wydali odezwę.

Dla Darka kilkanaście Czerwcowych godzin stało się okazją do przeżycia prawdziwie „męskiej” przygody, która w pewnym stopniu wpłynęła na jego późniejsze życie. W towarzyszącym pierwszym kadrom filmu monologu wypowiada wszakże znamienne słowa: Pamiętam to. To byt wyjatkowy dzień. 28 czerwca. Potem w moim życiu nic się już nie zdarzyło. Dowodzą one, iż relacje o przeszłych wydarzeniach mówią więcej o tym, co czujemy teraz, niż o tym, co zdarzyło się kiedy śl${ }^{143}$. Przytoczone zdania stanowią odzwierciedlenie świadomości nostalgicznej - wyrażają tęsknotę za bezpowrotnie utraconym czasem i za "dziecięcym” sobą w tym dawnym „,arkadyjskim” czasie. Początkowy (i jedyny w filmie) monolog z off-u ustanawia relację pomiędzy współczesnością („,teraz" - czas, w którym się opowiada) a przeszłością („,wtedy" - czas, o którym się opowiada). To właśnie dokonujące się w filmie „unieważnienie” współczesności (symptomatyczny jest brak ramy narracyjnej spinającej opowieść) umożliwiło - tak jednoznacznie manifestujące się w prologu - dowartościowanie przeszłości we wspomnieniu świadka: To był wyjątkowy dzień...

Struktura drugiej opowieści - należącej do niewidocznego w kadrze mężczyzny z prologu - została podporządkowana uniwersalnemu schematowi procesu inicjacji ${ }^{144}$ (który w Poznaniu 56 dotyczy zarówno

${ }^{143}$ Taka teza została sformułowana przez Daniela Schactera w pracy poświęconej mechanizmom pamięciowym. Zob. Barbara Szacka, Pamięć zbiorowa, dz. cyt., s. 27.

${ }^{144} \mathrm{~W}$ procesie inicjacji Darka z łatwością wyróżnić można poszczególne fazy klasycznego schematu van Gennepa:

1. Rytuał separacji - wyłączenie inicjowanego ze zwykłego otoczenia społecznego (Darek porzuca rodzinny dom i szkołę).

2. Rytuał progu i przemiany - przeniesienie inicjowanego w stan zawieszenia (betwix-and-between), w którym budowana jest więź ze sferą sakralną (wizyta Darka w kościele, "asystowanie” przy śmierci konfidenta UB i Piotrka) i/lub z centralnymi symbolami danej kultury („,edukacja patriotyczna” w oddziale Zenka).

3. Rytuał ponownego włączenia (stabilne społeczne usytuowanie Darka w nowej rodzinie). 
jednostki, jak i grupy społecznej ${ }^{155}$ ). Tym, co łączy obie narracje jest specyficzny sposób hierarchizacji zdarzeń. Dla Darka-dziecka liczy się wyłącznie emocjonująca "przygoda”. Dla Darka-dorosłego możliwość powrotu - poprzez akt opowiadania - w "tamten czas". A dla małego Piotrka - „ofiary niewinnej” - najważniejszym doświadczeniem Poznańskiego Czerwca okazało się smakowanie banana.

Egzotyczny owoc stał się w Poznaniu 56 symbolem hermetyczności dziecięcego świata - znakiem tajemnej własności, która kazała Rolandowi Barthesowi nazwać dzieciństwo „wiekiem prywatności zamkniętym w sobie, posiadającym specjalny status niby niewyrażalna i nieprzekazywalna esencja"146.

Niepodważalnym dowodem na istnienie - „mimo wszystko" - rajskiej krainy dzieciństwa jest poruszający fragment filmu, który poświęca Bajon ostatnim godzinom poprzedzającym śmierć Piotrka. Chłopiec odłącza się w pewnym momencie od swego towarzysza, by - nie zważając na odbywającą się tuż obok manifestację robotniczą i padające dookoła strzały - niepostrzeżenie wślizgnąć się na teren Targów Poznańskich. Smak pierwszego w życiu egzotycznego owocu okaże się najistotniejszym $\mathrm{z}$ „rewolucyjnych” doznań, zaś pokusa spenetrowania niedostępnego „innego" świata zwycięży nad chęcią uczestniczenia w historycznych zdarzeniach. Podekscytowany Piotrek zawoła na odchodnym: Zobacz. Weszli bez biletu. Nigdy nie byłem na Targach. Taka szansa!

$\mathrm{W}$ analizowanym fragmencie filmu wrażenie swoistego „zawieszenia" czasu uzyskane zostało za pomocą stricte filmowych środków. Sekwencja wizyty Piotrka na Targach zaczyna się od powolnej panoramy. Długie ujęcie w planie dalekim ukazuje wędrówkę chłopca wzdłuż opustoszałej alei $\mathrm{z}$ targowymi stoiskami. W pewnym momencie chłopiec, zachęcony przez mężczyznę obsługującego stoisko, wyciąga rękę po banana. Po chwili Piotrek znajduje ustronne miejsce i oddaje się rytuałowi smakowania owocu. Kamera niespiesznie przybliża się do twarzy dziecka pogrążonego w marzeniu. Wypełniające cały ekran zbliżenie zachowuje

zdolność wyrywania obrazu ze współrzędnych czasowo-przestrzennych, ażeby wydobyć czyste, wyrażone uczucie. Nawet miejsce jeszcze obecne w tle traci swoje współrzędne i staje się ,jakąkolwiek przestrzenią"147.

${ }^{145}$ Wydarzenia Poznańskie mają wszelkie cechy liminalności występującej w rytuałach inicjacyjnych. Ta faza przemiany - pisze Bachman-Medick - ucieleśnia we wszystkich kulturach, także w złożonych społeczeństwach przemysłowych, krytyczny rytualny próg, kiedy to „przeszłość zostaje na chwilę unicestwiona, a przyszłość jeszcze się nie zaczęła - moment czystej potencjalności". Zob. Doris Bachmann-Medick, Cultural turns, dz. cyt., s. 137.

${ }^{146}$ Roland Barthes, Mitologie, tłum. Adam Dziadek, Wyd. KR, Warszawa 2000, s. 197.

${ }^{147}$ Gilles Deleuze, Kino, dz. cyt., s. 108. 
Kompozycja filmowych kadrów stanowi wizualny ekwiwalent subiektywnego doświadczenia czasu. Czas „rzeczywisty” - czas Historii, w którym rozgrywa się właśnie kolejny akt robotniczej rewolty - zostaje unieważniony. Wkraczamy w czas wewnętrzny i wraz z Piotrkiem kontemplujemy chwilę umiejscowioną jakby "poza czasem”. Wyjątkowy to - choć nie jedyny w filmie - moment „unieruchomienia” czasu (fot. 4-5).
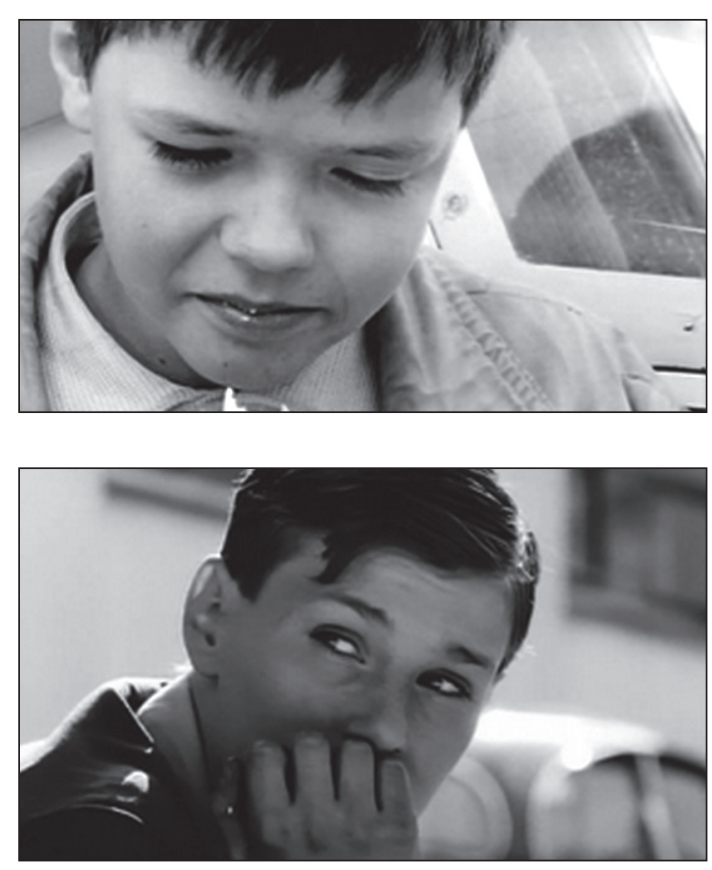

Fot. 4-5. Poznań 56 (1996, reż. Filip Bajon) "Czyste wyrażone uczucie"

W ramach przyjętej przez Bajona strategii „sekwencja targowa” stanowi doskonały przykład realizacji postulatu zejścia z pomnika. To element gry z widzem i prowokacja w stosunku do jego poznawczych oczekiwań. Poprzez skupienie uwagi na mało znaczącym - w kontekście „procesu dziejowego" - epizodzie z prywatnej dziecięcej mitologii zanegowana została reguła ukazywania na ekranie jedynie tego, co przynależy do dominującego porządku Wielkiej Historii. Dialog prowadzony podczas ponownego spotkania chłopców ujmuje w syntetycznym skrócie specyficzną dla Poznania 56 - i jakże zgodną z dziecięcym sposobem doświadczania świata - zasadę hierarchizowania zdarzeń:

Darek: Ty głupi dydku! Jakżeś se poszedł, to myśmy z Zenkiem obrobili chyba z pięć komend. [...] Widzisz głupku, ile straciłeś!

Piotrek: Ja nic nie straciłem. Ja jadłem banana. 
Z drugiej jednak strony analizowaną sekwencję można z łatwością $\mathrm{w}$ ten porządek historyczny wpisać. Zyskuje ona tym samym podwójne znaczenie. Stanowi integralny składnik mitologemu dzieciństwa, ale może być rozpatrywana także w szerszej - stricte historycznej perspektywie. O genezie robotniczego buntu będzie mowa w dalszej części rozważań. W tym miejscu warto zwrócić uwagę na funkcję elementów symbolizujących w Poznaniu 56 istnienie zakazanego „lepszego" świata, który dla szczunów stanowi nieodpartą pokusę. Obok wspomnianego banana pojawiają się przecież inne, wzbudzające pożądanie dzieci, obiekty. W scenie rozłączenia chłopców przedmiotem adoracji jest zagraniczny samochód. "Zdradzony" przez przyjaciela i osamotniony Darek z czułością gładzi lśniącą karoserię moskwicza zaparkowanego w pobliżu Targów. Za chwilę ulegnie kolejnemu impulsowi i przyłączy się do uzbrojonej grupy Zenka. Ale Bajona bardziej interesuje moment, w którym Darek przysiada na masce samochodu i z tęsknotą spogląda w kierunku otwartej bramy „raju z importu”. Ten - w dużej mierze autobiograficzny ${ }^{148}$ - fragment filmu doskonale wpisuje się $\mathrm{w}$ dyskurs historyków analizujących przyczyny Czerwca '56:

Poznaniacy mieli dodatkowe przyczyny do krytycznych refleksji, gdyż mogli porównać swój poziom życia z bogactwem i pięknem opakowań produktów "gnijącego kapitalizmu", prezentowanych na Międzynarodowych Targach Poznańskich (MTP). Porównywano nasz poziom życia z zachodnim i konstatowano, że u nas jest znacznie gorzej, także w porównaniu z innymi krajami demokracji ludowej. Denerwowało ludność specjalne zaopatrzenie Poznania w artykuły żywnościowe na okres Targów po to, by zrobić dobre wrażenie na gościach targowych i korespondentach prasy zagranicznej ${ }^{149}$.

W jednej z pierwszych sekwencji filmu chłopcy zakradają się do piwnicy w pilnie strzeżonym budynku zamieszkanym przez rodziny funkcjonariuszy Urzędu Bezpieczeństwa. Od „reszty świata” ubeckie osiedle oddziela szlaban i pilnujący porządku wartownik w mundurze. Darek - syn prominenta z UB - objaśnia zdumionemu koledze obco brzmiące napisy na etykietkach. Piotrek z rosnącą fascynacją przygląda się puszkom z bananami i egotycznej kiełbasie z osła. Kawałek salami, przeszmuglowany przez granicę podwórka, okaże się najcenniejszym trofeum piwnicznej eskapady (a wiele godzin później tragiczną pamiątką, którą ojciec Piotrka zabierze z więzienia do domu...).

${ }^{148}$ W wywiadzie-rzece Bajon wspomina: „Ale w tym dzieciństwie był jeszcze jeden element, bardzo istotny, z czego zdałem sobie sprawę dopiero później - Międzynarodowe Targi. [...] Wracając do Targów Poznańskich, myśmy na nie wchodzili przez dziurę w płocie i nagle znajdowaliśmy się na zachodzie". Zob. Włodzimierz Braniecki, Szczun, dz. cyt., s. 13-14.

${ }^{149}$ Edmund Makowski, Poznański Czerwiec 1956, dz. cyt., s. 25. 
Z pozoru humorystyczna scenka zakończona kradzieżą kiełbasy ma znacznie głębsze znaczenie - uzmysławia bowiem „,konsumpcyjną" przepaść pomiędzy robotnikami określanymi w oficjalnym dyskursie mianem klasy panującej a czerwoną elitą welfare state. „Klasa panująca” obnaży za chwilę propagandowy fałsz władzy ludowej, rozpoczynając na ulicach Poznania "rewoltę głodową", której symbolem stanie się transparent z napisem "Żądamy chleba”.

Scena w piwnicy to niezwykle sugestywne - choć dalekie od plakatowej deklaratywności - wprowadzenie w problematykę ekonomicznych motywów poznańskiego buntu ${ }^{150}$. Sekwencja wizyty Piotrka na Targach jest doskonałym uzupełnieniem owej sceny. Stanowi bowiem potwierdzenie koncepcji, zgodnie z którą

ludzie się buntuja gdy idzie „ku lepszemu”. Ta koncepcja wiąże się z tezą o roli „relatywnej deprywacji" - wiążącej bunt nie ze złą sytuacją definiowaną w kategoriach absolutnych, ale mierzoną dystansem pomiędzy oczekiwanym a doświadczanym stanem rzeczy. [...] Wszystko wskazuje na to, że takie wyjaśnienie częściowo stosuje się również do 1956 r. Wprawdzie czynnik dostrzeżenia możliwości egzystencji lepszej w sensie materialnym może odnosić się jedynie do poznańskiego fragmentu całego epizodu (rola Targów Poznańskich!) - ale z punktu widzenia „rozluźniania” politycznego Październik mógłby stać się wręcz podręcznikowym przykładem słuszności powołanych tez ${ }^{151}$.

W Роznaniu 56 możemy mówić o buncie w podwójnym znaczeniu. Pierwszy rodzaj buntu ma charakter zbiorowy i historyczny - manifestuje się w radykalnej postaci strajku robotników największych zakładów przemysłowych regionu. Drugi bunt rozgrywa się w mikroskali i dotyczy losów jednostki. Ale to właśnie ten rodzaj buntu konstytuuje zasadniczą dla filmu „uniwersalną" opowieść o poszukiwaniu autorytetu niezbędnego $\mathrm{w}$ procesie inicjacji.

Osieroconym dzieckiem - przede wszystkim w sensie symbolicznym - jest w filmie Bajona Darek. Emocjonalną i duchową przepaść pomiędzy chłopcem a ojcem w sposób szczególnie dramatyczny odzwierciedla scena, w której Darek „inscenizuje” przed rodzicem - wysokiej rangi

${ }^{150}$ Wydaje się, iż Bajon - poruszając kwestię ekonomicznych źródeł robotniczego protestu - diagnozuje zjawisko wykraczające poza historyczne ramy Czerwca. Pisze o tym - w kontekście dekonstrukcji solidarnościowego mitu „pełnego zaangażowania” Lech Nijakowski: „Byli ludzie, którzy nie chcieli zajmować stanowiska w sporze światopoglądowym, nie byli rozgrzewani przez spory historyczne, nie interesowali się losem opozycji. Dla nich liczyła się trudna codzienność, «mała historia», «mało heroiczna», gdzie stawką w walce był papier toaletowy, a nie nowy numer paryskiej «Kultury». [...] Poparcie dla Solidarności wiązało się także z wiarą w kraj zapełnionych półek sklepowych". Zob. Lech Nijakowski, Polska polityka pamięci, dz. cyt., s. 118.

${ }^{151}$ Marcin Kula, Ku jakiej syntezie polskiego Października?, [w:] Historia moja miłość (z zastrzeżeniami), Wyd. Uniwersytetu Marii Curie-Skłodowskiej, Lublin 2005, s. 228. 
oficerem UB - śmierć swojego kolegi. W obliczu bezwzględnej racji syna mężczyzna okazuje się całkowicie bezradny, czego dowodzi gwałtowność jego reakcji na tę dziecięcą manifestację sprzeciwu. Pod wpływem trwającego w zaciętym milczeniu dziecka, być może po raz pierwszy w życiu, okazuje "słabośćc, zlecając podwładnym zwolnienie z aresztu ojca zastrzelonego Piotrka.

Wydaje się jednak, iż rozpad więzi ojciec-syn dokonał się na długo przed rozpoczęciem czerwcowych strajków. To właśnie symboliczna nieobecność ojca zmusiła Darka do poszukiwania autorytetu "zastępczego". Substytutem ojca staje się strajkowy watażka Zenek, reprezentujący w oczach chłopca - w znacznie większym stopniu niż argumenty polityczne, których Darek nie pojmuje - pewność (On nigdy nie miał wątpliwości), bezkompromisowość i brawurę. Przy Zenku Darek przechodzi przyspieszony proces dojrzewania. Dla dziecka najbardziej tragiczna w skutkach okazuje się konfrontacja z głoszonymi przez ojca (także wśród najbliższych - o czym świadczy scena kłótni z żoną) ideami. Niemal na oczach Darka rozpada się przecież misterna ideologiczna konstrukcja oparta na dychotomicznym rozróżnieniu: my (przedstawiciele jedynie słusznych racji) - oni (wrogowie systemu). Darek spróbuje jeszcze, w akcie desperacji, bronić ojcowskiego świata. Podczas akcji pacyfikacyjnej $\mathrm{z}$ wyrzutem wykrzykuje w stronę pokornie oddających karabiny żołnierzy: Broni się nie oddaje! Kamera wnikliwie śledzi emocje uzewnętrznione na twarzy chłopca. To one zaświadczą najlepiej o dokonującej się na oczach widza przemianie. Ostatecznym potwierdzeniem tej przemiany jest wyczuwalne w głosie Darka wahanie: Mój tata ściga... wrogów. Proces dojrzewania wymaga czasu niezbędnego do autorefleksji. Darek - chociaż przez moment - musi zostać sam. W sytuacji będącej rodzajem próby chłopiec opowiedział się po stronie walczących, ale odchodzi z poczuciem klęski, która jest przede wszystkim klęską światopoglądu reprezentowanego przez formację ojca.

Dla Darka, którego pod opiekę bierze strajkowy przywódca, symboliczne zerwanie z ojcem staje się początkiem bolesnego procesu inicjacji. Ten proces będzie obejmował kolejno następujące po sobie etapy i dotyczył sfer dotychczas przez chłopca nie spenetrowanych. W czasie kilkunastu gorących godzin Czerwca Darek zostanie wtajemniczony w erotykę, sacrum i śmierć ${ }^{152}$. Zamysłem Bajona było

potraktować to wydarzenie jako wydarzenie modelowe dla dorastającego chłopca, który w ten jeden dzień przechodzi edukację, jaką niektórzy ludzie przechodzą przez całe życie. Pierwsze zetknięcie ze śmiercią. Uświadomienie sobie przyjaźni, dotknięcie Pana Boga, dotknięcie tajemnicy, poczucie sprawiedliwości, poczucie władzy,

${ }^{152}$ „Wrzucenie" dziecka w Historię rozumiane jako uniwersalny rytuał inicjacyjny to temat Malowanego ptaka Jerzego Kosińskiego. 
utrata przyjaciela, wejście świadome w konflikt z ojcem, to wszystko jest $\mathrm{w}$ ramach tego jednego dnia, który się wydarzył. Czyli użyłem tutaj pewnej techniki; Niemcy to nazywają powieścią rozwojową. Bohater prostaczek doświadcza w ramach tego dnia daru historii. I wychodzi mądrzejszy, lepszy, dojrzalszy ${ }^{153}$.

Etap wtajemniczenia w erotykę odzwierciedla w filmie wątek trudnej miłości Zenka i Zosi, której Darek dyskretnie patronuje. Podczas subtelnej sceny erotycznej w szpitalu chłopiec pełni rolę strażnika dbającego o to, by nikt nie zakłócił ulotnego szczęścia kochanków. To także Darek - z wyraźną satysfakcją - zaprowadzi w finale niczego nie podejrzewającego Zenka pod okno, w którym pojawia się Zosia. Odczytywany w zgodzie z ikonograficzną tradycją (a czy możliwe jest w tym wypadku inne odczytanie?) obraz ${ }^{154}$ brzemiennej kobiety staje się symbolem „kompensującej siły słabych" ${ }^{\prime 155}$ i znakiem biologicznej ciągłości pokoleń.

Wtajemniczenie w śmierć to droga, którą Darek przebywa wraz Zenkiem, i na której pojawiają się pierwsze ofiary: robotnicy przywitani kulami podczas ataku na powiatową komendę. $Z$ czasem tych ofiar będzie przybywać. Zastrzelony na polu trzcin kierowca, umierający niemal na rękach Darka konfident UB, anonimowi przechodnie... Najważniejsza w Poznaniu 56 jest jednak śmierć małego Piotrka. To jednocześnie śmierć najmniej heroiczna, "rozgrywająca się" w przestrzeni pozakadrowej w sferze wyobrażonego. Symboliczną zapowiedzią tej śmierci będzie oniryczna (a przecież historycznie udokumentowana) scena, w której Piotrek - uwiedziony „syrenim śpiewem” - podąży za prowadzonymi przez nauczyciela dziećmi z biało-czerwonymi chorągiewkami ${ }^{156}$.

Poruszony "aktem nawrócenia" ubeka Darek inicjuje "teologiczną" dyskusję z Piotrkiem. Inicjację w sferę sacrum reprezentuje piękna scena

${ }^{153}$ Włodzimierz Braniecki, Szczun, dz. cyt. s. 136.

${ }^{154}$ Wydaje się jednak, że również w tym wypadku Bajon nadaje ujęciu formę cytatu. Zosię widzimy przecież w obramowaniu okna, które tworzy w kadrze rodzaj symbolicznej ramy. Omawiane ujęcie stanowi także czytelne odwołanie do pierwszego literackiego opracowania tematu Wydarzeń Poznańskich - opowiadania Włodzimierza Odojewskiego Spisywane z pamięci (1963), w którym tragedia wspólnoty „czytana” jest poprzez tragedię jednostki (dla narratora Czerwiec'56 to przede wszystkim trauma utraty nienarodzonego dziecka). W opowiadaniu kilkakrotnie pojawia się - przywołany we wspomnieniu - obraz ciężarnej żony.

155 Wychodząc zaś poza oczywistą w wypadku analizowanego ujęcia symbolikę Matki Polki odwołam się na koniec do uniwersalizującej refleksji Victora Turnera. Autor podkreśla, że „kiedy świecką władzę strukturalną trzyma w rękach jedna grupa, a męskość traktowana jest jako źródło władzy, legitymizacji, urzędów i wszelkiego rodzaju ciągłości strukturalnej, tam jedność, ciągłość i kompensująca siła słabych, poczucie ostatecznej jedności całej społeczności, są często przypisywane kobiecie, a zwłaszcza symbolom macierzyństwa". Zob. Victor Turner, Gry społeczne, pola i metafory, dz. cyt., s. 124.

156 O przemarszu dzieci ulicami ogarniętego rewolucją Poznania wspomina m.in. Makowski. Zob. Edmund Makowski, Poznański Czerwiec 1956, s. 109. 
w kościele, zakończona dramatycznym pytaniem Darka: Czy Bóg może tak leżeć? Po tym pytaniu drobna figurka chłopca zdaje się wznosić do poziomu zajmującej centralną pozycję na ołtarzu Piety. Wychowanemu przez ojca-ateistę chłopcu, który nie zna pojęcia grzechu (nagłym wtargnięciem „profanuje” ołtarz), udaje się „dotknąć” sacrum i znaleźć blisko... Boga? Być może ten etap procesu inicjacji okazał się dla Darka najistotniejszy. Po wyjściu z kościoła chłopiec staje się bardziej wyciszony, refleksyjny. Przemianę, jaka się w nim dokonała, ilustruje scena ulicznych zamieszek. Po opuszczeniu świątyni osamotniony Darek idzie wolno, nie zwracając uwagi na mijający go rozgorączkowany tłum i padające od czasu do czasu strzały. Scena uliczna, następująca tuż po wizycie w świątyni, stanowi symboliczne odzwierciedlenie stanu bycia pomiędzy - „liminalności” objawiającej się w środkowej fazie procesu inicjacji:

W istocie liminalność może implikować raczej samotność niż otoczenie społeczne, dobrowolne lub niedobrowolne wycofanie się jednostki poza matrycę struktury społecznej. Może implikować raczej wyalienowanie ze społecznego bytowania niż bardziej autentyczny udział w tymż $\mathrm{e}^{157}$.

Przeżycie duchowe ${ }^{158}$, którego doznaje Darek w kościele, potwierdza problematyczny status inicjowanego i towarzyszącą rytuałowi przejścia ambiwalencję. Stan liminalności reprezentuje bowiem jednocześnie negację wielu, choć nie wszystkich - własności preliminarnej struktury społecznej (w tym wypadku za odrzuconą - a przynajmniej kwestionowaną - własność preliminarną można by uznać ateizm ojca) i afirmację (choć Bajon wskazuje jedynie na potencjalną możliwość afirmacji) innego porządku rzeczy (sacrum) i stosunków ${ }^{159}$.

Bajon, co wydaje się niezmiernie istotne, porusza problematykę sacrum wyłącznie w wymiarze jednostkowym, mimo iż liczne dokumenty poświęcone wydarzeniom Czerwca potwierdzają, że podczas manifestacji:

Żądano powrotu religii do szkół, śpiewano pieśni religijne, wznoszono okrzyki „Chcemy Polski katolickiej, a nie bolszewickiej”. Według jednego z raportów: „W czasie pochodu w kierunku MRN, gdy główna grupa przechodziła obok kościoła św. Marcina (ul. Armii Czerwonej), przed kościół nadbiegło dwóch zakonników, którzy ze stopni kościoła udzielali błogosławieństwa przechodzącym demonstrantom. Czołówka pochodu uklękła"160.

${ }^{157}$ Victor Turner, Gry społeczne, pola i metafory, dz. cyt., s. 40.

158 Ta formuła wydaje się znacznie bardziej adekwatna dla określenia istoty doświadczenia Darka niż radykalne pojęcie „nawrócenia” (do zastosowania tego pojęcia nie widzę w filmie dostatecznych podstaw).

${ }^{159}$ Victor Turner, Gry społeczne, pola i metafory, dz. cyt., s. 165.

160 Paulina Codogni, Rok 1956, Prószyński i S-ka, Warszawa 2006, s. 192. 
Przytoczony fragment dowodzi, iż w trakcie Wydarzeń Czerwcowych posłużono się symboliką religijna, która stała się ważnym narzędziem legitymizacji protestu.

„Prywatyzacja” doświadczenia religijnego to element przyjętej przez Bajona strategii. Opisana przez uczestnika zdarzeń scena błogosławieństwa udzielanego protestującym wydaje się Kunderowskim kiczem ${ }^{161}$ w czystej postaci. Przetransponowanie nasyconej kiczem rzeczywistości na ekran groziło tegoż kiczu spotęgowaniem - nadaniem mu statusu kiczu „uświęconego" (legitymizowanego w dziele sztuki).

Bajon, przeciwny wszelkim próbom zawłaszczania Czerwca '56, miał świadomość, iż najlepszym wspornikiem aktywności mitotwórczej jest immanentnie zawarty w rzeczywistości kicz patriotyczno-religijny. Dowodem potwierdzającym to przekonanie jest casus odsłoniętego 28 czerwca $1981 \mathrm{r}$. (w 25. rocznicę wydarzeń) Pomnika Ofiar Czerwca 1956. Pomnik stanowić może paradygmatyczny przykład upamiętniania rozumianego jako symboliczna kulturowa konstrukcja, w której dominujące narracje komemoracyjne komunikują ogólne znaczenia podzielanej przeszłości ${ }^{162}$. W akcie upamiętniania przeszłość jest bezwzględnie wtłaczana w schematy, które

${ }^{161}$ Rozwijam ten wątek w dalszej części tekstu.

${ }^{162}$ Zob. Elżbieta Hałas, Symbole i społeczeństwo, dz. cyt., s. 61. Zdaniem autorki: „Akty upamiętniania mniej lub bardziej otwarcie przekazują narrację o przeszłości, która uzasadnia zrytualizowane pamiętanie i niesie ze sobą ważne przesłanie moralne. Przekaz historyczny jest wykorzystywany dla takich celów selektywnie, komemoracje są zawsze w jakimś stopniu fragmentaryczne, a wybór tego, co zostaje upamiętnione i jakie znaczenia przeszłości zapanuja, jest częścią polityki pamięci". Doskonałym przykładem tego typu praktyk jest książka Zbigniewa Załuskiego Siedem polskich grzechów głównych. Opublikowany na początku lat 60. tekst miał w zamierzeniu autora stanowić polemiczną korektę „szyderczych" rozrachunków. W istocie wpisał się idealnie w ówczesną politykę pamięci, legitymizując - poprzez zabiegi "magiczne” [,"obok szwoleżera spod Somosierry, Ordona czy powstańca styczniowego pojawia się żołnierz z bitwy pod Lenino i żołnierz Gwardii Ludowej"] - komunistyczną władzę jako sukcesora całego ciągu czynów bohaterskich. Zob. Andrzej Werner, Polskie, arcypolskie..., dz. cyt., s. 206.

Zauważmy, że znaczący dla pamięci zbiorowej komunikat - skonstruowany na zasadzie selekcji i montażu - może wyrażać krytyczny stosunek do narodowej przeszłości. Posłużę się dla ilustracji projektem czołówki, która w pierwotnym zamyśle Andrzeja Wajdy miała otwierać Kanał: „Napisy czołowe filmu poprzedzają ujęcia przedstawiające ułanów na koniach biegnących do ataku. Są to ułani spod Samosierry, spod Rokitny, a wreszcie ci z 1939 roku, którzy zdobywali czołgi". Wedle Andrzeja Wernera tak pomyślany prolog do filmu o Powstaniu Warszawskim stanowi „reprezentatywny rejestr ówczesnych stereotypowych wyobrażeń ilustrujących zjawisko polskiej bohaterszczyzny". (Dla ścisłości dodajmy, że Wajda swego projektu nie zrealizował, zaś epilog filmu - zejście porucznika Zadry do piekła kanałów - odebrano jako recydywę „ułańskiej romantyki”). Tamże, s. 88-91. 
są jej tak obce, że sama nie może skutecznie zaprotestować przeciw naszym decyzjom dotyczącym jej upamiętniania ${ }^{163}$.

Warto podkreślić, iż ten wątek pojawia się także w poświęconym Wypadkom Poznańskim opowiadaniu Odojewskiego. W narracji komemoracyjnej „pomnikiem” może stać się zwykły przyszpitalny ogród. Bohater-narrator - uczestnik Czerwca - dowiaduje się, iż w klinice, do której zwożeni są ranni robotnicy tuż po wojnie mieściło się UB:

\begin{abstract}
Rozstrzeliwali i grzebali. Pan wie, akowców i wszystkich tych, co mieli jakieś znaczenie, albo nie taili, że myślą inaczej niż oni. Pod głównymi schodami północnego pawilonu jest taka komora. Wciąż jeszcze rdzawe plamy wychodzą ze ścian na wierzch. Choć parokrotnie bielono wapnem. Tam to się odbywało. Nikt nie wie po nazwisku kogo, nikt nie wie ilu. [...] Gdzie tylko się ruszyć sama krzywda. [...] Albowiem te groby, pokryte dla zamaskowania kwietnymi klombami, te rabaty, gazony, trawniki i grzędy przyzwoicie przystrzyżone, wyplewione poczęły puchnąć w [...] oczach, olbrzymiały, wznosiły się coraz wyżej, opanowywały całą dostępną dla wzroku przestrzeń i wyobraźnię, potem rozpadały się i upalna cisza otoczona wysokim murem ogrodu kliniki zapełniła się krzykiem, krokami, szurgotem wleczonych ciał, zgrzytem łopat odwalających ziemię, głuchym łoskotem zwłok zrzucanych w głąb dołów $[\ldots]^{164}$.
\end{abstract}

Poznańskie Krzyże dowodzą łatwości, z jaką wydarzenia historyczne można (o czym - zdaniem Barbary Szackiej - najlepiej przekonuje casus stanu wojennego)

czerpiąc z repertuaru rodzimej symboliki, przekształcić $\mathrm{w}$ symbol [...] walki i oporu wobec prześladowczej i z nadania obcego sprawowanej władzy i włączyć do pamięci zbiorowej. W pamięci tej bowiem wydarzenia i postacie nie występują inaczej niż $\mathrm{w}$ powiązaniu z istotnymi dla tożsamości grupy wartościami i antywartościami $[\ldots]^{165}$.

Przypadek Poznańskich Krzyży (a raczej przypadki, jeśli weźmiemy pod uwagę także pomnik Mickewicza ${ }^{166}$ ) ma charakter wzorcowy, obrazuje bowiem uniwersalny proces instytucjonalnego konstruowania pamięci zbiorowej poprzez (narzucającą określoną interpretację przeszłości)

\footnotetext{
${ }^{163}$ Frank Ankersmit, Narracja, reprezentacja, doświadczenie, dz. cyt., s. 389.

${ }^{164}$ Włodzimierz Odojewski, Spisywane z pamięci, [w:] Jedźmy, wracajmy, dz. cyt., s. 279-280.

165 Barbara Szacka, Czas przeszły - pamięć - mit, dz. cyt., s. 203.

${ }^{166}$ Mam na myśli dość powszechne w okresie PRL (choć wywodzące się jeszcze z czasów zaborów) zjawisko tzw. pomników utajonych. Taki „utajony pomnik” upamiętniający ofiary Czerwca został wzniesiony w 1960 r. w Poznaniu: „Jawnie był to pomnik Adama Mickiewicza. Jednakże artysta, rzeźbiąc postać poety, ubrał modela w togę adwokacka, w której występował obrońca robotników skazywanych w procesach politycznych po robotniczych protestach w czerwcu 1956 roku, o czym Poznań wiedział" (tamże, s. 63).

Niezwykle znaczący dla zjawiska wpisywania Czerwca w (odwieczną) tradycję patriotyczno-martyrologiczną jest fakt, iż pomniki ulokowano we wzajemnym sąsiedztwie (oba znajdują się na placu Adama Mickiewicza).
} 
selekcję i „,montaż” treści przekazu (choć oczywiście można dostrzegać tu również charakterystyczną dla miejsc pamięci potrzebę stwarzania „wrażenia ciągłości"167):

postarano się, ażeby pomniki męczeństwa zaznanego za komunizmu i walki z komunizmem [...] pokazywały bunt jako nawiązujący do tradycji zdefiniowanej jako martyrologiczna tradycja katolickiego narodu polskiego. [...] Na pomniku Poznańskiego Czerwca do słów "Za wolność, prawo i chleb" dołączono formułę „O Boga”. Chyba dodano ją niedawno, gdyż mosiądz tej części napisu jest jeszcze wyraźnie mniej spatynowany. Do dat 1956, 1968, 1970, 1976, 1980 dodano też rok $1981^{168}$. Tuż obok pomnika zrobiono specyficzny murek, na którym mosiężne litery układają się w napis: „Sacratissimo Cordi Polonia Restituta 1918-1989". Obok zarysowano w mosiądzu sylwetkę dawnego pomnika Chrystusa Króla [...]. Bardzo chętnie łączy się wszystkie zbrodnie komunistyczne $\mathrm{w}$ jeden logiczny ciąg. Widoczna jest $\mathrm{w}$ tym tendencja do spłaszczenia zmienności tego systemu [...], który dziś widzi się bardzo jednolicie - ze szkodą dla rozumienia biegu dziejów ${ }^{169}$.

167 Zob. Paul Ricoeur, Pamięć, historia, zapomnienie, dz. cyt., s. 537.

168 Przypomnijmy, że 14 sierpnia 1981 r. w trakcie uroczystych obchodów pierwszej rocznicy strajku w Stoczni im. Lenina na plac przed pomnikiem poległych stoczniowców w Gdańsku jako pierwszy wjechał tramwaj z symbolicznym numerem "1956" (kolejne tramwaje oznaczono numerami „1968”, „1970", „1976”, "1980”). Dwa miesiące później w programie przyjętym na pierwszym zjeździe "Solidarności” umieszczono wstęp o znamiennym tytule: Kim jesteśmy $i$ dokąd dążymy. We wstępie czytamy: „Protest ekonomiczny musiał być zarazem protestem społecznym; protest społeczny musiał być zarazem protestem moralnym. Ten społeczny i moralny protest nie zrodził się z dnia na dzień [podkr. moje - N.K.-R.]. Jest w nim dziedzictwo krwi robotników poznańskich z 1956 roku i grudnia 1970 na Wybrzeżu, bunt studentów w 1968 roku, cierpienia Radomia i Ursusa w 1976 roku. Jest w nim dziedzictwo niezależnych działań robotników, inteligencji i młodzieży, wysiłków Kościoła o przechowanie wartości, dziedzictwo wszystkich walk o godność ludzką w naszym kraju. Związek nasz wyrósł z tych walk i pozostaje im wierny". Zob. Bronisław Baczko, Wyobrażenia społeczne, dz. cyt., s. 244.

${ }^{169}$ Marcin Kula, O co chodzi w historii?, Wyd. Uniwersytetu Warszawskiego, Warszawa 2008 , s. 272-274. W opinii historyka casus poznańskiego pomnika pozwala wyjaśnić zjawisko tzw. alfabetu historycznego (praktyki komunikacyjnej polegającej na wykorzystywaniu pewnych elementów z przeszłości jako współczesnego „kodu”): „Na pomniku Czerwca 1956 r. wypisane są daty: 1956, 1968, 1970, 1976, 1980, 1981. W 2000 r. Andrzej Lepper zaproponował dopisanie roku 1999 (data złamania rolniczych blokad na drogach przez policję). Ciekawa była wyrażona $\mathrm{w}$ tej propozycji chęć zaakcentowania przesłania ruchu poprzez usytuowanie go wśród ważnych wydarzeń historii". Zob. Marcin Kula, Krótki raport o użytkowaniu historii, dz. cyt., s. 276. W tym kontekście warto także przypomnieć, iż poznański pomnik Czerwca - w formie znaku graficznego - widniał na solidarnościowych drukach kolportowanych w drugim obiegu po 1981 roku.

Zdaniem Roberta Traby alternatywą dla tradycyjnej funkcji pomników może być tzw. pomnikoterapia. Tym określeniem posługuje się Krzysztof Wodiczko dla nazwania własnych projektów artystycznych. Zdaniem Wodiczki celem budowy pomnika nie może być zastępowanie i „domykanie” pracy pamięci, lecz rozwój analitycznej zdolności zachowania pamięci poprzez przekazywanie prowokujących, konkurujących ze sobą i uciszanych dotąd "głosów". Zob. Robert Traba, Historia - przestrzeń dialogu, dz. cyt., s. 89-90. 
W kontekście przytoczonych powyżej słów niezwykle znaczący jest $\mathrm{w}$ filmie Bajona brak stricte religijnego aspektu robotniczej rewolty ${ }^{170}$. Sfera sacrum obecna jest tylko w subiektywnym doznaniu dziecięcego bohatera i nie znajduje odzwierciedlenia $w$ doświadczeniu zbiorowości. A przecież w zdesakralizowanej przestrzeni istotny staje się każdy znak wskazujący na istnienie innego - ponadludzkiego - porządku. W Poznaniu 56 oczywistym - choć wskazanym bardzo dyskretnie - symbolem sacrum „zdegradowanego" jest porzucony wśród zalegających piwnicę rupieci obraz Najświętszej Marii Panny z Dzieciątkiem (fot. 6-7).
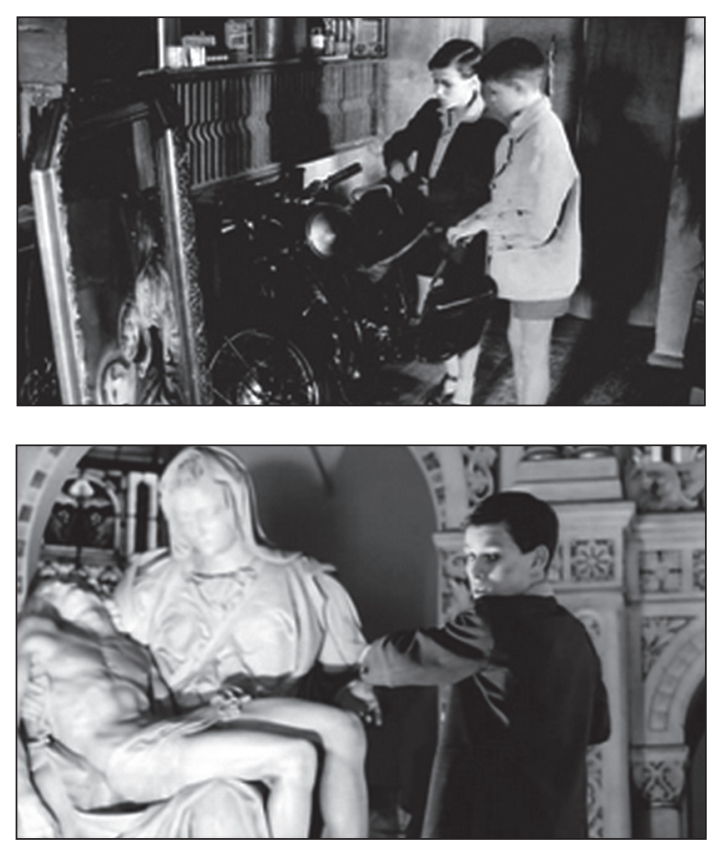

Fot. 6-7. Poznań 56 (1996, reż. Filip Bajon) Inicjacja w sacrum

Zdaniem większości krytyków dziecięca perspektywa oglądu zdarzeń stanowi potwierdzenie autobiograficznego charakteru filmowej wypowiedzi Bajona (w czerwcu 1956 r. reżyser był w wieku Darka). Zaryzykuję jednak tezę, iż w Poznaniu 56 Bajon nie zawiera z widzem - by posłużyć się terminologią Lejeune'a - paktu powieściowego, przy którym odbiorca,

${ }^{170}$ Bachtin podkreśla, iż wszelkie obrzędowo-widowiskowe formy karnawału miały konsekwentnie charakter pozakościelny i pozareligijny. Należały do całkowicie odmiennej niż Kościół i religia sfery istnienia. Zob. Michaił Bachtin, Twórczość Franciszka Rabelais'ego, dz. cyt., s. 63. 
opierając się na domniemanych przez siebie podobieństwach ma prawo sądzić, że zachodzi tożsamość autora i postaci ${ }^{171}$, lecz pakt fantasmagoryczny. W utworach, których lektura wymaga zawarcia $\mathrm{z}$ autorem tego rodzaju paktu pojawiają się wskazówki sugerujące odbiorcy, by potraktował dzieło jako fantazmat odkrywający prawdę o osobowości autora ${ }^{172}$. W Роznaniu 56 wspomnianych wskazówek należy poszukiwać głównie w tzw. wątku profesorskim.

Tę interpretacyjną intuicję uprawomocnia niezwykle osobista deklaracja Bajona:

nie lubiłem „Solidarności” z jednego powodu. Dla mnie to był kolejny masowy ruch robotniczy, tylko tym razem pod sztandarami Kościoła i solidaryzmu społecznego. Ja się źle czuję w masowych ruchach, zwłaszcza robotniczych, bo szczerze sobie powiedzmy, ja nie mam nic wspólnego z robotnikami. A hasła narodowe na mnie słabo działają. [...] W sojusz inteligencko-robotniczy nigdy nie wierzyłem. Było w tym dla mnie coś fałszywego z obu stron ${ }^{173}$.

Dokonując dekonstrukcji solidarnościowego mitu sojuszu inteligencko-robotniczego, Bajon wprowadza do filmu także perspektywę „drugiej strony". W jednej ze scen robotniczy przywódca Stach - przysłuchujący się histerycznemu monologowi Zosi o mieszkaniu - z nieskrywaną ironią rzuca w stronę Zenka: Nauczycielka. O czym ty z nia gadasz?!

${ }^{171}$ Philippe Lejeune, Wariacje na temat pewnego paktu. O autobiografii, dz. cyt., s. 34.

172 Tamże, s. 54.

${ }^{173}$ Włodzimierz Braniecki, Szczun, dz. cyt., s. 104. O solidarnościowym micie wspólnoty pozytywnej pisze Czapliński: „wbrew [literackim] diagnozom rozpadu, miazgowatości, i «zgnojenia», społeczność okazała się zdolna do odrodzenia mitów wspólnotowych. Mity te konsolidowały tożsamość zbiorowa, a równocześnie nadawały sens życiu jednostkowemu". Zob. Przemysław Czapliński, Polska do wymiany, dz. cyt., s. 188. Na temat solidarnościowego mitu porozumienia inteligencko-robotniczego w ciekawy sposób wypowiada się Jadwiga Staniszkis. Zob. Życie umysłowe i uczuciowe. Z Jadwiga Staniszkis rozmawia Cezary Michalski, Wyd. Czerwone i Czarne, Warszawa 2010, s. 152-153.

Sceptyczny stosunek Bajona do „Solidarności” można tłumaczyć w kontekście mechanizmów kształtowania świadomości zbiorowej. Zdaniem socjologów wraz z powstaniem ruchu solidarnościowego „w obiegu znalazły się przede wszystkim zmityzowane wersje przeszłych wydarzeń, podania przekazywane $\mathrm{w}$ rodzinie, uwidoczniły sie też stereotypy i uprzedzenia. Często język opisu przeszłych wydarzeń nie przystawał już do nowych czasów. Tematy takie, jak Katyń, gułag, Czerwiec ' 56 były to częściej figury dyskursu mitycznego, odsłanianego przed pokoleniami 20-40-latków, niż elementy historycznej debaty". Zob. Lech Nijakowski, Polska polityka pamięci, dz. cyt., s. 121-122.

W okresie pierwszej „,Solidarności”: „,codzienna komunikacja pełna była odwołań do powstań narodowych, okupacji i ruchu oporu. Języki społeczne lokowały «Solidarność» w panteonie polskich dziejów, rezerwując Sierpniowi miejsce tuż obok Powstania Warszawskiego, zaś doświadczenia stanu wojennego umieszczając gdzieś na Syberii". Zob. Przemysław Czapliński, Polska do wymiany, dz. cyt., s. 193. 
Czy można zatem uznać, że postawę reżysera - zdystansowanego poznańskiego inteligenta - reprezentują $\mathrm{w}$ filmie przedstawiciele naukowej elity uwięzieni na kolejowej bocznicy? Sposób poprowadzenia wątku profesorskiego (cztery sceny należące do tego wątku pojawiają się na zasadzie interludiów) przywołuje nieuchronne skojarzenia $\mathrm{z}$ grecką tragedia, w której istotną rolę pełnił komentujący wydarzenia chór. Profesorowie polskich uniwersytetów to jednak antyczny chór á rebours: „chór”, który widzi niewiele i niewiele rozumie. Inteligenci (intelektualiści) w filmie Bajona stanowią zatem byt w podwójnym sensie "zredukowany". Bourdieu definiuje:

Intelektualista jest, by tak rzec, bytem dwuwymiarowym. Może istnieć i przetrwać wtedy (i tylko wtedy), jeśli jest obdarzony autorytetem specyficznym, udzielanym przez świat intelektualny cieszący się autonomią (czyli niezależny od władzy religijnej, politycznej, ekonomicznej), którego specyficzne prawa uznaje, oraz wtedy (i tylko wtedy), jeśli angażuje ten specyficzny autorytet w walki polityczne ${ }^{174}$.

Symbolem nieprzekraczalnej granicy oddzielającej „inteligencki chór" od zrewoltowanych robotników ${ }^{175}$ jest niedające się otworzyć okno (motyw zamkniętego okna jest silnie eksponowany w całym wątku profesorskim) (fot. 8-9).

W najbardziej drastycznej scenie Poznania 56 - scenie masakry na dworcu - profesorowie biernie przyglądają się wypadkom. I właśnie podczas tego „wejścia” - jedyny raz w całym utworze - filmowani są przez kamerę ustawioną na zewnątrz wagonu i śledzącą ich reakcje przez szybę. Wydarzenia, których profesorowie stali się mimowolnymi świadkami, przekraczają zdolność konceptualizacji. Okazują się - w dosłownym tego słowa znaczeniu - niepojęte:

Profesor 1: Przecież panowie, to nie dziecinna grzechotka. Przecież to jest regularna...

Profesor 2: Strzelanina? To kolega miat na myśli?

${ }^{174}$ Pierre Bourdieu, Reguty sztuki, dz. cyt., s. 508.

${ }^{175}$ Przywołana scena - jak i cały „wątek profesorski” - stanowi czytelne odwołanie do silnie obecnego w publicznym dyskursie po 1989 r. wątku oderwania elit intelektualnych od mas i narastającej marginalizacji roli inteligencji w życiu społecznym (potwierdzeniem tego procesu były już wybory prezydenckie w 1990 r., podczas których głosowano na „Króla Ubu z Peru”). Paweł Śpiewak pisze: „zmiana pozycji i roli inteligenta otwierała nas też na pytanie o polską tożsamość, zrywającą z dawnymi, postromantycznymi i inteligenckimi właśnie, wyobrażeniami”. Zob. Paweł Śpiewak, Pamięć po komunizmie, dz. cyt., s. 100. Oczywiście można „wątek profesorski” interpretować w znacznie szerszym kontekście „obrachunków inteligenckich” (o literaturze obrachunkowej pisze m.in. Kazimierz Wyka w książce Pogranicze powieści). 
Profesor 3: Właśnie. Właśnie. Kto strzela? Do kogo? No? Ktoś przecież zabrał klucz od wagonu. Ktoś odłaczył lokomotywę. Ktoś wiedziat, co robi. [...]

Profesor 2: Zastanówmy się, co możemy wydedukować na podstawie naszej wiedzy i obserwacji? Tylko błagam, prędko.

Dziekan: Profesorze, sytuacja strajkowa w Poznaniu była już od dawna.

Profesor 3: Ależ oczywiście. Robotnicy chcieli podwyżki. Nie załatwili.

Profesor 5: W Poznaniu? Niemożliwe.

Profesor 2: Tak, to znaczy, że sie nic nie dzieje.

Profesor 3: Dzieje się. Dzieje. Dzieje. I nic nie możemy zrobić.

Profesor 2: Tak? A co by pan zrobił, gdyby pan mógt? Pytam tak tylko czysto teoretycznie, na podstawie takiej zabawy mózgowej dla pozamykanej profesury.
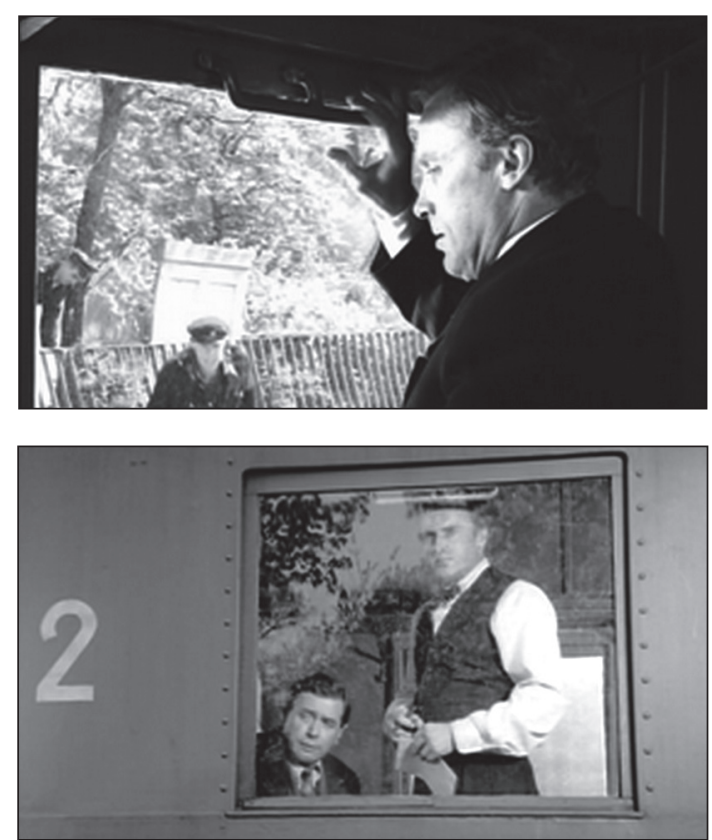

Fot. 8-9. Poznań 56 (1996, reż. Filip Bajon) „Zabawa mózgowa dla pozamykanej profesury"

Historia ukazywana w momencie "stawania się" jest chaosem. Później przychodzi egzegeza, prawda, nazwanie i opowiedzenie ${ }^{176}$. Tę funkcję „dyskursywną” ma do spełnienia inteligencja. Filmowe „rekonstrukcje historii” to fundamentalny we współczesnej kulturze czynnik determinujący pamięć zbiorową. Pamięć zbiorowa decyduje zaś o tożsamości grupowej oraz stopniu spoistości grup i zdolności do mobilizowania własnych członków m.in. poprzez mechanizm odwoływania się do

${ }^{176}$ Włodzimierz Braniecki, Szczun, dz. cyt., s. 134. 
postaci i wydarzeń z przeszłości, traktowanych jako symbole i wartości ${ }^{177}$. W odniesieniu do grupy definiowanej jako inteligencja (tu: $w$ znaczeniu elity intelektualnej kraju) Poznań 56 dekonstruuje dwie podstawowe funkcje pamięci zbiorowej: integracyjną (tożsamościową) oraz legitymizacyjno-adaptacyjną. Dodatkowy - jakże zgodny z "antybrązowniczą" strategią Bajona - sens zyskuje „wątek profesorski” w kontekście sławetnych słów wypowiedzianych przez Władysława Gomułkę: „My dopiero musimy wychować naszych profesorów". W tym ujęciu byłby zatem Poznań 56 gorzkim filmowym świadectwem tezy, iż przed październikową „odwilżą"

inteligencja w dawnym tego pojęcia znaczeniu i społecznej charakterystyce już nie istniała, trudno było także nawet marzyć o wyzwoleniu jej z wszechwładzy zideologizowanego państwa. Proces uzależniania warstwy, rozpoczęty po wojnie, przybrał w okresie stalinizmu postać całkowitego zawłaszczenia. Inteligencja, zgodnie z przypisaną jej rolą pełniła funkcje służebne wobec systemu, stając się instrumentem polityki indoktrynacji i ideologizacji życia kulturalnego ${ }^{178}$.

Twórca Poznania 56 z ogromnym sceptycyzmem odnosi się zwłaszcza do kulturotwórczej misji inteligencji:

Inteligencja zawsze dochodzi później. Ponieważ musi mieć więcej czasu. Jak już dochodzi, to ma gotowe formuły. Natomiast inteligencja, która ogląda coś, jest bezradna, sceptyczna, śmieszna i pozbawiona narzędzi do rozpoznania ${ }^{179}$.

Historyk - pisze Grażyna Gajewska - pisze historię ex post, sytuując przedmiot dociekań poza sferą własnych doświadczeń. Obserwuje ją bada i analizuje, ale w niej nie uczestniczy ${ }^{180}$. Wprowadzając do filmu wątek profesorski - spuentowany ironicznym dialogiem:

Dziekan: Proszę szanownego grona, myślę, że pora na jakieś podsumowanie, co?

Profesor 2: Podsumowanie to sobie kolega Dziekan przeczyta w jutrzejszej gazecie.

Profesor 3: Nie napisza...

Lech Nijakowski, Polska polityka pamięci, dz. cyt., s. 49.

${ }^{178}$ Rafał Habielski, Stużba i wartości. Konteksty oraz okoliczności debat o inteligencji polskiej (XIX-XXI wiek), [w:] Inteligencja w Polsce. Specjaliści, twórcy, klerkowie, klasa średnia, red. Henryk Domański, Wyd. IFiS PAN, Warszawa 2008, s. 232. W przywołanym kontekście film Bajona można uznać za kontynuację nurtu obrachunków inteligenckich w kinie moralnego niepokoju. W literaturze paradygmatycznym tekstem diagnozującym kryzys polskiej inteligencji w okresie stalinizmu jest oczywiście Zniewolony umyst (1953) Czesława Milosza.

${ }^{179}$ Włodzimierz Braniecki, Szczun, dz. cyt., s. 141.

${ }^{180}$ Grażyna Gajewska, O cierpieniu i przyjemności zwiąanej z (re)produkowaniem przeszłości, [w:] Kultura przyjemności. Rozważania kulturoznawcze, red. Jan Grad, Hanna Mamzer, Wyd. Naukowe UAM, Poznań 2005, s. 165. 
Profesor 4: Napisza, napisza. Przecież tu były Targi. To się działo na oczach świata...

Dziekan: Mam nadzieję, że nie ma kolega siebie na myśli.

Profesor 4: Nie. Przecież ja nic nie widziatem...

Dziekan: Znaczy się, nic żeśmy nie widzieli.

Profesor 2: Klamki w sraczu. To obejrzałem z detaliczna dokładnością.

reżyser zadaje również pytanie o wiarygodność przyszłych narracji historycznych (zmitologizowanych wyobrażeń) konstruowanych na podstawie obserwacji klamek w sraczu.

\section{„Walka z komunizmem" jako (Kunderowski) kicz}

Zanim zostaniemy zapomniani, przemieni się nas w kicz.

Kicz jest stacją tranzytową pomiędzy bytem a zapomnieniem.

Milan Kundera

Analizując przyczyny artystycznej porażki obrazu Kutza Śmierć jak kromka chleba, Filip Bajon posłużył się pojęciem „kiczu”. Prowokacją ze strony artysty było jednak odniesienie tego pojęcia nie tyle do filmowej „rekonstrukcji” wydarzeń Grudnia '81, ile do „rzeczywistości samej w sobie". Zdaniem Bajona:

Klęska „Wujka” polegała na tym, że Kutz rzeczywiście bardzo dokładnie sfilmował tę rzeczywistość 1981 roku, że po prostu ta rzeczywistość była tak kiczowata, że jak weszła na ekran i ją zobaczyliśmy, to się zrobił film niedobry. [...] ja na przykład rzeczywistość z "Solidarnością" w tle odbierałem źle, dlatego, że ta rzeczywistość była dla mnie pozbawiona jakiejkolwiek tajemnicy. Była dychotomiczna, albo człowiek jest zły, albo dobry. Dobry jest w „Solidarności”, zły jest poza „Solidarnością”. [...] I oczywiście to niebezpieczeństwo istniało przy "Poznaniu 56". Ja sobie zdawałem $\mathrm{z}$ tego sprawę od samego początku, że to jest mina, na którą wchodzę [... $]^{181}$.

Istotnym elementem procesu interpretacji Poznania 56 byłoby zatem wprowadzenie - nieobecnego w refleksji krytycznej poświęconej filmowi - „wątku Kunderowskiego". Podjęcie tego wątku pozwoli - przez odwołanie do konkretnych przykładów - zrekonstruować strategię twórcy i ujawni celowość budzących tak wielkie kontrowersje rozwiązań fabularno-formalnych.

${ }^{181}$ Włodzimierz Braniecki, Szczun, dz. cyt., s. 128-129. 
W przytoczonej wypowiedzi Bajon podkreślił zagrożenie - „zakodowane" w samej materii rzeczywistości - czyhające na artystę, pragnącego uniknąć pułapek (usprawiedliwionego etycznie?) redukcjonizmu. Na to zagrożenie zwracał uwagę Milan Kundera. Zdaniem Marioli Jankun-Dopartowej w prozie Kundery rzeczywistość tworzą

nawarstwiające się odmiany kiczu i nie ma między nimi żadnej łączności. Kicz ten jest wytworem zarówno indywidualnej percepcji i interpretacji, jak i życia zbiorowego, powstaje zarówno w kulturze wysokiej, jak i popularnej. [...] Człowiek, który rozcina płótno kiczu, pada ofiarą spłyconego, zredukowanego przez patrzących obrazu: powiela kicz prowokatora, kontestatora, dysydenta czy po prostu rozrabiacza - oswaja i uprzytulnia zimne, obce i przepastne prawdy. Groźna rzeczywistość zamienia się w ozdobiony sztucznymi kwiatami i falbankami pokoik z napisem „Postawy buntownicze” lub „Ból emigracji”. [...] Kundera ostrzegał: rzeczywistość krajów bloku wschodniego poniekąd skazała wartościowe jednostki na status „walki z komunizmem", co schwytało człowieka w estetyczną i etyczną pułapkę, wydzierającą mu podmiotowość i utrudniającą samopoznanie ${ }^{182}$.

Przystępując do realizacji Poznania 56 Bajon miał świadomość, iż wydarzenia Czerwca (zwłaszcza w oficjalnym „rocznicowym” dyskursie) zdążyły już ulec przekształceniu w „kicz”: stereotyp „walki z komunizmem". Wieloaspektowa rzeczywistość została w nim zredukowana do czytelnego dla wszystkich obrazu-symbolu, który dałoby się z łatwością przedstawić w postaci tableaux: „Ranne tramwajarki, upadający sztandar biało-czerwony i chłopiec, który przejął ten sztandar i stał z nim przed gmachem UB mimo strzelaniny"183.

Takiego obrazu próżno by jednak szukać w filmie Bajona. $\mathrm{O}$ „mitycznym" zdarzeniu wspomina się jedynie pod koniec filmu. W sekwencji szpitalnej starszy mężczyzna wygłasza na temat „małego bohatera” lakoniczny monolog, zakończony pełnym gorzkiej ironii komentarzem: $W a-$ riacja. Czysta wariacja. Wspomniany monolog uruchamia w pamięci widza ciąg skojarzeń wiodących do Munkowskiej Eroiki, której bohater - niemal tymi samymi słowami - podsumował Powstanie Warszawskie. Gdyby wśród rannych robotników znajdował się Dzidziuś Górkiewicz, mógłby na widok okaleczonego Zenka zakrzyknać: Głupota! Wariactwo! Nie szkoda zdolnego mężczyzny?! !184

Wiele lat po przedstawionych w filmie Bajona wydarzeniach badacze nadal nie są zgodni w ocenie Czerwca:

\footnotetext{
${ }^{182}$ Mariola Jankun-Dopartowa, Gorzkie kino Agnieszki Holland, słowo obraz/terytoria, Gdańsk 2000, s. 193-200.

${ }^{183}$ Edmund Makowski, Poznański Czerwiec 1956, dz. cyt., s. 116.

${ }^{184}$ Cytat z filmu Eroika.
} 
Od 1981 r., czyli od momentu, kiedy można było bardziej otwarcie pisać o tym, co się wydarzyło w Poznaniu, najczęściej używa się nazwy Poznański Czerwiec lub po prostu Czerwiec. Do dzisiaj wśród historyków toczy się debata, czy Poznański Czerwiec należy określić mianem powstania, czy też miał on tylko niektóre elementy zrywu narodowego ${ }^{185}$.

Kwestią sporną pozostaje zatem kwalifikacja zdarzeń. Dyskusje dotyczące Czerwca ogniskują się głównie wokół pytania, czy istnieją dostateczne podstawy (przy uwzględnieniu żywiołowego charakteru, braku zaplecza organizacyjnego i skonkretyzowanego programu ${ }^{186}$ ), by poznańską „,rewoltę głodową" zaliczyć w poczet polskich powstań narodowych? Podobne debaty mają w Polsce wieloletnią tradycję, a w poszukiwaniu jej źródeł należałoby się cofnąć do okresu zaborów. To wówczas bowiem

Protesty i strajki, spontaniczne lub planowane, szybko stawały się głośne wśród rodaków, stając się widomym znakiem oporu i narodowej niezależności. [...] Choć często bezpośredni cel strajku był pragmatyczny i wiązał się z obroną praw nabytych lub uzyskaniem koncesji od władz, to jednak bardzo szybko takie wystąpienia uzyskiwały wyrazisty, intencjonalny przekaz mający wzmacniać pamięć i tożsamość narodową ${ }^{187}$.

Przytoczona wypowiedź stanowić może potwierdzenie „podwójnego" charakteru pamięci zbiorowej. Pamięć ta - jak podkreśla Baczko - ma bowiem zarówno „wymiar zdarzeniowy”, jaki i „wymiar głęboki”, w którym przejawiają się długotrwałe struktury i tendencje. Podczas okresów "gorących" zdarzenia stają się okazją do ujawnienia owych tendencji i struktur ${ }^{188}$. W odniesieniu do Czerwca za "strukturę długotrwałą" należałoby uznać tradycję powstańczą (ze szczególnym uwzględnieniem tradycji Powstania Warszawskiego ${ }^{189}$ ), potwierdzającą ciągłość historii narodu i jego wolę niepodległości.

${ }^{185}$ Paulina Codogni, Rok 1956, dz. cyt., s. 214.

186 Zob. Krzysztof Ruchniewicz, Czerwiec i Październik 1956 r. w społecznym obrazie przeszłości Polski, [w:] Przemiany pamięci społecznej a teoria kultury, red. Bartosz Korzeniewski, Instytut Zachodni, Poznań 2007, s. 96.

${ }^{187}$ Lech Nijakowski, Polska polityka pamięci, dz. cyt., s. 87.

${ }_{188}$ Bronisław Baczko, Wyobrażenia społeczne, dz. cyt., s. 213.

189 Głęboki wymiar pamięci zbiorowej w kontekście oddziaływania „długotrwałej struktury" Powstania Warszawskiego ujawnił się w okresie pierwszej „Solidarności”: „Wiosną 1981 roku, kiedy konflikt z władzą zaostrza się i nieunikniona wydaje się gwałtowna konfrontacja, «młodzi» zwracają się do «starych», którzy przeszli przez ruch oporu, aby dowiedzieć się, jak zrobić «koktajl Mołotowa», jak zorganizować sieć podziemną itp. Ogólnie biorąc, wspomnienia z czasów ruchu oporu, zwłaszcza z Powstania Warszawskiego, cieszą się tym większym zainteresowaniem i prestiżem, że władza ograbiła z nich zarówno «starych», jak i «młodych»" (tamże, s. 236). 


\section{Z drugiej jednak strony sondaż OBOP przeprowadzony w roku pre-}

miery filmu Bajona ujawnił, iż

generalnie termin powstanie używany jest przez Polaków w odniesieniu do czasów przed 1945 r. Antykomunistyczne zrywy nie są przez społeczeństwo obdarzane takimi określeniami, w czym widzieć można zwycięstwo polityki historycznej uprawianej przez władze komunistyczne. [...] w kontrolowanym obiegu krajowym zwyciężyła koncepcja władz nazywania wszystkich kryzysów wewnętrznych mianem „wypadków”"190 i „wydarzen" ${ }^{191}$.

Badacze, udzielający pozytywnej odpowiedzi na pytanie, czy w Czerwcu doszło w do powstania narodowego, podkreślają, iż w 1956 r. żywe były sprawy wojny, AK, Powstania Warszawskiego, a historycznie ukształtowany w Polsce wzór powstańczy i konspiracyjny był obecny jako punkt odniesienia w Poznaniu ${ }^{192}$. Na podstawie analizy materiałów źródłowych zarchiwizowanych w Wojewódzkim UB wskazywano na

te elementy zachowań i postaw ludności Poznania, które miały charakter narodowy. Używanie barw narodowych w postaci flag i opasek, pieśni związane z tradycją narodową i katolicka, antyradzieckie i antyrosyjskie hasła ${ }^{193}$.

O tym, że był to wzór odpowiadający społecznym potrzebom świadczy fakt, iż „zdominował" on w świadomości zbiorowej inną tradycję - również w wydarzeniach Czerwca odzwierciedloną ${ }^{194}$ - robotniczych prote-

190 „Wypadki - definiuje Arendt - z definicji są zdarzeniami, które przerywają zwykły bieg rzeczy i zwykłe ustalone procedury [...]". Zob. Hannah Arendt, O przemocy. Niepostuszeństwo obywatelskie, tłum. Anna Łagodzka, Wojciech Madej, Wyd. Aletheia, Warszawa 1999, s. 12.

${ }^{191}$ Krzysztof Ruchniewicz, Czerwiec i Październik 1956 r. w społecznym obrazie przeszłości Polski, dz. cyt., s. 89-95.

${ }^{192}$ Marcin Kula, Ku jakiej syntezie polskiego Października?, dz. cyt., s. 235-236. Warto w tym miejscu odwołać się do świadectwa ikonograficznego - zrealizowanego w 1981 r. (premiera telewizyjna: 30 czerwca 1991 r.) dokumentu Tadeusza Litowczenki Poznań 1956. Marcin Kula posłużył się przykładem zaczerpniętym z tego właśnie filmu w kontekście analizy „obrazu powstań narodowych jako instrumentu rozpoznawania sytuacji w Polsce za komunizmu”: , pewien uczestnik tych [czerwcowych] wydarzeń opowiadał, że gdy został ranny w nogę, podeszły do niego dziewczyny, które przedstawiły się jako «Powstańcza Służba Sanitarna»; dalej ów człowiek mówił przed kamerą: «Poczułem się jak podczas Powstania Warszawskiego»". Zob. Marcin Kula, Krótki raport o użytkowaniu historii, dz. cyt., s. 314. Z drugiej strony to "aktywna” pamięć o Powstaniu Warszawskim (obok doświadczenia węgierskiego) stanowiła, być może, powód, dla którego poznańska "gorączka" nie ogarnęła w 1956 r. całego kraju (przeciw wystąpieniom typu powstańczego opowiedzieli się m.in. kardynał Wyszyński, przedstawiciele rządu RP na obczyźnie, generał Bór-Komorowski).

${ }^{193}$ Krzysztof Ruchniewicz, Czerwiec i Październik 1956 r. w społecznym obrazie przeszłości Polski, dz. cyt., s. 95.

${ }^{194}$ Przypomina o tym właśnie Marcin Kula: „Przez pewien czas w strajkach, jakie mimo wszystko wybuchały także w PRL, inspirowano się doświadczeniem przedwojennym. 
stów z okresu II Rzeczpospolitej. Wedle Marcina Kuli zadecydował o tym najważniejszy element „,społecznego lepiszcza”, jakim jest przelana krew ${ }^{195}$.

Za niezwykle znaczącą należy zatem uznać niechęć do posługiwania się wobec Wypadków Poznańskich odniesieniami do pojęcia „rewolucji” (definiowanego przez Reinharda Kosellecka jako powiązane z przemocą zamieszki powstania, które przerodzić się mogą $\mathrm{w}$ wojnę domowa, prowadząc do zmiany ustroju ${ }^{196}$ ). A przecież już w XVIII w. - jak podkreśla Koselleck - rewolucja stała się tytułem do legitymizacji zmian, które dotąd obejmowało tabu lub które nie weszły jeszcze do obszaru doświadczenia. Bycie buntownikiem miało konotację negatywna, bycie rewolucjonistą miało sens pozytywny ${ }^{197}$. Na marginesie warto zauważyć, iż rewolucyjne święta - o czym pisze Mona Ozouf w odniesieniu do Rewolucji Francuskiej - miały często wyraźny rys karnawałowy (tzw. kompensacyjna inwersja). Zdaniem autorki pojawiające się w strukturze tych świąt

epizody parodystyczne odsyłają nie tyle do innowacyjnych zdolności zbuntowanych mas, ile do rytualnych form karnawału: służą w istocie pożegnaniu starego świata i głoszeniu w prowokującej lub grożącej formie, prawa świata nowego ${ }^{198}$.

W wymiarze bardziej uniwersalnym pisze o naśladowaniu tradycyjnych wzorców (w tym wypadku: powstańczych) Victor Turner. Autor zwraca uwagę na zjawisko „kompulsji”. Zapożyczone od Freuda pojęcie oznacza proces przymusowej repetycji, podczas którego pewne działania zostają powtórzone w symbolicznym mimesis i stają się zrutynizowanymi formami struktury - wzorcami powtarzalnego zachowania społecznego ${ }^{199}$. Zdaniem Turnera historia powtarza głęboko zakorzenione mity kultury, powołane do życia podczas wielkich kryzysów społecznych, w punktach zwrotnychzwiastującychzmianę. W procesach pierwotnychaktualizowane są mity stanowiące modele procesów dramaturgicznych i narracyjnych.

[...] W 1956 r. w Poznaniu pochód, który wyruszył z ZISPO 28 czerwca, przeszedł tradycyjną trasą pochodów robotniczych w okresie międzywojennym". Zob. Marcin Kula, Krótki raport o użytkowaniu historii, dz. cyt., s. 238.

195 „Ona - podkreśla Kula - bardzo mocno jednoczy czy to naród, czy grupę, czy ruch społeczny. [...] Robotnicy Gdańska zjednoczyli się wokół pamięci 1970 r., gdyż była to pamięć ich zabitych kolegów. Potem ruch «Solidarności» z palety wydarzeń $1956 \mathrm{r}$. akcentował zwłaszcza bunt poznański. Były po temu różne przyczyny. Na bardzo ważnym miejscu wśród nich sytuowała się jednak przelana krew [...]" (tamże, s. 343).

196 Zob. Reinhart Koselleck, Dzieje pojęć. Studia z semantyki i pragmatyki języka społeczno-politycznego, tłum. Jarosław Merecki, Wojciech Kunicki, Oficyna Naukowa, Warszawa 2009, s. 260.

197 Tamże, s. 263.

198 Zob. Mona Ozouf, Święto rewolucyjne 1789-1799, tłum. Andrzej Siemek, Oficyna Naukowa, Warszawa 2008, s. 114-123.

199 Victor Turner, Gry społeczne, pola i metafory, dz. cyt., s. 210. 
Wydaje się - podkreśla Turner - że kiedy rozpoczyna się znaczący proces publicznej gry społecznej, ludzie - świadomie, podświadomie lub nieświadomie - przyjmują role, które nawet jeśli nie mają szczegółowo napisanych scenariuszy, z głębi swojej istoty narzucają [wykonawcy] grę i mówienie w ponadosobowy, reprezentatywny sposób zgodny z przyjętą rolą oraz przygotowanie pewnej kulminacji, pokrewnej kulminacji w niektórych centralnych mitach o śmierci lub [...] o zwycięstwie przez śmierć - za pomocą których wykonawcy byli intensywnie indoktrynowani lub socjalizowani, lub poddawani akulturacji $[\ldots]^{200}$.

\section{Za (mitycznym) powstańczym rodowodem Czerwca w sposób niezwy-} kle przekonujący przemawia sugestywny opis Edmunda Makowskiego:

Były podczas poznańskiego buntu sceny jakby żywcem przeniesione z Powstania Wielkopolskiego 1918/1919 i Powstania Warszawskiego 1944 roku: grupa dzieci z biało-czerwonymi choraggiewkami na czele pochodu ulicznego, wyrzucanie obcych choragiewek i zastępowanie ich narodowymi, obrzucanie i podpalanie czołgów butelkami z benzyna, biało-czerwone opaski na rękawach cywilnych bojowników i sanitariuszek, próba rozszerzenia buntu na teren $\mathrm{kraju}^{201}$.

W Роznaniu 56 wizualnym ekwiwalentem tego opisu jest sekwencja walki ulicznej. Kamera w powolnej panoramie odsłania „scenę powstańczą". Pierwszy plan wypełnia monumentalna sylweta czołgu sunącego ulicami miasta. W tle, pod osłoną murów, przemykają się uzbrojeni w karabiny „powstańcy”, a w anonimowym tłumie miga przez chwilę biały czepek sanitariuszki. Na ekranie - jak w pamiętnych dziełach polskiej szkoły filmowej - pojawiają się obrazy-znaki stanowiące doskonałą egzemplifikację idei kina narodowego konstruującego pewną symbolikę wydarzeń istotnych dla tożsamości Polaków ${ }^{202}$. Dzięki takiemu zabiegowi Warszawa z 1944 r. i Poznań z roku 1956 łączą się, tworząc - by posłużyć się metaforą Micheleta - „wspólne miasto”, gdzie umarli dzierżą najwyższą władzę nad działaniami żywych ${ }^{203}$.

200 Tamże, s. 101.

${ }^{201}$ Edmund Makowski, Poznański Czerwiec 1956, dz. cyt., s. 301. W trakcie lektury tak silnie działających na wyobraźnię opisów zaciera się - jakże ważna dla interpretacji Czerwca jako powstania - świadomość, iż wydarzenia z1956 r. miały scenariusz stricte interakcyjny. „Interakcjoniści symboliczni - jak pisze Elżbieta Hałas - słusznie wskazuja, że symboliczna natura protestu nie polega wyłącznie na działaniu komunikacyjnym grup protestujących, ponieważ znaczenie protestu zależy także od działań będących nań odpowiedziami". Zob. Elżbieta Hałas, Symbole i społeczeństwo, dz. cyt., s. 76. Przypomnijmy zatem, iż czerwcowe wystąpienie robotnicze miało charakter spontaniczny i w początkowych fazach było pokojowym protestem, a nie działaniem zbrojnym.

${ }^{202}$ Martyna Olszowska, Mit Powstania Warszawskiego a polskie kino narodowe, [w:] Kino polskie jako kino narodowe, dz. cyt., s. 152.

${ }^{203}$ Zob. Idith Zertal, Naród i śmierć. Zagłada w dyskursie i polityce Izraela, tłum. Jan Maria Kłoczowski, Universitas, Kraków 2010, s. 23-24. 
Wielkie klęski militarne - tłumaczy Idith Zertal - niczym fabryki produkujące ofiary uświęcane na ołtarzu narodu, są kluczowym elementem kształtowania tożsamości narodowej: wątek narodowej sagi budowany jest od początku do końca z opowieści o tych doświadczeniach. Opowieść zmienia się w baśń o bohaterstwie i triumfie, z której naukę czerpać mają dzieci-żołnierze-ofiary narodu. Z takich obrazów i wyobrażeń rodzi się pragnienie, by samemu polec na polu chwały ${ }^{204}$.

W „sekwencji powstańczej” kadry nasycone są szczegółami, zagęszczone do granic możliwości percepcyjnych widza. Drobiazgowa „rekonstrukcja” tamtych czasów nie wzmacnia jednak „wrażenia realności”, lecz - paradoksalnie - przyczynia się do jego osłabienia. Omawiana sekwencja zakorzeniona jest bowiem nie tyle w rzeczywistości 1956 r., ile... w kinie drugiej połowy lat $50 .{ }^{205}$ Bajon aktywizuje pamięć Powstania, nakładając na nią mediatyzujący filtr w postaci filmów szkoły polskiej. Nie odwołuje się przy tym do jakiegoś konkretnego filmu, ale do pewnego stylu wizualnego i typu narracji (konwencji wypowiedzi) „zakodowanych" w zbiorowej świadomości. W tym sensie można uznać, iż „,sekwencja powstańcza" stanowi przykład Baudrillardowskiej hiperrealnej rekonstrukcji2 ${ }^{206}$. Historia, która zostaje nam w ten sposób „zwrócona”

ma z "rzeczywistością historyczną" związek równie niewielki jak nowa figuracja w malarstwie z klasyczną figuratywnością rzeczywistości. Nowa figuracja stanowi przywołanie podobieństwa, lecz jest jednocześnie niepodważalnym dowodem zniknięcia przedmiotu w samym akcie jego przedstawienia: w hiperrzeczywistości ${ }^{207}$.

Uruchamianie rozmaitych tropów aluzyjnych to fundament procesu komunikacji z widzem. W ten sposób Bajon niejako zmusza odbiorcę, by rozszerzył interpretacyjny kontekst, w którym umieszczone zostały czerwcowe wydarzenia.

Proponuję uznać historyczną narrację szkoły polskiej - na wzór narracji romantycznej - za

${ }^{204}$ Tamże.

${ }^{205}$ W dalszej części wywodu zwracam uwagę na „Wajdowski” rodowód ujęć o wyjątkowym ładunku dramaturgicznym i semantycznym.

${ }^{206}$ Można by ją także uznać za przykład „autotematycznego hiperrealizmu”, który zdaniem Maryli Hopfinger jest „dialogiem z obrazem rzeczywistości reprodukowanej przez środki masowej komunikacji, której wyglądową jakość - obok mechanizmów reprodukcji fotograficznej - kształtują względy ideologiczne: gra interesów, polityczne racje, kulturowe standaryzacje, wreszcie reklamowo-konsumpcyjny styl. Hiperrealiści chcą $[. .$.$] obnażyć i odrzucić stereotypy widzenia [...]. Kwestionują dokumentarne$ uzurpacje mediów opartych na fotografii". Zob. Maryla Hopfinger, Doświadczenia audiowizualne. O mediach w kulturze wspótczesnej, Wyd. Sic!, Warszawa 2003, s. 106-107.

${ }^{207}$ Jean Baudrillard, Historia - scenariusz w stylu retro, [w:] Symulakry i symulacja, tłum. Sławomir Królak, Wyd. Sic!, Warszawa 2005, s. 59-60. 
„mowę mityczną", która „składa się z materii już przepracowanej tak, aby była właściwym źródłem porozumienia”. Czyli metajęzykiem, za pomocą jakiego każdy Polak może wejść w obszar wspólnoty i porozumieć się drugim $[\ldots]^{208}$.

W strukturze filmowego opowiadania - na poziomie metatekstowym - „sekwencja powstańcza” pełni funkcję cytatu zaczerpniętego z tak rozumianej „mowy mitycznej”. Znak (cytat) staje się wehikułem (wieloznacznego ${ }^{209}$ ) sensu:

stylizacja polityki na wzór poezji ${ }^{210}$ pozwalała w znaku zaczerpniętym z romantycznej rekwizytorni, w „stylu", który pozornie był tylko informacją o patriotyzmie, heroizmie, umiłowaniu wolności etc., ukryć nakaz tego patriotyzmu, heroizmu i walki o wolność. [...] Grając na analogii znaku (czyli formy) z treścią swego programu, każdy twórca takiego programu odsyłał swoich odbiorców do ",zawsze tego samego" [...]. Przez styl, gest, znak romantyczny oznajmiano mniej lub bardziej świadomie, że chodzi przecież "zawsze o to samo”, a dany program i dzieło jest tylko interpretacją tej samej wyższej prawdy, jej wykładnią zgodną z nakazami chwili i warunków ${ }^{211}$.

Zaryzykuję tezę, iż w filmie Bajona wizualny "cytat” odsyłający do „narodowego imaginarium" nie jest środkiem filmowym służącym kreowaniu „atmosfery etnicznej” w celu wywołania w widzach emocji narodowych ${ }^{212}$, lecz typowym dla Bajona elementem dystansującym. A biorąc po uwagę, iż Poznań 56 jest narracją o charakterze retrospektywnym (wspomnieniowym), odwołania do kanonicznych reprezentacji Powstania Warszawskiego odzwierciedlają proces strukturowania wspomnień, którym umysł nadaje uporządkowaną formę (powstańczego) mitu. Wspomniane odwołania mogą być także dowodem, iż „świat”, w którym tekst (filmowy) sam się sytuuje, jest „światem" dyskursu, „światem” tekstów i intertekstów ${ }^{213}$ (fot. 10-11).

${ }^{208}$ Marta Piwińska, Legenda romantyczna i szydercy, PIW, Warszawa 1973, s. 37.

${ }^{209}$ W znaku zakodowana została bowiem cechująca „metanarrację Szkoły Polskiej” dwuznaczność wobec romantycznej „mowy mitycznej”. Za pomocą znaków (cytatów) Bajon prowadzi wielostopniowy dyskurs polemiczny - krytycznie odwołuje się do romantycznych mitów oraz do filmów Szkoły Polskiej stanowiących równie krytyczną na te mity odpowiedź.

${ }^{210} \mathrm{~W}$ tym sensie powstańcy $1831 \mathrm{r}$. powoływali się na Wallenroda, powstańcy $1963 \mathrm{r}$. - na Dziady, powstańcy $1944 \mathrm{r}$. widzieli siebie czasem w „koronie cierniowych lip” polskiego mesjanizmu. Marta Piwińska, Legenda romantyczna i szydercy, dz. cyt., s. 38. Kontynuując wątek można uznać, iż w ten „łańcuch odwołań” wpisują się także „powstańcy” 1956 r. Wzorcem, do którego aspirują robotnicy Czerwca, byłby - zapośredniczony poprzez romantyzm - wzorzec Powstania Warszawskiego.

211 Tamże, s. 38-39.

${ }^{212}$ Zob. Tadeusz Lubelski, Nasza komedia narodowa, [w:] Kino polskie jako kino narodowe, dz. cyt., s. 209.

${ }^{213}$ Linda Hutcheon, Historiograficzna metapowieść: parodia i intertekstualność historii, dz. cyt., s. 383. Wydaje się, iż Bajon posłużył się strategią przeciwstawną do tej, która stała się 

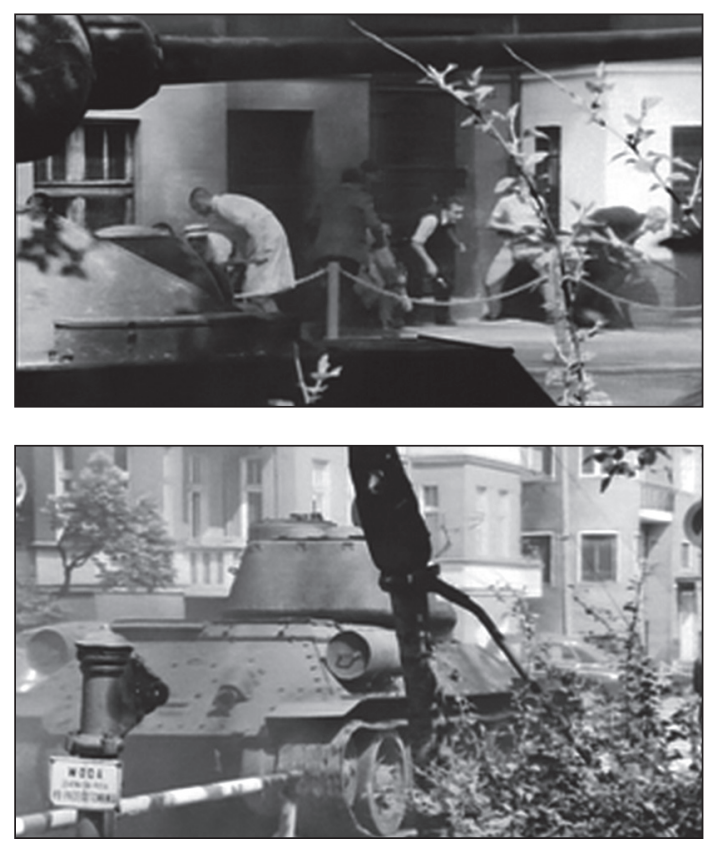

Fot. 10-11. Poznań 56 (1996, reż. Filip Bajon) „Powtórzenie w symbolicznym mimesis"

Analizowana sekwencja może także stanowić ilustrację fundamentalnego dla filmowych dyskursów historycznych paradoksu. Z jednej strony film, w którym nie zostały wykorzystane typowe dla danego wydarzenia „ikoniczne” reprezentacje (np. żółta gwiazda w filmach o Holocauście) może zostać uznany przez widzów za niewiarygodny, a nawet za „nierealistyczny" ${ }^{\prime 214}$. Z drugiej strony to właśnie nagromadzenie owych „ikon” wywołuje wrażenie, ,że obcujemy raczej z doskonałymi remake’ami, z nadzwyczajnymi produktami montażu, [...] z wielką maszynerią foto-, kino-, historiosyntezy itp., niż z prawdziwymi filmami"215. A w efekcie

obiektem krytyki w przypadku Listy Schindlera (1993). Spielbergowi zarzucano bowiem, iż w dążeniu do uzyskania „efektu realności” odwołał się do już istniejących filmowych reprezentacji Holocaustu, ale nie opatrzył ich cudzysłowem, udając tym samym, iż "opowiada historię po raz pierwszy". Zob. Miriam Bratu Hansen, "Schindler's List" is not Shoah: The Second Commandment, Popular Modernism, and Public Memory, [w:] The Historical Film: History and Memory in Media, ed. Marcia Landy, Rutgers University Press, New Jersey 2001, s. 206.

${ }^{214}$ Zob. Marnie Hughes-Warrington, History Goes to the Movies. Studying history on film, Routledge, New York 2007, s. 23.

${ }^{215}$ Jean Baudrillard, Historia - scenariusz w stylu retro, dz. cyt., s. 60. Komentując koncepcję Baudrillarda, Marnie Hughes-Warrington posłużyła się sekwencją „oczyszczania getta” z Listy Schindlera Stevena Spielberga. Kumulatywne nagromadzenie „znaków Holocaustu" - znanych widzowi z nieskończonej liczby innych filmów poświęconych Zagła- 
nawet tak traumatyczne wydarzenia, jak Powstanie Warszawskie czy Poznański Czerwiec, mogą wywoływać jedynie „chłodną mechaniczną przyjemność' ${ }^{216}$.

Bezpośrednie odniesienia do Powstania Warszawskiego pojawiają się nie tylko w omawianej „sekwencji powstańczej”, lecz również w scenie uznanej za najbardziej „,obrazoburczą" - rozmowy Staszka i Zosi w opuszczonej hali fabrycznej. Nurczyńska-Fidelska wyjaśnia intencje reżysera:

Być może, ta rozmowa wzburzyła wielu, zwłaszcza kombatanckich widzów filmu Poznań 56, w ich oczach coś zabierała wielkiej heroicznej legendzie. Ale to nie tak, ona jest wobec tej legendy uczciwa, ona ją dopowiada i czyni właśnie... poznańskąa217.

Dialog filmowych bohaterów potraktować można jako odautorski głos w dyskusji historyków. Wypowiedzi Staszka - podkreślające stricte ekonomiczne motywy „rewolucji” - puentują historiozoficzny wywód Bajona:

\footnotetext{
Zosia: Awantura w catym mieście. Był są, sądu nie ma, było więzienie, więzienia nie ma. Byty rodziny i rodzin też nie ma. Kto ci dat prawo? Kto?

Staszek: Zenek był uzbrojony. Nie ja! Nie ja, do kurwy nedzy!

Zosia: To co? Drugie powstanie chcieliście zrobić? O pierwszym nie wolno mówić, a oni robia drugie.

Staszek: Nie pieprz mi tu o powstaniu! Mamy na W7 tyle broni, że moglibyśmy rozpieprzyć to całe miasto. W dwie godziny byłoby nasze.

Zosia: Ale wtedy skad premie, stawki za nadgodziny, normy? Co? Trudno się wam przyznać, ze tu tylko o pieniadze chodzi.

Staszek: Tak, Zocha. Masz rację. Tu chodzi o bejmy. Zawsze chodzi o bejmy. Jak świat światem zawsze chodzito o pieniądze. Bo on się wokót tego kręci.
}

To zresztą nie jedyna w filmie scena tematyzująca problem „materialnych" podstaw poznańskiego buntu. Ten wątek przewija się nieustannie w rozmowach bohaterów. Pojawia się już na początku filmu w słowach rozhisteryzowanej Zosi, która - nie zważając na stojących obok robotników - błaga Zenka, by wrócił z nią do domu:

Zosia: A wy tu czego? On nigdzie nie pójdzie. On... On dostanie mieszkanie.

Staszek: A my wiemy, że dostat mieszkanie. Nawet wiemy, za co dostat...

Zosia: Ale oni mu odbiora, rozumiesz? Odbiora mu! Przecież oni mu tego nie daruja. A ja mam... Ja mam dosyć spania za zasłona i stuchania chrapania jego matki.

dzie - stanowi dla autorki paradygmatyczny przykład hiperrzeczywistości. Zob. Marnie Hughes-Warrington, History Goes to the Movies, dz. cyt., s. 104.

${ }^{216}$ Jean Baudrillard, Historia - scenariusz w stylu retro, dz. cyt., s. 61.

${ }^{217}$ Ewelina Nurczyńska-Fidelska, Czas i przesłona, dz. cyt., s. 197. 
Słowa Zosi świadczą o robotniczej nędzy, ale ujawniają także zwykły ludzki strach "o mieszkanie” - strach silniejszy niż pragnienie walki o wolność. To „mityczne” słowo odmieniane jest w filmie wielokrotnie. Artykulacja tego słowa sprawia jednak bohaterom ogromną trudność. Szczególnego znaczenia nabiera zatem scena przejęcia rozgłośni radiowej, w której Zenek - jakże nieporadnie - próbuje sformułować odezwę do „całego kraju”: Trzeba ludziom powiedzieć, co się dzieje w mieście. No niech żyje wolność, nie? Tak skończyć. Tak powiedzieć, nie... Za chwilę popłynie w eter zakazany "głos wolnej Polski" (Zagłuszanie zwalili?!). Gdyby tego nie było - deklaruje reżyser - mówiliby mięso, masło, a potem kartki na mięso i na masło, realny socjalizm. Tu padły inne słowa. I o to chodziło ${ }^{218}$. Dla wzmocnienia siły tych innych słów Bajon włączył do filmu „westernową" sekwencję ataku na posterunek milicji, spuentowaną - przynależącym do innego porządku - niezwykle sugestywnym, poetyckim obrazem szybujących w powietrzu kluczy. Ujęcie - za pomocą środków formalnych (zwolnione tempo) wyraźnie zaakcentowane w strukturze filmowego tekstu - staje się obrazem-symbolem, w którym zakodowany został sens innych słów (fot. 12-13).
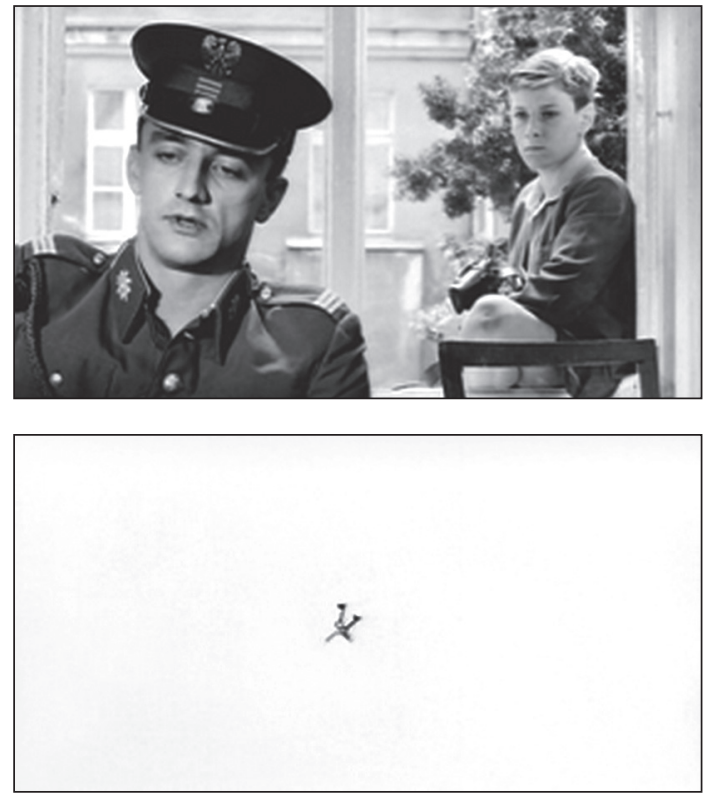

Fot. 12-13. Poznań 56 (1996, reż. Filip Bajon) Argumenty wolnościowe

${ }^{218}$ Włodzimierz Braniecki, Szczun, dz. cyt., s. 150. 
A przecież w „nieoficjalnych” wypowiedziach bohaterów próżno szukać „wolnościowych” argumentów. Doskonałym tego dowodem może być dialog, w którym Zenek stara się usprawiedliwić przez Staszkiem akty przemocy wobec przedstawicieli władzy (rozmowa ma miejsce tuż po drastycznej scenie wieszania czołgisty): A normy, które dostaniemy w przyszłym roku? A podwyżki za miesiąc? Dostaniemy. Wszyściutko, czegośmy chcieli. Wrażenie absolutnej - nie poddanej mitologizacji - prawdy zawartej w tych słowach podkreślają użyte przez Bajona środki formalne. Rozmowa filmowana jest przy zastosowaniu frazy ujęcie/przeciwujęcie, a twarze bohaterów ukazywane są w bardzo dużych zbliżeniach, ujawniających emocjonalny stan bohaterów. Bliskość kamery uwiarygodnia konflikt racji i nadaje całej scenie intymny - a nie stricte dyskursywny - charakter. Podkreśla także - zasadnicze dla przesłania filmu - towarzyszące bohaterom hit et nunc poczucie klęski. Bajon precyzuje:

tutaj w Poznaniu 56, w ramach jednego dnia, to była przegrana. [...] Historia ich walcuje. Ja nie szukałem tutaj kategorii tragizmu. Tragizm, który był tragizmem polskim, to tragizm Powstania Warszawskiego. Ja szukałem bardziej racjonalnych przesłanek. Na czym ta przegrana polega, jakie ta przegrana tworzy wartości, które są wartościami nieprzemijającymi, które są niekwestionowane ${ }^{219}$.

Reżyser świadomie nie wprowadza do filmu scen, które - w dużej mierze dzięki fotograficznym świadectwom - ukształtowały zbiorowe wyobrażenia na temat Czerwca '56. Jeśli takie sceny w filmie się pojawiaja, zostają opatrzone "cudzysłowem”, a zatem - w dosłownym znaczeniu „zacytowane”. Wystarczy wspomnieć analizowaną wcześniej sekwencję wiecu, którą otwiera seria statycznych kadrów. Dramaturgia zdarzenia została podporządkowana regułom "spektaklu” w sposób przywodzący na myśl „Grottgerowską" tradycję żywych obrazów (lub socrealistyczne plakaty przodowników pracy). Żywiołowa manifestacja unieruchomiona $\mathrm{w}$ pojedynczych kadrach ewokuje $\mathrm{w}$ pamięci widza zastygłe $\mathrm{w}$ bezruchu przedstawienia pantomimiczne, które cechowała wyrazistość mimiczna i gestyczna postaci, rzeźbiarskość pozy i frontalne ustawienie „aktorów” 220 (jedna z grup strajkujących ulokowana została na dachu tramwaju tworzącego tu rodzaj sceny - „karnawałowej platformy").

Dzięki wielkiemu nakładowi sił i środków komunistom przez długi czas udawało się sprawować totalną kontrolę nad sceną publiczną. Tym większym szokiem, skandalem, ale i groźbą były dla nich przypadki jej utraty na rzecz spontanicznych protesta-

219 Tamże, s. 149-150.

${ }^{220}$ Por. Alina Madej, Mitologie i konwencje, Universitas, Kraków 1994, s. 140. 
cji konkurencyjnych. [...] Manifestacje robotnicze stanowiły zagrożenie śmiertelne, ponieważ demaskowały fałsz przedstawieniowego monopolu, zrywały spektakl, który nie był inscenizacją władzy, ale właściwą jej formą istnienia. Walcząc z manifestacjami, komuniści nie walczyli o symbole, lecz o życie ${ }^{221}$.

W Poznaniu 56 plac przed Zamkiem staje się publiczną sceną. Jest przestrzenią „dramatyzacji” sił społecznych i obszarem konfrontacji (walki o dominację) dwóch „spektakli”: „inscenizacji” władzy i „inscenizacji" protestacyjnej. Robotnicy - jako twórcy protestacji - występują przeciw dominującemu dyskursowi i jego przedstawieniowej reprezentacji, wkraczając na wielką społeczną scenę z przedstawieniem, które zrywa fasadową komedię normalności ${ }^{222}$. Przejęcie strategicznej i nacechowanej semantycznie przestrzeni (,terenu należącego do teatru władzy") dowodzi wysokiego stopnia performatywnej świadomości „wykluczonych”. Inscenizacje protestacyjne

są zarazem prowokacjami, a ich cel stanowi zainicjowanie wydarzeń przebiegających - przynajmniej początkowo - w sposób spontaniczny, niedający się w pełni kontrolować. Ponieważ kontrola pozostaje po stronie władzy, teatralizacja protestacyjna ma przede wszystkim doprowadzić do rozbicia spójności reprezentacji i wkroczyć w powstałą w ten sposób szczelinę z własnym działaniem. Z zasady jednak działanie to ma charakter wyłącznie inicjujący, ponieważ jego celem jest aktywizacja dużych grup ludzkich, „ludowych mas”, które otrzymują szansę na przejęcie kontroli nad społeczną sceną i stworzenie własnej inscenizacji, będącej dramatyzacją i teatralizacją nieobecnych dotąd oficjalnie sił - zalążka nowego porządku ${ }^{223}$.

W sekwencji wiecu - zgodnie z zasadą kompozycji tableaux ${ }^{224}$ - postacie strajkujących utrwalono na zdjęciach w nienaturalnych, hieratycznych pozach. Monumentalizacji przedstawienia służy także "scenografia" - drugi plan tworzy potężna bryła zabudowań zamkowych (fot. 14-15).

${ }^{221}$ Dariusz Kosiński, Teatra polskie. Historie, Wyd. Naukowe PWN, Warszawa 2010, s. 405.

${ }^{222}$ Tamże, s. 401. Zdaniem autora pierwszą w Polsce performatywną akcją polityczną stanowiąca paradygmatyczny przykład manifestacji zbiorowej była łzw. czarna procesja (nawiązującą do symboliki konduktu pogrzebowego), czyli wystąpienie przedstawicieli 141 miast, którzy 2 grudnia 1789 r. przemaszerowali ulicami Warszawy, by wręczyć swoje postulaty rezydującemu na Zamku Królewskim Stanisławowi Augustowi. Pod koniec XIX w. w urządzaniu masowych protestacji wyspecjalizowały się partie i ugrupowania socjalistyczne (m.in. Organizacja Spiskowo-Bojowa utworzona w maju 1904 r.). Szczególnie aktywnych członków tych ugrupowań - prowodyrów i inicjatorów manifestacji - Kosiński określa mianem „performatywnych partyzantów”.

${ }^{223}$ Tamże, s. 401-402.

224 "Żywe obrazy" doskonale wpisują się w tradycję „święta”. Małe scenki dramatyczne tableaux - stanowiły stały element struktury karnawału. 

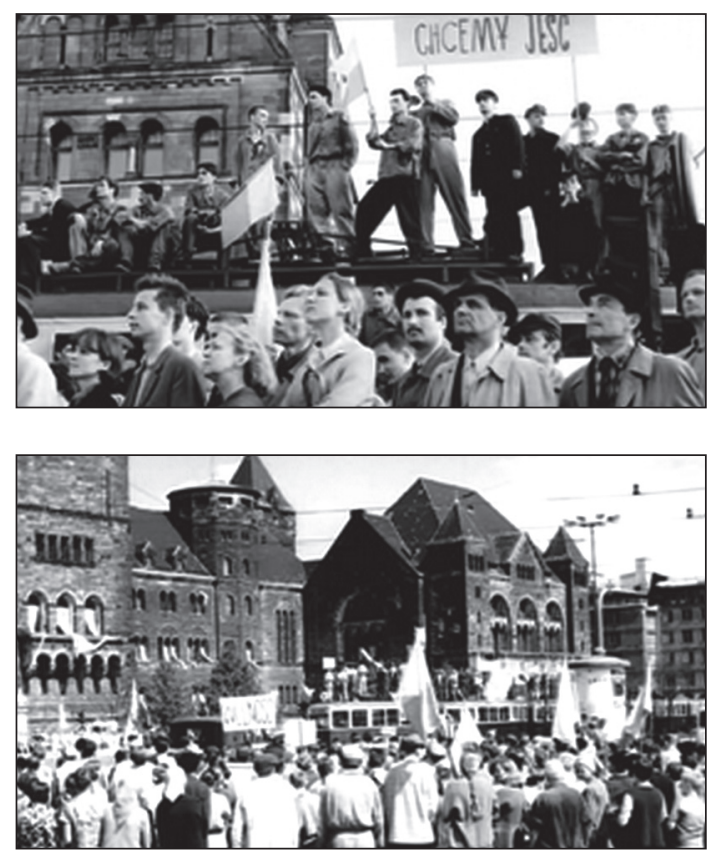

Fot. 14-15. Poznań 56 (1996, reż. Filip Bajon) „Rewolucyjna pozateatralna teatralizacja”

Zastosowane w prologu omawianej sekwencji rozwiązania formalne służą przekształceniu rzeczywistości w znak. Pikturyzacja przedstawień podkreśla umowność ekranowych wyobrażeń historii ${ }^{225}$. Filmowe obrazy stanowią zatem zapis rzeczywistości „steatralizowanej” i zapośredniczonej kulturowo. Do tego wątku powrócę w dalszej części rozważań.

Bajon potraktował rzeczywistość - kuszącą autora „filmu rocznicowego" typowym dla kiczu i powszechnie akceptowanym (a, jak dowodzą fragmenty recenzji zamieszczone we wstępie, również oczekiwanym) czarno-białym schematem - jak pułapkę. Taki uniwersalny - o czym świadczą liczne narracje historiograficzne - schemat determinuje wyraźny podział walczących stron na „swoich” (ofiary) i „obcych” (oprawcy).

Autorom tego typu prac system polityczny w Polsce po drugiej wojnie światowej (umieszczany jednoznacznie jako hegemoniczna część w totalitarnym systemie stalinowskim lub poststalinowskim) jawi się jako złowroga siła odpowiedzialna za sprawy "przerażające”, której przeciwstawia się inna siła, tym razem dobra, jaką jest

${ }^{225}$ Por. Marek Hendrykowski, Film jako źródło historyczne, dz. cyt., s. 23-25. Autor posługuje się - w odniesieniu do kina niemego - pojęciem pikturyzacji, definiowanym jako „zjawisko polegające na inscenizowaniu obrazów historycznych na ekranie w oparciu o powstałe wcześniej wizje malarskie danego wydarzenia" (tamże, s. 108). 
walczące ze złem społeczeństwo. W ten sposób narracja rozdarta jest manichejską walką dobra ze złem, w której jeden typ wzniosłości jest przeciwstawiony drugiemu. Jest to z jednej strony Kantowska wzniosłość „przerażająca”, a z drugiej - także Kantowska - wzniosłość „,szlachetna”"226.

Rezygnując $\mathrm{z}$ „manichejskiego" schematu, Bajon wprowadził do filmu wątek młodego czołgisty, którego przed powieszeniem ratuje delegat robotników - Staszek (a przy pożegnaniu wykonuje jakże „niekanoniczny” gest i ściska wrogowi rękę). Co więcej, reżyser nie wahał się podsumować tego wątku dyskusyjną - z punktu widzenia tzw. prawdy historycznej sceną wyroku wykonanego na "dezerterze" 227 .

Stan świadomości drugiej z walczących stron odzwierciedla dialog załogi czołgu zaatakowanego przez tłum uzbrojony w koktajle Mołotowa:

\begin{abstract}
Żołnierz I: O co im, kurwa, chodzi?
Żołnierz II: Walić?

Żołnierz I: Nie. Ani się waż. Pójdę, pogadam z nimi. Przecież my gówno wiemy, o co tu chodzi. Kurwa, tak nie może wyglądać amerykański desant. Ludzie! Ludzie, dlaczego chcecie mnie spalić? Ludzie, kto wy jesteście, powiedzcie. Wy jesteście imperialistycznymi agentami, tak? Ludzie, ja nie wiem, co ja tu robie... Ja nic nie wiem, no. Ja nic nie wiem...
\end{abstract}

System manichejski poczuwa się do obowiązku stworzenia doskonałego obrazu Dobra ${ }^{228}$. Najbardziej szokująca, a przecież doskonale wpisująca się w Bajonowską strategię walki z patriotyczno-religijnym kiczem, okazuje się w tym kontekście sekwencja linczu na poznańskim dworcu. To w tej sekwencji - w sposób najbardziej radykalny - została odebrana odbiorcy możliwość jednoznacznego zdefiniowania grupy,

${ }^{226}$ Jerzy Topolski, Jak się pisze i rozumie historię, dz. cyt., s. 248.

${ }^{227}$ Młody żołnierz, wbrew ostrzeżeniom Staszka, decyduje się wrócić do jednostki. Przy koszarowej bramie, na której widnieje godło Orła Białego, zostaje zastrzelony przez oficera ludowego wojska. Ta scena może budzić kontrowersje, gdyż do tej pory nie zostały potwierdzone informacje, jakoby podczas Wydarzeń Czerwcowych wykonano wyroki śmierci na 19 żołnierzach. O tej sprawie pisała m.in. Paulina Codogni: „Niewyjaśniona nadal pozostaje sprawa ewentualnego zabójstwa dziewiętnastu żołnierzy Oficerskiej Szkoły Wojsk Pancernych i Zmechanizowanych, którzy według plotek mieli zostać rozstrzelani na lotnisku Ławica za to, że walczyli po stronie demonstrantów lub też odmówili wykonania rozkazu strzelania do nich. [...] Późniejsze badania faktycznie dowiodły, że po wydarzeniach w Poznaniu aresztowano dziewięciu żołnierzy, ale do listopada 1956 r. wszystkich uwolniono, a ich sprawy umorzono. Zdecydowanie przeciwko teorii o rozstrzelaniu żołnierzy świadczy fakt, że nigdy żadna rodzina nie poszukiwała swoich bliskich ani nie wiązała ich śmierci z tą zagadką". Zob. Paulina Codogni, Rok 1956, dz. cyt., s. 208.

${ }^{228}$ Barthélemy Amengual, Demaskowanie mitologii, tłum. Grażyna Stryszowska, „Kwartalnik Filmowy" 1996/1997, nr 15-16, s. 240. 
której w martyrologicznej narracji Czerwca przyznano bezwarunkowo status ofiar. Dyskomfort widza potęguje fakt, iż to szokujące zdarzenie zmuszony jest obserwować z dystansu. Odbiorca zajmuje pozycję uwięzionych profesorów, którzy nie rozumieją - i nie słyszą! - nic z tego, co dzieje się na sąsiednim peronie. Bajon w żaden sposób nie ułatwia odbiorcy konceptualizacji zdarzenia. $\mathrm{O}$ tym, kto padł ofiarą rozszalałego tłumu, dowiadujemy się jedynie pośrednio - w jednej z późniejszych scen dwóch tajniaków wypytuje przyłapanego na szabrownictwie złodzieja: Na dworcu wdeptali w peron naszego kumpla. Byłeś tam? Byłeś?!

Tylko dzięki tej informacji zawartej w lakonicznym dialogu możemy odnieść analizowaną sekwencję do zdarzenia, które stało się podstawą oskarżeń w tzw. procesie trzech. O zdarzeniu pisze Makowski:

\begin{abstract}
Skrajnym przykładem nienawiści do UB było zmasakrowanie przez tłum kaprala UB Zygmunta Izdebnego. [...] W pogoni za uciekającym ktoś krzyczał, że zabił on kobietę i dziecko. To oskarżenie, rozszerzone później na zarzut zabicia kobiet i dzieci, powtarzane było wielokrotnie i mobilizowało do bicia Izdebnego. [...] Ktoś uderzył go w głowę kamieniem, co głównie przyczyniło się do jego zgonu. [...] Dopiero czwarty przyjazd karetki pogotowia i trzech samochodów z wojskiem spowodował, że tłum się rozpierzchł. Po przewiezieniu do szpitala Izdebny zmarł229.
\end{abstract}

Historycy analizujący ten jakże „niechlubny” epizod Czerwca zwracali uwagę na fakt, że do zdarzenia doszło w trakcie strajku robotników Poznania, których cechowało wysokie poczucie praworządności, dyscypliny oraz sumiennie wykonywanych obowiązkó $w^{230}$. W filmie Bajona ten aspekt został podkreślony w wypowiedzi jednego z profesorów. Z drugiej jednak strony wymuszony pozycją obserwatora dystans wobec rozgrywających się zdarzeń nadaje owym zdarzeniom charakter znacznie bardziej uniwersalny. Scena na peronie - „umocowana” w świadectwach historyków - staje się w sposób symboliczny odtworzeniem procesu „kozła ofiarnego" (podobny charakter będzie miała - nie pozbawiona również faktualnej legitymizacji231 - scena wieszania czołgisty). Przemoc - zdaniem Hannah Arendt - często rodzi się z wściekłości, która może być irracjonalna lub pa-

${ }^{229}$ Edmund Makowski, Poznański Czerwiec 1956, dz. cyt., s. 138.

${ }^{230}$ Tamże, s. 25. Należy dodać, iż żaden z trzech mężczyzn oskarżonych w tzw. procesie trzech nie był robotnikiem zatrudnionym w zakładach Cegielskiego.

${ }^{231}$ Makowski przywołuje epizod, który - w zmodyfikowanej formie - znalazł się w filmie Bajona: „Strzelanie przez żołnierzy po godz. 13.00 do demonstrantów wzbudziło nienawiść do wojska, ale występowały również przypadki obrony oficerów przez demonstrantów. [...] [Taką] sytuację przeżył por. Leopold Ciupał, który w grupie czołgów znalazł się na ul. Dąbrowskiego. Demonstranci zastąpili im drogę, wiec zatrzymał swój czołg. Gdy kierowca ponownie go uruchomił, ludzie rozstąpili się, ale po ujechaniu 100-150 m podpalili czołg butelkami z benzyną. Por. Ciupał wyskoczył z dwoma 
tologiczna. Ale wściekłość i gniew stają się irracjonalne dopiero wtedy, gdy kierują się przeciw substytutom ${ }^{232}$. Ten Girardowski wątek przewijał się wypowiedziach ekspertów zeznających w poznańskim "procesie trzech”. Specjaliści z zakresu psychologii i socjologii podkreślali:

Bardzo ważnie jest, że epizod ten odbył się w okresie, gdy trwała akcja zbrojna w rejonie gmachu UB, czyli epizod ten miał miejsce „w fazie zaawansowanej psychozy tłumu”. [...] Epizod ten polega na tym, że „nienawiść do Urzędu Bezpieczeństwa, dynamika nienawiści zostaje wyzyskana i skierowana na konkretną osobę"233.

Wydaje się, że Bajon idzie znacznie dalej w Girardowskiej interpretacji linczu. Obserwując zdarzenie in statu nascendi nie wiemy, że masakrowany mężczyzna jest funkcjonariuszem UB, nie słyszymy oskarżeń pod jego adresem. Widzimy jedynie rozhisteryzowany tłum „w fazie zaawansowanej psychozy" i przypadkową (niewinną?) ofiarę skanalizowanej nienawiści.

W scenach zbiorowych Poznania 56 - fundamentalnych dla dekonstrukcji heroicznego mitu - Bajon odkrywa janusowe oblicze czerwcowej rewolucji. $Z$ jednej strony - robotnicy maszerujący w pochodzie (,karni szli w ordynku, szli zdyscyplinowani i z duma, i godnością"234), z drugiej - żądne krwi masy. Widz - już samodzielnie - musi dokonać szokującego odkrycia, że robotniczy bunt wyrastał z tych samych rewolucyjnych korzeni, co panujący reżim ${ }^{235}$. Na pytanie Staszka: Kto pierwszy strzelit? ${ }^{236}$ pada przecież ironiczna odpowiedź: Aurora!

Wprowadzenie do filmu tak „niekanonicznych” scen stanowi dowód ogromnej odwagi reżysera, który postrzega rzeczywistość podobnie, jak bohaterowie Milana Kundery. To przecież Sabina z Nieznośnej lekkości bytu:

Chciała [...] powiedzieć, że za komunizmem, faszyzmem, wszystkimi okupacjami i inwazjami kryje się poważniejsze zło: obrazem tego zła jest maszerujący pochód ludzi, unoszących pięści i wykrzykujących unisono te same sylaby ${ }^{237}$.

żołnierzami, a wtedy został uderzony w tył głowy. Krzyczano, że zabił kogoś, rozbrojono go i zaciągnięto na pobliskie podwórze. Bito go i oskarżano, że jest zbrodniarzem, bo strzelał do ludzi. Ktoś wzywał, by go zastrzelić i postawiono go pod ścianę. Wtedy zasłonił go sobą 50-letni mężczyzna, który przekonywał, że to jest niewinny oficer, który do nikogo nie strzelał. Wywołało to różnicę zdań wśród atakujących i oficera udało się ukryć w pobliskim domu. Wkrótce pojawili się na tej ulicy żołnierze, którzy zabrali por. Ciupała" (tamże, s. 128).

${ }^{232}$ Hannah Arendt, O przemocy. Niepostuszeństwo obywatelskie, dz. cyt., s. 80-82.

${ }^{233}$ Edward Makowski, Poznański Czerwiec 1956, dz. cyt., s. 262.

${ }^{234}$ Tamże, s. 66.

235 Tadeusz Sobolewski, Wszystko osobno, dz. cyt., s. 12.

${ }^{236}$ Pytanie dotyczy strzelaniny pod gmachem Urzędu Bezpieczeństwa.

${ }^{237}$ Milan Kundera, Nieznośna lekkość bytu, tłum. Agnieszka Holland, PIW, Warszawa 1992, s. 75. 
W Poznaniu 56 niewiele jest scen ukazujących robotników jako solidarną (wykrzykujaca unisono te same sylaby), zjednoczoną wspólnym celem grupę. W strukturze filmowego opowiadania działania „instytucjonalne" zdecydowanie dominują nad działaniami „zorientowanymi na tożsamość" ${ }^{238}$. Zwraca uwagę fakt, iż Bajon nie poświęcił zbyt dużo uwagi pierwszej pokojowej fazie strajku, którą - wedle definicji Arendt - można by określić mianem „nieposłuszeństwa obywatelskiego” (jego cechą charakterystyczną jest bowiem niestosowanie przemocy $)^{239}$. Symbolem nadziei, towarzyszących $w$ tej fazie protestującym, jest zbliżenie twarzy roześmianego młodego mężczyzny, który punktualnie o ósmej rano uruchomił zakładową syrenę. Inicjacyjny moment formowania pochodu ${ }^{240}$ pokazany już został z perspektywy stojącego w bramie Zenka. Chłopak spokojnie zapala papierosa i bez większego zainteresowania spogląda na przechodzących obok niego ludzi.

W strukturze całego filmu Bajon akcentuje - głównie za pomocą środków formalnych - znaczenie scen świadczących o postępującej dezintegracji portretowanej zbiorowości. Do pierwszego wyraźnego konfliktu dochodzi podczas wielokrotnie przywoływanej sekwencji wiecu. W grupie strajkujących wyodrębniają się dwa obozy: pierwszemu przewodzi "legalista” Staszek, drugiemu - „radykał” Zenek. Żadnemu z nich nie zostanie przyznana bezwzględna racja, a w finale obaj ponoszą klęskę. Według Kundery

ci, którzy walczą przeciwko tak zwanym totalnym reżymom, z trudem mogliby walczyć za pomocą pytań i wątpliwości. Oni również potrzebują pewników i prostych prawd, które byłyby zrozumiałe dla jak najszerszych kręgów i wywoływałyby kolektywne łkanie ${ }^{241}$.

${ }^{238}$ Wyróżnione dwa typy działań zbiorowych zostały scharakteryzowane w obrębie socjologicznej koncepcji symboliczno-interakcyjnej. „Działania instytucjonalne” (instytucjonalizacja nie jest tu rozumiana jako formalne uregulowanie) zmierzają do osiągnięcia pewnych zamiarów, wartości czy celów (jak w przypadku strajku płacowego). „Działania zorientowane na tożsamość" odnoszą się do zbiorowego podmiotu - "my" traktowanego jako wartość. W Poznaniu 56 to właśnie owo zbiorowe „my" wydaje się kategorią najbardziej dyskusyjną. Zob. Elżbieta Hałas, Symbole i społeczeństwo, dz. cyt., s. 49-50.

${ }^{239}$ Hannah Arendt, O przemocy. Nieposłuszeństwo obywatelskie, dz. cyt., s. 172.

${ }^{240}$ Tę „euforyczną” fazę Wydarzeń Poznańskich wspomina (14-letnia wówczas) Jadwiga Staniszkis: „Widziałam naprawdę ten pochód w Czerwcu, radosny, pełen przekonania o swojej sile, do którego zaraz potem strzelano, a którym ludzie szli także dlatego - jestem tego pewna, mogę przysiąc - że nie wierzyli, że władza będzie do nich strzelała, co było brakiem wyczucia..." Zob. Życie umysłowe i uczuciowe, dz. cyt., s. 44.

${ }^{241}$ Milan Kundera, Nieznośna lekkość bytu, dz. cyt., s. 191. 
A przecież bohaterowie Poznania 56 walczą - tak niezgodnie z patriotyczno-martyrologicznym schematem - głównie za pomoca pytań $i$ watpliwości. Film Bajona (podobnie jak najwybitniejsze dzieła szkoły polskiej) stanowi wstrząsający zapis procesu pozbywania się złudzeń i narastającego zwątpienia w sensowność walki.

W scenie rozgrywającej się przed Urzędem Miasta - zaledwie cztery godziny po rozpoczęciu strajku - wyraźnie zaznacza się zmiana nastojów. Znika euforia, opada napięcie. Zmęczeni robotnicy na próżno oczekują rządowej delegacji, z którą mogliby rozpocząć negocjacje. Padają mocne słowa: Jeszcze raz nas oszukali. Nikt nie przyszedt. Ja tam od razu wiedziałem, że premier ma nas w dupie. W sferze obrazowej przytłaczające poczucie klęski odzwierciedla geometryczna kompozycja kadru i niezwykła pozycja kamery. Długie ujęcie z góry ujmuje pomniejszone i ledwie rozpoznawalne sylwetki robotników, którzy - w powolnym hipnotycznym rytmie "chocholego tańca" - poruszają się wewnątrz fontanny uformowanej w kształt („,błędnego”) koła. To kolejna, jakże wyrazista, filmowa artykulacja archetypicznego w polskiej kulturze symbolu ${ }^{242}$. I znowu, jak w Eroice Munka (choć próżno by szukać u Bajona pochwały mitu wyrażonej w obrębie demitologizującej narracji ${ }^{243}$ ), intencjonalny kierunek akcji jest tu jeden - odzyskanie wolności - lecz realnie wszystko toczy się po kole, jak zaklęte ${ }^{244}$ (fot. 16).

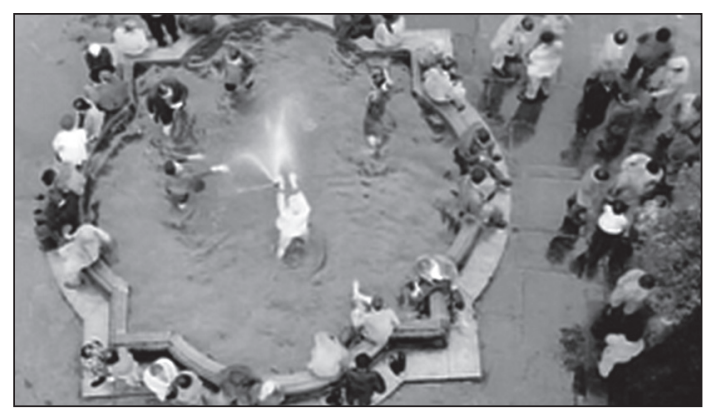

Fot. 16. Poznań 56 (1996, reż. Filip Bajon)

Chocholi taniec

${ }^{242}$ Przywodząca także na myśl symbolikę rewolucyjnego święta (taniec w kole). „Ten właśnie obraz - pisze Ozouf - każe wybierać figurę kolistą jako najdoskonalszą dla przestrzeni święta. Koło jest symbolem jednomyślności narodowej [...]". Zob. Mona Ozouf, Święto rewolucyjne 1789-1799, dz. cyt., s. 166.

${ }^{243}$ Zob. Andrzej Werner, Polskie, arcypolskie..., dz. cyt., s. 98.

${ }^{244}$ Bronisława Stolarska, Zakładnicy nadziei, „Kwartalnik Filmowy” 1997, nr 17, s. 64. 
Z omawianą sceną koresponduje - na zasadzie zwierciadlanego odbicia - scena wieszania młodego żołnierza ${ }^{245}$. Bezruch i niekontrolowana aktywność to dwa bieguny tego samego zjawiska. Apatia i przemoc wynikają z frustracji i bezsilności. W scenie przy fontannie expressis verbis wyrażone zostało przekonanie, że winę - jak zawsze - ponoszą "oni" (Oszukali nas). Aby ta scena nie uległa przekształceniu w kicz (zgodnie ze schematem: oni-my) Bajon, za pomocą niezwykłego kąta ustawienia kamery i ruchu wewnątrzkadrowego, nadaje jej polisemiczny charakter. W „zaklętym kręgu niemożności” rozmywa się - zawsze waloryzowana przez kicz pozytywnie - kategoria "my".

Scena samosądu jest już świadectwem procesu autorefleksji. Efektem tego procesu jest świadome przejęcie odpowiedzialności za klęskę (także - a może przede wszystkim - w sensie etycznym) przez Staszka, jednego z przywódców strajku ${ }^{246}$.

Staszek: Do domu wiara! Do domu! Do domu! Ino mi się tu nie wygłupioć. To nie tok miało być! Nie tok! Do kurwy nędzy, nie tok! [...] Nie po to wiara wychodziła na miasto, żeby sie takie rzeczy dziaty.

Zenek: Stary, to ty nie wiesz, gdzie żyjesz! To jest teraz nasze miasto! Nasze!

Staszek: No nie chcesz mi chyba powiedzieć, że jak ten bidok zadynda na drzewie, to to będzie sprawiedliwie. Taki głupi to ty już nie jesteś. [...] Ja już się boję. Boję się takich ludzi jak ty.

Zenek: Dobra. Dobra. Dobra, będzie sąd. Będzie sprawiedliwie. Ludzie! Będzie sąd! Będzie sprawiedliwie!

Staszek: Ludzie! Ludzie! Ale my nie możemy być sędziami! Nie wolno nam! Nie wolno. Nie. [...] Ja wiem, oszukaliśmy ich.

Zenek: No, wygrywaja.

Staszek: Mogliśmy go tylko zabić. Tylko go zabić.

Zenek: A oni moga? Maja to wpisane do dowodu?

Staszek: I nic więcej. Nic więcej.

W wymiarze osobistym potwierdzeniem tej klęski będzie scena, w której storturowany Stach z nabożną czcią zbiera do chusteczki kilka

${ }^{245}$ Przywołana scena mogłaby stanowić ilustrację słów wypowiedzianych przez Adama Michnika w trakcie obrad Okrąłego Stołu. Michnik - ostrzegając przed „irracjonalnymi wybuchami społecznymi, samodegradacją w konfliktach i nienawiściach" - przypominał: „zasadniczą cechą stalinowskiego komunizmu jest rozkład więzi społecznych, rozkład kultury prawnej i wtedy bunt takiej społeczności jest buntem niewolników, buntem ludzi, którzy najlepiej potrafią budować szubienice". Zob. Paweł Śpiewak, Pamięć po komunizmie, dz. cyt., s. 22.

24628 czerwca pierwszy poważny kryzys uwidocznił się po rozbiciu przez jedną z grup strajkujących Centralnego Więzienia przy ul. Młyńskiej. „Więźniowie w pasiakach na ulicy i przy paleniu akt - podkreśla Makowski - budzili aplauz, ale u części demonstrantów także wątpliwości. Na widok ludzi w pasiakach Kaniewski powiedział do Matyji, że «wszystko poszło nie po naszej drodze», a inny pracownik ZISPO, Nowakowski, uznał, że «robotnicy już nie mają z tym nic wspólnego»". Zob. Edmund Makowski, Poznański Czerwiec 1956, dz. cyt., s. 106. 
przedmiotów znalezionych przy zwłokach zastrzelonego synka. I nic więcej. Nic więcej...

Od tego momentu zdarzenia prezentowane będą wyłącznie $w$ perspektywie "przegranej rewolucji”. Wstrząsające wrażenie wywołuje scena "zainscenizowanego" przez ubeków rozstrzelania przywódców strajku. To już koniec Poznańskiego Czerwca. Tłum się rozproszył. „Prowokatorów" wyłapały wojskowo-milicyjne patrole. Wszystko odbywa się noca, w całkowitej ciszy przerywanej jedynie ordynarnymi wyzwiskami rzucanymi przez oficerów UB. Szok wywołuje przemoc fizyczna i psychiczna: upokarzanie ofiar ${ }^{247}$. Niewielka grupa aresztantów stoi w milczeniu, ze spuszczonymi głowami czekając na wyrok. W tej scenie „mogłaby zabrzmieć polska modlitwa: od powietrza, głodu, ognia i wojny. I powstań, które tak mocno nas doświadczyły, zachowaj nas, Panie $^{\prime 248}$. Ale najgłębiej zapada w pamięć zbliżenie zakrwawionej, pełnej godności twarzy Stacha i spływające po jego policzku łzy. Czy można mocniej zaakcentować klęskę? Klęskę, której Bajon nie poddaje - godząc tym samym w tradycyjny dyskurs polskich powstań narodowych - procesowi heroizacji i sakralizacji.

Historiozoficzny dyskurs Bajona rozpięty jest pomiędzy dwoma obrazami: zbliżeniem uśmiechniętej twarzy robotnika (w inicjacyjnej fazie strajku) i zbliżeniem storturowanego oblicza Stacha (w czerwcowym „epilogu”) (fot. 17).

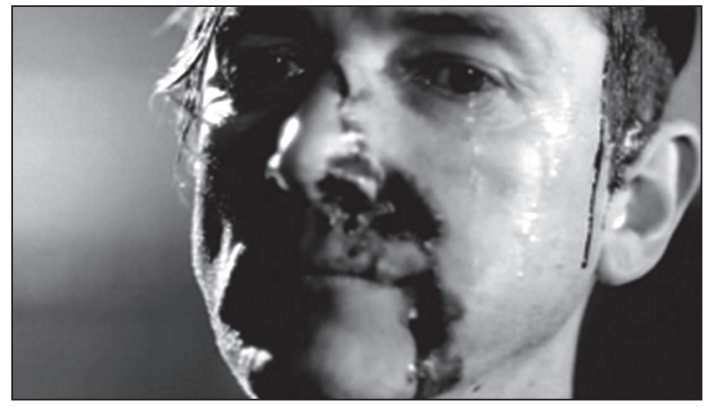

Fot. 17. Poznań 56 (1996, reż. Filip Bajon) Świadectwo klęski

Jest w Poznaniu 56 jeszcze inna scena o podobnym charakterze, lecz generująca sensy wykraczające poza historyczny konkret. To scena rozgrywająca się w szpitalu, do którego już po wszystkim trafia ranny Zenek. Jesteśmy świadkami jego przejmującego monologu:

\footnotetext{
${ }^{247}$ Historycy podkreślaja, iż ludność Poznania, mająca świeżo w pamięci niemiecką okupację, przyrównywała UB do gestapo i SS (tamże, s. 108).

${ }^{248}$ Tomasz Łubieński, Ani triumf, ani zgon..., dz. cyt., s. 67.
} 
A jakie to ma znaczenie? Jakie znaczenie, pytam? Jeden czy dwóch. Siedmiu, dwudziestu, stu. Tu się przecież nic nie stało. Tu się przecież nic nie stało. Byłem w radio. Chciałem nadać komunikat. O wolności. Bo tu wolność była, nie? Mielimy miasto, rzadzilimy, nie? A ten redaktor, to on mówi, że on nie może teraz mi powiedzieć, bo nie wie, co będzie wieczorem. To ja myśle, że zawsze tak jest, że co innego jest w dzień... a co innego wieczorem. W dzień miatem giwere, a tera jestem ślepy, nie?

A przecież nie chodzi wyłącznie o sens wypowiedzianych przez Zenka słów. Równie ważny okazuje się sposób zakomponowania sceny. Bohater zajmuje centralne miejsce $w$ kadrze. Jego oczy skrywają przesiąknięte krwią opatrunki. Chłopak bezsilnie miota się po szpitalnej sali przypominającej pobojowisko. Nie widzi rannych i operujących tuż obok lekarzy. Inscenizacja, w której główny akcent spoczywa na postaci ociemniałego bohatera nieuchronnie ewokuje w pamięci finałową sekwencję Wajdowskich Popiołów, prezentującą wyrażaną w całym filmie myślową linię interpretacyjna, którą określa poczucie tragicznej ironii ciążącej nad losem narodu $u^{249}$. Tak zainscenizowana scena - podobnie jak u Andrzeja Wajdy - najsilniej w całym filmie wyraża „głos” podmiotu-autora, który ten film podpisał ${ }^{250}$ (fot. 18-19).
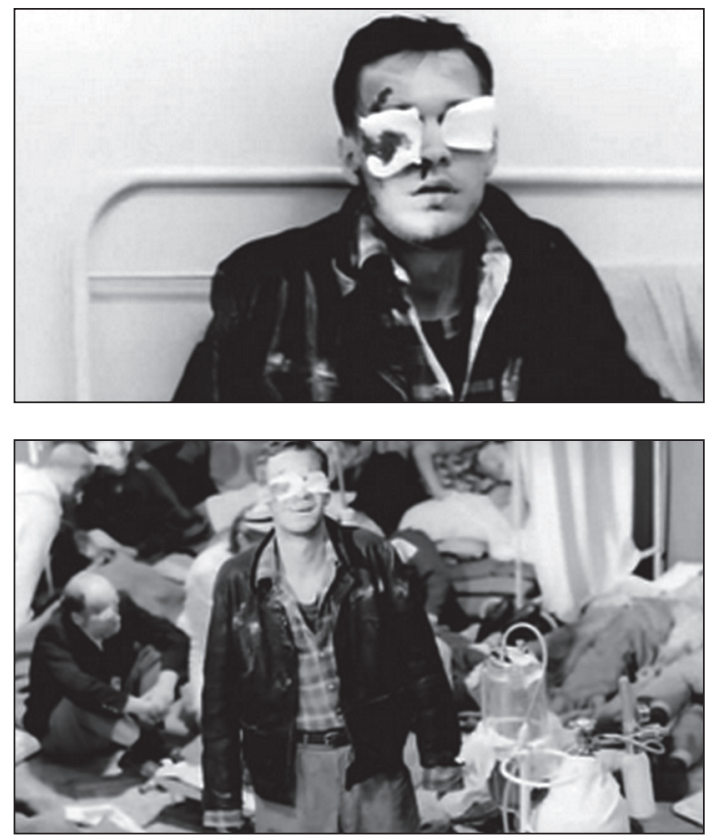

Fot. 18-19. Poznań 56 (1996, reż. Filip Bajon) Ironia tragiczna

${ }^{249}$ Ewelina Nurczyńska-Fidelska, Polska klasyka literacka wedtug Andrzeja Wajdy, Wyd. Uniwersytetu Łódzkiego, Łódź 2010, s. 42.

250 Tamże. 
Historiozoficzny wywód Bajona puentuje epilog, którego akcja rozgrywa się w listopadzie 1956 r. Zastosowanie elipsy czasowej pozwoliło na wyeliminowanie z filmu wszelkich oznak narastających w Polsce nastrojów "odwilżowych" lub odniesień do rewelatorskiego VIII Plenum KC PZPR, podczas którego Władysław Gomułka zrehabilitował inicjatorów Czerwca. Wkrótce po zdarzeniach ukazanych $\mathrm{w}$ filmie $\mathrm{w}$ prasie zachodniej pojawiły się przecież komentarze, iż Poznański Czerwiec świadczył o moralno-politycznym bankructwie komunizmu w Polsce ${ }^{251}$. W kraju przemówienie Gomułki było odbierane jako dowód, iż

Polska po 28 czerwca była krajem, w którym zarówno rządzący, jak i rządzeni zdawali sobie sprawę, że kontynuacja dotychczasowych metod rządzenia i dotychczasowej polityki społeczno-ekonomicznej jest w praktyce niemożliwa, utrzymywanie za wszelką cenę politycznego i społecznego status quo groziłoby nieobliczalnymi konsekwencjami. [...] Nie będzie przesady w stwierdzeniu, że to właśnie poznański Czerwiec odegrał kluczową rolę w przygotowaniu polskiego Października ${ }^{252}$.

W epilogu Poznania 56 nie odnajdziemy śladów owej świadomości. Bajon rezygnuje z podstawowego zabiegu mitologizującego, jakim jest profetyzacja (mechanizm polegający na prognozowaniu - w wypadku zjawisk waloryzowanych dodatnio - pozytywnej roli faktów historycznych w kształtowaniu przyszłych losów ludzkości ${ }^{253}$ ). Na długie lata Czerwiec miał zostać wymazany ze społecznej pamięci ${ }^{254}$. Finałowe ujęcia zdają się potwierdzać - wypowiedziane w poczuciu absolutnego triumfu - słowa oficera Urzędu Bezpieczeństwa: A za parę dni nikt słowa o tej całej grandzie nie powie! Nikt! Słowa te stanowią trawestację słynnej wypowiedzi Gomułki skierowanej do rodzin pomordowanych: „Chociaż rodzina

${ }^{251}$ Edmund Makowski, Poznański Czerwiec 1956, dz. cyt., s. 209-214.

${ }^{252}$ Zob. Paulina Codogni, Rok 1956, dz. cyt., s. 236-236.

${ }^{253}$ Jerzy Topolski, Jak się pisze i rozumie historię, dz. cyt., s. 274.

254 „Marginalizowaniu - pisze Ruchniewicz - przeinaczaniu, a w końcu przemilczaniu przez władze wydarzeń 1956 r. próbowała przeciwstawić się polska emigracja polityczna. Czyniła ona wiele, by je udokumentować i upowszechnić. Formą tego były, rzecz jasna, audycje polskojęzycznych rozgłośni, na czele z sekcją polską Radia Wolna Europa, relacjonujące wydarzenia w kraju na bieżąco (na miarę posiadanych informacji), jak i przypominające je w kolejne rocznice". Zob. Krzysztof Ruchniewicz, Czerwiec i Październik 1956 r. w społecznym obrazie przeszłości Polski, dz. cyt., s. 92.

Przypomnijmy, że audycji Radia Wolna Europa słuchają w czerwcu 1956 r. młodzi bohaterowie Dreszczy Marczewskiego. Gombrowiczowski "gwałt przez uszy” dokonany - za pomocą odbiornika radiowego - na jednym z uczestników obozu staje się bezpośrednią przyczyną tragedii (samobójczej śmierci chłopca). Młodzież ma zatem możliwość konfrontacji dwóch, wzajemnie wykluczających się interpretacji Czerwca: „oficjalnej” i „emigracyjnej”. W konsekwencji Wypadków Poznańskich następuje likwidacja obozu. 
dotknięta takim nieszczęściem nigdy o nim zapomnieć nie może, to zawsze stara się najgłębiej zapuścić na swoją tragedię żałobną kurtynę milczenia". Wkrótce po dojściu do władzy

Gomułka zwalczał wszystko, co mogłoby podważyć jego linię polityczną. I inaczej być nie mogło. Także najświeższe, niewygodne mu tradycje, by wskazać na tradycję poznańskiego Czerwca 1956 r. - poznańskiego powstania robotniczego, chociaż bunt robotników poznańskich uznał w Październiku 1956 r. za uzasadniony, Tradycja ta miała całkowicie zniknąć ze świadomości społecznej, i w dużym stopniu zniknęła. Równocześnie władze nie zapomniały o uczestnikach wydarzeń czerwcowych w Poznaniu, szykanowano ich $[\ldots]^{255}$.

Wedle koncepcji Bachtina lud razem z końcem zimy świętuje - przez antycypację - śmierć starego świata i zwycięstwo nowego porządku społecznego ${ }^{256}$. W epilogu Poznania 56 Bajon pokazuje społeczeństwo „post-karnawałowe” pogrążone w kataleptycznym „zimowym śnie”. Wszechobecna biel nadaje ostatnim filmowym kadrom odrealniony, niemal surrealistyczny charakter. Siedziby władz ochraniają umundurowani funkcjonariusze. W grupie apatycznie gromadzących się na ulicy ludzi można dostrzec - jak zawsze - te same znajome twarze tajniaków z UB. Wprowadzając na ulice siły nadzoru, władza potwierdza odzyskanie kontroli nad miastem („publiczną sceną”). A zatem Poznański Czerwiec byłby więc tylko „karnawałem” -

chwilowym powstrzymaniem funkcjonowania oficjalnego systemu, wraz ze wszystkimi jego zakazami i barierami hierarchicznymi. Na krótki czas życie wychodziło ze zwykłych prawomocnych uświęconych kolein i wstępowało w sferę utopijnej wolności ${ }^{257}$.

W finałowych ujęciach Poznania 56 tkwi in potentia fundamentalne dla strategii Bajona pytanie, czy widz jest w stanie zaakceptować filmowe wyobrażenie historycznych zdarzeń, które mógłby wieńczyć napis: Tu się przecież nic nie stało? 258

255 Tadeusz Kisielewski, Październik 1956. Punkt odniesienia, Wyd. Neriton, Warszawa 2001, s. 54 .

${ }^{256}$ Suzanne Chappaz-Wirthner, Z dziejów badań nad karnawałem, tłum. Łada Jurasz-Dudzik, [w:] Karnawat. Studia historyczno-antropologiczne, dz. cyt., s. 105.

257 Michaił Bachtin, Twórczość Franciszka Rabelais'ego, dz. cyt., s. 165.

${ }^{258}$ Przytoczone słowa zostały wypowiedziane przez Zenka w analizowanej wcześniej sekwencji szpitalnej. 


\section{„Piękne ujęcia" jako element strategii dystansu}

Ja lubię piękne ujęcia, ja lubię film jako pewne zjawisko estetyczne.

Filip Bajon

Jak pamiętamy, jeden z najczęściej artykułowanych zarzutów wobec filmu Bajona miał charakter faktograficzny. Reżyser pośrednio odpowiedział na ten zarzut w wywiadzie:

To, co mnie najbardziej denerwuje, to jest pewien oblig w stosunku do historii, którą muszę opowiedzieć. Natomiast to, co najbardziej zawsze lubię w każdym swoim filmie, to jest to, kiedy jest taka autentyczna radość zrobienia świetnego ujęcia. [...] Historia zaoferowała mi pewien pakiet wydarzeń. Atak na komendę jest wydarzeniem bardzo filmowym, to z przyjemnością się filmuje. Tam była cała masa wydarzeń, zdobywanie komendy, wyjazd za miasto, zabranie motocykla, jazda do radia, próba nadania komunikatu, rozwalenie anteny, to są wydarzenia. To są sytuacje filmowe ${ }^{259}$.

Wyszukane rozwiązania formalne mają zatem w filmie charakter autoteliczny - służą kreowaniu świetnych ujęć. Ale sprowadzenie znaczenia środków formalnych jedynie do funkcji estetycznej oznacza nieuchronną redukcję sensów dzieła. Świetne ujęcia mają - jak zawsze u Bajona - samoistną wartość, ale rzecz na tym się nie wyczerpuje. Forma jest bowiem sposobem sygnalizowania dystansu nie tylko wobec historii - mimo pozorów w tejże historii zanurzenia, ukazywania jej niejako od wewnątrz - lecz także wobec sposobów jej filmowej reprezentacji.

Paradygmatycznym przykładem sytuacji filmowej jest szturm na więzienie - wydarzenie, w którym, na wzór zdobycia Bastylii, w sposób paradygmatyczny ujawnia się społeczna potrzeba tworzenia rewolucyjnej symboliki. Zawłaszczanie przestrzeni, której granice trzeba otworzyć lub sforsować, jest pierwszą radością rewolucyjną ${ }^{260}$. „Nagi” fakt szybko stał się symbolem czegoś innego:

Zdobycie Bastylii [jak „przejęcie” więzienia czy gmachu UB podczas Wydarzeń Czerwcowych] z konieczności staje się przedmiotem spojrzenia i dyskursu, które nadają uogólniający sens następującym po sobie wydarzeniom oraz biorącym w nich udział różnorodnym aktorom. [...] zjawisko, jakim był rewolucyjny tłum, wymaga nie tylko zbiorowej obecności i zalążka organizacji, ale także wspólnoty wyobraźni.

\footnotetext{
${ }^{259}$ Włodzimierz Braniecki, Szczun, dz. cyt., s. 133, 147.

${ }^{260}$ Zob. Mona Ozouf, Święto rewolucyjne 1789-1799, dz. cyt., s. 159.
} 
Dlatego też Bastylia, stara forteca, już przedtem otoczona niechęcią i różnymi mitami, staje się właśnie symbolem arbitralnej władzy, czyli tego wszystkiego, co w danym ustroju było archaiczne, przestarzałe i niesprawiedliwe. Tłum nadaje sobie tożsamość, stawiając przed sobą swój idealny obraz - obraz Narodu, który powstał przeciwko tyranii i przemocy, których uosobieniem były zmurszałe mury i ich obrońcy $[\ldots]^{261}$.

Każda rewolucja - zwłaszcza w wersji ekranowej - musi mieć swój moment kulminacyjny ${ }^{262}$. W Październiku Eisensteina rewolucja kulminuje w sekwencji szturmu na Pałac Zimowy, w Poznaniu 56 - w sekwencji ataku na więzienie. Bajon wyzyskał potencjał „filmowości” zawarty $\mathrm{w}$ samym wydarzeniu, ale $\mathrm{w}$ dużo większym stopniu wydarzenie to posłużyło jako pretekst do wykreowania na ekranie pewnego zjawiska estetycznego. Sekwencja ataku na poznańską „Bastylię” rozpoczyna się od serii bardzo krótkich ujęć. Przy drugim ujęciu - w prawym górnym rogu - pojawia się napis informujący o miejscu i dokładnym czasie zdarzeń. Taki zabieg formalny - typowy dla dyskursów faktualnych - mógłby stanowić zapowiedź procedur filmowania, które uwydatniają potencjał zapisu jako obiektywnego przekazu rzeczywistości ${ }^{263}$. Procedury te zdaniem Mirosława Przylipiaka - polegają na zminimalizowaniu czynnika technicznego oraz czynnika ekspresyjnego m.in. poprzez używanie czysto „obserwacyjnych" punktów widzenia i planów ${ }^{264}$. W analizowanej sekwencji istnieje nieustanne napięcie pomiędzy trzema równoprawnymi punktami widzenia. W pierwszych sześciu ujęciach zastosowano naprzemiennie "subiektywny” i "obiektywny” punkt widzenia. Dla przykładu, ujęcie inicjalne ma charakter zdecydowanie subiektywny kamera przyjmuje punkt widzenia jednego z napierających na bramę robotników. Nie widać twarzy, jedynie ręce ujmujące drewnianą belkę, która służy manifestantom jako taran. Ujęcie drugie to "obiektywne” spojrzenie na fragment więziennych zabudowań. Ujęcie trzecie stanowi powtórzenie "subiektywnego" ujęcia pierwszego itd. W ujęciu siódmym perspektywa oglądu zdarzeń ulega gwałtownej zmianie. Kamera, ulokowana wysoko ponad głowami manifestantów, filmuje szturmujący tłum z zaskakującego - jakby „ponadludzkiego” - punktu widzenia,

${ }^{261}$ Bronisław Baczko, Wyobrażenia społeczne, dz. cyt., s. 56.

${ }^{262}$ Zob. Robert Rosenstone, October as History, "Rethinking History: The Journal of Theory and Practice" 2001, no. 5. Tekst dostępny na stronie: www.culturahistorica.es/rosenstone/october_as_history.

${ }^{263}$ Mirosław Przylipiak, Poetyka kina dokumentalnego, Wyd. Uniwersytetu Gdańskiego, Gdańsk-Słupsk 2004, s. 60.

${ }^{264}$ Tamże. 

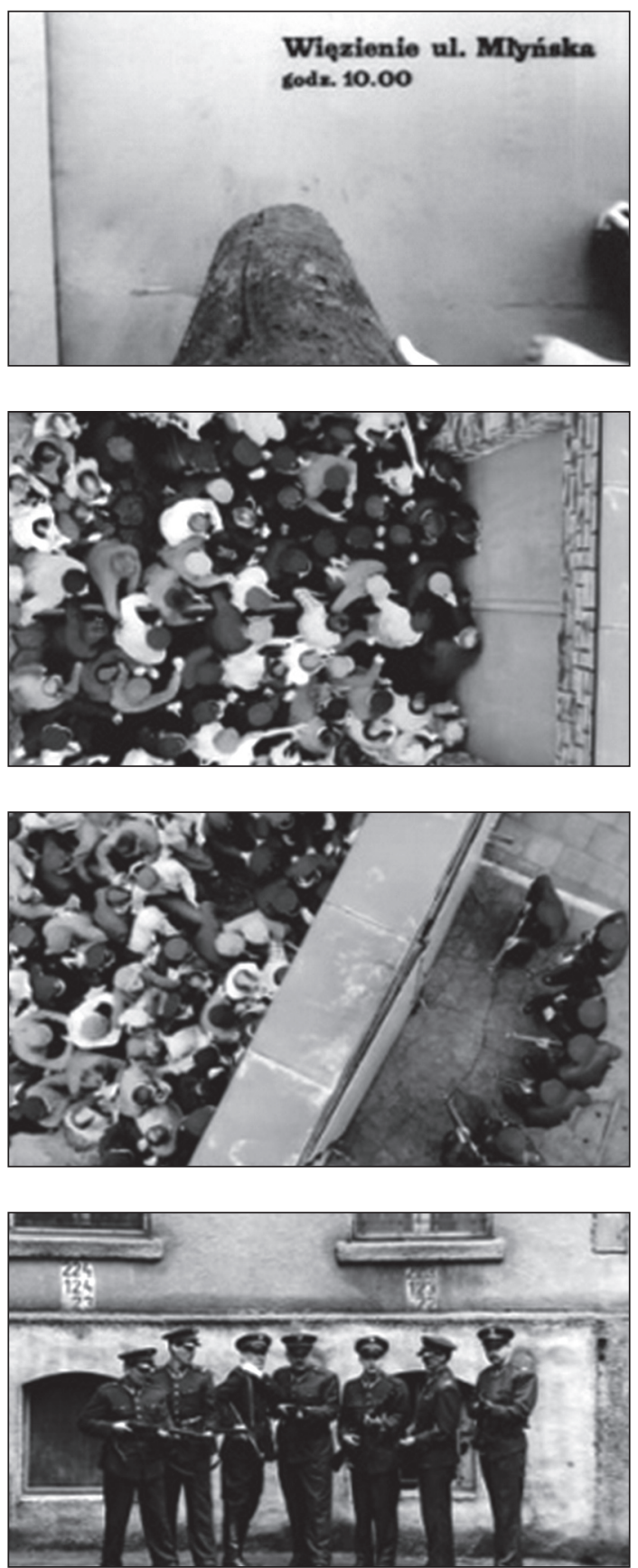

Fot. 20-23. Poznań 56 (1996, reż. Filip Bajon) Zdobycie „Bastylii” 
nieuzasadnionego wymogami dramaturgii. Ujęcie siódme ma charakter autoreferencyjny - ujawnione w nim spojrzenie kamery autonomizuje się. W ujęciu ósmym powracamy do spojrzenia "obiektywnego", ale statyczny kadr - kontrastowo zestawiony z poprzednim, niezwykle dynamicznym ujęciem - wywołuje wrażenie sztuczności. Ową sztuczność podkreśla, ujawnione w ujęciu dziesiątym, zakłócenie logiki przestrzennej. Grupa strażników z ujęcia ósmego została „malowniczo” zakomponowana na tle więziennego muru. W ujęciu dziesiątym ta sama grupa - nie zmieniając pozycji - stoi tuż przy bramie. Dodatkowo ujęcie jedenaste (podobnie jak ujęcie siódme i dziewiąte) - zrealizowane przy użyciu kamery umieszczonej w górze - odsłania przed widzem akcję rozgrywającą się jednocześnie po dwóch stronach barykady.

Nieustanna zmiana punktów widzenia, paradoksalnie, nie jest narzędziem rzetelnego i wielostronnego opisu. Akcentowanie omnipotencji kamery, przy jednoczesnej rezygnacji z czysto „obserwacyjnych” punktów widzenia i systematycznym zakłócaniu płynności ujęć, okazuje się elementem strategii dystansu (fot. 20-23).

Ewidentnym przykładem Brechtowskiego chwytu formalnego jest wprowadzenie do sceny rozmowy Zosi i Zenka (w której ujęcia w planach średnich montowane są naprzemiennie ze zbliżeniami twarzy kobiety) „drugiego ekranu”. W lusterku zaparkowanego przy ulicy samochodu odbijają się sylwetki maszerujących w tle robotników, co w dużej mierze przyczynia się do dystrakcji uwagi patrzącego. Obrazy symultanicznie „wyświetlające się" na „wewnętrznym ekranie” nie zostały sfunkcjonalizowane dramaturgicznie, a wyrafinowana formalnie inscenizacja podkreśla metatekstowy charakter całej sceny. Tego typu ujęcia mają charakter jawnie autorefleksyjny. Ujawnia się w nich - w sposób eksplicytny - strategia, która ma na celu

demistyfikację poprzez stwarzanie świadomości medium. Jako widzowie zachowujemy dystans w Brechtowskim sensie tego słowa, co umożliwia nam wgląd w stosunek twórcy do medium oraz do wydarzeń przed kamerą. Refleksywność odsłania proces filmowania i ujawnia, że medium to tylko medium ${ }^{265}$ (fot. 24-25).

${ }^{265}$ Warren Bass, Obiektywność filmowa a styl wizualny, [w:] Panorama wspótczesnej myśli filmowej, red. i tłum. Alicja Helman, Universitas, Kraków 1992, s. 139. 

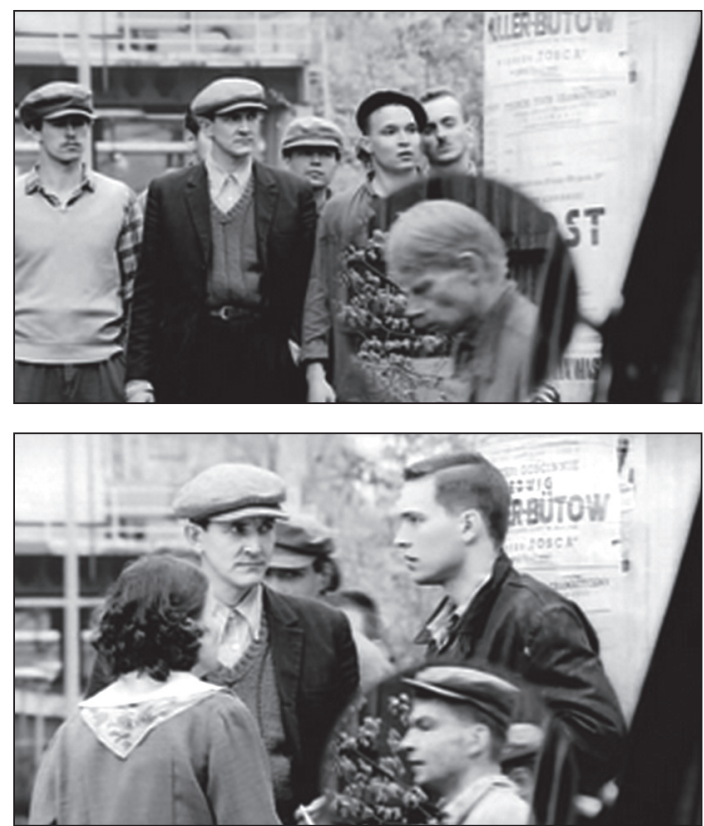

Fot. 24-25. Poznań 56 (1996, reż. Filip Bajon) Projekcja na wewnętrznym ekranie

Bajon stosuje chwyty formalne także $\mathrm{w}$ tych partiach filmu, które obarczone zostały wyjątkowym ładunkiem emocjonalnym. Ewidentnym przykładem jest stylizacja scen śmierci. Metoda prezentowania śmierci na ekranie została podporządkowana zasadzie decorum. Jest to szczególnie widoczne w "ekspresjonistycznej” scenie konania - bo ta śmierć nie jest „zwyczajnym” umieraniem - tajniaka. Nienaturalnie wygięte ciało mężczyzny spoczywa w poprzek schodów stanowiących tu rodzaj proscenium. Ostatnie słowa umierającego wzmacniają niezwykły patos całej sceny, nadając jej charakter „operowy” (fot. 26).

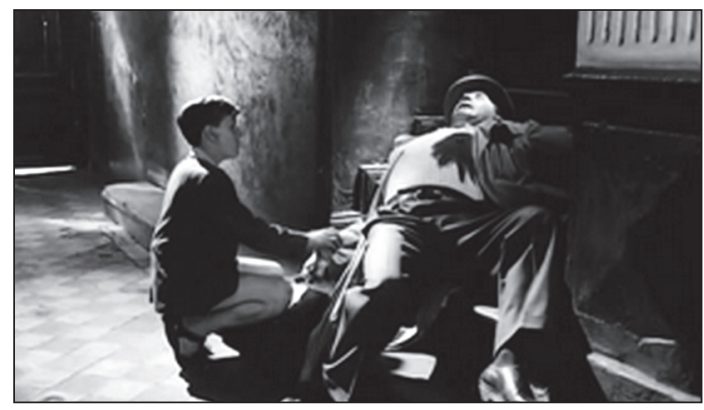

Fot. 26. Poznań 56 (1996, reż. Filip Bajon) Operowe decorum śmierci 
W podobnie teatralny sposób została zakomponowana sekwencja, w której ciężko ranny zostaje Zenek. To jedna z licznych w filmie wypowiedzi odautorskich i metatekstowych ${ }^{266}$. Oszalały z wściekłości chłopak wychodzi na całkowicie wyludnioną ulicę-scenę. Wzywa mordercę Piotrka do ujawnienia się. Kamera ukazuje rzędy pustych okien - jedynych świadków dramatu. Padają strzały. Zenek konwulsyjnie (niczym Chełmicki w Popiele $i$ diamencie) zwija się na bruku. Czas ulega spowolnieniu. U wylotu ulicy pojawia się „anielska” postać sanitariuszki, która niespiesznie „płynie" w kierunku leżącego. W omawianej sekwencji zwraca uwage prawie niedostrzegalna zmiana punktu widzenia: obrazy "obiektywne" płynnie przechodzą w osobliwa niewidzialna subiektywnośćc67. Oniryczne ujęcie z sanitariuszką to już subiektywna wizja tracącego świadomość Zenka.

Najbardziej znacząca wydaje się jednak scena, w której Zenek odnajduje zwłoki zastrzelonego Piotrka. Śmierć chłopca została, w dosłownym tego słowa znaczeniu, zainscenizowana ${ }^{268}$ przez Bajona. Kompozycja sceny z Piotrkiem stanowi czytelne odwołanie do utrwalonych w relacjach świadków opisów śmierci Romka Strzałkowskiego ${ }^{269}$, który - wzorem Małego Powstańca z 1944 r. - stał się symbolem (paradygmatyczną „ofiarą niewinną") Poznańskiego Czerwca, a zarazem elementem konstytutywnym dla "powstańczego" mitu ${ }^{270}$. Wedle tych opisów ciało trzynastolatka

znaleziono w pozycji siedzącej przywiązane do krzesła na terenie garażów należących do Urzędu Bezpieczeństwa. Zginął w niewyjaśnionych do dzisiaj okolicznościach - do końca nie ma pewności, czy został z premedytacją zamordowany, czy też stał się ofiarą zbłąkanej kuli, choć zdecydowana większość informacji przemawia za pierwszą wersją ${ }^{271}$.

Filmową inscenizację śmierci Piotrka należy potraktować zatem jako efekt "gestu" - ujawnionego już w samej formie inscenizacji. W ten sposób Bajon daje widzowi do zrozumienia, że przywołuje zdarzenie, które w społecznej świadomości (także za sprawą przekazów kulturowych) zostało zmitologizowane:

${ }^{266}$ Kompozycja sceny nasuwa nieuchronne skojarzenia z dokumentalnym „półkownikiem" Litowczenki.

${ }^{267}$ Gilles Deluze, Kino, dz. cyt., s. 235.

${ }^{268}$ Scenę ostatecznej rozprawy Darka z ojcem - podczas której chłopiec odtwarza („inscenizuje") śmierć kolegi - należałoby w tym wypadku potraktować jako przykład inscenizacji „drugiego stopnia”. W obu wypadkach Bajon sugeruje widzowi „metatekstowy” charakter stylizacji scen śmierci: mamy do czynienia z przedstawieniem/inscenizacją.

${ }^{269}$ Próbę wyjaśnienia tajemniczych okoliczności śmierci chłopca podjął w 1982 r. Marek Drążewski w dokumentalnym filmie Jeszcze czekam.

${ }^{270}$ Wyrazem społecznej legitymizacji „Warszawskiego” rodowodu Czerwca jest poznański pomnik Dzieci Czerwca '56, wzorowany na stołecznym pomniku Małego Powstańca.

271 Paulina Codogni, Rok 1956, dz. cyt., s. 197. 
ludzie mówili, że jakiś chłopiec pobiegł w stronę gmachu, powiewając biało-czerwoną choragiewka, być może, aby zatknąć ją u wejścia i że nagle padł strzał i chłopiec dostał kula, co mogło być prawdą [podkr. moje - N.K.-R.], bo ten niewielki kawałek biało-czerwonego płótna, skrwawionego i oddartego od drzewca obnoszono i pokazywano $[\ldots]^{272}$.

Nierozstrzygniętą pozostaje jedynie kwestia, czy odwołanie się do „mitu Romka Strzałkowskiego” („ofiary niewinnej”) wzmacnia tragizm śmierci Piotrka, czy też czyni ją - poprzez element inscenizacji - śmiercią stricte filmową (fot. 27-28).
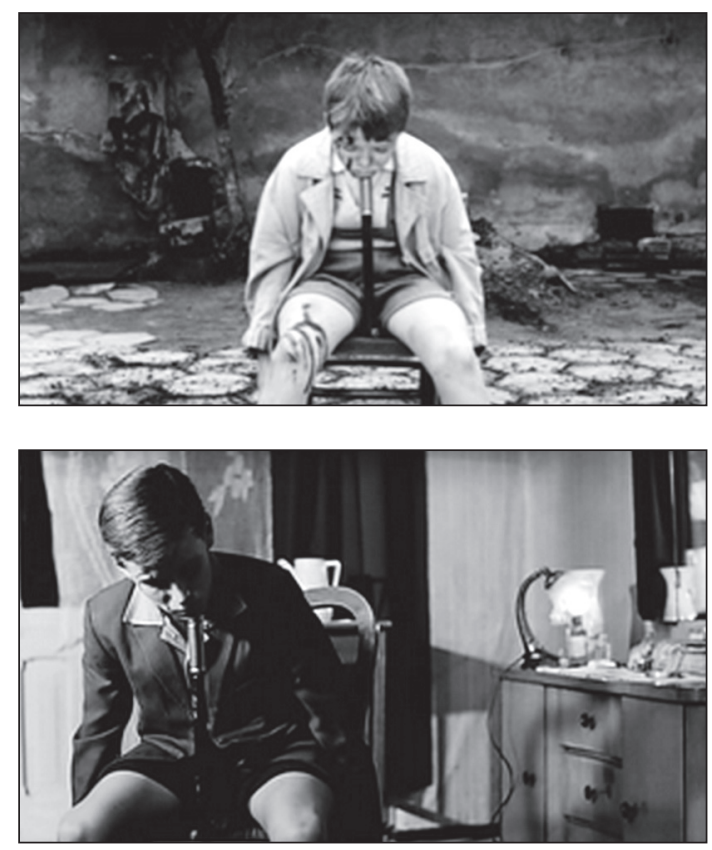

Fot. 27-28. Poznań 56 (1996, reż. Filip Bajon) Inscenizacja ofiarniczo-żałobna

${ }^{272}$ Włodzimierz Odojewski, Spisywane z pamięci, dz. cyt., s. 271. Pisze o tym również Makowski: „Grupa demonstrantów obnosiła po mieście podarty, poplamiony krwia, biało-czerwony sztandar i głosiła, że to jest krew 16-letniego chłopca zabitego przez ubowców". Zob. Edmund Makowski, Poznański Czerwiec 1956, dz. cyt., s. 144. Skorelowanie symboliki „ofiary niewinnej” (dziecko) z symboliką narodową (skrwawiony biało-czerwony sztandar) i religijną (w zasadzie nieobecną u Bajona) jest bardzo silnie widoczne w narracji Grudnia '70, zogniskowanej wokół śmierci „mitycznego” Janka Wiśniewskiego (młodziutkiego, zaledwie 18-letniego Zbyszka Godlewskiego). Warto pod tym kątem porównać Poznań 56 z Czarnym czwartkiem Antoniego Krauzego. Bajon nie przywołuje wydarzenia związanego ze śmiercią Romka Strzałkowskiego w sposób bezpośredni, a jedynie poprzez „cytat”. Krauze czyni ze śmierci Janka Wiśniewskiego 
Opatrzenie sceny śmierci tak wyraźnym cudzysłowem stanowić może formę obrony przed kiczem. Celem kiczu jest

przeistoczenie odbiorcy z istoty myślącej w istotę czującą - kogoś, kto przedkłada wzruszenie nad poznanie. Uczucie jest „bronią masowego rażenia” kiczu, mierzącą w tłumy na wiecach politycznych, w salach kinowych i przed telewizorami. Najskuteczniej można poruszyć masy, operując archetypowymi, mocno zakorzenionymi w świadomości obrazami. Kiczu nie tylko nie trzeba, ale wręcz nie należy rozumieć, wystarczy się wzruszaćc73.

Kicz żeruje na motywach, które gwarantują silny rezonans emocjonalny ze strony widza, a tragiczna śmierć dziecka to temat $\mathrm{w}$ tej grupie motywów uprzywilejowany. W analizowanej scenie Bajon nie odwołuje się jednak do uczuć odbiorcy, lecz do jego wiedzy i kulturowych kompetencji. Uzyskuje tym samym efekt dystansu. Czy tak "zaprojektowany” widz przestaje być jednak istota czujaca?

Podobne wątpliwości, co do intencji twórcy wzbudzać może sekwencja ataku na komendę. Tym bardziej, że wzorzec konstrukcyjny, do którego Bajon się w tej sekwencji odwołuje, został „utajniony” i niejako wmontowany w dyskurs. Struktura sekwencji - począwszy od momentu opuszczenia przez grupę Zenka restauracji do momentu załadowania rannych na ciężarówkę - oparta jest na klasycznym schemacie westernowym. Finałowa strzelanina - dramaturgiczny climax westernu - odbywa się w scenerii opustoszałego miasteczka. Zastraszeni mieszkańcy z bezpiecznej odległości kibicują bohaterom (robotnikom) gotującym się do ostatecznej rozgrywki z siłami wroga (milicją). Zło jest anonimowe (strzały od strony komendy padają z ukrycia) i w pewnym sensie abstrakcyjne. Sposób filmowania reprezentantów "dobra" (kamera ustawiona za plecami postaci) zdradza filmową proweniencję - grupa Zenka to przecież „pięciu wspaniałych" (fot. 29-30).

(i jej konsekwencji w postaci pochodu maszerującego z ciałem zabitego chłopca) dramaturgiczną oś dzieła (na to, iż fakt owej śmierci stanie się ośrodkiem sensotwórczym filmu, wskazuje podtytuł Czarnego czwartku: Janek Wiśniewski padł). W sekwencji pochodu szczególną uwagę zwraca jedna scena: w momencie zamieszania (chaos spowodowany strzałami) dwóch mężczyzn wynosi z pobliskiego kościoła krucyfiks, który zostaje natychmiast umieszczony przy zwłokach („przyozdobionych” wcześniej białymi i czerwonymi goździkami).

W kontekście symboliki „ofiary niewinnej” niezwykle ważna informacja pojawia się w materiale dodatkowym dołączonym do płytowego wydania filmu. W dokumencie Czarny czwartek. Gdynia '70. Dlaczego? umieszczone zostały materiały archiwalne, m.in. zapis nasłuchu radiowego funkcjonariuszy SB. Z zachowanych taśm dowiadujemy się, iż na sztandarze niesionym przez jedną z mniejszych grup formujących „pochód Janka Wiśniewskiego" został umieszczony napis „krew dzieci”.

273 Agnieszka Morstin-Popławska, Historia pewnego złudzenia. Teorie kiczu i "Podwójne życie Weroniki” Krzysztofa Kieślowskiego, „Kwartalnik Filmowy” 2009, nr 66, s. 146. 

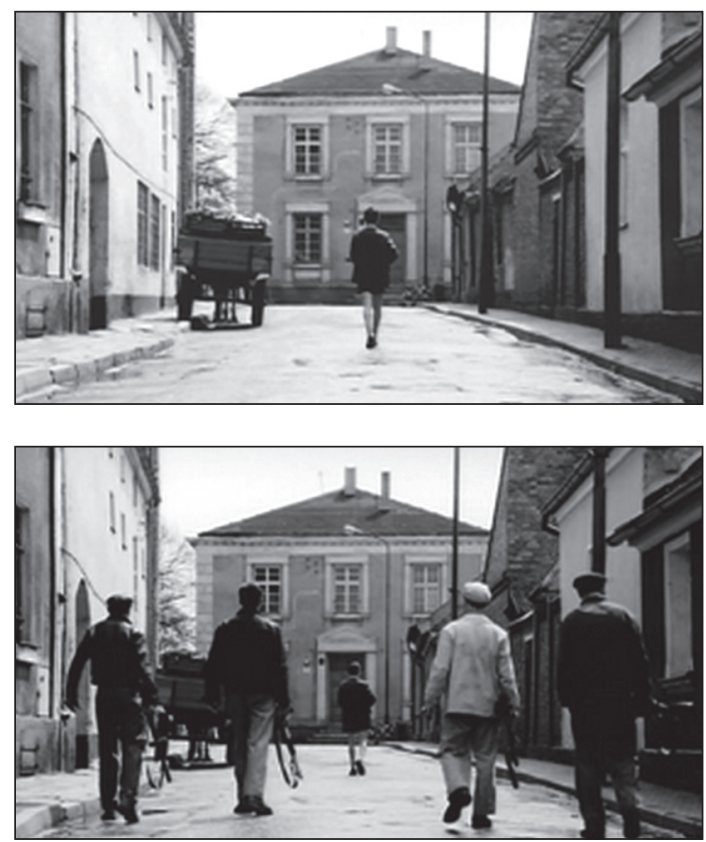

Fot. 29-30. Poznań 56 (1996, reż. Filip Bajon) „W samo południe” i „Pięciu wspaniałych"

W kadrze pojawia się nawet charakterystyczny dla ikonografii westernu element: „konny zaprzęg” (ze skrzynkami swojskiej kapusty). Zdaniem Bajona ",atak na komendę jest wydarzeniem bardzo filmowym”. Ujawnienie westernowego wzorca dowodzi, iż analizowana sekwencja ma swój rodowód w kinie - nie w historii. Na koniec przypomnijmy zatem, iż wedle pierwotnego zamysłu reżysera Poznań 56 miał się zaczynać od ujęcia pochodzącego z filmu braci Lumière Wyjście robotników z fabryki w Lyonie, płynnie przechodzącego w scenę wyjścia robotników z poznańskiego „Cegielskiego" 274 .

W refleksji nad Poznaniem 56 nieustannie przewija się motyw fotografii. Czynność fotografowania została wyeksponowana na poziomie tekstualnym - zdjęcia wykonuje anonimowy obserwator na wiecu, ubek $\mathrm{w}$ więzieniu, tajniak z teczką i kobieta $\mathrm{w}$ oknie. Uwiecznienia na zdjęciu-dokumencie domagają się strajkujący. Na widok zagranicznych gości Targów ludzie idący w pochodzie skandują: Róbcie nam zdjęcia! A przecież nie tylko do funkcji dramaturgicznej da się sprowadzić akt fotografowania. Estetyka czarno-białej fotografii staje się nadrzędną zasadą organizującą sensy filmu Bajona ${ }^{275}$. Na marginesie warto zauważyć, iż brak koloru

${ }^{274}$ Zob. Ewelina Nurczyńska-Fidelska, Czas i przesłona, dz. cyt., s. 192.

${ }^{275}$ Brak koloru można by interpretować jako przykład Brechtowskiego „efektu obcości”, 
można interpretować - niezależnie od deklaracji samego twórcy - jako przykład Brechtowskiego „efektu obcości”, zakłócającego w doświadczeniu odbiorczym „wrażenie realizmu”. Wydaje się bowiem, iż Bajon posłużył się w filmie rozwiązaniem formalnym, które niezwykle trafnie scharakteryzowała Mieke Bal w odniesieniu do Listy Schindlera:

Wykorzystanie techniki filmu czarno-białego, często błędnie rozumiane jako aspirowanie do historycznej adekwatności, można również uznać za część tej antyrealistycznej strategii, która odrealnia to, co widzimy, nawet jeśli konotuje „historyczność" 276 .

Argumentu usprawiedliwiającego wybór takiej estetyki reżyser poszukuje w rezerwuarze własnej pamięci:

Chciałem sfotografować swój Poznań... Ten swój czarno-biały Poznań z lat pięćdziesiątych. Bo pamiętam go w czerni i bieli. Nie było wtedy kolorów, był szary asfalt, szare domy, szare. Na tym to polegało, że chciałem odfotografować ten Poznań277.

Subiektywne odczucie artysty legitymizuje impresyjna relacja przypadkowego świadka czerwcowych zdarzeń, w której na plan pierwszy wysuwa się wrażenie... dojmującej nieobecności koloru:

po wyjściu z domu zauważyłem niezwykły tłum. Przesuwał się ulicami Wildy w kierunku śródmieścia. Dominowała szarość. Była to szarość kombinezonów. Brakowało mi znanych z pochodów pierwszomajowych kolorów ${ }^{278}$.

W przypadku Poznania 56 odwoływanie się do wspomnień - własnych albo cudzych ${ }^{279}$ - stanowi jedynie rodzaj wiarygodnego alibi skrywającego motywy nie tylko o charakterze stricte estetycznym. W przywołanej wypowiedzi Bajon dwukrotnie - w sposób niezwykle znaczący - posługuje się określeniem fotografować dla opisu procesu tworzenia filmu. Tym samym sugeruje kierunek przyszłej lektury. Analiza poszczególnych filmowych kadrów pozwoli ujawnić podstawowe źródło, z którego wzięła początek

zakłócającego w doświadczeniu odbiorczym „wrażenie realizmu”. „A jednak - jak zauważa Alicja Helman - jeśli odwołamy się do samych filmów, zrodzi się podejrzenie, czy przypadkiem nie miał racji Kracauer pisząc, że realistyczny jest dźwiękowy film czarno-biały [podkr. moje - N.K.-R.] o standardowym formacie ekranu, podczas gdy każda innowacja techniczna nas od niego oddala". Zob. Alicja Helman, Á propos realizmu, „Kwartalnik Filmowy” 2011, nr 75-76, s. 48.

${ }^{276}$ Mieke Bal, Narratologia. Wprowadzenie do teorii narracji, tłum. zbiorowe, Wyd. Uniwersytetu Jagiellońskiego, Kraków 2012, s. 45.

277 Włodzimierz Braniecki, Szczun, dz. cyt., s. 138.

278 Zob. Edmund Makowski, Poznański Czerwiec 1956, dz. cyt., s. 63-64.

${ }^{279}$ Współautorem filmu był poznański pisarz Andrzej Górny - uczestnik Czerwca. Nowela filmowa Górnego Za późno, za wcześnie, już czas stała się podstawą scenariusza Poznania 56. 
wyrafinowana forma dzieła. Jest nim fotografia. Zdjęcia stanowią wspornik ulotnej pamięci artysty, pragnącego odfotografować swój Poznań.

Świat szybko i radykalnie wymyka się podobieństwu ze zdjęciem, które przecież właśnie z powodu podobieństwa zostało wykonane. Tylko na fotografii świat pozostaje takim, jakim niegdyś był. [...] Świat staje się w fotografii archiwum obrazów. Również obrazy fotograficzne pozostają niemymi wspomnieniami naszych przeszłych spojrzeńn ${ }^{280}$.

Bajon nie interpretuje jednak fotografii w duchu filozofii Rolanda Barthesa jako "dowodu" - świadectwa "tego-co-było". Zdjęcia - także reportażowe - postrzega w kategoriach „śladów”, które zawsze mają charakter poetycki ${ }^{281}$. Nie są one reprodukcją (,,pasywnym zapisywaniem materialnego odniesienia" ${ }^{282}$ ) rzeczywistości, lecz jej twórczym przekształceniem i subiektywną interpretacją. Fotografia organizuje formalną strukturę dzieła Bajona. W niej ma swoje źródło - tak krytykowana przez recenzentów - poetyka fragmentu. Fotografia wymyka się zasadom porządkowania narracji historycznej - podkreśla Gajewska - nie tworzy kontekstów, ciągów narracyjnych, ani nie buduje logicznej linii wywodu. Dlatego, według Barthes'a, fotografie są świadectwem tego, co było, ale nie stanowią źródła wiedzy o przeszłości; są świadkami, których dyskurs historii nie potrafi oswoić ani wtłoczyć w swe ramy ${ }^{283}$. Poprzez segmentację - widzenie wszystkiego osobno - fotografia prowadzi do kumulowania ogromnych ilości cząstkowych punktów widzenia, fragmentów i strzępów rzeczywistości: powstaje chaos obrazów, w którym nerwowo poszukuje się jedności $^{284}$. Zdaniem Susan Sontag estetyczny dystans jest wbudowany w samo doświadczenie towarzyszące oglądaniu zdjęć285. W przypadku Poznania 56, którego forma tak doskonale odzwierciedla fotograficzny chaos obrazów, to doświadczenie staje się udziałem widza.

Poznań 56 to filmowy palimpsest, w którym każdy kadr odsyła do kolejnych kadrów-zdjęć, stanowiących materialny ślad innych spojrzeń. To właśnie one pozwalają widzowi odkrywać coraz głębsze pokłady obrazowej materii:

${ }^{280}$ Hans Belting, Antropologia obrazu. Szkice do nauki o obrazie, tłum. Mariusz Bryl, Universitas, Kraków 2007, s. 260-261.

${ }^{281}$ François Soulages, Estetyka fotografii. Strata i zysk, tłum. Beata Mytych-Forajter, Wacław Forajter, Universitas, Kraków 2007, s. 7.

${ }^{282}$ André Rouillé, Fotografia. Między dokumentem a sztuka współczesna, tłum. Oskar Hedemann, Universitas, Kraków 2007, s. 252.

${ }^{283}$ Grażyna Gajewska, O cierpieniu i przyjemności zwiąanej z (re)produkowaniem przeszłości, dz. cyt., s. 164-165.

${ }^{284}$ André Rouillé, Fotografia, dz. cyt., s. 116-117.

${ }^{285}$ Susan Sontag, O fotografii, tłum. Sławomir Magala, Wyd. Artystyczne i Filmowe, Warszawa 1986, s. 25. 
Nie chodzi już o imitowanie natury, lecz o imitację kultury, a więc mamy do czynienia w tym wypadku z imitacją wyższego stopnia. [...] nie chodzi o ukazanie istoty za pośrednictwem obrazów, lecz ukazanie obrazów poprzez palimpsest²86.

Pomiędzy rzeczywistością historyczną i jej filmową reprezentacją znajduje się nieskończona liczba innych obrazów, niewidocznych, lecz działających, które tworzą wizualny porządek, narzucając ikonograficzne zalecenia i estetyczne schematy ${ }^{287}$. Formuła „fotograficznego palimpsestu" odzwierciedla stosunek Bajona do historii. Poznań 56 nie jest rekonstrukcją czerwcowych wydarzeń, lecz sprawozdaniem-wspomnieniem $\mathrm{z}$ lektury pozostawionych przez te wydarzenia w kulturze głównie ikonicznej - „śladów". Akt wspominania nigdy nie jest prostą reprodukcją zakłada re-konstrukcję przeszłości, w którą wplecione są wrażenia i informacje z teraźniejszości; to kreacja wychodząca od istniejących uprzednio wzorów ${ }^{288}$.

W statycznym kadrze zamykającym filmową opowieść o Czerwcu 1956 r. widzimy uśmiechniętego chłopca w charakterystycznych ciemnych okularach. Ten rozświetlony - „biorący rzeczywistość w cudzysłów" - kadr-cytat ewokuje w pamięci widza inny obraz niewidoczny, lecz działajacy. Czy ten chłopiec umieszczony w odmiennym czasie mógłby się nazywać Maciek Chełmicki? (fot. 31).

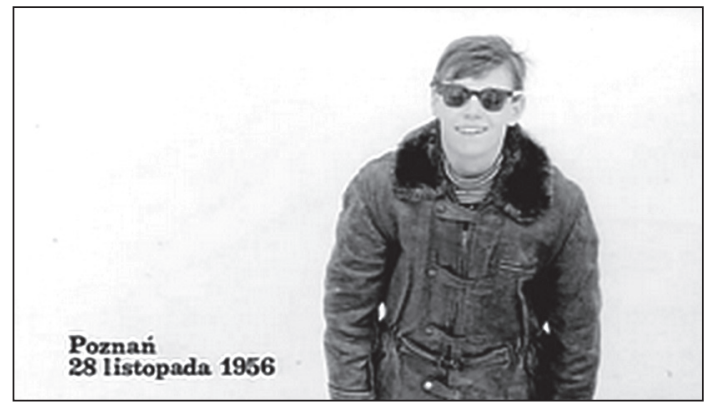

Fot. 31. Poznań 56 (1996, reż. Filip Bajon) Filmowy palimpsest

W końcu nikt nie widzi sensu historii - przypomina Przemysław Czapliński - w której żyje, dopóki historia nie przeminie, czyniąc rozumienie spóźnionym. Nie o uchwycenie sensu historii wiec chodzi, lecz o wypracowanie języka, który, będąc moim, pozwoli mi zrozumieć cudze mówienie o historiii ${ }^{289}$.

\footnotetext{
${ }^{286}$ André Rouillé, Fotografia, dz. cyt., s. 443.

287 Tamże, s. 12.

${ }^{288}$ Jan Kordys, Kategorie antropologiczne i tożsamość narracyjna, dz. cyt., s. 152.

289 Przemysław Czapliński, Języki niezależności, dz. cyt., s. 44.
} 


\section{CzĘŚĆ TRZeCIA}

\section{Spojrzenie (post)historyka}

Dzisiejsze pokolenie interpretatorów, podobnie jak pokolenia poprzednie, jest jedyną istniejącą władzą semantyczną: $w$ historii to my jesteśmy źródłem tego, co znaczy dla nas przeszłość.

Keith Jenkins

Jeżeli nawet przyznamy, że każde pokolenie ma prawo pisać własną historię, to odmówimy mu prawa do przerabiania faktów w imię zgodności z własną perspektywą widzenia.

Hannah Arendt

History needs to be rewritten.

Oliver Stone 



\section{Rozdział IV}

\section{Czy Sikorski mógł zginąć w Dallas? Generat. Zamach na Gibraltarze Anny Jadowskiej}

To jasne, że nie istnieje żadna absolutna różnica pomiędzy mitem, fikcją i historia, i że wszystkie opowieści - mityczne, fikcjonalne bądź historyczne - można ocenić, spoglądając na inne opowieści. Nie można ich oceniać - i dotyczy to zarówno historii, jak i fikcji - poprzez spoglądanie na rzeczywistość.

Peter Munz

Narracje historyczne są interpretacjami przeszłości. Z punktu widzenia logiki, interpretacje narracyjne są ze swej natury propozycjami (widzenia przeszłości z pewnego punktu widzenia). Propozycje mogą być użyteczne albo nie, owocne albo nie, ale nie mogą być ani prawdziwe, ani fałszywe; to samo można powiedzieć o narracjach historycznych.

Frank Ankersmit

Postawione w tytule pytanie wydaje się jedynie chwytem retorycznym służącym wzbudzeniu zainteresowania potencjalnego czytelnika. W istocie odnosi się ono do problemu relacji pomiędzy wydarzeniami historycznymi a faktami (czyli ich tekstową reprezentacją ${ }^{1}$ ). Jest także

1 W tekście wykorzystuję typologię Haydena White'a, który Leibnizjański podział na prawdę faktów i prawdę rozumu "przekłada" na pojęcia "zdarzenia" (rozumianego jako zajście, „które miało miejsce w czasie i przestrzeni w świecie rzeczywistym”) i "faktu” (definiowanego jako „twierdzenie o tym zdarzeniu, które ma formę predykatu”). White pisze: „Zdarzenia zachodzą i są poświadczone w sposób mniej lub bardziej adekwatny w źródłach pisanych, śladach i pomnikach przeszłości; fakty zaś tworzone są konceptualnie w akcie refleksji i/lub figuratywnie w wyobraźni i istnieją tylko w myśli, języku lub dyskursie”. „A w innym miejscu dodaje: „[...] fakty nie mówią same za siebie, to historyk mówi zamiast nich, w ich imieniu, i modeluje fragmenty przeszłości w całość, której integralność jest - jako reprezentacja - czysto dyskursywna". Zob. Hayden White, Proza historyczna, tłum. zbiorowe, Universitas, Kraków 2009, s. 119 i 92.

W podobny sposób ujmuje tę kwestię Frank Ankersmit. Historyk wskazuje na fundamentalną opozycję pomiędzy opisem a reprezentacją. W ujęciu Ankersmita - podążające- 
pytaniem o granice swobody twórcy „wchodzącego” częściowo w kompetencje historyka ${ }^{2}$. Historyka - dodajmy uprzedzając nieco późniejsze konstatacje - postmodernisty ${ }^{3}$, który postuluje epistemologiczny sceptycyzm ${ }^{4}$ i na miejsce koncepcji poznania rozumianego jako dochodzenie do prawdy (w ujęciu klasycznym) proponuje koncepcję poznania rozumianego jako konstruowanie obrazu poprzez narrację (w oparciu o dokumenty traktowane jako teksty ${ }^{5}$ ), które obywa się bez pojęcia prawdy ${ }^{6}$. Teoria postmodernistyczna koncentruje się na samozwrotności i problemach konstrukcji literackiej: jak historyk jako autor konstruuje swoje teksty, jak wywoływane jest wrażenie autentyczności, w jaki sposób stwarzane jest poczucie zgodności z faktami i niegdysiejszą rzeczywistością („efekt prawdy”)7. To, co historyk-tradycjonalista traktuje jako zdarzenie, które istotnie miało miej-

go tropem XIX-wiecznych historyków niemieckich - opozycję tę można ująć za pomocą terminów: „badania historyczne” (tj. czynności historyka zmierzające do ustalenia faktów dotyczących przeszłości: kiedy coś się wydarzyło, z jakiego powodu, co o tym zdarzeniu mówi źródło) oraz „pisarstwo historyczne” (najbardziej przekonująca - w opinii historyka - „reprezentacja” części przeszłości). Przejście od „badań” do „pisarstwa” oznacza przeniesienie się z poziomu opisu na poziom przedstawiania, którym kieruje inny rodzaj logiki. Zob. Frank Ankersmit, Narracja, reprezentacja, doświadczenie. Studia z teorii historiografii, tłum. zbiorowe, Universitas, Kraków 2004, s. 33. W kontekście typologii Ankersmita casus katastrofy Gibraltarskiej wydaje się niezwykle interesujący. W tym szczególnym przypadku historykowi nieodstępny jest "poziom opisu” (mam na myśli przede wszystkim fundamentalną niemożność jednoznacznej odpowiedzi na pytanie: „z jakiego powodu doszło do zdarzenia stanowiącego przedmiot badań?”).

2 Dla przykładu, Oliver Stone - tuż przed przystąpieniem do realizacji JFK - na łamach "Dallas Morning News" określił się mianem cinematic historian, a sam film zapowiedział jako „lekcję historii”. Zob. Michael L. Kurtz, Oliver Stone, JFK, and History, [w:] Oliver Stone's USA, ed. Robert Brent Toplin, University Press of Kansas, Lawrence 2000, s. 167.

3 Można jednak - jak czyni to Robert Rosenstone - odwrócić wspomnianą relację i uznać, iż przykładów postmodernistycznej historiografii należy poszukiwać raczej na ekranie, niż na kartach książek. Zwolennicy tzw. posthistorii wskazują na zaskakująco niewielką liczbę publikacji spełniających ich kryteria. Zob. Robert Rosenstone, The Future of the Past. Film and the Beginnings of Postmodern History, [w:] The Persistence of History. Cinema, Television and the Modern Event, ed. Vivian Sobchack, Routledge, New York-London 1996, s. 206.

4 Dla White'a podstawową wartością modernistycznych technik służących reprezentacji traumatycznych zdarzeń XX w. jest poczucie niepewności - epistemologiczny sceptycyzm - odczuwane wobec pewników wiedzy historycznej. Zob. Robert Burgoyne, Modernism and the Narrative of the Nation in "JFK", [w:] The Persistence of History, dz. cyt., s. 118.

5 Jacques Le Goff - polemizujący z White'em zwolennik tezy o stricte naukowym statusie historii - pisze jednak: „każdy dokument jest pomnikiem albo tekstem i nigdy nie występuje «w stanie czystym», tzn. nie jest absolutnie obiektywny". Zob. Jacques Le Goff, Historia i pamięć, tłum. Anna Gronowska, Joanna Stryjczyk, Wyd. Uniwersytetu Warszawskiego, Warszawa 2007, s. 172.

6 O krytyce epistemologii na gruncie postmodernizmu pisze Dorota Wolska. Zob. taż, Odzyskać doświadczenie. Sporny temat humanistyki wspótczesnej, Universitas, Kraków 2012, s. 74.

7 Joyce Appleby, Lynn Hunt, Margaret Jacob, Powiedzieć prawdę o historii, tłum. Stefan Amsterdamski, Zysk i S-ka, Poznań 2000, s. 240. 
sce $\mathrm{w}$ przeszłości, historyk-postmodernista postrzega jako konstruowany i interpretowany przez badacza "tekst" istniejący wyłącznie w teraźniejszościs. Wielu badaczy wiąże tę „epistemologiczną rewolucję" nie tylko ze zwrotem lingwistycznym - o którym za chwilę - lecz także ze zjawiskiem zdominowania mediów przez wirtualną rzeczywistość historyczna, która z mocy definicji pytania o autentyczność czyni bezprzedmiotowymi.

Badacze poddający obecnie rewizji granice historii jako dyscypliny robią to w różny sposób: fikcjonalizują przeszłość, w ramach nowych badań kulturowych zajmują się miejscami wspólnymi filmu i historii, skupiają się bardziej na badaniu pamięci, niż historii, próbują różnych form pisarskich i innych sposobów przedstawiania ${ }^{10}$.

Zdaniem badaczy z kręgu narrative turn (stanowiącego część znacznie szerszego zjawiska, określanego jako zwrot lingwistyczny, w obrębie którego akcentowana jest niestabilność rzeczywistości i jej uwikłanie w dyskurs) nie istnieje różnica pomiędzy dyskursem historycznym i dyskursem literackim. Operacja fabularyzacji, jakiej dokonać muszą zarówno historycy, jak i twórcy literatury, likwiduje opozycję pomiędzy dwoma wspomnianymi powyżej typami dyskursu. Zdaniem Haydena White'a

8 Zob. Gertrude Himmelfarb, Telling it as you like it: postmodernist history and flight from fact, [w:] The Postmodern History Reader, ed. Keith Jenkins, Routledge, London-New York 2005, s. 162.

9 Zob. Andrzej Szpociński, Autentyczność przeszłości jako problem kultury współczesnej, [w:] Wobec przeszłości. Pamięć przeszłości jako element kultury wspótczesnej, red. Andrzej Szpociński, Wyd. Instytutu im. Adama Mickiewicza, Warszawa 2005, s. 297. Zdaniem autora remedium na obserwowany od wielu lat w naukach humanistycznych kryzys przedstawienia może być kontakt z przeszłością, który: 1) dokonuje się poza (czy ponad) kulturą w sposób naturalny (czy quasi-naturalny); taki charakter ma poznanie/ doświadczenie zmysłowe, opozycyjne wobec poznania rozumowego (intelektualnego);

2) realizuje się raczej poprzez zmysł dotyku niż wzroku.

Obie formy kontaktu łączą się w analizowanym przez Franka Ankersmita „doświadczeniu („doznaniu” w ujęciu Johana Huizingi) historycznym”. Ankresmit pisze: „Najważniejsze cechy «doświadczenia historycznego» zostały opisane przez Huizingę. Według niego, doświadczenie historyczne jest zazwyczaj wywoływane przez stosunkowo trywialne przedmioty [sam Huizinga przeżył doświadczenie historyczne w trakcie zwiedzania wystawy obrazów Van Eycka, które trudno byłoby określić jako «trywialne przedmioty»] [...]. Po drugie, doświadczenie historyczne jest - jak to ujął Huizinga - «oszołomieniem chwilą». Jest to coś, co historyk bardziej przeżywa, niż jest w stanie świadomie wywołać czy powtórzyć. I po trzecie, w doświadczeniu historycznym historyk ma wrażenie bycia w bezpośrednim i absolutnie autentycznym kontakcie z przeszłością. Mówi się w związku z tym, że Huizinga wiąże zjawisko doświadczenia historycznego bardziej ze zmysłem dotyku niż wzroku czy słuchu". Zob. Frank Ankersmit, Narracja, reprezentacja, doświadczenie, dz. cyt., s. 212-213.

10 Zob. Dipesh Chakrabarty, Historie mniejszości, przeszłości podrzędne, tłum. Ewa Domańska, [w:] Teoria wiedzy o przeszłości na tle współczesnej humanistyki, red. Ewa Domańska, Wyd. Poznańskie, Poznań 2010, s. 404. 
ponieważ pisarstwo historyczne jest rodzajem dyskursu, a zwłaszcza dyskursu narracyjnego, to nie ma zasadniczej różnicy pomiędzy reprezentacjami rzeczywistości historycznej a reprezentacjami wyobrażonych wydarzeń i procesów. [...] jakiekolwiek przedstawianie rzeczywistości w formie narracji z konieczności fikcjonalizuje swój przedmiot bez względu na to, jak dalece byłoby ono oparte na faktach. [...] Z tego wynika zaś, że użycie narracyjnego trybu dyskursu do przedstawienia rzeczywistości historycznej skutecznie zaciera różnicę między historią a fikcją czyni z historiografii jedynie szczególny rodzaj dyskursu „literackiego"11.

W tym ujęciu fikcjonalizacja stanowi immanentną cechę każdej narracji. W dyskursie narracyjnym (tj. w opowieści) postać historyczna zostaje przekształcona w „figurę”, tzn. wyposażona w określoną funkcję (,zamieniona z aktora w aktanta" ${ }^{\prime 2}$. Konsekwencją takiego rozumowania jest teza, iż narracje historyczne należy rozpatrywać jako „wytwory werbalnej fikcji, których treść jest tyleż rezultatem o d k r y c i a, co produktem i n w e n cji, a których forma ma więcej wspólnego z ich odpowiednikami w literaturze pięknej aniżeli w naukach ścisłych" ${ }^{13}$.

„Nowa historia" dowodzi, iż tradycyjne dyskursy historyczne utwierdzały czytelników w przekonaniu, iż jedynie racjonują to, co w rzeczywistości konstruują. Roland Barthes nazywa to zjawisko „iluzją referencyjną", gdyż przysłania ono subiektywną lub emotywną obecność historyka, wywołując fałszywe wrażenie, że przedmiot opowieści istnieje niezależnie od samej opowieści ${ }^{14}$. Przeciwnicy „nowej historii” widzą w niej niebezpieczeństwo ulegania złudzeniu, które można wyrazić za pomoca podwójnego równania: pisanie historii $=$ wymyślanie rzeczywistości historycznej = tworzenie rzeczywistości historycznej ${ }^{15}$. Dla interpretatora uznanie faktu, iż autorzy takich filmów jak JFK czy Generał świadomie budują przekaz w oparciu o to podwójne równanie, ma znaczenie fundamentalne ${ }^{16}$.

11 Zob. Hayden White, Proza historyczna, dz. cyt., s. 77-158.

12 Zob. Hayden White, Poetyka pisarstwa historycznego, tłum. zbiorowe, Universitas, Kraków 2010, s. 339.

13 Tamże, s. 80.

14 Zob. Joan W. Scott, Po historii?, tłum. Paulina Ambroży, [w:] Pamięć, etyka i historia, red. Ewa Domańska, Wyd. Poznańskie, Poznań 2002, s. 209-210.

15 Zob. Hans Ulrich Gumbrecht, Gdy przestaliśmy uczyć się od historii, [w:] Pamięć, etyka i historia, dz. cyt., s. 194.

16 Teza o zasadniczym wpływie przekazów audiowizualnych i multimedialnych na historiografię nie wymaga już głębszego uzasadnienia. Należałoby podjąć badania nad wpływem dostrzegalnych na gruncie badań historycznych turns na twórczość filmową. W niniejszym rozdziale zajmuję się Generałem w aspekcie „zwrotu narracyjnego". Równie ciekawy jest casus filmu Mistyfikacja (2010) w reżyserii Jacka Koprowicza, który należałoby analizować w kontekście tzw. allohistory - historii kontrfaktycznej. Zwolennicy tej orientacji badawczej (trudno bowiem mówić w tym wypadku o „zwrocie”) posuwają się do stwierdzenia, iż bez zbudowania alternatywnych czy hipotetycznych obrazów 
W ujęciu posthistoryków ${ }^{17}$ o strukturze narracji historiograficznej decydują przede wszystkim wzorce fabularyzacji (tragedia, komedia, romans, satyra) oraz tropy retoryczne (metafora, metonimia, synekdocha, ironia). Zdaniem Borisa Uspienskiego takie dążenie do przebudowy historii, do nowego zorganizowania informacji, zdradza podejście do historii jako do deszyfrowanego tekstu ${ }^{18}$. Im bardziej absurdalne są takie próby - podsumowuje Uspienski - z tym większą wyrazistością ujawnia się to dążenie ${ }^{19}$. Kryterium prawdy zostało zastąpione przez kryterium akceptowalności, a w efekcie prawda okazuje się kategorią „społecznie negocjowalną". W rezultacie możemy wybierać pomiędzy oferowanymi reprezentacjami przeszłości, nie istnieje bowiem

żaden aprioryczny schemat, który pozwalałby określić, jak dalece udane są poszczególne reprezentacje narracyjne: powodzenie danej reprezentacji jest zawsze kwestią wyboru spośród różnych konkurencyjnych narracji. Porównuje się narracyjne reprezentacje przeszłości między soba, nie zaś poszczególne reprezentacje narracyjne z przeszłościa jako taka (tzn. z sytuacją opisaną pojedynczym prawdziwym twierdzeniem) ${ }^{20}$.

przeszłości nie można rekonstruować przeszłej rzeczywistości. W próbie odpowiedzi na pytanie: "co by było, gdyby...?" nie chodzi o "snucie niedorzecznych pomysłów" czy „kreowanie fikcyjnych postaci lub instytucji”, ale o sformułowanie „prawdopodobnych" alternatywnych obrazów przeszłości. Zob. Marek Woźniak, Przeszłość jako przedmiot konstrukcji. O roli wyobraźni w badaniach historycznych, Wyd. Uniwersytetu Marii Curie-Skłodowskiej, Lublin 2010, s. 204-213.

17 Figura posthistoryka funkcjonuje tu w opozycji do figury historyka tradycyjnego (lub historyka pozytywisty). Określeniem „historia tradycyjna” (rzadziej „historia pozytywistyczna") posługuje się Ewa Domańska w rozumieniu historii faktograficznej czy zdarzeniowej, nastawionej na ustalanie i opis faktów: „Historię tę charakteryzuje także podejście genetyczne (ukazywanie chronologicznego ciągu zdarzeń), odwoływanie się do klasycznej koncepcji prawdy oraz promowanie postawy badacza jako obiektywnego i biernego rekonstruktora faktów". Zob. Ewa Domańska, Historie niekonwencjonalne, Wyd. Poznańskie, Poznań 2010, s. 19.

18 Podobne spostrzeżenie pojawia się w refleksji Ernsta Cassirera. Wedle Cassirera historyk, na początku swych badań, znajduje nie świat przedmiotów fizycznych, lecz świat symboliczny. Winien zatem postępować jak lingwista - traktować materiały źródłowe (dokumenty i zabytki) nie jako martwe relikty przeszłości, lecz jako teksty, które przemawiają do nas swoim własnym językiem: „Jeśli historykowi nie uda się rozszyfrować symbolicznego języka jego zabytków, historia pozostanie dla niego zamkniętą księgą. [...] Nie znajduje swych tekstów tylko w książkach, annałach czy pamiętnikach. Musi odczytywać hieroglify lub napisy klinowe, musi obserwować kolory na płótnie, oglądać posągi z marmuru lub brązu, katedry i świątynie, monety i klejnoty". Zob. Ernst Cassirer, Esej o człowieku. Wstęp do filozofii kultury, tłum. Anna Staniewska, Czytelnik, Warszawa 1998, s. 284-287.

19 Boris Uspienski, Historia i semiotyka, tłum. Bogusław Żyłko, słowo/obraz terytoria, Gdańsk 1998, s. 30.

20 Frank Ankersmit, Pochwała subiektywności, [w:] Pamięć, etyka i historia, dz. cyt., s. 76. 
Gdy jedna interpretacja wygrywa z inną - zauważa Stanley Fish - to nie dlatego, że pozostaje ona w zgodzie faktami, lecz dlatego, że to z perspektywy jej założeń fakty są teraz ustalane ${ }^{21}$. Zasady, wedle których ocenia się interpretacje, negocjowane są wewnątrz danej wspólnoty, co nie oznacza jednak, iż są one stabilne i niezmienne. Zdaniem Fisha w praktyce de facto wszyscy odrzucamy niemożliwe do zaakceptowania odczytania i częściej zgadzamy się, niż nie zgadzamy co do tego, które z odczytań winny zostać odrzucone ${ }^{22}$. Historyk winien zatem mówić o przeszłości zgodnie z kodem/standardem obecnym (i powszechnie akceptowanym) $\mathrm{w}$ jego kulturze ${ }^{23}$. W dyskursie historiograficznym pojawia się pragmatyczna idea „prawd możliwych"

które opierałyby się na konsensualnym i racjonalnym rozumieniu faktów historycznych i dowodów. Aby naród mógł skutecznie funkcjonować, rezygnując jednocześnie z roszczeń do wywyższającej go „,wielkiej narracji”, prawdy te muszą być zachowane, by instytucje i grupy ludzkie były w stanie dokonywać wyborów pomiędzy sprzecznymi historiami i interpretacjami ${ }^{24}$.

Na poziomie metatekstowym postawione $\mathrm{w}$ tytule pytanie stanowi czytelne odwołanie do kontrowersyjnego filmu Olivera Stone'a JFK, w którym reżyser podjął się wyjaśnienia tajemnicy zabójstwa prezydenta Kennedy'ego - zdarzenia generującego, podobnie jak katastrofa w Gibraltarze, liczne teorie spiskowe. Oba filmy łączy typowy dla docudramy „motyw śledztwa"25 (u Stone’a ujawniony na płaszczyźnie tekstualnej, u Jadowskiej-głównie w paratekście ${ }^{26}$ ). W obu przypadkach realizowana jest strategia detektywistyczna przefiltrowana przez conspiracy theory (wedle

21 Stanley Fish, Co czyni interpretacje możliwa do przyjęcia, [w:] tenże, Interpretacja, retoryka, polityka. Eseje wybrane, tłum. Andrzej Szahaj, Universitas, Kraków 2008, s. 102.

22 Tamże, s. 104.

${ }^{23}$ Zob. Marek Woźniak, Przeszłość jako przedmiot konstrukcji, dz. cyt., s. 162.

24 Zob. Dipesh Chakrabarty, Historie mniejszości, przeszłości podrzędne, dz. cyt., s. 394.

25 Zdaniem Stevena Lipkina postępowanie procesowe/śledcze to w przypadku docudramy fundamentalna strategia artykulacji znaczeń. W tym hybrydycznym gatunku, lokującym się pomiędzy dokumentem a fikcją, materiał faktualny "filtrowany" jest przez struktury narracyjne typowe dla kina hollywoodzkiego (melodramat). W klasycznym melodramacie - podobnie jak w docudramie - sugeruje się widzowi, iż zakwestionowany porządek moralny może zostać przywrócony. Zob. Steven N. Lipkin, Real Emotional Logic. Film and Television Docudrama as Persuasive Practice, Southern Illinois University Press, Carbondale-Edwardsville 2002, s. 5. Podążając za tokiem wywodu autora, można uznać, iż celem prowadzonego w docudramie śledztwa (JFK, Generał) jest przede wszystkim przywrócenie (moralnego) status quo.

26 Zob. Gérard Genette, Palimpsesty. Literatura drugiego stopnia, tłum. Aleksander Milecki, [w:] Wspótczesna teoria badań literackich za granica, t. IV, red. Henryk Markiewicz, Wyd. Literackie, Kraków 1992, s. 320. 
której/których zarówno zamach na Kennedy'ego, jak i katastrofa gibraltarska to wynik spisku), zaś widz otrzymuje przesłanki, dzięki którym może dostąpić „wtajemniczenia”:

Niespójność formalna dzieła ${ }^{27}$ - pisze o JFK Piotr Witek - jego nieprzezroczystość przezwyciężana jest tu przez spiskowo-detektywistyczną wizję historii, która wydaje się doskonałą protezą dla będących w rozsypce obrazów. Co więcej, chaotyczny audiowizualny kolaż zbudowany w oparciu o sprzężenia typu „inter” paradoksalnie służy tu za dobre narzędzie potęgowania poczucia wiarygodności stawianych hipotez ${ }^{28}$.

Odległe w czasie wydarzenia łączy, podkreślana przez historyków, specyficzna aura tajemniczości. Tajemnica, generująca wspomniane teorie spiskowe, to w dużej mierze efekt utajnienia dokumentów ${ }^{29}$ oraz braku dostępu do źródeł. Te zaś dokumenty, które zostały historykom udostępnione, wciąż budzą rozliczne wątpliwości. W przypadku katastrofy gibraltarskiej za nielogiczny uznano już raport pierwszej komisji, wedle którego:

27 Dotychczasowe analizy JFK koncentrowały się głównie na problemie relacji pomiędzy dyskursem faktualnym a kreatywną rekonstrukcją. W tym kontekście niezwykle interesującą interpretację filmu Stone'a zaproponował Robert Burgoyne. Zdaniem autora kolażowa struktura narracyjna filmu (radykalnie różniąca się od klasycznej narracji historiograficznej) odzwierciedla zachwianie poczucia tożsamości narodowej w wyniku utraty wyidealizowanego symbolu, wokół którego ta tożsamość się organizowała: „Jeśli naród jest wyobrażonym konstruktem [,wyobrażoną wspólnotą" w klasycznym ujęciu Andersona], którego egzystencja zależy od aparatu kulturowej fikcji, fragmentaryczna forma JFK sugeruje rozpad społecznej tożsamości”. Z drugiej strony „obsesyjne koncentrowanie się na zdarzeniu historycznym jest formą afirmowania historii jako fundamentu tożsamości narodowej". Zob. Robert Burgoyne, Modernism and the Narrative of the Nation in "JFK", dz. cyt., s. 118-119. Adaptując tę koncepcję do analizy filmu Jadowskiej, można by uznać, iż sfragmentatyzowana narracja stanowi w tym wypadku odzwierciedlenie poczucia rozpadu tożsamości zbiorowej Polaków po śmierci (zabójstwie?) premiera emigracyjnego rządu (przypomnijmy, iż śmierć Sikorskiego uznawana jest za fundamentalną przyczynę inicjującą postępujący proces marginalizacji pozycji Polski na międzynarodowej arenie politycznej).

28 Zob. Piotr Witek, Kultura - film - historia. Metodologiczne problemy doświadczenia audiowizualnego, Wyd. Uniwersytetu Marii Curie-Skłodowskiej, Lublin 2005, s. 264.

29 Akcję „oczyszczania” archiwów rozpoczęto natychmiast po lipcowej katastrofie. Tadeusz Modelski - szef wywiadu w Ministerstwie Spraw Wewnętrznych - wspomina: „Wszystkie dokumenty dotyczące lotu do oraz z Gibraltaru w dniach 4-5 lipca 1943 r. zostały «przez przypadek» spalone w biurze w nocy z 5 na 6 lipca 1943 r." Zob. Tadeusz Modelski, Byłem szefem wywiadu u Naczelnego Wodza, tłum. Mira Modelska-Creech, Bellona, Warszawa 2009, s. 114.

Wedle Kurtza, o sile oddziaływania filmu Stone'a na opinię publiczną (i Kongres USA) świadczy utworzenie w 1992 r. archiwum gromadzącego odtajnione materiały dowodowe związane z zamachem w Dallas. Zob. Michael Kurtz, Oliver Stone, JFK, and History, dz. cyt., s. 174-175. 
przyczyną tego tragicznego wypadku było zablokowanie sterów wysokości, które nastąpiło wkrótce po starcie samolotu, powodując jego niesterowność. Szczegółowe zbadanie wszelkich dostępnych materiałów dowodowych, łącznie z zeznaniami pilota, nie pozwoliło na ustalenie, co było przyczyną tego zablokowania. Jednocześnie wykluczono możliwość sabotażu ${ }^{30}$.

\section{Według Tadeusza Kisielewskiego niekompletność dowodów dotyczą- cych zagadkowej śmierci generała Sikorskiego}

stawia badacza w sytuacji podobnej do tej, w jakiej znalazł się Jim Garrison, były prokurator okręgowy (a następnie sędzia) w Nowym Orleanie. Opierając się na zapisach filmowych i laboratoryjnych analizach balistycznych, bez wątpienia obalił on główną tezę raportu Warrena, jakoby John Kennedy zginął z rąk samotnego strzelca, nie mógł jednak udowodnić procesowo, że prezydent padł ofiarą spisku ${ }^{31}$.

Dla współczesnego badacza śmierć Sikorskiego i zabójstwo Kennedy'ego to wydarzenia historyczne posiadające status „nieobserwowalnych" - z tej racji nie mogą one stanowić pewnego przedmiotu wiedzy naukowej. W przekonaniu Haydena White'a dystans czasowy usprawiedliwia jednak

powrót do szacownej tradycji przedstawiania pojedynczych zdarzeń, takich jak zamach na trzydziestego piątego prezydenta Stanów Zjednoczonych, jako opowieści i próby ich wyjaśnienia przez narratywizację (fabulację), tak jak zrobił to Oliver Stone $\mathrm{w}$ filmie $J F K^{32}$.

Istotne znaczenie ma tu nie tylko podobieństwo „faktów” historycznych, lecz także sposobów ich filmowej reprezentacji, która w obu przypadkach (JFK, Generał) przybrała formę "dokumentu fikcjonalnego" (mockdocumentary) lub - wedle określenia Haydena White'a - „filmu figuratywnego" ${ }^{\prime 33}$. Można także potraktować wspomniane dzieła jako filmowe odpowiedniki - scharakteryzowanej przez Lindę Hutcheon - historiograficznej metapowieści. Ta jest bowiem jawnie i zdecydowanie historyczna, ale

30 Cytuję za: Justin Whiteley, Śmierć generała Sikorskiego, tłum. Katarzyna PiotrowskaFletcher, Bellona, Warszawa 2007, s. 45.

31 Tadeusz Kisielewski, Zamach. Tropem zabójców generata Sikorskiego, Rebis, Poznań 2005, s. 234.

32 Hayden White, Proza historyczna, dz. cyt., s. 294.

33 Polemizując z krytykami zarzucającymi Stone'owi przekłamywanie faktów, Hayden White napisał: „Osobiście sugerowałbym, że JFK nie jest ani faktualny, ani fikcjonalny, ale raczej figuratywny i powinien być potraktowany przede wszystkim jako figura" (tamże, s. 286). 
w sposób ironiczny i problematyczny, zgodnie z którym historia nie jest przezroczystym zapisem żadnej niezbitej ",prawdy”34.

JFK i Generał lokują się również w paradygmacie „historii niekonwencjonalnej", która optuje za nielinearnym podejściem do czasu, hołduje subiektywizmowi, w narracji łamie porządek przyczynowo-skutkowy i podejrzliwie traktuje kryterium prawdy, eksperymentuje ze sposobami przedstawiania i stosuje różne media przekazu ${ }^{35}$. Wspólną cechą wspomnianych "gatunków zmąconych" jest - o czym pisała Marita Sturken w odniesieniu do JFK - to, iż odsłaniają one strukturalną i narracyjną złożoność audiowizualnej opowieści historycznej i sygnalizują niemożność jednej i jednoznacznej narracji historycznej, prezentującej określoną wersję historii z jedynego uprzywilejowanego punktu widzenia, która byłaby wiernym odwzorowaniem jakiejś historycznej realności ${ }^{36}$. Pojawienie się w kulturze tego typu tekstów wydaje się logiczną konsekwencją kryzysu reprezentacji literackiej, w której fakty są jedynie „efektami realności” (Barthes), a sama narracja - nieustanną cyrkulacją znaków (Peirce) lub idealistyczną iluzją (Derrida) ${ }^{37}$. Kryzys reprezentacji w zasadniczy sposób przyczynił się do zmiany statusu narracji historiograficznej:

Ricoeur podkreśla, że każdy opis wydarzeń historycznych sprowadza się siłą rzeczy do "dramatyzacji” rzeczywistości uchwyconej w czasie (mise en intrigue), a wtóruje mu Genette, powtarzając za Searle’em, iż „,nie ma własności tekstualnej, syntaktycznej lub semantycznej (ani, w konsekwencji, narratologicznej), która by pozwoliła udowodnić, że dany tekst jest fikcyjny. Ale można też podobnie zdefiniować sytuację odwrotna, twierdząc, że nie ma właściwości tekstualnej, syntaktycznej lub semantycznej (a więc, w konsekwencji, narracyjnej), która by pozwoliła uznać dany tekst za nie-fikcyjny"38.

34 Linda Hutcheon, Historiograficzna metapowieść: parodia i intertekstualność historii, [w:] Postmodernizm. Antologia przekładów, red. Ryszard Nycz, tłum. Zdzisław Łapiński, Wyd. Baran i Suszyński, Kraków 1997, s. 389.

35 Ewa Domańska, Historie niekonwencjonalne, dz. cyt., s. 54.

36 Zob. Piotr Witek, Kultura - film - historia, dz. cyt., s. 252.

37 Zob. Maria Delaperriére, Pod znakiem antynomii. Studia i szkice o polskiej literaturze XX wieku, Universitas, Kraków 2006, s. 90.

38 Tamże. Autorka, odtwarzając genealogię tego zjawiska, dookreśla: „Pierwszego wyłomu dokonał Nietzsche głosząc, że nie fakty się liczą, ale interpretacje. W tym samym kierunku zdawał się zmierzać Marc Bloch, podkreślając rolę selekcji w zapisie historycznym, który siłą rzeczy nie może być przywróceniem przeszłości, lecz jedynie jej odtworzeniem. Natomiast dla Barthes'a fakty historyczne będą już tylko faktami językowymi. Odtąd nie ma już wątpliwości, że historia jest wielką metafora, której aporetyczność jest cechą inherentną każdego dyskursu, a Wielka Historia przestaje być zespołem inwariantów, jest jedynie przechodzeniem z interpretacji do interpretacji, z których żadna nigdy nie jest w pełni zadowalająca. Wreszcie szkoła dekonstrukcjonistów wysunie tezę, że opowiadanie paradoksalnie wyprzedza Historię, ponieważ ta musi najpierw zaistnieć w języku" (tamże, s. 105-106). 
Powracając na koniec do postawionego w tytule pytania, trzeba także - last but not least - potraktować je jako rodzaj prowokacji. Sytuujemy się w ten sposób w kręgu problematyki związanej z - fundamentalnym dla funkcjonowania w obrębie pola produkcji artystycznej - stosunkiem młodego twórcy (debiutującego ${ }^{39}$ na obszarze "zawłaszczonym" przez "mistrzów") do dominującej w tym polu "tradycji”. Bourdieu zwraca bowiem uwagę, że:

każdy debiutant musi liczyć się z porządkiem ustanowionym w polu, z regułami gry tkwiącymi w samej grze, której poznanie i uznanie (illusio) jest milcząco narzucane tym wszystkim, którzy do gry wchodzą. [...] [Ale] nawet jeśli dziedzictwo kulturowe, istniejące $\mathrm{w}$ stanie zmaterializowanym oraz $\mathrm{w}$ stanie wcielonym ( $\mathrm{w}$ formie habitusu funkcjonującego jako swoista sfera transcendencji historycznej) posiada swe własne prawa, transcendentne $\mathrm{w}$ stosunku do świadomości oraz woli indywidualnych, to w sposób efektywny (czyli jako aktywne) istnieje i trwa tylko w i poprzez walki, których miejscem są pola produkcji kulturowej $[\ldots]^{40}$.

Zdaniem Bourdieu to właśnie debiutanci są motorem zmian dokonujących się w polu produkcji kulturowej ${ }^{41}$.

\section{Katastrofa w Gibraltarze: jedno „wydarzenie”, niezliczone "fakty"}

Odrzucając tezę, zgodnie z którą generał Sikorski zginał 4 lipca 1943 r. w wyniku tragicznego wypadku, wkraczamy w labirynt-pułapkę rozlicznych dyskursów (quasi)historycznych. Tadeusz Kisielewski pisze:

Śmierć Sikorskiego wciąż jest największą i najważniejszą zagadką najnowszej historii Polski. W pewnym sensie ta sprawa jest podobna do katyńskiej, to znaczy od początku wszyscy „wiedzieli” (w potocznym rozumieniu tego słowa), że w Gibraltarze nie było

39 Generat jest pierwszym filmem „historycznym” Anny Jadowskiej. Wcześniejszy dorobek reżyserski Jadowskiej to offowy Dotknij mnie (2003), zrealizowany w czasie studiów w łódzkiej PWSFTviT we współpracy z Ewą Stankiewicz oraz kameralny dramat psychologiczny Teraz ja (2004).

40 Pierre Bourdieu, Reguty sztuki, tłum. Andrzej Zawadzki, Universitas, Kraków 2001, s. 414-415.

41 Autor stwierdza: „Prawdą jest, że inicjatywa zmian przypada, niemal z definicji, świeżo przybywającym, czyli młodszym, którzy są jednocześnie w najwyższym stopniu pozbawieni kapitału specyficznego i którzy w świecie, gdzie istnieć to różnić się, czyli zajmować pozycję oddzielną i oddzielająca, istnieją tylko o tyle, o ile - choć nie muszą nawet chcieć tego - udaje im się potwierdzić swą tożsamość, czyli różnicę, sprawić, że zostanie poznana i uznana $[\ldots]$ ]" (tamże, s. 366). 
wypadku, a w Katyniu, Charkowie i Twerze do polskich oficerów nie strzelali Niemcy. Jednak na tym podobieństwo obu spraw się kończy. [...] Należy liczyć się z tym, że polskie władze nigdy nie zostaną oficjalnie poinformowane o politycznym podłożu, rozkazodawcach, bezpośrednich wykonawcach i przebiegu zamachu w Gibraltarze ${ }^{42}$.

Wedle Paula Ricoeura historyk podejmuje poszukiwania archiwalne uzbrojony w pytania, a co najważniejsze (zwłaszcza w kontekście analizowanego filmu), przekonany jest, iż dokumenty nie przemówia, jeśli nie skłoni się ich do zweryfikowania, tzn. potwierdzenia pewnej hipotezy $^{43}$. Nie oznacza to $\mathrm{w}$ żadnym razie instrumentalnego traktowania źródeł. W tym miejscu historiograficznej refleksji Ricoeura pojawia się pojęcie $d \nmid u g u$ :

w odróżnieniu od fikcji konstrukcje tworzone przez historyka zamierzają być rekonstrukcjami przeszłości. Przez dokument i za pomocą dowodu dokumentalnego historyk jest podporządkowany temu, co niegdyś było. Ma on dtug względem przeszłości, dług wdzięczności względem umarłych, który czyni z niego niewypłacalnego dłużnika ${ }^{44}$.

Nie wikłając się w problematykę etycznych powinności historyka względem umartych wypada jednak zapytać, jakie "fakty” doprowadziły do ,jednej z najbardziej delikatnych i najpilniej strzeżonych tajemnic mocarstwowych" 45 związanych ze śmiercią generała Sikorskiego? Tajemnicy, która po dziś dzień wzbudza ${ }^{46}$ - choć może raczej należałoby powiedzieć: „wzbudzała” - ożywione dyskusje nie tylko w kręgu historyków? Wzmożone zainteresowanie sprawą katastrofy gibraltarskiej wiązało się, jak sądzę, przede wszystkim ze śledztwem prowadzonym przez IPN. Po ogłoszeniu wyników śledztwa nastąpił dość gwałtowny spadek społecznego zainteresowania tym tematem. Wydaje się jednak, iż marginalizacja „sprawy Sikorskiego” w publicznym dyskursie jest częścią znacznie szerszego zjawiska, o którym pisze Robert Traba na przykładzie zbrodni

42 Tadeusz Kisielewski, Zamach, dz. cyt., s. 7.

43 Paul Ricoeur, Pamięć, historia, zapomnienie, tłum. Janusz Margański, Universitas, Kraków 2006, s. 235-236.

44 Paul Ricoeur, Czas i opowieść, t. III, tłum. Urszula Zbrzeźniak, Wyd. Uniwersytetu Jagiellońskiego, Kraków 2008, s. 202.

45 Tadeusz Kisielewski, Zamach, dz. cyt., s. 7.

46 Badania przeprowadzone w 2004 r. przez OBOP na próbie ogólnopolskiej wykazały, iż wśród wydarzeń z okresu II wojny światowej, które najszybciej wymagają wyjaśnień, wymieniano związane ze stosunkami ze wschodnim sąsiadem: Katyń (30,0\%), wywózki Polaków w głąb ZSRR w okresie wojny i po wojnie (22,1\%), napaść Związku Radzieckiego na Polskę w roku 1939 (17,6\%). Z pozostałych jedynie śmierć generała Sikorskiego uzyskała znaczącą liczbę wskazań (29,0\%). Zob. Barbara Szacka, Czas przeszły - pamięć - mit, Wyd. Naukowe Scholar, Warszawa 2006, s. 156. 
sowieckiej w Katyniu. Zdiagnozowana przez autora „ucieczka od historii” to efekt zmęczenia historyczną materia, niewytrzymującą bezpośredniej konfrontacji z atrakcyjnością oferty nowoczesnych, komercyjnych przemian. Zjawisko to dotyczy nawet najświeższych pokładów polskiej pamięci zbiorowej:

Po okresie eksplozji zainteresowania w ramach zapisywania tzw. białych plam, tragedia katyńska [podobnie jak katastrofa gibraltarska] coraz bardziej ulega marginalizacji w publicznej dyskusji i potocznej świadomości społecznej ${ }^{47}$.

Odwołując się do metafory tektonicznych nawarstwień $\mathrm{w}$ pamięci zbiorowej można zaryzykować stwierdzenie, iż opisana przez Trabę marginalizacja tragedii katyńskiej wynika nie tylko ze „zmęczenia historią", lecz z faktu pojawiania się $\mathrm{w}$ dyskursie publicznym innych "dyskusyjnych wątków". Katyń stał się „składnikiem” elementarnej wiedzy historycznej (daleka jestem od określenia zbrodni katyńskiej mianem „historii martwej”), a „żywą" część pamięci zbiorowej (tzw. pamięć funkcjonalną wedle terminologii Aleidy Assmann, na którą składają się treści historyczne bezpośrednio oddziałujące na postawy społeczne) tworzą obecnie: Jed wabne (o czym świadczy dyskusja wokół filmu Pokłosie z 2012 r.) i Smoleńsk (planowany na wiosnę 2014 r. film w reżyserii Antoniego Krauzego). Zanim spróbuję odpowiedzieć na związane z katastrofą gibraltarską (i filmem Jadowskiej) pytanie o "fakty”, muszę poczynić istotne zastrzeżenie. Sformułowanie tego pytania nie oznacza - wbrew pozorom - powrotu do pozytywistycznego modelu uprawiania historii, skupiającego się na kolekcjonowaniu i opisie faktów, głoszącego naiwny obiektywizm i transparentną (niezależną od języka i poznającego podmiotu) ideę prawdy $^{48}$. Generat stanowi efekt ewolucji myślenia historycznego, przebiegającej wedle wzoru: przeszłość jako przedmiot wiary $\rightarrow$ przeszłość jako przedmiot wiedzy $\rightarrow$ przeszłość jako przedmiot konstrukcji. Dla „modelu konstrukcyjnego" fundamentalną kwestią okazuje się pytanie:

w jaki sposób historyk konstruuje swe teksty; jak wywoływane jest wrażenie autentyczności; jak stwarzane jest poczucie zgodności z faktami. Poszukiwanie prawdy o przeszłości zostaje zastąpione analizą zabiegów stosowanych przez historyków w celu wywołania „efektu prawdy". A zatem już nie „prawdziwość”, ale „skuteczność" - i jej mechanizmy - różnych wersji przeszłości staje się celem refleksji teoretycznej (ale i praktycznej) nad historiografią [podkr. moje - N.K.-R.] ${ }^{49}$.

\footnotetext{
${ }^{47}$ Zob. Robert Traba, Historia - przestrzeń dialogu, Instytut Studiów Politycznych PAN, Warszawa 2006, s. 223.

48 Zob. Ewa Domańska, Historie niekonwencjonalne, dz. cyt., s. 257.

49 Marek Woźniak, Przeszłość jako przedmiot konstrukcji, dz. cyt., s. 56.
} 
W przypadku filmu Jadowskiej zakotwiczenie fabuły w zdywersyfikowanym korpusie materiałów źródłowych stanowi jeden z podstawowych zabiegów służących wywoływaniu "efektu prawdy". W tych materiałach kryją się interesujące historyka-śledczego „fakty”.

25 maja 1943 r. generał Władysław Sikorski - premier emigracyjnego rządu i Naczelny Wódz Sił Zbrojnych - rozpoczął podróż na Bliski Wschód. Motywy owej podróży nie są do końca znane. Oficjalnym celem Sikorskiego była wizytacja 2. Korpusu generała Andersa i poprawa napiętych stosunków pomiędzy dowódcami. Podłożem konfliktu była sporna kwestia lokalizacji oddziałów sformowanych w ZSRR na mocy zawartego 30 lipca 1941 r. układu Sikorski-Majski. Anders zdecydowanie nalegał na wyprowadzenie polskich jednostek z terytorium Stalina, motywując swą decyzję trudnościami z aprowizacją wojska (w depeszy z 7 czerwca 1942 r. meldował Sikorskiemu o katastrofalnych warunkach $\mathrm{w}$ armii ${ }^{50}$ ).

Naczelny Wódz - podkreśla Zbigniew Wawer - był przeciwny ewakuacji Armii Polskiej z ZSRR, uważając, że dla dobra sprawy powinna ona po uzyskaniu pełnego uzbrojenia i przeszkoleniu walczyć na froncie wschodnim. W odróżnieniu od gen. Andersa, Naczelny Wódz nie widział podwójnej gry Stalina, dla którego przydatne mogło być tylko wojsko podporządkowane i kierowane przez władze sowieckie ${ }^{51}$.

Ugodowe stanowisko względem Sowietów ${ }^{52}$ stało się najpoważniejszym argumentem politycznych przeciwników Sikorskiego ${ }^{53}$. O atmosferze

50 „Nasza sytuacja wojskowa tutaj - informował Anders - zbliża się ku katastrofie. [...] Żołnierze głoduja, mam już kilkanaście procent kurzej ślepoty. Nie ma żadnej nadziei na polepszenie, odwrotnie, położenie pogarsza się stale. [...] Wkraczanie w nasze życie wewnętrzne coraz większe. [...] Wskutek powyższego morale wojska utrzymuje się wyłącznie nadzieją wyjścia z ZSRR i wielką narodową dyscypliną". Zob. Zbigniew Wawer, Monte Cassino. Walki 2. Korpusu Polskiego, Bellona, Warszawa 2009, s. 33-34.

51 Tamże, s. 34.

52 Dowodem na potwierdzenie tej tezy miała być (wyrwana z kontekstu) „pojednawcza” deklaracja Sikorskiego („,[...] ułożenie przyjaznych stosunków z Rosją Radziecką było i jest nadal jedną z głównych wytycznych rządu i narodu polskiego"), złożona 3 maja 1943 r., a więc już po ogłoszeniu przez stronę niemiecką odkrycia w lesie pod Katyniem masowych grobów oficerów zamordowanych przez NKWD. Powołujący się na tę wypowiedź komentatorzy „przeoczyli” fragment pochodzący z tego samego radiowego przemówienia: „Istnieją bowiem granice ustępstw, których nikt w narodzie polskim nie przekroczy".

53 Komuniści chętnie podkreślali „odrębność” stanowiska Sikorskiego wobec ZSRR w stosunku do poglądów głoszonych przez działaczy emigracyjnych. We wspomnieniu z 1943 r. poświęconym Naczelnemu Wodzowi Wanda Wasilewska odnotowała: „,[...] nie był związany z rządami pomajowymi, [...] nie miał nic wspólnego z Beckiem i Ścigłym [...]. W myśl tego, co głosił od lat - że Niemcy są głównym wrogiem Polski [...] zawarł sojusz ze Związkiem Radzieckim. Zawarł go wbrew protestom niektórych swoich współpracowników - ale też to było jego ostatnim stanowczym postawieniem sprawy". 
panującej wśród Polaków skupionych w londyńskim hotelu „Rubens” pisał Eugeniusz Cękalski:

\begin{abstract}
Nasi „narodowcy” prorokowali upadek Rosji w trzy tygodnie, a wszyscy prawie po cichu życzyli Hitlerowi zwycięstwa - takiego, żeby się sam wykrwawił i Rosję zdusił - a my wrócimy na swoje. [...] I gdy Sikorski zawarł umowę z Sowietami, rzucili się na niego po cichu i jawnie ludzie, których przez całe pokolenie wychowywano $\mathrm{w}$ nienawiści do Sowietów ${ }^{54}$.
\end{abstract}

W kręgach londyńskiej emigracji spekulowano, iż rzeczywistym celem podróży generała na Bliski Wschód było nawiązanie poufnych kontaktów ze stroną radziecką. Zdaniem historyków było tajemnicą poliszynela, że w Iraku - wśród najbliższego otoczenia Andersa - szykowano pucz przeciwko Sikorskiemu ${ }^{55}$, do którego jednak nie doszło ze względu na nikłe poparcie wśród oficerów.

\begin{abstract}
„Zamach" ów - uważa Justin Whiteley - w formie, w jakiej był planowany, winien mieć charakter polityczny i pokojowy, a nie być brutalnym zamachem wojskowym i z całą pewnością zabójstwo nie leżało w zamiarach jego głównych inicjatorów. Nie wyklucza to jednak możliwości, że w otoczeniu Andersa były również osoby o bardziej radykalnym nastawieniu, których zdaniem zabójstwo Sikorskiego to czyn konieczny i w pełni usprawiedliwiony, a nawet obowiązek patriotyczny ${ }^{56}$.
\end{abstract}

Zob. Wanda Wasilewska, Tragedia Władystawa Sikorskiego, [w:] Jenerał Sikorski. Antologia, red. Jacek Danel, Wyd. R-I-D Studio, Mielec-Zamość 2008, s. 262.

Zdaniem niektórych historyków stosunek władz komunistycznych do Sikorskiego (zwłaszcza w latach 1944-1948) może być świadectwem braku całkowitego zerwania ciągłości z II Rzeczpospolitą. Włodzimierz Suleja pisze: „Oszczędzano Mikołajczyka, usprawiedliwiano Sikorskiego, a całą winę - zwłaszcza za kształt stosunków polsko-radzieckich - zrzucano na Raczkiewicza, Sosnkowskiego, Andersa oraz krajowe dowództwo AK". Zob. Włodzimierz Suleja, Mit niepodległości w dobie PRL, [w:] Polskie mity polityczne XIX i XX wieku, red. Zyta Kwiecińska, Wyd. Uniwersytetu Wrocławskiego, Wrocław 1996, s. 77. W późniejszym okresie potwierdzeniem konstatacji Suleja może być film Poręby Katastrofa w Gibraltarze (1984), doskonale wpisujący się w politykę historyczną PRL.

54 Eugeniusz Cękalski, Ostatnia jesień, „Nowa Polska” 1943, nr 1, s. 38.

55 Sikorski wiedział o planowanym puczu. Wspomina o tym gen. Anders: „27 maja 1943 powitałem w Kairze gen. Sikorskiego [...]. Już w pierwszych rozmowach, które przeprowadziłem z gen. Sikorskim po wylądowaniu i w dniu następnym, wyczułem, że generał nieprzychylnie był nastrojony [...] do stanu rzeczy na Bliskim Wschodzie. Twierdził, że otrzymał w Londynie wiadomości przestrzegające go przed przyjazdem do Armii Polskiej na Wschodzie, gdzie rzekomo przygotowywano na niego zamach [...]. Wyjaśniłem gen. Sikorskiemu, że to, co mu mówiono, nie odpowiada rzeczywistości $[\ldots]$, że włos mu z głowy nie spadnie [...]". Zob. Władysław Anders, Bez ostatniego rozdziału. Wspomnienia 1939-1946, fragment, [w:] Jenerał Sikorski. Antologia, dz. cyt., s. 85.

56 Justin Whiteley, Śmierć generała Sikorskiego, dz. cyt., s. 174. 
Operacja zaszyfrowana pod kryptonimem „Mur" - choć nie została „sfinalizowana” w Iraku - miała jednak dalekosiężne skutki. Wykorzystano ją bowiem dla udowodnienia tezy, iż katastrofa gibraltarska była $\mathrm{w}$ istocie zamachem przygotowanym przez Andersa.

\begin{abstract}
W powojennej zniewolonej przez Związek Sowiecki Polsce - komentuje Whiteley śmierć największego męża stanu w sposób nieunikniony stała się narzędziem w rękach marksistowskiej propagandy. Aż do upadku „bloku wschodniego" w 1989 roku w duchu tej właśnie propagandy każde polskie dziecko uczone było na lekcjach historii, że Władysław Sikorski poniósł śmierć z rąk zachodnich antykomunistów ${ }^{57}$. Po raz pierwszy ten dogmat ogłosił publicznie w sejmie 24 czerwca 1947 roku generał dywizji Gustaw Paszkiewicz, dowódca Warszawskiego Okręgu Wojskowego. Według niego na czele spisku mającego na celu zabójstwo Sikorskiego stał generał Anders ${ }^{58}$.
\end{abstract}

Dowodem obciążającym $w$ tej sprawie był fakt aresztowania w 1943 r. przez władze Wielkiej Brytanii Jerzego Klimkowskiego ${ }^{59}$ - byłego adiutanta Andersa na Bliskim Wschodzie - pod zarzutem udziału w tajnym spisku przeciwko Sikorskiemu. Warto także odnotować, że dowódca Polskiej Misji Morskiej w Gibraltarze, Ludwik Łubieński, po śmierci Naczelnego Wodza został adiutantem Andersa ${ }^{60}$. Aresztowanie

57 Autor dopuścił się nadużycia - w peerelowskich podręcznikach historii katastrofę gibraltarską określano w sposób „neutralny” jako wypadek lotniczy. Podobne „nieścisłości" skłoniły wydawcę, by opatrzył książkę Whiteley’a stosownym wstępem: „Opracowanie zawiera co prawda pewne osądy kontrowersyjne, a przynajmniej odmienne od przyjętych przez polskich historyków [...] niemniej jednak pozostawiamy je bez zmian czy komentarzy w trosce o poszanowanie prawa autorskiego i wierne przybliżenie polskiemu czytelnikowi poglądów reprezentatywnych dla anglosaskiej historiografii i publicystyki" (tamże, s. 7).

58 Tamże, s. 81.

59 Po wojnie Klimkowski wrócił do Polski i wstąpił do partii. W 1965 r. ukazała się w Warszawie jego książka Katastrofa w Gibraltarze, w której opowiedział się za forsowaną przez partię wersja, wedle której śmierć Sikorskiego była wynikiem akcji brytyjskich służb specjalnych działających na rozkaz Winstona Churchilla.

${ }^{60}$ Niechęć Łubieńskiego - byłego sekretarza przedwojennego ministra spraw zagranicznych Józefa Becka - mogła wynikać z postawy Naczelnego Wodza wobec polityków sanacyjnych i zwolenników Piłsudskiego (wielu oficerów z obozu Marszałka zostało w czasie wojny - na mocy rozkazu Sikorskiego - osadzonych w obozie izolacyjnym na wyspie Bute). Tadeusz Kisielewski pisze o Sikorskim: „Trzynaście lat «W odstawce» [po przewrocie majowym Sikorski został odsunięty od polityki i czynnej służby w armii], podczas których kumulowała się w nim frustracja, zrobiły swoje. [...] Był liberalnym demokrata, który nie mógł się pogodzić z autorytarnymi, na poły wojskowymi rządami w sanacyjnej Polsce. Zamierzał nie dopuścić do powrotu takich rządów w powojennej Polsce". Zob. T. Kisielewski, Przedmowa, [w:] Władysław Sikorski, Przyszła wojna, Universitas, Kraków 2010, s. 31-32. Nieprzychylny stosunek działaczy sanacyjnych wobec Sikorskiego był także pochodną faktu, iż generał nie brał udziału w kampanii wrześniowej, a zatem - w opinii społecznej - nie był współautorem klęski przypisywanej sanacji. 
Klimkowskiego i sugerowanie dwuznacznej roli Łubieńskiego w lipcowej „,akcji” leżało niewątpliwie również w interesie brytyjskiej racji stanu, gdyż - jak zauważa Kisielewski - jeżeli kiedyś rząd brytyjski będzie zmuszony przyznać, że Sikorski zginął w wyniku zamachu, to prawdopodobnie zrobi wszystko, by wykazać, że jego inicjatorami, organizatorami i wykonawcami byli wyłącznie Polacy ${ }^{61}$.

Interesujących świadectw oddziaływania komunistycznej propagandy na świadomość zbiorową Polaków dostarczają teksty, w których odnaleźć można ślady recepcji powstałych w czasie wojny filmów dokumentalnych tematycznie związanych z Sikorskim ${ }^{62}$. Wieść o katastrofie w Gibraltarze - pisze Stanisław Ozimek - 4 lipca 1943 r. była przyjęta z ulga przez opozycję w hotelu „Rubens” i w dowództwie Armii Polskiej stacjonującej na Bliskim Wschodzie ${ }^{63}$. W nowej sytuacji politycznej odmiennego znaczenia nabrały ujęcia zarejestrowane przez kronikarzy wojennych. Zdaniem Ozimka, przykładem uwiecznionego przez frontowego operatora obrazu, który

w pierwotnym zamiarze miał być tylko pokwitowaniem szablonowej sytuacji, może być scena odjazdu gen. Sikorskiego po odbyciu przez niego inspekcji na Bliskim Wschodzie. Oglądana po latach scena pożegnania z dowódcą II Korpusu gen. Andersem, po wizycie, w czasie której tylko zręczność dyplomatyczna Sikorskiego unicestwiła zaplanowaną frondę oficerów Andersa, prowokuje do szukania dodatkowych znaczeń. W zbliżeniach, pod maską uprzejmości i powściągliwych uśmiechów, widać twarz Sikorskiego zmieniona, zmęczoną i postarzałą w porównaniu z wcześniejszymi o kilka miesięcy ujęciami. Odwrotnie - opanowana twarz Andersa ma w sobie coś z satysfakcji gracza, który niedawno wstał od stołu po wygranej partii. Czy wie już, co stanie się pod Gibraltarem? ${ }^{64}$

W dyskurs propagandowy doskonale wpisuje się pełnometrażowy film fabularny Bogdana Poręby Katastrofa w Gibraltarze (1984). Twórcy nie stawiają wprawdzie żadnej tezy dotyczącej przyczyn śmierci Sikorskiego, ale w sposób jednoznaczny sugerują udział Andersa w wydarzeniach z lipca 1943 r. Najważniejszym wątkiem, który zdecydowanie dominuje nad tzw. Wielką Historia, są dzieje narastającego konfliktu pomiędzy Naczelnym Wodzem i dowódcą 2. Korpusu. W filmie Poręby Anders publicznie wypowiada Sikorskiemu posłuszeństwo i - wbrew rozkazom

61 Tadeusz Kisielewski, Zamach, dz. cyt., s. 111.

62 Najbardziej znanym filmem z tego okresu pozostaje Niedokończona podróż (1943), zrealizowana w Londynie przez Eugeniusza Cękalskiego na zlecenie Ministerstwa Informacji i Dokumentacji. Filmowy esej Cękalskiego miał być pośmiertnym hołdem złożonym Sikorskiemu. W polskiej wersji językowej komentarz czytał Antoni Słonimski, w wersji angielskiej - John Gielgud.

63 Stanisław Ozimek, Film polski w wojennej potrzebie, PIW, Warszawa 1974, s. 84.

${ }^{64}$ Tamże, s. 222. 
zwierzchnika - gotów jest podporządkować armię dowództwu brytyjskiemu ${ }^{65}$. Za kluczową pod względem dramaturgicznym scenę można uznać moment otrzymania przez Sikorskiego depeszy gratulacyjnej od premiera Churchilla. Pewne "teorie spiskowe" (wątek depeszy pojawia się m.in. w książce Davida Irvinga, o której piszę dalej) sugerują iż to właśnie ta depesza (zgodnie z intencjami rozkazodawców odczytana jako bezzwłoczne wezwanie do powrotu) miała na celu zwabienie Sikorskiego do pułapki zastawionej przez Brytyjczyków w Gibraltarze.

Dla historyka badającego materiały źródłowe związane z katastrofą gibraltarską fascynujący okazuje się zasięg teorii głoszącej czynny udział brytyjskich służb specjalnych w zabójstwie Sikorskiego. W 1965 r. doszło w Monachium do spotkania Davida Irvinga ${ }^{66}$ i Rolfa Hochhutha. Niezwykła współpraca pomiędzy „brytyjskim prawicowym historykiem i niemieckim lewicowym dramaturgiem" zaowocowała dwoma tekstami, dzięki którym Zachód ponownie zainteresował się niewyjaśnioną tajemnicą śmierci polskiego Naczelnego Wodza. Niemiecka premiera ${ }^{67}$ dramatu

65 Zdaniem wielu historyków koncepcja, wedle której Anders przygotowywał operację "Mur" w porozumieniu z Brytyjczykami, wydaje się całkowicie pozbawiona podstaw. Świadczy o tym reakcja Churchilla na raport ministra Casey'a, w którym znalazły się informacje o wewnętrznych rozgrywkach personalnych w polskiej armii: „Mamy tu do czynienia z wszystkimi przejawami niestabilności, które w ciągu wieków prowadziły Polskę do ruiny niezależnie od osobistych zalet i cnót Polaków. Według mnie, nie powinno się w żaden sposób popierać wywrotowych tendencji w Wojsku Polskim [...]". Zdaniem brytyjskiego premiera Sikorski był jedynym polskim przywódcą mogącym zachować wiarygodność polskiego emigracyjnego rządu wobec aliantów i Stalina. Zob. Evan McGilvray, Polski rząd na uchodźstwie, tłum. Zofia Kaleta, Świat Książki, Warszawa 2011, s. 121.

66 Autor opublikowanej w 1967 r. książki Wypadek. Śmierć generała Sikorskiego (polskie wydanie ukazało się w 2000 r.) jest postacią niezwykle kontrowersyjną. W 2000 r. historyk przegrał w Anglii proces w sprawie „kłamstwa oświęcimskiego”. W uzasadnieniu werdyktu Irving usłyszał, że „,jest antysemitą i rasistą, neguje Holocaust, manipuluje materiałem historycznym i korzystnie przedstawia Hitlera. Skądinąd Irving miał już na swoim koncie grzywnę orzeczoną przez sąd w Bawarii, zakaz wjazdu do Niemiec, Kanady, Włoch i Austrii [w austriackim wiezieniu historyk spędził rok z trzech zasądzonych przez tamtejszą jurysdykcję] oraz wniosek o ekstradycję, sformułowany wobec Anglii przez rząd niemiecki. Wstępu odmówiło mu również (1998) Muzeum Auschwitz-Birkenau, gdzie chciał filmować i korzystać z archiwum. Sam Irving twierdzi, że nie neguje Holocaustu. Pomniejsza «jedynie» liczbę zamordowanych, kwestionuje istnienie komór gazowych i twierdzi, że Hitler nie wiedział o «ostatecznym rozwiązaniu». Wyznaczył nawet nagrodę dla historyka, który znajdzie polecenie realizacji planu z podpisem Hitlera". Zob. Marcin Kula, Krótki raport o użytkowaniu historii, Wyd. Naukowe PWN, Warszawa 2004, s. 454.

${ }_{67}$ O wystawienie Żotnierzy na prestiżowej scenie londyńskiego Teatru Narodowego bezskutecznie zabiegał kierownik literacki teatru Kenneth Tynan. Sztuka oceniona przez radę nadzorczą teatru jako „,atak na człowieka, który w pamięci żyjących wciąż ludzi 
Żotnierze Hochhutha w październiku 1967 r. zbiegła się w czasie z publikacją kontrowersyjnej książki Irvinga Wypadek. Śmierć generała Sikorskiego. Nie jest dziełem przypadku, iż obaj autorzy dowodzili explicite, że Sikorski został zamordowany na osobisty rozkaz Churchilla. O tym, iż "rewelacji” ujawnionych przez Irvinga i Hochhutha nie uznano za przykład „klasycznej teorii spiskowej" świadczy fakt, iż do złożenia stosownych wyjaśnień w sprawie katastrofy gibraltarskiej został wezwany ówczesny premier Wielkiej Brytanii Harold Wilson. W wystąpieniu z 11 lutego 1969 r. Wilson w sposób niezwykle dyplomatyczny ${ }^{68}$ zeznał: „stwierdzam, że nieznane mi są żadne dowody, które sugerowałyby, iż katastrofa liberatora, do której doszło w Gibraltarze, była czymś innym niż prawdziwym wypadkiem ${ }^{\prime \prime 9}$. Słowa premiera najwyraźniej przekonały obywateli Wielkiej Brytanii, skoro wiele lat po wystąpieniu Wilsona wnuk zabitego w katastrofie gibraltarskiej brygadiera Johna Whiteleya napisał: „Prawda jest jednak taka, że generał Sikorski oraz towarzyszące mu osoby zginęły w wyniku tragicznego wypadku"70.

\section{Generat: scenariusz (nie)możliwy?}

Ta reprezentacja przeszłości, która jest najbardziej ryzykowna i najmniej prawdopodobna, jeśli uwzględnia się istniejącą wiedzę historyczną, której jednak nie można na tej samej podstawie odrzucić, jest reprezentacją o największym zakresie.

Frank Ankersmit

Film Anny Jadowskiej Generat. Zamach na Gibraltarze powstał w okresie wzmożonego zainteresowania katastrofa, która miała miejsce 4 lipca 1943 r. Okoliczności śmierci generała Sikorskiego to druga - po zbrodni katyńskiej - z niewyjaśnionych spraw okresu II wojny światowej domagających się rewizji, którą umożliwiły dopiero przemiany polityczne dokonujące się w Polsce po 1989 r. Wobec owego "roszczenia prawdy" środowisko historyków pozostaje po dziś dzień podzielone. Tajemnica

ocalił swój naród" została zaprezentowana na deskach Teatru Nowego dzięki prywatnym funduszom Tynana. O perypetiach dramatu Hochhuta pisze Justin Whiteley w cytowanej książce Śmierć generata Sikorskiego.

68 Ostrożność premiera w formułowaniu sądów wynikała zapewne z obawy, iż Hochhuth faktycznie dysponuje "tajnymi dokumentami”, które - jak twierdził dramaturg - nie zostały dotychczas ujawnione ze względu na bezpieczeństwo informatora.

${ }^{69}$ Cyt. za: J. Whiteley, Śmierć generała Sikorskiego, dz. cyt., s. 111.

70 Tamże, s. 181. 
śmierci Sikorskiego nie może być rozpatrywana jedynie na „płaszczyźnie epistemologicznej". Od samego początku (biorąc pod uwagę jedynie okres powojenny) postać generała stanowiła bowiem obiekt politycznej rozgrywki, która - paradoksalnie - nie zakończyła się w momencie transformacji ustrojowej. Marcin Kula podkreśla, iż już w 1981 r. ${ }^{71}$ (w maju tego roku przypadała setna rocznica urodzin Sikorskiego ${ }^{72}$ ) podjęto starania

${ }^{71}$ Jako symboliczne potwierdzenie polityki władz w "sprawie Sikorskiego" (gorącym orędownikiem sprowadzenia zwłok do Polski był Mieczysław Moczar) potraktować można zrealizowany w 1981 r. dokument Władysław Sikorski w reżyserii Krzysztofa Szmagiera (trzy lata później powstała fabularna Katastrofa w Gibraltarze).

Warto odnotować, iż próby sprowadzenia prochów Sikorskiego z Londynu były podejmowane znacznie wcześniej. Helena Sikorska - wdowa po generale - wspominała w audycji (nadanej 5 lipca 1952 r.) Rozgłośni Wolna Europa o naciskach ze strony władz polskich, czynionych już w latach 1946-1949. W Polce opanowanej przez komunistów - podkreśla Jacek Daniel - w pierwszych latach po zakończeniu wojny osobę gen. Sikorskiego cynicznie propagandowo wykorzystywano, przedstawiając społeczeństwu polskiemu generała jako bohatera, który pierwszy podpisał umowę ze Związkiem Sowieckim. Kolejne (bezskuteczne) działania podjęto po Październiku 1956 r. Na początku lat 70. do przełomu w tej sprawie przyczyniła się postawa Heleny Sikorskiej, która - ku oburzeniu środowisk emigracyjnych (aktywną rolę w oprotestowaniu decyzji wdowy odegrał m.in. Jan Nowak Jeziorański) - poinformowała polskie władze (w listach do Władysława Gomułki, Józefa Cyrankiewicza i Mieczysława Moczara) o woli sprowadzenia prochów męża do kraju. Tym razem na przeszkodzie stanęła sporna kwestia miejsca pochówku (Sikorska wskazała na katedrę wawelska, polskie władze - Aleję Zasłużonych Cmentarza Powązkowskiego, gdzie generał miał spocząć obok... Karola Świerczewskiego, Juliana Marchlewskiego czy Bolesława Bieruta). Pod koniec kwietnia 1981 r. kardynał Franciszek Macharski poinformował media o przygotowaniu sarkofagu w kapicy św. Leonarda, w którym miałaby być złożona trumna. Nie zakończyło to jednak sporu władz PRL z londyńskim środowiskiem emigracyjnym. Zob. Jacek K. Daniel, Spory wokót powrotu prochów generała Sikorskiego do Ojczyzny 1943-1981, [w:] Jenerat Sikorski. Antologia, dz. cyt., s. 273-288.

72 W dniu 23 marca 1981 r. Prezydium Ogólnopolskiego Komitetu Frontu Jedności Narodu przyjęło uchwałę dotyczącą uroczystych obchodów tej rocznicy. Dzień później ambasada PRL w Londynie zwróciła się do rządu brytyjskiego z prośbą o pomoc w sprowadzeniu prochów. Uroczystości pogrzebowe przewidziane na maj 1981 r. miały stanowić kulminacyjny moment obchodów. Ponieważ decyzja polskiego rządu została poparta przez „Solidarność", można było publicznie ogłosić, że „sprowadzenie doczesnych szczątków generała jest wolą narodu, której wykonawcami są jedynie władze Polski Ludowej".

Działania władz spotkały się z oporem londyńskiej emigracji i władz RP na uchodźstwie. W liście protestacyjnym Rady Organizacji Kombatanckich czytamy: „Szczątki Wodza Naczelnego powrócą do Kraju wraz ze sztandarami bojowymi [...], kiedy Kraj będzie rządzony przez władze wybrane przez naród i kiedy będzie można uczcić w Ojczyźnie Generała jako wielkiego bojownika o niepodległość. Teraz Jego szczątki stałyby się przedmiotem jeszcze jednej manipulacji propagandowej dla zakłamywania historii, w tym wypadku do wmawiania młodemu pokoleniu, że cele, do których dążył i wskazywał swoim żołnierzom, zostały osiągnięte. Agent zaś Moskwy, Mieczysław Moczar, który wystąpił z tym zamiarem, ma sumienie obciążone zbrodniami terroru w okresie 
o sprowadzenie z Londynu szczątków Sikorskiego (starania nie przyniosły spodziewanego rezultatu, gdyż - zgodnie decyzją londyńskiego rządu emigracyjnego - generał mógł spocząć jedynie w „wolnej i niepodległej Ojczyźnie"). Było to działanie o charakterze symbolicznym, doskonale wpisujące się w strategię mającą na celu „legitymizowanie władzy komunistycznej poprzez historię". Praktyki służące instrumentalizacji historii (i bieżącym interesom różnych ugrupowań politycznych) nie ustały po 1989 r. Spektakularnym dowodem owych praktyk może być - zdaniem Kuli - śledztwo IPN w sprawie katastrofy gibraltarskiej:

Badanie doczesnych szczątków gen. Władysława Sikorskiego dla mnie było niedopuszczalnym naruszeniem spokoju śmierci, populistycznym spektaklem [podkr. moje - N.K.-R.] oraz próbą działania w kierunku rozliczania historii w płaszczyźnie międzynarodowej. Nie mam na to, rzecz jasna, żadnych dowodów, ale podejrzewam, że ludzie ${ }^{73}$, którzy zdecydowali o otwarciu trumny, byliby najszczęśliwsi, gdyby znaleźli kawałek ołowiu z napisem „Sdiełano w SSSR"74.

W 1992 r. profesor Jerzy Maryniak z Instytutu Techniki Lotniczej Politechniki Warszawskiej ogłosił ${ }^{75}$ wyniki ekspertyzy numerycznie symulowanego lotu liberatora AL523 oraz badań laboratoryjnych tonięcia przeprowadzonych na modelu tego samolotu. Ustalenia Maryniaka podważyły obowiązującą dotąd wersję wydarzeń, zgodnie z którą - jak głosił raport powołanej 7 lipca 1943 r. komisji badającej okoliczności katastrofy - przyczyną wypadku było zablokowanie sterów wysokości. Wyniki badań Maryniaka nie pozostały bez wpływu na śledztwo prowadzone przez historyka i redaktora programu „Rewizja Nadzwyczajna” Dariusza Baliszewskiego. W serii artykułów opublikowanych na łamach „Newsweek Polska" w 2002 r. Baliszewski przedstawił szokujące wyniki owego śle-

utwierdzania w Polsce narzuconej władzy i prześladowaniami oraz śmiercią żołnierzy polskich, wiernym wskazaniom Generała Sikorskiego" (tamże, s. 279).

Jacek Daniel podsumowuje: „Władze PRL przegrały batalię o prochy generała Władysława Sikorskiego z emigracją polityczna, którą uważały za środowisko bez znaczenia i poparcia w wolnym świecie. Przez kolejne dwanaście lat sarkofag postawiony na przyjęcie kości generała stał pusty w kaplicy św. Leonarda na Wawelu. [...] Prochy Naczelnego Wodza powróciły do Ojczyzny wolnej i niepodległej w rocznicę inwazji sowieckiej na Polskę - 17 września 1993 r. i zostały pochowane na Wawelu" (tamże, s. 288).

73 Można w tym miejscu zadać pytanie: w czyim interesie działali owi „ludzie"? Przypomnijmy, że postulat ekshumacji zwłok poparł zarówno ówczesny prezydent PR Lech Kaczyński, jak i premier Donald Tusk.

74 Zob. Marcin Kula, Naród, historia i... dużo kłopotów, Universitas, Kraków 2011, s. 231-232.

75 Pełna wersja ekspertyzy została opublikowana w 113 numerze „Zeszytów Naukowych Politechniki Śląskiej” (Gliwice 1993), a po uzupełnieniu komentarzami, w numerze 1/2003 i 2/2003 czasopisma "Nauka - Innowacje - Technika”. 
dztwa, które stały się podstawą scenariusza filmu Anny Jadowskiej ${ }^{76}$. Określenie „śledztwo" odnosi się nie tylko do typu procedury zastosowanej przez Baliszewskiego, lecz w szerszym znaczeniu dookreśla metody powszechnie stosowane $\mathrm{w}$ historiografii.

Hayden White przyjmuje założenie, iż każda narracja historyczna jest efektem pracy tzw. wyobraźni konstruktywnej:

Podejmując wysiłki w celu nadania sensu źródłom historycznym, które okazują się fragmentaryczne i zawsze niekompletne, historycy zmuszeni są uciekać się do tego, co Collingwood nazywał „wyobraźnią konstruktywną”, podpowiadającą im - podobnie jak wytrawnym detektywom - co "przypuszczalnie ${ }^{77}$ miało miejsce”, zważywszy na osiągalny materiał dowodowy i właściwości formalne uchwytne dla świadomości zdolnej do zadania właściwych pytań [podkr. moje - N.K.-R.] $]^{78}$.

Wzorując się na tropologii ${ }^{79}$ White'a oraz integralnie ${ }^{80}$ związanej z nią koncepcji „wzorców fabularyzacji” ${ }^{81}$, możemy uznać, iż narracja historyczna Baliszewskiego wpisuje się w pewien łatwo rozpoznawalny kod (formułę thrillera politycznego). Niezwykle interesującą - w kontekście filmu Jadowskiej - analizę tropologii White'a zaproponował Paul Ricoeur. Zdaniem filozofa tropologia opiera się na założeniu, iż

pomiędzy opowieścią a biegiem wydarzeń nie istnieje relacja odtwarzania, podwajania, równoważności, lecz relacja metaforyczna: czytelnik zostaje skierowany ku takiemu rodzajowi wyobrażenia, które przystosowuje wydarzenia relacjonowane do formy narracyjnej, z jaką oswoiła nas nasza kultura ${ }^{82}$.

${ }^{76}$ W efekcie współpracy Dariusza Baliszewskiego z telewizją TVN (producenta filmu Anny Jadowskiej) powstał czteroodcinkowy serial dokumentalny (również wyreżyserowany przez Jadowską), który znalazł się na dwupłytowej edycji specjalnej Generała. Do serialu włączono sceny, które nie znalazły się w kinowej wersji Generała.

77 W tekstach White'a zwraca uwagę częstotliwość posługiwania się trybem warunkowym - jak w słynnym zdaniu: „każdy zapis [historyczny] jest epizodem konfliktu między poetyckimi przedstawieniami prawdopodobnych wersji przeszłości". Zob. Hayden White, Poetyka pisarstwa historycznego, dz. cyt., s. 105.

78 Tamże, s. 82.

79 Fabularyzacja wydarzeń dokonuje się za pomocą figur retorycznych, na skutek czego nabierają one znaczeń (moralnych i etycznych) wykraczających poza ich „zdarzeniowy" sens. Fabularyzacja jest zatem jednocześnie alegoryzacją (tamże, s. 349-350).

80 „Dla White'a - pisze William Guynn - każdy typ figuracji uprzywilejowuje specyficzny gatunek opowiadania. Metafora jest powiązana z romansem, metonimia z tragedia, synekdocha z komedia, ironia z satyrą". Zob. William Guynn, Przekształcanie historii w filmie, tłum. Teresa Rutkowska, Karolina Kosińska, „Kwartalnik Filmowy” 2010, nr 69, s. 10.

81 W narracji historyka wydarzenia nabierają spójności charakterystycznej nie dla opowiadania w ogóle (gdyż coś takiego nie istnieje), lecz dla pewnego określonego typu fabularnej struktury gatunkowej (tamże, s. 348).

82 Paul Ricoeur, Czas i opowieść, dz. cyt., s. 221. White zakłada, iż istnieje pewna liczba kodów, które determinują narracje historyczne (choć oczywiście istnieją także "anty-narracyjne” 
Jest to założenie - jak dowodzą dyskusje prowadzone nie tylko w kręgu historyków - niezwykle kontrowersyjne. Sprzeciw wywołuje bowiem teza, do której - wedle Katarzyny Rosner - sprowadzić można teoretyczne wywody White'a:

Kodem o zasadniczym znaczeniu okazuje się kod narracyjny, czy raczej jego różne odmiany, mające źródła w mitach, leżących u źródeł kultury zachodniej. [...] Ponieważ obydwie odmiany tekstów wykorzystują te same kody kultury, różnica między statusem poznawczym literatury i historiografii pozostaje zamazana. [...] W obu zatem przypadkach trudno mówić o prawdziwości wytworu [podkr. moje - N.K.-R.]; jego wartość utożsamiona jest z efektywnościa, skutecznością [...] procedury „usensowniania". Ta zaś jest przede wszystkim funkcją koherencji opowieści i jej retorycznej mocy perswazyjnej ${ }^{83}$.

Dwóch wymienionych przez Rosner cech (koherencja, retoryczna moc perswazyjna) z pewnością nie można odmówić narracji Baliszewskiego traktowanej jako opowieść (historyczna). Kontrowersje może budzić jednak zasadność posłużenia się formułą gatunkową (,,kodem narracyjnym") w odniesieniu do tak "tragicznego" epizodu polskiej historii. Opatrzenie słowa: tragiczne cudzysłowem jest już logiczną konsekwencją przyjęcia założenia o "aksjologicznej neutralności” wydarzeń historycznych $^{84}$. Oddajmy głos White'owi:

formy pisarstwa historycznego: medytacja czy streszczenie). Narracje te są „skonfigurowane” wedle wzorca komedii, tragedii, romansu albo satyry. Ricoeur wyjaśnia: „historia w swoim pisaniu naśladuje typy zawiązania intrygi przejęte z tradycji. W ten sposób widzieliśmy, jak Hayden White zapożycza od Northropa Frye'a kategorie tego, co tragiczne, tego, co komiczne, tego, co powieściowe, ironii etc., i owe gatunki literackie łączy w pary z tropami należącymi do tradycji retorycznej. Otóż owe zapożyczenia czerpane przez historię z literatury nie powinny być ograniczane jedynie do płaszczyzny kompozycji, a zatem do momentu konfiguracji. Zapożyczenie dotyczy także przedstawieniowej funkcji wyobraźni historycznej: konkretny ciąg wydarzeń uczymy się widzieć jako tragiczny, jako komiczny itd." (tamże, s. 269-270).

Wypada jednak podkreślić, iż Ricoeur zachowuje w stosunku do tez formułowanych przez White'a daleko posunięty sceptycyzm. Filozof przestrzega: „,tropologiczna arbitralność nie powinna powodować, byśmy zapomnieli o niejakim przymusie, który wydarzenie przeszłe wywiera na dyskurs historyczny za pośrednictwem znanych dokumentów, wymagając od tego dyskursu, by się nieustannie korygowal' (tamże, s. 222-223).

83 Katarzyna Rosner, Narracja, tożsamość i czas, Universitas, Kraków 2003, s. 83. Powyższy cytat stanowi komentarz do tezy White'a: „W gruncie rzeczy historii - zmieniającemu się w czasie realnemu światu - nadajemy sens w taki sam sposób, w jaki stara mu się go nadać poeta czy powieściopisarz, przypisując temu, co z początku wydaje się problematyczne i tajemnicze, jakąś rozpoznawalna, czyli znaną już wcześniej formę. Nie ma znaczenia, czy chodzi o świat realny czy tylko wyobrażony; w obu przypadkach sposób nadawania sensu jest taki sam". Hayden White, Poetyka pisarstwa historycznego, dz. cyt., s. 106.

84 Zdaniem Le Goffa postawiona przez White'a teza prowadzi do wniosku, iż wybór strategii wyjaśniania historycznego (i wybór wzorca fabularyzacji) wynika bardziej z po- 
żadne historyczne wydarzenie nie jest samo w sobie tragiczne; można je najwyżej tak postrzegać $\mathrm{z}$ pewnego punktu widzenia lub w obrębie określonego kontekstu wyznaczonego przez ustrukturowany szereg wydarzeń, w ramach którego zajmuje ono uprzywilejowaną pozycję. [...] Jako potencjalne elementy opowieści, wydarzenia historyczne są aksjologicznie neutralne. [...] Jeśli dany splot wydarzeń przybiera narracyjny kształt „tragedii”, oznacza to po prostu, iż historyk opisał je w taki sposób, aby wy w ołać w nas skojarzenie z formą literacką związaną z pojęciem "tragiczności" 85 .

Wybór określonego „kodu” nie zależy jednak wyłącznie od arbitralnej decyzji piszącego, lecz jest efektem negocjacji pomiędzy historykiem a publicznościa, dla której pisze. Oznacza to konieczność uwzględnienia (podzielanych zarówno przez historyka, jak i odbiorców jego dzieł) wstępnych wyobrażeń co do możliwych typów fabularyzacji pewnego typu wydarzeń - wyobrażeń nie tyle natury historycznej, ile ideologicznej, estetycznej i mitycznej ${ }^{86}$.

Ten sam zespół wydarzeń - podkreśla White - może dostarczyć elementów do opowieści tragicznej bądź komicznej [...]. Nie wydaje mi się, aby ktokolwiek był skłonny przystać na fabularyzację życia prezydenta Kennedy'ego w kategoriach komedii, ale kwestią otwartą pozostaje, czy należy je fabularyzować jako romans, tragedię czy satyrę. Istotne jest, że większość sekwencji wydarzeń historycznych daje się sfabularyzować na kilka różnych sposobów, co pozwala na różne ich interpretacje i przydaje im różnych znaczeń. [...] W jaki s posób dana sytuacja historyczna zostanie skonfigurowana, zależy od stopnia subtelności ${ }^{87}$ [podkr. moje - N.K.-R.], z jaką historyk dobierze specyficzną strukturę fabularną do zespołu wydarzeń, którym zamierza nadać określone znaczenia. W gruncie rzeczy jest to operacja właściwa literaturze $[\ldots]^{88}$.

budek moralnych i/lub estetycznych niż epistemologicznych. Zob. Jacques Le Goff, Historia i pamięć, dz. cyt., s. 179.

85 Hayden White, Poetyka pisarstwa historycznego, dz. cyt., s. 83-94.

86 Tamże, s. 85.

87 Odwoływanie się do kryterium „subtelności” (w odniesieniu do historyka) czy „akceptowalności" (w odniesieniu do odbiorcy) jest wysoce dyskusyjne. White ma tego świadomość, o czym świadczy przytoczony przykład: „[Saul Friedländer] oskarżył historie, powieści i filmy o to, że pod pozorem wiernego przedstawienia przerażających faktów z życia Niemiec hitlerowskich w istocie estetyzują cały obraz i przekształcają jego zawartość w fetysze i przedmioty sadomasochistycznych fantazji. Jak zaznaczył Friedländer, takie «uwznioślanie» przedstawień Trzeciej Rzeszy zazwyczaj było «nie do przyjęcia» niezależnie od trafności czy prawdziwości faktograficznej zawartości, ponieważ obrażało moralność i dobry smak. Fakt, że w ciągu ostatnich dwudziestu lat owe przedstawienia upowszechniły się, a tym samym stały się bardziej «akceptowalne», wskazuje na zasadniczą zmianę w społecznie sankcjonowanych standardach moralności i dobrego smaku" (tamże, s. 217).

88 Tamże, s. 84-85. 
Teksty Baliszewskiego opublikowane na łamach „Newsweek Polska” stanowić mogą paradygmatyczny przykład potwierdzający postmodernistyczną tezę o tzw. intertekstualności przedstawienia historycznego. A jeśli „przedstawienie jest przede wszystkim zaprzeczeniem innych przedstawień, to owe odrzucone przedstawienia moga zostać określone jako «pod-tekst» (subtext) tekstu historyka. W tym sensie możemy powiedzieć, że przedstawienie jest tym, czym nie jest $[\ldots]^{\prime \prime 89}$.

Istotnym problemem, przed którym już na wstępie staje interpretator filmu Jadowskiej, okazuje się - z pozoru oczywista - klasyfikacja Generała („film faktu”/,film fikcji”). W czołówce filmu pojawia się plansza, którą potraktować należy jako formę paratekstu, zawierającego odautorskie wskazówki dotyczące (możliwej) interpretacji dzieła. Możemy z niej odczytać informację o kluczowym - z punktu widzenia epistemologicznego statusu tekstu - znaczeniu: Film oparty zostat na wynikach wieloletnich badaniach historycznych Dariusza Baliszewskiego i jest próba rekonstrukcji tych wydarzeń.

Idąc za tą odautorską wskazówka, należałoby potraktować film jako docudrame - udramatyzowaną rekonstrukcję historii.

Termin docudrama (dokument fabularyzowany) - pisze Peter Burke - wymownie przypomina o owym napięciu między ideą dramatu a ideą dokumentu, między antyklimaksami i niedookreśleniem przeszłości a odczuwaną przez reżysera [...] potrzebą formy ${ }^{90}$.

Konfuzję wywołuje przede wszystkim użyte przez twórców słowo „wydarzenia”. Abstrahując już nawet od przyjętej na użytek tej analizy typologii White'a, musimy przyznać, iż w przypadku Generała „rekonstrukcja” nie mogła dotyczyć sfery „wydarzen”" czy "faktów”, lecz wyłącznie sfery czyichś (dalece subiektywnych) twierdzeń o tym "wydarzeniu". Przypomnijmy, iż film powstał w oparciu o wyniki badań Baliszewskiego, które - mimo zgromadzonej przez historyka imponującej dokumentacji - miały wyłącznie charakter hipotezy (jednej z wielu, jakie pojawiły się po śmierci Sikorskiego ${ }^{91}$. Widza - za pomocą niezwykle efektywnych „procedur usensowniania" - zmusza się, by zapomniał o tym zastrzeżeniu i potraktował owe hipotezy jako „fakty”. Podstawową funkcją reali-

89 Frank Ankersmit, Narracja, reprezentacja, doświadczenie, dz. cyt., s. 209.

90 Peter Burke, Naoczność, tłum. Justyn Hunia, Wyd. Uniwersytetu Jagiellońskiego, Kraków 2012, s. 185.

91 Tadeusz Kisielewski, autor wielu opracowań poświęconych katastrofie gibraltarskiej, zaleca zachowanie $\mathrm{w}$ stosunku do tez formułowanych przez Baliszewskiego niezbędnego krytycyzmu: „,Redaktor Baliszewski [...] jest z wykształcenia historykiem, jednak bywa, że przeważa w nim temperament publicysty i formułuje zbyt daleko idące uogólnienia, nie mając ku temu należytych podstaw. Trzeba jednak przyznać, że generalizacje te zwykle mają formę pytań lub hipotez, a nie kategorycznych stwierdzeń". Zob. Tadeusz Kisielewski, Zamach, dz. cyt., s. 97. 
zowaną przez film okazuje się funkcja perswazyjna. Tymczasem Generał powinien wzbudzić etyczne wątpliwości podobne do tych, które wywołał wcześniej JFK. Sceptyczny widz winien zatem zadać pytania sformułowane pod adresem Stone'a przez Stevena Lipkina:

1. Czy przedstawiona w filmie "teoria spiskowa" zasługuje na to, by zostać opowiedziana?

2. W którym miejscu przebiega granica pomiędzy „re-kreacją” (wynikającą z samej natury medium i hybrydycznej formy docudramy) a czystą „spekulacją"? ?2

Zdaniem Mirosława Przylipiaka twórca przekazów niefikcjonalnych często przyjmuje rolę oficera śledczego, gdyż wyrok, który swoim filmem wydaje, choć nie ma konsekwencji prawnych, może mieć poważne konsekwencje społeczne, dlatego z tym większą odpowiedzialnością trzeba rozważyć wszystkie "za" i „przeciw” ${ }^{\prime \prime}$. Problem społecznych konsekwencji ekspansji obrazu jako źródła wiedzy (nie wspominając o kwestii statusu ontologicznego - i o tzw. wrażeniu realności - generowanych cyfrowo „symulakrów") stał się przedmiotem zainteresowania historyków zwłaszcza w odniesieniu do II wojny światowej i Holocaustu ${ }^{94}$ Na społeczną funkcję komunikowania za pośrednictwem przekazów audiowizualnych (nie tylko faktualnych) zwraca uwagę Marek Hendrykowski:

Zarówno w kinie, jak i poza nim obaj uczestnicy aktu komunikacji, to znaczy autor i jego odbiorca, należą do określonej zbiorowości rozumianej jako wspólnota. Od tego, jak się komunikuja, o czym ze sobą rozmawiają i w jaki sposób się porozumiewają (co zostanie przekazane i jaki ostatecznie będzie w danym przekazie udział fałszu lub prawdy), zależy poziom świadomości jednostki i danego społeczeństwa jako większej wspólnoty. Konsekwencje społeczne tego procesu okazują się bardziej doniosłe, niż mogłoby się wydawać ${ }^{95}$.

92 Zob. Steven S. Lipkin, Real Emotional Logic, dz. cyt., s. 50.

93 Mirosław Przylipiak, Poetyka kina dokumentalnego, Wyd. Uniwersytetu Gdańskiego, Gdańsk-Słupsk 2004, s. 63. Na ten problem zwraca uwagę Michael Kurtz w odniesieniu do JFK. Autor podkreśla, iż po premierze filmu wielu widzów poczuło się zdradzonych przez rząd, który oszukał ich w sprawie tego, co tak naprawdę zdarzyło się (what really happened) w Dallas 22 listopada 1963 r. Zob. Michael Kurtz, Oliver Stone, JFK, and History, dz. cyt., s. 166.

$94 \mathrm{~W}$ tej kwestii istnieje zdecydowana polaryzacja stanowisk. Zdaniem White'a docudrama - programowo pozbawiona wszelkich ujęć totalizujących i koherentnej narracji - stanowić może reprezentacje „niewyrażalnych" traum XX w. Odmienny punkt widzenia przyjmuje Janet Steiger, która podkreśla, iż nieumiejętność odróżniania "faktów” od "spekulacji” prowadzić może do kwestionowania twardych faktów (autorka podaje, iż w ankiecie przeprowadzonej w 1993 r. 22\% dorosłych Amerykanów uznało za możliwe, że „Holocaust nigdy się nie wydarzył”). Zob. Janet Staiger, Cinematic Shots. The Narration of Violence, [w:] The Persistence of History, dz. cyt., s. 52.

95 Marek Hendrykowski, Dokument - fikcja-realizm, „Kwartalnik Filmowy” 2011, nr 7576, s. 107 
Powyższa konstatacja w szczególnym stopniu wydaje się dotyczyć filmowych „rekonstrukcji historycznych". „Wspólnotową" funkcję przekazów bezpośrednio odwołujących się do historycznych źródeł podkreśla Anthony Smith w artykule Images of the Nation. Zdaniem badacza, począwszy od sztuk Szekspira opartych na kronikach historycznych, ustalił się obowiązujący do dzisiaj - pewien typ praktyki odbiorczej. „Rekonstrukcje historyczne" mają charakter funkcjonalny: dostarczają odbiorcy "mapę" narodowych dziejów, by w ten sposób wytworzyć w nim silne poczucie związku z tożsamością narodową ${ }^{96}$. A tym samym mogą doskonale wpisywać się w aktualną politykę historyczną (stanowiąc często jej legitymizację).

$\mathrm{W}$ dyskursach narodowych pojęcie narodu konstruowane jest często w oparciu o opozycje binarne. Dla potrzeb niniejszego wywodu najistotniejsza wydaje się opozycja: „amnezja vs pamięć/historia”" "W przypadku Generała ta kwestia, z uwagi na rangę tematu - przez lata konsekwentnie przemilczanego (usuwanego z pamięci zbiorowej) - wydaje się niezwykle istotna.

Twórcy filmu zadbali o to, by Generał miał wszelkie cechy utworu ugruntowanego na podstawie źródłowo udokumentowanych faktów. Gwarantem wiarygodności filmowej „rekonstrukcji” jest nazwisko historyka - „eksperta" 98 - wymienione na początku filmu. Powoływanie się na autorytet „eksperta" w celu wzmocnienia wiarygodności wywodu to typowy dla narracji historiograficznej „,argument”, służący uzyskaniu pożądanego efektu perswazyjnego ${ }^{99}$.

W paratekście faktualność dyskursu podkreśla protokolarny styl narracji historycznej (notę o badaniach Baliszewskiego poprzedzają napisy informujące o sytuacji politycznej w ogarniętej wojną Europie). Tę samą funkcję pełnią - stanowiące uprawomocnienie owej narracji (i stwarzające efekt bezpośredniego kontaktu z przeszłością ${ }^{100}$ ) audiowizualne „materiały źródłowe" 101 (fragmenty kronik, na których zarejestrowano etapy bliskowschodniej podróży Sikorskiego, m.in. spotkanie z ministrem Caseyem i wizytę w sztabie generała Andersa). Jak pisze André Rouillé:

96 Zob. Anthony Smith, Images of the nation: cinema, art and national identity, [w:] Cinema and Nation, ed. Mette Hjort and Scott MacCenzie, Routledge, London-New York 2000, s. 52.

97 Zob. Susan Hayward, Framing national cinemas, [w:] Cinema and Nation, dz. cyt., s. 98.

98 Por. Marnie Hughes-Warrington, History Goes to the Movies. Studying history on film, Routledge, New York 2007, s. 17.

99 Zob. Jerzy Topolski, Jak sie pisze i rozumie historię. Tajemnice narracji historycznej, Oficyna Wyd. Rytm, Warszawa 1996, s. 106-107.

${ }^{100}$ Zob. Hans Ulrich Gumbrecht, Gdy przestaliśmy uczyć się od historii, dz. cyt., s. 206.

${ }^{101}$ Oczywiście materiał źródłowy wykorzystany w Generale nie ogranicza się wyłącznie do archiwalnych filmów i zdjęć. Dzięki „dokumentom z epoki” faktualny charakter zyskał „wątek warszawski” związany z Gralewskim i jego żoną Alicją. Towarzysząca retrospekcjom narracja w trybie voice over powstała w oparciu o opublikowaną w Londynie wojenną korespondencję Gralewskich. Zob. Alicja Iwańska, Wojenne odcinki 1940-1943, Londyn 1982). 
Obraz odwołuje się do przekonań widza [...]. Dokument zaś w mniejszym stopniu wymaga podobieństwa czy nawet dokładności, a bardziej przekonania lub zaufania do roli, jaką ma spełnić. Z chwila, gdy niektóre zdjęcia fotograficzne - te w szczególności, które należą do obszaru dokumentalnego - mogą być odbierane jako kwintesencja "dokładności, prawdy, samej rzeczywistości", różnią się one od zwykłych przedmiotów, których właściwości moglibyśmy zbadać i określić. Zdjęcia stają się magicznymi przedmiotami, które domagają się od nas tego, aby ich cechy i właściwości uznać za wiarygodne ${ }^{102}$ (fot. 1-2).
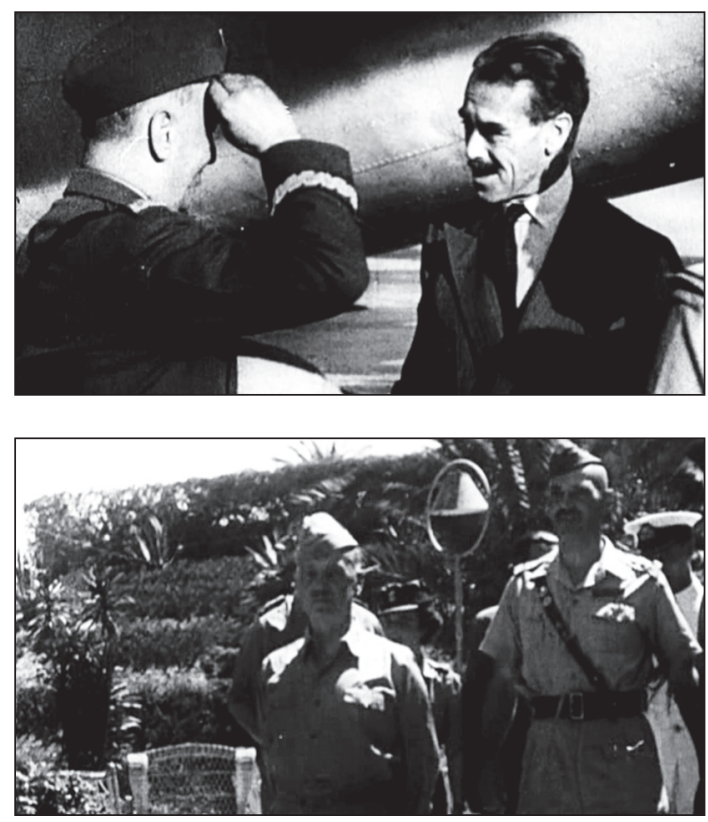

Fot. 1-2. Generat. Zamach na Gibraltarze (2009, reż. Anna Jadowska). „Efekt prawdy”

W dużej mierze to właśnie filmowe archiwalia powoduja, iż w doświadczeniu odbiorczym Generał może stać się (tekstową) retrospekcja umożliwiającą widzowi zajrzenie w czas miniony - w przeszłość, do której ontologicznie dostęp pozostaje dlań zamknięty ${ }^{103}$. A przecież - jak dowodzi Robert Rosenstone - nawet w przypadku obrazów dokumentalnych, które poprzez indeksalną relację z rzeczywistością mogą dostarczyć

102 André Rouillé, Fotografia. Między dokumentem a sztuka współczesna, tłum. Oskar Hedemann, Universitas, Kraków 2007, s. 65.

${ }^{103}$ Zob. Marek Hendrykowski, Film jako źródło historyczne, dz. cyt., s. 36. Zdecydowałam się umieścić słowo "tekstową" w nawiasie, gdyż - jak sądzę - przyznawanie zdjęciom dokumentalnym statusu "tekstu” nie jest powszechną praktyką odbiorczą (wymaga ona bowiem - postulowanej przez Hendrykowskiego - postawy sceptycznej). 
niezapośredniczonego doświadczenia przeszłości, mamy do czynienia $\mathrm{z}$ rodzajem mistyfikacji. Film dokumentalny regularnie stosuje nie czas teraźniejszy, ale specyficznie wizualny/filmowy czas, który moglibyśmy nazwać „nostalgią”. Takie obrazy - podsumowuje Rosenstone - nigdy nie mogą przynieść bezpośredniego doświadczenia przeszłości, ponieważ upływające lata zawsze zakłócają świadomość widza ${ }^{104}$.

Niezależnie od sformułowanych powyżej zastrzeżeń można uznać, iż zawarta w czołówce wskazówka interpretacyjna ukierunkowuje "faktualne" nastawienie odbiorcy wobec tekstu ${ }^{105}$. Zgodnie ze "zdroworozsądkową" definicją filmu dokumentalnego „w takim zakresie, w jakim dokument opowiada historię, historia ta jest raczej wiarygodnym przedstawieniem tego, co się zdarzyło, a nie imaginacyjną interpretacją tego, co mogło się zdarzyć" ${ }^{106}$, można przyjąć, iż przekaz oparty na wieloletnich badaniach historycznych i wsparty na mocnym fundamencie filmowych archiwaliów zostanie potraktowany jako "obiektywny i weryfikowalny”. A zatem uznany za "reprezentację" czyli „propozycję najlepszego (tekstowego) substytutu danego fragmentu przeszłości"107. To wstępne założenie autorów filmu okaże się słuszne jedynie wówczas, gdy widzowie Generała podzielają pogląd, zgodnie z którym wszelkie konstatacje historyków dotyczące zdarzeń i postaci historycznych powinny być "obiektywne" i opierać się na wiarygodnych dowodach ${ }^{108}$.

${ }^{104}$ Robert Rosenstone, Zobaczyć przeszłość, przeł. Piotr Witek, [w:] Teoria wiedzy o przeszłości na tle wspótczesnej humanistyki, red. Ewa Domańska, Wyd. Poznańskie, Poznań 2010, s. 329.

105 To twierdzenie jest prawdziwe, o ile zakwestionujemy tezę Siegfrieda Kracauera, iż konwencje filmu historycznego pozostają w sprzeczności z naturą medium filmowego, które dąży do werystycznego prezentowania świata. Zdaniem Kracauera „przeszłość historyczna musi być inscenizowana za pomocą kostiumów i dekoracji całkowicie oderwanych od współczesnego życia. W konsekwencji widz, wrażliwy na specyficzne właściwości kina, musi odczuwać ich nieodpartą teatralność. [...] Świat, który ukazuja, odtwarzając przeszłość, jest sztuczną kreacją [...]. W porównaniu z cudownym filmem dokumentalnym, który sugeruje nieskończoność rzeczywistości [...] idealnie doskonały film historyczny byłby jedynie rekonstrukcją pozbawioną filmowego życia". Zob. Siegfried Kracauer, Teoria filmu, tłum. Wanda Wertenstein, słowo/obraz terytoria, Gdańsk 2008, s. 107-109. Warto odnotować, iż początek Generała został skonstruowany na wzór JFK - w filmie Stone'a funkcję introdukcji pełnią zmontowane fragmenty archiwalnych kronik filmowych.

${ }^{106}$ Zob. Bill Nichols, Jak możemy zdefiniować film dokumentalny?, „Kwartalnik Filmowy” 2011, nr 75-76, s. 244.

${ }^{107}$ Frank Ankersmit, Pochwała subiektywności, [w:] Pamięć, etyka i historia, dz., cyt., s. 71. Autor podkreśla, iż w narracji historycznej można odnaleźć trzy odmiany dyskursu: „po pierwsze, stanowi ona reprezentację przeszłości, pod drugie, reprezentacja ta składa się z prawdziwych twierdzeń o określonym ładunku poznawczym, i wreszcie, po trzecie, reguły etyczne i wartości współkształtują opis przeszłości proponowany przez historyka [...]" (tamże, s. 74-75).

${ }^{108}$ Komentarzem do poczynionego powyżej zastrzeżenia może być opinia Barbary Szackiej: „nawet jeżeli w obrębie historii istnieja, a raczej pojawiają się, kierunki kwestio- 
W tym miejscu należy poczynić jeszcze jedno istotne zastrzeżenie. Wydaje się bowiem, iż z czołówki filmu płyną w stronę widza sprzeczne wskazówki. Napisy obsadowe pojawiają się na tle czarno-białych zdjęć wzburzonego morza. Taki początek sugeruje (mylnie) typową dla tzw. filmu nostalgicznego retrospektywną stylizację, której podstawową funkcją jest kreowanie atmosfery, stylu oraz poetyki zawartych $\mathrm{w}$ filmach i fotografiach powstałych w przedstawianej przez reżysera epoce historycznej ${ }^{109}$. W kolejnych ujęciach barwa wody nieoczekiwanie ulega zmianie - fale nabierają zdecydowanie żółtawego odcienia. Kolor jest tak ostentacyjnie "nienaturalny", że musi wywołać u widza wrażenie efektu uzyskanego cyfrowo. Po napisach ponownie pojawiają się czarno-białe ujęcia powierzchni morza, w które za chwilę uderzy (wygenerowany komputerowo) samolot typu liberator.

Czołówka Generała stanowi ewidentny przykład „technologicznej hybrydyzacji", czyli funkcjonowania obok siebie dwóch odmiennych typów „zapisu”. Na ogół jednak przejścia pomiędzy zapisem cyfrowym i analogowym są starannie wymazywane i stają się niewidoczne dla widza - od tego zależy bowiem wiarygodność obrazu ${ }^{110}$. Praktykę symulowania tradycyjnego języka filmu określa się nawet mianem „niewidzialnego efektu” definiowanego jako „poprawianie przy użyciu komputera scen, które dla widzów będą łudząco podobne do ujęć kręconych na planie $z$ udziałem prawdziwych aktorów, ale w rzeczywistości powstałych z połączenia materiału cyfrowego z tradycyjnym materiałem filmowym"111. W przypadku dzieła Jadowskiej wspomniana reguła „niewidzialnego efektu” najwyraźniej nie obowiązuje. $W$ niespełna dwuminutowym fragmencie nastąpiła dwukrotna - niczym nie umotywowana - zmiana tonacji kolorystycznej. Celem takiego zabiegu formalnego nie było zasugerowanie widzowi, by utożsamiał pojawiające się $\mathrm{w}$ filmie ujęcia czarno-białe $\mathrm{z}$ dyskursem faktualnym, a ujęcia zrealizowane w kolorze $\mathrm{z}$ dyskursem fikcjonalnym. Chodziło raczej o wskazanie, iż pomiędzy tymi dwoma typami dyskursu będzie się w filmie toczyła nieustanna gra. To właśnie owa gra "faktu" $\mathrm{i}$,fikcji” wywołuje paradoksalne reakcje odbiorcze:

nujące sensowność jej dążeń do obiektywności, to w odbiorze społecznym historia jest postrzegana jako zmierzająca w tym kierunku i takie są wobec niej oczekiwania. Dobrym przykładem są budzące silne emocje wydarzenia w Jedwabnem i w czasie tak zwanej krwawej niedzieli w Bydgoszczy, których przebieg był i jest przedmiotem gorących sporów. W obu wypadkach zwrócono się do historyków, w przekonaniu, że badania prowadzone zgodnie $\mathrm{z}$ regułami ich profesji pozwolą poznać prawdę, w takiej mierze, w jakiej jest ona poznawalna". Zob. Barbara Szacka, Czas przeszły - pamiećc - mit, dz. cyt., s. 25.

${ }_{109}$ Piotr Witek, Kultura - film - historia, dz. cyt., s. 262.

110 Zob. Sylwia Galanciak, Rzeczywistość vs komputer. Efekty cyfrowe a filmowa ontologia, [w:] „Kwartalnik Filmowy” 2006, nr 56, s. 82-85.

111 Zob. Lev Manowitch, Język nowych mediów, tłum. Piotr Cypryański, Wyd. Artystyczne i Profesjonalne, Warszawa 2006, s. 446. 
wiara-niewiara tworzy w procesie odbioru filmu biegunowy układ przeciwieństw, pomiędzy którymi przez cały czas dokonuje się indywidualna weryfikacja przekazu. Weryfikacja, na mocy której dany film zostaje, lub nie zostaje, uznany przez odbiorcę - zarówno zwykłego widza, jak i profesjonalnego badacza - za przekonywające (czytaj: wiarygodne) źródło historiii ${ }^{112}$.

Podsumowując, możemy przyjąć, iż czołówka Generała pełni podwójną funkcję:

1. Na zasadzie figury pars pro toto wskazuje na "dyskursywne szwy", a tym samym ujawnia ,"autorefleksyjny” charakter całego tekstu (w samej strukturze czołówki zakodowane jest zalecenie „lektury podejrzliwej”).

2. Wskazuje, że Generat jest utworem pod względem rodzajowym hybrydycznym, a typ relacji pomiędzy elementami fabularnymi i dokumentalnymi nosi tu wszelkie cechy konfluencji (zjawiska polegającego na łączeniu i mieszaniu się rodzajów filmowych ${ }^{113}$.

Zdaniem Marka Hendrykowskiego to właśnie wspomniane napięcie istniejące pomiędzy dwoma biegunami komunikacji filmowej współtworzy w świadomości widza ",suspens epistemologiczny z ontologią w tle"114.

Fundamentalne dla interpretacji filmu Jadowskiej pojęcie gry - której zapowiedź odnajdujemy już w czołówce - odnosi się nie tylko do relacji pomiędzy dyskursem fikcjonalnym i faktualnym, lecz także do kategorii czasu. Ujęcie spadającego do wody samolotu awizuje liczne w filmie zakłócenia linearnego porządku narracyjnego. Operowanie czasem retrospektywno-prospektywnym, tj. włączanie do narracji wiedzy o tym, co było przed i co było po, czyli rozszerzanie jej zawartości czasowej, jest grą historyka z czasem, jest formą konstruowania narracji historycznej ${ }^{115}$. Takie ruchy w czasie - podsumowuje William Guynn - są jednak dość powszechne $\mathrm{w}$ narracjach historycznych, nie jest dla historyka niczym nadzwyczajnym rozpoczynanie opowieści od zakończenia po to, by połączyć je z sytuacja, w której jest zakorzenione ${ }^{116}$.

W celu wytworzenia „efektu realności” posłużono się w Generale procedurami obiektywizowania typowymi dla dyskursów faktualnych. Za-

\footnotetext{
${ }_{112}$ Marek Hendrykowski, Film jako źródło historyczne, dz. cyt., s. 52.

${ }_{113}$ Zob. Marek Hendrykowski, Dokument - fikcja - realizm, dz. cyt., s. 95-96.

114 Tamże, s. 97.

115 Jerzy Topolski, Jak się pisze i rozumie historię, dz. cyt., s. 118-119. Autorki książki Powiedzieć prawdę o historii piszą: „W snuciu opowieści fascynuje, że zaczynają się one od końca. [...] Nieszczęśliwe zakończenie staje się natomiast punktem wyjścia do zadawania pytań. Opowieść ma wyjaśnić rozpad tego, co kiedyś było całościa, a każdy element narracji stanowić ma przesłankę zakończenia. Zadawanie pytań zaczyna się od zainteresowania zdarzeniem zamykającym jakiś ciąg, a pytania wiodą do znaczących w tym ciągu faktów". Zob. Joyce Appleby, Lynn Hunt, Margaret Jacob, Powiedzieć prawdę o historii, dz. cyt., s. 274-275.

116 William Guynn, Przekształcanie historii w filmie, dz. cyt., s. 23.
} 
stosowano m.in. metodę polegającą na zapożyczaniu procedur obiektywizacji właściwych dziedzinie, o której film opowiada. Generał łączy w sobie elementy filmu historycznego i filmu kryminalnego opartego na formule reportażu śledczego ${ }^{117}$ (podtytuł filmu: Zamach na Gibraltarze to kolejna wskazówka odsyłająca widza do konwencji gatunkowej np. thrillera politycznego). Zdaniem Przylipiaka film o wydarzeniu historycznym może być obiektywny na tej samej zasadzie, co traktat historyczny. Autor filmu z dziedziny reportażu śledczego wchodzi w rolę detektywa, usiłującego dociec prawdy o jakimś zdarzeniu, niekiedy o charakterze kryminalnym ${ }^{118}$. Do formuły reportażu śledczego nawiązuje chociażby powszechnie stosowana w Generale praktyka umieszczania w lewym dolnym rogu kadru informacji o miejscu i dokładnym czasie ${ }^{119}$ rozgrywających się zdarzeń („faktów”).

W charakterystyczny dla docudramy sposób połączono partie dokumentalne i fabularne. Często stosowanym w filmie zabiegiem formalnym jest pionowy podział kadru na dwie symetryczne części. Po jednej stronie ekranu (z reguły lewej - choć nie jest to zasada przestrzegana restrykcyjnie) widzimy materiał archiwalny, po drugiej - inscenizowany. Paradygmatycznym przykładem takiego rozwiązania jest sekwencja górskiej wspinaczki Gralewskiego. Choć symultanicznie ukazujące się w kadrze obrazy nie zawsze dotyczą tych samych "faktów”, widz może odnieść wrażenie ścisłej przyległości semantycznej archiwaliów (anonimowi kurierzy) i filmowej fikcji (Gralewski). W analizowanej sekwencji kluczem do rozstrzygnięcia statusu pojawiających się na ekranie obrazów może być kolor. Twórcy nie posługują się jednak kodem kolorystycznym w sposób konsekwentny. Dla przykładu - w jednej z początkowych sekwencji rozgrywającej się na lotnisku zarówno zdjęcia archiwalne, jak i inscenizowane są czarno-białe (fot. 3-4).

${ }^{117}$ W tym kontekście niezwykle interesująca mogłaby się okazać analiza porównawcza dwóch filmów: Generała i zrealizowanej w 1977 r. Śmierci prezydenta. Dokonana przez Kawalerowicza - przy użyciu całkowicie odmiennych („protokolarnych”) środków rekonstrukcja stanowi, w opinii Marka Hendrykowskiego, „niecodzienny przykład doskonałego posłużenia się źródłową wiedzą historyczną przez filmowców, których zamiarem było możliwie najbardziej sumienne, iście detektywistyczne [podkr. moje - N.K.-R.] wyjaśnienie przyczyn, okoliczności i mechanizmów zbrodni, jaką stał się grudniowy zamach na prezydenta Gabriela Narutowicza w 1922 roku". Zob. Marek Hendrykowski, Film jako źródło historyczne, dz. cyt., s. 80.

${ }^{118}$ Mirosław Przylipiak, Poetyka kina dokumentalnego, dz. cyt., s. 63.

119 Odtworzenie czasu, w jakim rozegrały się „wydarzenia” historyczne, jest zabiegiem niezwykle ryzykownym. O ile można bowiem dość precyzyjnie określić godzinę pojawienia się polskiej delegacji na lotnisku North Front (około 22.30) czy uderzenia samolotu w morze (wiele źródeł wskazuje na 23.07), o tyle ustalenia, wedle których akcja zbrojna w pałacu Gubernatora rozpoczęła się o 15.00, a zakończyła o 16.30 należy uznać - ze względu na status samego „faktu” - za stricte hipotetyczne. 

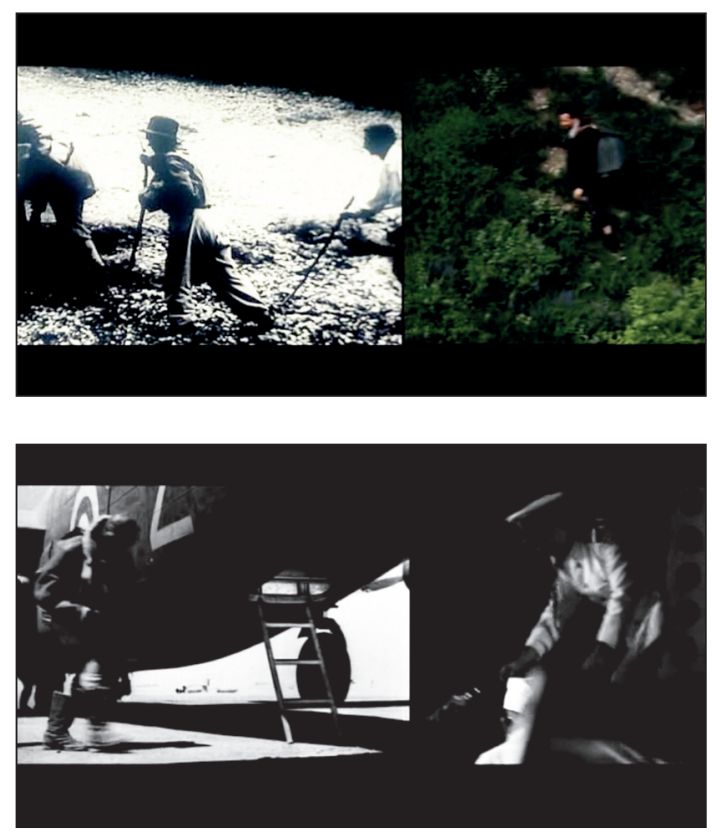

Fot. 3-4. Generat. Zamach na Gibraltarze (2009, reż. Anna Jadowska). „Dialektyka” obrazu

W doświadczeniu odbiorczym tego typu zabiegi montażowe mogą skutkować niemożnością ustalenia - w sposób jednoznaczny - statusu obrazów archiwalnych. Tę ambiwalencję można wyjaśnić, odwołując się do pojęcia dialektyk $i$ - w rozumieniu Didi-Hubermana - która „wprowadza zbawienną wątpliwość dotyczącą statusu obrazu, nie kwestionując za to jego wartości dokumentalnej"120. Nadmierna ilość wspomnianych rozwiązań montażowych może spowodować, iż zbawienna watpliwość przerodzi się w sceptycyzm obejmujący swym zasięgiem cały tekst ${ }^{121}$.

Warto także prześledzić, $w$ jaki sposób partie inscenizowane montowane są ze zdjęciami archiwalnymi tak, aby w doświadczeniu odbiorczym powstawało wrażenie continuum ${ }^{122}$. Doskonałym przykładem takiego rozwią-

${ }^{120}$ Georges Didi-Huberman, Strategie obrazów. Oko historii 1, tłum. Janusz Margański, korporacja ha!art, Kraków 2011, s. 42.

${ }^{121}$ Przypomnijmy, iż wedle Marka Hendrykowskiego to właśnie Obywatel Kane (1941) Orsona Wellesa, w mistrzowski sposób łączący fikcję fabularną i paradokumentalna, stał się impulsem decydującym o przemianach spojrzenia na film jako (wiarygodne) źródło historyczne. Zob. Marek Hendrykowski, Film jako źródło historyczne, dz. cyt., s. 11.

${ }^{122}$ Wielu krytyków filmowych uznaje tego typu praktyki montażowe za manipulację. Oliverowi Stone'owi zarzucano, iż stosowane przez niego w JFK techniki osłabiają zdolność odróżniania zdarzeń realnych od wymyślonych. Stone tak skutecznie mieszał sceny rekonstruowane ze zdjęciami archiwalnymi, że w efekcie młodzi ludzie, którym 
zania jest wmontowanie pomiędzy dwie sekwencje inscenizowane (przygotowania do startu na lotnisku wojskowym w Kairze, przybycie delegacji Sikorskiego na dziedziniec pałacu Gubernatora MacFarlane’a) materiału archiwalnego ukazującego gibraltarską Skałę filmowaną z pokładu samolotu, lecącego liberatora AL523 oraz widoczny z góry pas startowy lotniska North Front. Taki zabieg formalny można uznać za ekwiwalent - nieosiągalnego w dyskursie fikcjonalnym - obiektywizmu „indeksalnego" (fot. 5-7).
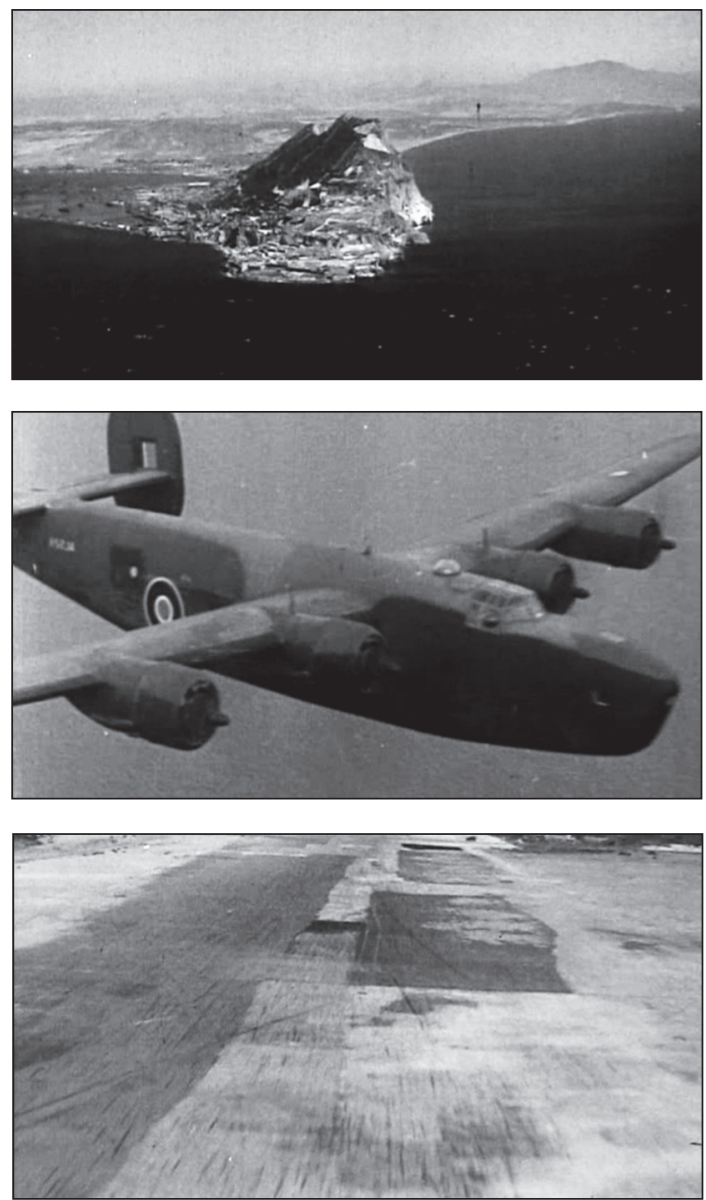

Fot. 5-7. Generat. Zamach na Gibraltarze (2009, reż. Anna Jadowska). „Obiektywizm indeksalny”

reżyser dedykował swój film, potraktowali jego wizję dosłownie. Zob. Hayden White, Proza historyczna, dz. cyt., s. 289.

Michael Kutz pisał o „hipnotycznym efekcie”, jaki film Stone'a wywołuje na odbiorcach. Temu efektowi najwyraźniej nie oparł się Robert Rosenstone, który nazwał JFK jednym z najważniejszych dzieł amerykańskiej historii, jakie kiedykolwiek pojawiły się na ekranie. Zob. Michael Kurtz, Oliver Stone, JFK, and History, dz. cyt., s. 172. 
Na podobnej zasadzie w zainscenizowaną sekwencję przeglądania dokumentów katyńskich ${ }^{123}$ wkopiowano autentyczne zdjęcia znalezione podczas ekshumacji przy zwłokach zamordowanych oficerów. W kilkusekundowych (przy ustalaniu czasu trwania poszczególnych ujęć w sposób ewidentny pogwałcona została zasada "minimum percepcyjnego") przebitkach wykorzystane zostały materiały pochodzące z pierwszego filmu dokumentującego zbrodnię katyńską (zrealizowanego przez niemieckich operatorów w 1943 r. - tuż po odkryciu przez Niemców masowych grobów polskich żołnierzy - Der Massenmord im Walde von Katyn). Włączone $\mathrm{w}$ obręb struktury filmowego opowiadania ujęcia dokumentalne należą do sfery pozadiegetycznej: $\mathrm{w}$ analizowanej sekwencji Sikorski ogląda fotografie, widz - fragmenty filmu.

Dodatkowym elementem uwiarygodniającym jest $w$ omawianej sekwencji - włączona do filmowego dialogu Sikorskiego z Zosią - wypowiedź Winstona Churchilla dotycząca ofiar katyńskiego mordu: Jeśli nie żyja, nic, co Pan uczyni, ich nie wskrzesi ${ }^{124}$. Pamiętajmy jednak, iż cały zabieg polegający na arbitralnym włączeniu w obręb sekwencji inscenizowanej zdjęć dokumentalnych potraktować można jako chwyt dy-

${ }^{123}$ Zdaniem Baliszewskiego to właśnie te dokumenty były bezpośrednim powodem zamordowania Sikorskiego. Ich ujawnienie groziło bowiem rozpadem koalicji antyhitlerowskiej. O cennych materiałach, z którymi nie rozstawał się Naczelny Wódz, pisze m.in. Tadeusz Modelski: „Zaginęła teczka przytwierdzona do lewego nadgarstka generała Sikorskiego metalowym uchwytem (coś w rodzaju kajdanek), kiedy ten wchodził na pokład Liberatora AI 523. [...] W miesiąc po śmierci Sikorskiego, Churchill i Roosevelt w czasie konferencji «Quadrant» (Quebec) decyduja, że po zakończeniu wojny Polska znajdzie się w sferze wpływów Związku Sowieckiego". Zob. Tadeusz Modelski, Byłem szefem wywiadu u Naczelnego Wodza, dz. cyt., s. 114-115. Istnieją jednak hipotezy, wedle których spiskowcom chodziło o materiały przewożone przez towarzyszącego Sikorskiemu pułkownika Victora Cazaleta i to on był rzeczywistym celem zamachu. Zob. Lynn Picknett, Clive Prince, Stephen Prion, Od własnej kuli. Tajna wojna między aliantami, tłum. Sławomir Kędzierski, Bellona, Warszawa 2007, s. 300-301.

${ }^{124}$ Leśniowska cytuje fragment, który znalazł się w książce Winstona Churchilla Druga wojna światowa. Churchill odnotował w niej spotkanie z Sikorskim w trakcie „kryzysu katyńskiego": „Na początku kwietnia 1943 r. Sikorski przyszedł na lunch do numeru 10. Powiedział mi, że ma dowody, iż rząd sowiecki zamordował 15 tys. polskich oficerów i innych jeńców, którzy znajdowali się w jego rękach, i że zostali oni pogrzebani w ogromnych mogiłach w lasach, głównie wokół Katynia. Miał mnóstwo dowodów. Powiedziałem: «Jeśli nie żyją, nic, co Pan uczyni, nie wskrzesi ich»". Zob. Winston Churchill, Druga wojna światowa, t. IV, ks. 2, fragment, [w:] Jenerat Sikorski. Antologia, dz. cyt., s. 119.

Premier Wielkiej Brytanii wielokrotnie podkreślał, że trzeba zmusić Polaków do nieporuszania tematu Katynia. Potwierdzeniem oficjalnego stanowiska Brytyjczyków w tej sprawie był list Churchilla do ministra Edena wysłany na wieść o zerwaniu przez Stalina stosunków dyplomatycznych z emigracyjnym rządem polskim: „Nie ma żadnego pożytku z chorobliwego kręcenia się wokół pochodzących sprzed trzech lat grobów pod Smoleńskiem". Zob. Evan McGilray, Polski rząd na uchodźstwie, dz. cyt., s. 129. 
stansujący. William Guynn pisze o tym problemie w kontekście tzw. dokumentu kompilacyjnego. Zdaniem badacza w przypadku umieszczania archiwalnych dokumentów w sekwencji zachodzi operacja figuratywna, która wskazuje na organizującą obecność narratora historycznego ${ }^{125}$.

Należy także wziąć pod uwagę, iż historycy niejednokrotnie podnosili kwestię problematycznego statusu zdjęć archiwalnych. Robert Rosenstone podkreśla, iż zawsze gdy film wykorzystuje oryginalne zapisy (również fotografie czy artefakty) z określonego czasu i miejsca, by stworzyć „realistyczne” wrażenie momentu z przeszłości, musimy pamiętać, że na ekranie nie oglądamy samych wydarzeń, nie oglądamy też wydarzeń takimi, jakimi doświadczali ich lub nawet, jakimi postrzegali je ich uczestnicy. Oglądamy wybrane obrazy tych wydarzeń, starannie ułożone w sekwencje, które budują dramaturgię opowieści lub precyzję wywodu ${ }^{126}$.

Film Anny Jadowskiej odzwierciedla tezę, iż - jak pisze Derrida „faktyczność" jest czymś wytworzonym; ważne jest, by wiedzieć, z czego się ją wytwarza, lecz jeszcze bardziej niezbędna jest świadomość, że się ją wytwarza ${ }^{127}$. Obecność scharakteryzowanych powyżej procedur obiektywizujących nie oznacza, iż Generat przedstawia historię w sposób „klasyczny” („realistyczny”), gdyż do tego konieczne byłoby „ukrywanie statusu opowieści" jako „przekazu” ${ }^{128}$.

Według Marka Hendrykowskiego w klasycznym filmie historycznym opartym na tradycyjnej formule rekonstrukcji przeszłości właściwym obiektem zainteresowania filmowców nie jest sama przeszłość, lecz reprodukcja („perfekcyjnie wykonana imitacja”) historii ${ }^{129}$. Film tego typu można uznać za ekranowy odpowiednik „obiektywnego" dyskursu historycznego, w którym wspomniana „obiektywność” jest produktem „iluzji referencjalnej” („,historyk stara się sprawić, by przedmioty, do których odnosi się jego wypowiedź, mówiły same") ${ }^{130}$. W filmach typu Generał (czy JFK) uwaga twórców koncentruje się głównie na warstwie dyskursywnej. Dla odróżnienia dwóch modeli filmowej rekonstrukcji historii („,realistycznej” i „dyskursywnej”) przydatna może się okazać kategoria „filmu eksperymentalnego". William Guynn w odniesieniu do autorefleksyjnych

${ }^{125}$ William Guynn, Przekształcanie historii w filmie, dz. cyt., s. 14.

${ }^{126}$ Zob. Robert Rosenstone, Historia w obrazach/historia w stowach: rozważania nad możliwościa przedstawienia historii na taśmie filmowej, [w:] Film i historia. Antologia, red. Iwona Kurz, Wyd. Uniwersytetu Warszawskiego, Warszawa 2008, s. 106.

${ }^{127}$ Cyt. za: Keith Jenkins, Żyć w czasie, lecz poza historia, [w:] Pamięć, etyka i historia, dz. cyt., s. 238.

${ }^{128}$ Hayden White, Proza historyczna, dz. cyt., s. 147.

${ }^{129}$ Marek Hendrykowski, Film jako źródło historyczne, dz. cyt., s. 75.

130 Zob. Roland Barthes, Dyskurs historii, tłum. Adam Rysiewicz, Zbigniew Kloch, „Pamiętnik Literacki" 1984, nr 75, s. 229. 
narracji historycznych (również filmowych) wprowadza - za Robertem Rosenstonem ${ }^{131}$ - pojęcie „historii jako eksperymentu”:

Filmy eksperymentalne zwracają się do nas na sposób bardzo odmienny od tak zwanych filmów realistycznych i konstruują wielce odmienny świat historyczny. Produkcje głównego nurtu włączają bezproblemową i moralnie krzepiącą narrację, [...] ukazują ideę przeszłości przez fetyszystyczne przywiązanie do „stylu epoki” oczyszczonego ze znaczenia historycznego. Filmy eksperymentalne, przeciwnie, kontestują konwencje klasycznej reżyserii filmowej, oferując dzieła analityczne, pozbawione emocji, zdystansowane, wieloprzyczynowe; [...], postmodernistyczne; historie, które nie pokazuja nam zwyczajnie przeszłości, ale także opowiadaja o tym, jak i co ona znaczy dla reżysera albo dla nas dzisiaj. W filmach eksperymentalnych dostrzegamy znaki interwencji historyka/reżysera w [...] Brechtowskim dystansowaniu widza czy jawnej sztuczności mise-en-scéne ${ }^{132}$.

Dekonstrukcja tradycyjnego dyskursu faktualnego dokonuje się w Generale głównie na płaszczyźnie języka narracji, który ma charakter autoreferencyjny ${ }^{133}$. Zabiegi obiektywizujące nadają Generałowi charakter docudramy („,historycznej metafikcji”), ale docudramy postmodernistycznej ${ }^{134}$. To właśnie postmodernizm - zdaniem historyków - odpowiedzialny jest za kryzys przedstawiania i ostateczne zerwanie z teorią korespondencji pomiędzy narracją historyczną i przeszłością samą w sobie ${ }^{135}$.

${ }^{131}$ Por. Robert Rosenstone, The Historical Film: Looking at the Past in a Postliterate Age, [w:] The Historical Film: History and Memory in Media, ed. Marcia Landy, Rutgers University Press, New Jersey 2001, s. 57-59.

132 William Guynn, Przeksztatcanie historii w filmie, dz. cyt., s. 15. W przywoływanym wcześniej tekście Rosenstone’a Zobaczyć przeszłość ten typ wypowiedzi filmowej został określony jako „opozycyjny czy niekonwencjonalny film historyczny” (Robert Rosenstone, Zobaczyć przeszłość, dz. cyt., s. 329).

${ }^{133}$ Ciekawym zabiegiem byłoby porównanie pod tym kątem Generała z historycznymi rekonstrukcjami (Wolne miasto, Westerplatte) Stanisława Różewicza. U Różewicza - jak podkreśla Marek Hendrykowski - dominował protokolarny styl narracji, nadając jego filmom - podbudowanym dodatkowo zdjęciami archiwalnymi - charakter kronikarskiego zapisu. Zob. Marek Hendrykowski, Stanisław Różewicz, Wyd. Ars Nova, Poznań 1999, s. 29.

${ }^{134}$ Klasyczną docudramą byłby film Różewicza Westerplatte, o którym Marek Hendrykowski pisze: „Jest filmem o wojnie, a ściślej - tzw. docudrama, czyli paradokumentalną rekonstrukcją przebiegu wydarzeń historycznych. [...] Liczy się w niej przede wszystkim sposób zrelacjonowania tego, co naprawdę się wydarzyło, unikający jakichkolwiek apriorycznych sądów o rzeczywistości". Zob. Marek Hendrykowski, Stanisław Różewicz, dz. cyt., s. 74 .

W docudramie postmodernistycznej dąży się do przeformułowania reguł gatunkowych i zatarcia granicy pomiędzy faktem i fikcją. Na obszarze kina dokumentalnego w sposób modelowy realizuje te strategie Michael Moore (Bowling for Columbine, Fahrenheit 9/11). Por. Ira Jaffe, Hollywood Hybrids. Mixing Genres in Contemporary Films, Rowman \& Littlefield Publishers Inc., Lanham 2008, s. 33-54.

135 Zob. Jerzy Topolski, Historia jako nauka po postmodernizmie, [w:] Pamięć, etyka i historia, dz. cyt., s. 33. 
W postmodernistycznej dokudramie - stwierdza White - albo historycznej metapowieści mamy do czynienia nie tyle z odwróceniem relacji, w której rzeczywiste zdarzenia nabierają cech fikcyjnych, a fikcyjne rzeczywistych, ile z zawieszeniem samej dystynkcji między rzeczywistością a wyobraźnią. Wszystko przedstawione jest tak, jakby zarówno realne, jak i wyobrażeniowe, realistycznie wyobrażone i wyobrażeniowo realne, należało do tego samego porządku ontologicznego, co w konsekwencji osłabia referencyjną funkcję obrazów zdarzeńn ${ }^{136}$.

Dystynktywną cechą postmodernistycznych "rekonstrukcji” historii są elementy dystansujące. Funkcją uzyskiwanego dzięki tym elementom Brechtowskiego „efektu obcości” jest pokazać, że się pokazuje, a więc nie kłamać na temat epistemicznego statusu reprezentacji - przekształcić obraz w zagadnienie poznawcze, nie w iluzję ${ }^{137}$. Obecność elementów dystansujących w tekście dowodzi, że postmodernistyczna „obiektywność” jest świadoma swej własnej natury konstruktu i czyni proces konstruowania przedmiotem swojego dyskursu ${ }^{138}$. W przypadku Generała elementami dystansującymi byłyby przede wszystkim wszelkie zabiegi montażowe ${ }^{139}$, których widz - nawet obeznany z poetyką mediów cyfrowych (interfejs okienkowy) nie może w pełni „znaturalizować” (tj. uznać za transparentne). Zdaniem Anne Friedberg multiplikacja „okienek” na płaszczyźnie ekranu (multiple-frame images) to rodzaj nowej syntaksy wizualnej, wykorzystywanej dla przepracowania kodów języka obrazowego. Podzielony ekran (według terminologii Lva Manovicha "montaż przestrzenny”) trudno jednak uznać za powszechnie stosowany kod stylistyczny filmu fabularnego, który wciąż pozostaje w tradycyjnym (single-frame, single-screen) paradygmacie (nieliczne na obszarze kina "głównego nurtu" eksperymenty w rodzaju Time Code Mike'a Figgisa jedynie potwierdzają tę regułę). W obrębie kodów przyjętych dla tego typu kina split screen stanowi przykład strategii autorefleksyjnej (self-reflexive strategy) ${ }^{140}$ (fot. 8).

Ujęcia z „montażem przestrzennym” zakłócają powszechnie akceptowalne $\mathrm{w}$ filmie fabularnym wrażenie realności, wywoływane $\mathrm{w}$ dużej mierze za pomocą jednolitej przestrzeni ujętej w ramach pojedynczego kadru. O ile jednak „okienka” na ekranie komputera nie muszą pozostawać ze sobą w jakichkolwiek relacjach przestrzennych, o tyle w montowa-

\footnotetext{
${ }^{136}$ Hayden White, Proza historyczna, dz. cyt., s. 286.

137 Georges Didi-Huberman, Strategie obrazów. Oko historii 1, dz. cyt., s. 69.

${ }^{138}$ Hayden White, Proza historyczna, dz. cyt., s. 75.

139 Za element dystansujący uznać można także ilustrację muzyczna, która pojawia się $\mathrm{w}$ pewnych partiach filmu - paradygmatycznym przykładem jest aranżacja muzyki w scenie wymarszu mirandczyków z koszar, a także orkiestracja prologu do sekwencji uroczystego obiadu.

${ }_{140}$ Zob. Anne Friedberg, The Virtual Window, MIT Press, Cambridge 2009, s. 192-194.
} 
nych „przestrzennie” scenach Generata obserwujemy postacie przemieszczające się w granicach przestrzeni, dającej się (na ogół) zidentyfikować jako ciągła i jednorodna.

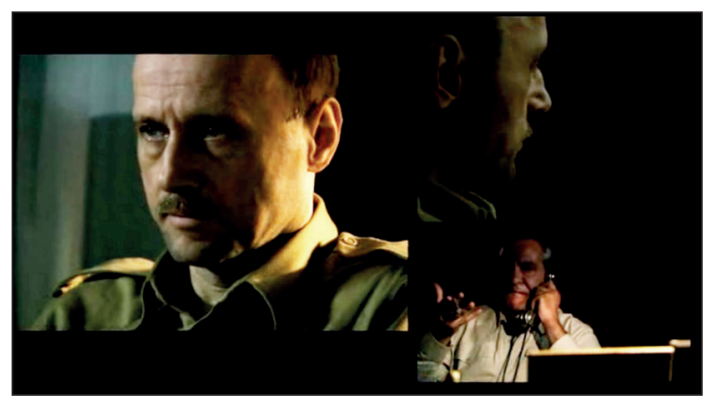

Fot. 8. Generat. Zamach na Gibraltarze (2009, reż. Anna Jadowska). „Interfejs okienkowy”

Bill Nichols podkreśla, iż zabiegi montażowe zaburzające poczucie jednolitej przestrzeni są często stosowane w kinie dokumentalnym:

Montaż ciągły na przykład, który sprawia, że cięcia między ujęciami w filmie fabularnym są niewidoczne, ma tu niższy priorytet. To, co w filmie fabularnym jest osiągnięte przez montaż ciągły, w filmie dokumentalnym jest osiągane przez historię: rzeczy budują relację w czasie i przestrzeni nie za sprawą montażu, ale rzeczywistych, realnych powiązań. [...] Montaż ciągły został tu zastąpiony formą montażu dokumentalnego, którą możemy nazwać „montażem dowodowym”. Zamiast porządkujących przejść montażowych w obrębie danej sceny, by zaprezentować sens jednej, zunifikowanej czasoprzestrzeni, w której śledzimy działania głównych postaci, montaż dowodowy porządkuje przejścia montażowe w obrębie danej sceny, by zaprezentować wrażenie jednej, wspartej logicznie, przekonującej propozycji ${ }^{141}$.

Zdaniem teoretyków filmu w przypadku kina dokumentalnego obecność elementów dystansujących w tekście zwraca uwagę na złożoność relacji między reprezentacją a realnością. Według Nicholsa strategie autorefleksywne stosowane $\mathrm{w}$ dokumencie mogą podważyć sam akt reprezentacji, a przypominanie widzom o konstruowaniu realności, którą widzimy, o elemencie kreacyjnym, podcina samo przeświadczenie o prawdzie i autentyczności, od których dokument jest uzależniony ${ }^{142}$. W przypadku gatunków hybrydycznych elementy dystansujące nie determinują efektu realności, ale każą zwrócić uwagę na „niestabilność” tekstu i zakwestionować tradycyjnie zajmowaną przez widza pozycję „w tekście”.

${ }^{141}$ Bill Nichols, Jak możemy zdefiniować film dokumentalny?, dz. cyt., s. 255-256.

142 Tamże, s. 250. 
Ujawnienie mechanizmów tworzenia iluzji - podkreśla Lev Manovich - stała obecność kanału komunikacyjnego w przekazie nie pozwalają użytkownikowi na pogrążenie się w iluzyjnym marzeniu, zmuszają go na przemian do koncentrowania się na obiekcie i dystansowania się od niego. [...] Cykliczne przejścia od iluzji do jej destrukcji ani nie przeszkadzają ani nie pomagają w jej doświadczaniu. [...] Jednak bez wątpienia mamy tu do czynienia z czymś, co wykracza poza tradycyjny realizm ery analogowej. Ten nowy realizm można by nazwać metarealizmem, jako że zawiera również krytykę samego siebie. [...] Klasyczny realizm [...] wymaga od podmiotu całkowitego zaakceptowania iluzji. Natomiast nowy metarealizm jest oparty na oscylowaniu między iluzją i jej zaprzeczeniem, między zanurzeniem użytkownika w iluzji a bezpośrednim zwracaniem się do niego ${ }^{143}$.

Elementami dystansującymi są w Generale zabiegi montażowe, nie mające charakteru "dowodów" („montaż dowodowy” wedle typologii Nicholsa), lecz „chwytów formalnych” (w znaczeniu przyjętym przez formalistów rosyjskich). Autorzy wykorzystują owe chwyty, by wysunąć na plan pierwszy samą wypowiedź, celem zwrócenia uwagi na struktury formalne kosztem desygnatów zewnętrznych. W efekcie tych zabiegów film staje się „autoreferencyjną strukturą odniesień wewnętrznych", tworzonych przez grę konwencji oraz specyficznych kodów filmowych.

W klasycznym kinie „efekt realności” uzyskiwany był w dużej mierze za pomocą montażu równoległego ${ }^{144}$. W Generale powszechnie stosowanym typem montażu jest montaż przestrzenny, grupujący obrazy współistniejące symultanicznie. Na komentarz zasługuje zwłaszcza niekonwencjonalny sposób montowania scen dialogowych rozgrywających się $\mathrm{w}$ jednym pomieszczeniu. Nie są one konstruowane za pomocą planów pełnych czy średnich lub za pomocą klasycznej frazy ujęcie/przeciwujęcie, lecz poprzez pionowy podział kadru na dwie symetryczne części. O tym, iż postacie znajdują się $\mathrm{w}$ tym samym pomieszczeniu świadczy jedynie zgodność kierunku spojrzenia. Efekt „uniezwyklenia” potęguje dysproporcja planów - postać ukazywana po prawej stronie kadru ujmowana jest zazwyczaj w półzbliżeniu, zaś postać po stronie lewej - w zbliżeniu (rozmowa Gralewskiego z żołnierzem, rozmowa Gubernatora z Perrym) (fot. 9-10).

Segmentacja kadru pozwala także na multiplikację tj. jednoczesne i zwielokrotnione ukazywanie postaci, która filmowana jest - w obrębie tej samej sceny $-\mathrm{z}$ jednego (Zosia podczas rozmowy telefonicznej z matką) bądź dwóch (Sikorski w trakcie oglądania zdjęć) ustawień kamery. Montaż przestrzenny umożliwia jednoczesną prezentację dwóch lub trzech scen, które widź musi usytuować w strukturalnym porządku

${ }^{143}$ Lev Manovich, Język nowych mediów, dz. cyt., s. 320-322.

${ }^{144} \mathrm{~W}$ odniesieniu do typów montażu posługuję się terminologią Lva Manovicha. 
opowiadania. Dla przykładu warto przeanalizować jedną z sekwencji pałacowych, zrealizowanych przy użyciu dwóch typów montażu - przestrzennego i równoległego. W strukturze omawianej sekwencji można wyróżnić dwie sceny: pierwsza rozgrywa się w gabinecie Gubernatora, druga - w sypialni Perry'ego. Pierwsza scena (Gubernator rozmawia przez telefon - dźwięk jest niesłyszalny) awizowana jest w obrębie sekwencji poprzedniej (Gubernatora widzimy w prawym dolnym rogu kadru). Ujęcia należące do sceny drugiej (Perry poprawia mundur przed lustrem i kieruje się w stronę drzwi) i pierwszej (Gubernator siedzi przy biurku, oczekując na podwładnego) pokazywane są symultanicznie za pomocą montażu przestrzennego. W kontynuacji sceny pierwszej Perry pojawia się u MacFarlane'a i odbiera od niego rozkazy. Stopień komplikacji intensyfikuje wmontowanie w obręb sceny pierwszej montowanych przestrzennie ujęć zastępujących klasyczną frazę ujęcie/przeciwujęcie. Analizowana sekwencja pokazuje także, w jaki sposób segmentacja kadru umożliwia awizowanie następujących po sobie scen. Z lewej strony kadru widzimy kontynuację sceny wcześniejszej, z prawej (lub w prawym dolnym rogu) - zapowiedź kolejnej. Efekt wizualny wzmocniony jest za pomocą asynchronicznego montażu dźwiękowego - śledząc akcję rozgrywającą się w lewym segmencie kadru, słyszymy już dialogi pochodzące $\mathrm{z}$ następnej sceny.
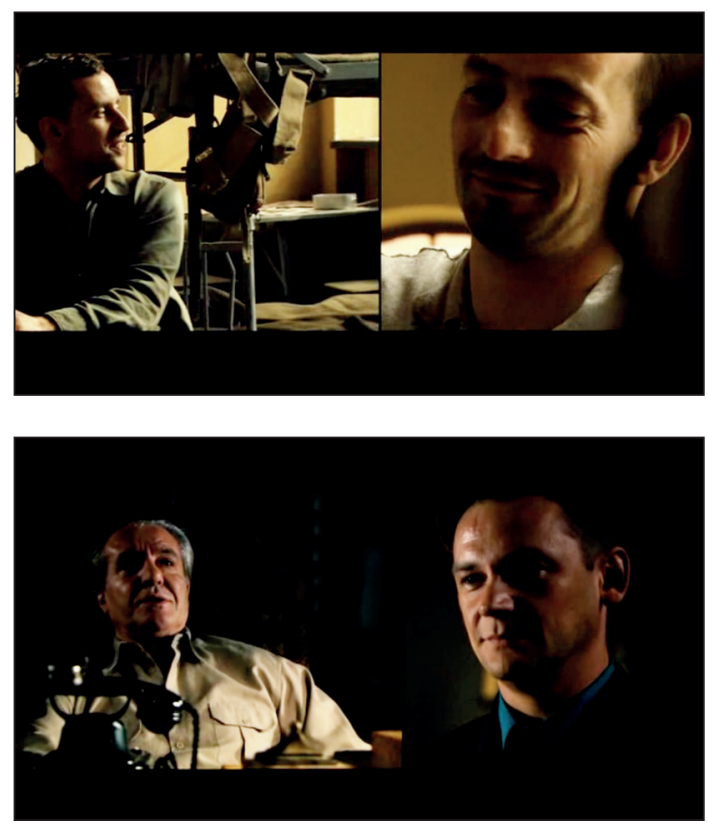

Fot. 9-10. Generat. Zamach na Gibraltarze (2009, reż. Anna Jadowska). Efekt uniezwyklenia 
Sukcesywnie pojawiające się $\mathrm{w}$ filmie sekwencje $\mathrm{z}$ montażem przestrzennym zaburzają efekt realności, czyniąc widocznymi wszelkie operacje dokonywane na czasie ekranowym. Charakterystyczna dla kina logika wymiany - zdaniem Manovicha - ustępuje miejsca logice addycji i koegzystencji. Czas poddawany jest spacjalizacji i dystrybuowany na powierzchni ekranu. W montażu przestrzennym o niczym się nie zapomina i niczego nie usuwa ${ }^{145}$. Nietypowe rozwiązania w zakresie montażu świadczą o arbitralnym podejściu twórców do zagadnienia czasu. Porządek sekwencji współczesnych zaburzają partie retrospektywne, co prowadzi do zerwania ciągłości czasoprzestrzennej. Dla przykładu - w sekwencję przyjęcia wydanego przez MacFarlane'a wczesnym popołudniem 4 lipca 1943 r. wmontowano retrospekcję ukazującą wcześniejszy o kilka miesięcy moment przekazania Gralewskiemu rozkazu od „przełożonych z Warszawy"146.

Zakłócenia $\mathrm{w}$ relacjach czasoprzestrzennych ilustruje także inna scena retrospektywna - tym razem rozgrywająca się w warszawskim lokum Gralewskich. Alicja słucha recytacji, którą niespodziewanie przerywa pukanie do drzwi. Zaniepokojona kobieta wstaje i odwraca głowę w stronę źródła dźwięku. Po cięciu montażowym widzimy fragment klatki schodowej i wbiegających na górę mężczyzn. Możemy zatem przypuszczać, że to oni za chwilę pojawią się w mieszkaniu Alicji. Tymczasem drzwi otwiera porucznik Łubieński i orientujemy się, że akcja przeniosła się w "teraźniejszość" - do pałacu Gubernatora, gdzie rozpoczyna się właśnie akcja zbrojna. Omawiana scena stanowi świadectwo niezwykle swobodnego podejścia twórców do kwestii chronologii. Montaż narusza czasową ciągłość ujęć - w doświadczeniu odbiorczym powstaje wrażenie paradoksalnego continuum, na które składają się dwa momenty w sposób ewidentny oddalone od siebie w czasie i przestrzeni.

Można zaryzykować tezę, iż Generał jest przykładem opowiadania transmedialnego, które powstaje poprzez poszerzanie możliwości narracyjnych. Jeśli ocenimy te (tzn. transmedialne) filmy - pisze Jenkins - według starych kryteriów, mogą nam się wydać bardziej poszatkowane, ale fragmenty te istnieją po to, by widz mógł je złożyć w całość w swoim czasie i na swój sposób ${ }^{147}$. W Generale montażowy „nokaut techniczny”"148 nie pozostawia odbiorcy czasu na refleksję, warunkującą możliwość weryfikacji

${ }^{145}$ Lev Manowich, Język nowych mediów, dz. cyt., s. 464.

${ }^{146}$ Informację, że scena w hiszpańskim obozie Miranda del Ebro rozegrała się kilka tygodni wcześniej możemy zrekonstruować wyłącznie na podstawie dialogu.

${ }^{147}$ Henry Jenkins, Kultura konwergencji, tłum. Małgorzata Bernatowicz, Mirosław Filiciak, Wyd. Artystyczne i Profesjonalne, Warszawa 2007, s. 117.

${ }^{148}$ Takiego określenia używano dla opisu praktyk montażowych w JFK. 
„faktów”. Nieoczekiwane przejścia montażowe zakłócają także płynność opowiadania i utrudniają orientację w filmowej diegezie.

W zakończeniu filmu, tuż po napisach końcowych, pojawia się informacja wymuszająca na widzu odbiór retroaktywny:

Film jest inspirowany autentycznymi zdarzeniami i stanowi próbę rekonstrukcji - w oparciu o badania historyczne Dariusza Baliszewskiego - okoliczności śmierci generała Sikorskiego oraz wydarzeń, które do niej doprowadzity. Obok postaci oraz wydarzeń autentycznych filmie przedstawione zostały również postacie oraz sytuacje fikcyjne, a dla potrzeb fabuły niektóre zdarzenia lub postacie zostaty zmodyfikowane.

Wprowadzenie kluczowej dla ustalenia statusu tekstu informacji dopiero w zakończeniu filmu jest typowym zabiegiem stosowanym w mockdokumencie. Funkcją takiego zabiegu jest osłabienie referencyjnego potencjału dzieła poprzez zakwestionowanie wiarygodności przekazu i pozostawienie widza z pytaniem o realność tego, co zobaczył ${ }^{149}$. Nie oznacza to jednak, iż sama "fikcjonalizacja” - kreacja postaci czy zdarzeń, które nigdy nie zaistniały - nadwyręża historyczne intencje reżysera i przekreśla znaczenie filmu jako instrumentu docierania do prawdy ${ }^{150}$. Wedle Marka Hendrykowskiego o tym, że dany obraz filmowy uznajemy za prawdziwy lub nieprawdziwy decyduje złożony zestaw procedur weryfikacyjnych. Warunkiem podstawowym i niezbędnym do przeprowadzenia weryfikacji obrazu rzeczywistości, który został zaprezentowany w filmie dokumentalnym bądź fikcjonalnym, jest przyjęcie postawy zdystansowanej. Aby się obronić przed manipulacja,

niezbędna jest sceptyczna postawa widza (i rzecz jasna badacza), ich nieufny - oparty na krytycznym rozumowaniu i osobistym doświadczeniu - stosunek do ekranowego przedstawienia. Sceptycyzm odbiorcy przekazu nie gwarantuje automatycznie poznania prawdy, ale pozwala się uchronić przed skutkami manipulacji dokonanej przez jego nadawcę ${ }^{151}$.

Jest to szczególnie istotne przy lekturze dzieł hybrydycznych, które wymagają od widza szczególnej aktywności epistemologicznej.

Przyznanie opowieści statusu „fikcji” (lub sugerowanie takiej możliwości jej odczytania) uwalnia twórców od zarzutu zniekształcania, który zazwyczaj stawiamy błędnemu przedstawieniu pragnącemu uchodzić za

${ }^{149}$ Beata Kosińska-Krippner, „Mock-documentary” a dokumentalne fatszerstwa, „Kwartalnik Filmowy" 2006, nr 54-55, s. 196.

${ }^{150}$ Zob. William Guynn, Przeksztatcanie historii w filmie, dz. cyt., s. 12.

${ }^{151}$ M. Hendrykowski, Dokument - fikcja - realizm, dz. cyt., s. 104. 
zwykłą relację ze zdarzeń, „jakie naprawdę się rozegrały"152. Ostentacyjne - choć ujawnione dopiero w finale - zacieranie granicy pomiędzy „faktem” i „fikcją"153 ma sprowokować krytyczne zaangażowanie odbiorcy i zaktywizować "rozumienie przyłączeniowe”. Film spełniałby w tym wypadku rolę „aktywatora kulturowego", uruchamiającego możliwość odszyfrowywania, spekulacji, opracowania ${ }^{154}$. Opowiadanie transmedialne integruje niezliczone teksty kultury, by stworzyć opowieść tak wielka, że nie zmieściłaby się w jednym tylko środku przekazu ${ }^{155}$.

„Rozumienie przyłączeniowe" ułatwia interpretację tych partii filmu, których funkcja w obrębie struktury opowiadania wydaje się niedookreślona. Jako przykład posłużyć może scena niezobowiązującej pogawędki Zosi z adiutantami Sikorskiego. Rozmowa ma miejsce tuż po dramatycznej sekwencji przekazania pilotom tajnego rozkazu wodowania. Scena na tarasie wydaje się pełnić jedynie funkcję retardacyjną (opóźnia dramaturgiczną kulminację) i/lub służyć zmianie emocjonalnej tonacji filmu. Widz zapewne odbierze ją jako próbę „uczłowieczenia historii” poprzez wgląd $\mathrm{w}$ „prywatność" bohaterów (swobodne zachowanie postaci świadczy o familiarnych stosunkach ${ }^{156}$ panujących wśród najbliższych współpracowników Naczelnego Wodza). Kluczowe dla rozszyfrowania znaczenia omawianej sceny - możliwego dzięki źródłom pozafilmowym zawierającym istotne dla widza wskazówki - jest (pozornie) neutralne słowo: bransoletka. Należąca do Zosi biżuteria została odnaleziona kilka dni po katastrofie gibraltarskiej w kairskim hotelu, co posłużyło Dariuszowi Baliszewskiemu do stworzenia hipotezy, według której Leśniowską wywieziono do łagrów

152 Zob. Hayden White, Proza historyczna, dz. cyt., s. 169.

153 Wedle Jerzego Topolskiego tego typu zabieg wskazuje na "przekroczenie granicy” (crossing border). Badacz podkreśla, iż zasadniczą „różnicą między narracją historyczną (w sensie tekstu historiograficznego) a narracją literacką jest to, że w tej pierwszej nie powinno być zdań odnoszących się do wymyślonych (fikcyjnych, nie mających odniesienia do źródeł historycznych krytycznie zweryfikowanych) indywidualnych faktów czy stanów rzeczy, podczas gdy w literaturze takiego ograniczenia nie ma". Zob. Jerzy Topolski, Jak się pisze i rozumie historię, dz. cyt., s. 8.

W innym miejscu Topolski wprowadza kryterium „,́́wiadomej intencji”: „Historycy, podobnie jak pisarze, nie mogą wymyślać faktów i osób (świadomie, ponieważ nieświadomie robią to cały czas)". Zob. Jerzy Topolski, Historia jako nauka, [w:] Pamięć, etyka $i$ historia, dz. cyt., s. 35.

${ }^{154}$ Henry Jenkins, Kultura konwergencji, dz. cyt., s. 95.

155 Tamże.

156 Z sielankową sceną ",tarasową" kontrastuje scena ",audiencji” u Gubernatora. MacFarlane przyjmuje podwładnych w wannie, dzięki czemu ujawniony został (homo)seksualny podtekst relacji panujących w pałacu. Chorobliwa skłonność do zażywania kąpieli w asyście oficerów to element charakterystyki Gubernatora, który w filmie Jadowskiej stał się nadużywającym alkoholu sybarytą o perwersyjnych upodobaniach. 
w ZSRR (najprawdopodobniej) na pokładzie samolotu ambasadora Majskiego przebywającego w tym samym czasie na Skale (widź dowiaduje się wprawdzie o wizycie Majskiego, ale w żaden sposób nie jest w stanie skojarzyć tej informacji ze słowem ",bransoletka") ${ }^{157}$.

W scenie rozgrywającej się w mieszkaniu Gralewskich jedynie zastosowanie „klucza przyłączeniowego" pozwoli widzowi rozszyfrować sens skądinąd niezrozumiałej wypowiedzi Janka: Zająca zapomniałem ${ }^{158}$. Na podobnej zasadzie można zinterpretować także sekwencję masakry w rezydencji MacFarlane'a. Niezwykle dynamiczny, cięty montaż (poszatkowane ujęcia) utrudnia śledzenie akcji oraz identyfikację biorących w niej udział postaci. Dzięki „rozumowaniu przyłączeniowemu” skonsternowany widz ma szansę ustalić, dlaczego wszyscy zamachowcy posługują się jednym nazwiskiem: Gralewski.

Jedna z ostatnich sekwencji filmu rozgrywa się na pokładzie samolotu. Tuż przed startem dochodzi do szamotaniny z zamachowcami, w trakcie której udaje się uciec rannemu mężczyźnie. Zastosowany w omawianym fragmencie niski klucz oświetleniowy i bardzo szybki montaż praktycznie uniemożliwiają ustalenie tożsamości zbiega. Mężczyzna zostaje zastrzelony na płycie lotniska. Ta informacja stanowi cenną wskazówkę dla widza, który wie o (rzekomym) istnieniu tajnego (i do dziś nie zweryfikowanego) raportu przekazanego do Polski przez legendarną łączniczkę AK "Zo" (Elżbietę Zawacką). Wedle tego raportu ciało Gralewskiego nie zostało wyłowione z morza - jak głosiła oficjalna wersja - lecz znalezione na pasie startowym z raną postrzałową głowy. Niepewny status ontologiczny tego „zdarzenia” dodatkowo komplikuje to, iż sceny agonii Gralewskiego na lotnisku montowane są niemal symultanicznie ze scenami śmierci Zygmunta Białego w podziemiach pałacu. Wątek otrucia Białego ma charakter stricte fikcjonalny, a historycy do dziś nie ustalili prawdziwej tożsamości (i dalszych losów) kuriera (?) ukrywającego się pod tym pseudonimem ${ }^{159}$.

Semantyczne „zakłócenia” pojawiające się w diegezie filmu można wyeliminować, odwołując się do przekazów „pozafilmowych”. Nie oznacza to jednak, iż przekazy te zawierają kompletny i spójny pod

${ }^{157}$ Dariusz Baliszewski, Bransoletka Zofii, „Wprost” 2004, nr 1152/1153.

${ }^{158}$ Wypowiedź ta dotyczy figurki miniaturowego zajączka, którą Alicja ofiarowała mężowi. Historię rodzinnego talizmanu opowiedziała Baliszewskiemu wdowa po Gralewskim podczas zdjęć do serialu.

159 Tadeusz Kisielewski, próbując ustalić personalia potencjalnych zamachowców, nie wspomina o tej postaci. Pewne wskazówki umieszczone w filmie sugerują iż pod pseudonimem „Biały” kryje się Wiktor Suchy - jeden z trzech „Gralewskich” przebywających w tym czasie na Skale. 
względem logicznym „pakiet informacyjny”. Widz, próbujący uczynić filmowe opowiadanie koherentnym, w procesie "rozumowania przyłączeniowego" natrafi na rozległą sieć wzajemnie wykluczających się informacji zawartych $\mathrm{w}$ materiałach źródłowych ${ }^{160}$. W odniesieniu do katastrofy gibraltarskiej możemy mówić o relatywizmie źródeł - badacz ma wprawdzie do dyspozycji ogromną ilość dokumentów, ale niewielką możliwość ich weryfikacji. Film Jadowskiej stanowi odzwierciedlenie tego relatywizmu. Autorka przeprowadza wprawdzie szczegółową rekonstrukcję wydarzeń, które - zdaniem Baliszewskiego - doprowadziły do śmierci Sikorskiego, ale pozostawia otwartymi fundamentalne kwestie. Próżno zatem poszukiwać w Generale odpowiedzi na pytanie: z czyjego polecenia działał MacFarlane - Brytyjczyków ${ }^{161}$ (o czym świadczyłaby wypowiedź: Gdyby to ode mnie zależało, te dokumenty byłyby już na biurku w Londynie) czy Rosjan (czego z kolei dowodzi zdanie: Ten Rusek dzwoni tu co pót godziny)? Nie dowiemy się również, kim byli (i jaką opcję polityczną reprezentowali) wykonawcy „wyroku” ze strony polskiej (agentami Andersa? Churchilla? a może Stalina?). W tym sensie film może stanowić potwierdzenie tezy, iż dramatyczny potencjał docudramy tkwi nie tyle w dowodzeniu, iż pewne zdarzenia miały miejsce i wyjaśnianiu przyczyn ich zaistnienia, ile $\mathrm{w}$ ukazywaniu przebiegu owych zdarzeń (not why but how) ${ }^{162}$.

W okresie realizacji Generała tezy Baliszewskiego mogły brzmieć przekonywająco, do czego w dużej mierze przyczyniła się niezwykle sugestywna forma ich filmowej prezentacji. Nowy kontekst interpretacyjny dla filmu Jadowskiej ustanowiony został za sprawą śledztwa, które 3 września 2008 r. wszczął Instytut Pamięci Narodowej. W wyniku tego śledztwa 25 listopada 2008 r. dokonano ekshumacji szczątków Naczelnego Wodza. Mimo złego stanu zwłok lekarze i eksperci z Katedry Medycyny Sądowej Uniwersytetu Jagiellońskiego w sposób jednoznaczny określili przyczynę

${ }^{160}$ Wystarczy porównać wersję Baliszewskiego, „dowodzącą” udziału Ludwika Łubieńskiego w zamachu na Sikorskiego, z raportami samego Łubieńskiego sporządzonymi w lipcu 1943 r. Zob. Ludwik Łubieński, Raporty o tragicznej śmierci gen. Sikorskiego oraz Ostatnia rozmowa z śp. gen. Sikorskim w Gibraltarze, [w:] Jenerał Sikorski. Antologia, dz. cyt., s. $48-56,181-187$.

Niewyjaśnioną kwestią pozostaje również, czy w Gibraltarze doszło do spotkania Sikorskiego z Majskim (jak utrzymują twórcy filmu). Z zapisków MacFarlane'a wynika, że ze względów dyplomatycznych ukryto przed Majskim obecność polskiej delegacji. Zob. Justin Whiteley, Śmierć generała Sikorskiego, dz. cyt., s. 36-37.

${ }^{161}$ Wskazywałoby na to m.in. przybycie do Gibraltaru - na dwa dni przed katastrofą przedstawiciela brytyjskiego wywiadu wojskowego MI6, o którym wspomina Modelski. Zob. T. Modelski, Byłem szefem wywiadu u Naczelnego Wodza, dz. cyt., s. 114.

162 Por. Steven N. Lipkin, Real Emotional Logic, dz. cyt., s. 47. 
śmierci Sikorskiego ${ }^{163}$. Na konferencji, która odbyła się 29 stycznia 2009 r. poinformowano, że

generał Sikorski zginął na skutek obrażeń wielonarządowych [...] charakterystycznych dla katastrof komunikacyjnych. Co niezmiernie ważne, na podstawie charakteru pięciu niegroźnych dla życia złamań kości udało się ustalić, że w chwili odniesienia śmiertelnych obrażeń generał był żywy i przytomny [...]. Tym samym wykluczone zostały inne hipotezy [...] na temat bezpośredniej przyczyny zgonu. Ostała się tylko jedna, która odtąd jest udowodnioną tezą: generał Sikorski zginął na skutek obrażeń odniesionych podczas wodowania ${ }^{164}$.

Ogłoszenie wyników badań w żaden sposób nie wpłynęło na ostateczny kształt filmu ${ }^{165}$, który miał swoją premierę 3 kwietnia $2009 \mathrm{r}$.

Zdaniem narratywistów historyczny wgląd ma charakter stereoskopowy: rodzi się w przestrzeni mieszczącej się pomiędzy konkurencyjnymi narracyjnymi interpretacjami, a zatem ustanawiany jest wyłącznie w historiograficznych kontrowersjach i dzięki nim ${ }^{166}$. Czy „rewelatorskie” ustalenia ekspertów medycyny sądowej - które uznać by można za odwet (historycznej) prawdy na tych, którzy ośmielili się jej przeczyć167 - czynią z Generała film anachroniczny? A przecież - jak podkreśla Frank Ankersmit - (nowe) odkrycia w dziedzinie „faktów” nie muszą przekreślać znaczenia narracji historycznej:

Być może pisarstwo historyczne weszło w stadium, w którym sens staje się ważniejszy od rekonstrukcji i genezy; stadium, w którym celem, jaki wyznaczyli sobie

${ }^{163}$ Wielostronicowy dokument z ekshumacji generała Sikorskiego dostępny jest na oficjalnej stronie internetowej filmu Generat (www.generał.tvn.pl).

164 Tadeusz Kisielewski, Gibraltar i Katyń. Co kryja archiwa rosyjskie i brytyjskie, Rebis, Poznań 2011, s. 156.

${ }^{165}$ W ostatnim odcinku serialu TVN Baliszewski krytycznie odniósł się do ustaleń IPN i podtrzymał przedstawioną w Generale wersję zdarzeń.

166 Zob. Frank Ankersmit, Narracja, reprezentacja, doświadczenie, dz. cyt., s. 66.

${ }^{167} \mathrm{~W}$ obronie Baliszewskiego można posłużyć się wykorzystywanym przez zwolenników „historii niekonwencjonalnej” kryterium szczerości. Wedle Domańskiej szczerość „z jednej strony dotyczy odwagi autora co do ujawniania swojej postawy, emocji i przeświadczeń, z drugiej może dotyczyć odwagi wobec opisywanych zdarzeń. [...] Kryterium szczerości może pełnić zadanie podstawowe do przeprowadzenia [...] rozróżnienia [pomiędzy błędem a kłamstwem]: historyk bowiem na podstawie informacji zaczerpniętych ze źródeł może szczerze wierzyć, że przekazywane przez niego dane na temat interesującego go zdarzenia są prawdziwe (nawet jeżeli jego informacje okażą się błędne, nie można go wtedy oskarżyć o kłamstwo); jednakże, kiedy szczerość w wypowiedzi historyka nie występuje, a jego twierdzenia są fałszywe, jego stwierdzenia można określić jako kłamstwa". Zob. Ewa Domańska, Historie niekonwencjonalne, dz. cyt., s. 66. Wydaje się, iż wspomniane kryterium jest niezwykle dyskusyjne, głównie ze względu na brak metod pozwalających zweryfikować „szczerość” historyka. 
historycy, jest odkrycie sensu podstawowych konfliktów w naszej przeszłości przez wydzielenie ich z przeszłości i ukazanie aktualności. [...] Nie twierdzę, że prawda historyczna i pewność nie mają znaczenia [...], ale [...], że metaforyczny wymiar historiografii jest potężniejszy od literalnego i faktualnego [podkr. moje - N.K.-R.] ${ }^{168}$.

Paradoksalnie, to właśnie dzięki wynikom śledztwa IPN utwór Anny Jadowskiej zyskał postulowany przez (post)historyków metaforyczny wymiar. Ostatecznie opowieści historyczne są zawsze (moralnymi) alegoriami (Hayden White) ${ }^{169}$.

Zdaniem krytyków przyczyny frekwencyjnej klęski Generała należy upatrywać głównie w rewelatorskim charakterze fabuły demaskującej fałsz oficjalnego - i zmitologizowanego - dyskursu historycznego:

Film Jadowskiej nie stał się jednak zarzewiem demitologizującej dyskusji, a zapewne byłaby ona tylko otwarciem puszki Pandory. Dyskusja mogłaby wszak dotyczyć nie tylko realnego znaczenia Polski na arenie II wojny światowej i tego, czy znalazła się ona w gronie zwycięzców, czy przegranych, lecz także owej wewnętrznej opozycji stojącej w filmie w tle gibraltarskich wydarzeń i być może zmierzającej do „zmiany frontu" przez Polskę w trakcie wojny, a to byłaby już prawdziwa puszka Pandory ${ }^{170}$.

Wydaje się jednak, iż odrzucenie dzieła Jadowskiej nie zostało spowodowane brakiem społecznej gotowości do podjęcia "demitologizującej dyskusji"171. Dobitnym świadectwem owej gotowości może być casus filmu Róża Wojciecha Smarzowskiego. O ile jednak Smarzowski prowadzi swój historyczny dyskurs $\mathrm{w}$ „rejestrach najwyższego tragizmu”, a dominującym trybem opowiadania jest tryb oznajmujący („tak było"), o tyle Jadowska ów tryb właśnie czyni obiektem dekonstrukcyjnych zabiegów (ważniejsze jest to ,jak się opowiada" niż to, „o czym opowiadanie traktuje”). „Rekonstrukcja” przeprowadzona w hipotetycznym trybie jak gdyby utwierdza nas w przekonaniu, że Generat to dzieło subwersywne wobec tradycyjnych - dominujących w rodzimym kinie - dyskursów na tematy narodowe.

${ }^{168}$ Frank Ankersmit, Historiografia i postmodernizm, tłum. Ewa Domańska, [w:] Postmodernizm. Antologia przekładów, dz. cyt., s. 170-171.

169 Zob. Ewa Domańska, Historia egzystencjalna, Wyd. Naukowe PWN, Warszawa 2012, s. 38.

${ }^{170}$ Marcin Adamczak, Katyń i Generat "Nil”, „Kwartalnik Filmowy” 2012, nr 77-78, s. 91.

${ }^{171} \mathrm{Z}$ drugiej jednak strony casus recepcji filmu Generał mógłby stanowić interesujący przyczynek do dyskusji nad długofalowym wpływem polityki historycznej z lat 2005-2007, której założeniom - w większym być może stopniu niż dokonana przez Jadowską „rekonstrukcja" katastrofy gibraltarskiej - odpowiadała hagiografia księdza Popiełuszki (przypomnijmy, iż w tym samym 2009 r. miał swoją premierę obraz Rafała Wieczyńskiego Popietuszko. Wolność jest w nas). 
W prozie powstającej po 1989 r. można mówić o zjawisku dyskursywizacji opowieści. W utworach należących do tego nurtu czyni się

z warstwy dyskursywnej płaszczyznę właściwego przebiegu ",akcji”, podczas gdy tradycyjnie rozumianej story przypisuje się rolę expemplum, fragmentarycznej ilustracji procesu demonstrowanego na poziomie dyskursu i przykuwającego uwagę czytelnika tak, jak w tradycyjnych przekazach czyniła to anegdota fabularna ${ }^{172}$.

Można zaryzykować stwierdzenie, że w Generale fabuła jest takim właśnie exemplum - wehikułem służącym produkcji wyobrażeń, które („,tradycyjnie zorientowany"173) widz może uznać za "prawdziwe” lub „fikcyjne”. Sądzę jednak, iż celem autorki filmu nie była rekonstrukcja "zdarzeń", którą należałoby oceniać w kategoriach „prawdy” lub „fałszu”. Proponując odbiorcy swego rodzaju grę dyskursów fikcjonalnych i faktualnych, przedmiotem zainteresowania uczyniła ona przede wszystkim procesy (w których współcześnie zasadniczą role odgrywają reprezentacje ikoniczne) determinujące nasze rozumienie przeszłości. Nie chodziło zatem o rekonstrukcje prawdziwych przyczyn katastrofy, lecz o skonstruowanie prawdopodobnej i akceptowalnej (uzgodnionej społecznie) narracji.

Praktyki „dyskursywizacji”, omówione nieco wcześniej w kontekście współczesnej polskiej literatury „post-transformacyjnej”, znacznie rzadziej stosowane są na obszarze kina. Jednym z nielicznych przykładów tego typu praktyk może być Rewers (2009) Borysa Lankosza. W czołówce filmu - podobnie jak miało to miejsce w Generale - posłużono się elementem dystansującym ${ }^{174}$ (kadr rozświetlony snopem światła z projektora kinowego), wskazującym w sposób jednoznaczny na autorefleksyjny charakter wypowiedzi. W odniesieniu do praktyk dyskursywizacji Generat

${ }^{172}$ Hanna Gosk, Historia w prozie polskiej o tematyce wspótczesnej po roku 1989, [w:] Co dalej, literaturo? Jak zmienia się wspótcześnie pojęcie i sytuacja literatury, red. Alina Brodzka-Wald, Hanna Gosk i Andrzej Werner, Instytut Badań Literackich PAN, Warszawa 2008, s. 22.

${ }^{173}$ Określenia „tradycyjnie zorientowany” nie traktuję w sposób wartościujący. Myślę raczej o widzu, do którego nie przemawiają zastrzeżenia formułowane przez przedstawicieli nowej historii: „o historycznej reprezentacji nie można właściwie powiedzieć, że jest «prawdziwa» czy «fałszywa», tak jak to można powiedzieć w technicznie poprawny sposób o zdaniach. Użycie pojęcia «prawdziwy» czy «fałszywy» zakłada bowiem, że mamy, po pierwsze, pojęcie-podmiot (subject-term), a po drugie, pojęcie-predykat (predicate-term). Zdanie jest prawdziwe, jeśli odpowiedni predykat jest przypisany do odpowiedniego obiektu, do którego odnosi się pojęcie-podmiot. Założenie to nie jest oczywiście satysfakcjonujące dla reprezentacji, bowiem w reprezentacji nie można wydzielić owych dwóch składników, tak jak to się robi w przypadku zdań (prawdziwych lub fałszywych)". Zob. Frank Ankersmit, Narracja, reprezentacja, doświadczenie, dz. cyt., s. 32-33.

${ }^{174}$ Podobną funkcję pełni w tym filmie muzyka. 
jest jednak filmem zdecydowanie bardziej konsekwentnym i - w zakresie generowanych sensów - niejednoznacznym.

Film Jadowskiej, podobnie jak JFK Stone’a, prezentuje jednocześnie dwie historie:

Pierwszą jest zamknięta, kompletna historia zbudowana w oparciu o detektywistyczną strategię intrygi [...], która jest poszukiwaniem i próbą odkrycia jakiejś prawdy, tajemnicy przeszłości. [...] W przypadku drugiej historii mamy do czynienia z audiowizualną opowieścią o obrazach [posiadających] zdolność do wiarygodnego kreowania wielce (nie)wiarygodnych historii, które w trakcie aktualizacji dzieła często postrzegane są przez widzów jako prawdziwe. [...] Historia druga [...] jest [...] narzędziem zawieszania i podważania wiarygodności historii pierwszej. Autor wydaje się sugerować, że opowiedzenie jakiejś prawdziwej jednoznacznej historii jest niemożliwe. Każda bowiem historia, opowiadana nawet przy użyciu najbardziej wiarygodnych strategii, konwencji realizmu, przekonujących teorii, źródeł historycznych, jest tylko konstruktem, wielowymiarową audiowizualną strukturą metaforyczną, otwartą na szereg różnorodnych aktualizacji i intrerpretacji ${ }^{175}$.

W okresie PRL podawanie w wątpliwość Historii było postawą samoobronną wobec historii zideologizowanej. Interesującego przykładu tak rozumianej „reakcji samoobronnej” dostarczyć mogą powieści Tadeusza Parnickiego, w których hipoteza zastępowała "narrację asertywną", stając się punktem wyjścia do wyobrażeń o losach "przeciwdziejowych”, zgodnie z zasadą że „mogło być tak właśnie"176. Film Jadowskiej powstał

${ }^{175}$ Piotr Witek, Kultura - film - historia, dz. cyt., s. 264-266. Koncepcja „dwóch historii” została zaczerpnięta z tekstu Roberta Burgoyne'a, który w odniesieniu do JFK pisze o dwóch rywalizujących paradygmatach. Zob. Robert Burgoyne, Modernism and the Narrative of the Nation in "JFK", dz. cyt., s. 119-120.

${ }^{176}$ Maria Delaperriére, Pod znakiem antynomii, dz. cyt., s. 114. Nie jest to oczywiście jedyna dopuszczalna interpretacja analizowanego zjawiska. Odwołując się do eseju Prawda i polityka Hannah Arendt, zaryzykuję przypuszczenie, iż może być ono także świadectwem prób przepracowania traumy związanej z typowym dla systemów totalitarnych doświadczeniem „poprawiania historii”. Arendt pisze: „rezultatem konsekwentnego i totalnego zastępowania prawdy o faktach kłamstwami nie jest to, że teraz kłamstwa będą uznawane za prawdę, a prawda za kłamstwo, lecz to, że zniszczony zostaje zmysł, za pomocą którego orientujemy się w rzeczywistym świecie, a do tego celu służą umysłowi między innymi kategorie prawdy i fałszu". Zob. Hannah Arendt, Prawda i polityka, [w:] Między czasem minionym a przyszłym: osiem ćwiczeń z myśli politycznej, tłum. Mieczysław Godyń, Wojciech Madej, Wyd, Aletheia, Warszawa 2011, s. 309. O właściwym machinie totalitarnej niwelowaniu różnicy między prawdą i „słusznością" pisał w $1984 \mathrm{r}$. w Totalitaryzmie i zaletach kłamstwa Leszek Kołakowski.

$\mathrm{W}$ efekcie tego typu refleksji w latach 90. zaczęto pisać o rodzimym wariancie postmodernizmu: soc-postmodernizmie. Dominikanin ojciec Maciej Zięba pisał, iż brak rozliczeń z komunizmem, niewiedza o przeszłości wynikają z dominującej w kręgach III Rzeczpospolitej prefilozofii postmodernistycznej zwanej soc-postmodernizmem. Gdy założymy, że wszystko jest relatywne, jest pochodną czasu i doświadczeń życiowych, 
jednak w zupełnie innym kontekście politycznym. Byłby to zatem utwór reprezentatywny (a przecież $\mathrm{w}$ rodzimym kinie niewątpliwie prekursorski) dla zjawiska, o którym pisze Delaperriére:

Subiektywizm, niewyrażalność, fenomenologiczna chwiejność nabrały jednak decydującego znaczenia dopiero w literaturze [i, jak dowodzi przykład Generała, także $\mathrm{w}$ filmie] ostatniego dziesięciolecia, kiedy nowe spojrzenie na historiografię oficjalna, usilne próby jej odkłamywania, prostowania, odkrywania białych plam zbiegają się z napływającymi z Zachodu trendami postmodernistycznymi, podważającymi wierzytelność każdego dyskursu ${ }^{177}$.

Film prezentujący (maskowaną za pomocą procedur obiektywizujących) fikcjonalną wersję ostatnich godzin życia generała Sikorskiego podważa typowe dla polskiej kinematografii konwencje przedstawiania (wyobrażania) wydarzeń historycznych. Multiplikacja obrazów stanowi projekcję kilku równoprawnych punktów widzenia ${ }^{178}$. Film kwestionuje w ten sposób możliwość jednej, uprzywilejowanej - z racji pozycji zajmowanej przez obserwatora - interpretacji „zdarzen”. Spekulatywny tryb dyskursu pozwala przekroczyć antynomię: „prawda albo fikcja” strukturującą nasze myślenie. Ujawnia niestabilność przeszłości i jej zależność od dyskursów, które w danym momencie historycznym nadają jej znaczenie. Film staje się wymownym świadectwem, iż historia, pretendująca do roli obiektywnej strażniczki przeszłości została sprowadzona do wielu różnych opowiadań o tym, jak mogło być, a nie o tym, jak naprawdę było ${ }^{179}$.

Generat jest utworem polemicznym - nie tyle nawet wobec „oficjalnych wersji" historii, ile wobec sposobów ich tekstowej reprezentacji. Podobnie jak JFK - o czym pisał historyk (!) Robert Rosenstone - zmusza

prawda jawi się jako kategoria opresyjna, nie sposób rozstrzygnąć, co było dobre, a co złe, wówczas nie sposób ocenić wydarzeń z przeszłości. Ten relatywistyczny pogląd pogłębia chaos moralny. Zob. Paweł Śpiewak, Pamięć po komunizmie, słowo/obraz terytoria, Gdańsk 2007, s. 200.

${ }^{177}$ Maria Delaperriére, Pod znakiem antynomii, dz. cyt., s. 115. Według autorki w sytuacji, gdy „naukowa wartość historiografii została podana w wątpliwość, literatura nabrała nowego znaczenia, już nie tylko jako naśladowanie (czy popularyzacja) historiografii, ale jako samodzielny namysł o Historii i dyskursie historycznym". Zdaniem autorki odzwierciedleniem tego fenomenu jest twórczość Jerzego Pilcha, Stefana Chwina, Magdaleny Tulli czy Olgi Tokarczuk.

178 Taką wielokontekstową formę prezentacji zdarzeń Burgoyne określa mianem „kubistycznej". Zob. Robert Burgoyne, Modernism and the Narrative of the Nation in "JFK", dz. cyt., s. 119.

179 Zob. Grażyna Gajewska, O cierpieniu i przyjemności zwiąanej z (re)produkowaniem przeszłości, [w:] Kultura przyjemności. Rozważania kulturoznawcze, red. Jan Grad, Hanna Mamzer, Wyd. Naukowe UAM, Poznań 2005, s. 165. 
ludzi do myślenia o przeszłości i rewizji tradycyjnych wartości ${ }^{180}$. W tym sensie film Jadowskiej stanowi doskonały przykład dzieła rewizjonistycznego. Zdaniem Haydena White'a

skuteczny rewizjonizm historyczny zazwyczaj przyjmuje formę re-figuracji wydarzeń, które już zostały przedstawione figuralnie w jakiejś kanonicznej formie. Nie jest to więc tylko ani też przede wszystkim wprowadzenie nowego korpusu informacji faktycznych o danym podmiocie historycznym ${ }^{181}$.

Generat to jedno z nielicznych w dorobku polskiej kinematografii dzieł, które wskazują na konieczność różnych sposobów przedstawiania (re-figuracji) przeszłości zamiast skupiać się wyłącznie na tym, co powinno zostać przedstawione. Kwestionując wiarę w "prawdziwość” ikonicznych dyskursów faktualnych, doskonale wpisuje się w paradygmat iconic turn. Jednym z wiodących postulatów tego zwrotu kulturowego jest wszakże wypracowanie metod krytycznej nauki o obrazach, której zadaniem byłoby nie tylko podważenie naiwnego zaufania do obrazów rzekomo dokumentalnych, ale także zdemaskowanie polityki operującej obrazami dla celów retoryki perswazyjnej ${ }^{182}$.

W rezultacie przeprowadzonego przez IPN śledztwa Generał Anny Jadowskiej lokuje się dziś na peryferiach dyskursów (quasi)faktualnych (docudrama). Być może należałoby go umieścić w paradygmacie "gatunków zmąconych", a zatem w rejonach mockdokumentu, którego celem jest sprowokowanie odbiorcy do namysłu nad dokumentem jako „trzeźwym dyskursem", jak również nad sposobami dokumentalnego przedstawiania wybranych aspektów kultury ${ }^{183}$. A wedle reguł obowiązujących w tym właśnie gatunku, generał Sikorski mógł zginąć nawet w Dallas ${ }^{184}$.

${ }^{180}$ Zob. Michael Kurtz, Oliver Stone, JFK, and History, dz. cyt., s. 172.

${ }^{181}$ Hayden White, Kosmos, chaos i następstwo, [w:] Pamięć, etyka i historia, dz. cyt., s. 102.

182 Doris Bachmann-Medick, Cultural turns, tłum. Krystyna Krzemieniowa, Oficyna Naukowa, Warszawa 2012, s. 428. Zdaniem autorki „krytyczna nauka o obrazach odkrywa przede wszystkim możliwość manipulowania obrazami, czego przykładem może być [...] artykuł o manipulacjach zdjęciami satelitarnymi w Światowej Radzie Bezpieczeństwa, jakich dopuścił się Collin Powell w lutym 2003 r. Aby dowieść istnienia broni masowego rażenia w Iraku i tym samym usprawiedliwić wojnę, sięgnięto do obrazów, które ostatecznie okazały się falsyfikatami".

${ }^{183}$ Zob. Agnieszka Ogonowska, "Mock-dockumentary" $i$ "faction-genre”, [w:] Kino po kinie, red. Andrzej Gwóźdź, Oficyna Naukowa, Warszawa 2010, s. 271.

${ }^{184}$ Dla porównania można by się posłużyć przykładem filmu Zabić prezydenta (2006) Gabriela Range'a. Kontrowersyjny obraz Range'a to (mock)dokumentalna „rekonstrukcja” zamachu na George W. Busha utrzymana - podobnie jak Generat - w konwencji thrillera politycznego. 
Autorka Generała zapewne zgodziłaby się z poglądami postmodernistycznych historyków, wedle których

pożądanym celem historycznego przestawiania przeszłości winno być raczej mnożenie interpretacji doniosłych zdarzeń historycznych niż tworzenie monolitycznego „konsensusu” interpretacyjnego, który pozorując „,bezinteresowność”, ukrywa swoje zainteresowanie utrzymaniem społecznego status $q u o^{185}$.

A jeśli nawet odrzucimy taką wykładnię, możemy ogladać („,niewiarygodną") rekonstrukcję historyczną jak znakomity (czytaj: wizualnie atrakcyjny) film ${ }^{186}$.

${ }^{185}$ Hayden White, Proza historyczna, dz. cyt., s. 125.

${ }^{186} \mathrm{O}$ fenomenie odbiorczego przyzwolenia na fikcjonalizację historii pisze Paul Ricoeur: „Tym, co przyczynia się do długowieczności pewnych wielkich dzieł historycznych, których czysto naukową wiarygodność podważył postęp w dokumentacji, jest właśnie charakter ich poetyki i retoryki, który dokładnie odpowiada ich sposobowi widzenia przeszłości. To samo dzieło może być zatem wspaniałą książką historyczną i znakomitą powieścią. Zadziwiające jest to, że owo przeplatanie się fikcji z historią nie osłabia właściwego tej ostatniej projektu zastąpienia, lecz przyczynia się do jego spełnienia". Zob. Paul Ricoeur, Czas i opowieść, dz. cyt., s. 270.

W konsekwencji możliwy jest model lektury zaproponowany przez Marię Delaperiére w odniesieniu do wojennych wspomnień Władysława Szpilmana. Autorka podsumowuje: „historia Szpilmana pozostaje historią unikalna, która budzi nasze zainteresowanie jak każda inna nadzwyczajna opowieść, prawdziwa lub zmyślona [podkr. moje - N.K.-R.]". Zob. Maria Delaperiére, Pod znakiem antynomii, dz. cyt., s. 103. Podobną tezę stawia Robert Rosenstone: „historia, która pojawia się na ekranie, nigdy w pełni nie zadowoli historyka jako historyka, ale może być satysfakcjonująca dla historyka jako widza. W kinie wszyscy jesteśmy przez chwilę więźniami historii". Zob. Robert Rosenstone, Historia w obrazach/historia w stowach, dz. cyt., s. 100. 


\section{Zakończenie}

Andre Bazin ufundował ontologię kina na wierze - wierze w obraz, który zaspokaja podstawową potrzebę psychologii ludzkiej: potrzebę obrony przed czasem ${ }^{1}$. Funkcją sztuki (nie tylko filmowej) jest ocalenie istnienia przez ocalenie jego zewnętrznego wyglądu - przed śmiercią. Kino, ulegając Bazinowskiej „obsesji podobieństwa” i próbując osiagnąć absolutną zbieżność z rzeczywistością zmierza do hiperrealizmu - do wyłącznej zbieżności z ...samym sobą ${ }^{2}$. Obraz nie jest już „lustrem obdarzonym pamięcią", lecz lustrem, które odbijać może tylko inne lustro ${ }^{3}$. Z tego względu przyczynia się do „śmierci” historii: „Wskrzesza jedynie upiory i w nich się zatraca”"

1 Andre Bazin, Ontologia obrazu fotograficznego, [w:] Film i rzeczywistość, tłum. Bolesław Michałek, Wyd. Artystyczne i Filmowe, Warszawa 1963, s. 6.

2 Baudrillard analizuje to zjawisko, posługując się m.in. przykładem filmu Chinatown (1974) Romana Polańskiego. Dla Frederica Jamesona obraz Polańskiego jest paradygmatyczną realizacją formuły tzw. filmu nostalgicznego. Według Jamesona film nostalgiczny nigdy nie żywił staromodnej ambicji „reprezentowania” rzeczywistości historycznej, tylko ujmował przeszłość za pomocą konotacji stylistycznych: nośnikiem "przeszłościowej" aury były w nim wizualne smaczki, zaś „lata trzydzieste" czy „lata pięćdziesiąte” przywoływano za pomocą odpowiednich kostiumów. W filmie nostalgicznym historia stylów estetycznych zajmuje miejsce „prawdziwej” historii, a głównym bohaterem, aktantem i pełnoprawną "postacią historyczną" jest styl i ton całej epoki. Zob. Frederic Jameson, Postmodernizm, czyli logika późnego kapitalizmu, tłum. Maciej Płaza, Wyd. Uniwersytetu Jagiellońskiego, Kraków 2011, s. 19-20, 379.

Podstawową cechą filmu nostalgicznego jest „stylizacja retrospektywna”. „W odróżnieniu od tradycyjnych filmów historycznych - podkreśla Paul Rabinow, komentując tezy Jamesona - których celem jest odtworzenie obrazu z innych epok jako odmiennych, filmy mode rétro starają się wprawić widza w nastój uczuciowy poprzez zastosowanie detali i środków stylistycznych zacierających granice czasowe. [...] Namnożenie metaodniesień do innych przedstawień spłaszcza i wyjaławia ich treść. [...] To, czego filmy te dokonuja, to przedstawianie naszych wyobrażeń o innych epokach". Zob. Paul Rabinow, Wyobrażenia sa faktami społecznymi: modernizm i postmodernizm w antropologii, tłum. Joanna Krzemień, [w:] Amerykańska antropologia postmodernistyczna, red. Michał Buchowski, Instytut Kultury, Warszawa 1999, s. 107.

3 Zob. Linda Williams, Truth, History and the New Documentary, "Film Quarterly" 1993, vol. 46, no. 3, s. 10. Na tym polega paradoks współczesnej kultury. Z jednej strony głosimy tezę, iż nie istnieje żadna "prawda”, do której odnosi się obraz, z drugiej - zarejestrowane amatorską kamerą nagranie staje się materiałem dowodowym $\mathrm{w}$ procesie sądowym (casus sprawy Rodneya Kinga).

4 Jean Baudrillard, Historia - scenariusz w stylu retro, [w:] Symulakry i symulacja, tłum. Sławomir Królak, Wyd. Sic!, Warszawa 2005, s. 63. 
Historia - wyegzorcyzmowana z naszego życia - coraz częściej nawiedza i opanowuje kino. Zdaniem Baudrillarda myli się jednak ten, kto wierzy w możliwość „zdobywania świadomości historycznej za pomocą kina”:

\begin{abstract}
Za zasłoną nastawionej na osiąganie jak najlepszych wyników, skutecznej i demonstratywnej logiki: obsesja historycznej wierności, doskonałego przedstawienia [...], owa negatywna i zażarta wierność wobec materialności czasu przeszłego, wierność każdej scenie przeszłości [...]. Fotografia i kino w ogromnej mierze miały udział w sekularyzacji historii, w jej unieruchomieniu i utrwaleniu pod widzialna „obiektywną" postacia, za cenę utraty mitów, które ją przeszywały ${ }^{5}$.
\end{abstract}

Metafory stanowiące zaplecze pojęciowe dla refleksji nad zdobywaniem świadomości historycznej za pomoca kina zdają się być bardziej stosowne w odniesieniu do „filozofii horroru”. Oto myśl ewoluująca od Bazniowskiego „kompleksu mumii” do Baudrillardowskich „wskrzeszonych upiorów" nie potrafi już dostrzec w obrazie-symulakrum nawet słabego refleksu przeszłych zdarzeń. Czy oznacza to klęskę epistemologicznego projektu New History, która pod hasłem historiofotii chce przywrócić obrazowi funkcję „podstawowego medium reprezentacji dyskursywnej”?

Baudrillard pisał o historycznych filmach - „cudownych artefaktach pozbawionych wad" - wywołujących efekt cool. O (nazbyt) doskonałych produktach kultury kombinatorycznej, stanowiących już tylko hiperrealną rekonstrukcję uprzednio istniejących... filmów. Teoretycy z obszaru „Nowej Historii" zainteresowani są filmami (zarówno fabularnymi, jak i dokumentalnymi $\left.{ }^{6}\right)$, w których wyraźnie manifestuje się metakrytyczne podejście wobec przeszłości. Filmy te traktowane są w refleksji badawczej jako świadectwa strategii autorefleksyjnej - podkreślającej status tekstu jako świadomie skonstruowanej narracjī. Filmy tego typu „opowiadają więcej niż jedną historię", a licznie pojawiające się w nich elementy dystansujące (metatekstowe) stanowią odpowiednik trybu przypuszczającego w narracji historiograficznej ${ }^{8}$.

W analizowanym przeze mnie okresie historycznym niewiele można znaleźć przykładów filmów, które mogłyby stanowić przedmiot zainteresowania "nowych historyków”. Pod tym względem - a dotyczy to zwłaszcza filmów realizowanych po 1989 r. - kino powiela wzorzec typowy dla rodzimego pisarstwa historycznego. Zdaniem Ewy Domańskiej

\footnotetext{
Tamże.

Zob. Linda Williams, Truth, History and the New Documentary, dz. cyt.

Zob. Vanessa R. Schwartz, Film and History, [w:] Film Studies, ed. James Donald and Michael Renov, Sage, Los Angeles-London-New Delhi-Singapore 2008, s. 206.

8 Zob. Natalie Zemon Davis, "Any Resemblance to Persons Living or Dead": Film and the Challenge of Authenticity, “The Yale Review” 1987, vol. 76, issue 4, s. 478-480.
} 
alternatywny sposób pisania o przeszłości jest słabo dostrzegany w historiografii polskiej. Wątki egzystencjalno-etyczne i autorefleksja są jeszcze mniej widoczne. Być może dzieje się tak dlatego, że badacze [...] chowają się w kątach zadeklarowanego obiektywizmu i w swych tekstach z upodobaniem stosują bezpieczną formułę "my"

Filmy odnoszące się do przeszłości - podobnie jak historia pisana - są wyobrażeniem przeszłości, a nie samą przeszłością. W obu wypadkach to wyobrażenie kształtowane jest za pomocą konwencji gatunkowych i językowych. Historia nie istnieje zanim się jej nie stworzy ${ }^{10}$.

Narracje - podkreśla Rosenstone - czyli spójne opowieści posiadające początek, środek i zakończenia, są konstruowane przez historyków, którzy próbują nadać sens przeszłości. [...] narracje pisane przez historyków to w rzeczywistości „fikcje werbalne". [...] Język nie tyle odzwierciedla przeszłość, co raczej ją stwarza, nadaje jej strukturę i nasyca znaczeniem. [...] W tej mierze, w jakiej opowieści pisane są fikcjami werbalnymi, narracje oparte na obrazie będą fikcjami wizualnymi, a więc - raz jeszcze - nie będą stanowić zwierciadła dla przeszłości, ale jej przedstawienie ${ }^{11}$.

O fundamentalnej rozbieżności na linii wydarzenie-opowieść (opowieść rozumiana $\mathrm{w}$ tym przypadku w podwójnym niejako sensie: jako opowieść konstruowana a posteriori przez narratora-bohatera i jako opowieść - „fikcja wizualna" konstruowana przez artystę próbującego nadać sens przeszłości) mówi przede wszystkim Poznań $56^{12}$. Co istotne, film Bajona pozwala spojrzeć na wydarzenie historyczne nie tylko jak na „werbalną (wizualną) fikcję konstruowaną przez historyka", lecz także jak na tekst prowokujący do lektury „w głąb”. Analiza szczegółów składających się na dane wydarzenie historyczne (tu: grupa dzieci z biało-czerwonymi choragiewkami na czele pochodu ulicznego, wyrzucanie obcych choragiewek $i z a-$ stepowanie ich narodowymi, obrzucanie i podpalanie czołgów butelkami z benzyna, biało-czerwone opaski na rękawach) ujawnia jego tekstualny charakter: zejście na poziom mikroskopowy w celu odsłonięcia pewnych szerszych

9 Ewa Domańska, Mikrohistorie, Wyd. Poznańskie, Poznań 1999, s. 285.

10 Robert Rosenstone, Historia w obrazach/historia w słowach: rozważania nad możliwościa przedstawienia historii na taśmie filmowej, [w:] Film i historia. Antologia, red. Iwona Kurz, Wyd. Uniwersytetu Warszawskiego, Warszawa 2008, s. 113.

11 Tamże, s. 106-107.

${ }^{12}$ Niezwykle sugestywnego opisu tego typu rozbieżności dostarcza przeprowadzona przez Farge i Revela analiza „,wiernej i weryfikowalnej na bazie zachowanych źródeł” relacji dotyczących paryskiej rewolty z 1750 r. Autorzy komentują: „A jednak jest ona całkowicie zwodnicza, ponieważ pomiędzy rozbłyski rewolty wprowadza zarówno porządek, jak i koherencję. Jej wątek chronologiczny sugeruje pewną intrygę, powiązanie perypetii, które lepiej lub gorzej układają się od początku do końca. Tymczasem nawet minimalne spójności zawarte w relacji są do głębi obce doświadczeniom dni majowych". Zob. Tomasz Falkowski, Myśl i zdarzenie. Pojęcie zdarzenia historycznego w historiografii francuskiej XX wieku, Universitas, Kraków 2013, s. 158. 
historycznych treści, a więc przekształcenie tworzących go szczegółów w szczegóły znaczące, czyni z niego rodzaj tekstu do odczytania ${ }^{13}$. Tekstu - dodajmy - który aktorzy społeczni tworzą na poczekaniu, ale opierając się na zastanych wzorach ${ }^{14}$.

W większości przypadków polscy twórcy wyobrażeń historycznych starają się stworzyć widzowi złudzenie, iż film stanowić może „okno na przeszłość" (Śmierć jak kromka chleba, Czarny czwartek). Dominującym modelem wypowiedzi filmowej jest scharakteryzowany przez Rosenstone'a konwencjonalny film historyczny (czy, biorąc pod uwagę polskie realia produkcyjne, możemy uznać Bitwę warszawska Jerzego Hoffmana - „cudowny artefakt pozbawiony wad”, a raczej „zdepersonalizowane wizualne kuriozum"15 - za przykład Baudrillardowskiego hiperrealizmu?). Tym więcej uwagi poświęcić należy nielicznym dziełom przełamującym tę formułę. Pełnią one trzy - wyróżnione przez Rosenstone'a - fundamentalne funkcje:

1. Wizualizują historię, pozwalając nam („protetycznie”?) doświadczyć przeszłości w jej „materialnym” (flesh and blood) kształcie.

2. Kontestują historię, proponując interpretacje sprzeczne $\mathrm{z}$ powszechnie podzielanymi przekonaniami.

3. Dokonują rewizji historii, ukazując przeszłość w nieoczekiwany (sprzeczny z konwencjami realistycznego opowiadania) sposób ${ }^{16}$.

$\mathrm{Na}$ wzór ponowoczesnej historiografii (gatunku kulturowego, który oddzielił się od gatunku wiedzy historycznej ${ }^{17}$ ) realizują one podwójną strategię: zmuszają nie tylko do refleksji nad przeszłością, lecz także nad sposobami jej tekstowej reprezentacji. W miejsce monologu (single linear story with a single meaning) proponują dialog (competing voices and images ${ }^{18}$ ), nie zakładają bowiem a priori, iż istnieje tylko jedna narodowa narracja historyczna. Wymuszają zajęcie stanowiska, nawet jeśli będzie to oznaczać sprzeciw wobec zaprezentowanej wizji („konstrukcji”) przeszłości. Zamiast pytać: „W jaki sposób można prawdziwie ukazać przeszłość?”, formułują pytanie: „Czy wyobrażenie przeszłości musi odwoływać się do kryterium prawdy?” I czy w dobie „po(st) Historii” oraz konkurujących ze sobą cultural turns musimy w ogóle zadawać sobie takie pytania?

13 Tamże, s. 182.

14 Tamże, s. 176.

15 Zob. Frederic Jameson, Postmodernizm, czyli logika późnego kapitalizmu, dz. cyt., s. XIX.

16 Robert Rosenstone, Oliver Stone as Historian, [w:] Oliver Stone's USA, ed. Robert Brent Toplin, University Press of Kansas, Lawrence 2000, s. 35-36.

17 Zob. Frederic Jameson, Postmodernizm, czyli logika późnego kapitalizmu, dz. cyt., s. 381.

18 Robert Rosenstone, The Historical Film: Looking at the Past in a Postliterate Age, [w:] The Historical Film: History and Memory in Media, ed. Marcia Landy, Rutgers University Press, New Jersey 2001, s. 58. 


\section{Bibliografia}

Adamczak Marcin, Katyń i Generat „Nil”, „Kwartalnik Filmowy” 2012, nr 77-78.

Amengual Barthélemy, Demaskowanie mitologii, tłum. Grażyna Stryszowska, „Kwartalnik Filmowy" 1996/1997, nr 15-16.

Ankersmit Frank, Narracja, reprezentacja, doświadczenie. Studia z teorii historiografii, tłum. zbiorowe, Universitas, Kraków 2004.

Appleby Joyce, Hunt Lynn, Jacob Margaret, Powiedzieć prawdę o historii, tłum. Stefan Amsterdamski, Zysk i S-ka, Poznań 2000.

Arendt Hannah, O przemocy. Niepostuszeństwo obywatelskie, tłum. Anna Łagodzka, Wojciech Madej, Wyd. Aletheia, Warszawa 1999.

Arendt Hannah, Prawda i polityka, [w:] Między czasem minionym a przyszłym: osiem ćwiczeń z myśli politycznej, tłum. Mieczysław Godyń, Wojciech Madej, Wyd. Aletheia, Warszawa 2011.

Ariés Philippe, Czas historii, tłum. Bella Szwarcman-Czarnota, Wyd. Marabut, Gdańsk 1996.

Attridge Derek, Jednostkowość literatury, tłum. Paweł Mościcki, Universitas, Kraków 2007.

Babcock Barbara, "Poukładaj mnie w nieporzadek": fragmenty i refleksje na temat rytualnego błazeństwa, [w:] Rytuat, dramat, święto, spektakl. Wstẹp do teorii widowiska kulturowego, red. John J. MacAloon, tłum. Katarzyna Przyłuska-Urbanowicz, Wyd. Uniwersytetu Warszawskiego, Warszawa 2009.

Bachmann-Medick Doris, Cultural turns, tłum. Krystyna Krzemieniowa, Oficyna Naukowa, Warszawa 2012.

Bachtin Michaił, Twórczość Franciszka Rabelais'ego, tłum. Anna i Andrzej Goreniowie, Wyd. Literackie, Kraków 1975.

Baczko Bronisław, Wyobrażenia społeczne. Szkice o nadziei i pamięci zbiorowej, tłum. Małgorzata Kowalska, Wyd. Naukowe PWN, Warszawa 1994.

Bal Mieke, Narratologia. Wprowadzenie do teorii narracji, tłum. zbiorowe, Wyd. Uniwersytetu Jagiellońskiego, Kraków 2012.

Baliszewski Dariusz, Bransoletka Zofii, „Wprost” 2004, nr 1152/1153.

Banasiak Bogdan, (Aktywne) Zapomnienie, „Lamus. Pismo kulturalno-artystyczne” 2008, nr 2.

Barańczak Stanisław, Etyka i poetyka, Znak, Kraków 2009.

Barbour Ian G., Mity, modele, paradygmaty, tłum. Marek Krośniak, Znak, Kraków 1984.

Barthes Roland, Dyskurs historii, tłum. Adam Rysiewicz, Zbigniew Kloch, „Pamiętnik Literacki" 1984 , nr 75.

Barthes Roland, Mitologie, tłum. Adam Dziadek, Wyd. KR, Warszawa 2000.

Barthes Roland, Światło obrazu, tłum. Jacek Trznadel, Wyd. KR, Warszawa 1996.

Bartoszewski Władysław, "Kanat”. Czy film o Powstaniu Warszawskim?, [w:] Pisma wybrane 1942-1957, t. I, Universitas, Kraków 2007.

Bass Warren, Obiektywność filmowa a styl wizualny, [w:] Panorama współczesnej myśli filmowej, red. i tłum. Alicja Helman, Universitas, Kraków 1992. 
Bauman Zygmunt, Wieloznaczność nowoczesna, nowoczesność wieloznaczna, tłum. Janina Bauman, Wyd. Naukowe PWN, Warszawa 1995.

Bazin Andre, Ontologia obrazu fotograficznego, [w:] Film i rzeczywistość, tłum. Bolesław Michałek, Wyd. Artystyczne i Filmowe, Warszawa 1963.

Belting Hans, Antropologia obrazu. Szkice do nauki o obrazie, tłum. Mariusz Bryl, Universitas, Kraków 2007.

Berger Peter L., Luckmann Thomas, Społeczne tworzenie rzeczywistości, tłum. Józef Niżnik, PWN, Warszawa 2010.

Błoński Jan (artykuł), Biedni Polacy patrza na getto, „Tygodnik Powszechny” 1987, nr 2.

Błoński Jan (książka), Biedni Polacy patrza na getto, Wyd. Literackie, Kraków 2008.

Błoński Jan, Dramat i przestrzeń, [w:] Przestrzeń i literatura, red. Michał Głowiński, Ossolineum, Wrocław 1978.

Baudrillard Jean, Historia - scenariusz w stylu retro, [w:] Symulakry i symulacja, tłum. Sławomir Królak, Wyd. Sic!, Warszawa 2005.

Bojarska Katarzyna, Żałoba i melancholia w "Tworkach”, czyli na co badaczowi Zagłady freudowska psychoanaliza, [w:] Freud i nowoczesność, red. Zofia Rosińska, Universitas, Kraków 2009.

Borowski Tadeusz, Alicja w krainie czarów, [w:] "Chamuły”, "gnidy”, „przemilczacze”... Antologia dwudziestowiecznego pamfletu polskiego, red. Dorota Kozicka, Universitas, Kraków 2010.

Bourdieu Pierre, Reguly sztuki, tłum. Andrzej Zawadzki, Universitas, Kraków 2001.

Braniecki Włodzimierz, Szczun. Z Filipem Bajonem o Poznaniu, o jego wielkopolskiej trylogii filmowej rozmowy prawie o wszystkim, Wyd. „W drodze”, Poznań 1998.

Brzozowski Stanisław, Głosy wśród nocy. Studia nad przesileniem romantycznym kultury europejskiej, Wyd. Krytyki Politycznej, Warszawa 2007.

Buczyńska-Garewicz Hanna, Miejsca, strony, okolice. Przyczynek do fenomenologii przestrzeni, Universitas, Kraków 2006.

Burke Peter, Naoczność, tłum. Justyn Hunia, Wyd. Uniwersytetu Jagiellońskiego, Kraków 2012.

Burzyńska Anna, Kulturowy zwrot teorii, [w:] Kulturowa teoria literatury. Główne pojęcia i problemy, red. Michał Paweł Markowski, Ryszard Nycz, Universitas, Kraków 2006.

Cassirer Ernst, Esej o człowieku. Wstęp do filozofii kultury, tłum. Anna Staniewska, Czytelnik, Warszawa 1998.

Cękalski Eugeniusz, Ostatnia jesień, „Nowa Polska” 1943, nr 1.

Chudy Wojciech, Społeczeństwo zakłamane, Oficyna Naukowa, Warszawa 2007.

Cinema and Nation, ed. Mette Hjort and Scott MacCenzie, Routledge, London-New York 2000.

Coates Paul, The Red and the White. The Cinema of People's Poland, Wallflower Press, LondonNew York 2005.

Codogni Paulina, Rok 1956, Prószyński i S-ka, Warszawa 2006.

Cyganek Beata, Dzieciństwo. Ciężar samotności, [w:] Odwiecznie od nowa. Wielkie tematy w kinie przełomu wieków, red. Tadeusz Lubelski, Wyd. Rabid, Kraków 2004.

Czapliński Przemysław, Polska do wymiany. Późna nowoczesność i nasze wielkie narracje, Wyd. W.A.B., Warszawa 2009.

Czapliński Przemysław, Wzniosłe tęsknoty. Nostalgie w prozie lat dziewięćdziesiatych, Wyd. Literackie, Kraków 2001.

Czermińska Małgorzata, Autobiograficzny trójkąt. Świadectwo, wyznanie i wyzwanie, Universitas, Kraków 2000.

Cześć, starenia! Wspomnienia o Zbyszku Cybulskim, red. Mariola Pryzwan, PIW, Warszawa 2007.

Czocher Anna, W okupacyjnym Krakowie, Wyd. Oskar, Gdańsk 2011. 
Danek Danuta, Oblicze. Gombrowicz i śmierć, [w:] Sztuka rozumienia. Literatura i psychoanali$z a$, Instytut Badań Literackich PAN, Warszawa 1997.

Davis Zemon Natalie, "Any Resemblance to Persons Living or Dead": Film and the Challenge of Authenticity, "The Yale Review" 1987, vol. 76, issue 4.

Delaperriére Maria, Pod znakiem antynomii. Studia i szkice o polskiej literaturze XX wieku, Universitas, Kraków 2006.

Deleuze Gilles, Kino, tłum. Janusz Margański, słowo/obraz terytoria, Gdańsk 2008.

Deleuze Gilles, Nietzsche i filozofia, tłum. Bogdan Banasiak, Wyd. Spacja, Warszawa 1993.

Didi-Huberman Georges, Strategie obrazów. Oko historii 1, tłum. Janusz Margański, korporacja ha!art, Kraków 2011.

Domańska Ewa, Historia egzystencjalna, Wyd. Naukowe PWN, Warszawa 2012.

Domańska Ewa, Historie niekonwencjonalne, Wyd. Poznańskie, Poznań 2010.

Domańska Ewa, Mikrohistorie, Wyd. Poznańskie, Poznań 1999.

Douglas Mary, Jak myśla instytucje, tłum. Olga Siara, Wyd. Naukowe PWN, Warszawa 2011.

Douin Jean-Luc, Wajda, czyli polski los, tłum. Grażyna Stryszowska, „Kwartalnik Filmowy” 1996/1997, nr 15-16.

Eberhardt Konrad, Mówić własnym głosem, „Kino” 1975, nr 11.

Eberhardt Konrad, O polskich filmach, Wyd. Artystyczne i Filmowe, Warszawa 1982.

Falkiewicz Andrzej, Polski kosmos. 10 esejów przy Gombrowiczu, Wyd. A, Wrocław 1996.

Ferro Marc, Film i historia, tłum. Tomasz Falkowski, Wyd. Naukowe PWN, Warszawa 2001.

Film i historia. Antologia, red. Iwona Kurz, Wyd. Uniwersytetu Warszawskiego, Warszawa 2008.

Fish Stanley, Interpretacja, retoryka, polityka. Eseje wybrane, tłum. Andrzej Szahaj, Universitas, Kraków 2008.

Foucault Michel, Kim jest autor?, [w:] Szaleństwo i literatura, tłum. Michał Paweł Markowski, Wyd. Aletheia, Warszawa 1999.

Foucault Michel, Powrót do historii, [w:] Filozofia, historia, polityka: wybór pism, tłum. Damian Leszczyński, Lotar Rasiński, Wyd. Naukowe PWN, Warszawa-Wrocław 2000.

Freud Zygmunt, Niesamowite, [w:] Pisma psychologiczne, tłum. Robert Reszke, Wyd. KR, Kraków 1997.

Friedberg Anne, The Virtual Window, MIT Press, Cambridge 2009.

Galanciak Sylwia, Rzeczywistość vs komputer. Efekty cyfrowe a filmowa ontologia, „Kwartalnik Filmowy" 2006, nr 56.

Gall Alfred, Humanizm performatywny. Polemika z filozofia w praktyce literackiej Witolda Gombrowicza, tłum. Grzegorz Sowiński, Universitas, Kraków 2011.

Genette Gérard, Palimpsesty. Literatura drugiego stopnia, tłum. Aleksander Milecki, [w:] Wspótczesna teoria badań literackich za granica, t. IV, red. Henryk Markiewicz, Wyd. Literackie, Kraków 1992.

Głowiński Michał, Gombrowicz i nadliteratura, Wyd. Literackie, Kraków 2002.

Gombrowicz i krytycy, red. Jan Błoński, Wyd. Literackie, Kraków 1984.

Gombrowicz Rita, Gombrowicz w Argentynie. Świadectwa i dokumenty 1939-1963, tłum. Anna Husarska, Sophie Bogdan, Ossolineum, Wrocław-Warszawa-Kraków 1991.

Gombrowicz Witold, Dziennik 1953-1956, Wyd. Literackie, Kraków 1989.

Gombrowicz Witold, Dziennik 1957-1961, Wyd. Literackie, Kraków 1988.

Gombrowicz Witold, Dziennik 1961-1966, Wyd. Literackie, Kraków 1986.

Gombrowicz Witold, Ferdydurke, Wyd. Literackie, Kraków 1986.

Gombrowicz Witold, Kosmos, Wyd. Literackie, Kraków 1988.

Gombrowicz Witold, Pornografia, Wyd. Literackie, Kraków 1997.

Gombrowicz Witold, Ślub, [w:] tenże, Dramaty, Wyd. Literackie, Kraków 1988.

Gombrowicz Witold, Testament. Rozmowy z Dominique de Roux, Wyd. Literackie, Kraków 1996. 
Gombrowicz Witold, Trans-Atlantyk, Wyd. Literackie, Kraków 1988.

Gombrowicz Witold, Wspomnienia polskie. Wędrówki po Argentynie, Res Publica, Warszawa 1990.

Gosk Hanna, Historia w prozie polskiej o tematyce wspótczesnej po roku 1989, [w:] Co dalej, literaturo? Jak zmienia się współcześnie pojęcie i sytuacja literatury, red. Alina Brodzka-Wald, Hanna Gosk i Andrzej Werner, Instytut Badań Literackich PAN, Warszawa 2008.

Graczyk Ewa, Przed wybuchem wstrząsnać. O twórczości Witolda Gombrowicza w okresie międzywojennym, słowo obraz/terytoria, Gdańsk 2004.

Grodź Iwona, Zaszyfrowane w obrazie. O filmach Wojciecha Hasa, słowo/obraz terytoria, Gdańsk 2008.

Guérin-Castel Anne, Dwoista forma "Szyfrów" Wojciecha Jerzego Hasa - prawda do rozszyfrowania, tłum. Teresa Rutkowska, „Kwartalnik Filmowy” 2000, nr 29/30.

Guynn William, Przekształcanie historii w filmie, tłum. Teresa Rutkowska, Karolina Kosińska, „Kwartalnik Filmowy” 2010, nr 69.

Gwóźdź Andrzej, Obrazy i rzeczy. Film między mediami, Universitas, Kraków 2003.

Habielski Rafał, Stużba i wartości. Konteksty oraz okoliczności debat o inteligencji polskiej (XIXXXI wiek), [w:] Inteligencja w Polsce. Specjaliści, twórcy, klerkowie, klasa średnia, red. Henryk Domański, Wyd. IFiS PAN, Warszawa 2008.

Halbwachs Maurice, Społeczne ramy pamięci, tłum. Marcin Król, PWN, Warszawa 1969.

Hałas Elżbieta, Symbole i społeczeństwo. Szkice z socjologii interpretacyjnej, Wyd. Uniwersytetu Warszawskiego, Warszawa 2007.

Helman Alicja, Á propos realizmu, „Kwartalnik Filmowy” 2011, nr 75-76.

Helman Alicja, O podstawach wzajemnego oddziaływania subkodów dźwiękowych w dziele filmowym, „Studia Semiotyczne” 1977, t. VII.

Helman Alicja, Rzeczywistość mówi językiem znaków, [w:] Widziane po latach. Analizy i interpretacje filmu polskiego, red. Małgorzata Hendrykowska, Wyd. Poznańskiego Towarzystwa Przyjaciół Nauk, Poznań 2000.

Hendrykowska Małgorzata, Film polski wobec wojny i okupacji, Wyd. Naukowe, Poznań 2011.

Hendrykowski Marek, Autor, [w:] Stownik pojęć filmowych, t. 3, red. Alicja Helman, Wyd. „Wiedza o Kulturze”, Wrocław 1992.

Hendrykowski Marek, Dokument - fikcja - realizm, „Kwartalnik Filmowy” 2011, nr 75-76.

Hendrykowski Marek, Film jako źródło historyczne, Wyd. Ars Nova, Poznań 2000.

Hendrykowski Marek, Stanisław Różewicz, Wyd. Ars Nova, Poznań 1999.

Hendrykowski Marek, Styl i kompozycja "Popiołu i diamentu” Andrzeja Wajdy, [w:] Analizy i interpretacje. Film polski, red. Alicja Helman, Tadeusz Miczka, Wyd. Uniwersytetu Śląskiego, Katowice 1984.

Herbert Zbigniew, Wiersze wybrane, red. Ryszard Krynicki, Wyd. a5, Kraków 2004.

Himmelfarb Gertrude, Telling it as you like it: postmodernist history and flight from fact, [w:] The Postmodern History Reader, ed. Keith Jenkins, Routledge, London-New York 2005.

Historia: o jeden świat za daleko?, red. Ewa Domańska, Wyd. Instytutu Historii UAM, Poznań 1997.

Hopfinger Maryla, Doświadczenia audiowizualne. O mediach w kulturze współczesnej, Wyd. Sic!, Warszawa 2003.

Hughes-Warrington Marnie, History Goes to the Movies. Studying history on film, Routledge, New York 2007.

Iggers Georg G., Historiografia XX wieku, tłum. Agnieszka Gadzała, Wyd. Naukowe PWN, Warszawa 2010.

Iwańska Alicja, Wojenne odcinki 1940-1943, Londyn 1982. 
Jaffe Ira, Hollywood Hybrids. Mixing Genres in Contemporary Films, Rowman \& Littlefield Publishers Inc., Lanham 2008.

Jameson Frederic, Postmodernizm, czyli logika późnego kapitalizmu, tłum. Maciej Płaza, Wyd. Uniwersytetu Jagiellońskiego, Kraków 2011.

Janicka Elżbieta, Sztuka czy naród? Monografia pisarska Andrzeja Trzebińskiego, Universitas, Kraków 2006.

Janion Maria, Forma gotycka Gombrowicza, [w:] taż, Prace wybrane. Romantyzm i jego media, Universitas, Kraków 2001.

Janion Maria, Ironia Calka Perechodnika, [w:] Bohater, spisek, śmierć. Wykłady żydowskie, Wyd. W.A.B, Warszawa 2009.

Janion Maria, Niesamowita Stowiańszczyzna, Wyd. Literackie, Kraków 2006.

Janion Maria, Płacz generała. Eseje o wojnie, Wyd. Sic!, Warszawa 1998.

Janion Maria, Wojna i forma, [w:] Literatura wobec wojny i okupacji, red. Michał Głowiński, Janusz Sławiński, Ossolineum, Wrocław 1976.

Jankun-Dopartowa Mariola, Gorzkie kino Agnieszki Holland, słowo obraz/terytoria, Gdańsk 2000.

Jarzębski Jerzy, Gra w Gombrowicza, PIW, Warszawa 1982.

Jarzębski Jerzy, Podglądanie Gombrowicza, Wyd. Literackie, Kraków 2000.

Jasiewicz Katarzyna, Olędzki Łukasz, Od nostalgii do fascynacji - doświadczanie przeszłości, [w:] Kultura przyjemności. Rozważania kulturoznawcze, red. Jan Grad, Hanna Mamzer, Wyd. Naukowe UAM, Poznań 2005.

Jay Martin, Historia i doświadczenie. Dilthey, Collingwood, Scott i Ankersmit, [w:] Pieśni doświadczenia. Nowoczesne amerykańskie $i$ europejskie wariacje na uniwersalny temat, tłum. Agnieszka Rejniak-Majewska, Universitas, Kraków 2008.

Jenerat Sikorski. Antologia, red. Jacek Danel, Wyd. R-I-D Studio, Mielec-Zamość 2008.

Jenkins Henry, Kultura konwergencji, tłum. Małgorzata Bernatowicz, Mirosław Filiciak, Wyd. Artystyczne i Profesjonalne, Warszawa 2007.

Karnawat. Studia historyczno-antropologiczne, red. Wojciech Dudzik, Wyd. Dromena, Warszawa 2011.

Kępiński Marcin, Gombrowicza gry z kultura, Wyd. Akademickie i Profesjonalne, Warszawa 2006.

Kępiński Tadeusz, Witold Gombrowicz. Studium portretowe, Wyd. Literackie, Kraków 1988.

Kijowski Andrzej, Granice literatury. Wybór szkiców krytycznych i historycznych, t. I, Biblioteka „Więzi”, Warszawa 1991.

Kijowski Andrzej, Szósta dekada, PIW, Warszawa 1972.

Kijowski Andrzej, Szyfry, [w:] Pseudonimy. Zbiór opowiadań, Czytelnik, Warszawa 1964.

Kino polskie jako kino narodowe, red. Tadeusz Lubelski, Maciej Stroiński, korporacja ha!art, Kraków 2009.

Kisielewski Tadeusz, Gibraltar i Katyń. Co kryja archiwa rosyjskie i brytyjskie, Rebis, Poznań 2011.

Kisielewski Tadeusz, Październik 1956. Punkt odniesienia, Wyd. Neriton, Warszawa 2001.

Kisielewski Tadeusz, Przedmowa, [w:] Władysław Sikorski, Przyszła wojna, Universitas, Kraków 2010.

Kisielewski Tadeusz, Zamach. Tropem zabójców generała Sikorskiego, Rebis, Poznań 2005.

Kłopotowski Krzysztof, Wajdy flirty z władza, „W Sieci” 2012, nr 3.

Kłoskowska Antonina, Kultury narodowe u korzeni, Wyd. Naukowe PWN, Warszawa 2005.

Kłoskowska Antonina, Socjologia kultury, Wyd. Naukowe PWN, Warszawa 1983.

Kłys Tomasz, Polifonia i naoczność idei: "Iluminacja” Krzysztofa Zanussiego, [w:] Kino polskie: reinterpretacje, red. Ewelina Nurczyńska-Fidelska i Konrad Klejsa, Wyd. Rabid, Kraków 2008.

Kolski Jan Jakub, Pamięć podróżna. Fragmentozbiór filmowy, Wyd. PWSFTviT, Łódź 2011. 
Kolski Jan Jakub, Piotrkowska i inne okolice kina, Wyd. Silesia Film, Katowice 1998.

Konwicki Tadeusz, Nic albo nic, Czytelnik, Warszawa 1973.

Konwicki Tadeusz, Wschody i zachody księżyca, Oficyna Wyd. Interim, Warszawa 1990.

Korczarowska Natasza, Ojczyzny prywatne, Wyd. Rabid, Kraków 2007.

Kordys Jan, Kategorie antropologicznie i tożsamość narracyjna. Szkice pogranicza neurosemiotyki i historii kultury, Universitas, Kraków 2006.

Kornatowska Maria, Wodzireje i amatorzy, Wyd. Artystyczne i Filmowe, Warszawa 1990.

Korzeniewski Bartosz, Transformacja pamięci. Przewartościowania w pamięci przeszłości a wybrane aspekty funkcjonowania dyskursu publicznego o przeszłości w Polsce po 1989 roku, Wyd. Poznańskiego Towarzystwa Przyjaciół Nauk, Poznań 2010.

Koselleck Reinhart, Dzieje pojęć. Studia z semantyki i pragmatyki języka społeczno-politycznego, tłum. Jarosław Merecki, Wojciech Kunicki, Oficyna Naukowa, Warszawa 2009.

Kosińska-Krippner Beata, „Mock-documentary” a dokumentalne fałszerstwa, „Kwartalnik Filmowy" 2006, nr 54-55.

Kosiński Dariusz, Teatra polskie. Historie, Wyd. Naukowe PWN, Warszawa 2010.

Kowalczyk Agnieszka, Rodzina jako źródło cierpień w twórczości Witolda Gombrowicza, Universitas, Kraków 2006.

Kracauer Siegfried, Teoria filmu, tłum. Wanda Wertenstein, słowo/obraz terytoria, Gdańsk 2008.

Kristeva Julia, Czarne słońce. Depresja i melancholia, tłum. Michał P. Markowski, Remigiusz Ryziński, Universitas, Kraków 2007.

Kula Marcin, Krótki raport o użytkowaniu historii, Wyd. Naukowe PWN, Warszawa 2004.

Kula Marcin, Ku jakiej syntezie polskiego Października?, [w:] Historia moja miłość (z zastrzeżeniami), Wyd. Uniwersytetu Marii Curie-Skłodowskiej, Lublin 2005.

Kula Marcin, Naród, historia i... dużo kłopotów, Universitas, Kraków 2011.

Kula Marcin, O co chodzi w historii?, Wyd. Uniwersytetu Warszawskiego, Warszawa 2008.

Kultura narodowa i polityka, red. Joanna Kurczewska, Oficyna Naukowa, Warszawa 2000.

Kultura po przejściach, osoby z przeszłościa. Polski dyskurs postzależnościowy - konteksty i perspektywy badawcze, red. Ryszard Nycz, Universitas, Kraków 2011.

Kulturowa teoria literatury. Główne pojęcia i problemy, red. Michał Paweł Markowski, Ryszard Nycz, Universitas, Kraków 2006.

Kulturowa teoria literatury 2. Poetyki, problematyki, interpretacje, red. Teresa Walas, Ryszard Nycz, Universitas, Kraków 2012.

Kundera Milan, Nieznośna lekkość bytu, tłum. Agnieszka Holland, PIW, Warszawa 1992.

Kundera Milan, Sztuka powieści, tłum. Marek Bieńczyk, Czytelnik, Warszawa 1991.

Kurtz Michael L., Oliver Stone, JFK, and History, [w:] Oliver Stone's USA, ed. Robert Brent Toplin, University Press of Kansas, Lawrence 2000.

Kuryluk Ewa, Goldi, Wyd. „Twój Styl”, Warszawa 2004.

Kurz Iwona, Twarze w tłumie. Wizerunki bohaterów wyobraźni zbiorowej w kulturze polskiej 1955-1969, Wyd. Świat Literacki, Warszawa 2005.

Kühl Olaf, Gęba erosa. Tajemnice stylu Witolda Gombrowicza, tłum. Krzysztof Niewrzęda, Maria Tarnogórska, Universitas, Kraków 2005.

Kwieciński Bartosz, Obrazy i klisze. Między biegunami wizualnej pamięci Zagłady, Universitas, Kraków 2012.

LaCapra Dominick, Bachtin, marksizm i karnawat, tłum. Łukasz Wróbel, [w:] Ja - Inny. Wokót Bachtina. Antologia, t. 1-2, red. Danuta Ulicka, Universitas, Kraków 2009.

LaCapra Dominick, Historia w okresie przejściowym. Doświadczenie, tożsamość, teoria krytyczna, tłum. Katarzyna Bojarska, Universitas, Kraków 2009. 
Landsberg Alison, America, the Holocaust, and the Mass Culture of Memory: Toward a Radical Politics of Empathy, "New German Critique" 1997, no. 71.

Landsberg Alison, Prosthetic memory: the ethics and politics of memory in an age of mass culture, [w:] Memory and popular film, ed. Paul Grainge, Manchester University Press, Machester-New York 2003.

Legierski Michał, Modernizm Witolda Gombrowicza, Instytut Badań Literackich PAN, Warszawa 1999.

Le Goff Jacques, Historia i pamięć, tłum. Anna Gronowska, Joanna Stryjczyk, Wyd. Uniwersytetu Warszawskiego, Warszawa 2007.

Lejeune Philippe, Wariacje na temat pewnego paktu. O autobiografii, tłum. zbiorowe, Universitas, Kraków 2001.

Leociak Jacek, Doświadczenia graniczne. Studia o dwudziestowiecznych formach reprezentacji, Instytut Badań Literackich PAN, Warszawa 2009.

Lipkin Steven N., Real Emotional Logic. Film and Television Docudrama as Persuasive Practice, Southern Illinois University Press, Carbondale-Edwardsville 2002.

Lipszyc Adam, Sprawiedliwość na końcu języka. Czytanie Waltera Benjamina, Universitas, Kraków 2012.

Lubelski Tadeusz, Bohater Konwickiego, [w:] Człowiek z ekranu. Z antropologii postaci filmowej, red. Mariola Jankun-Dopartowa, Mirosław Przylipiak, Wyd. Arcana, Kraków 1996.

Lubelski Tadeusz, Historia niebyła kina PRL, Znak, Kraków 2012.

Lubelski Tadeusz, Salto Konwickiego, czyli artysta i odbiorcy, [w:] Studia filmoznawcze, t. III, red. Jacek Trzynadlowski, Wyd. Uniwersytetu Wrocławskiego, Wrocław 1981.

Lubelski Tadeusz, Strategie autorskie w polskim filmie fabularnym lat 1945-1961, Wyd. Rabid, Kraków 2000.

Lubelski Tadeusz, Wajda, Wyd. Dolnośląskie, Wrocław 2006.

Lury Celia, Prosthetic Culture. Photography, Memory and Identity, Routledge, London-New York 1998.

Łubieński Tomasz, Ani triumf, ani zgon... Szkice o Powstaniu Warszawskim, Wyd. Nowy Świat, Warszawa 2009.

Machcewicz Piotr, Historia nie ożyła, „Polityka” 1997, nr 6.

Madej Alina, Mitologie i konwencje, Universitas, Kraków 1994.

Makowski Edmund, Poznański Czerwiec 1956. Pierwszy bunt społeczeństwa w PRL, Wyd. Poznańskie, Poznań 2006.

Manowitch Lev, Jęyk nowych mediów, tłum. Piotr Cypryański, Wyd. Artystyczne i Profesjonalne, Warszawa 2006.

Marcus Alan S., Metzger Scott Alan, Paxton Richard J., Stoddard Jeremy D., Teaching History with Film. Strategies for Secondary Social Studies, Routledge, New York-London 2010.

Maron Marcin, Dramat czasu i wyobraźni. Filmy Wojciecha J. Hasa, Universitas, Kraków 2010.

Maruszewski Tomasz, Pamięć autobiograficzna, Gdańskie Wyd. Psychologiczne, Gdańsk 2005.

McGilvray Evan, Polski rząd na uchodźstwie, tłum. Zofia Kaleta, Świat Książki, Warszawa 2011.

Mencwel Andrzej, Polityka historyczna i wizja polityczna, [w:] Rodzinna Europa po raz pierwszy, Universitas, Kraków 2009.

Metz Christian, Fotografia i fetysz, tłum. Anna Oleńska, Sławomir Sikora, „Kwartalnik Filmowy" 2006, nr 54.

Michałowska Marianna, Fragment - fetysz - fotografia, „Kwartalnik Filmowy” 2006, nr 56.

Miller Alice, Zniewolone dzieciństwo. Ukryte źródła tyranii, tłum. Barbara Przybyłowska, Media Rodzina, Poznań 1999.

Miłosz Czesław, Wyprawa w dwudziestolecie, Wyd. Literackie, Kraków 2011.

Miłosz Czesław, Zniewolony umyst, Krajowa Agencja Wydawnicza, Kraków 1990. 
Modelski Tadeusz, Byłem szefem wywiadu u Naczelnego Wodza, tłum. Mira Modelska-Creech, Bellona, Warszawa 2009.

Morstin-Popławska Agnieszka, Historia pewnego złudzenia. Teorie kiczu i "Podwójne życie Weroniki” Krzysztofa Kieślowskiego, „Kwartalnik Filmowy” 2009, nr 66.

Morstin-Popławska Agnieszka, Jak daleko stąd do raju? Religia jako pamięć w polskim filmie fabularnym, Universitas, Kraków 2010.

Morstin Agnieszka, Mocne filmy i głębokie kompleksy, „Kwartalnik Filmowy” 2012, nr 77-78.

Nałkowska Zofia, Dzienniki czasu wojny, Czytelnik, Warszawa 1970.

Nichols Bill, Jak możemy zdefiniować film dokumentalny? , „Kwartalnik Filmowy” 2011, nr 75-76.

Nietzsche Friedrich, Pożyteczność i szkodliwość historii dla życia, [w:] Niewczesne rozważania, tłum. Leopold Staff, Wyd. Zielona Sowa, Kraków 2003.

Nijakowski Lech, Polska polityka pamięci. Esej socjologiczny, Wyd. Akademickie i Profesjonalne, Warszawa 2008.

Nurczyńska-Fidelska Ewelina, Czas i przesłona. O Filipie Bajonie i jego twórczości, Wyd. Rabid, Kraków 2003.

Nurczyńska-Fidelska Ewelina, Polska klasyka literacka według Andrzeja Wajdy, Wyd. Uniwersytetu Łódzkiego, Łódź 2010.

Odojewski Włodzimierz, Koń pułkownika, [w:] Jedźmy, wracajmy, Wyd. Książkowe „Twój Styl", Warszawa 2008.

Ogonowska Agnieszka, "Mock-dockumentary" i "faction-genre", [w:] Kino po kinie, red. Andrzej Gwóźdź, Oficyna Naukowa, Warszawa 2010.

Ozimek Stanisław, Film polski w wojennej potrzebie, PIW, Warszawa 1974.

Ozouf Mona, Święto rewolucyjne 1789-1799, tłum. Andrzej Siemek, Oficyna Naukowa, Warszawa 2008.

Pamięć, etyka i historia, red. Ewa Domańska, Wyd. Poznańskie, Poznań 2002.

Pamięć i polityka historyczna. Doświadczenia Polski i jej sąsiadów, red. Sławomir M. Nowinowski, Jan Pomorski, Rafał Stobiecki, Wyd. Ibidem, Łódź 2008.

Pamięć zbiorowa i kulturowa. Wspótczesna perspektywa niemiecka, red. Magdalena Saryusz-Wolska, Universitas, Kraków 2009.

The Persistence of History. Cinema, Television and the Modern Event, ed. Vivian Sobchack, Routledge, New York-London 1996.

Picknett Lynn, Prince Clive, Prion Stephen, Od własnej kuli. Tajna wojna między aliantami, tłum. Sławomir Kędzierski, Bellona, Warszawa 2007.

Piwińska Marta, Legenda romantyczna i szydercy, PIW, Warszawa 1973.

Podniesińska Zofia, (Re)konstrukcje dzieciństwa traumatycznego, [w:] Trauma, pamięć, wyobraźnia, red. Zofia Podniesińska, Józef Wróbel, Wyd. Uniwersytetu Jagiellońskiego, Kraków 2001.

Postmodernizm. Antologia przekładów, red. Ryszard Nycz, tłum. Zdzisław Łapiński, Wyd. Baran i Suszyński, Kraków 1997.

Poznańskie szczuny. Z F. Bajonem rozmawia Z. Pietrasik, „Polityka” 1996, nr 26.

Przemiany pamięci społecznej a teoria kultury, red. Bartosz Korzeniewski, Instytut Zachodni, Poznań 2007.

Przylipiak Mirosław, Poetyka kina dokumentalnego, Wyd. Uniwersytetu Gdańskiego, Gdańsk-Słupsk 2004.

Revisioning History. Film and the Construction of a New Past, ed. Robert Rosenstone, Princeton University Press, Princeton 1995.

Rabinow Paul, Wyobrażenia sa faktami społecznymi: modernizm i postmodernizm w antropologii, tłum. Joanna Krzemień, [w:] Amerykańska antropologia postmodernistyczna, red. Michał Buchowski, Instytut Kultury, Warszawa 1999.

Ricoeur Paul, Czas i opowieść, t. III, tłum. Urszula Zbrzeźniak, Wyd. Uniwersytetu Jagiellońskiego, Kraków 2008. 
Ricoeur Paul, O sobie samym jako innym, tłum. Bogdan Chełstowski, Wyd. Naukowe PWN, Warszawa 2003.

Ricoeur Paul, Pamięć, historia, zapomnienie, tłum. Janusz Margański, Universitas, Kraków 2006.

Rose Gillian, Interpretacja materiałów wizualnych, tłum. Ewa Klekot, Wyd. Naukowe PWN, Warszawa 2010.

Rosenstone Robert, Historia w obrazach/historia w słowach: rozważania nad możliwościa przedstawienia historii na taśmie filmowej, [w:] Film i historia. Antologia, red. Iwona Kurz, Wyd. Uniwersytetu Warszawskiego, Warszawa 2008.

Rosenstone Robert, Oliver Stone as Historian, [w:] Oliver Stone's USA, ed. Robert Brent Toplin, University Press of Kansas, Lawrence 2000.

Rosenstone Robert, The Historical Film: Looking at the Past in a Postliterate Age, [w:] The Historical Film: History and Memory in Media, ed. Marcia Landy, Rutgers University Press, New Jersey 2001.

Rosner Katarzyna, Narracja, tożsamość i czas, Universitas, Kraków 2003.

Rouillé André, Fotografia. Między dokumentem a sztuka wspótczesna, tłum. Oskar Hedemann, Universitas, Kraków 2007.

Salgas Jean-Pierre, Witold Gombrowicz lub ateizm integralny, tłum. Jan Maria Kłoczowski, Czytelnik, Warszawa 2004.

Schwartz Vanessa R., Film and History, [w:] Film Studies, ed. James Donald and Michael Renov, Sage, Los Angeles-London-New Delhi-Singapore 2008.

Sobolewski Tadeusz, Wszystko osobno, „Gazeta Wyborcza” 1997, nr 12.

Sontag Susan, O fotografii, tłum. Sławomir Magala, Wyd. Artystyczne i Filmowe, Warszawa 1986.

Soulages François, Estetyka fotografii. Strata i zysk, tłum. Beata Mytych-Forajter, Wacław Forajter, Universitas, Kraków 2007.

Sowa Jan, Fantomowe ciało króla. Peryferie zmagania z nowoczesna forma, Universitas, Kraków 2011. Stolarska Bronisława, Zakładnicy nadziei, „Kwartalnik Filmowy” 1997, nr 17.

Suleja Włodzimierz, Mit niepodległości w dobie PRL, [w:] Polskie mity polityczne XIX i XX wieku, red. Zyta Kwiecińska, Wyd. Uniwersytetu Wrocławskiego, Wrocław 1996.

Syndrom konformizmu? Kino polskie lat sześćdziesiątych, red. Tadeusz Miczka, Wyd. Uniwersytetu Śląskiego, Katowice 1994.

Szacka Barbara, Czas przeszły - pamięć - mit, Wyd. Naukowe Scholar, Warszawa 2006.

Szacki Jerzy, Tradycja, Wyd. Uniwersytetu Warszawskiego, Warszawa 2001.

Szpulak Andrzej, Filmy Wojciecha Marczezskiego, Wyd. Naukowe UAM, Poznań 2009.

Śpiewak Paweł, Pamiećc po komunizmie, słowo/obraz terytoria, Gdańsk 2007.

Teoria wiedzy o przeszłości na tle wspótczesnej humanistyki, red. Ewa Domańska, Wyd. Poznańskie, Poznań 2010.

Tokarska-Bakir Joanna, Barabasz" i Żydzi. Z historii oddziatu AK „Wybranieccy”, [w:] Okrzyki pogromowe. Szkice z antropologii historycznej Polski lat 1939-1946, Wyd. Czarne, Wołowiec 2012.

Topolski Jerzy, Jak się pisze i rozumie historię. Tajemnice narracji historycznej, Oficyna Wyd. Rytm, Warszawa 1996.

Tożsamość polska w odmiennych kontekstach. Tożsamości osób, zbiorowości, instytucji, red. Leon Dyczewski, Dariusz Wadowski, Wyd. KUL, Lublin 2009.

Traba Robert, Historia - przestrzeń dialogu, Instytut Studiów Politycznych PAN, Warszawa 2006.

Traba Robert, Przeszłość w teraźniejszości. Polskie spory o historię na początku XXI wieku, Wyd. Poznańskie, Poznań 2009.

Trznadel Jacek, Hańba domowa, Wyd. Antyk, Komorów 2006. 
Turner Victor, Gry społeczne, pola i metafory, tłum. Wojciech Usakiewicz, Wyd. Uniwersytetu Jagiellońskiego, Kraków 2005.

Uspienski Boris, Historia i semiotyka, tłum. Bogusław Żyłko, słowo/obraz terytoria, Gdańsk 1998.

Wajda Andrzej, Moje notatki z historii, „Kwartalnik Filmowy” 1996/1997, nr 15-16.

Waldenfels Bernhard, Topografia obcego, tłum. Janusz Sidorek, Oficyna Naukowa, Warszawa 2002.

Wawer Zbigniew, Monte Cassino. Walki 2. Korpusu Polskiego, Bellona, Warszawa 2009.

Werner Andrzej, Czarno-biała, biało-czerwona?, [w:] Sporne sprawy polskiej literatury wspótczesnej, red. Alina Brodzka, Lidia Burska, Instytut Badań Literackich PAN, Warszawa 1998.

Werner Andrzej, Polskie, arcypolskie..., Wyd. Biblioteki „Więzi”, Warszawa 2011.

White Hayden, Poetyka pisarstwa historycznego, tłum. zbiorowe, Universitas, Kraków 2010.

White Hayden, Proza historyczna, tłum. zbiorowe, Universitas, Kraków 2009.

Whiteley Justin, Śmierć generała Sikorskiego, tłum. Katarzyna Piotrowska-Fletcher, Bellona, Warszawa 2007.

Williams Linda, Truth, History and the New Documentary, "Film Quarterly" 1993, vol. 46, no. 3.

Witek Piotr, Kultura - film - historia. Metodologiczne problemy doświadczenia audiowizualnego, Wyd. Uniwersytetu Marii Curie-Skłodowskiej, Lublin 2005.

Witold Gombrowicz - nasz współczesny, red. Jerzy Jarzębski, Universitas, Kraków 2010.

Wobec przeszłości. Pamięć przeszłości jako element kultury współczesnej, red. Andrzej Szpociński, Wyd. Instytutu im. Adama Mickiewicza, Warszawa 2005.

Wolska Dorota, Odzyskać doświadczenie. Sporny temat humanistyki wspótczesnej, Universitas, Kraków 2012.

Woźniak Marek, Przeszłość jako przedmiot konstrukcji. O roli wyobraźni w badaniach historycznych, Wyd. Uniwersytetu Marii Curie-Skłodowskiej, Lublin 2010.

Wyka Kazimierz, Życie na niby. Pamiętnik po klęsce, Wyd. Literackie, Kraków 1984.

Wyspiański Stanisław, Wyzwolenie. Noc listopadowa, Wyd. Literackie, Kraków 1987.

Wróblewski Janusz, Krajobraz po bitwie, „Kino” 1997, nr 1.

Zaleski Marek, Formy pamięci, Instytut Badań Literackich PAN, Warszawa 1996.

Załuski Zbigniew, Siedem polskich grzechów głównych, Wyd. Iskry, Warszawa 1968.

Zawadzki Andrzej, Hermeneutyka śladu i hermeneutyka świadectwa, [w:] Nowoczesność jako doświadczenie, red. Ryszard Nycz, Anna Zeidler-Janiszewska, Universitas, Kraków 2002.

Zertal Idith, Naród i śmierć. Zagłada w dyskursie i polityce Izraela, tłum. Jan Maria Kłoczowski, Universitas, Kraków 2010.

Zwierzchowski Piotr, "Jak być kochana" i "Szyfry" - wojna, pamięć i kino polskie lat sześćdziesiatych, [w:] Filmowe ogrody Wojciecha Jerzego Hasa, red. Małgorzata Jakubowska, Kamila Żyto, Anna M. Zarychta, Wyd. PWSFTviT, Łódź 2011.

Zwierzchowski Piotr, Przygody Franka Dolasa albo co Giuseppe robit w Warszawie, „Kwartalnik Filmowy" 2012, nr 77-78.

Žižek Slavoj, Kruchy absolut, tłum. Maciej Kropiwnicki, Wyd. Krytyki Politycznej, Warszawa 2009.

Żmijewski Artur, „Katyń", „Karole”, „Świadectwo”, czyli praca ideologii, [w:] Kino polskie 1989-2009. Historia krytyczna, Wyd. Krytyki Politycznej, Warszawa 2010.

Życie umystowe i uczuciowe. Z Jadwiga Staniszkis rozmawia Cezary Michalski, Wyd. Czerwone i Czarne, Warszawa 2010. 


\section{Spis fotografii}

SZYFrY (1966, REŻ. WojCIECH JERZY HAS)

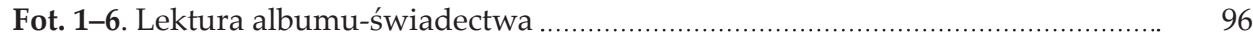

Fot. 7-9. „Mumifikacja” obiektu .................................................................................. 104

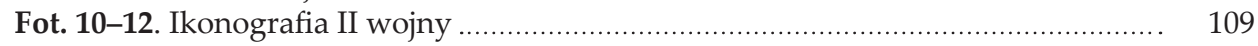

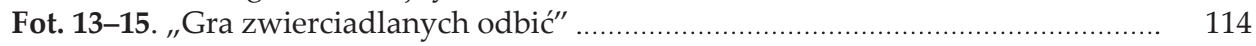

Pornografia (2003, Reż. Jan JAKub Kolski)

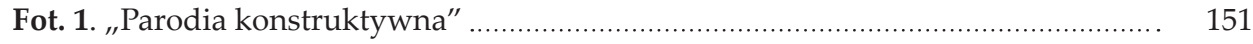

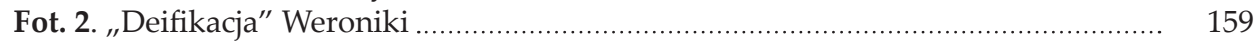

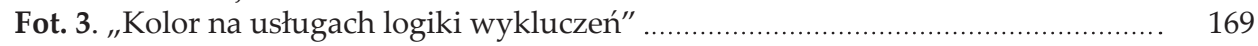

POZNAŃ 56 (1966, REŻ. Filip BAJON)

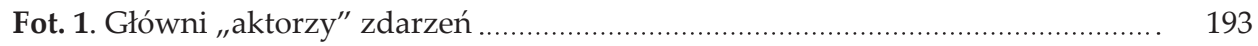

Fot. 2-3. Protestacja przekształcona w karnawał ..................................................... 208

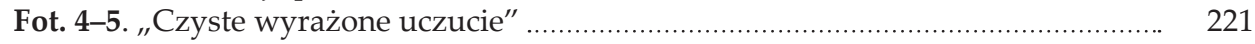

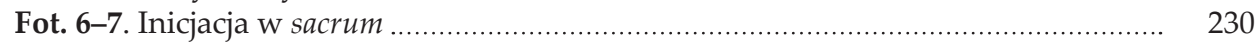

Fot. 8-9. "Zabawa mózgowa dla pozamykanej profesury” ......................................... 233

Fot. 10-11. „Powtórzenie w symbolicznym mimesis" .................................................. 243

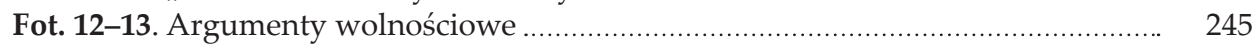

Fot. 14-15. „Rewolucyjna pozateatralna teatralizacja” ............................................ 248

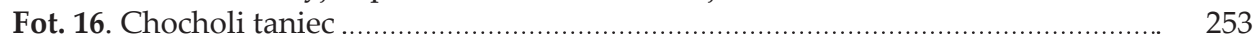

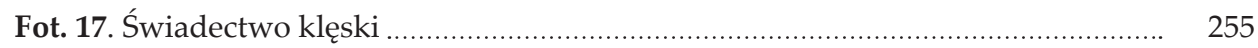

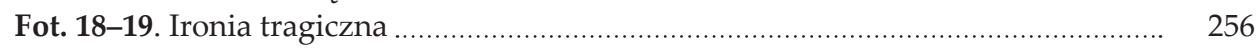

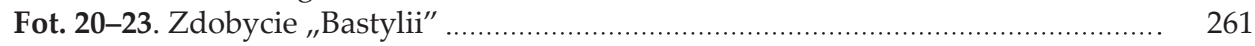

Fot. 24-25. Projekcja na wewnętrznym ekranie .......................................................... 263

Fot. 26. Operowe decorum śmierci ..................................................................................... 263

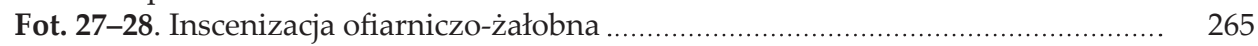

Fot. 29-30. „W samo południe” i „Pięciu wspaniałych” ............................................. 267

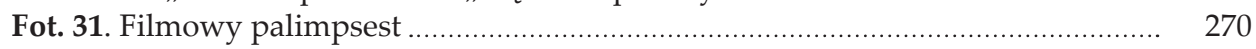

Generat. Zamach na Gibraltarze (2009, Reż. Anna Jadowska)

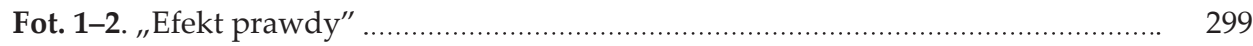

Fot. 3-4. "Dialektyka” obrazu ........................................................................................ 304

Fot. 5-7. „Obiektywizm indeksalny” ............................................................................... 305

Fot. 8. „Interfejs okienkowy” ............................................................................... 310

Fot. 9-10. Efekt uniezwyklenia ........................................................................ 312 



\section{Another Way. Representations of History in the Films of Wojciech Jerzy Has, Jan Jakub Kolski, Filip Bajon and Anna Jadowska - a Case Study}

(Summary)

Another Way considers the way in which four film directors present unique vision of the Polish national history (World War II, Poznań June'56) and challenge established ideas about "historical film" perceived as a "window onto the past". According to the author, films selected for the purpose of the book do not try to tell its viewers "what really happened" or to revise the history itself (impossible task) but discuss with the tradition of historical representation (by multiplying narrative perspective, mixing genres and blurring the distinction between documentary and fiction). The aim of this book is to explore the strategies by which filmmakers undertook three basic tasks: contesting, visioning and revisioning history.

The films are analyzed in the paradigm of cultural turns: interpretative turn (Szyfry), postcolonial turn (Pornografia), performative turn (Poznań 56) and narrative turn (Generat. Zamach na Gibraltarze) and in the context of historiophoty defined by Hayden White as "the representation of history and our thought about it in visual images and filmic discourse". The fundamental argument is that nowadays films are the most influential and powerful way of visioning history (prosthetic culture) but - as historian Robert Rosenstone points out - must be seen not in terms of how they compare to the written history but as a way of recounting the past with its own rules of representation. 



\section{Od Redakcji}

Natasza Korczarowska-Różycka - doktor nauk humanistycznych, adiunkt w Zakładzie Historii i Teorii Filmu Instytutu Kultury Współczesnej Uniwersytetu Łódzkiego. Opublikowała książkę Ojczyzny prywatne. Mitologia przestrzeni prywatności w filmach Tadeusza Konwickiego, Jana Jakuba Kolskiego i Andrzeja Kondratiuka (Kraków 2007) oraz kilkanaście tekstów naukowych i popularnonaukowych poświęconych kinu polskiemu i światowemu. Autorka artykułów o tematyce żydowskiej, które ukazały się w serii Gefilte film. Wątki żydowskie w kinie.

Od początku pracy naukowej jej zainteresowania naukowe skupiają się przede wszystkim wokół badań związanych z powojenną historią filmu polskiego. Od 2008 r. współpracuje z Państwowym Instytutem Sztuki Filmowej w Warszawie. Brała udział w projekcie edukacyjnym „Filmoteka Szkolna", skierowanym do nauczycieli szkół gimnazjalnych i licealnych. Od 2010 r. pełni funkcję koordynatora programowego i opiekuna naukowego Akademii Polskiego Filmu - ogólnopolskiego projektu PISF przeznaczonego dla studentów wszystkich wyższych uczelni. W ramach projektu uczestniczy w warsztatach i seminariach organizowanych przez PISF, wykłada w Łodzi i innych ośrodkach naukowych w Polsce. 
